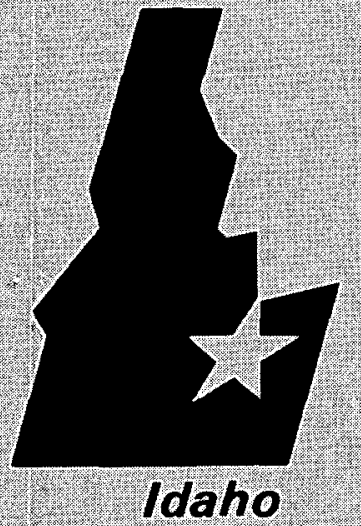

National

Engineering

Laboratory

Managed

by the US.

Department

of Energy
EGG-EP-11414

August 1994

\title{
Geothermal Well Site Restoration and Plug and Abandonment of Wells
}

\author{
DOE Gladys McCall Test Site \\ Cameron Parish, Louisiana \\ and \\ DOE Willis Hulin Test Site \\ Vermilion Parish, Louisiana
}

Ben N. Rinehart, INEL 


\section{DISCLAIMER}

This report was prepared as an account of work sponsored by an agency of the United States Government. Neither the United States Government nor any agency Thereof, nor any of their employees, makes any warranty, express or implied, or assumes any legal liability or responsibility for the accuracy, completeness, or usefulness of any information, apparatus, product, or process disclosed, or represents that its use would not infringe privately owned rights. Reference herein to any specific commercial product, process, or service by trade name, trademark, manufacturer, or otherwise does not necessarily constitute or imply its endorsement, recommendation, or favoring by the United States Government or any agency thereof. The views and opinions of authors expressed herein do not necessarily state or reflect those of the United States Government or any agency thereof. 


\section{DISCLAIMER}

Portions of this document may be illegible in electronic image products. Images are produced from the best available original document. 
This document contains new concepts or the author(s) interpretation of new calculations and/or measurements; accordingly, EG\& G Idaho, Inc. is required by the United States Government to include the following disclaimer:

\section{DISCLAIMER}

This report was prepared as an account of work sponsored by an agency of the United States Government. Neither the United States Govemment nor any agency thereof, nor any of their employees, makes any warranty, express or implied, or assumes any legal liability or responsibility tor the accuracy, completeness, of usefulness of any intormation. apparatus. product or process disclosed, or represents that its use would not infringe privately owned nights. Relerences herein to any specific commercial product. process, or service by trade name, trademark, manutacturer, or otherwise, does not necessarily constitute or imply its endorsement, recommendation, or favoring by the United States Govemment or any agency thereof. The views and opınions of authors expressed herein do not necessarily state or reflect those of the United States Govemment or any agency thereot. 


\title{
Geothermal Well Site Restoration and Plug and Abandonment of Wells
}

\author{
DOE Gladys McCall Test Site \\ Cameron Parish, Louisiana \\ and \\ DOE Willis Hulin Test Site \\ Vermilion Parish, Louisiana
}

Ben N. Rinehart

Published August 1994

Idaho National Engineering Laboratory

EG\&G Idaho, Inc.

Idaho Falls, Idaho 83415

Prepared for the

U.S. Department of Energy

Assistant Secretary for Energy Efficiency and Renewable Energy

Under DOE Idaho Operations Office

Contract DE-AC07-76ID01570 

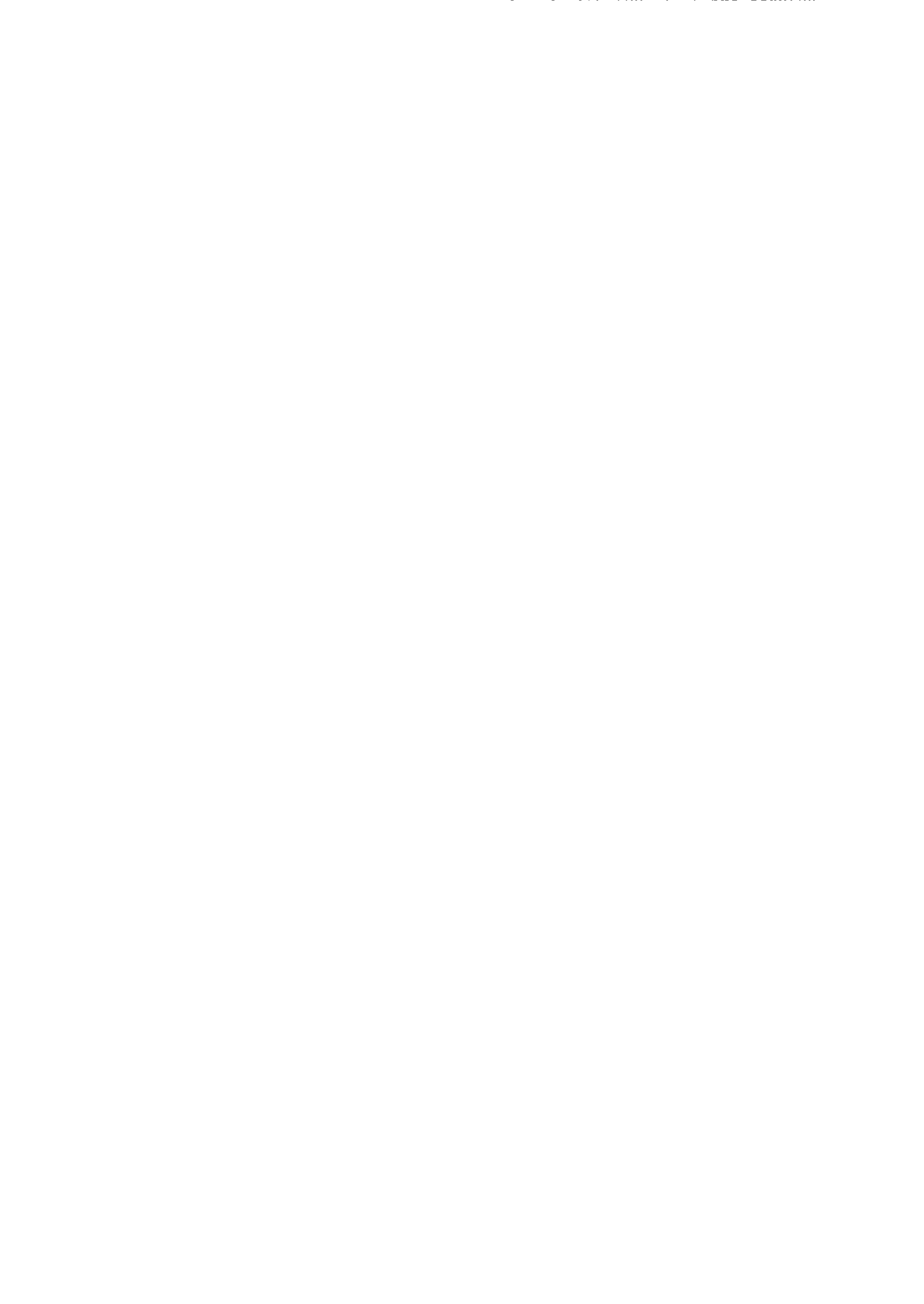


\begin{abstract}
A report is presented on the final phase of an energy research program conducted by the U.S. Department of Energy (DOE) involving two geothermal well sites in the State of Louisiana-the Gladys McCall site and the Willis Hulin site. The research program was intended to improve geothermal technology and to determine the efficacy of producing electricity commercially from geopressured resource sites. The final phase of the program consisted of plug and abandonment (P\&A) of the wells and restoration of the well sites. Restoration involved (a) initial soil and water sampling and analysis; (b) removal and disposal of well pads, concrete, utility poles, and trash; (c) plugging of monitor and freshwater wells; and (d) site leveling and general cleanup. Restoration of the McCall site required removal of naturally occurring radioactive material (NORM), which was costly and time-consuming. Exhibits are included that provide copies of work permits and authorizations, P\&A reports and procedures, daily workover and current conditions reports, and cost and salvage reports. Site locations, grid maps, and photographs are provided.
\end{abstract}




\section{CONTENTS}

ABSTRACT $\ldots \ldots \ldots \ldots \ldots \ldots \ldots \ldots \ldots \ldots \ldots \ldots \ldots \ldots \ldots \ldots \ldots \ldots \ldots$

1. GENERAL BACKGROUND . . . . . . . . . . . . . . . . . . $1-1$

1.1 Well Site Locations $\ldots \ldots \ldots \ldots \ldots \ldots \ldots \ldots \ldots \ldots \ldots \ldots \ldots \ldots \ldots$

1.2 Well Identification Numbers $\ldots \ldots \ldots \ldots \ldots \ldots \ldots \ldots \ldots \ldots \ldots \ldots \ldots \ldots$

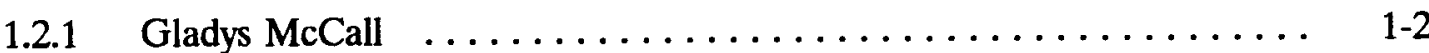

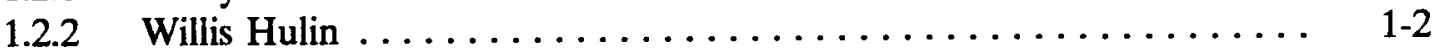

1.3 Production Operations $\ldots \ldots \ldots \ldots \ldots \ldots \ldots \ldots \ldots \ldots \ldots \ldots \ldots \ldots \ldots \ldots$

2. RESTORATION PLAN AND SCHEDULE $\ldots \ldots \ldots \ldots \ldots \ldots \ldots \ldots \ldots \ldots \ldots$

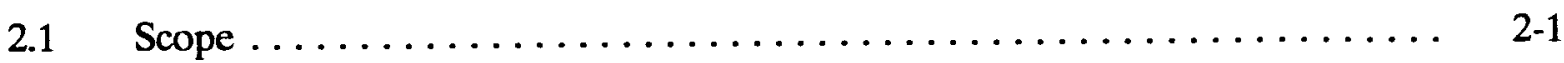

2.2 Major Task Components $\ldots \ldots \ldots \ldots \ldots \ldots \ldots \ldots \ldots \ldots \ldots \ldots \ldots \ldots \ldots$

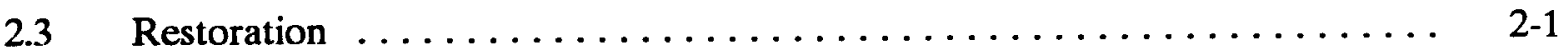

3. PLUGGING OF WATER WELLS $\ldots \ldots \ldots \ldots \ldots \ldots \ldots \ldots \ldots \ldots \ldots \ldots \ldots$

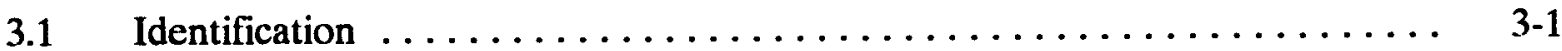

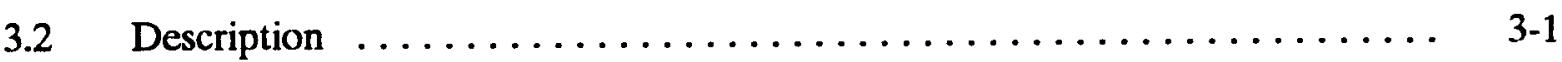

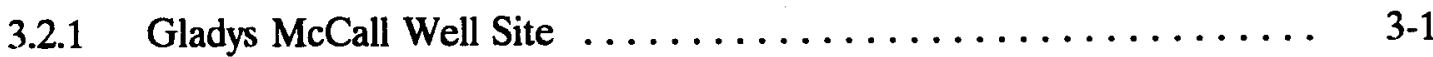

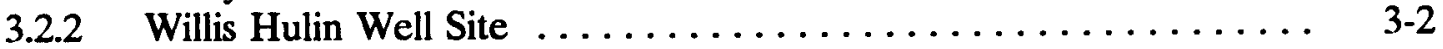

$3.3 \quad$ Well Plugging $\ldots \ldots \ldots \ldots \ldots \ldots \ldots \ldots \ldots \ldots \ldots \ldots \ldots \ldots \ldots$

4. SOIL AND WATER SAMPLING AND ANALYSIS $\ldots \ldots \ldots \ldots \ldots \ldots \ldots \ldots$

$4.1 \quad$ General $\ldots \ldots \ldots \ldots \ldots \ldots \ldots \ldots \ldots \ldots \ldots \ldots \ldots \ldots \ldots \ldots \ldots \ldots \ldots \ldots$

$4.2 \quad$ Water Samples $\ldots \ldots \ldots \ldots \ldots \ldots \ldots \ldots \ldots \ldots \ldots \ldots \ldots \ldots \ldots \ldots \ldots \ldots$

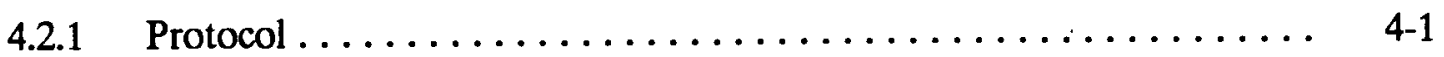

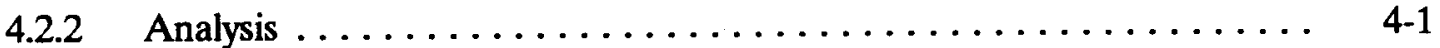

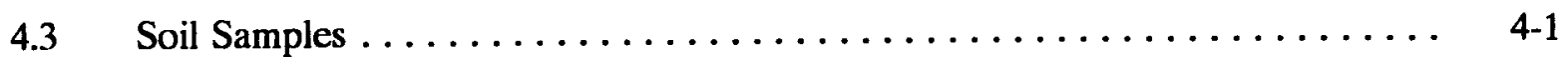

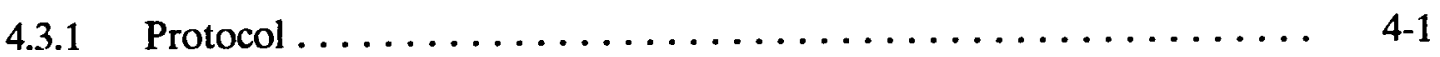

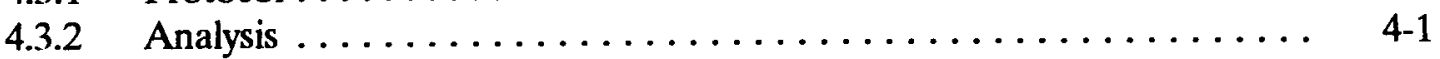

5. NORM SURVEY $\ldots \ldots \ldots \ldots \ldots \ldots \ldots \ldots \ldots \ldots \ldots \ldots \ldots \ldots \ldots \ldots \ldots$ 
$5.1 \quad$ General

5.2 Protocol for Survey

5.3 Results

6. PLUG AND ABANDONMENT OF GEOTHERMAL WELLS

\section{FIGURES}

1-1. Location and directions to Gladys McCall well site in Cameron Parish,

Louisiana . . . . . . . . . . . . . . . . . . . . . . . . . . . . . . .

1-2. Location and directions to Willis Hulin well site in Vermilion Parish,

Louisiana ....................................... 1-4

1-3. EOC/DOE Gladys McCall, Well No. 1, Cameron Parish, Louisiana . . . . . . . 1-5

1-4. EOC/DOE Willis Hulin Test Site, Vermilion Parish, Louisiana $\ldots \ldots \ldots \ldots \ldots$

2-1. View of entrance off Highway 82 to Gladys McCall well site $\ldots \ldots \ldots \ldots \ldots \ldots$

2-2. View of entrance at bridge adjacent to Gladys McCall well site $\ldots \ldots \ldots \ldots \ldots$

2-3. View of north side of Gladys McCall well site $\ldots \ldots \ldots \ldots \ldots \ldots \ldots \ldots \ldots$

2-4. View of east side of Gladys McCall well site $\ldots \ldots \ldots \ldots \ldots \ldots \ldots \ldots \ldots$

2-5. View of south side of Gladys McCall well site $\ldots \ldots \ldots \ldots \ldots \ldots \ldots \ldots \ldots$

2-6. View of west side of Gladys McCall well site $\ldots \ldots \ldots \ldots \ldots \ldots \ldots \ldots \ldots \ldots$

2-7. View of gate entrance to Willis Hulin well site $\ldots \ldots \ldots \ldots \ldots \ldots \ldots \ldots \ldots$

2-8. View of inside entrance to Willis Hulin well site $\ldots \ldots \ldots \ldots \ldots \ldots \ldots \ldots$

2-9. View of inside south side of Willis Hulin well site $\ldots \ldots \ldots \ldots \ldots \ldots \ldots$

2-10. View of south side of Willis Hulin well site $\ldots \ldots \ldots \ldots \ldots \ldots \ldots \ldots \ldots$

2-11. View inside east end of Willis Hulin well site $\ldots \ldots \ldots \ldots \ldots \ldots \ldots \ldots \ldots$

2-12. View of east end of Willis Hulin well site $\ldots \ldots \ldots \ldots \ldots \ldots \ldots \ldots \ldots \ldots \ldots$

6-1. Gladys McCall well schematic as recompleted by T-F\&S,

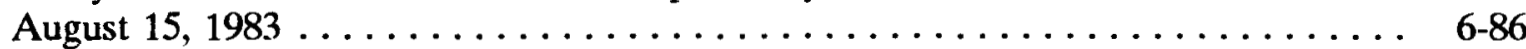

6-2a. Gladys McCall No. 1 production wellhead description schematic 
6-2b. Gladys McCall No. 1 production wellhead description schematic

as of June $1990 \ldots \ldots$. . . . . . . . . . . . . . . . . . . . . . . . . . . . . .

6-3. Willis Hulin No. 1 well schematic as completed by EOC,

January 3, 1990

6-4. Willis Hulin No. 1 well schematic as completed by EOC,

February 28, 1989

6-5a. Willis Hulin No. 1 wellhead dimensions as of October 1990

6-5b. Willis Hulin No. 1 wellhead dimensions as of October 1990

6-6a. Willis Hulin CVW No. 1 disposal wellhead dimensions as completed by EOC, February 1989 .

6-6b. Willis Hulin CVW No. 1 disposal wellhead dimensions as completed by EOC, February 1989

\section{EXHIBITS}

2-A. U.S. DOE Idaho Operations Office Inspection and Project Transfer, Inspection Group Approval, and Transfer Approval . . . . . . . . .

3-A. Louisiana Department of Transportation and Development, Water Resources

Section, Gladys McCall Well Number 1, Serial Number 174825 . . . . . . . . . . . .

3-B. Louisiana Department of Transportation and Development, Water Resources

5-A. Turnkey Bid for Gladys McCall Well

5-B. Louisiana Radioactive Material License $\ldots \ldots \ldots \ldots \ldots \ldots \ldots \ldots \ldots \ldots \ldots$

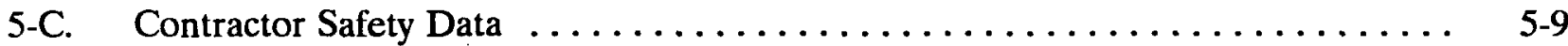

5-D. Petroleum Environmental, Inc. (Letter and Survey Plots) $\ldots \ldots \ldots \ldots \ldots \ldots \ldots$ 5-11

5-E. State of Louisiana Department of Environmental Quality

(Fax Cover and Letter)

5-F. State of Louisiana Department of Natural Resources (Two Letters) $\ldots \ldots \ldots$. . 5-21

5-G. State of Washington Department of Ecology (N.A.R.M. Site Use Permit) . . . . 5-25

5-H. Source Environmental Services, Inc. (Gladys McCall Letter, Map, and Release

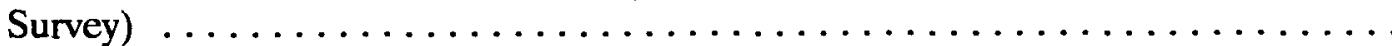

5-I. $\quad$ Source Environmental Services, Inc. (Willis Hulin Confirmatory Survey) $\ldots \ldots$. . $5-33$ 
6-A. State of Louisiana-McCall Work Permit No. $575-93 \ldots \ldots \ldots \ldots \ldots \ldots \ldots$

6-B. McCall Work Permit UIC-30 Application $\ldots \ldots \ldots \ldots \ldots \ldots \ldots \ldots \ldots$

6-C. State of Louisiana Plug and Abandon Report (Hulin Work Permit No. 576-93) .. . 6-7

6-D. State of Louisiana Plug and Abandon Report (Hulin Work Permit No. 012314) . . 6-7

6-E. State of Louisiana Plug and Abandon Report (McCall Work Permit 11/3/93) . . . 6 6-9

6-F. State of Louisiana Plug and Abandon Report (McCall Work Permit 11/29/93) . . . 6-12

6-G. State of Louisiana Plug and Abandon Report (Hulin Work Permit 3/11/94) . . . . 6-15

6-H. State of Louisiana Plug and Abandon Report (McCall Work Permit 3/7/94) . . . . 6-18

6-I. Eaton Operating Company Plug and Abandonment Procedure for McCall

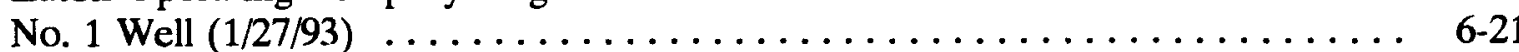

6-J. PAW Drilling \& Well Service Plug and Abandonment Procedure for McCall SWD ...................................... $6-22$

6-K. Eaton Operating Company Plug and Abandonment Procedure for Hulin

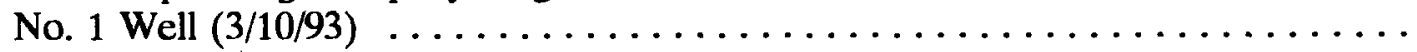

6-L. Eaton Operating Company Plug and Abandonment Procedure for McCall

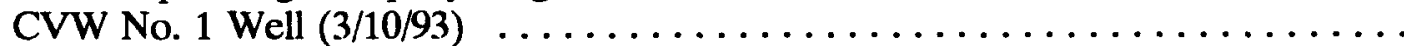

6-M. Daily Workover Reports for Gladys McCall Site From 9-18-93 Through 11-19-93

6-N. Current Condition of Gladys McCall Well Site .

6-O. Daily Workover Reports for Willis Hulin Well Site From 2-7-94 Through 3-17-94

6-P. Current Condition of Willis Hulin Well Site

6-Q. Turnkey Bids for McCall and Hulin Sites $\ldots \ldots \ldots \ldots \ldots \ldots \ldots \ldots \ldots \ldots$. $\ldots \ldots 1$

6-R. Cost Savings Report From EG\&G Idaho, Inc. . . . . . . . . . . . . 6-157

6-S. PAW P\&A Cost and Salvage Report $\ldots \ldots \ldots \ldots \ldots \ldots \ldots \ldots \ldots$ 6.161 


\title{
Geothermal Well Site Restoration and Plug and Abandonment of Wells
}

\author{
DOE Gladys McCall Test Site \\ Cameron Parish, Louisiana \\ and \\ DOE Willis Hulin Test Site \\ Vermilion Parish, Louisiana
}

\section{GENERAL BACKGROUND}

For a variety of reasons, thousands of oil and gas wells have been abandoned in the Gulf Coast Region of the United States. Many of these wells penetrated geopressured zones whose potential for power generation was undervalued or ignored. The U.S. Department of Energy (DOE) Geopressured-Geothermal Research Program was chartered to improve geothermal technology to the point where electricity could be commercially produced from a substantial number of geopressured resource sites. This research program focused on technical issues that are unique to geopressured resources, such as the ability to predict reservoir production capacity based on preliminary flow tests. The two well sites selected for this research program in Louisiana were the Gladys McCall site and the Willis Hulin site. The final phase of the research program, which consisted of plug and abandonment (P\&A) of the wells and site restoration, is covered in this report. Eaton Operating Company of Houston, Texas, was responsible for the operations of both well sites, and EG\&G Idaho, Inc., of the Idaho National Engineering Laboratory, Idaho Falls, Idaho, was contracted by DOE-ID (Contract DE-AC07-76ID01570) for the P\&A of the wells when the DOE contract with the Eaton Operating Company was terminated.

The property lease agreement of the Gladys McCall site was held by Eaton Operating Company under DOE Contract No. DG-AC07-85ID12578, until the contract was canceled on July 19, 1993, at which time DOE-ID took over the lease agreement. The property lease agreement for the Willis Hulin site was held by DOE under Lease Agreement No.

DE-R-84NV10374.

\subsection{Well Site Locations}

The Gladys McCall well site is located in Crab Lake field, Cameron Parish, Louisiana (Figure 1-1), and the Willis Hulin well site is located in South Erath field, Vermilion Parish, Louisiana (Figure 1-2). The Gladys McCall site (map shown in Figure 1-3) was completely surrounded by water except for the entrance road, and the Willis Hulin site (map shown in Figure 1-4) was completely surrounded by the Hulin farm. 


\subsection{Well Identification Numbers}

\subsubsection{Gladys McCall}

- $\quad$ Production Well-Serial No. 174825, API No. 17-02321648

- $\quad$ Disposal Well-Serial No. 159587.

\subsubsection{Willis Hulin}

- $\quad$ Production Well-Serial No. 158468 , API No. $17-113207850000$

- $\quad$ Disposal Well-Serial No. 972009, API No. 17-113880870000.

\subsection{Production Operations}

Operations on the well sites consisted primarily of high-pressured brine production with some natural gas production; although at the time of closure, the production and injection wells and all associated activity had been shut down for several years. Figures 1-3 and 1-4 show the general layout of the sites with production and injection well locations. 


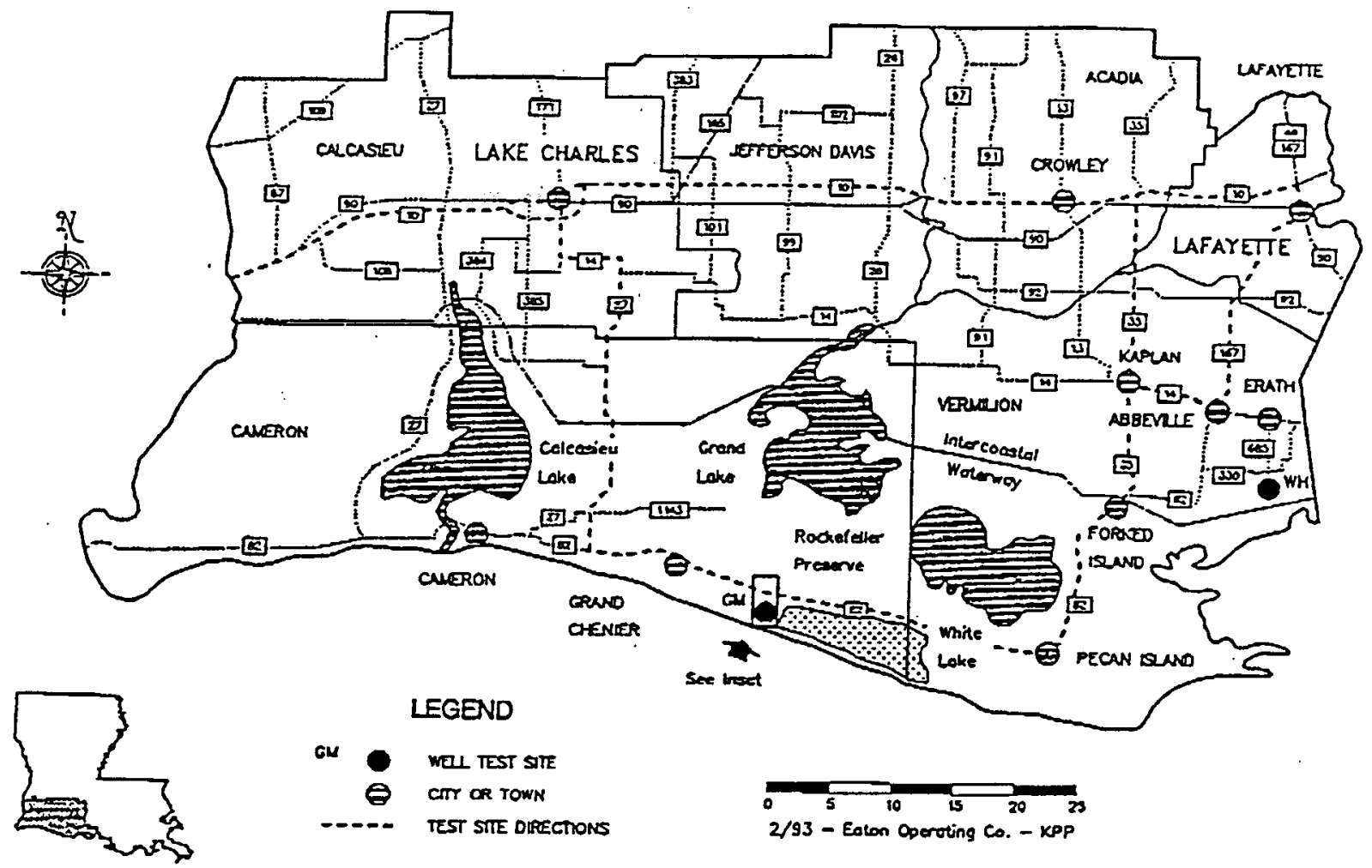

Map Inset

- From Houston, exit Interstate Highway (IH) 10 onto IH-210 Bypass of Lake Charles, LA, exiting IH-210 at Exit 8 onto State Highway (SH) 14. Follow SH-14 to the intersection with SH-27 and take SH-27 to the intersection with SH-82. Turn left (east) on SH-82 and proceed through Grand Chenier. The access road to Gladys McCall well site is located approximately 8 miles east of Grand Chenier on the south side of SH-82 at Mile Marker 69.

- From Lafayette, take SH-167 south to Abbeville, turn right (west) on SH-14, and follow to Kaplan. Turn left (south) on SH-35 and follow to the intersection with SH-82, near Forked Island. Take SH-82 through Pecan Island, staying on SH-82 until reaching the access road to the Gladys McCall well site on the south side of the highway, at Mile Marker 69.

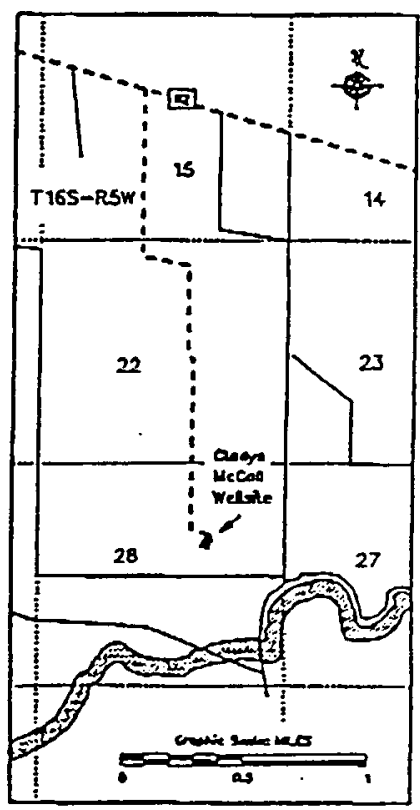

Figure 1-1. Location and directions to Gladys McCall well site in Cameron Parish, Louisiana. 


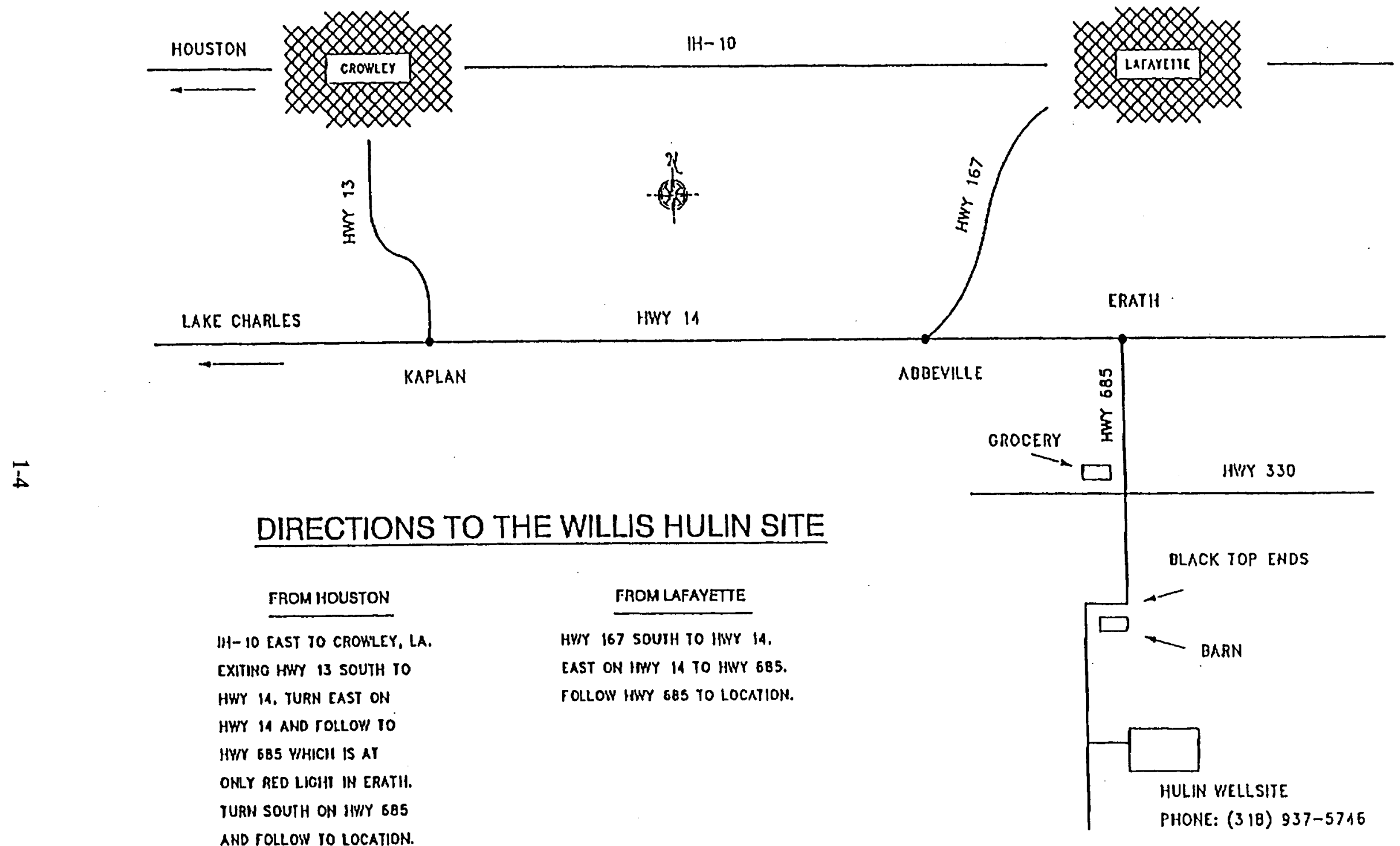

Figure 1-2. Location and directions to Willis Hulin well site in Vermilion Parish, Louisiana. 


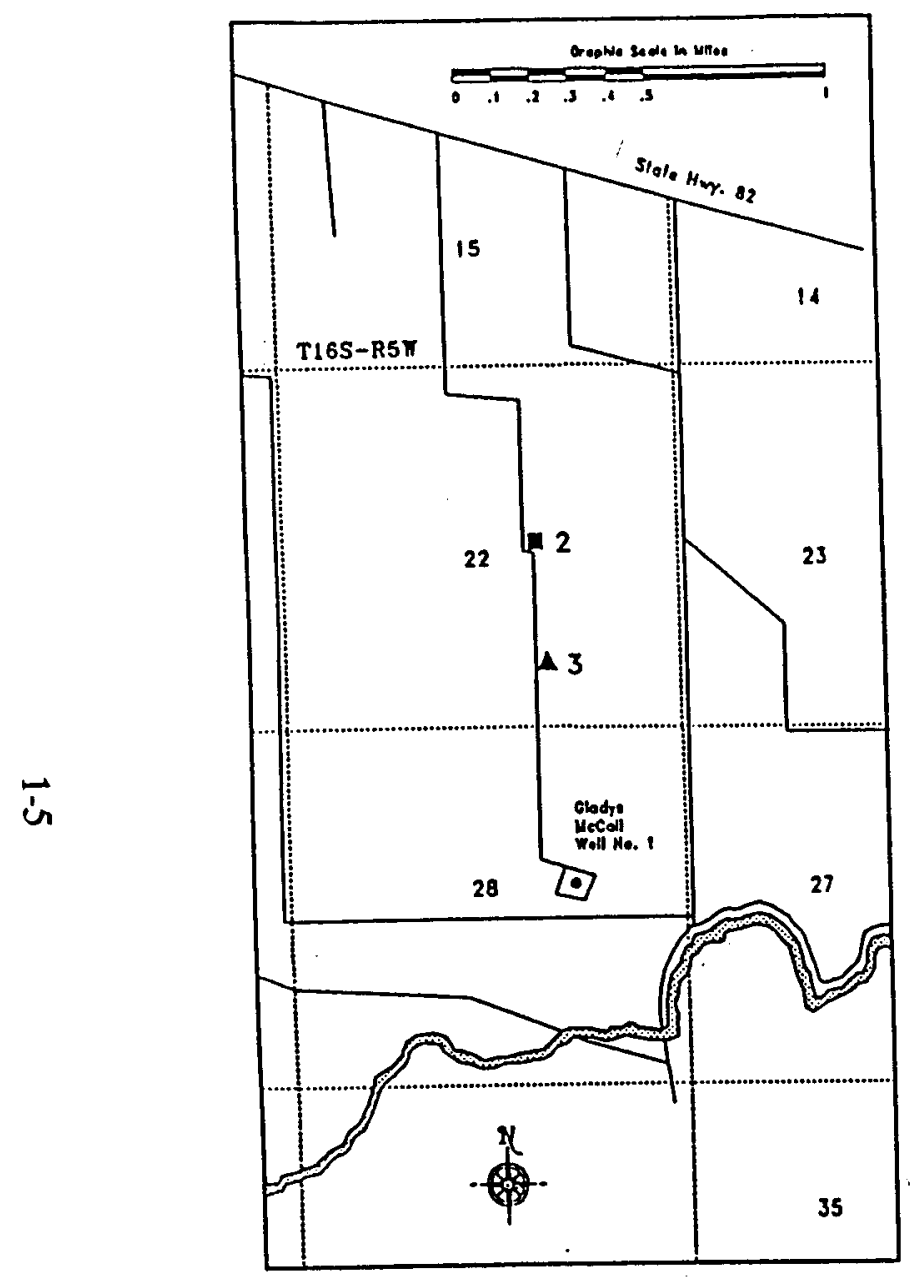

A Ground Waler Sampling Slle

- Surface Waler Sampling Slle

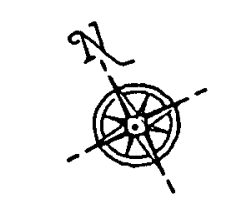

Figure 1-3. EOC/DOE Gladys McCall, Well No. 1, Cameron Parish, Louisiana. 


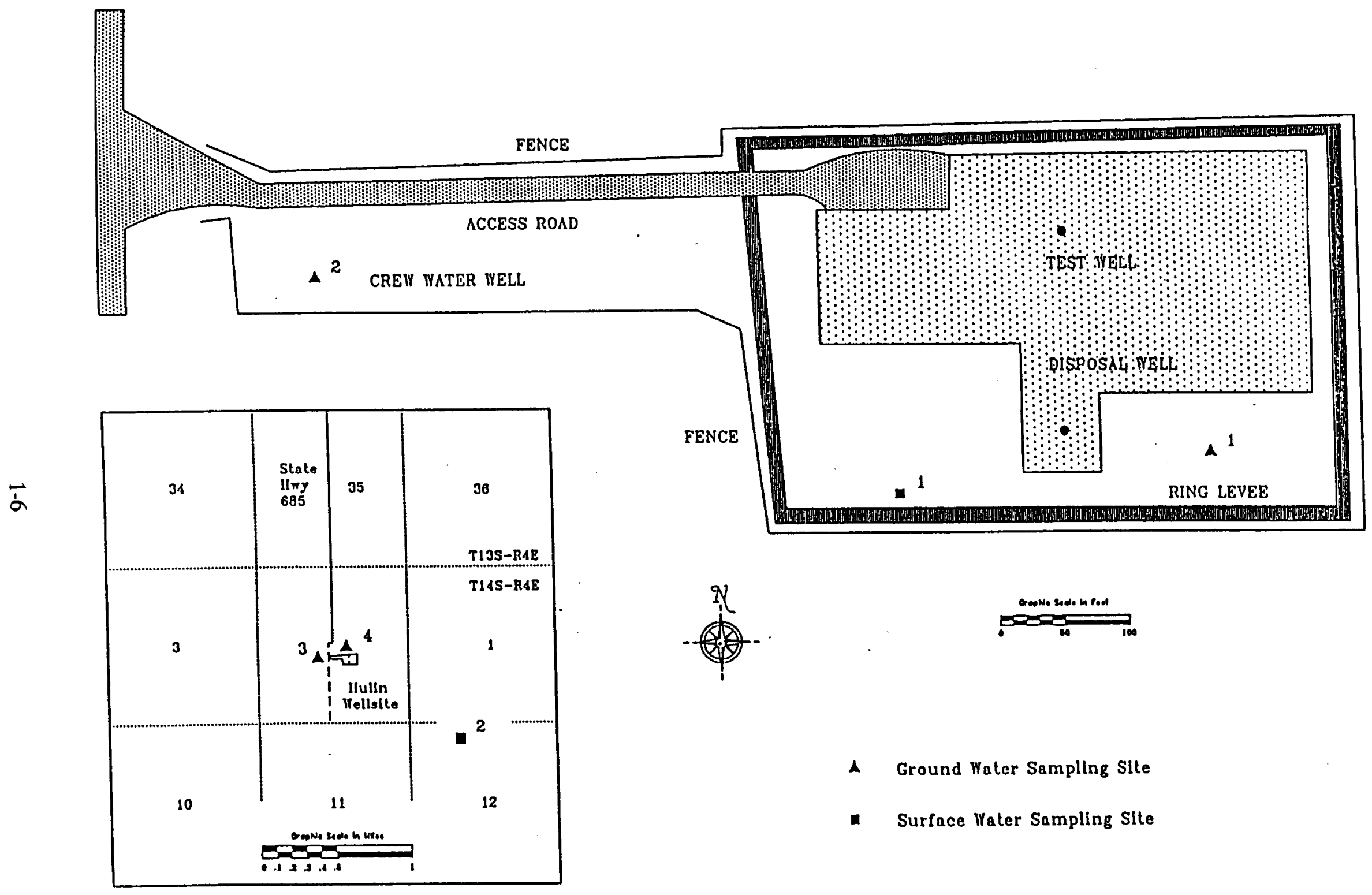

Figure 1-4. EOC/DOE Willis Hulin Test Site, Vermilion Parish, Louisiana. 


\section{RESTORATION PLAN AND SCHEDULE}

\subsection{Scope}

Because of relatively "clean" operations (brine and gas production), and because there had been no activity for a number of years at the Willis Hulin well site, cleanup operations and the restoration plan required very little work because the owner allowed most of the items to stay in place. Contamination concern was centered around the well pad areas originating from location boards, but tests showed none existed.

The Gladys McCall site, however, was just the opposite. Relative to the operations (brine and gas production), and because there had been no activity for a number of years at this site, cleanup operations and the restoration plan required more work than the Willis Hulin site because naturally occurring radioactive material (NORM) was present and required removal. The process for removing the NORM was costly and timely. Contamination concern was centered around the well pad areas and equipment.

\subsection{Major Task Components}

The restoration plan was made up of the following general tasks:

- Initial soil and water sampling and analysis

- Removal and disposal of concrete, utility poles, and trash

- Removal and disposal of well pads

- $\quad$ Plugging of monitor and freshwater wells

- $\quad$ Site leveling and general dirt work/cleanup.

\subsection{Restoration}

Central Industries, Inc., of Scott, Louisiana, was awarded the contract for the restoration and closeout of the two sites. The restoration activities began as soon as the plug and abandonment (P\&A) contractor had plugged both wells on each site and had removed all the site surface equipment and pipe from each location. It was estimated that completion of the restoration and cleanup of the sites could be accomplished in approximately $\mathbf{3 0}$ days provided that all surface equipment, trailers, and pipe were off the site. Work began on the Gladys McCall site in September 1993, and was completed on January 14, 1994, and the work on the Willis Hulin site was started in February 1994, and completed on April 13, 1994. (Note: There was a break in work days for the Hulin site-only a total of 5 days were worked.) Figures 2-1 through 2-9 are photos of the restored sites. 


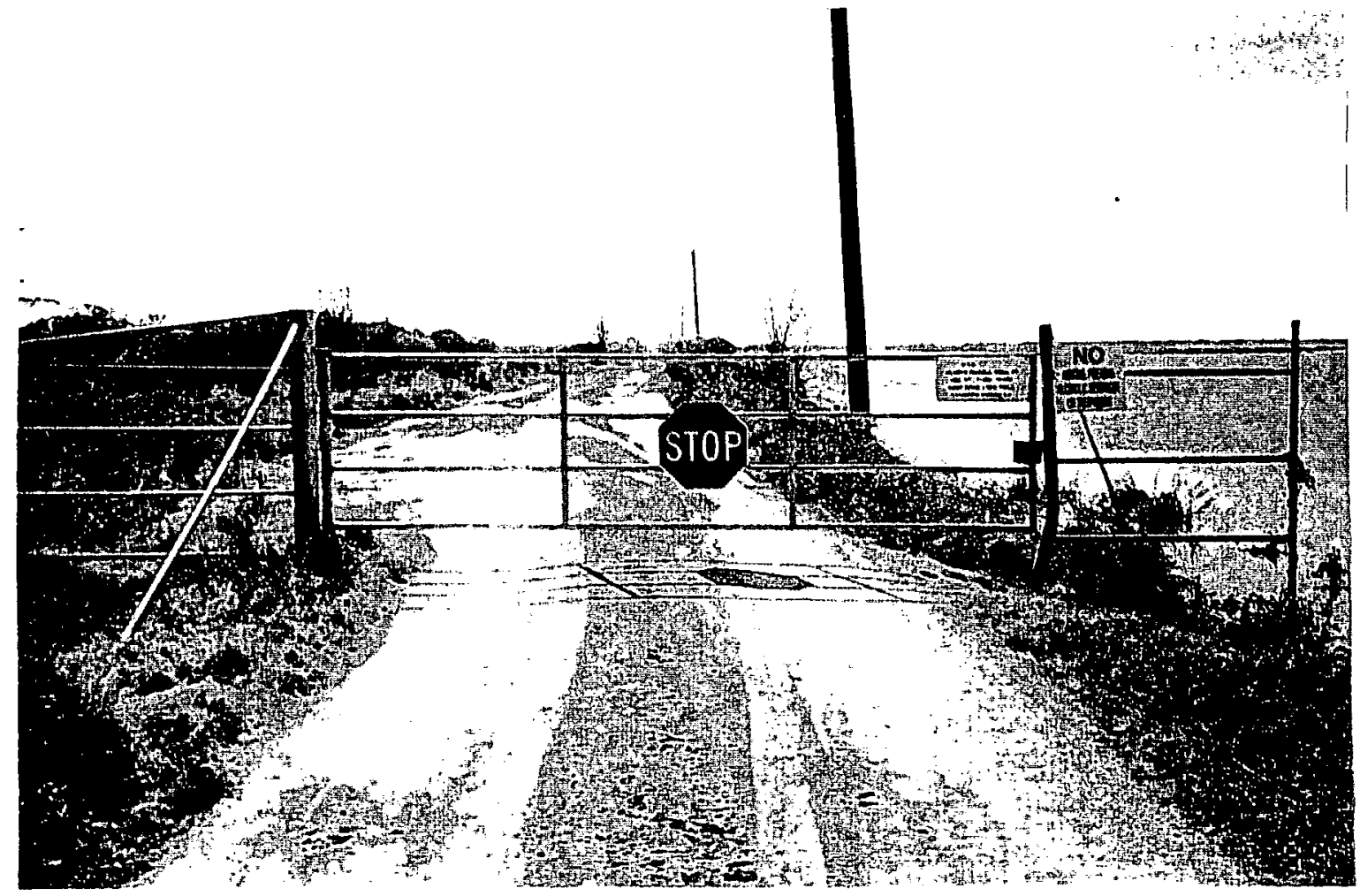

Figure 2-1. View of entrance off Highway 82 to Gladys McCall well site.
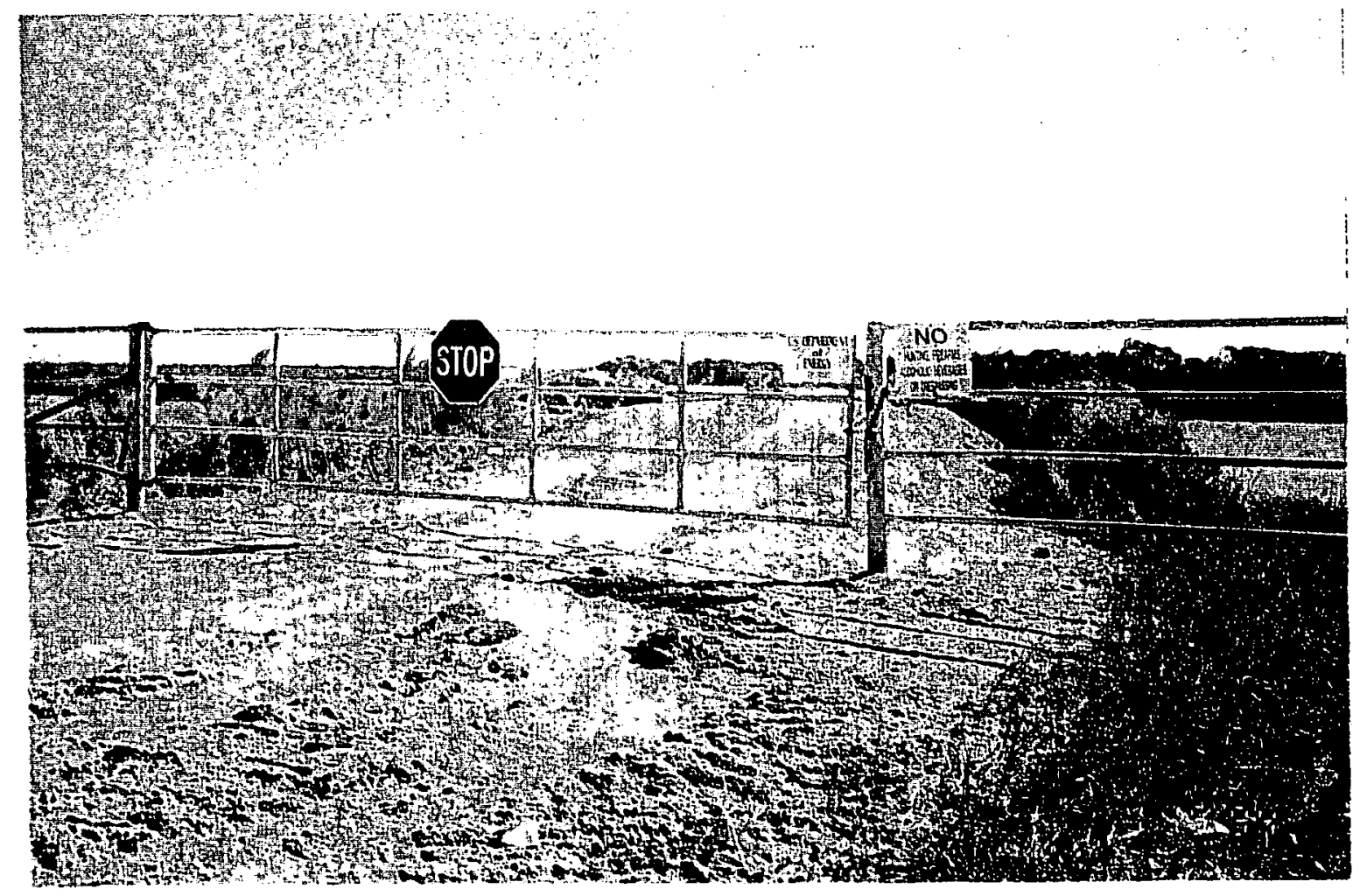

Figure 2-2. View of entrance at bridge adjacent to Gladys McCall well site. 


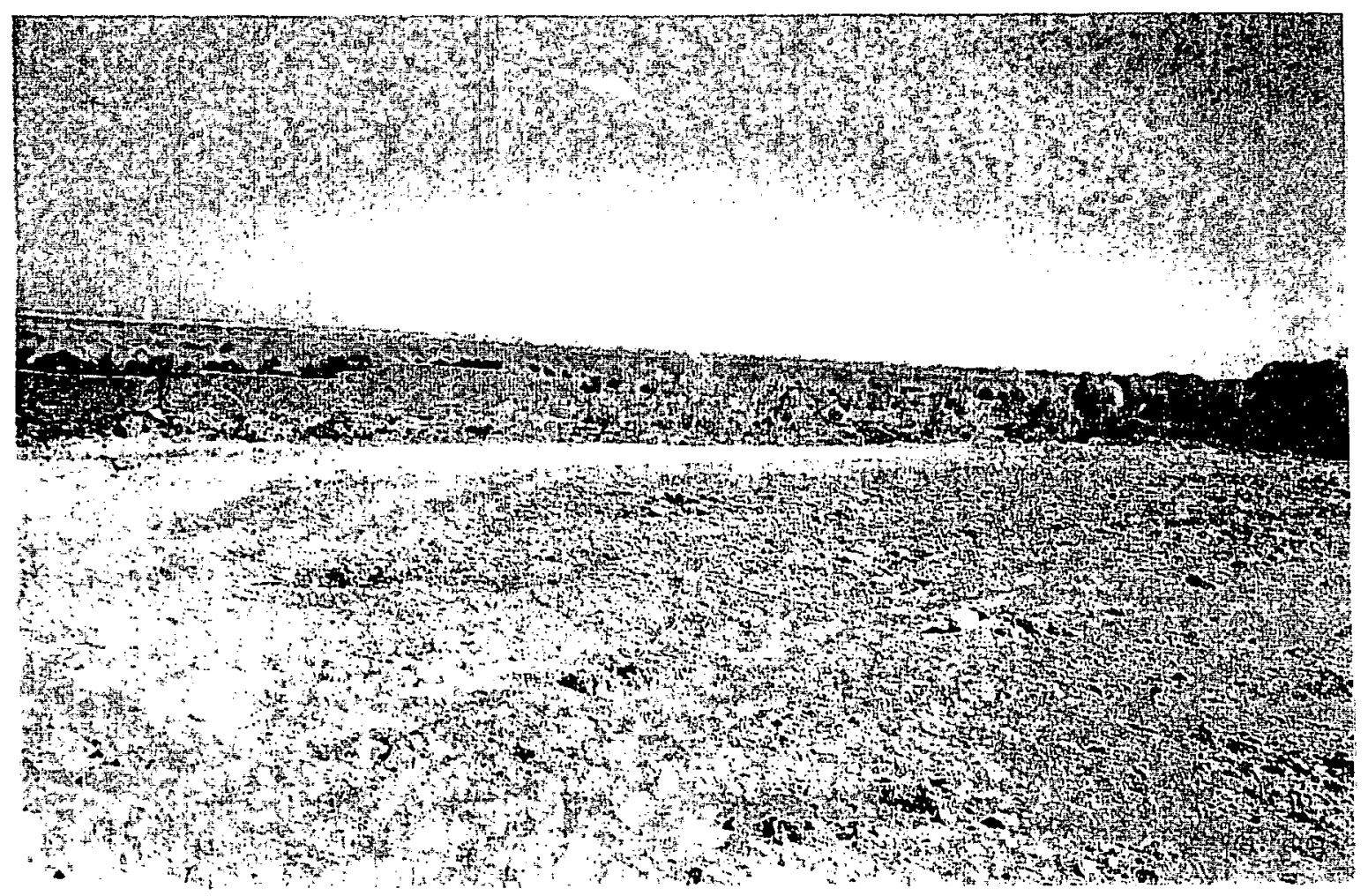

Figure 2-3. View of north side of Gladys McCall well site.

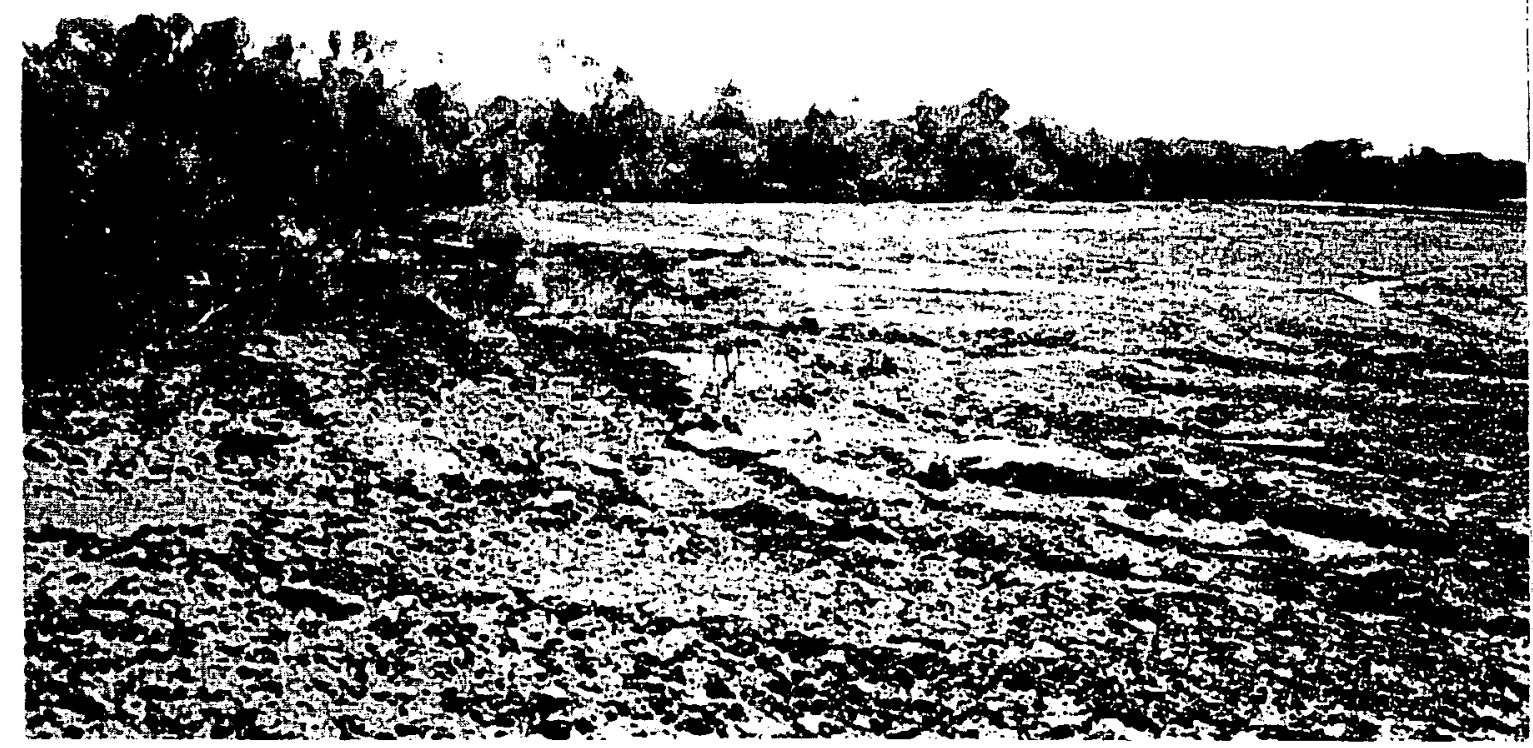

Figure 2-4. View of east side of Gladys McCall well site. 


$$
2-4
$$

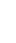




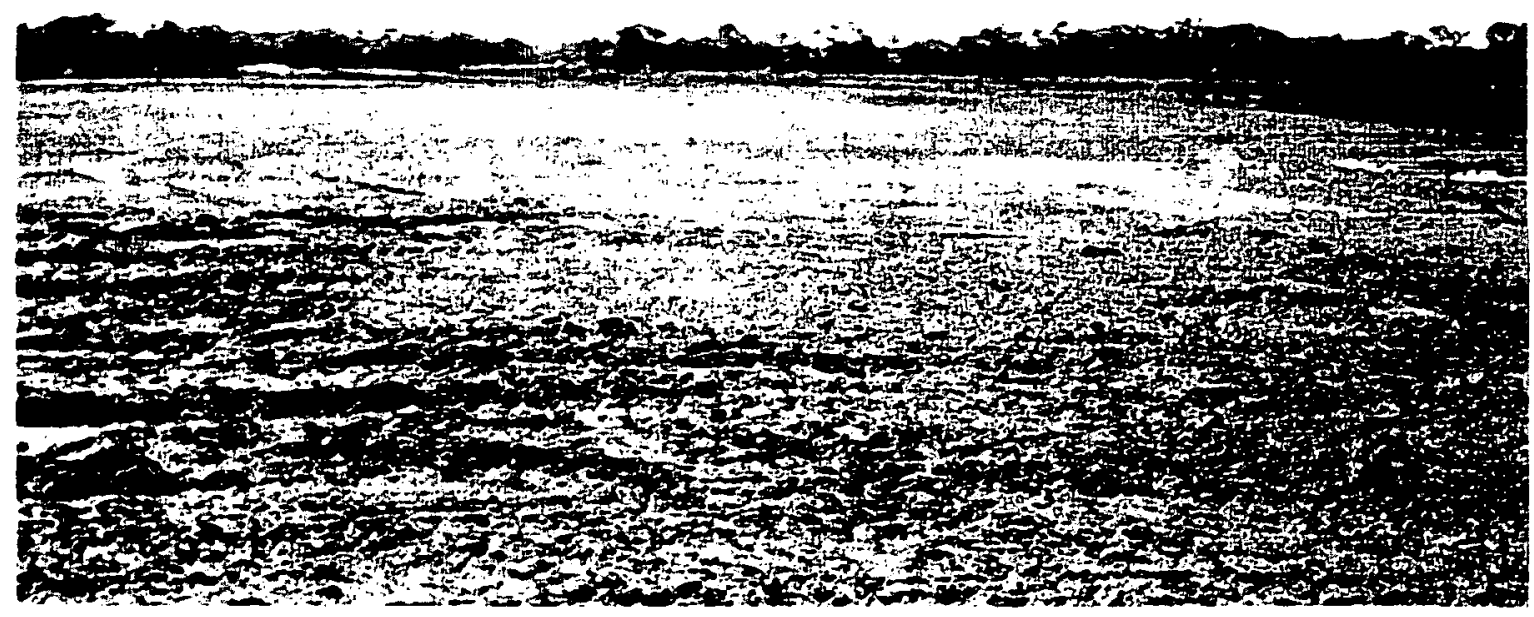

Figure 2-5. View of south side of Gladys McCall well site.

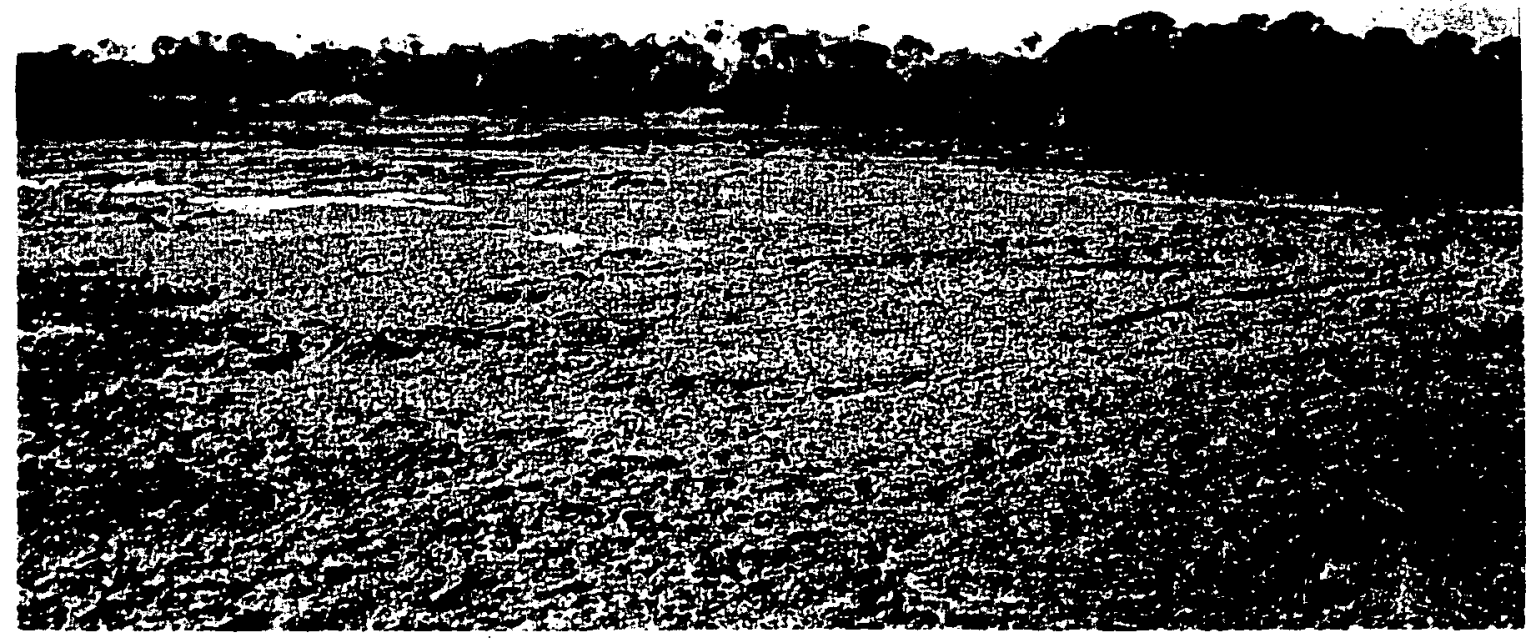

Figure 2-6. View of west side of Gladys McCall well site. 


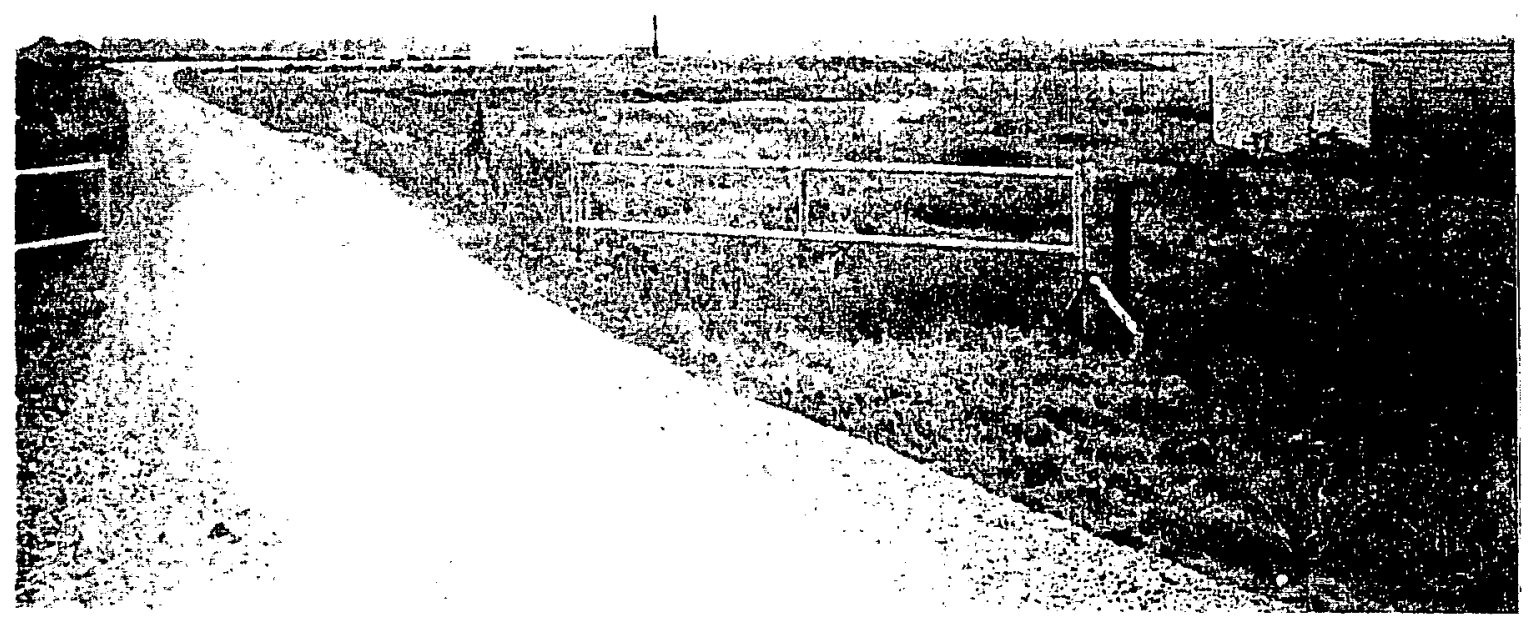

Figure 2-7. View of gate entrance to Willis Hulin well site.

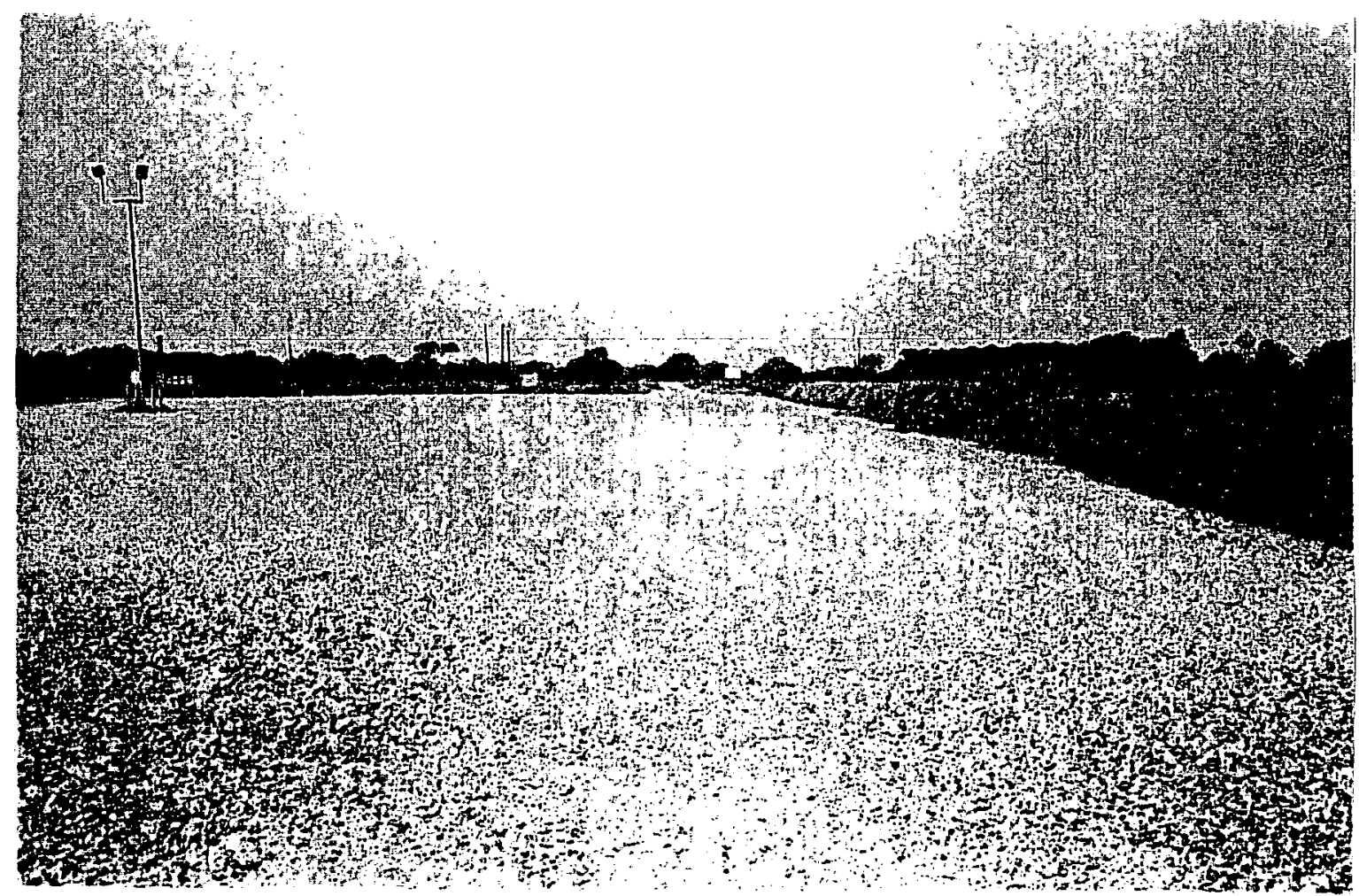

Figure 2-8. View inside entrance to Willis Hulin well site. 


$$
\text { 2-8 }
$$

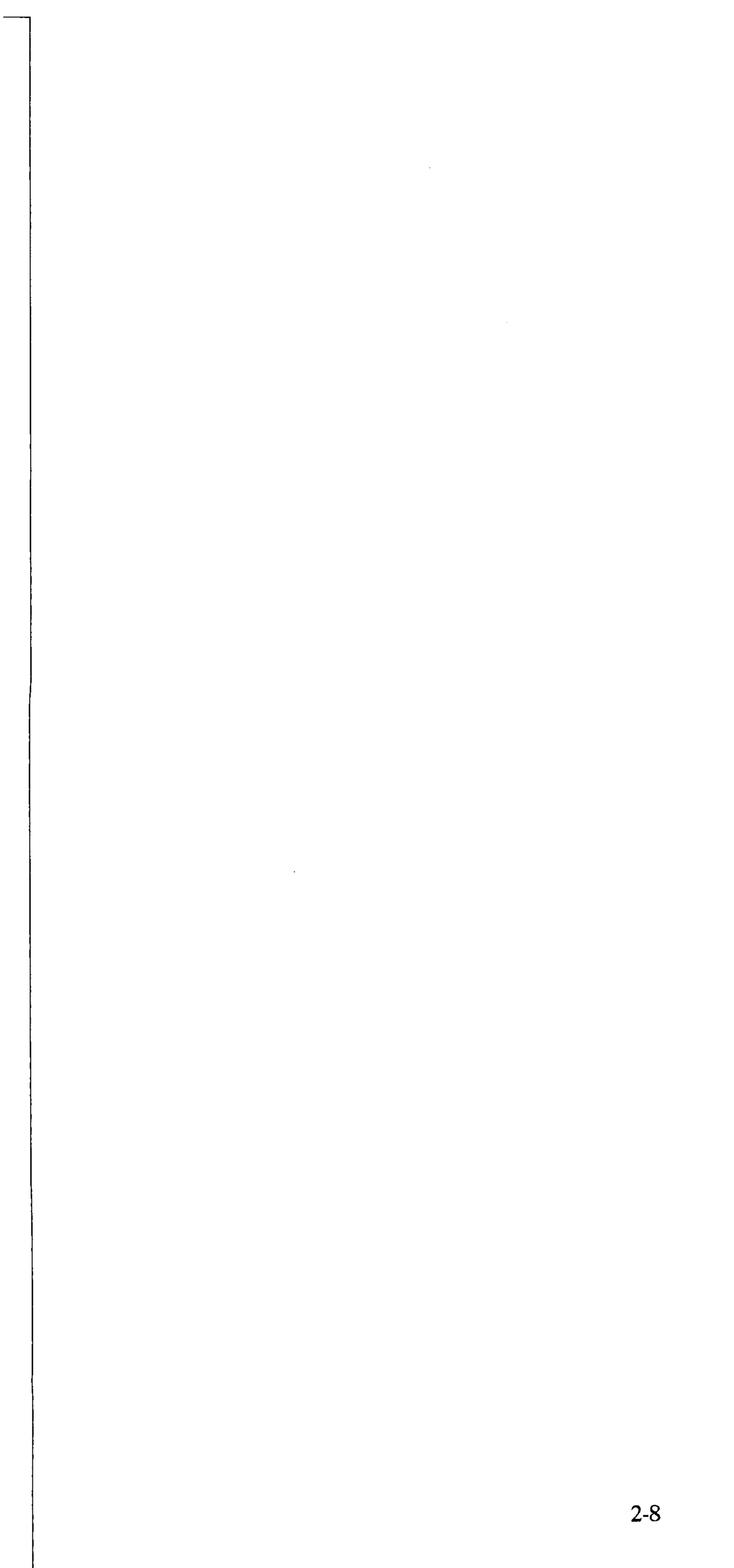




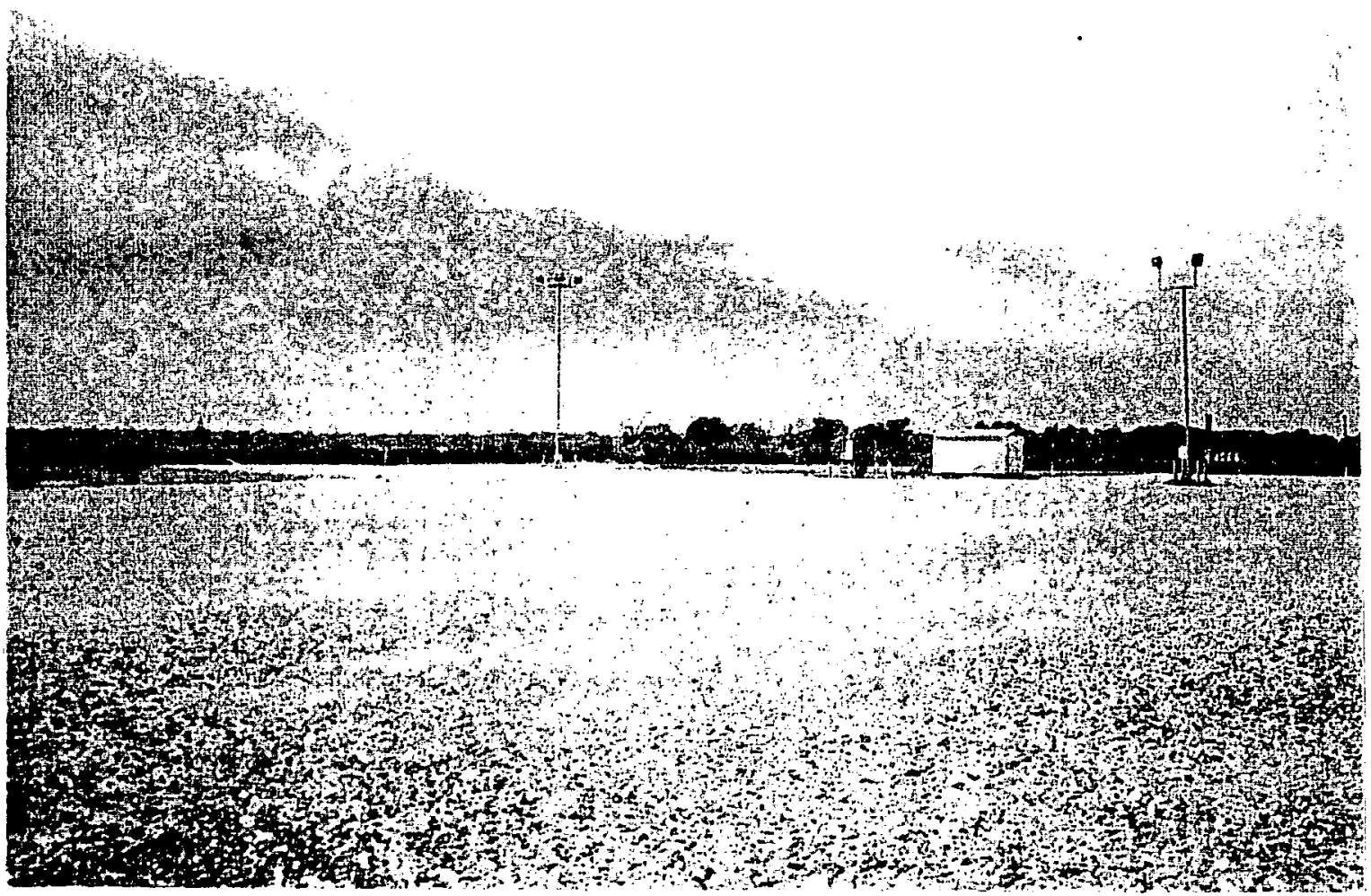

Figure 2-9. View inside south side of Willis Hulin well site.

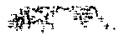
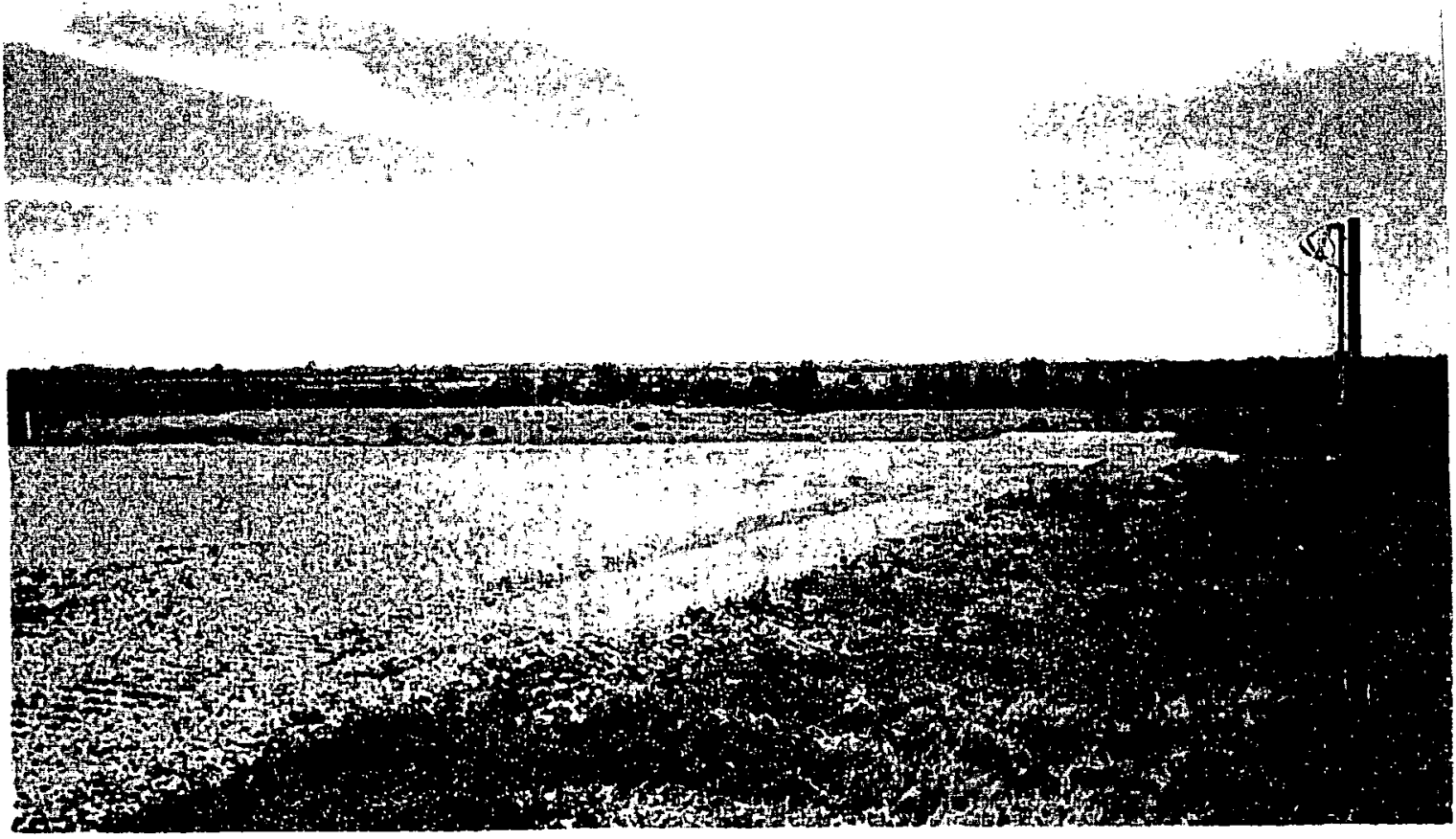

Figure 2-10. View of south side of Willis Hulin well site. 


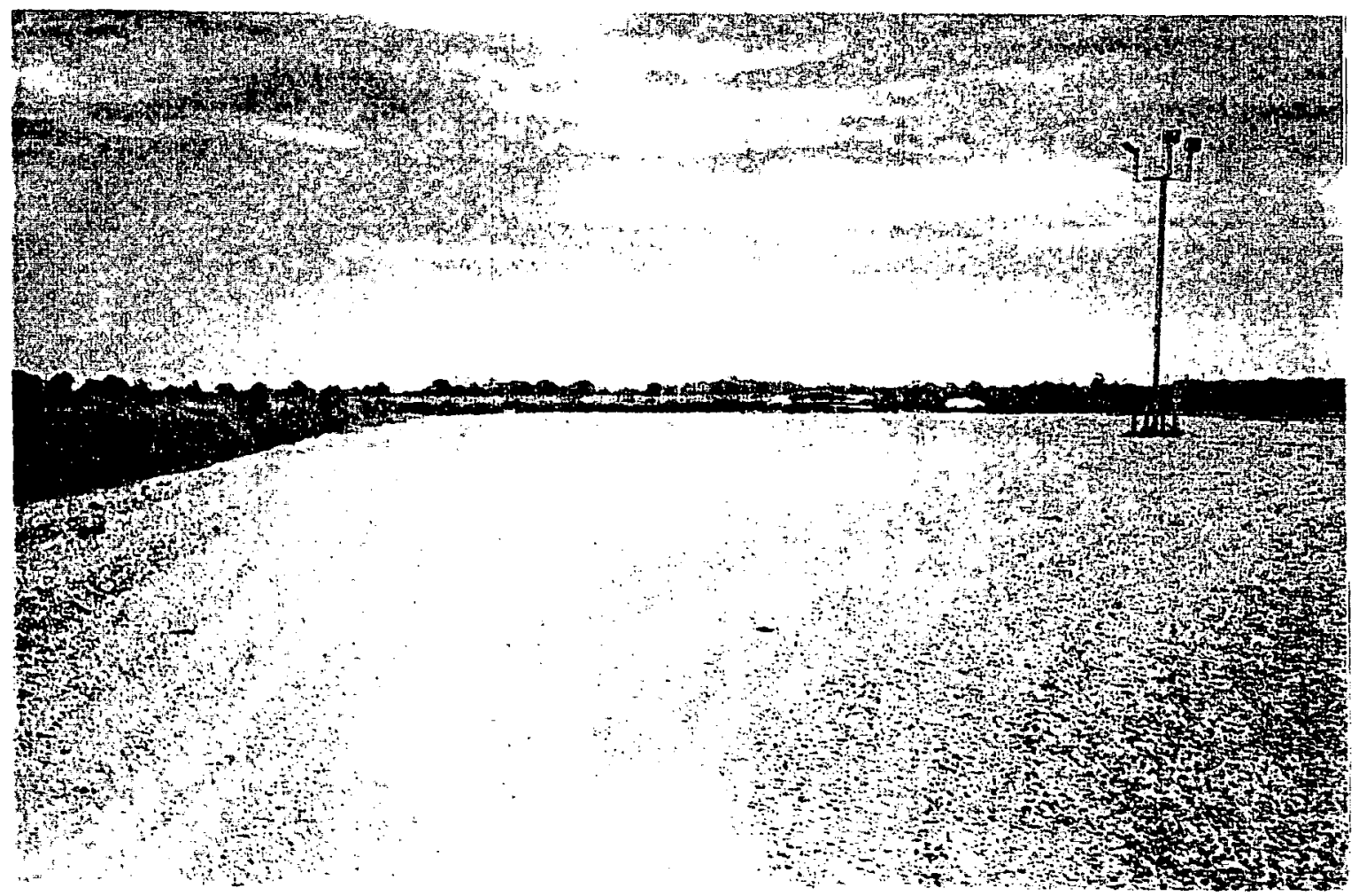

Figure 2-11. View inside east end of Willis Hulin well site.

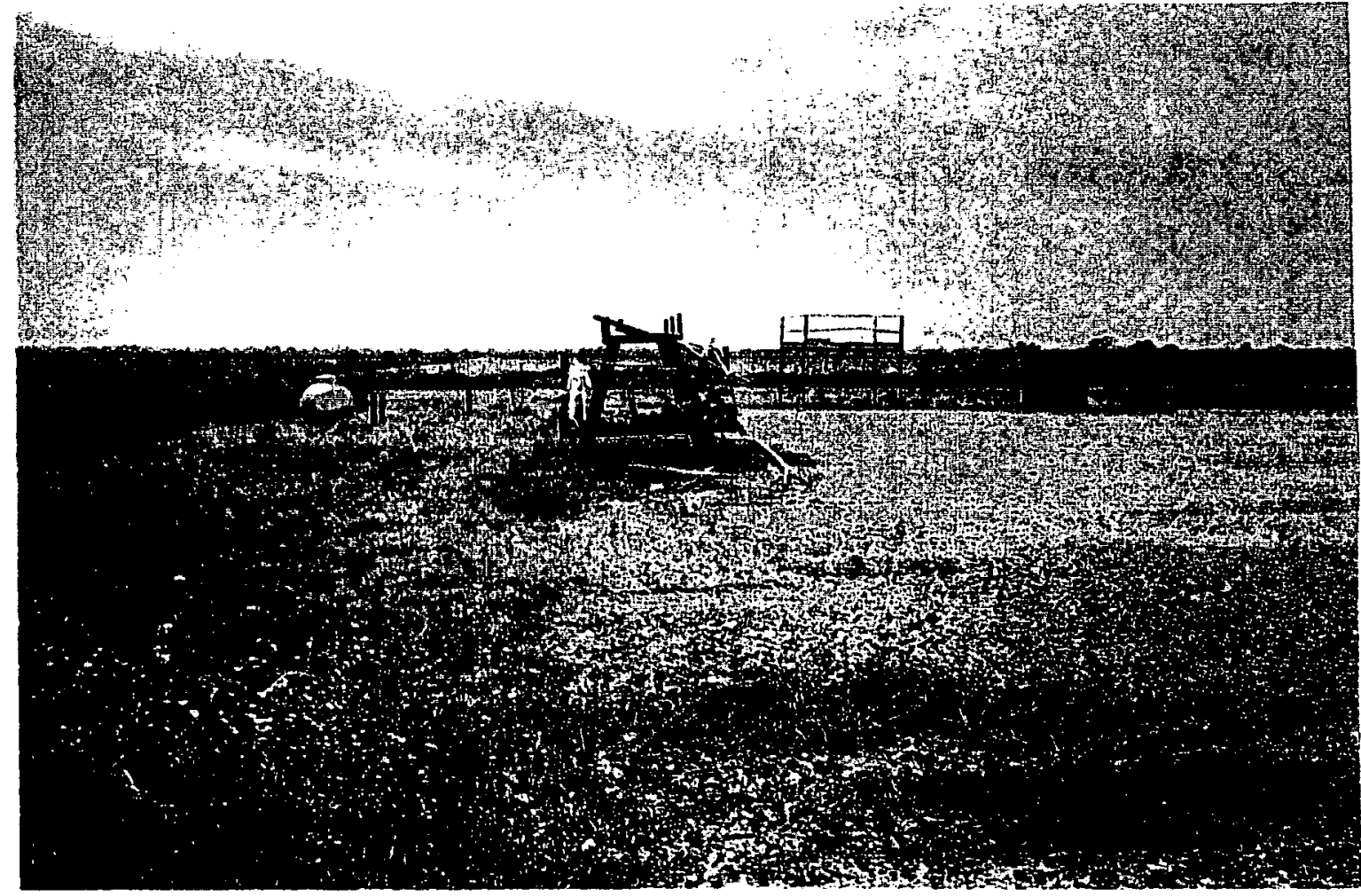

Figure 2-12. View of east end of Willis Hulin well site. 


$$
\text { 2-12 }
$$

$2-12$

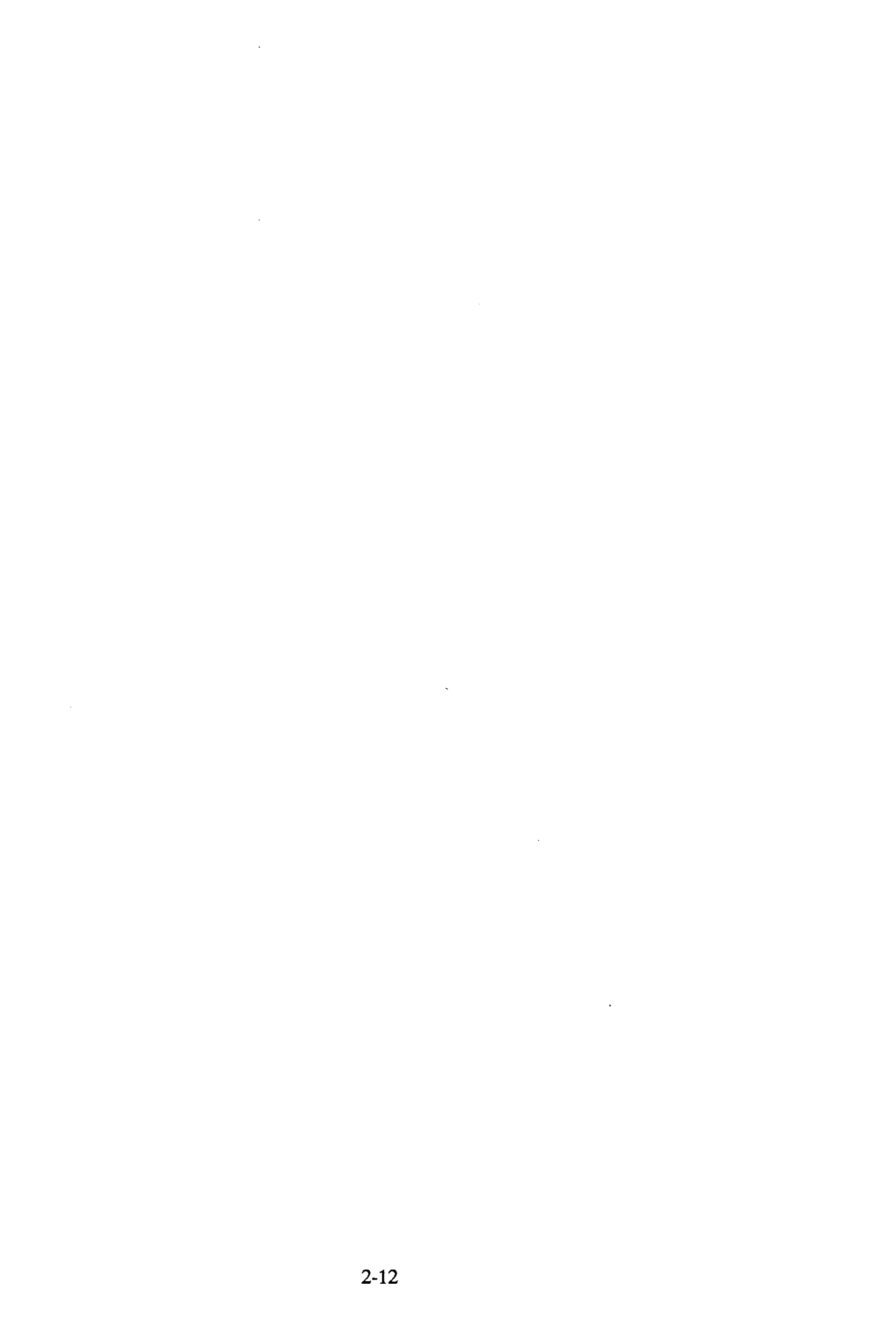




\title{
EXHIBIT 2-A
}

\section{United States Department of Energy Idaho Operations Office}

\author{
Inspection and Project Transfer \\ Inspection Group Approval \\ Transfer Approval
}




$$
2-14
$$

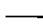


MAY-09-1994 16:16 FROM CENTRAL INEUSTRIES, INC. TO

Hey. 9. 1994 1:29P: EG\&G SUB COKITRACT:
12085267744

P. ENA

No. 8626

P. $\$$

\section{UNITED STATES DEPARTMENT OF ENEROY IDAHO OPERATIONS OFFICE \\ MISPECTION \& PROJECT TRANSFER \\ FINAL}

Aul. 10 nowne

Final No:

Dets:

PROJECT TITLE:

Willis-Hulin Well Site Remedietion

(Sub)Contrad Titlo

On thle dato en inepoctlon was made of the following project: Willis-HuI in WelI Site Remedtation Project

as oonztrueted by Central Industries, inc.

under the torme of $\mathrm{C93-160681}$

(name of (SUb)contratoton)

The project was found by the Inspeotion Oroup (Slgnatures as shown below) to be complete in accordanoe wlth the contraotual cooumente except for aubh exoippllone speolfteally noted below.

Exerpllons:"

Commentz:*

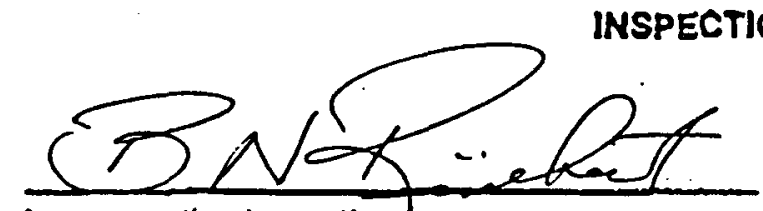

Reprosentatlve, Inspoction

Operaling Contmetor

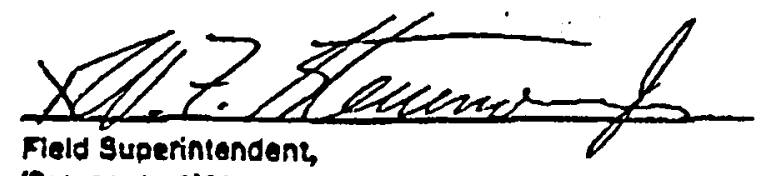

(SUE) oontractor

\section{(Sub)Contrect No.}


CONSTAUCTION (SUB)CONTAACTOR:

I eently on behalt of Central industrtes. Inc.

subject to the penalties provided under 18 U.S.C., Section 1001, that our personnel have accompllehad the oontract work and, to the bost of my knowledge, the work was pertormed or accompllehed in accordance with the contractival documents, inoluding afl approveo changoe.

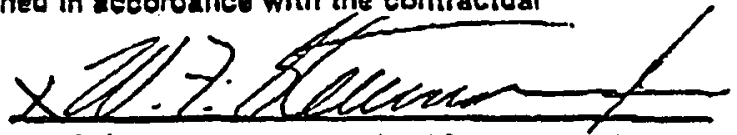

(Sub)eontrestor Authortzed Aepretentalive

\section{CONGTRUGTION MANACEA:}

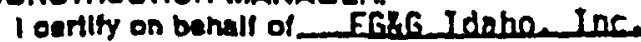

that the administiatlon of the contraet for the above nemed prolect is, to the beat of my knowladge, complete to the extent required for this Proleot Transfer and/or olose out of the contract.

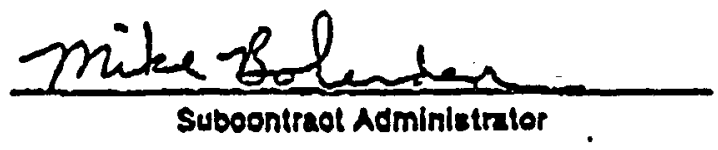

I certily that the above namod project has been oompleted in acoordanoe with the plans and technleatepecifleatlons, including all approved changes.

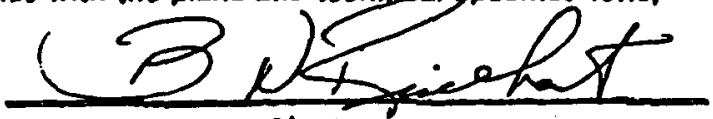

slie mansoor

OPERATINO CONTRACTOE:

loertify on behall of EG\&G Idaho, Inc.

that our personnel heve monitored the deslgn, fabriestlen and constructlon of the project and to the best of my

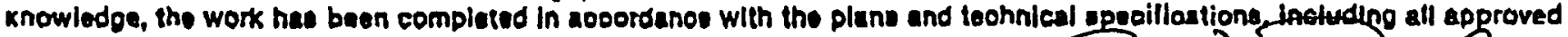
changes.

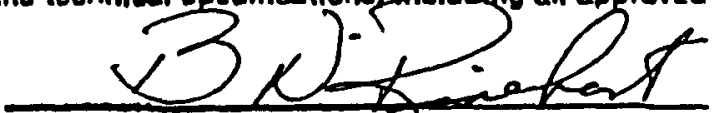

Projeot Manager (Rop)

The prolect to hereby aooepted for the Government. From the sbove date on

$5 / 28 / 65$ acting under the applicable torms of lta Contreos with the Unilod States of Amoriea raprescinted by itso-bepagtment of Energy 1009 acoepte total fesponsiblity for the maintenanoe and cuatody of the frojert

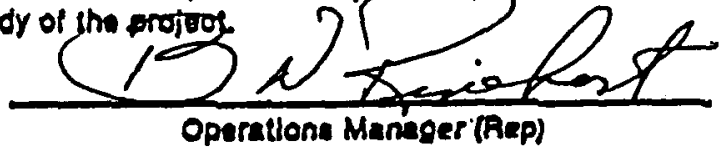

\section{U.8. DEPARTMENT OF ENERGY:}

The projeat is hereby soesoled undar the sondlions and with the exoeptions ctalad abore.

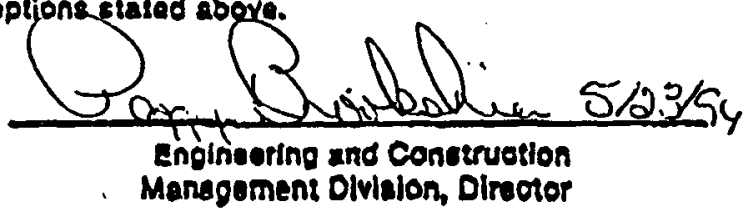

DIstalaUtion: slonatories, dun:

TOTAL P. 05

DOR-10 Direeror, (Reepanalbles Program Div. (3)

DOF.1D Chlet Counsel

DOE-1D Direolor, IRCM DIvElon

DOE DO Direczor, Oontraote Mansegement Diva

OOE-10 Indvetrial Aeletions

DOEJD mald Reprotentuthe

DOE-10 pmratoel Becurity Brman

(Bub)cohtraotor(D) 


\section{PLUGGING OF WATER WELLS}

\subsection{Identification}

The water wells associated with the Gladys McCall well site consist of five monitor wells and one freshwater well. Figure 1-3 shows the approximate location of the water wells that were plugged. The water wells associated with the Willis Hulin well site consist of four monitor wells and two freshwater wells. It was also requested that one of the freshwater wells (outside of fence by entrance road) be left for future use and, therefore, was not plugged. Figure 1-4 shows the approximate location of the Hulin well site water wells that were plugged.

\subsection{Description}

\subsubsection{Gladys McCall Well Site}

GMGW No. 1

- Location: Crew well at well site

- Depth: $185 \mathrm{ft}$

- Casing Design: 4-in. steel casing on top, followed by polyvinyl chloride (PVC) casing to the screen

- $\quad$ Screen Depth: 175 to $185 \mathrm{ft}$

- Production: Groundwater sample via submersible pump set on 1-in. tubing set at approximately $90 \mathrm{ft}$

- $\quad$ Production Rate: Approximately $55 \mathrm{gpm}$.

\section{GMGW No. 2}

- Location:

- Depth:

- Casing Design:

- Screen Depth:

- Production:

- Production Rate:
At well site

$650 \mathrm{ft}$

2-in. PVC casing to the screen

650 to $660 \mathrm{ft}$ (screen likely but presence unconfirmed)

Groundwater sample via surface pump with $3 / 4$-in. tubing at approximately $90 \mathrm{ft}$

Approximately $30 \mathrm{gpm}$.

\section{GMGW No. 3}

- Location:

Approximately $1 / 2$ mile north of well site on access road 
- Depth:

- Casing Design: 2-in. PVC casing to the screen (originally completed with 1 -in. PVC tubing from screen to surface-1-in. PVC tubing was pulled with bottom joint, approximately $20 \mathrm{ft}$ being left in the well-access to screen likely obstructed)

- Screen Depth: 300 to $310 \mathrm{ft}$

- Production: $\quad$ Groundwater sample drawn by 2-in. pump or bailing $90 \mathrm{ft}$

- Production Rate: Approximately 4 to $10 \mathrm{gpm}$.

\section{GMSW No. 1}

- Location:

At well site

- Depth:

Surface sample

- Production:

Sample obtained by grab method.

\section{GMWW No. 2}

- Location:

- Depth:

- Production:

\subsubsection{Willis Hulin Well Site}

\section{HUGW No. 1}

- Location:

At well site

- Depth:

- Casing Design:

- Screen Depth:

- Production:

\section{$358 \mathrm{ft}$} 338 to $358 \mathrm{ft}$
Approximately $3 / 4$ mile north of well site, on access road

Surface sample

Sample obtained by grab method.

4-in. PVC casing to $120 \mathrm{ft}$, then 2-in. PVC tubing to the screen

Groundwater sample via submersible pump set on 1-in. tubing at approximately $90 \mathrm{ft}$

- $\quad$ Production Rate: Approximately 35 gpm.

HUGW No. 2-Note: This well was left in place by property owner.

- Location:

Crew at well site 
- Depth:

- Casing Design:

- Screen Depth:

- Production:

- Production Rate:

\section{HUGW No. 3}

- Location:

- Depth:

- Casing Design:

- Screen Depth:

- Production:

- Production Rate:

\section{HUGW No. 4}

- Location:

- Depth:

- Casing Design: Unknown-2-in. steel casing at surface

- Screen Depth: Estimated between 250 to $300 \mathrm{ft}$

- Production:

4-in. PVC casing to the screen

260 to $275 \mathrm{ft}$

Groundwater sample via submersible pump set on 1-in. tubing at approximately $90 \mathrm{ft}$

Approximately $38 \mathrm{gpm}$.

Approximately $300 \mathrm{ft}$ west northwest of well site access road

250 to $300 \mathrm{ft}$ (well not registered-depth based on water quality)

Unknown-2-in. steel casing at surface

Estimated between 250 to $300 \mathrm{ft}$

Groundwater sample via submersible pump set on 1-in. tubing at approximately $90 \mathrm{ft}$

Approximately 20 gpm.

Approximately $700 \mathrm{ft}$ northeast of HUGW No. 3

250 to $300 \mathrm{ft}$ (well not registered-depth based on water quality)

Groundwater sample via surface pump with 1 -in. tubing at approximately $90 \mathrm{ft}$

- Production Rate: Approximately 20 gpm.

\section{HUSW No. 1}

- Location:

At well site (obtained from ring levee ditch)

- Depth:

Surface water sample

- Production:

Sample obtained by grab method. 


\section{HUSW No. 2}

- Location: Approximately $3 / 4$ mile southeast of well site

- Depth: Surface water sample

- $\quad$ Production: $\quad$ Sample obtained by grab method.

\subsection{Well Plugging}

All wells were plugged by a certified water well contractor. Well plugging and abandonment was certified by well plugging and abandonment forms (DOTD-GW-2) submitted to the Louisiana Department of Transportation and Development, Water Resources Section; copies of the forms DOTD-GW-2 are shown in Exhibits 3-A and 3-B. 


\section{EXHIBIT 3-A}

Louisiana Department of Transportation and Development Water Resources Section

Water Well Plugging and Abandonment Form DOTD-6W-2

Gladys McCall Well Number 1

Serial Number 174825 


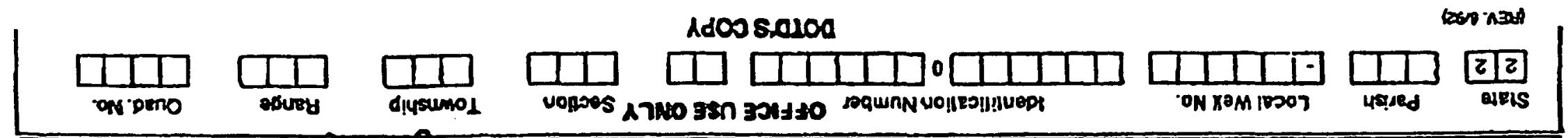

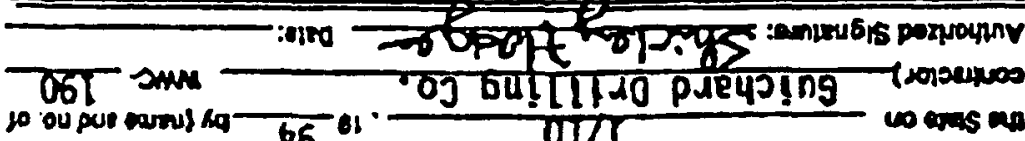

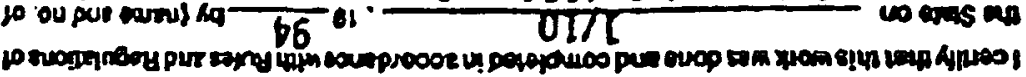
$=$

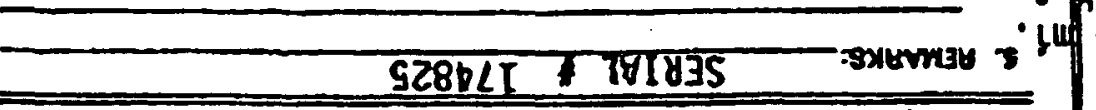

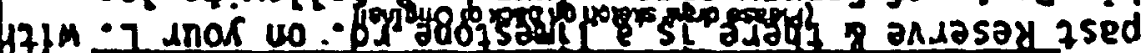

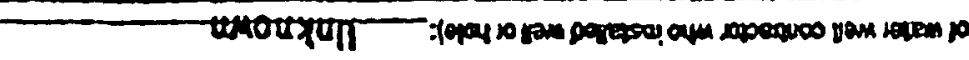

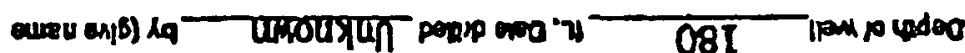
" "

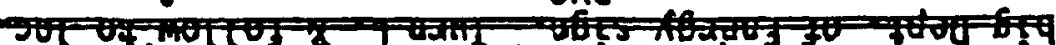
$S^{\prime} \varepsilon$ og - andasay dallataysoy of daluaya puedg of purels!

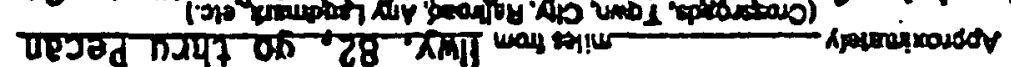

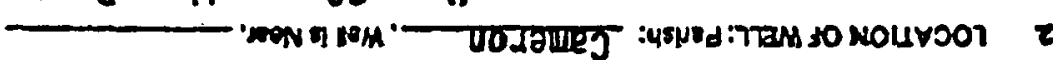

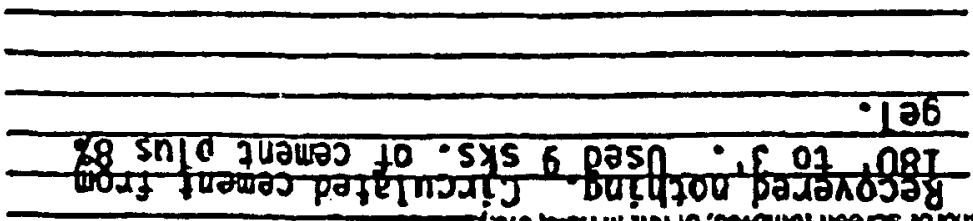
Tyo

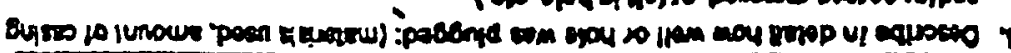

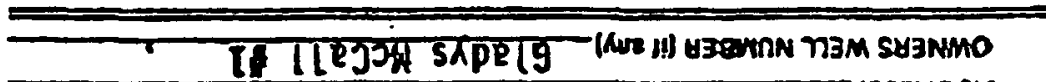

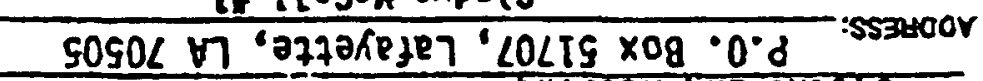
DU!

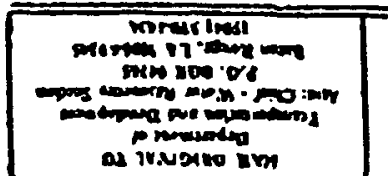

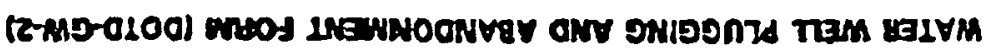

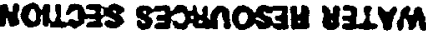

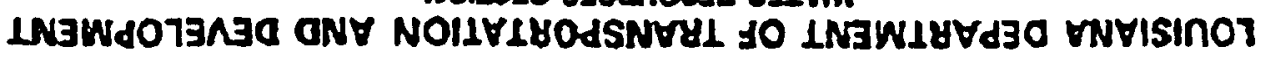




\section{EXHIBIT 3-B}

Louisiana Department of Transportation and Development Water Resources Section

Water Well Plugging and Abandonment Form DOTD-6W-2 Willis Hulin Well Number 1

Serial Number 158468 


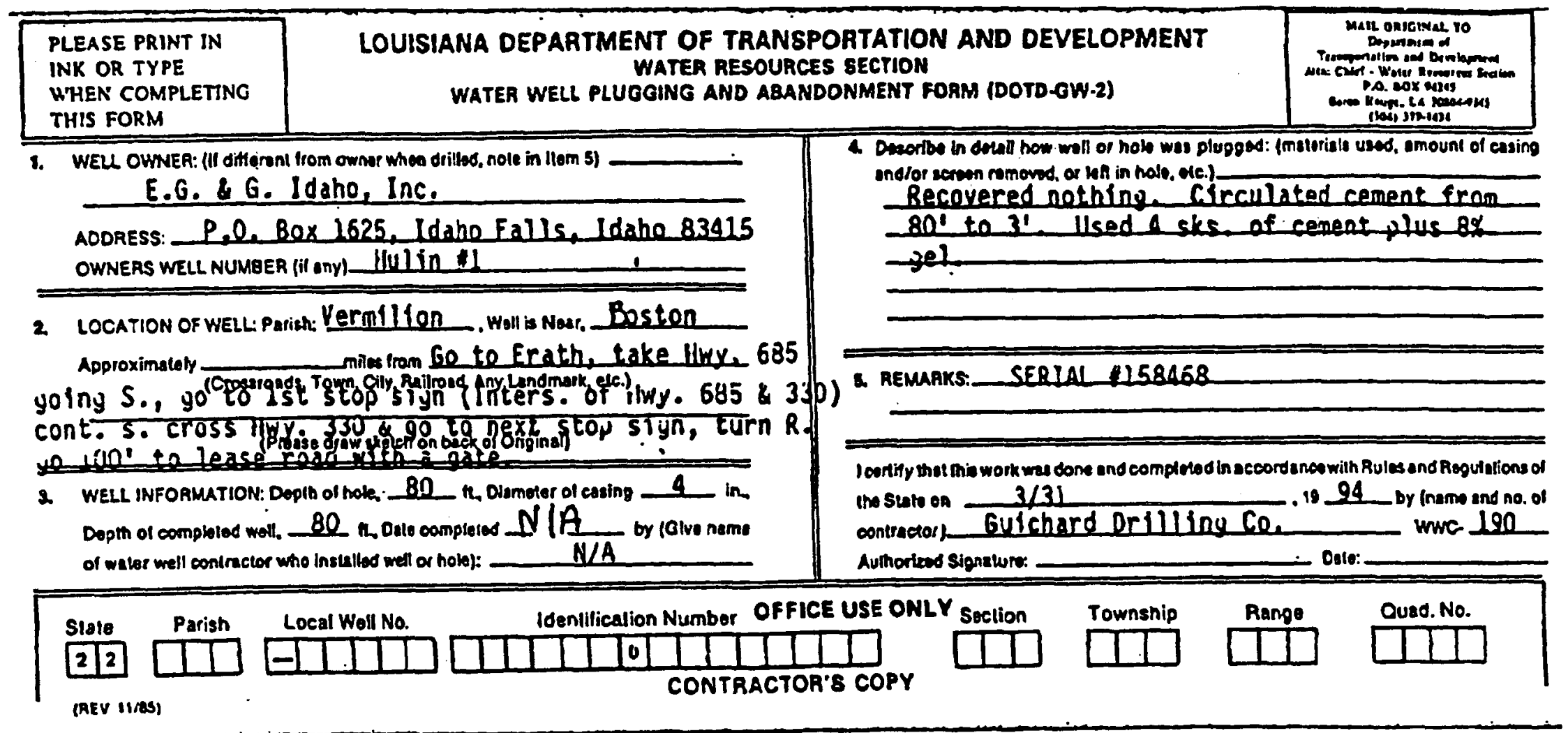




\section{SOIL AND WATER SAMPLING AND ANALYSIS}

\subsection{General}

The soil and water sampling program consisted of retrieving a water sample from each of the Gladys McCall and Willis Hulin water wells to be plugged and retrieving soil samples in and around the well pad areas.

\subsection{Water Samples}

\subsubsection{Protocol}

The method of sampling the water wells was to use a new boiler/sample tube for each well. A volume of twice the wellbore volume was bailed and then a single sample taken from each well. The sample was tagged and recorded on the Chain of Custody form.

\subsubsection{Analysis}

Four water samples were obtained and analyzed. All water samples were tested for metals and chloride concentration using Environmental Protection Agency (EPA) methods EPA/200.7 and SM17 4500-C1 B. All readings were below regulatory limits.

\subsection{Soil Samples}

\subsubsection{Protocol}

In order to increase the area of investigation, composite samples were obtained by taking three separate soil portions on a grid pattern laid over the two well pad areas. A total of 10 complete soil samples were obtained: five from a depth of 6 in. and five from a depth of 18 in. show the grid sampling method in Exhibits 5-H and 5-I .

\subsubsection{Analysis}

All soil samples were tested for toxicity characterization leaching procedure (TCLP) metals. Additionally, soil sample No. 4 was also tested for pentachlorophenol (PCP). This sample was retrieved from under the center of the test well pad, which would best characterize any contamination from the location board mats. Test methods include Method 1311 and EPA test methods for evaluating waste.

Based on the parameters tested, the samples did not exceed the EPA regulatory threshold for Resource Conservation and Recovery Act (RCRA) characteristics and TCLP toxicity characteristics. 

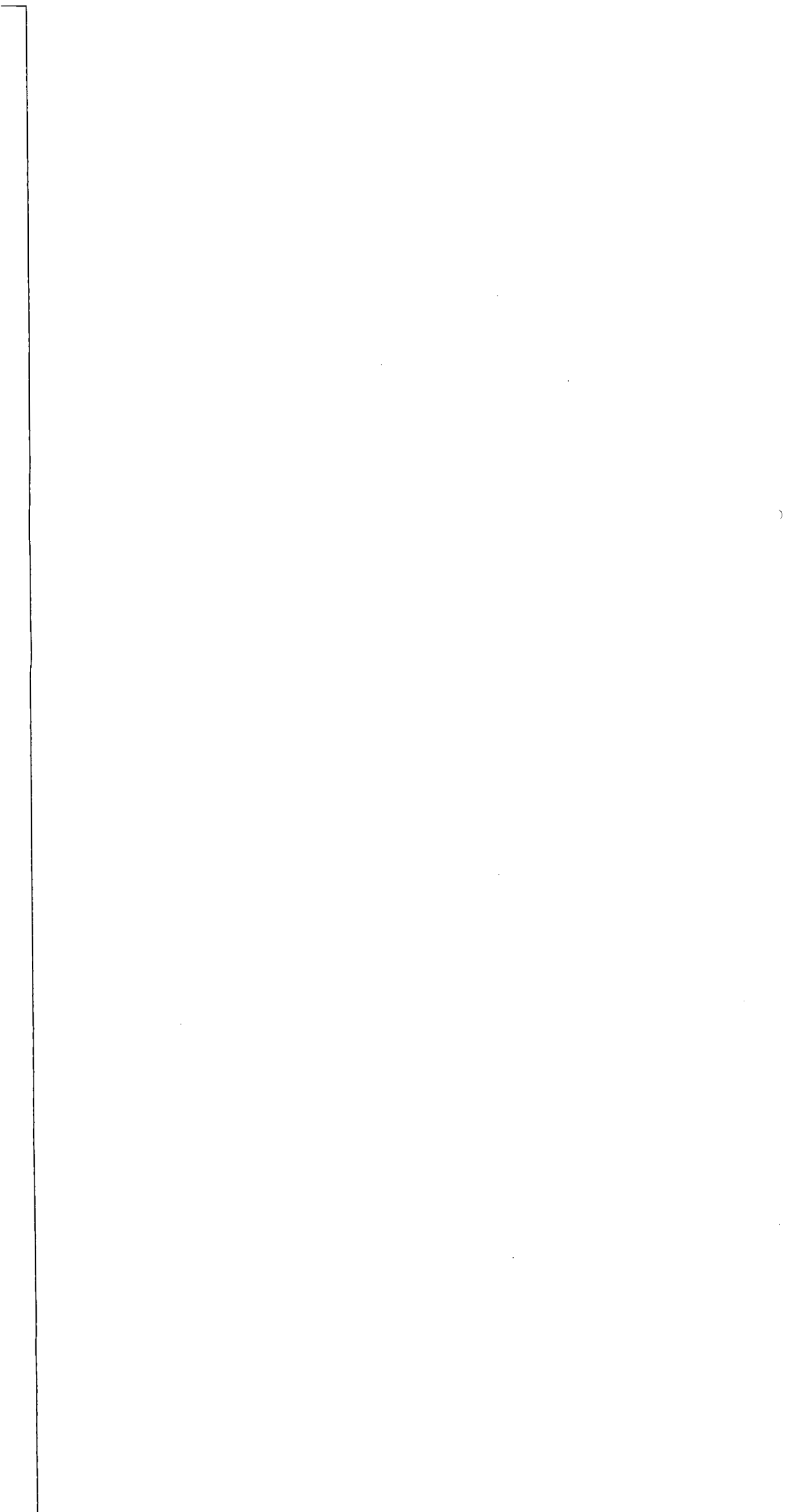


\section{NORM SURVEY}

\subsection{General}

A survey for naturally occurring radioactive material (NORM) was performed at Gladys McCall and Willis Hulin well sites. NORM was found at the Gladys McCall site, thus cleanup was performed.

\subsection{Protocol for Survey}

The method used to perform the NORM survey was to lay out a 20 - by $20-\mathrm{ft}$ grid over the well pad areas for the test well pad and the injection well pad. Meter readings were taken at each point on the grids and recorded. A control point reading was also taken $20 \mathrm{ft}$ outside the area of investigation. A Ludlum Model 19 Micro R Meter was used to perform the survey, as indicated in Exhibit 5-D.

\subsection{Results of Survey}

Exhibits 5-H and 5-I show the grid maps of the test well and injection well pads with readings obtained from the survey. All readings taken were under regulatory threshold limits at the Willis Hulin site and above limits prior to cleanup at the Gladys McCall site.

Exhibits in this section include the following:

- Exhibit 5-A-Turnkey Bid for Gladys McCall Well

- Exhibit 5-B-Louisiana Radioactive Material License

- Exhibit 5-C-Contractor Safety Data

- Exhibit 5-D-Petroleum Environmental, Inc. (Letter and Survey Plots)

- Exhibit 5-E-State of Louisiana Department of Natural Resources (Letters)

- $\quad$ Exhibit 5-F-State of Louisiana Department of Natural Resources (Two Letters)

- Exhibit 5-G-State of Washington Department of Ecology (N.A.R.M. Site Use Permit)

- Exhibit 5-H-Source Environmental Services, Inc. (Gladys McCall Letter, Map, and Release Survey)

- Exhibit 5-I-Source Environmental Services, Inc. (Willis Hulin Confirmatory Survey) 


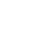




\section{5-A - Turnkey Bid for Gladys McCall Well}




\section{GLADYS MCCALL LOCATION}

TURNKEY BID FOR NORM DECONTAMINATION OF THE

GLADYS MCCALL LOCATION

BID MATRIX

IF $\overline{B-G M}-93-5-26$

ITEM NO. $\quad$ LINE ITEM DESCRIPTION

ITEM NO. 1: Turnkey bid to provide: all labor, equipment, and materials

necessary to decontaminate the $54^{\prime \prime} \times 30^{\prime}$ low pressure separator and an approximate twenty (20) foot length of $6 "$ pipe, which makes up the manifold for the site?s blowdown tanks, of an estimated volume of 6 to 7 bbls of NORM. Cost to include all transportation, rig-up/rig down and decontamination time for bidder's and bidder's subcontractors' (if any) equipment.

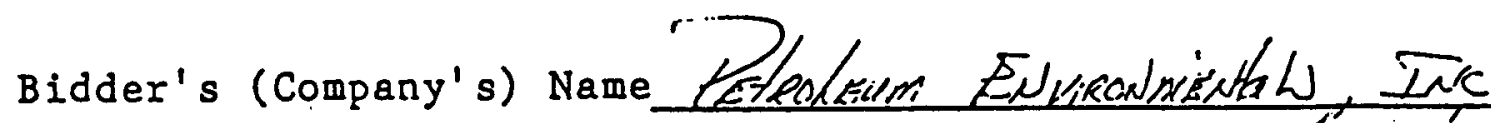
Signature of Authorized Company Representative $<$ Cis. Date: a luxie 3199.3 
5-B - Louisiana Radioactive Material License 


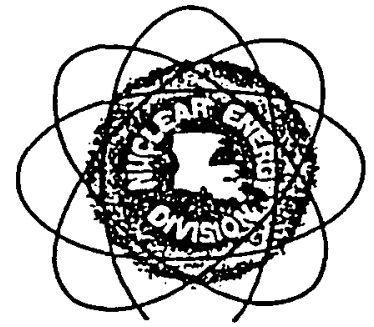

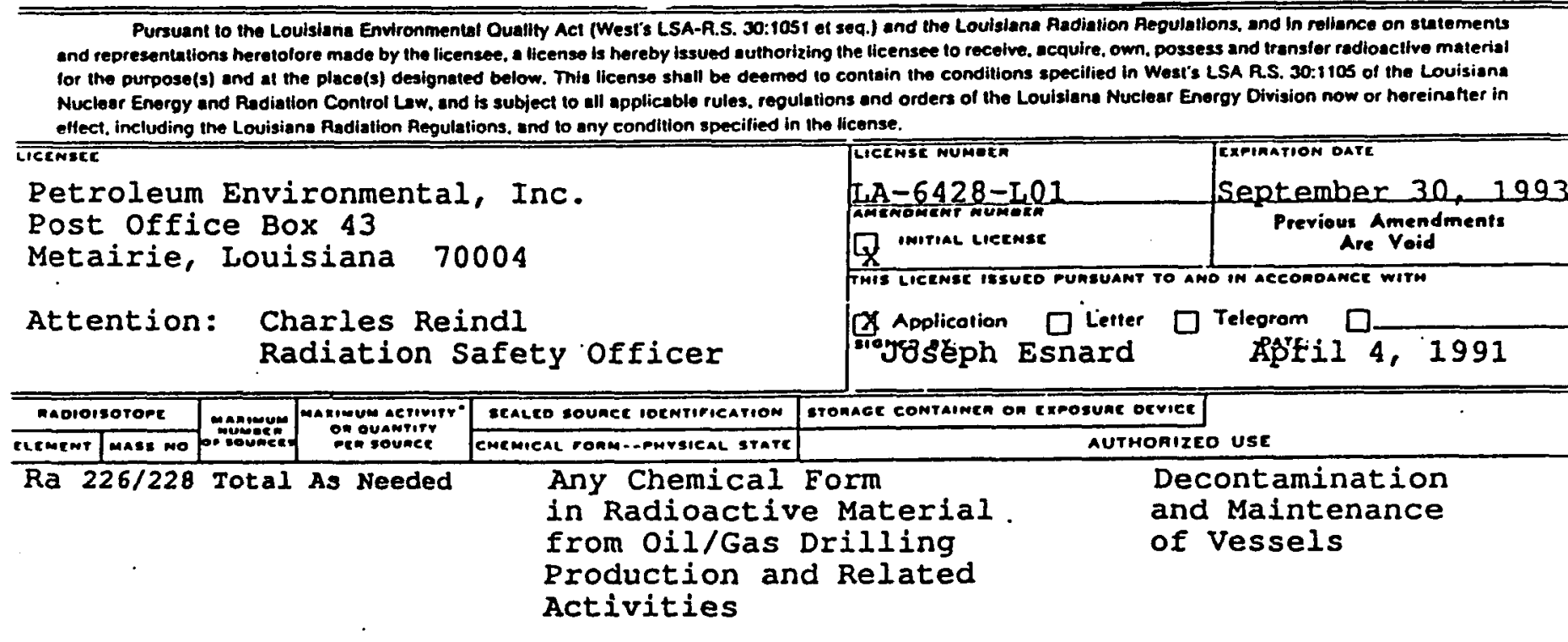

1. A. Radioactive material shall be used only at temporary jobsites of the licensee in and offshore Louisiana.

B. Prior to operation at temporary jobsites, the licensee shall comply with applicable provisions of. other regulations of the Department of Environmental Quality, and obtain all applicable state and local permits.

C. The Division shall be notified and shall approve each temporary location in writing prior to start-up of cleaning activities at each location.

2. Radioactive material shall be handled by individuals who have received training in safe handling of radioactive materials which has been approved by the Division, and who have been designated by Charles Reindl.

3. Pursuant to Sections 104 and 442 of Volume 15 of Title 33 of the Louisiana Administrative Code (IAC $33: \mathrm{XV}$ ), records of receipt, transfer, and disposal of NORM-contaminated material shall be maintained for five years for inspection by the Division.

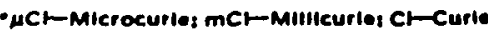

An./ $A$ An. . Mike D. McDariel, Ph.D.


DEPARTMENT OF NATURAL RESOURCES

OFFICE OF ENVIRONMENTAL AFFAIRS

LOUISIANA NUCLEAR ENERGY DIVISION

BATON ROUGE, LOUISIANA

\begin{tabular}{|c|c|c|c|c|c|c|c|}
\hline \multirow{2}{*}{\multicolumn{2}{|c|}{ Petroleum }} & \multicolumn{2}{|c|}{ Environmental, } & & $L A-6428-L 01$ & \multirow{2}{*}{ 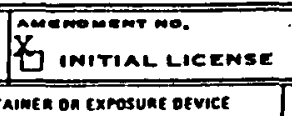 } & September 30,1993 \\
\hline & & \multirow{2}{*}{ 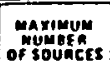 } & \multirow{2}{*}{ 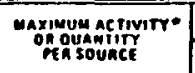 } & \multirow{2}{*}{\multicolumn{2}{|c|}{ 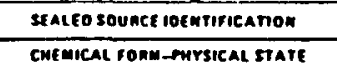 }} & & \\
\hline fetwent & mass wo. & & & & ICAL STATE & \multicolumn{2}{|c|}{ AUTWORIzEO USE } \\
\hline
\end{tabular}

4. Each container holding NORM-contaminated waste must be permanently marked pursuant to Section 422.F.2. of the Louisiana Administrative Code (IAC $33: \mathrm{XV})$ with an identification number traceable to records documenting the original source of the contents.

5. A quarterly report of job activities shall be submitted to the Division which includes customer name, jobsite location and dates, amount of waste generated, and date the waste was transferred. Such reports shall be submitted to the Division no later than 30 days after the end of each calendar quarter.

6. Contamination surveys shall be performed at each temporary location at the beginning and conclusion of every job. Survey records shall be maintained for inspection by the Division.

7. Transfer shall only be to persons specifically licensed to receive such material, or to persons generally licensed under Section 1410 of LAC 33:XV.

8. Except as specifically provided otherwise by this license or IAC $33: \mathrm{XV}$, the licensee shall possess and use radioactive material in the schedule of this license in accordance with statements, representations, and procedures contained in the licensee's application dated April 4, 1991, and in all subsequent correspondence.

RPB : sd

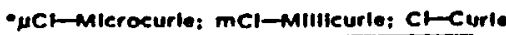

man " ommeont Mike D. McDaniel, Ph.D. Assistant Secretary

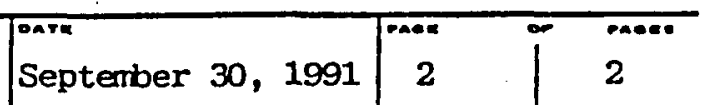




\section{5-C - Contractor Safety Data}


-rsentas

ONTRACTOR SAFETY DATA

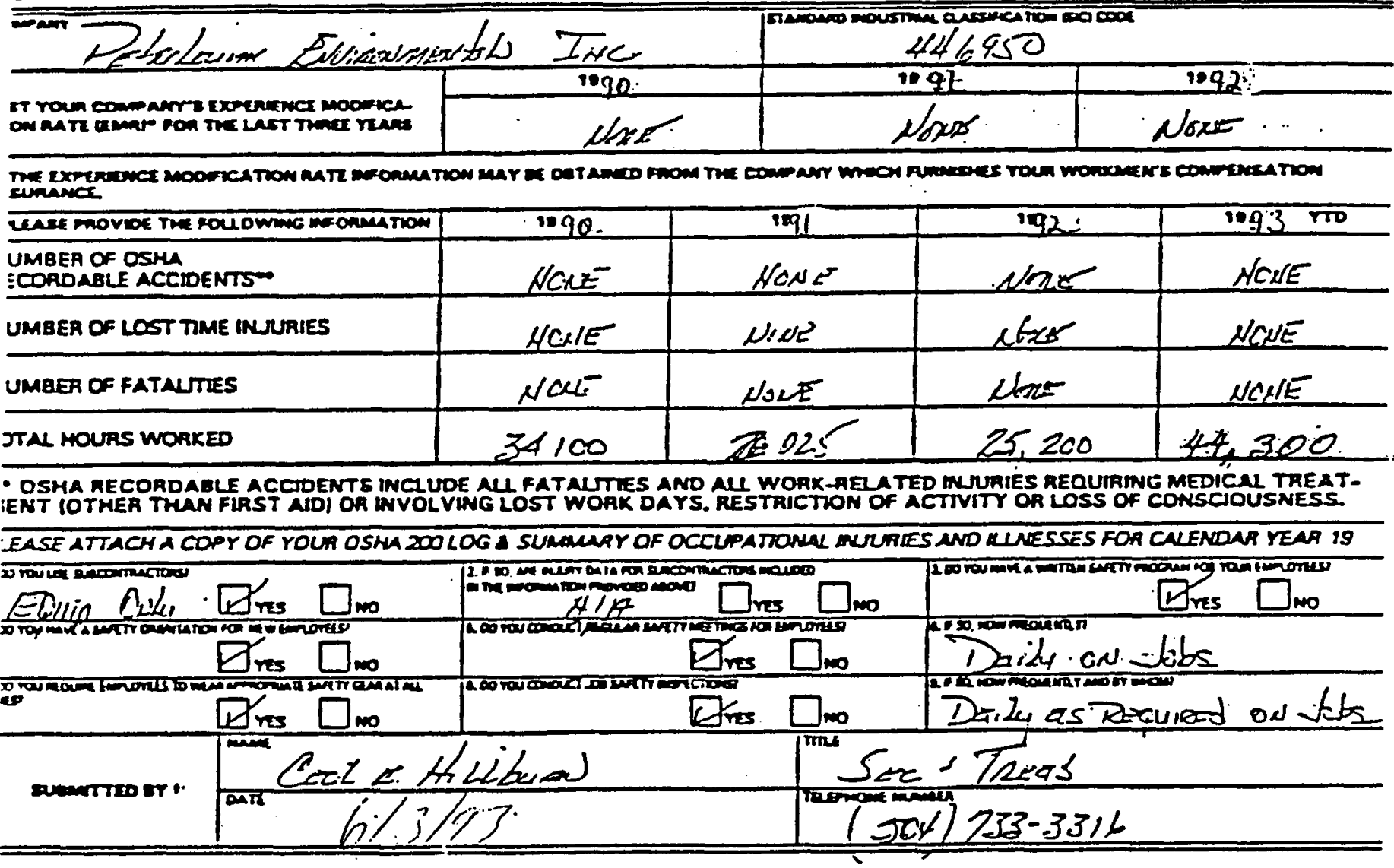




\section{5-D - Petroleum Environmental, Inc. (Letter and Survey Plots)}




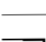


PETROLEUM ENVIRONMENTAL, INC.

P. O. BOX 43

METAIRIE, LOUISIANA 70004

(504) 733-3316

E. G. \& G. IDAHO, INC.

P. O. Box 1625

Idaho Falls, Idaho 83415

Attention: Mr. Ben Rinehart

Subject: "NORM" survey of the glady's MC CALL SITE

Survey of the Low Pressure seperator showed that the insoluble solids inside the seperator from the man way hatch through out the lenght of the seperator had readings as follows:

Vessel Manway
Feet From Manway

0
$3^{\prime}$
$6^{\prime}$
$9^{\prime}$
$12^{\prime}$
$15^{\prime}$
$18^{\prime}$
$21^{\prime}$
$24^{\prime}$
$27^{\prime}$

Scintillation counter Reading

$90 \mathrm{M} / \mathrm{R}$
$90 \mathrm{M} / \mathrm{R}$
$100 \mathrm{M} / \mathrm{R}$
$150 \mathrm{M} / \mathrm{R}$
$200 \mathrm{M} / \mathrm{R}$
$300 \mathrm{M} / \mathrm{R}$
$350 \mathrm{M} / \mathrm{R}$
$400 \mathrm{M} / \mathrm{R}$
$600 \mathrm{M} / \mathrm{R}$
$900 \mathrm{M} / \mathrm{R}$

The scintillation dector used is a Ludlum Model 19 that was last calibrated $6 / 13 / 93$.

The land inside the Ring Levee was tested as well as the Ring Levee and land outside of Ring Levee. As drawing (enclosed) will show the Hot spots that were found throughout the location. Location was surveyed by using the $10^{\prime} \times 10^{\prime}$ grid method.

P.E.I. also surveyed and tested the land which the Glady's Mc Cal Site is located using the $10^{\prime} \times 10^{\prime}$ Grid Method for area and the Ludlum Model 19 for "Norm" Dector. The area tested included the land inside the Ring Levee, the Ring Levee and the land outside of the Ring Levee. Twelve "HOT sPOTS" were detected. (see diagram)

After the "Norm" Contaminated solids were removed by shovels-and a backhoe and placed into 1517 H DOT approved drums and labled "NORM" and their readings: 
P.E.I.

Page -2-

DRUM

$\begin{array}{rrrrrrrr}(1) & 130 & M / R & 6) & 170 & M / R & 11) & 30 \mathrm{M} / \mathrm{R} \\ \text { 2) } & 600 & \mathrm{M} / \mathrm{R} & 7) & 120 \mathrm{M} / \mathrm{R} & 12) & 600 \mathrm{M} / \mathrm{R} \\ \text { 3) } & 250 \mathrm{M} / \mathrm{R} & 8) & 700 \mathrm{M} / \mathrm{R} & 13) & 60 \mathrm{M} / \mathrm{R} \\ \text { 4) } & 400 \mathrm{M} / \mathrm{R} & 9) & 900 \mathrm{M} / \mathrm{R} & 14) & 85 \mathrm{M} / \mathrm{R} \\ \text { 5) } & 300 \mathrm{M} / \mathrm{R} & 10) & 75 \mathrm{M} / \mathrm{R} & 15) & 50 \mathrm{M} / \mathrm{R}\end{array}$

Drums 16 thru 20 were marked empty $O M / R$. All drums left at the site. Disposal to be handled by the generator.

After seperator was cleaned and removed and the site leaned, P. E. I. took another 10 feet $x 10$ feet grid sample using a Ludlum Model 19 detector and surveyed for Hot Spots.

The normal background readings of site and surrounding area was between 3 and $5 \mathrm{M} / \mathrm{R}$. All 12 HOT SPOTS were reduced to less than or equal to the area's background.

All sampling and closure of the Glady's McCall Well site was done in accordance with the ste of Louisiana Rules and Regulations - 29B.

Regards,

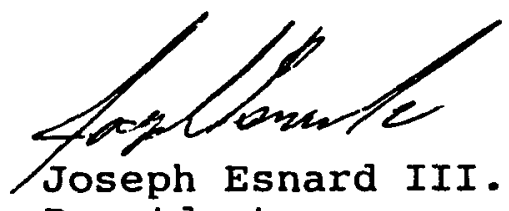

President

PETROLEUM ENVIRONMENTAL, INC. 
CLIENT; B.G.S.G.

LOCATION: GLADYS MCCALL SWD WELL
DATE: $12 / 23 / 93$

REMARKS: SHADED AREA WHERE CONTAMINATED DRUMS STORED

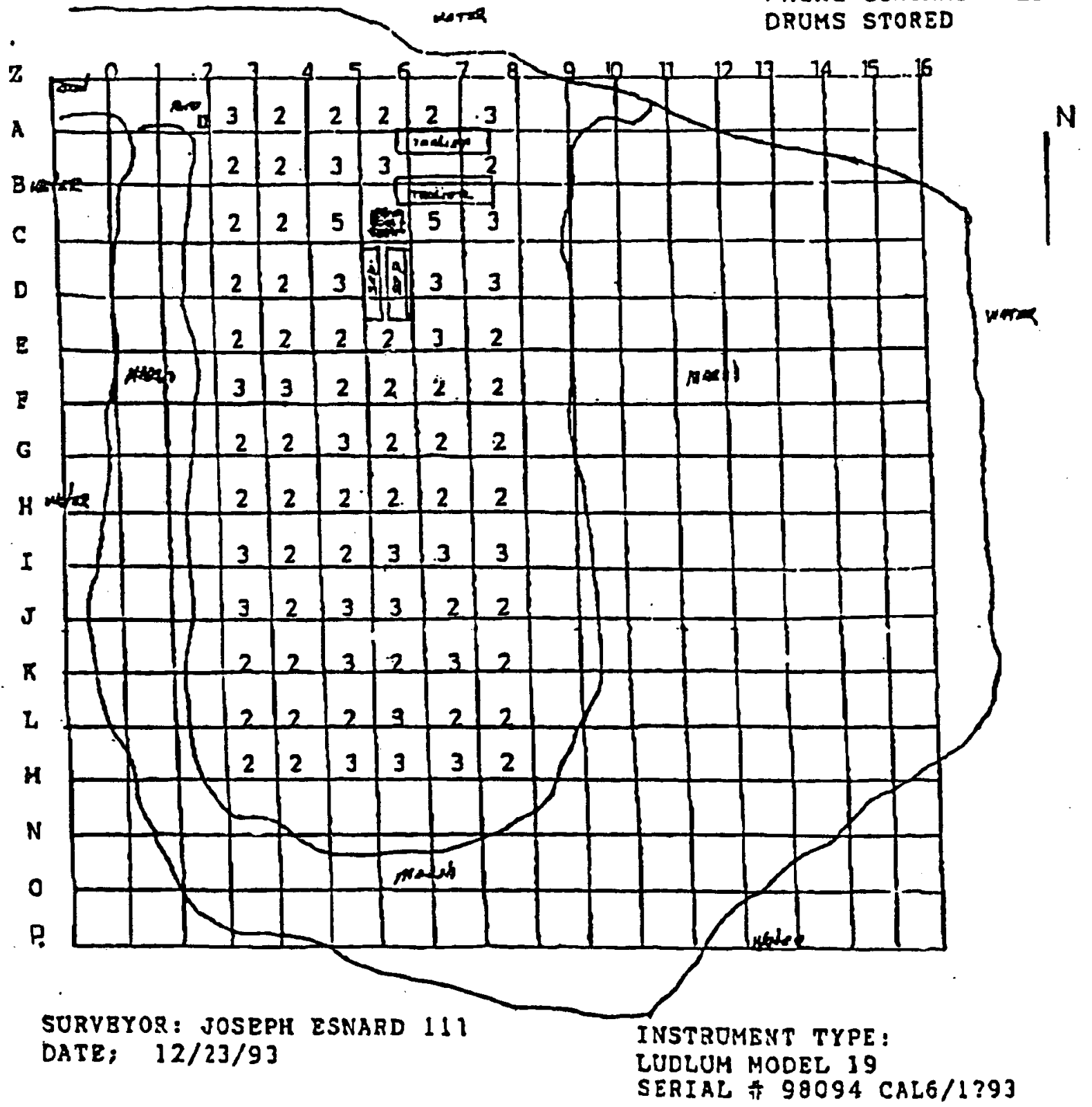




\section{DPELImINARV SWAVE \\ Drawing "।}

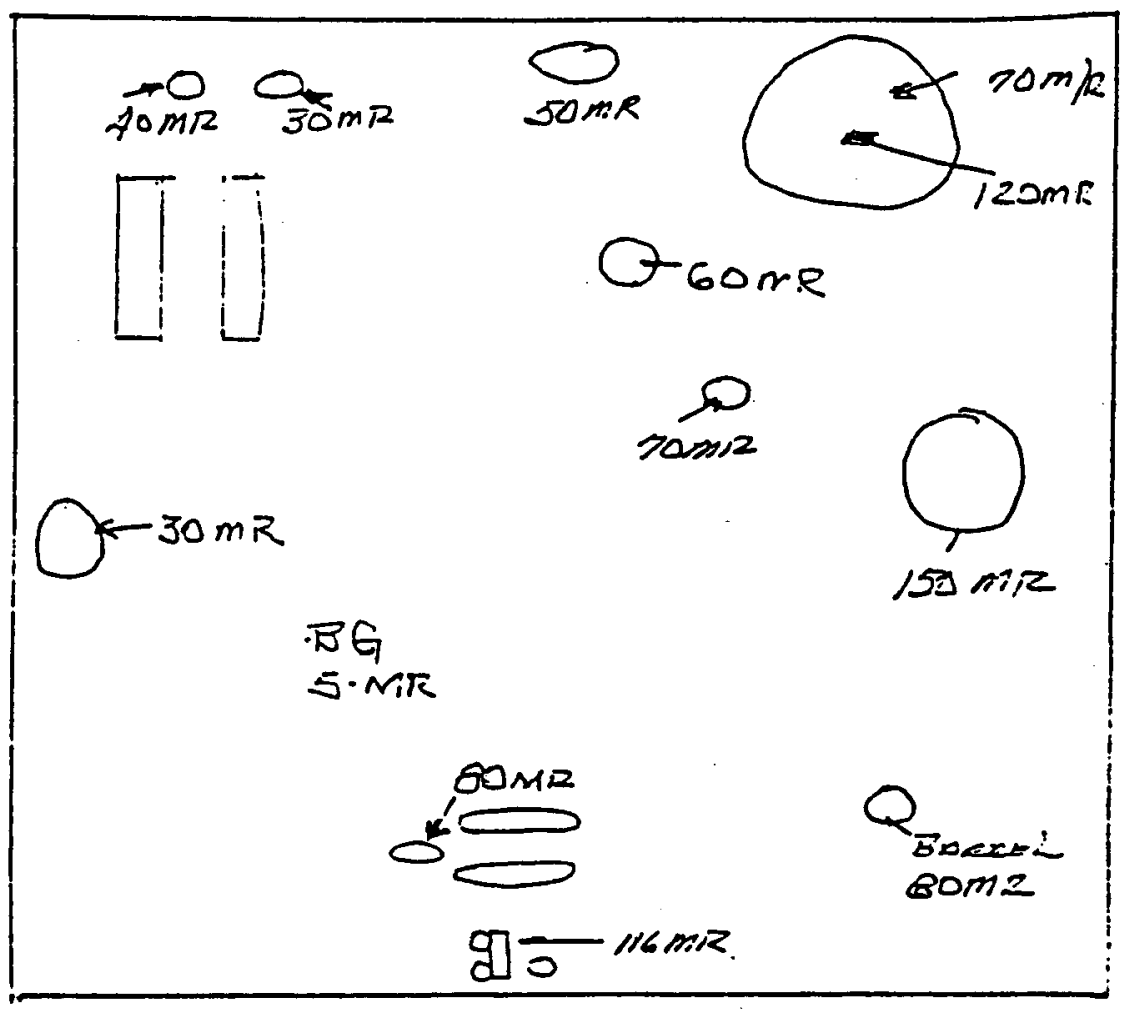

DRAwing 2

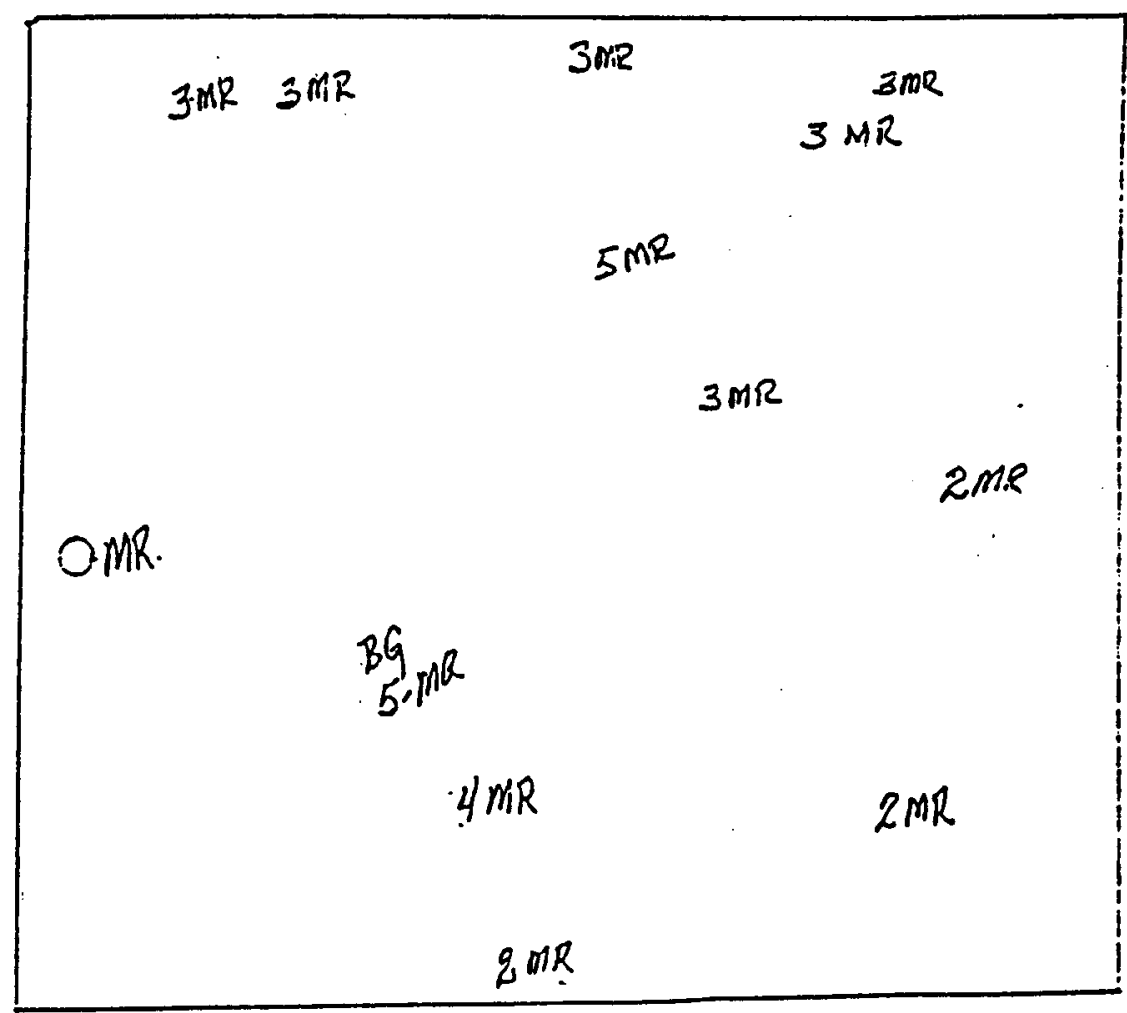




\section{5-E - State of Louisiana \\ Department of Environmental Quality \\ (Fax Cover and Letter)}




\section{State of Louisiana (1) Department of Environmental Quality Radiation Protection Division NORM Section}

\section{COVER SHEET}

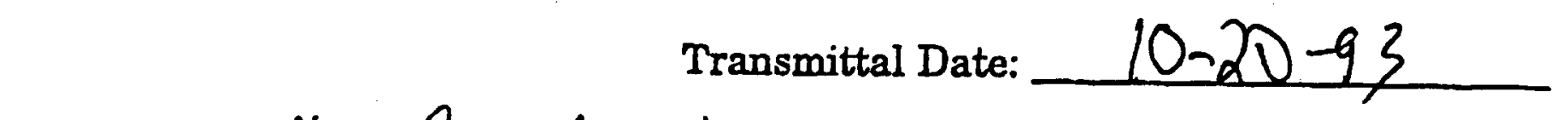

TO: Mr Benkinehart

(Person - Company/Department)

FROM:

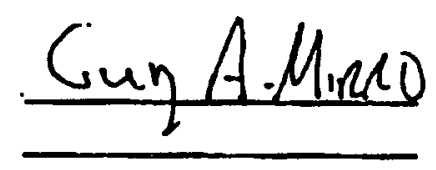

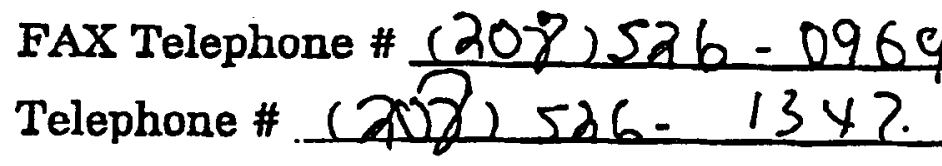
Louisiana Radiation Protection Division Department of Environmental Quality P.O. Box 82135

Baton Rouge, Louisiana 70884-2135

or

Radiation Protection Division 7290 Bluebonnet Road

Baton Rouge, Louisiana 70810

Fax Telephone \# Business Telephone \# Radon Toll-Free Hot-line \# (800) 256-2491 IRANSMISSION INCLUDES THIS COVER SHEET PLUS THE FOLLOWING PAGE(S). SPECIAL INSTRUCTIONS (If any):

\section{Operator:}




\section{Stăte of Louisiana}

Department of Environmental Quality

Edwin W. Edwards

Governor

October 5, 1993

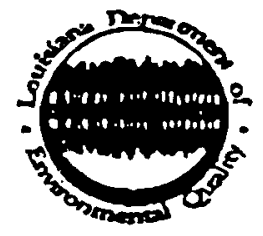

Mr. Ben N. Rinehart, Manager - Procurement and Contracts

Dept. of Energy/EG\&G Idaho, Inc.

P. O. BOX 1625

Idaho Falls, Idaho 83415

Dear Mr. Rinehart:

This is in response to a previous Deptartment of Energy/Eaton Operating Company correspondence dated November 16, 1992 and your recent request as Department of Energy/EG\&G Idaho, Inc. dated July 30,1993 relative to the disposal of NORM waste in a plugged and abandoned wellbore.

Pursuant to your request, authorization is hereby granted for the disposal of NORM waste to be slurried and pumped inside the cased wellbore of the Gladys McCall SWD No. 1 well, ocrial number 159587, of Section 27. Township 15 south, Range 5 West, Crab Lake Field, located in Cameron Parish, Louisiana. The Department understands that. this well is to be plugged and abandoned and authorization will be granted for activities to begin on date of this letter and to be completed on or about December 31, 1993. Such disposal shall be conducted in accordance with the mechanical procedures described in your correspondence and approved by the off1ce of Conservation (UIC-30/Work Permit No. 011607, dated November 16, 1992 and July 30, 1993) and the health physics procedures submitted by Petroleum Environmental. Inc. to the Radiation Protection Diviaion on September 30, 1991.

Prior to conducting such operations, verbal notiflcation to the Radiation Protection Division is requested, and a report of these activities shall be submitted to the division upon completion. This report should include information such as the location of the well. office of Conservation serial number. details of the disposal. and tha date of completion. It is further suggested that a copy of this information be furnished to the office of Conservation District Manager having oversight of the well in question.

This authorization does not extend to the encapsulation of fluids used to clean radioactive scale from tubing or other types of radioactive liquide. This is a matter for separate consideracion.

If you have any questions regarding this authorization, or if the Division may be of ary additional assistance in thic matter, please contact this office.

GVB: gam

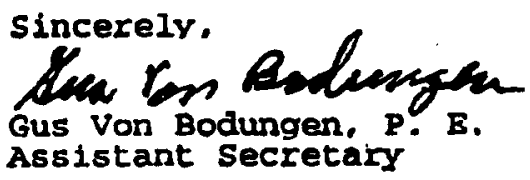

UFFICE OF AIR OUALITY RADIATION PAOTECTION DIVISION P.O. BOX 82135 BATON ROUGE. LOUISIANA 70984.2135 TELSPHONE (504) 765.0160 FAX (504) 765-0220

AN EOUA: OPPORTUNITY EMPLOYER

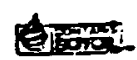

TOTAL P. 82 


\section{5-F - State of Louisiana Department of Natural Resources \\ (Two Letters)}


EDWIN W. EDWARDS OOVERNOR

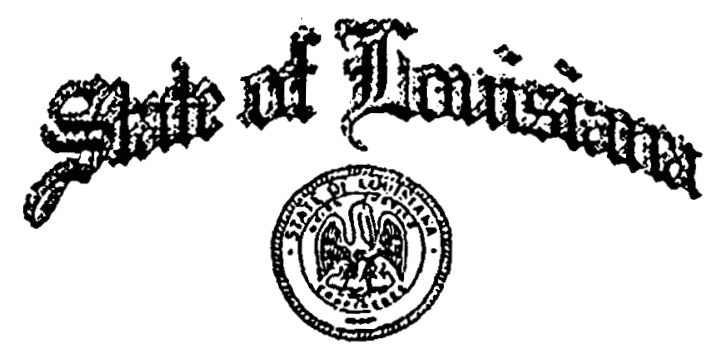

DEPARTMENT OF NATURAL RESOURCES
JOKN F, NLS SECRETARY

H. W. THOMPSON COMMISSIONER AMD ASSISTANT SECRETARY

July 30,1993

Ben N. Rinehart

DOB/EGEG Idaho, Inc.

P. O. Box 1625

Idaho Falls, Idaho 83415

Ref: I \& M Application No. 011607

Gladys MCCall SWD No. 1

Serial No. 159587

Section 27, Township 15 South, Range 5 West

Crab Iake Field, Cameron Parish

Dear Mr. Rinehart:

The above referenced approved work permit issued to DOE/Eaton Operating Company, Inc., will be accepted by this office as an approved work permit for your company to perform the P\&A of the well for NORM disposal.

Should you have any questions regarding this matter, please contact Mr. Ed Buford of this office at (504) 342-5515.

very truly yours,

H. W. THOMPSON, COMAISSIONER

OFFICE OF CONSERVATION

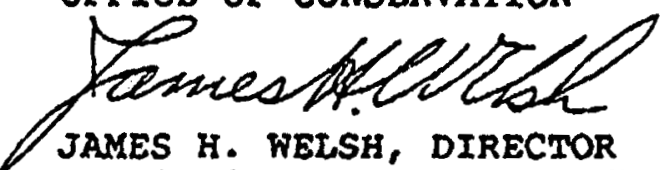

INJECTION AND MINING DIVISION

HWT : JKW \& EB

OFPTCE OF CONSERVATION P.O. BOX MA27S BATON ROUGE, LOUISIANA 2OSOLP27S PHONE: (SOA) 322.35SO

AN EOUAL OFPORTUNITY EMPLOYER 
EDWIN W. EDWARDS GOVERNOR

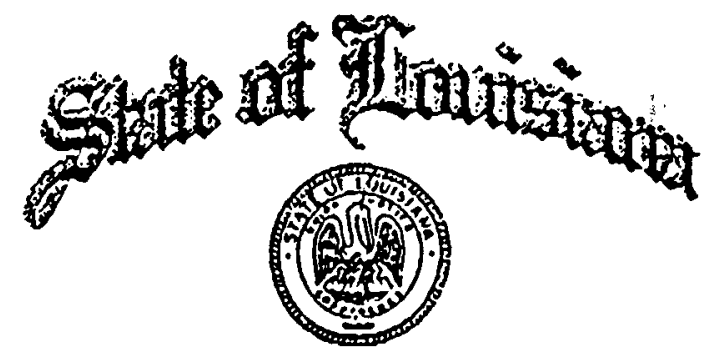

DERARTMENT OF NATURAL RESOURCES

November 16,1992
JOHN F. ALES SECRETARY

H. W. THOMPSON COMMISSIONER AND ASSISTANT SECRETARY

DOE/Eaton Operating Company, Inc.

1240 Blalock, Suite 100

Houston, Texas 77055

Attention: Doug Graham

Re: Form UIC-30/Work Permit No. 011607

Gladyo McCall SWD No. 1

Serial No. 259587

Section 27, Township 15 South, Range 5 West

Crab Lake Field, Cameron Parish, Ia.

Dear Mr. Graham:

The attached Form UIC-30 has been approved for the disposal of NORM during plugging and abandonment (P\&A) of the above-referenced well.

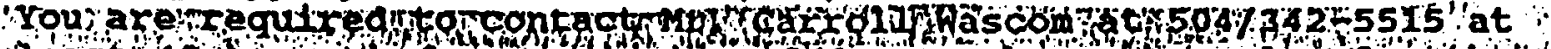

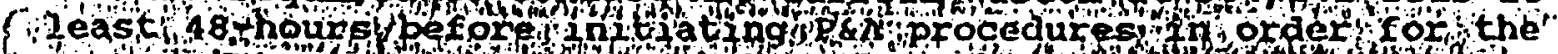

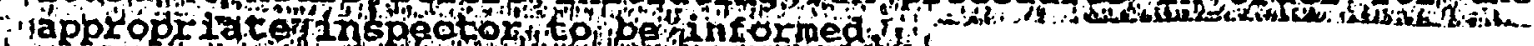
Tap o.

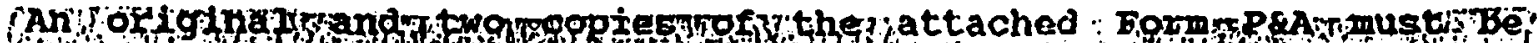

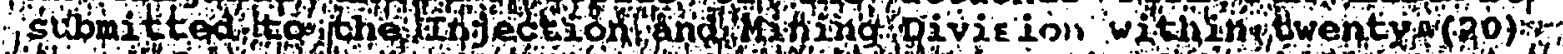

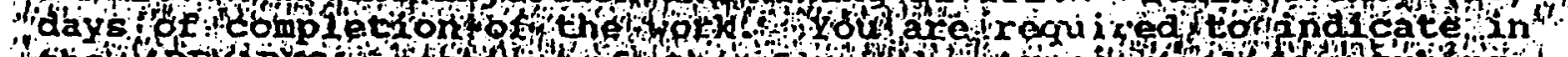

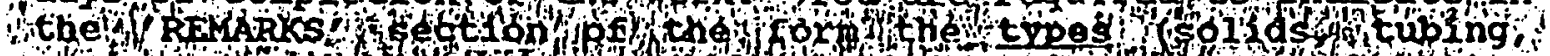

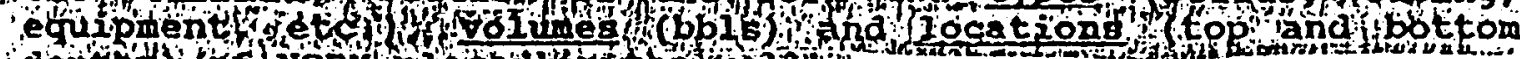

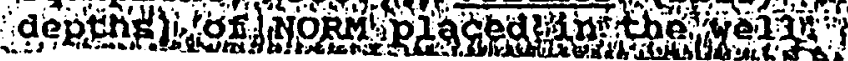

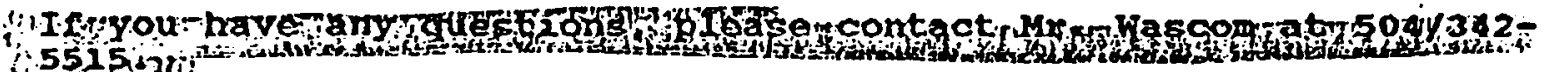

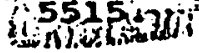

Yours very truly,

H. W. Thompson, Commissioner

offies of conservation

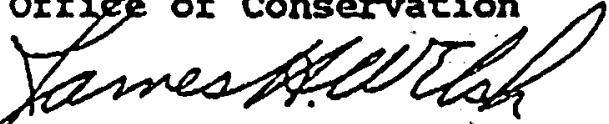

James H. Welsh, Director

Injection and Mining Division

CDF: mk

CC: Chris simms, DEQ

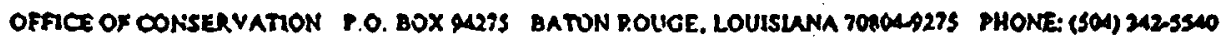

TUTHL F.UZ 


\section{UIC-30}

WOFK PERMTT

to

Plug and Abandon a Well

Uliticed for NORM Disposal
Olfice of Consarvation

Injoction and Mining Division

Wol Soriai No

159587

Wak Protoik Na

$\Lambda-C$

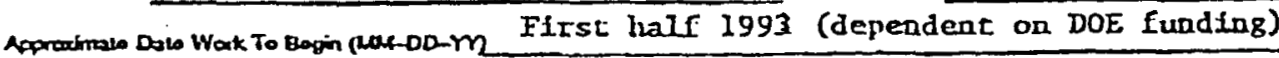

Wor Narwa Na DOE/EOC Gladys HCCall SWDW No. I

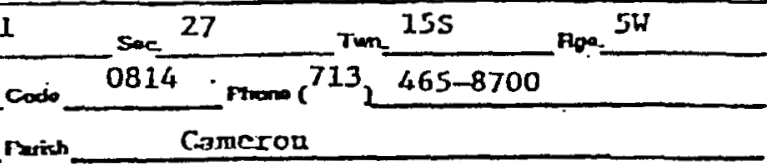

Find DOE/Eaton Operating Co., InC.

Parish Shur-in

Tow Deph 3,514' Condiain od wat

Pudoced iremaiks) $3,050^{\prime}$ to $3,500^{\circ}$

\begin{tabular}{|c|c|c|c|c|c|c|c|}
\hline \multicolumn{4}{|c|}{ EXISTING CASING PROGRAM } & \multicolumn{4}{|c|}{ PROPOSEO CEMENT PLWGS (2) } \\
\hline casave & IRaE & DETH & TOP OF & Oonilo & russ & sences & Hor \\
\hline STZE & SDE & sex & conartas & mon & ro & correrr & puctert \\
\hline $16^{n}$ & $20^{\prime \prime}$ & $167^{\prime}$ & - Surface & $3,500^{\prime}$ & $1,800^{\prime}$ & & Pumping* \\
\hline $10-3 / 4_{4} "$ & $14-3 / 4^{\prime \prime}$ & $3,552^{\prime}$ & Surface & $1,800^{r}$ & Surt & & Pumpingt \\
\hline $7^{\prime \prime} \mathrm{Tbg}$ & $10-3 / 4_{4}^{\prime \prime}$ & $2,015^{\prime}$ & $N / A$ & & & & \\
\hline & & & & CSee at & ached Figh & Ires) & \\
\hline & & & & & & & \\
\hline & & & & & & & \\
\hline & & & & & & & \\
\hline
\end{tabular}

Depth to bese ef Lommont USOW: 1,016

(40000 ppon Tos) soures Ed Buford/UIC 8/21/92

PROPOSED CAST IROH BRDGE FUUG SETING DEPIL N/A

NORH CONTAMULCED TUBONG

powr of orveate None

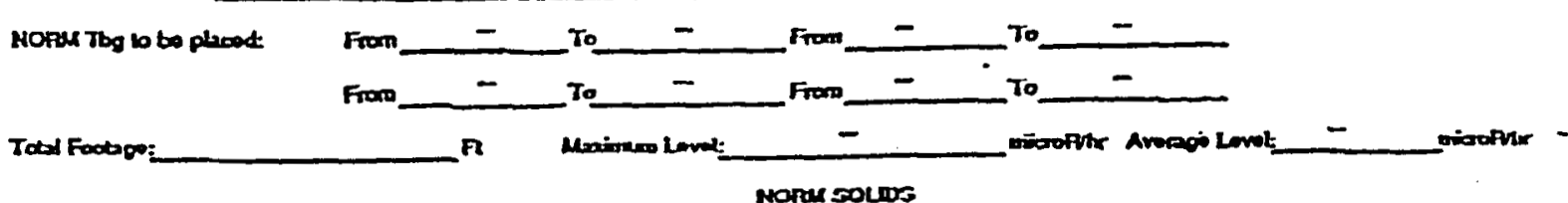

powt of orwan (1_) Low pressure separator, (2.) Two ft. section of 6 " piping manifold.

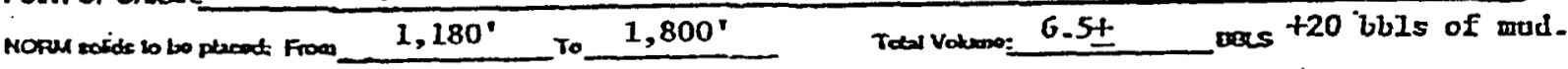

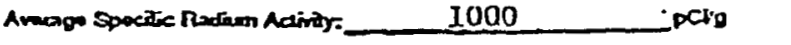

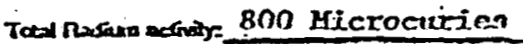

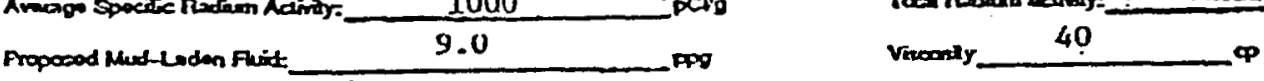

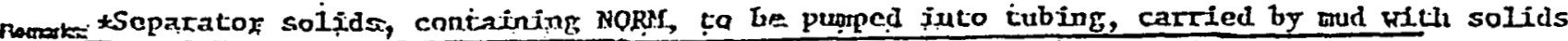
in suspension to be isolated with cemenr (above \& belon)

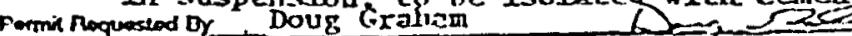
8 Grat singrenture

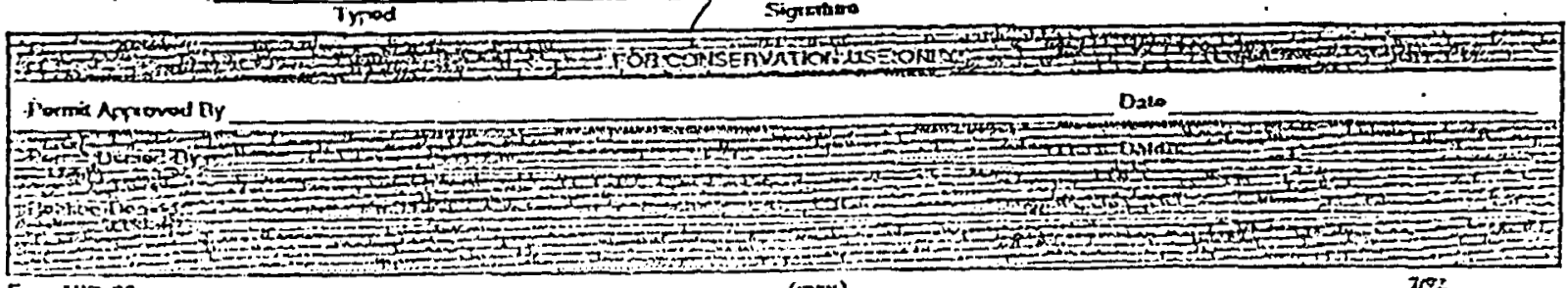




\section{5-G - State of Washington Department of Ecology \\ (N.A.R.M. Site Use Permit)}


STATE OF WASHINGTON

DEPARTMENT OF ECOLOGY

N4056

PERMIT NUMBER:

MS 1126 manapement of radioactive waste

\section{N.A.R.M.* STTE USE PERMIT}

for Commercial Low-Level Radioactive Waste Disposal Site

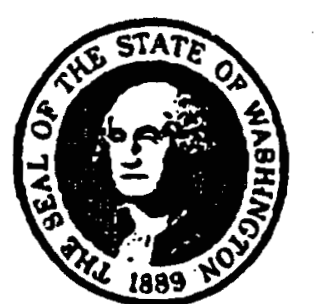

$2 / 28 / 95$

EXPIRATION DATE:

Registrant: U.S.D.O.E. (IDAHO OP'NS OFC)

850 ENERGY DRIVE

IDAHO FAIIS ID 83401-156

The person or fim to whem this cerificate is issued must comply with applicable lederal and state regulations reiated to the sale

- Waturally Occurring and Accelerator Produced Radioactive Material)

Permit Does Not Imply Approval 
5-H - Source Environmental Services, Inc. (Gladys McCall Letter, Map, and Release Survey) 
Ms. Karen Fisher-Brasher

Department of Environmental Quality

Radiation Protection Division

N.O.R.M. Section

P. O. Box 82135

Baton Rouge, LA 70884-2135

RE: Department of Energy/Gladys McCall SWD\#l

General License \#0812N01/Serial \#N159587

Crab Lake Field, Cameron Parish, Louisiana

\section{Dear Karen:}

On behalf of our client, the Department of Energy, we would like to request that the Gladys McCall well site be released for unrestricted use. All N.O.R.M. contaminated materials have been removed from the location, which would render it safe to human health and the environment.

The confirmatory survey performed by source, showing no readings above twice background, is attached along with directions to the jobsite. Source would like to accompany your representative to the jobsite for its inspection tour if you would advise us when to schedule this meeting.

I hereby certify under penalty of law that I have personally examined and am familiar with the information submitted in this document and all attachments and that, based on my personal inquiry of those individuals immediately responsible for obtaining the information, I hereby represent in writing that 
Department of Environmental Quality April 14, 1994

Page Tพо

the information contained herein is true, accurate and complete to the best of knowledge, information and belief. I am aware that there are significant penalties for submitting false information, including the possibility of fines and imprisonment or both.

\section{sincerely yours,}

SOURCE ENVIRONMENTAL SERVICES, INC.

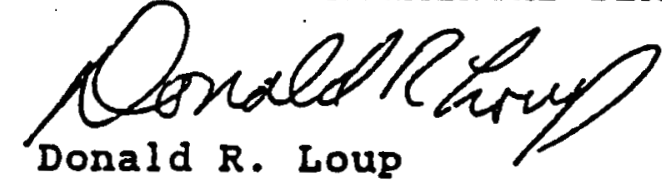

DRL : jsb

Enclosures 


\section{EOC/DOE Gladys McCall Test Site Cameron Parish, Louisiana}

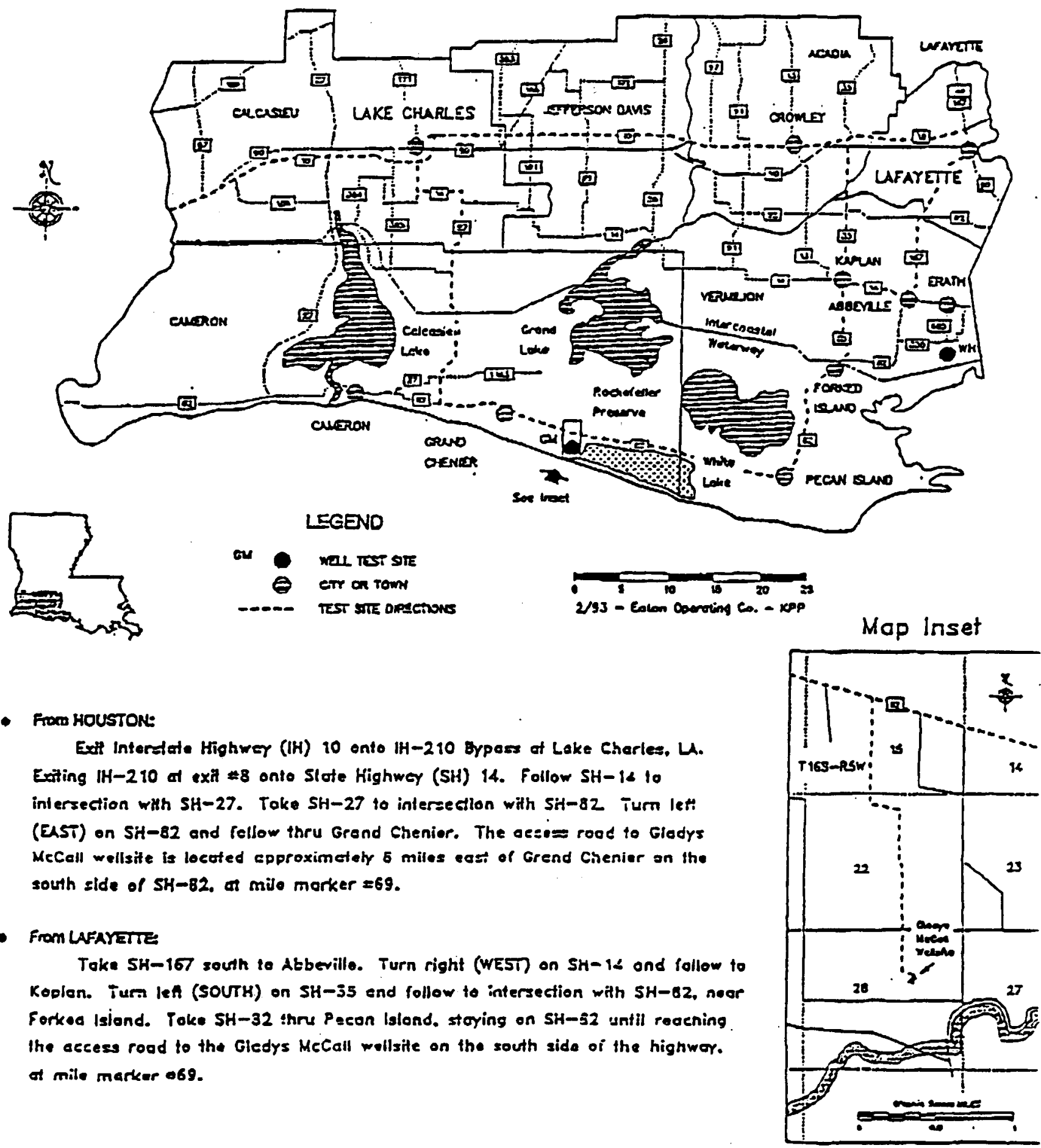

Directions To Wellstte 


\section{S. Source Environmental Services, Inc.}

Site Survey

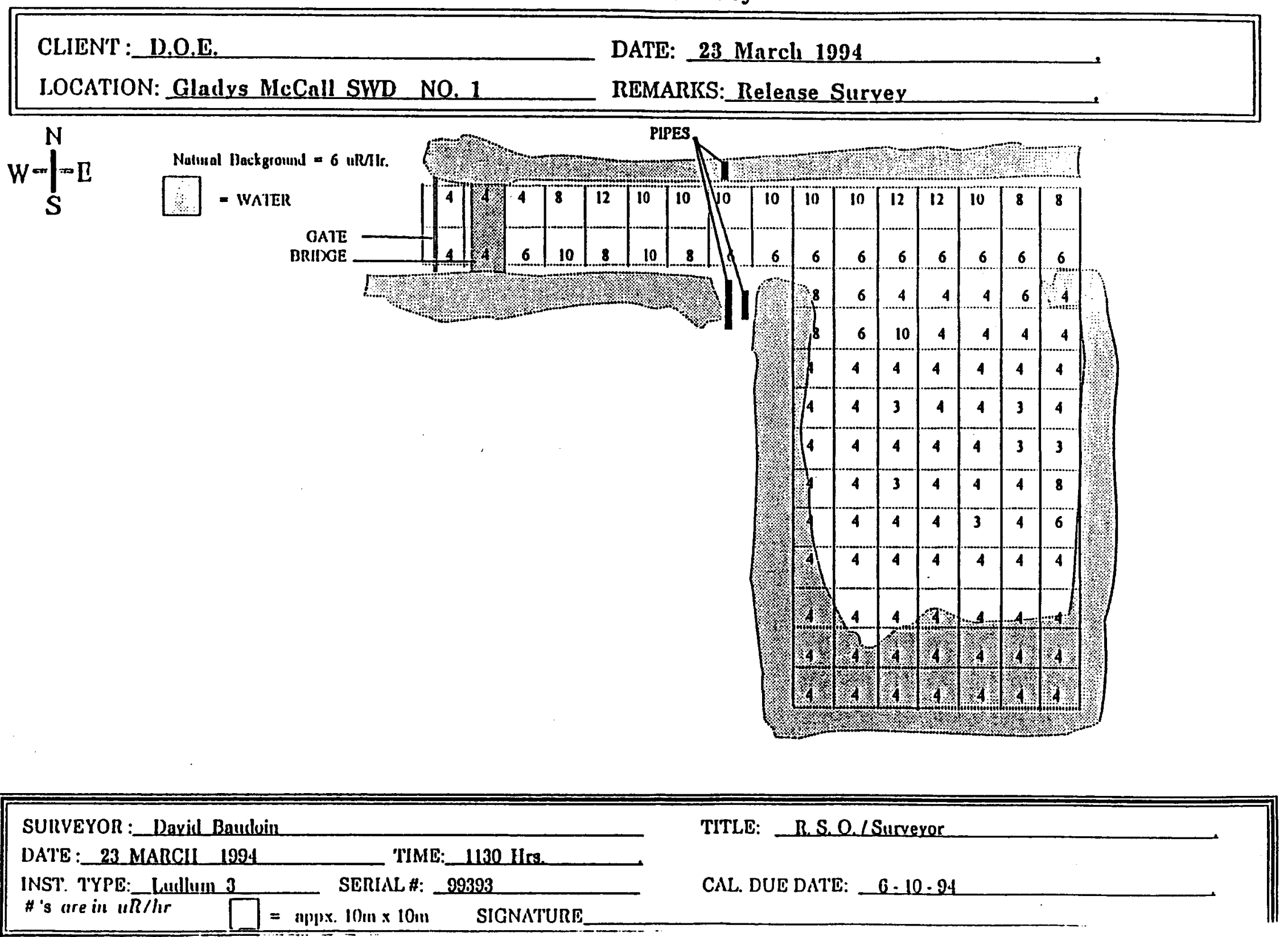




\section{5-I - Source Environmental Services, Inc. (Willis Hulin Confirmatory Survey)}




\section{Source Environmental Services, Inc. Site Survey}

CLIENT: D.Q.F.

LOCATION: Jewitt Hulln. Frath. La.
DATE: $\mathbb{E}$ May 1994 REMARKS:Confirmatory Surrey
Natural Background $=8$ uR/Hr.

$x 1$ - Soll Swaple Location : Devoid of regetation 0"-6" - Lieht tan ciay 6"-18" - Dark brown olay

22 - Soil Somplo Location : Dovold of vegetetion 0"-18"- Tan/gray clay 18"-24"- Dark gray/black clay

x3-Soil Bamplo Lweation : Dovold of regetation $0 "-12$ "-Light gray clay/dark gray clay 12"-18"-Light gray clay

xt-Soil Sample Location: Sparoe vegetation 0"-6" - Light brown clay 6"-12"-Dark gray andy clay/black clay 12"-18"-Light tan clay

IS-Soil Sanmple Location : Devoid of veretation $0 "-6 "$ "Ligbt browe/eray clay 6"-18"-Dark brown clay/black olly clay 18"-24"-Lipht brown olay

A - Sunp /owitch and 3" PVC plpo protruding from ground

B - 4" PVC pipe protruding from grouthd, 23 uR/tr.

C - (2 localtown) Eloctrical Boxeas

D. $6 \times 6^{\prime}$ Concrete alab

E - (2 location) Pipe deck atrucluree

F - Rack of trath pipe, PVC pipe, erating, 10 uR/tr.

G - Cablo waruing inaker, 8" pipo protrudiog from groumd, 12 uR/Hr.

H - 2 bolea in levee, 23 uRAHr.

L - Light polae (2)

T - Propane lonk

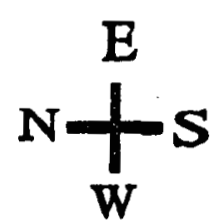




\section{PLUG AND ABANDONMENT OF GEOTHERMAL WELLS}

State of Louisiana Department of Conservation Work Permits and Authorizations for the Gladys McCall well site and the Willis Hulin well site are in Exhibits 6-A and 6-B and in Exhibits 6-C and 6-D, respectively.

State of Louisiana Office of Conservation Plug and Abandon Report documents for the Gladys McCall well site are presented in Exhibits 6-E and 6-F. State of Louisiana Office of Conservation Plug and Abandon Report documents for the Willis Hulin well site are presented in Exhibits 6-G and 6-H.

Plug and Abandonment (P\&A) Procedures are provided in Exhibits 6-I and 6-J for the Gladys McCall well site and in Exhibits 6-K and 6-L for the Willis Hulin well site. Daily Workover Reports are presented in (a) Exhibit 6-M for the Gladys McCall well site for the period 9-18-93 through 11-19-93 and (b) Exhibit 6-O for the Willis Hulin well site for the period 2-7-94 through 3-17-94. Current Condition of Well documents (with attachments) are presented in Exhibit 6-N for the McCall well site and in Exhibit 6-P for the Hulin well site.

Exhibit 6-Q provides copies of the Turnkey Bids for Independent P\&A Oerations for the McCall and Hulin well sites as submitted by PAW Drilling \& Well Service, Inc. Exhibit 6-R is a Cost Savings Report prepared by EG\&G Idaho, Inc., that indicates cost savings of more than $\$ 3$ million when quality project management procedures were instituted to implement restoration of the well sites. Exhibit 6-S is a Cost and Salvage Report submitted to EG\&G Idaho, Inc., by PAW Drilling \& Well Service, Inc. 


$$
\text { 6-2 }
$$

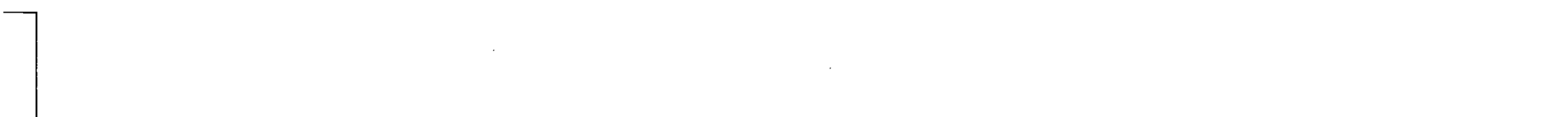




\section{EXHIBITS 6-A THROUGH 6-S}

Page

6-A — State of Louisiana-McCall Work Permit No. 575-93 . . . . . . . . . . 6-5

6-B - McCall Work Permit UIC-30 Application . . . . . . . . . . . . . . . . 6-6

6-C - State of Louisiana Plug and Abandon Report

(Hulin Work Permit No. 576-93) .................... 6-7

6-D - State of Louisiana Plug and Abandon Report

(Hulin Work Permit No. 012314) . . . . . . . . . . . . . . . . . . . .

6-E - State of Louisiana Plug and Abandon Report

(McCall Work Permit 11/3/93) . . . . . . . . . . . . . . . . . . . 6-9

6-F - State of Louisiana Plug and Abandon Report

(McCall Work Permit 11/29/93) . . . . . . . . . . . . . . . . . . .

6-G - State of Louisiana Plug and Abandon Report

(Hulin Work Permit 3/11/94) . . . . . . . . . . . . . . . . . . . . . . 6-15

6-H - State of Louisiana Plug and Abandon Report

(Hulin Work Permit 3/7/94) . . . . . . . . . . . . . . . . . . . . . . . 6-18

6-I - Eaton Operating Company Plug and Abandonment

Procedure for McCall No. 1 Well (1/27/93) . . . . . . . . . . . . . . 6 6-21

6-J - PAW Drilling \& Well Service Plug and Abandonment Procedure for McCall SWD . . . . . . . . . . . . . . . . . . . . . . . .

6-K - Eaton Operating Company Plug and Abandonment Procedure for Hulin No. 1 Well $(3 / 10 / 93) \ldots . . . . . . . . . . . . . .$.

6-L - Eaton Operating Company Plug and Abandonment Procedure for McCall CVW No. 1 Well $(3 / 10 / 93)$. . . . . . . . . . . . . . . . . . 6-24

6-M - Daily Workover Reports for Gladys McCall Well Site From 9-18-93 Through 11-19-93 


\section{EXHIBITS 6-A THROUGH 6-S (Cont.)}

6-N - Current Condition of Gladys McCall Well Site $\ldots \ldots \ldots \ldots \ldots .6$ 6-83

6-O - Daily Workover Reports for Willis Hulin Well Site From

2-7-94 Through 3-17-94 . . . . . . . . . . . . . . . . . 6-97

6-P - Current Condition of Willis Hulin Well Site . . . . . . . . 6-131

6-Q - Turnkey Bids for Gladys McCall and Willis Hulin Sites . . . . . . 6 6-151

6-R - Cost Savings Report From EG\&G Idaho, Inc. . . . . . . . . . 6-157

6-S - PAW P\&A Cost and Salvage Report $\ldots \ldots \ldots \ldots \ldots \ldots \ldots \ldots$ 6-161 


\section{Work Permil \\ STATE OF LOUISIANA DEPARTMENT OF CONSERVATION}

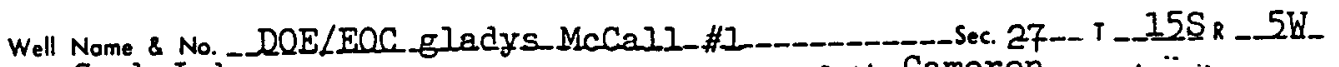

Field Crab Lake
Permit Seriol No. 17 L

Squeeze_perfs 15,160-15470_with 150_sks;-izull and LD_5"

Descriplion of Work $7^{7}$ at $5500^{\prime}$ set cmt plug from 5600_to 5400'. Spot_plug from -

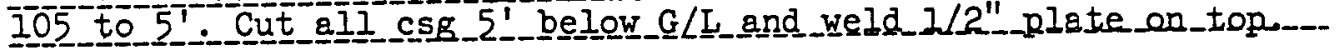

Sąnd \& Reservoir To Be Tested

P\&A

TI . $-16,510$

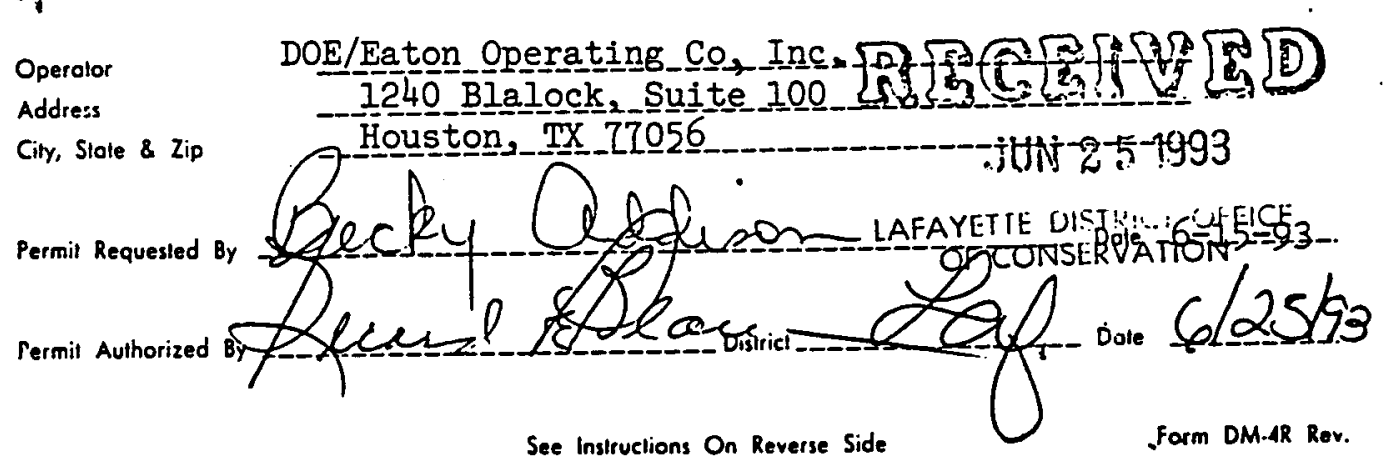




\section{$\operatorname{UIC}-30$}

\section{WORK PERMIT}

to

Plug and Abandon a Well

Uttreed for NORM Disposal
Offica of Conservation

Injoction and Maning Division

UIC AAPLICATIOL' NO. 01/60?

Wad satil No

159587

Wort Porrix Na

$A-C$

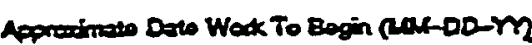

First half 1993 (dependent on DOE funding)

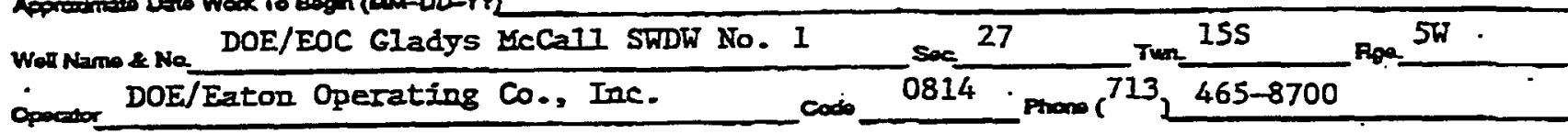

Fuld Crab Iake

Parish

Cameron

Toxi opos

3,514' $\mathrm{PBCD}$

Contioin of wat

Shut-in

Pacooted Irenai(s)

$$
3,050^{r} \text { to } 3,500^{\circ}
$$

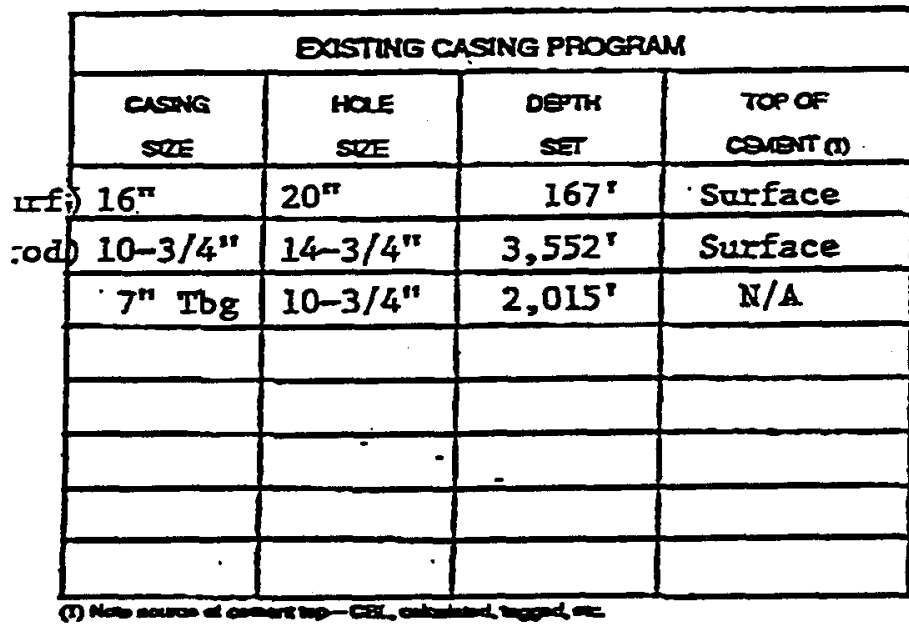

Depth to Bepe of Lommat usoves

$1,016^{\circ}$
PROPOSED CENENT PLUGS (2)

\begin{tabular}{|c|c|c|c|}
\hline \multicolumn{4}{|c|}{ PROPOSED CENERT PLUGS (D) } \\
\hline \multicolumn{2}{|c|}{ DETH OF:RUSS } & \multirow{2}{*}{$\begin{array}{l}\text { chacs } \\
\text { cenerert }\end{array}$} & \multirow{2}{*}{ mor } \\
\hline mon & To & & \\
\hline $3,500^{\prime}$ & $1,800^{\circ}$ & & Pumping* \\
\hline $1,800^{\prime}$ & Surf & & Prmping* \\
\hline & & & \\
\hline & & & \\
\hline CSee .at & Eached Figh & (ares) & - \\
\hline & & & \\
\hline & & & - \\
\hline & & & \\
\hline
\end{tabular}

(40000 ppo TOS Sameo IEd Buford/OIC 8/21/92

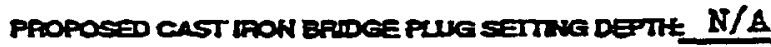

\section{NORU CONTAMUTTED TUEANG}

Pont of OFuent None

MOFar Iog bo be phout

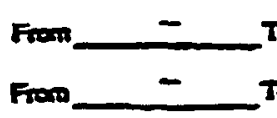

Tot Footonges F

Unoines Lonk

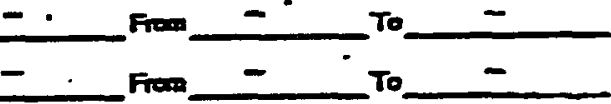

\section{Now solus}

pont of ofucin (1.) Low pressure separator, (2.) Tro ft. section of $6^{n}$ piping manfold.

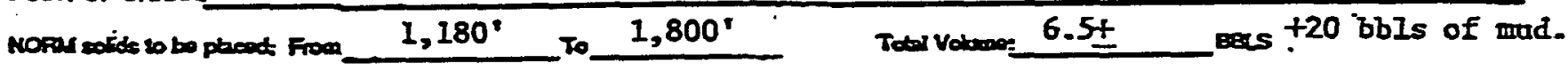

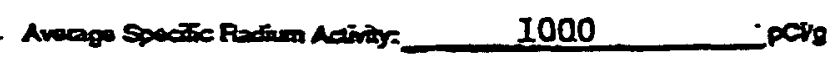

Propeod Musteden firit

9.0

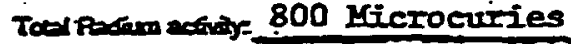

Visenty 40

$$
40
$$

$\boldsymbol{9}$

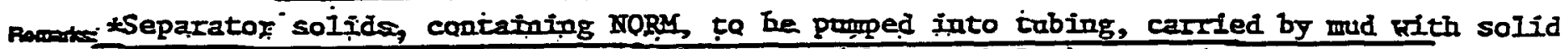

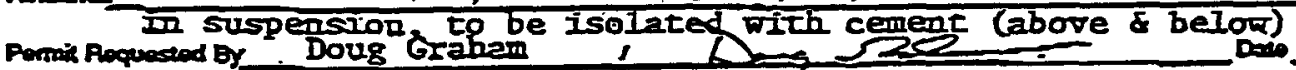

$$
\text { Typod }
$$

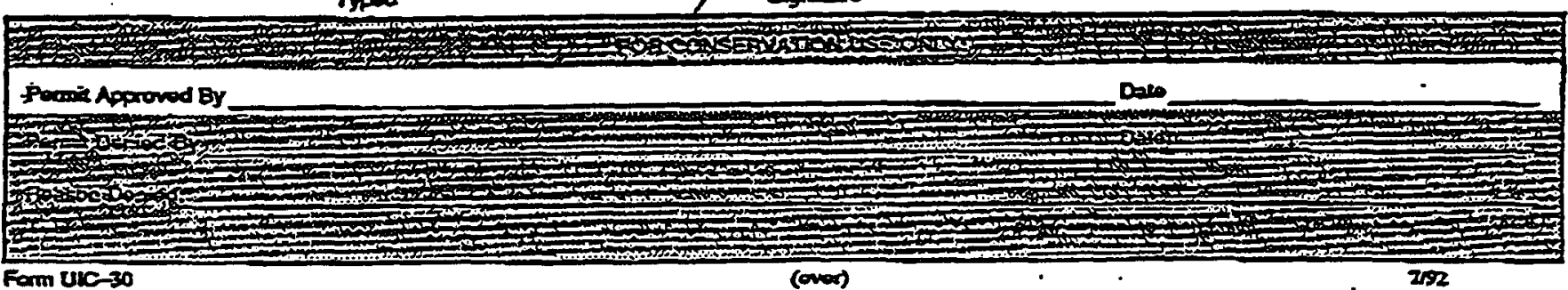


Work Permil
STATE OF LOUISIANA DEPARTMENT OF CONSERVATION

Well Name \& No. DOE/EOC Willis Hulin \#I

Field. South_Erath

Permit Seriol No. _- $158 \underline{1} \underline{6}$

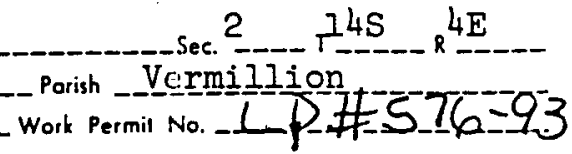

Description of Work Squeeze_perfs with 150 sks_at 21 2059__ut 6"_at 6000!

Spot cmt plug from 6200 to $5800^{1}$ Cut 2 2/8 at 4000 , spot_cmt

plug from 4200 to $3800^{\prime}$ Cut 11 3/4 at 3000 ', spot plug from.

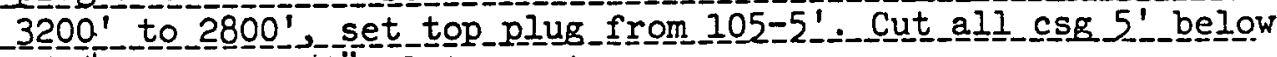

$G / L$ and weld $1 / 2 "$ plate on top.

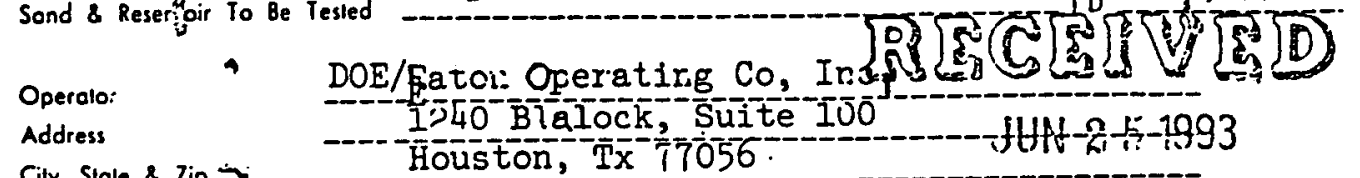

Gily, Slale \& Zip $>$

$\cdot \cdot-$

Permil Requested By

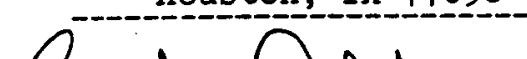

LAFAYETTE DISTRICI OFFICE

Permit Requesled By

Permil Authorized By

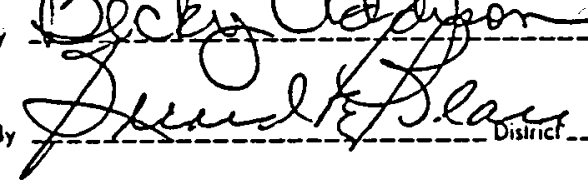

See Inslruclions On Reverse Side

OF CONSERVATIRN $15-93$
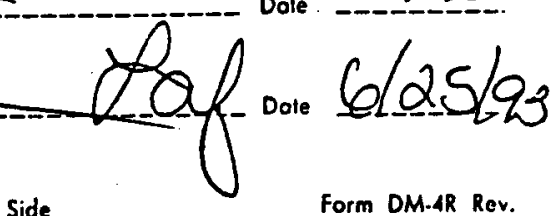

Exhibit 6-C

$\because$

Work Permit

STATE OF LOUISIANA DEPARTMENT OF CONSERVATTON

Well Name \& No. Willis Hullin_CVW_\#I-_-

Field ._South_Erath

Description of Work - Squeeze perfs_at 6590-6530 with 100 sks. s. spot_plug.

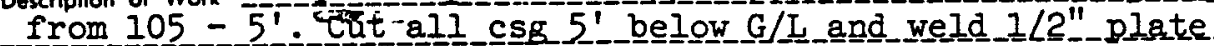

on top.

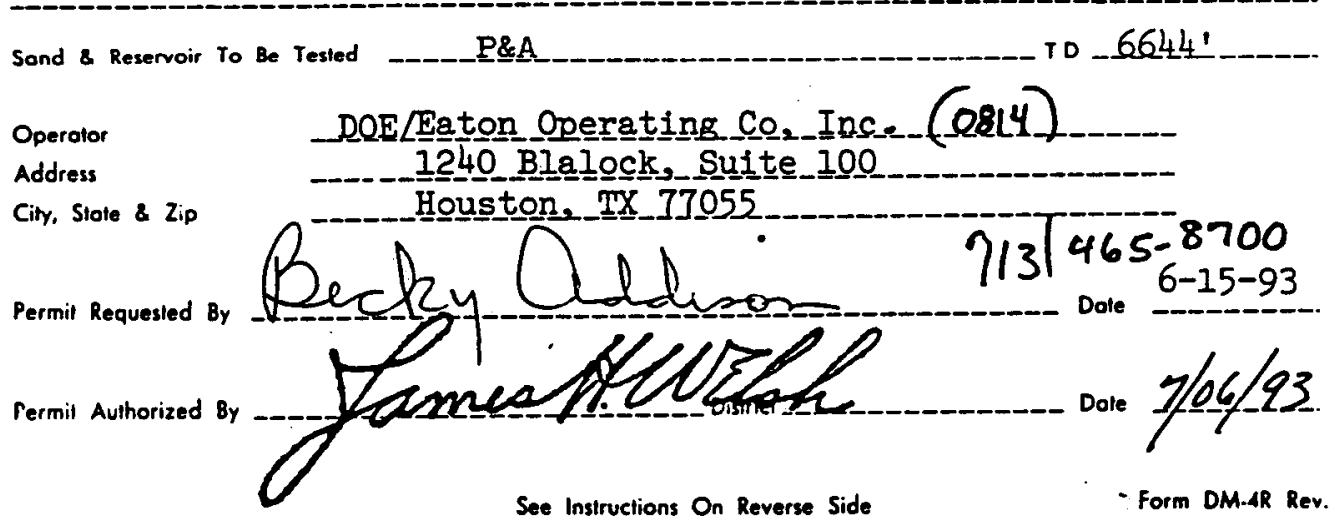


STATE OF LOUISIANA

OFFICE OF CONSERVATION

PLUG AND ABANDON REPORT

WORK PERMIT NO.

LP. \# 575-93

WELL SERIAL NO.

174825
TOTAL DEPTH
LAFAYEITE DISTRICT
DATE WORK FINISHED (MM-DD-M
$11-3-93$
(Three Copies to be Filed with the District Otfice)

NOTE: This Report Will Be Retumed if Not Properly Completed And Signed
Field
CRAB LAKE
Parish
CAMERON
Sec. 27 Twp. $15 \mathrm{~S}$ Rge. $5 \mathrm{~W}$
Operator DOE

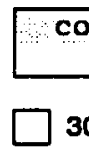
Well Name
DOE GLADYS MCCALL
Well No. 1
comandowion be $\square 29$ DAY HOLE
30 FORMERLY ACTIVE
18 TEMPORARILY ABANDONED (All But Top Plug Set)

Depth Casing Cut Below Plow Depth Or Mud Line 5

Weight of Mud Left In Well After Abandonment 15.8

Setting Depths Of Bridge Plugs And/Or Cement Retainers

Is This Well A Multiple Completion? Yes Other Serial No(s). In Space Provided.

No $\mathrm{X}$ - If Yes, Submit Additional Repon For Other Well(s) And Indicate

\begin{tabular}{|c|c|c|}
\cline { 2 - 3 } \multicolumn{1}{c|}{} & CASING & CASING \\
\hline 301 & SIZE & PULLED \\
\hline 302 & $7^{\prime \prime}$ & 3000 \\
\hline 303 & & \\
\hline 304 & & \\
\hline 305 & & \\
\hline 306 & & \\
\hline 307 & & \\
\hline
\end{tabular}

\begin{tabular}{|c|c|c|c|c|}
\hline अ। & ॥: & & MENT PLUG: & \\
\hline FROM & TO & NO SACKS & SLURAY WT & १PLACEMENT METHOD \\
\hline 15479 & 15160 & 150 & 15.5 & CMT SYSTEM \\
\hline 3100 & 2900 & 75 & 15.5 & CMT SYSTEM \\
\hline 100 & 5 & 10 & 15.5 & CMT SYSTEM \\
\hline & & & & \\
\hline & & & & \\
\hline & & & & \\
\hline & & & & \\
\hline
\end{tabular}

- List Casing Sizes And Plug Depths In Descending Order

Remarks: CUT AT CASING 5' BETOW G/L

This work was done according to the Rules and Regulations of the Office of Conservation.

\section{$\frac{\text { Aouglas Touchet }}{\text { WITNESS }}$}

ronu ras (ReV was)
DOE

Decky OPERATOR (Company Name)




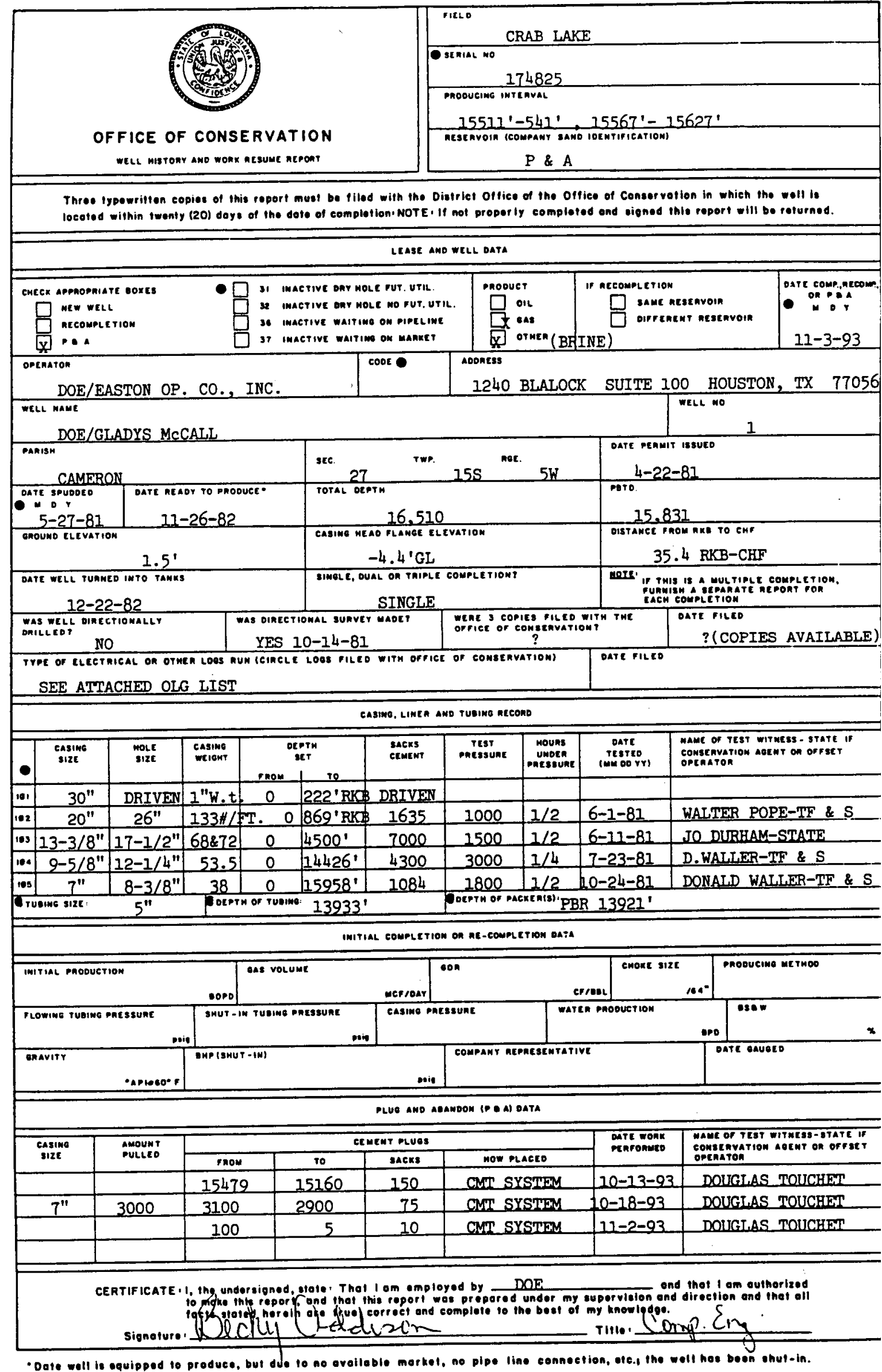




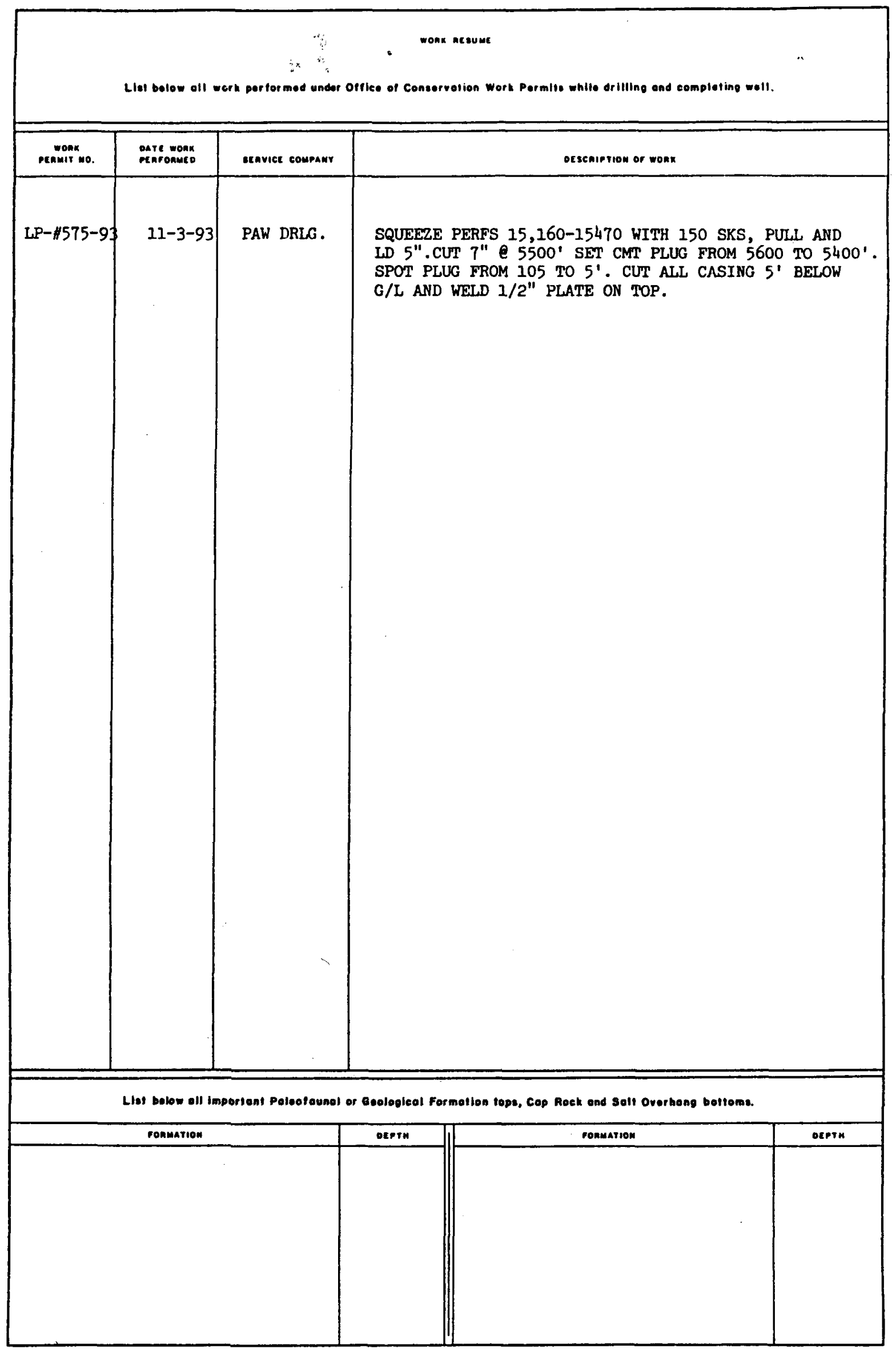


STATE OF LOUISIANA

OFFICE OF CONSERVATION

PLUG AND ABANDON REPORT

WORK PERMIT NO. 012699

WELL SERIAL NO.

159587

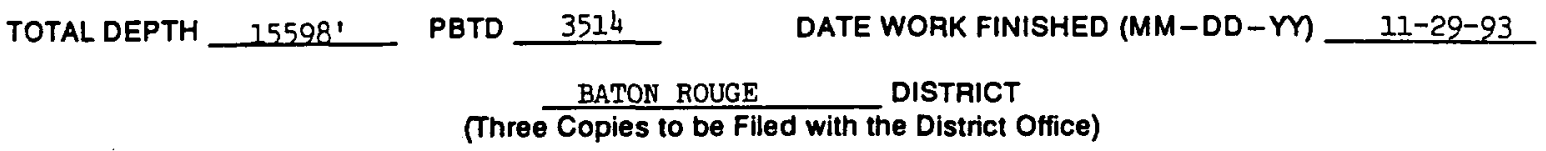

NOTE: This Report Will Be Returned If Not Properly Completed And Signed

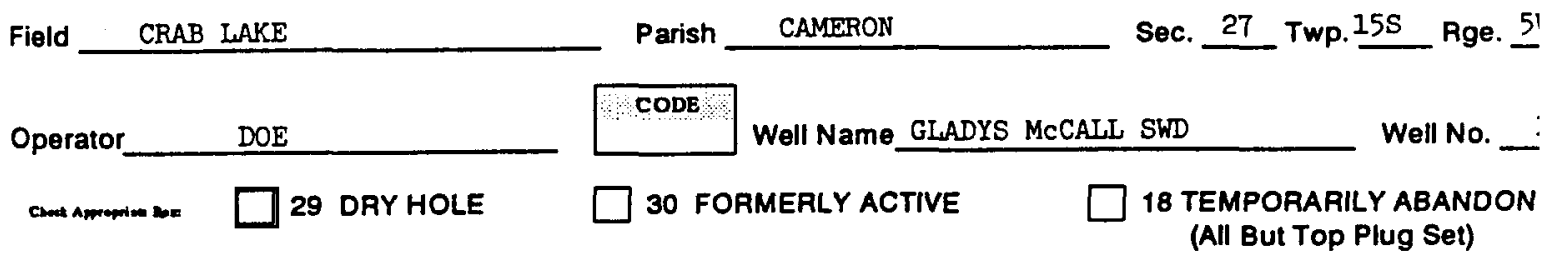

Depth Casing Cut Below Plow Depth Or Mud Line $55^{\prime} \quad$ Weight of Mud Left in Well After Abandonment 9 \#\#

Setting Depths Of Bridge Plugs And/Or Cement Retainers

is This Well A Multiple Completion? Yes

No $\mathrm{X}$ - If Yes, Submit Additional Report For Other Well(s) And Indica Other Serial No(s). In Space Provided.

\begin{tabular}{|c|c|c|}
\cline { 2 - 3 } \multicolumn{1}{c|}{} & CASING & CASING \\
\hline 301 & SIZE & PULLED \\
\hline 302 & $103 / 4$ & 2019 \\
\hline 303 & & \\
\hline 304 & & \\
\hline 305 & & \\
\hline 306 & & \\
\hline 307 & & \\
\hline
\end{tabular}

\begin{tabular}{|c|c|c|c|c|}
\hline & \multicolumn{5}{|c|}{ CEMENT PLUGS } \\
\hline FROM & TO & NO, SACKS & SLUAAYWT & PLACEMENT METHOD \\
\hline 3030 & 1876 & 475 & 15.5 & CMT SYSTEM \\
\hline 55 & 5 & 27 & 15.5 & CMT SYSTEM \\
\hline & & & & \\
\hline & & & & \\
\hline & & & & \\
\hline & & & & \\
\hline
\end{tabular}

-List Casing Sizes And Plug Depths In Descending Order

Remarks: CUT ALI CASING 5' BELOW G/L \& WELD 1/2" PLATE ON TOP.

This work was done according to the Rules and Regulations of the Office of Conservation.

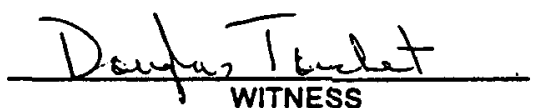

ronu ras (Rev wo)
DOE

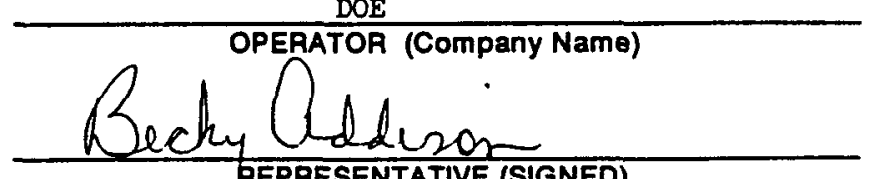

AEPAESENTATIVE (SIGNED) 


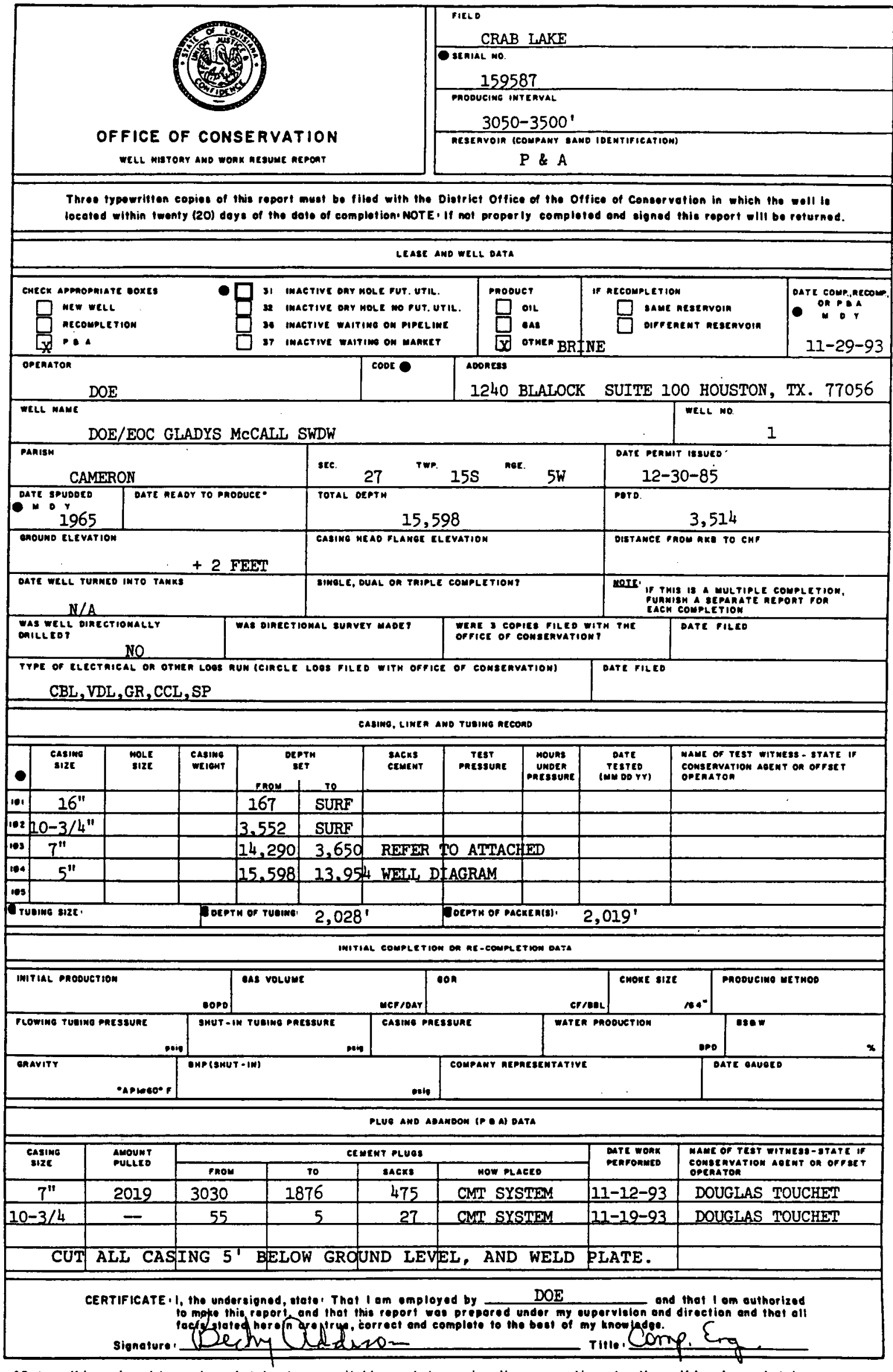

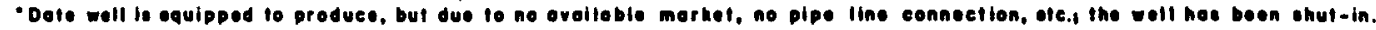




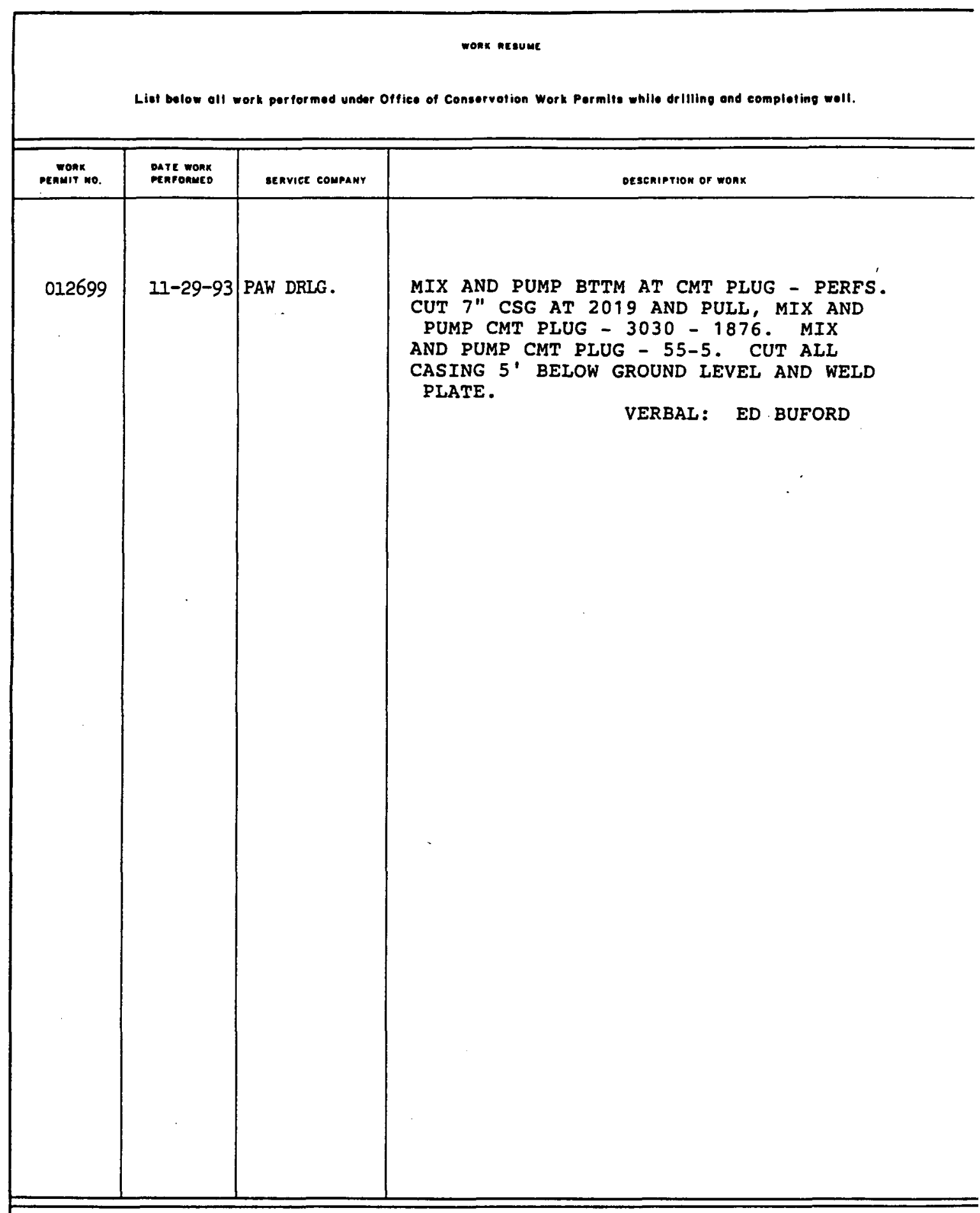

Llat bolow all important Paloofounal or Goologieal Formation tops, Cop Roek and Salt Overhong bottoms.

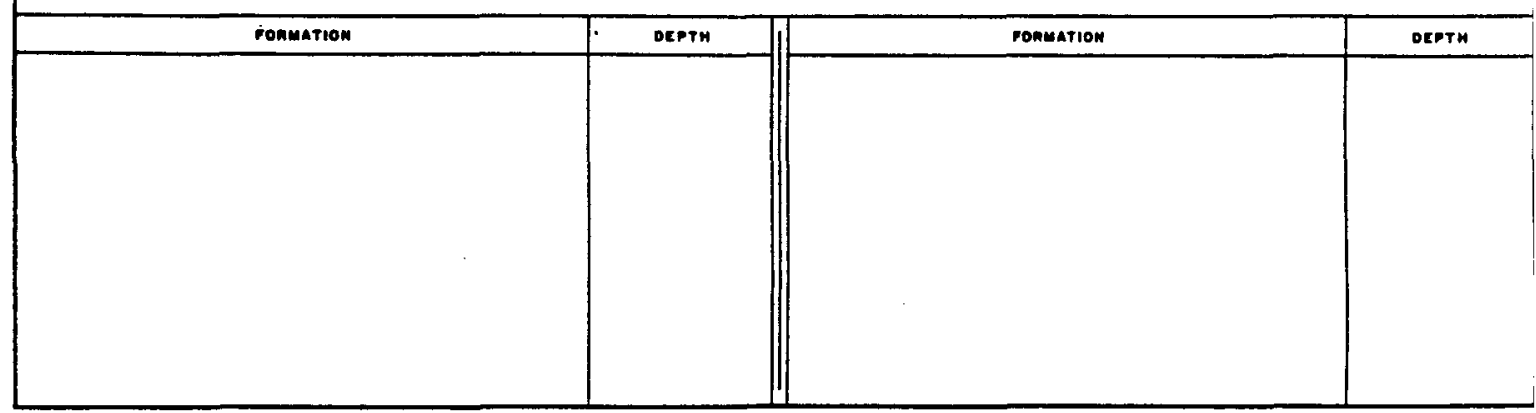




\section{STATE OF LOUISIANA \\ OFFICE OF CONSERVATION \\ PLUG AND ABANDON REPORT}

WORK PERMIT NO. LP \#131-94

WELL SERIAL NO. 158468
TOTAL DEPTH 21,559 PBTD 21,225
DATE WORK FINISHED (MM-DD-Y) 3-11-94

$$
\text { (Three Copies to be Filed with the District Office) }
$$

NOTE: This Report Will Be Returned If Not Properly Completed And Signed

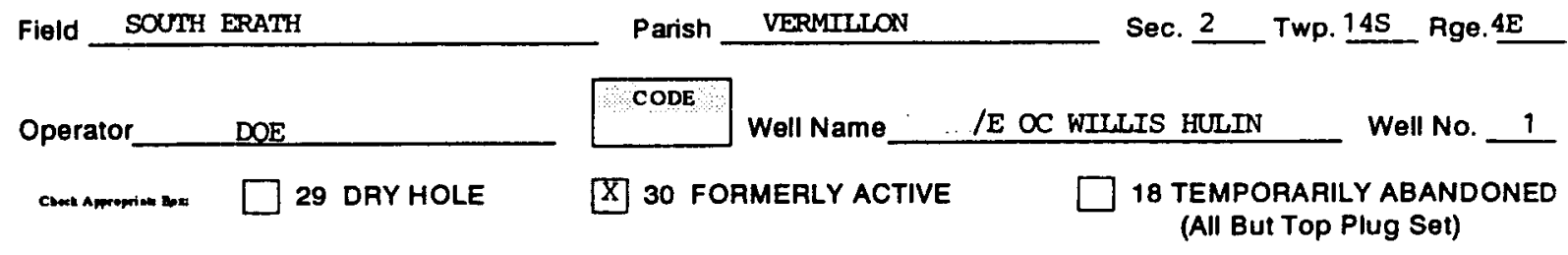

Depth Casing Cut Below Plow Depth Or Mud Line _ $5 \quad$ Weight of Mud Left In Well After Abandonment 18

Setting Depths Of Bridge Plugs And/Or Cement Retainers

Is This Well A Multiple Completion? Yes___No N_ - If Yes, Submit Additional Report For Other Well(s) And indicate Other Serial No(s). In Space Provided.

\begin{tabular}{|c|c|c|c|c|}
\hline \multirow{3}{*}{\begin{tabular}{|l|} 
FAOM \\
21.059 \\
\end{tabular}} & \multirow{2}{*}{ TO } & \multicolumn{2}{|c|}{ CEMENT PLUGS } & \multirow{2}{*}{ P. PLACEMENT METHOD } \\
\hline & & NO. & SLUAAYWT & \\
\hline & 20.220 & $3 m$ & daSS H & BIHAFES \\
\hline 6.200 & 5,800 & 250 & & CMT SWSIEM \\
\hline 4200 & 3,800 & 200 & 15.5 & OML SVSIIM \\
\hline 3235 & 3,035 & 90 & 15.5 & CMT SKSTEM \\
\hline $30 \mathrm{~m}$ & $2,8 \mathrm{~m}$ & 255 & 15.5 & OMT STSIEM \\
\hline 2500 & 2,300 & 250 & 15.5 & aNT SKSIIM \\
\hline 10,00 & 800 & 200 & 15.5 & gT SYSTIEY \\
\hline
\end{tabular}

\begin{tabular}{|c|c|c|}
\cline { 2 - 3 } \multicolumn{1}{c|}{} & CASING & CASING \\
\hline 301 & & PULE \\
\hline 302 & $6^{\prime \prime}$ & 6000 \\
\hline 303 & $95 / 8$ & 4000 \\
\hline 304 & $113 / 4$ & 3000 \\
\hline 305 & & \\
\hline 306 & & \\
\hline 307 & & \\
\hline
\end{tabular}

Remarks: CUT ATI. CASING 5' BELOW GROUND TEVEI.

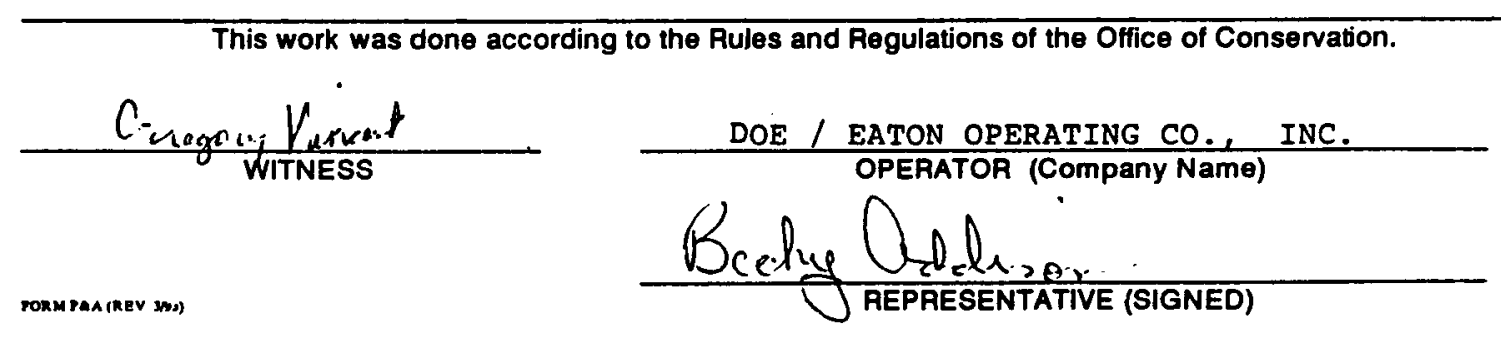




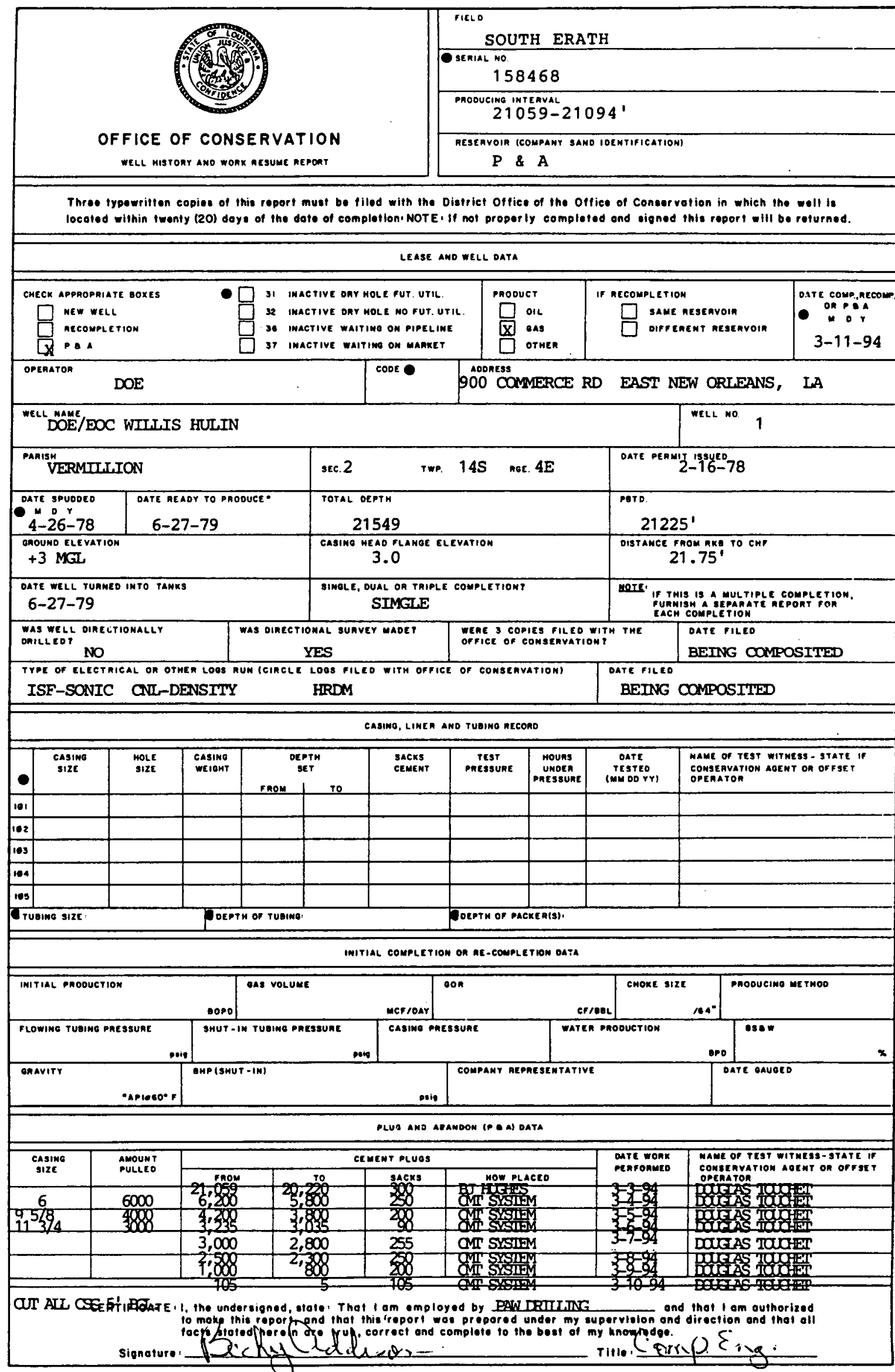

- Date well is equipped to produce, but due to no ovalloble morket, no pipe line connection, ote, the well has been thut-in. 


$$
\frac{15}{I I}
$$


WORK PERMIT NO. 012314

TOTAL DEPTH PBTD

WELL SERIAL NO. 972009 DATE WORK FINISHED (MM-DD- $Y$ ), 3-7-94 BATON ROUGE DISTRICT (Three Copies to be Filed with the District Office)

NOTE: This Aeport Will Be Retumed If Not Properly Completed And Signed

Field SOUTH ERATH

Operator DOE EATON OPERATING COMPANY
29 DRY HOLE
Parish VERMIITION

\section{CODB}

0814

[X] 30 FORMERLY ACTIVE
Sec. 2 Twp. 145 Age. 4E Well No. 1

Depth Casing Cut Below Plow Depth Or Mud Line 5 (All But Top Plug Set)

Setting Depths Of Bridge Plugs And/Or Cement Petainers

Is This Well A Multiple Completion? Yes No $X$ - If Yes, Submit Additional Report For Other Well(s) And Indica Other Serial No(s). In Space Provided.

Weight of Mud Left In Well After Abandonment 9.6

\begin{tabular}{|c|c|c|}
\cline { 2 - 3 } \multicolumn{1}{c|}{} & CASING & CASING \\
\hline 301 & & PULLED \\
\hline 302 & & \\
\hline 303 & & \\
\hline 304 & & \\
\hline 305 & & \\
\hline 306 & & \\
\hline 307 & & \\
\hline
\end{tabular}

\begin{tabular}{|c|c|c|c|c|}
\hline \multicolumn{5}{|c|}{ 1.7\%, } \\
\hline FAOM & \%O & NO SACKE & SLUARYWT & PPACEMENT METHOD \\
\hline 6590 & 6530 & 105. & 15.5 & ans sumpM \\
\hline 105 & 5 & 35 & 15.5 & OMT SWIIFM \\
\hline & & & & \\
\hline & & & & \\
\hline & & & & \\
\hline & & & & \\
\hline 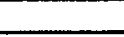 & 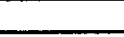 & 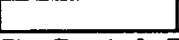 & 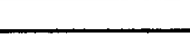 & 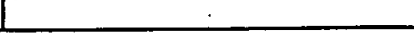 \\
\hline
\end{tabular}

-List Casing Sizes And Piug Depths In Descending Order

Remarks: OII ATI. OSTIE 5' ETOW GROND IEVT.

.....:

This work was done according to the Rules and Regulations of the Office of Conservation.

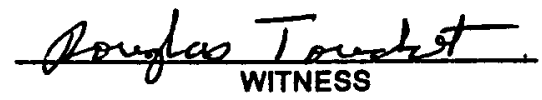

POAM rea (ReV ms)
DEE EATON CFRATING D., InC. OPERATOR (Company Name)

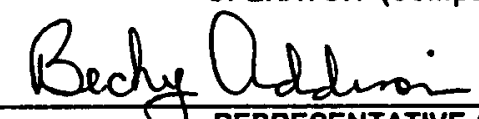

REPAESENTATIVE (SIGNED) 


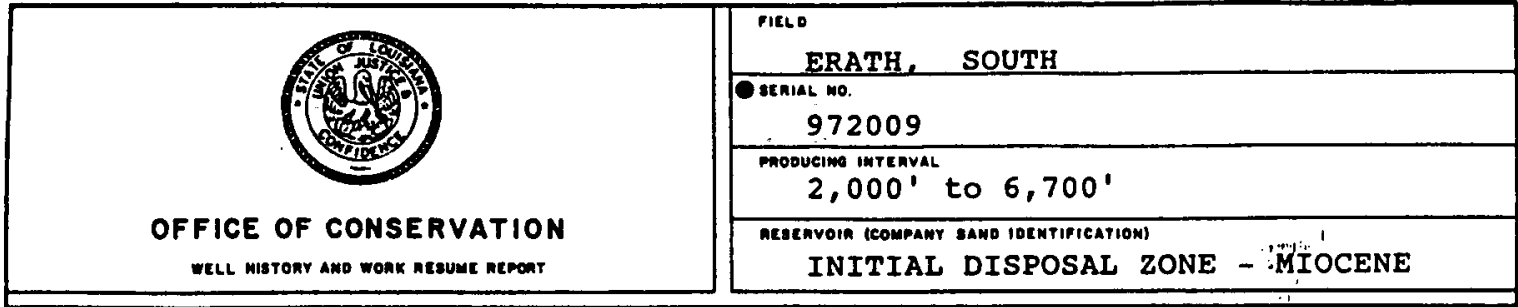

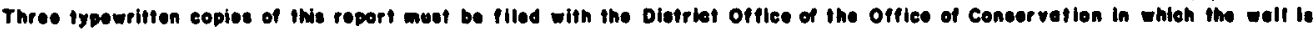
loested within twenty (20) days of the date of eomplotion NOTE. If not properity completed ond signed thle report will be refurned.

LEABE AMO WELL DATA

\begin{tabular}{|c|c|c|c|c|c|c|}
\hline cueck & $\begin{array}{l}\text { APONOPMIATE Doxes } \\
\text { MEW WEL } \\
\text { MECOMPLETHON } \\
\text { a A }\end{array}$ & 3e & 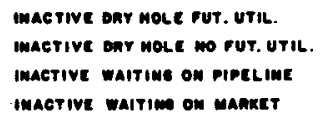 & $\begin{array}{l}\square \text { oll } \\
\square \text { onoduct } \\
\square \text { otwer-SA }\end{array}$ & 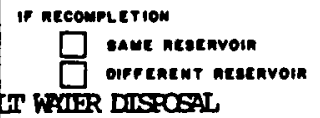 & $\mid \begin{array}{l}\text { Date componecom } \\
\text { of ? in } \\
3-7-94\end{array}$ \\
\hline
\end{tabular}

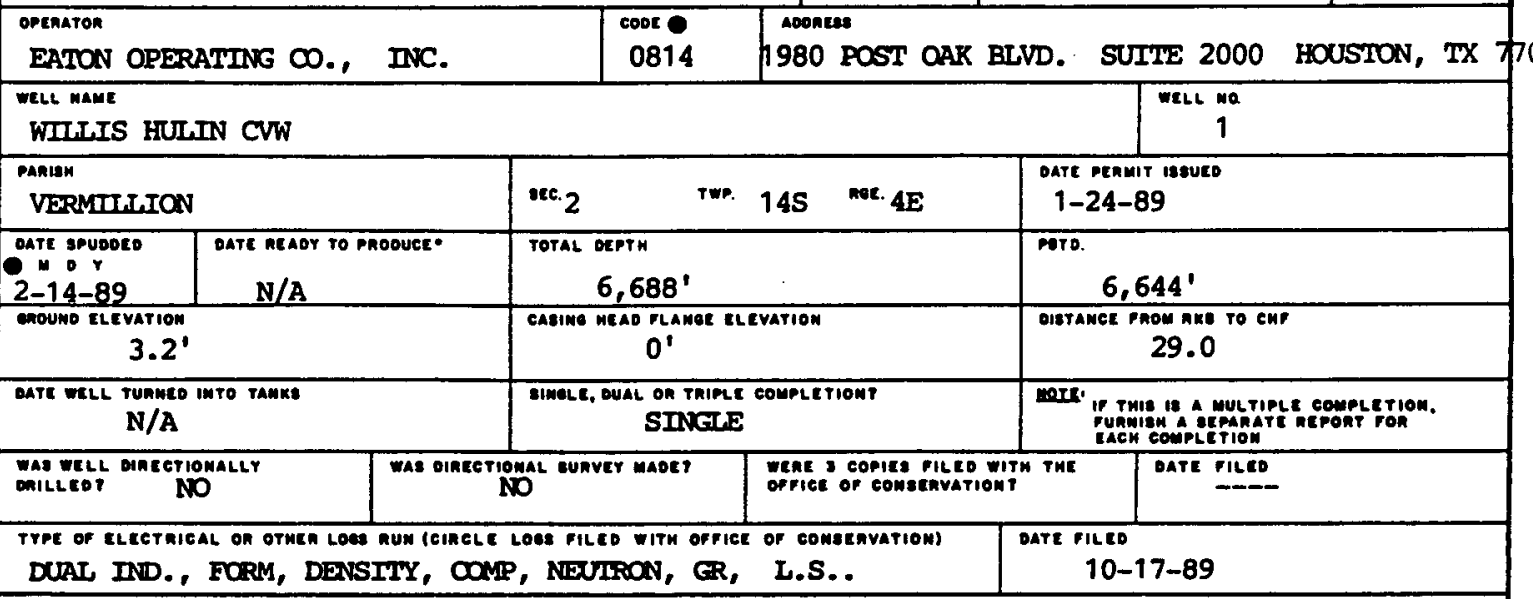

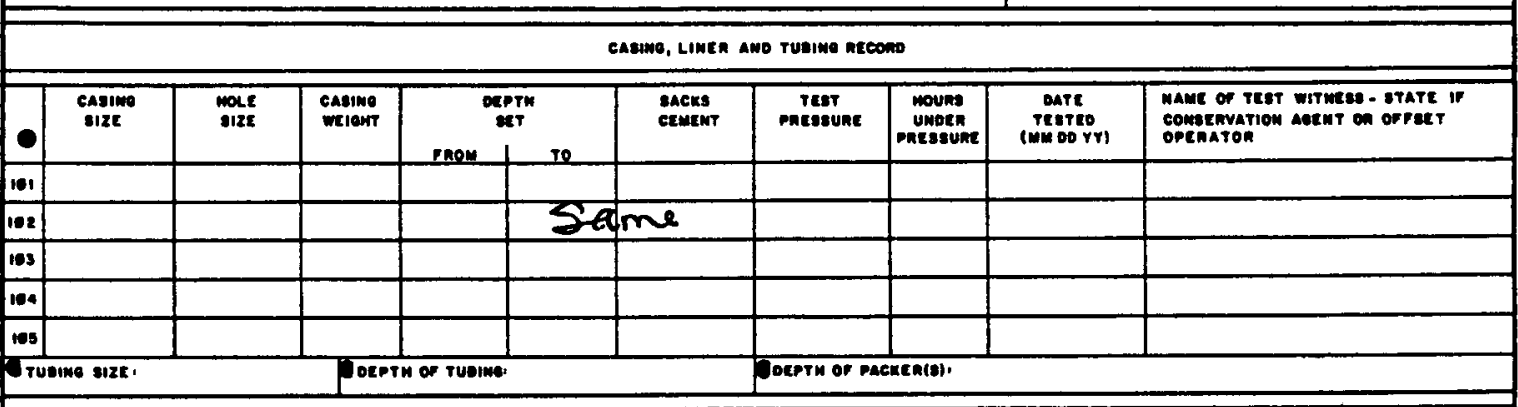

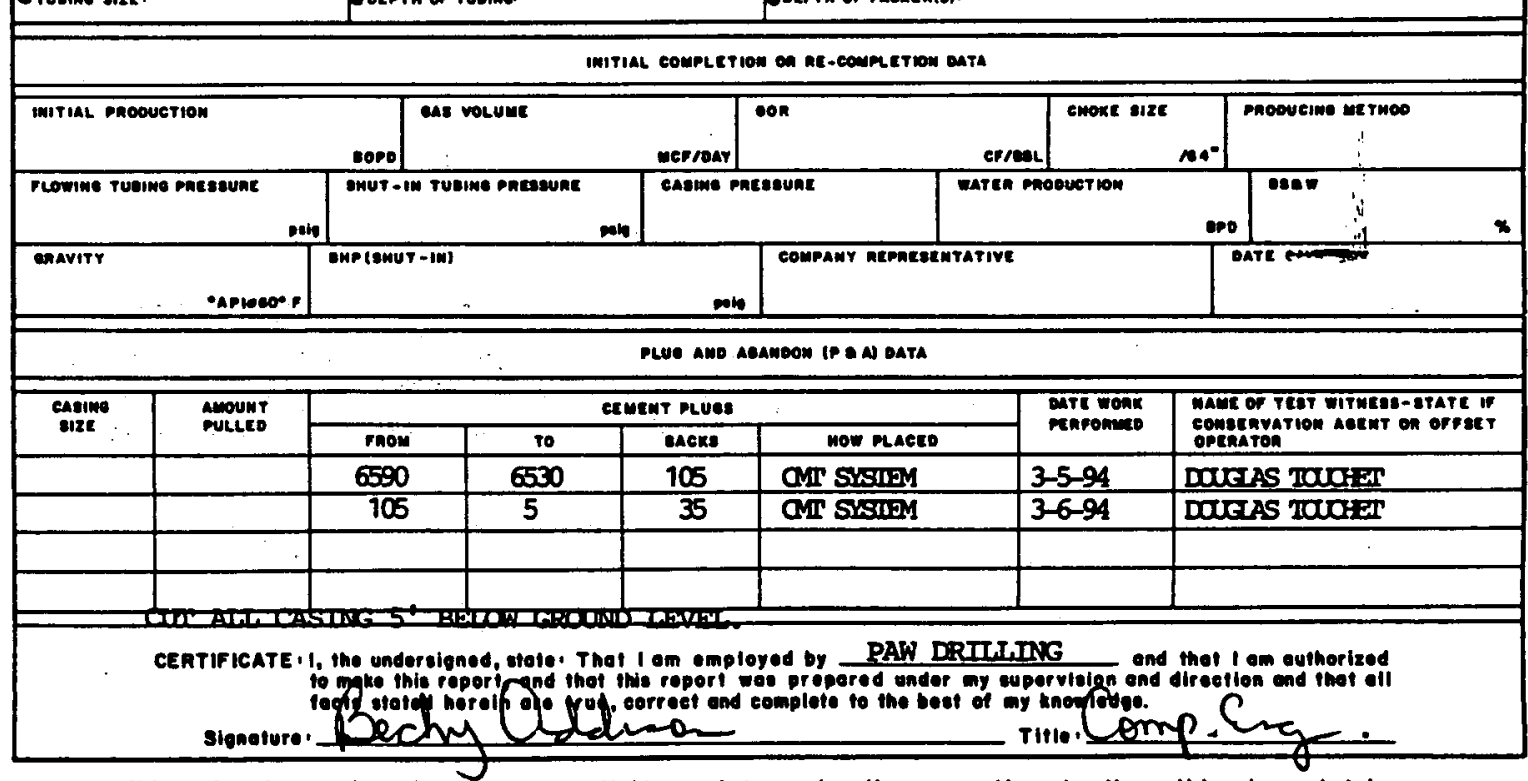

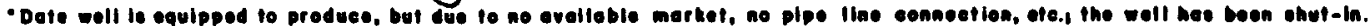




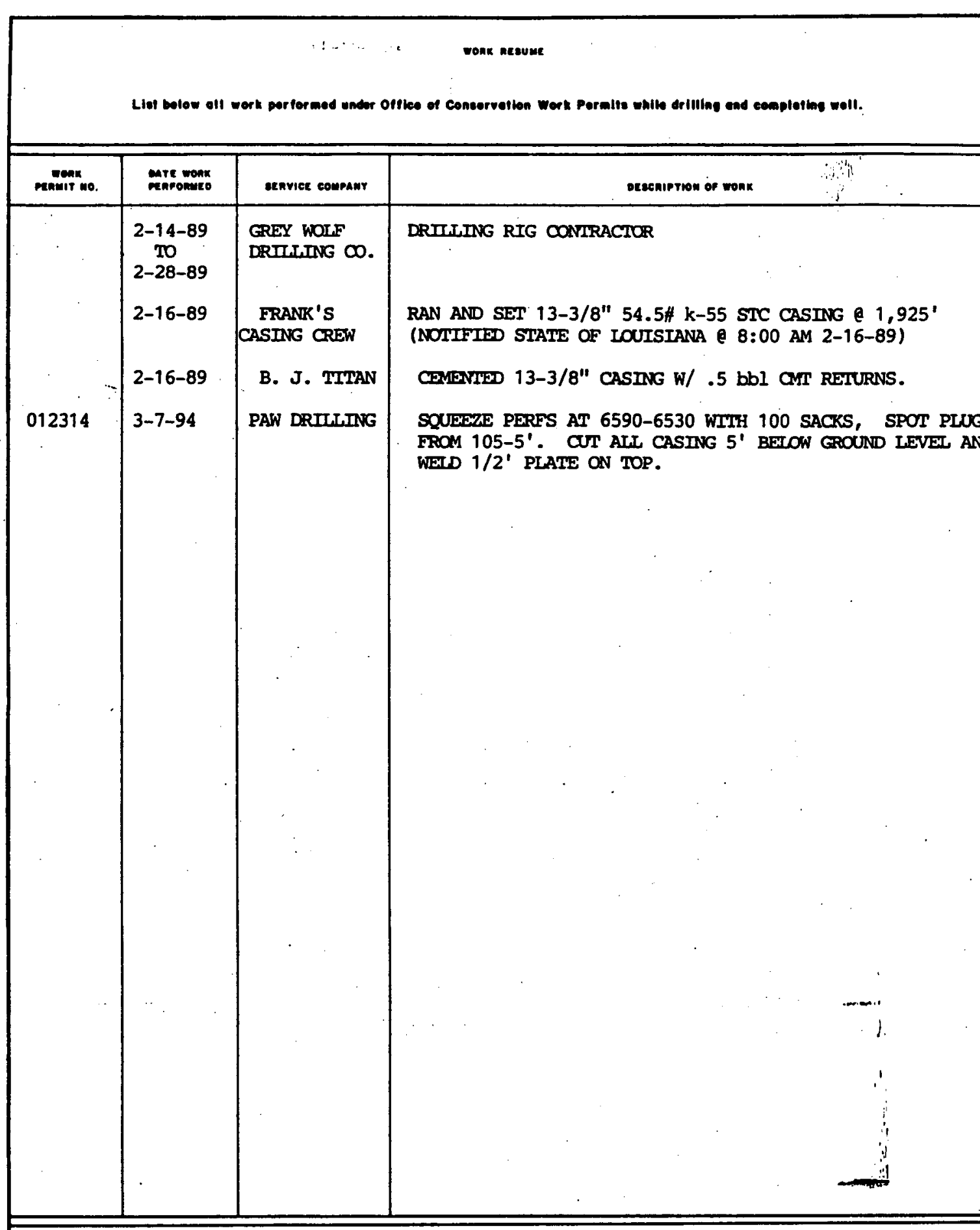

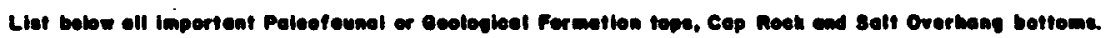

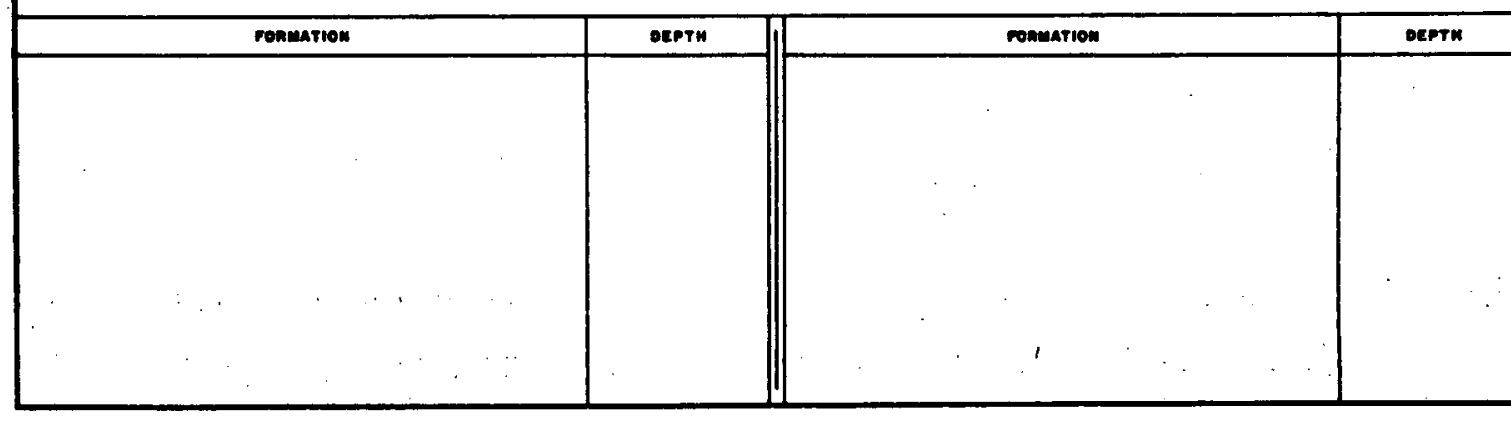


COMPANY: EATON OPERATING

WELL \#: MCCALL \#1

BID \# : 0117-017

FILE \#: 0117-054

API \#:
DATE: $01 / 27 / 93$

LOCATION: CAMERON PA, LA

STATUS: APPROUED

SUBMITTED: $03 / 18 / 93$ LEASE/WELL \#:

P\&A PROCEDURE

Provided by PaW Drilling \& Hell Service, Inc.

1. Check and record all tubing and casing pressures. Fill tubing and casing with 15.8 \#/gal plug mud. Kill well as needed. Mote: If cannot pump into well we will run a thru tubing plug through $7 "$ casing \& pump 100' cmt on top of plug. Bleed pressure and pump an additional cement plug at 14,000'. All 'calcium chloride and/or brine water will be pumped into existing SWD.

2. Rig up pump on 5" P-110 tubing and bullhead squeeze the perfs down the 5" tubing with 100 sx Class " $H$ " cement. Displace cement with 300bbls plug mud. Plug will be from $15,470^{\prime}$ to $15,160^{\prime}$. Let plug set a minimum of 24 hours. Presure test or tag plug.

3. Move on location w/ P\&A equipment. Hold safety meeting, discuss procedures and work schedule.

4. Release packer and $\mathrm{POOH} w / 5 "$ tubing. Lay down tubing. Note: If unable to release packer cut $5^{\prime \prime}$ tubing above packer. Fill wellbore w/ sufficient weighted plug mud (9.0H/gal min).

5. GIH $w / S / L$ and explosive charge. Cut $7 "$ casing at $+/-5,500^{\prime}$. Lay down casing.

6. Pick up workstring and RIH to casing stub $\mathrm{e}+/-5,500^{\prime}$. Pump 60 sx cement plug from 5,600' to 5,400' (100' in and 100' out).

7. POOH w/ tubing. Pump 10 sx cemcnt plug from $33^{\prime}$ to $3^{\prime}$.

8. Cut 9 5/8", 13 3/8", 20", and 30" casing 3' below ground level and weld steel plate on top of casing.

9. Restore location to condition prior to På operation. RDMO.

Note: If required by state regulations, all plugs to be pressure tested or tagged and an additional plug will be placed accross the lowest known USDW. 
Workover

Drilling

Turnkoy

Onehore

Ottshore
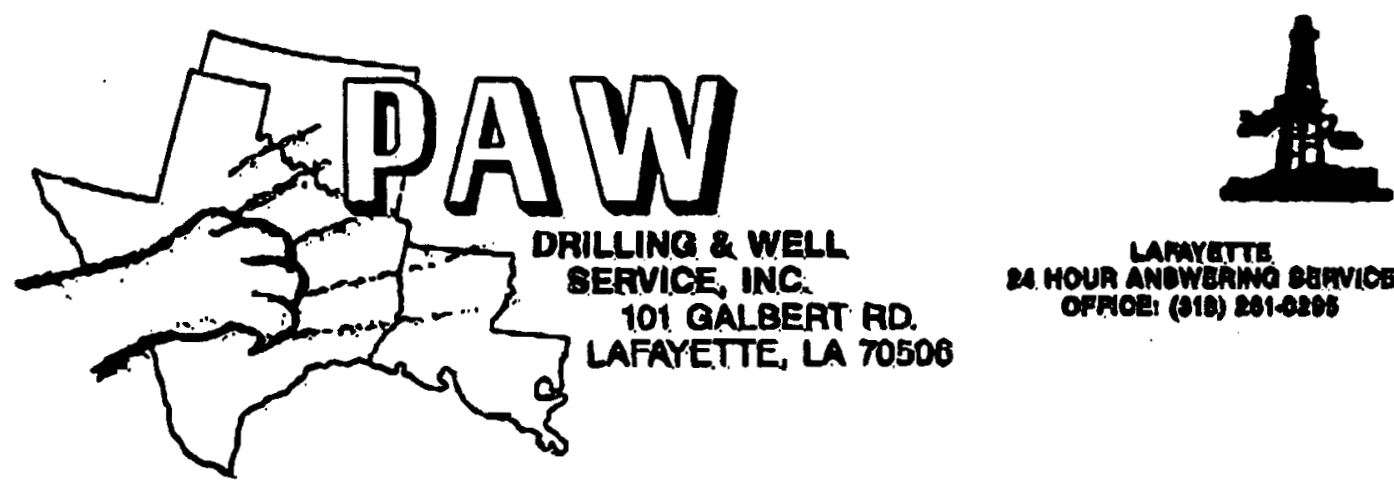

P A A PROCEDURE - G MCCALI SWD - GRAND CHENIER, IA

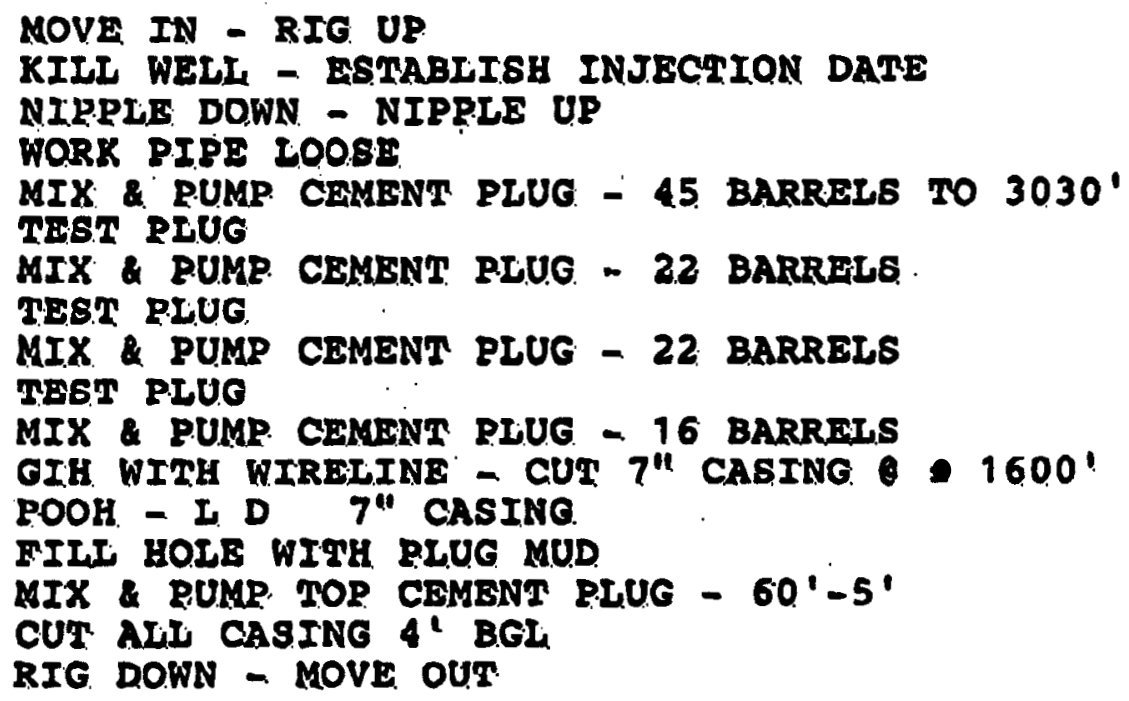


Prouided by PaW Drilling \& Well Service, Inc.

- $\quad$ 1. Bullhead squeeze the open perfs down the $31 / 2$ "-tubing with 100 sacks Class " $H$ " cement + retarder and displace with 200 bbls of plug mud: (Plug will be from 20,700' to 20,200'. Let plug set for a minimum of 24 hours.

If unable to pump into well, set CIBP inside $31 / 2^{\prime \prime}$ tubing at 'packer. perforate $31 / 2$ " tubing above CIBP and circulate sufficienzement to leave $300^{\circ}$ plug inside $31 / 2$ " tubing and 300 cement plug inside the $31 / 2^{\prime \prime} \times 6^{\prime \prime}$ annulus. Set additional CIBP aboue cement in $31 / 2$ " tubing. (Note: Gas cap and diesel to be bled off before bullhead squeeze.)

2. Move on location w/ P\&A equipment. Hold safety meeting, discuss procedures and work schedule.

3. Check and record all tubing and casing pressures.

4. Release from Backer FB-1 packer and $\mathrm{POOH} w /$ tubing. Note: If unable to release from packer see step 1 above.

5. RU S/L and cut $6^{\prime \prime}$ casing at $+/-6,000^{\circ}$. $\mathrm{POOH}$ and lay down 6" casing.

6. RIH open-ended to casing stub $\left(+/-6,000^{\prime}\right)$ and pump a $200^{\prime}$ cement plug from $7,000^{\prime}$ to $5,000^{\prime}$. $\mathrm{POOH}$ with tubing.

7. RU S/L and cut 9 5/8" casing at $+/-3,150^{\prime} \mathrm{POOH}$ and lay down casing.

8. RU S/L and cut $113 / 4^{\prime \prime}$. casing at $+/-3,000^{\prime}$. POOH and lay down casing .

9. RIH open ended to $3,250^{\prime}$. Pump 315 sx cement plug from $3,250^{\prime}$ to $2,900^{\prime}$.

10. POOH w/ tubing. Pump 35 sx cement plug from $33^{\prime}$ to $3^{\prime}$.

11. Cut 16" and 30" casing 3' below ground level and weld steel plate on top of casing.

12. Restore location to condition prior to P\&A operation. RDMO.

Note: If required by state regulations, all plugs will be pressure tested or tagged and an additional plug will be placed accross the lowest known USDW. 
BID \#: 0305-035

FILE \#: 0305-116

API \#:

DATE: $03 / 10 / 93$

LOCATION: UERMILLION PA, LA

STATUS: APPROUED

P\&A PROCEDURE

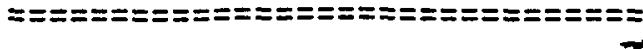

Provided by PAW Drilling \& Well Seruice, Inc.

1. Move on location $w / P \& A$ equipment. Hold safety meeting, discuss procedures and work schedule.

2. Check and record all tubing and casing pressures and kill well with FSW if necessary. RIH $w / S / L$, to determine sand $f i l l$ in casing. If sand $f i l l$ is encountered above perfs, PU 2 3/8" workstring and wash down to perfs. POOH w/ workstring.

3. Bullhead squeeze 50 sack cement plug from 6,590' to 6,530'. Release from packer and circulate $9.0 \# / g a l$ plug mud to surface.

4. POOH w/ tubing. Pump 15 sx cement plug from 33' to $3^{\prime}$.

5. Cut 9 5/8" and $133 / 8^{\prime \prime}$ casing 3' below ground level and weld steel plate on top of casing.

6. Restore location to condition prior to P\&A operation. RDMO.

Note: If required by state regulations, all plugs will be pressure tested or tagged and an additional plug will be placed accross the lowest known USDW. 


\section{EXHIBIT 6-M}

\section{PAW Drilling \& Well Service, Inc. Daily Workover Reports for Gladys McCall Site From 9-18-93 Through 11-19-93}


Drilung

Wonxow

Complotion

Tem Batery inselabion

Purrom Somos

Salt Wover Wolle

Plus 2 abantion $\int\left[\omega_{0}\right.$

I P ORILUNG \& WELL SERVICE, INC.

T2. 101 GALBEAT RD.

(319) 25, 10295

DAILY WORKOVER REPORT

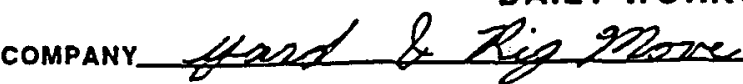

FIELD

LEASE

PARISH OR COUNTY

Present Pertorations

Total Deplh

Present Depth

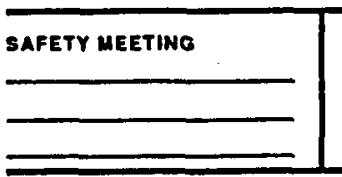

B. O. P. TEST PRESSURES

Rens

Mud Trpe

Hyoril.

Weight Vis

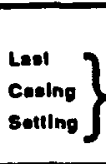

Sotting
PAOOUCTION PAESSURE SETTING

Make 1 Model

Depth
TICKET $580=$

REPORT NO.
DATE $9-18-23$

WELL NO.

RIG NO

Present Packer Senting

Type Plug

\section{Tubing Solting}

$\sin$

Trow

Am

DRLL DEEPER

Cboing Doph

Bit Size.

Opering Depth

Bit Type

Foorage Made

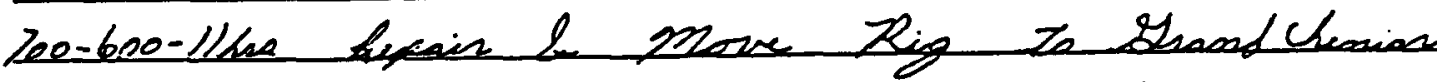

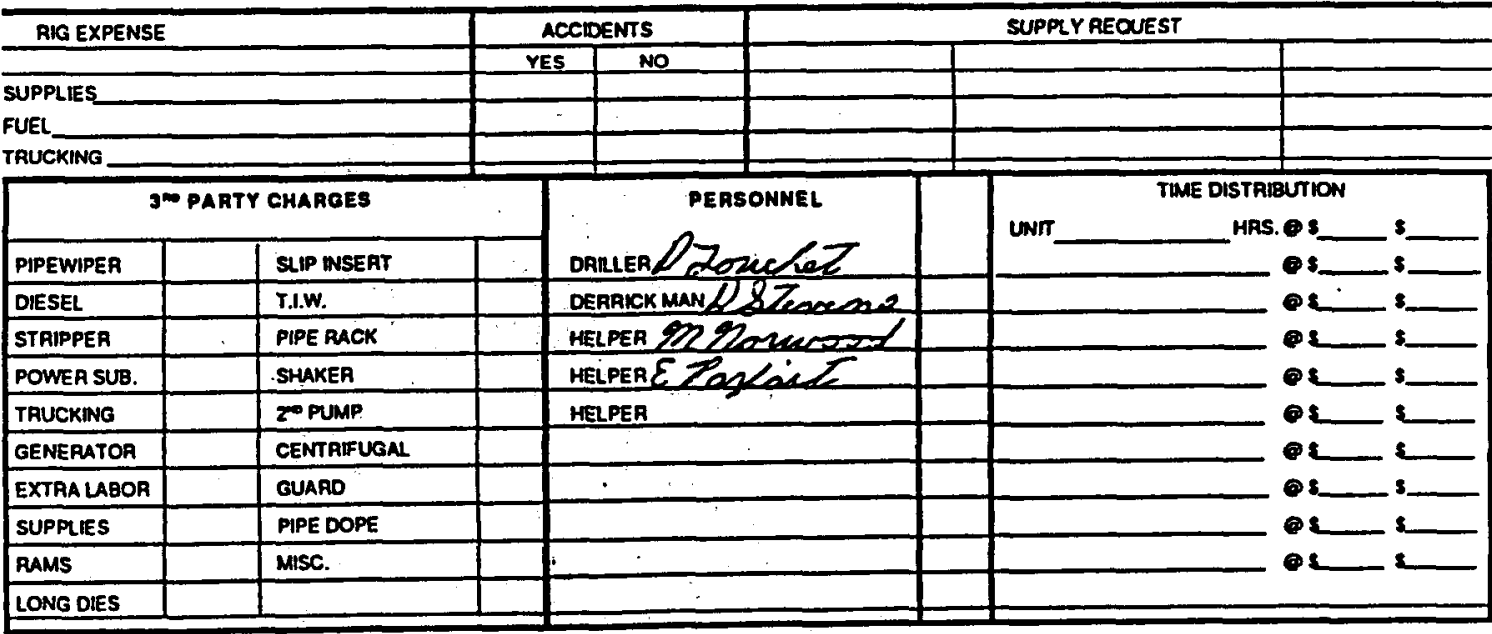

tOOLPUSHer fonglas zouche Z

JOB NO 24.5 ORDER NO.
COMPANY REPRESENTATIVE

CONTRACT NO
JOB

TERMS: NET 30 DAYS. Accounts over 30 days will be charged $11 / 2 \%$ per month not to exceed $18 \%$ ann:lly.

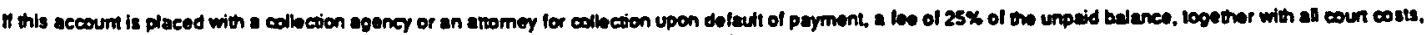
anomeys' loes, garnishment letes and $10 \%$ interest from maturty is hereby authorized.

Exhibit 6-M 
Driting

Wornover

Tent Bestery insterituon

Purroing Sermose

Sult Woin Wels

Plivo \& Abindon

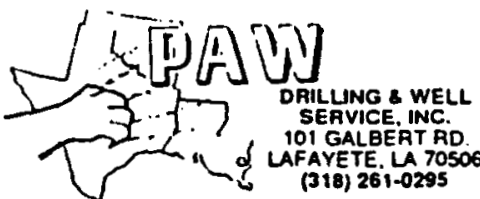

DAILY WORKOVER REPORT
TICKET 5805

REPORT NO. 1

companY DQE

FIELO Sast calt rake LEASE Sladye Mcall DATE $9-20-93$ PARISH OR COUNTY CaconcaOn state Ll2 WELL NO. 1 AIG NO 5

Present Periorations.

Present Packer Setting

Total Depin

Present Depth

Type Plug

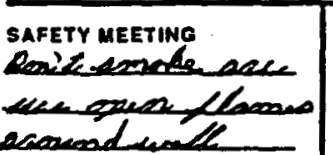
B. O. P. TEST PRESSURES

Aems

Murd Type Hydarl

Woight vis.

$\left.\begin{array}{l}\text { Loot } \\ \text { cooling } \\ \text { sotting }\end{array}\right\}$

\section{Tubino Sorting}

Sine

Troe. Amt

DAMI DEEPER

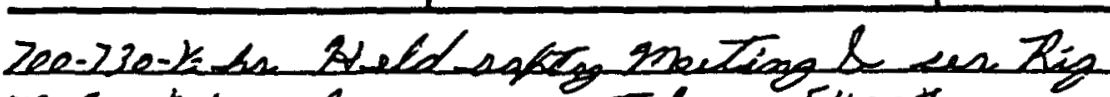

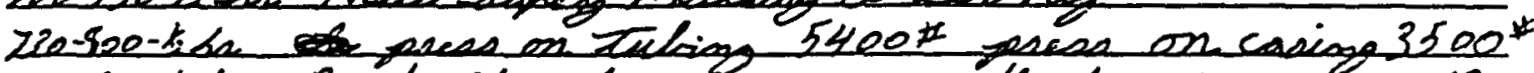

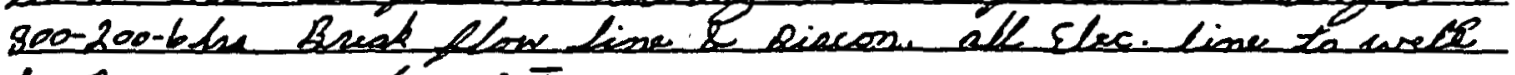
\& Remose work eatateson

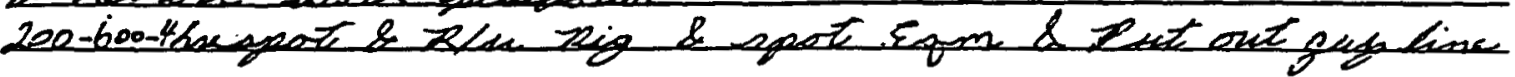

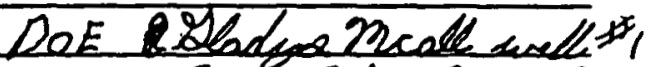
Sec. 27-T/15 B buc East Cal lake field Comenen thais. Ls Senial $n_{0} / 74825$

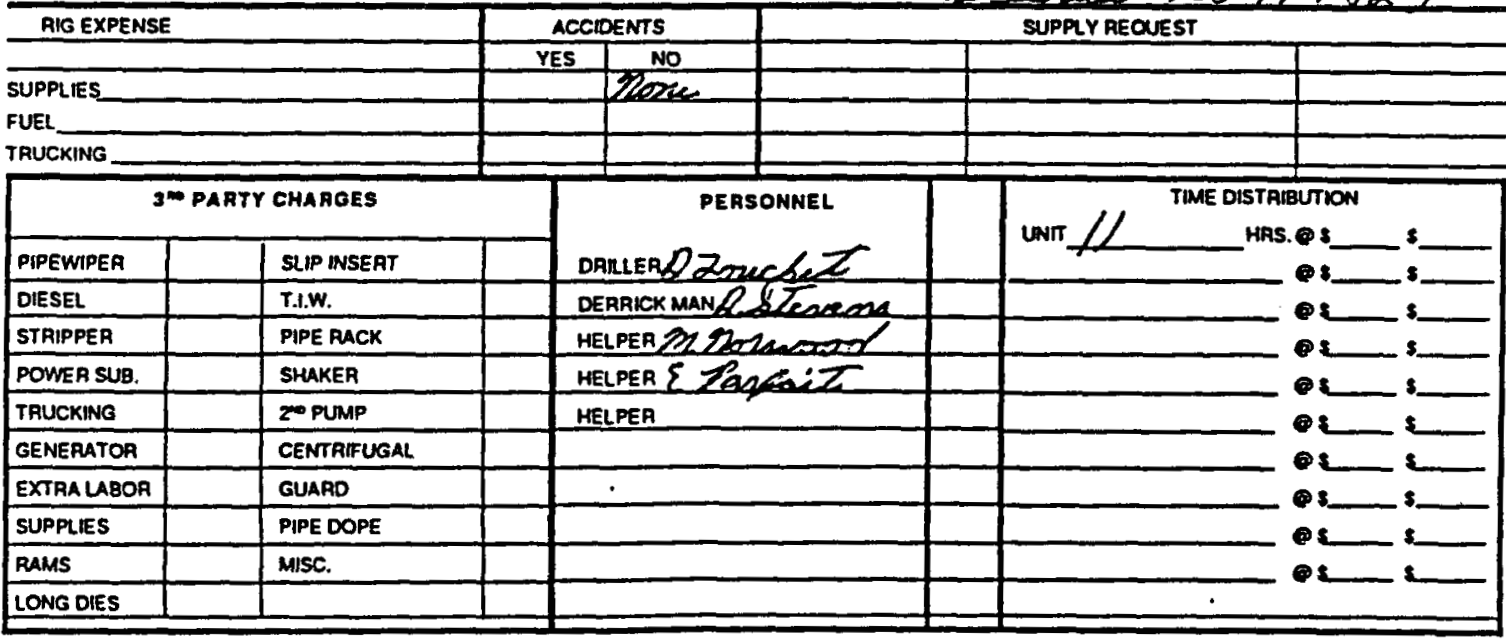

TOOLPUSHER Roughe Zowech T دOB NO $24-5$ ORDER NO.
COMPANY REPRESENTATIVE

CONTRACT NO. $\operatorname{sos} 24-5$

TERMS: NET 30 DAYS. Accounts over 30 days will be charged $11 / 2 \%$ per month not to exceed $18 \%$ annilly.

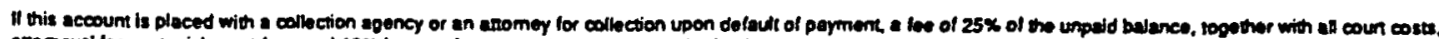
atromeys' kes, gamiehmon kesh and $10 \%$ interest trom manuthy bs hereby authorized. 
Driling

Workover

Complivion

Tunk Eation instanason

Purroing Sermoses

San Water Wolls

Plup 8 abancoon

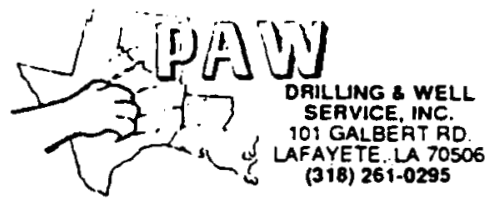

DAILY WORKOVER REPORT
TICKET $580 \%$

REPORT NO. 2

DATE_2-21-93 WELL NO. 1 RIG NO 5

COMPANY $20 E$

FIELD East cask Lake

LEASE Sheadeos 9 meall STATE $2 / 2$

Present Packer Setting

Present Perforations Type Piug

Total Depth Present Depth

Tubing Serting

Szo.

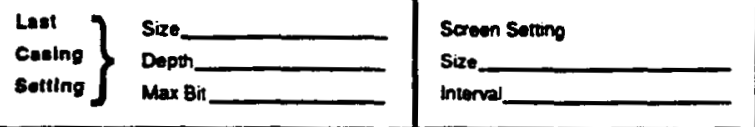

Liál zeses. Lian sodkte ziderencion

PRODUCTION PRESSUAE SETTING

Rams B. O. P. TEST PRESSURES

Mud Type Aydril

Woight Vis. Make 8 Model

Sizo

Depth

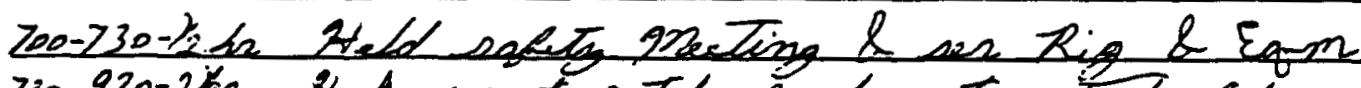

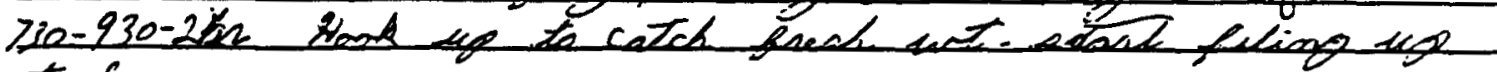
tanka

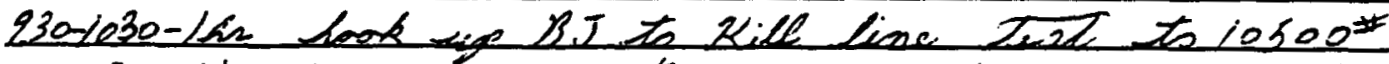

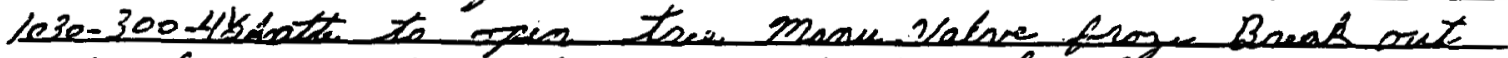

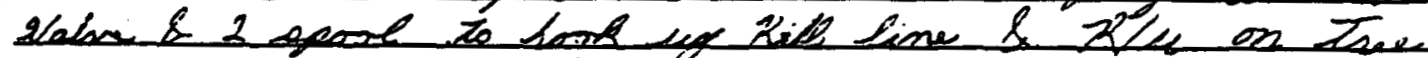

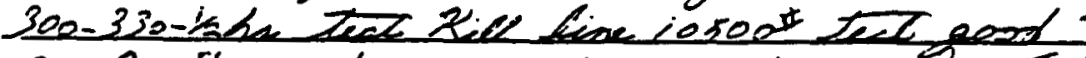
3.30-9pe-5k work on vonks on thee \& Zake on mud

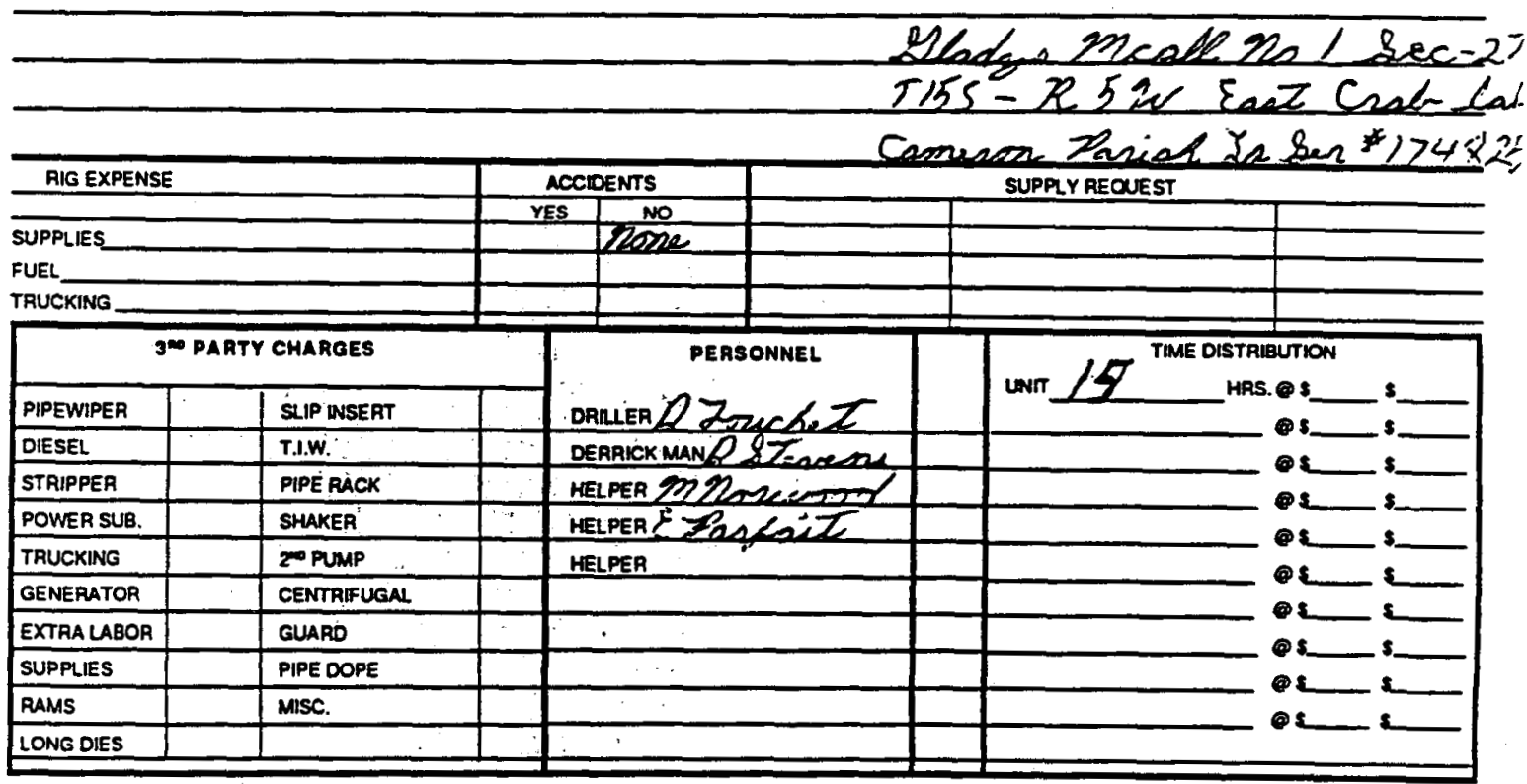

TOOLPUSHer Lozglar Zozuchet

ЈOB NO $24-5$
ORDER NO.
COMPANY REPRESENTATIVE

CONTRACT NO $\operatorname{sos} 24-5$

TERMS: NET 30 DAYS. Accounts over 30 days will be charged $11 / 2 \%$ per month not to exceed $18 \%$ ann!lly.

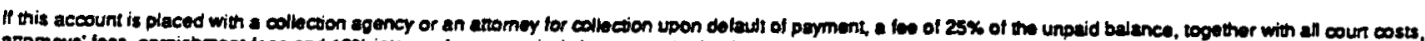
atromeys' loes, garnishment tees and $10 \%$ interest from manurity is horeby authorized. 

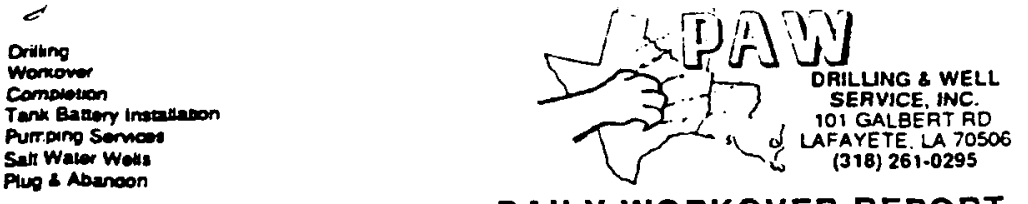

TICKET SऽŨ்

REPORT NO. 3

\section{DAILY WORKOVER REPORT}

company $D O E$

FIELD East Crak iske

PARISH OR COUNTY Comenom

LEASELLaderemestl state 20

DATE $9-22-93$

WELL NO. RIG NO 5

Present Periorations

Present Packer Sotting

Total Depth

Present Depth

Type Plug

\begin{tabular}{|c|c|c|c|c|c|}
\hline 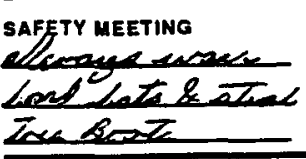 & $\begin{array}{l}\text { Lost } \\
\text { Casing } \\
\text { Sotting }\end{array}$ & $\begin{array}{l}\text { Size_- } \\
\text { Dopth_- } \\
\text { Max Bit_ }\end{array}$ & $\begin{array}{l}\text { Soreen Sotting } \\
\text { Size } \\
\text { interval }\end{array}$ & & $\begin{array}{l}\text { Tubing Solting } \\
\text { Size } \\
\text { Typo } \\
\text { Amil }\end{array}$ \\
\hline \multicolumn{2}{|c|}{ B. O.P. TEST PAESSURES } & \multicolumn{2}{|c|}{ PAODUCTION PRESSURE SETTING } & \multicolumn{2}{|r|}{ DRLL DEEPER } \\
\hline \multicolumn{2}{|l|}{ ___ Hydril__ } & \multirow{3}{*}{\multicolumn{2}{|c|}{$\begin{array}{l}\text { Make \& Model - } \\
\text { Size } \\
\text { Depth }\end{array}$}} & \multirow{3}{*}{$\begin{array}{l}\text { Closing Depth. } \\
\text { Opening Depth } \\
\text { Footape Made. }\end{array}$} & _ Bit Size_- \\
\hline Mud Ty & & & & & \\
\hline Weing & & & & & \\
\hline
\end{tabular}

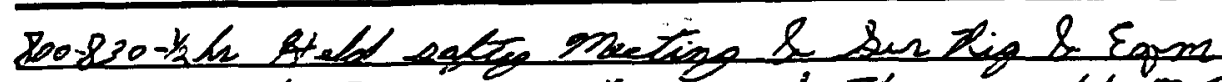

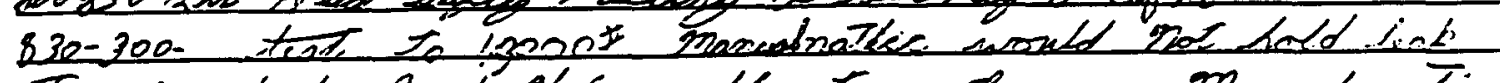

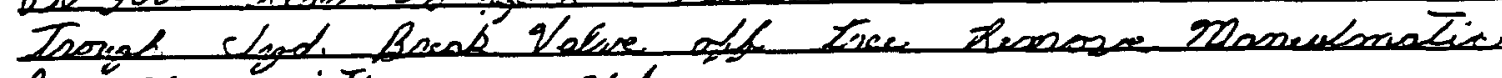
\& Réplace with crown Volne

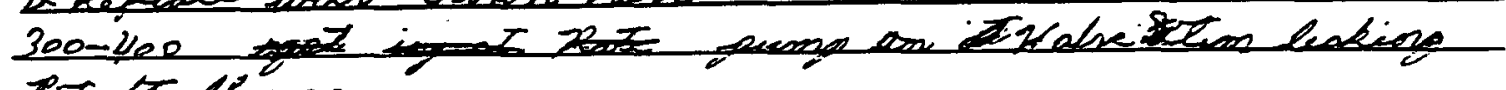
Litipte tiogen

$400-500-162$ peong it to well $4 B B L^{\prime}$ s mion at 5677

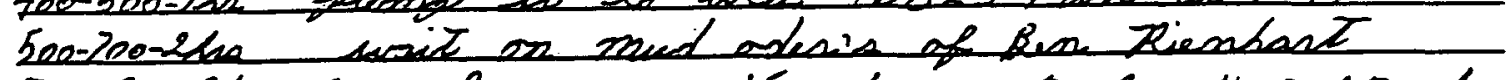
$700-900-2 h x$ mia \& pupe 150 eh cont fas 430 et palup

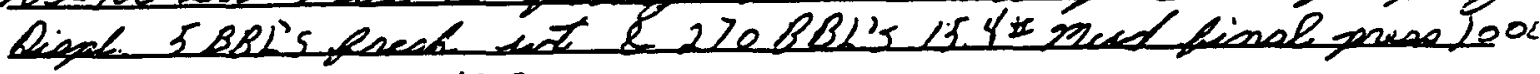
Zor ont at 14673

200-1100-2he shut well ine \& Tranghr mied th tho tank

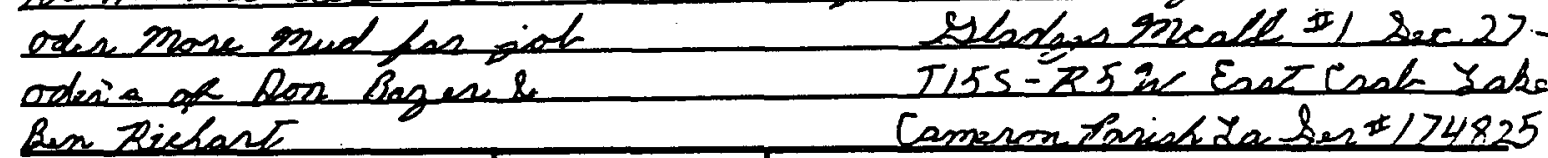

RIG EXPENSE
SUPPLIES
FUEL
TRUCKING

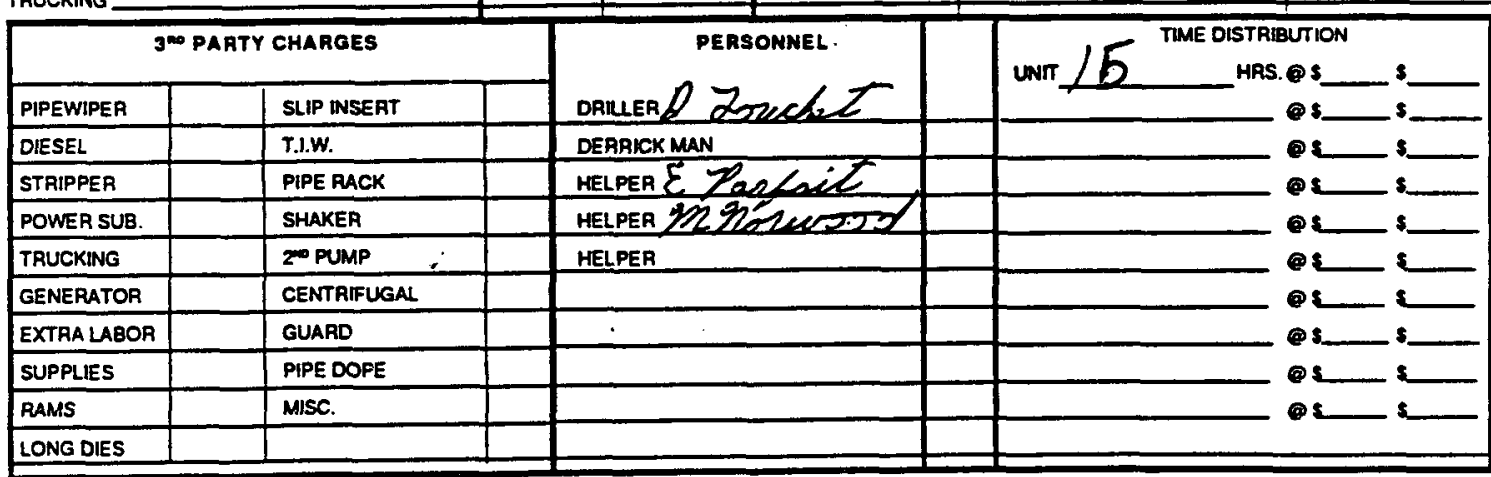

TOOLPUSHER bouglas ZzucheZ JOB NO $24-5$ ORDER NO. COMPANY REPRESENTATIVE CONTRACT NO__ JOB_ $24-5$

TERMS: NET 30 DAYS. Accounts over 30 days will be charged $11 / 2 \%$ per month not to exceed $18 \%$ annilly.

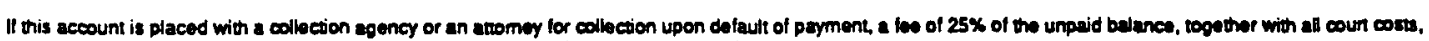
anomeys' fees, garnienment tees and $10 \%$ interest trom maturty is hereby authorized. 
Driling

Womower

Compision

Tanx Banory Inatatabion

Purrong Servon:

Salt Waier Wolls

Plus 8 Abenoon
S

DAILY WORKOVER REPORT
TICKET 5809

REPORT NO. 4 DATE $9-24-9$ WELL NO RIG NO

company Q 25

FIELD Sact Caak Lake

PARISH OR COUNTY COOMECOOS
LEASELLadangenall STATE Lैa
Present Packer Senting

Type Plug

Total Depth

Present Depth

Tubing Seting

Sare

Trpe

Ami

DPII DEEPER

PRODUCTION PRESSURE SETTING Make a Moder

B. O. P. TEST PRESSURES

Rams

Mud Type

Woight saren Sotion

Interval

200-730-kh beld ugheg 23eting b sen tig \& Eqp

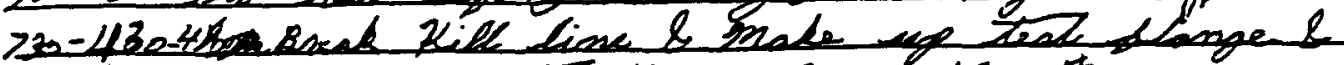

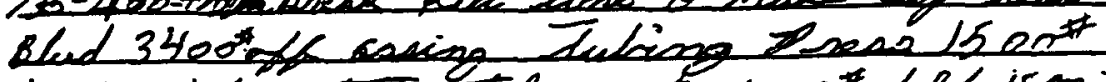

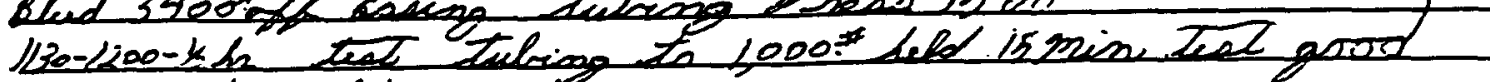
$1200-100-1 \mathrm{hr}$ K/u adl

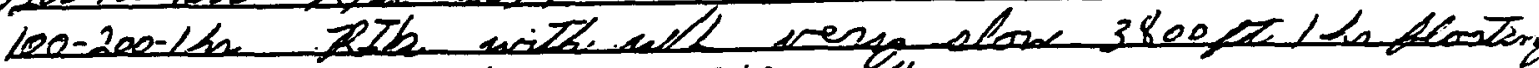

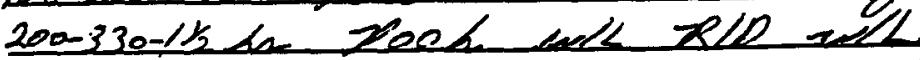

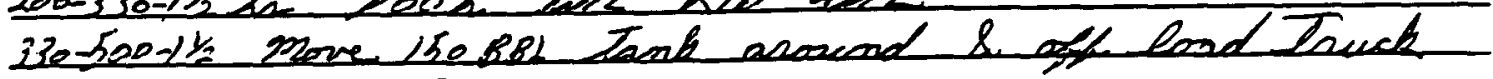
Bacek Talore on Taes

Sladyos Meall nal

THSS-R5W Eastrask Zake

Comenom Paried 24 des $\$ 174825$

\begin{tabular}{l|l|l}
\hline RIG EXPENSE & \multicolumn{2}{|c}{ ACCIDENTS } \\
\hline & YES & NO \\
\hline SUPPLIES & & ZETYC \\
FUEL & & \\
TRUCKING & & \\
\hline
\end{tabular}

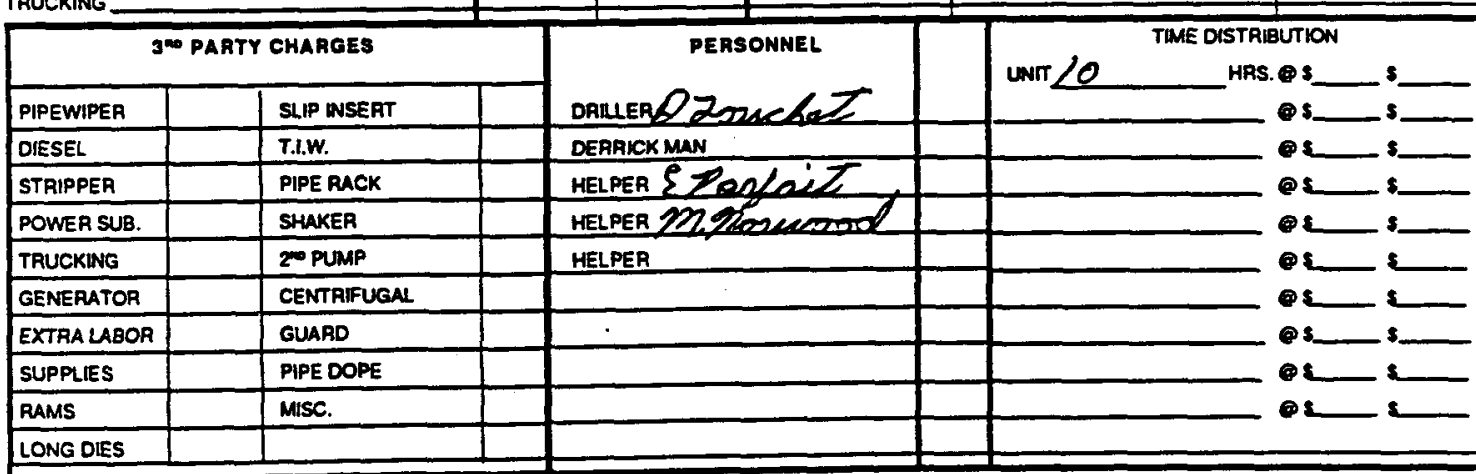

TOOLPUSHER bouglas Zsuchete JOB NO $24-5$ ORDER NO COMPANY REPRESENTATIVE CONTRACT NO $\operatorname{sos} 24-5$

TERMS: NET 30 DAYS. Accounts over 30 days will be charged $11 / 2 \%$ per month nol to exceed $18 \%$ ann:lly.

If this account is placed with a collection agency or an anomey for collection upon delauth of payment, a wo of $25 \%$ of the unpeid balance, togethar with all coun costs. attomeys' tees, garnishment foes and $10 \%$ interest trom maturity is hereby authorized. 
company $20 E$

DAILY WORKOVER REPORT

REPORT NO. 5

FIELGastCond dake

PARISH OR COUNTY Comenom Zanió

Present Pertorations

DATE $9-25-93$

WELL NO. L 1

Total Depth

RIG NO 5

Present Packer Setting

SAFETY MEETING

coles teroviog Eq

with Thuce dont

stancoting travex

B. 0. P. TEST PRESSURES

Rams

Musd Type _ Hydril__

Weigh: Vis. state $\mathcal{L}$
Present Depth

Type Plug

$\left.\begin{array}{l}\text { Laut } \\ \text { Casing } \\ \text { Sotting }\end{array}\right]$

\begin{tabular}{|c|c|}
\hline Size_ & Sacen Sotring \\
\hline Deptr_ & Size_ \\
\hline $\max 1$ & theoval_ \\
\hline
\end{tabular}

PAOOUCTION PAESSURE SETTING Make \& Model

Sizo Depth

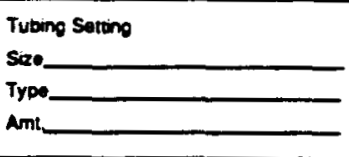

DRILL DEEPER

Closing Depth_____ Bir Size Oponimg Dept __ Bil Typo Fooupe Made

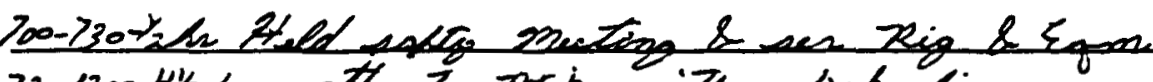

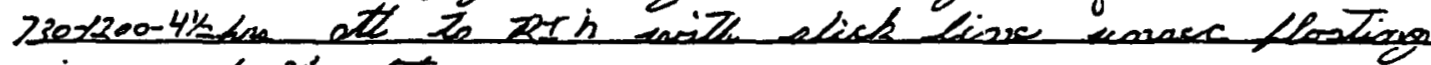
in and 3400 L 1200-230-2kh 700 h will wall add mose withose

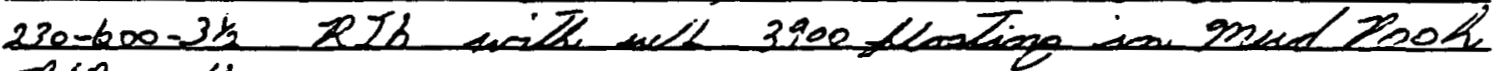
210 nell

Hlady encall noLT155 Z52. sast cant Jake

\begin{tabular}{|c|c|c|}
\hline \multicolumn{2}{|l|}{ RIG EXPENSE } & $\mathrm{ACC}$ \\
\hline \multirow{2}{*}{\multicolumn{3}{|c|}{ SUPPLIES }} \\
\hline & & \\
\hline \multicolumn{3}{|l|}{ FUEL } \\
\hline \multicolumn{3}{|l|}{ TRUCKING } \\
\hline \multicolumn{3}{|c|}{ 30 PARTY CHARGES } \\
\hline PIPEWIPER & SLIP INSEAT & \\
\hline DIESEL & T.I.W. & \\
\hline STRIPPEA & PIPE PACK & \\
\hline POWER SUB. & SHAAKER & \\
\hline TRUCKING & 20 PUMMP & \\
\hline GENERATOR & CENTRIFUGAL & \\
\hline EXTRA LABOR & GUARD & \\
\hline SUPPLIES & PIPE DOPE & \\
\hline RAMS & Misc. & \\
\hline LONG DIES & & \\
\hline
\end{tabular}

Camson Pasiak La sen *17482: JOB NO $24-5$ ORDER NO. COMPANY REPRESENTATIVE

TERMS: NET 30 DAYS. Accounts over 30 days will be charged $11 / 2 \%$ per month not to exceed $18 \%$ ann!lly. If this account is placed with a collecion apency or an atiomey for collecjion upon detault of payment, a wee of $25 \%$ of the unpeid balance, togecther with all court coses anomeys' tees, garnishment foes and $10 \%$ interest trom maurity is hereby authorized. 
Drilung

Comover

Compition

Tantin Batrony Inatallatoon

Purfing Servons

Salt Waver Wets

Plug \& abendon $\left[\int_{\text {DAILUNG \& WELL }}\right.$

SERVICE. INC.

101 GALBERT RD.

(318) 261-0295

DAILY WORKOVER REPORT company $D E$

FIELDEat Cral Lake

PARISH OR COUNTY CAOME 202

Present Pertorations

Total Depth

Present Depth

SAFETY MEETINC

natm KVT with

hameancasere

colystan sonde

B. O. P. TEST PRESSURES

Rams

Mud Type Hrdril

Weight Vis.
LEASE Stadeos meall STATE Za
TICKET 6811

REPORT NO. 6

DATE $9-26-93$ WELL NO._ 1

RIG NO

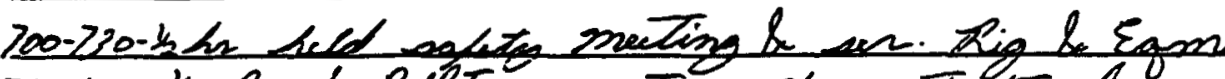

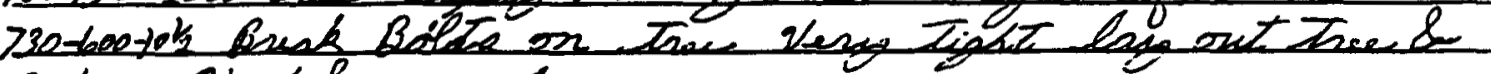
iille Ayet \& yeoret

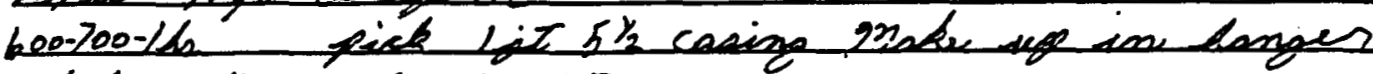

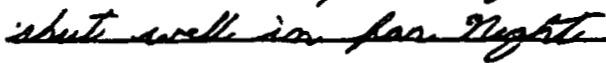

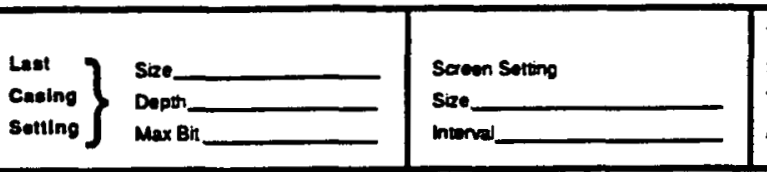
Nake 8 model

Size.

Desth
Cbaing Depth

Opening Depeth

Foover unde
DALL DEEPER

Typo Plug

Tubing Sotting

Siza

Typo

Amt.

git Sizo

Bit Type

$$
\text { }
$$

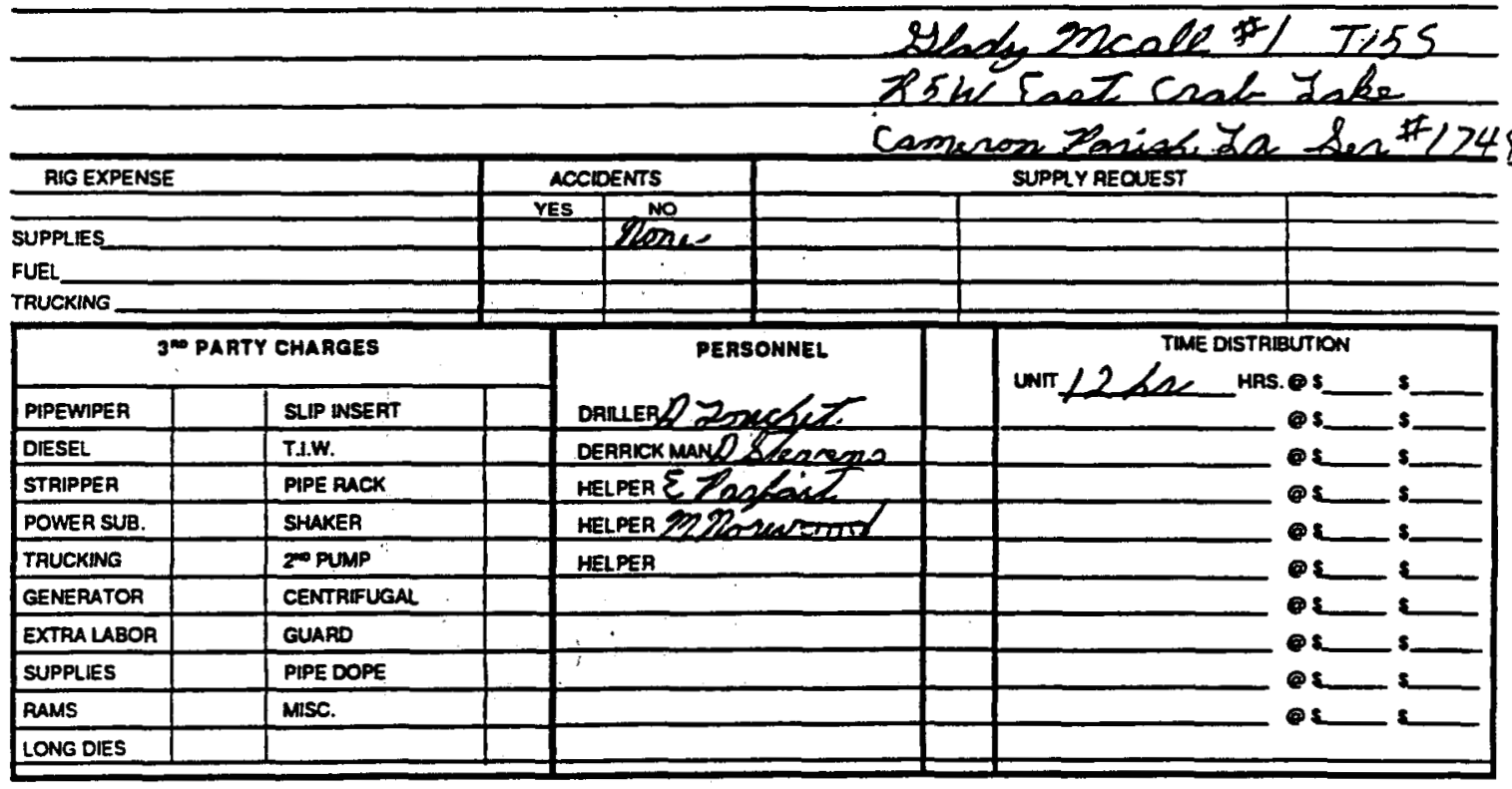

TOOLUSHERblonglas Zoructet JOB NO 24- 5 ORDER NO
COMPANY REPRESENTATIVE CONTRACT NO.
Jo8 $24-5$

TERMS: NET 30 DAYS. Accounts over 30 days will be charged $11 / 2 \%$ per month not to exceed $18 \%$ annilly.

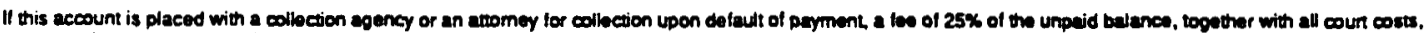
anomeys' tees, garnienment tees and $10 x$ inerest trom meturity is hereby authorized. 


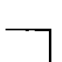


companybn

FIELDENT cask Ink LEASELLadarmealle DATE. $=28-9.3$

PARISH OR COUNTY CAMmenen state 32 WELL NO._ )

PARISH OR COUNר

Present Packer Setting

Total Depth

Present Depth

Type Plug

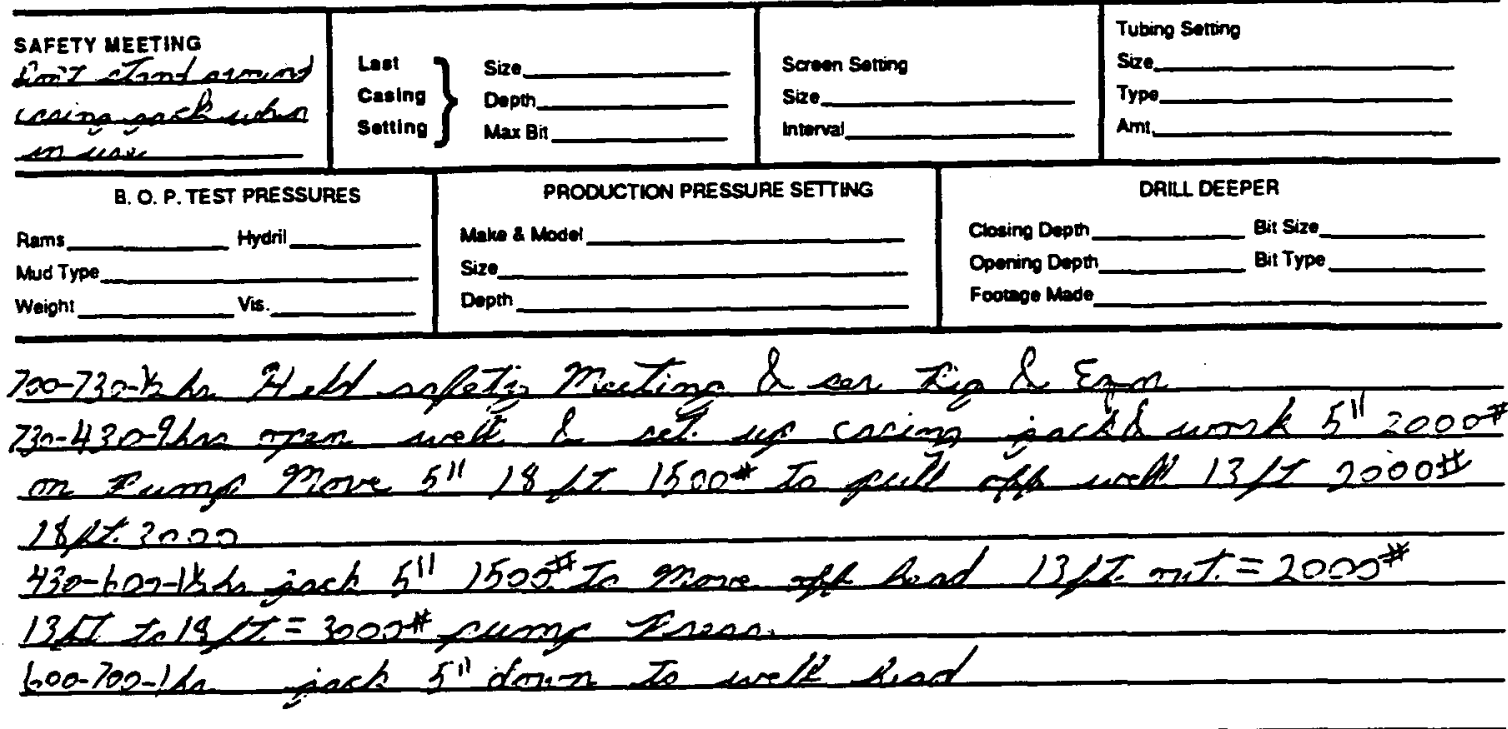

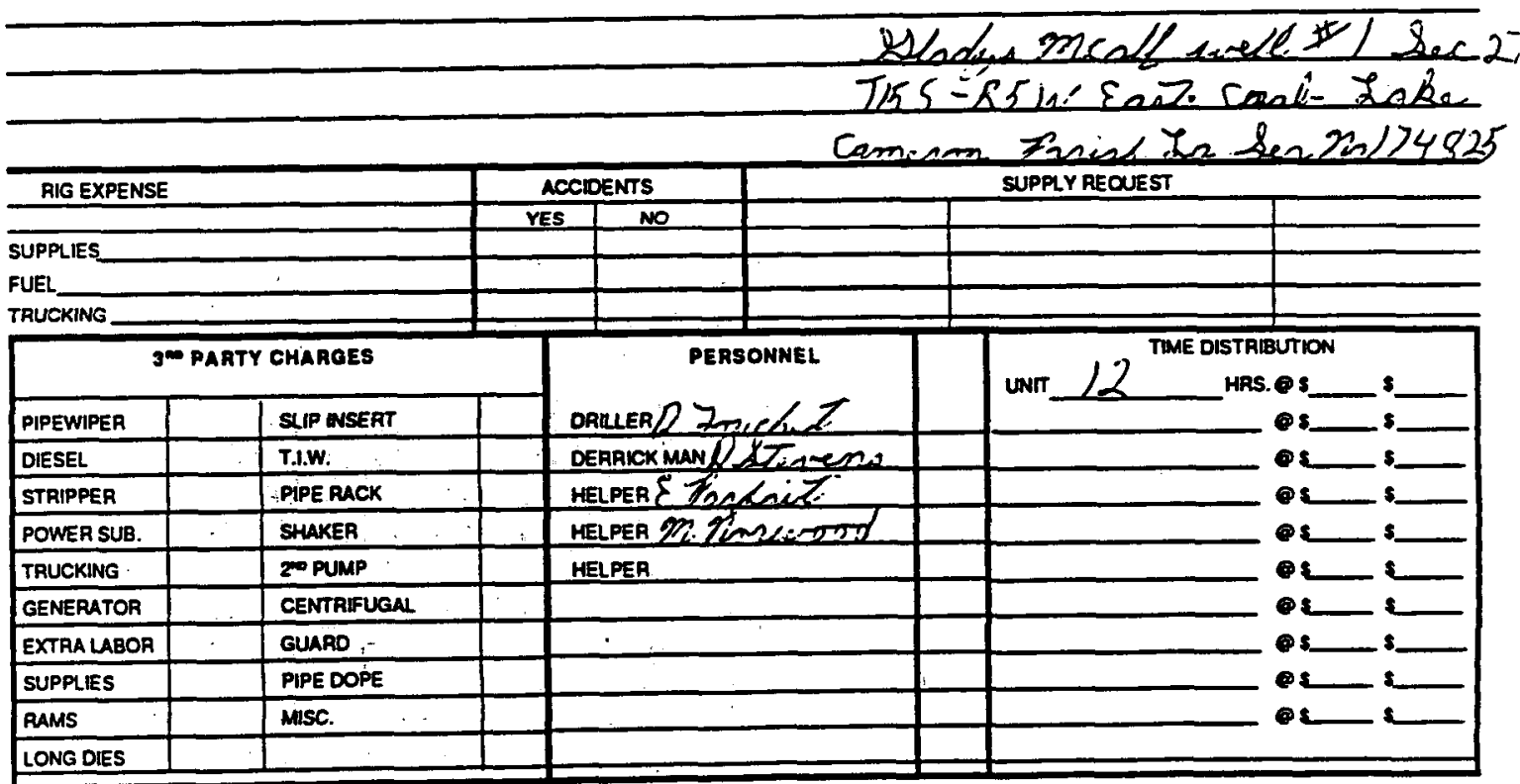

TOOLPUSHER horglos Zopechat

ЈOB NO $24-5$

ORDER NO
COMPANY REPRESENTATIVE CONTRACT NO
Jos $24-5$

TERMS: NET 30 DAYS. Accounts over 30 days will be charged $11 / 2 \%$ per month not to exceed $18 \%$ ann:lly.

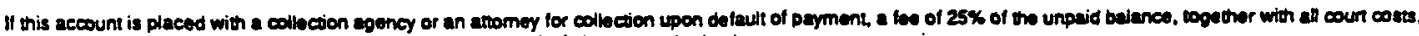
atiomeys' tees, gamienment tees and $10 \%$ interest from maturity is hereby authorized. 
company $20 E$ state 2ैa RIG NO 5

Present Perforations.

Present Packer Setting

Total Depth

Present Depth

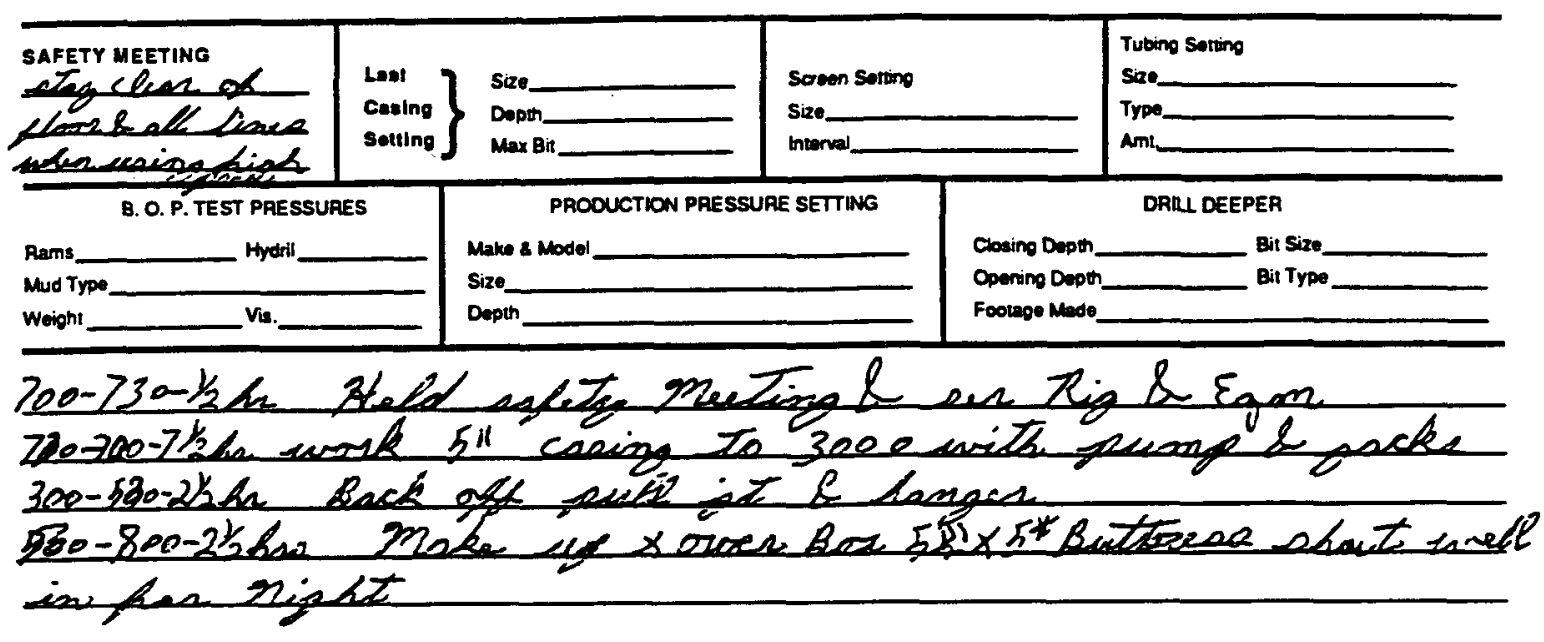

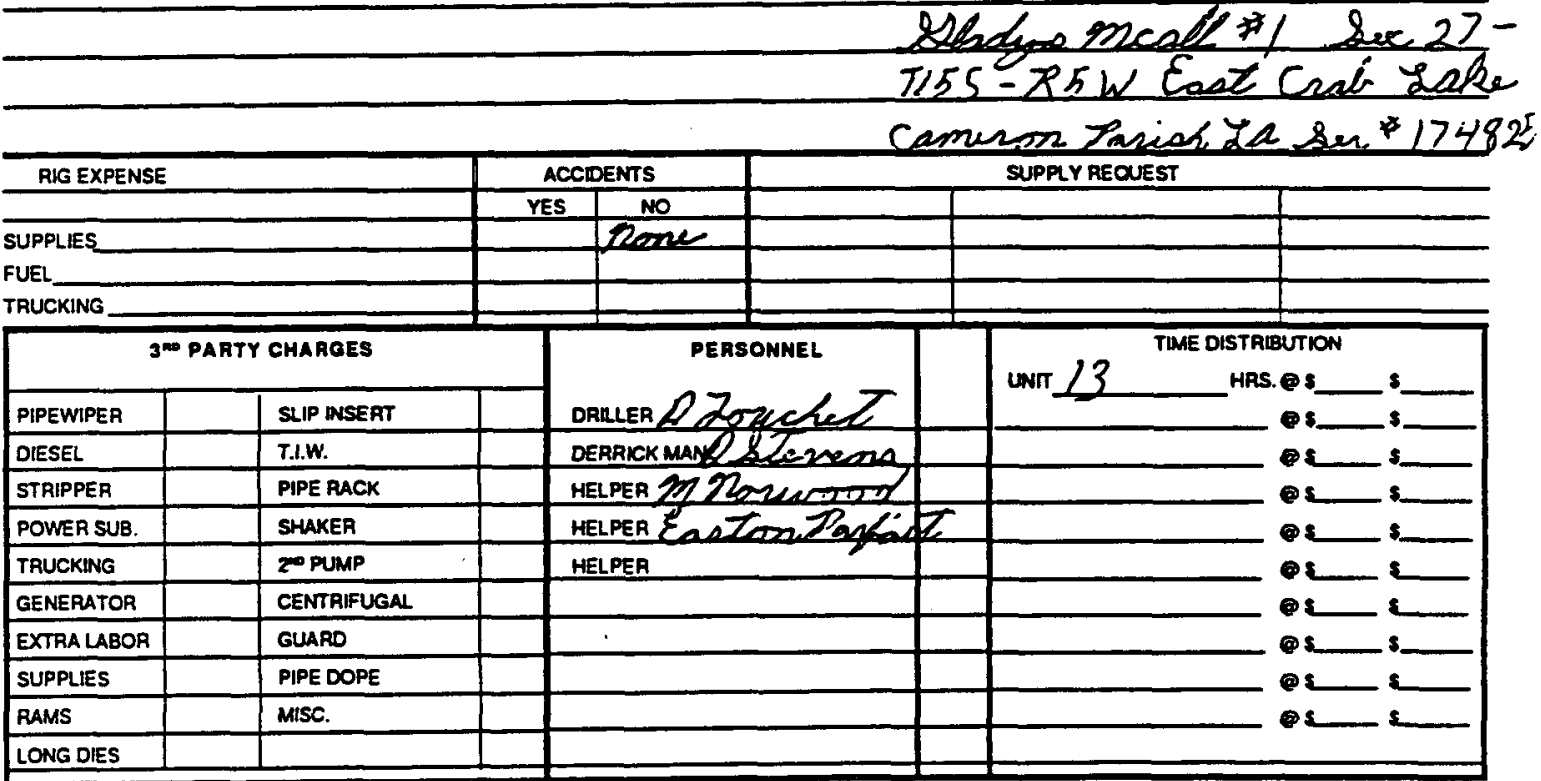

TOOLPUSHER forgzlas Zoveche JOB NO $24-5$ ORDER NO.
COMPANY REPRESENTATIVE CONTRACT NO.
$\operatorname{JOB} 24-5$

TERMS: NET 30 DAYS. Accounts over 30 days will be charged $11 / 2 \%$ per month not to exceed $18 \%$ annilly.

It this accoum is placed with a collection apency or an atbomey for collection upon dolaut of payment, a fie of $25 \%$ of the unpedd belence, together with all coun coms, atromeys' fees, garnishment loes and $10 x$ interost trom maunty is horeby authorized. 
DAILY WORKOVER REPORT

DATE $2-30-93$

FIEL kade Cank tahe. PARISH OR COUNTY Camasar Lease Eladre Mcall WELL NO. 1 RIG NO 5

Present Pertorations Present Packer Setting

Total Depih Present Depth Type Plug

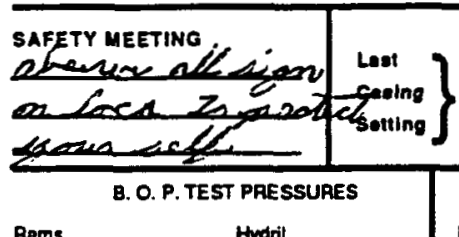

Rams Hydril

Nud Typo. vas.

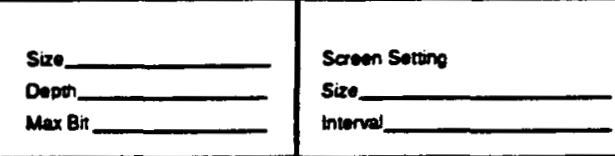

PRODUCTION PAESSUAE SETTING Make 8 Model Size Dopth

Footerse Made

\section{Tubing Sorting}

Sze

Troo

Amt

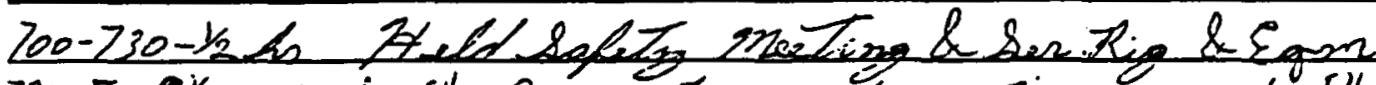

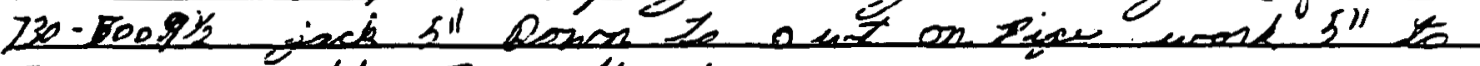
523000 wosalle to pull tser

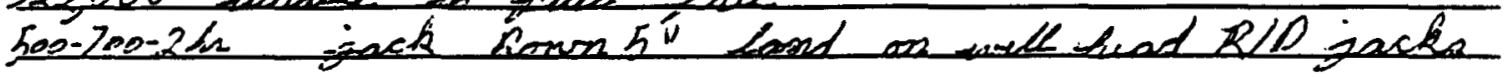

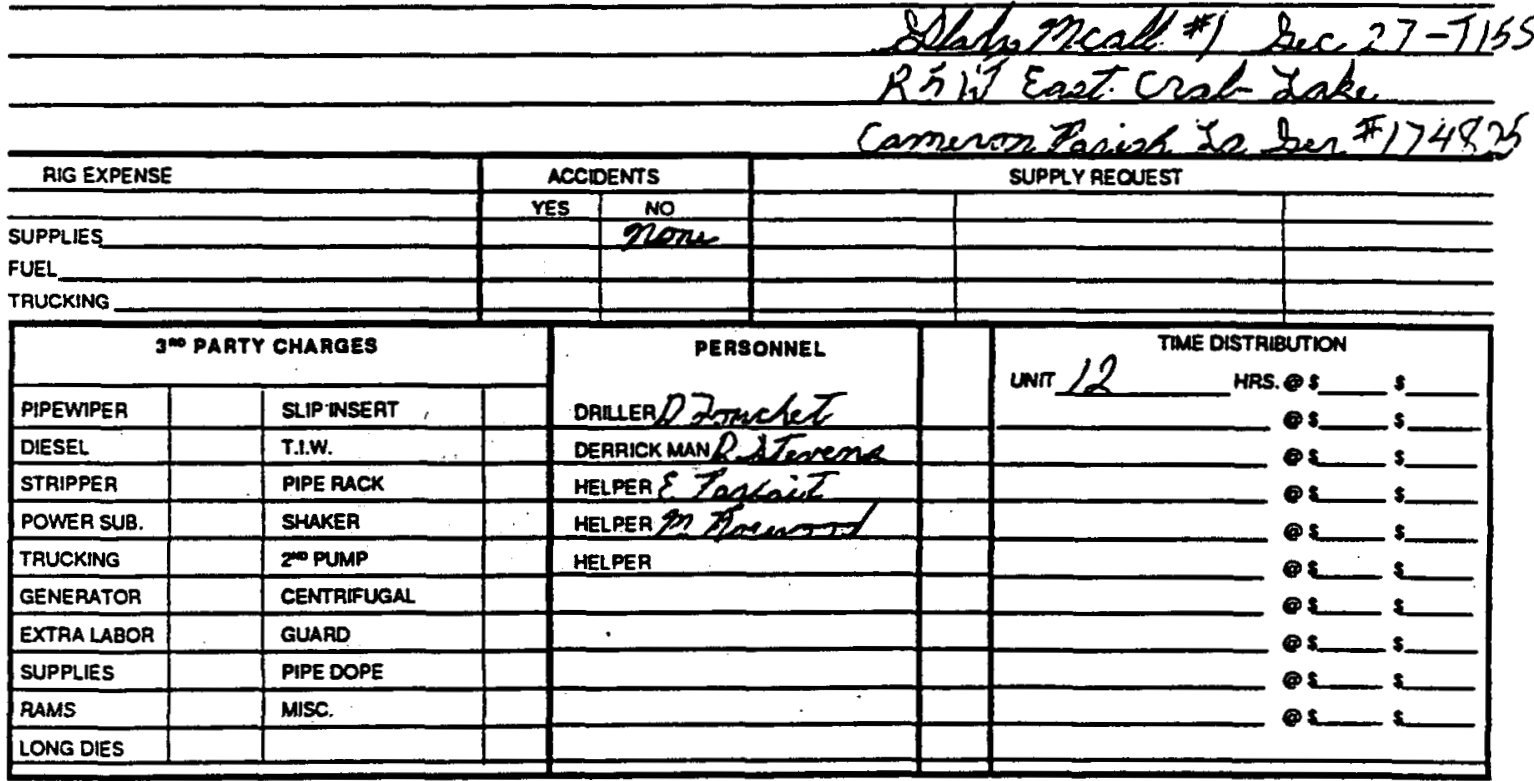

TOOLPUSHERblowg-as Zauchet. JOB NOS-5 ORDER NO.
COMPANY REPRESENTATIVE

CONTRACT NO.
JOB $24-5$

TERMS: NET 30 DAYS. Accounts over 30 days will be charged $11 / 2 \%$ per month not to exceed $18 \%$ ann:lly.

II this accoumt is placed with a collection agency or an atromey for collection upon dolaut of ptyment, a be of $25 \%$ of the unpaid belance. together with all court costs. anomeys' toes, gamisnment loes and 1056 interest from maturity is heroby authorized. 
Drilling

compun

Tenx Baraery insulason

Turroing Sernces

Satt Water Wella

Plus \& Abancon

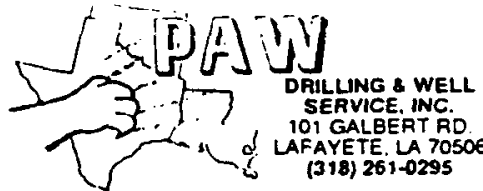

(318) 261-0295
(3YTE. LA 7OSO6
TICKET $581 \overline{8}$

REPORT NO. 11

DAILY WORKOVER REPORT

DATE $10-1-93$

company DO 0

FIELDEsot Crab Lake

LEASE Yladter 7 meall.

WELL NO._ )

PARISH OR COUNTY Cameron. state ja RIG NO

Present Pertorations

Present Packer Setting

Total Depth

Present Depth Type Plug

SAFETY MEETING trolos outyea ench olken suthen pickige ucsice B. O. P. TEST PRESSUAES

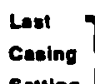

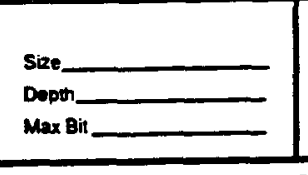

PRODUCTION PRESSURE SETTING

Rems

Masd Type Hydril

Weight vis. vis. Make a Model Size Depth

Sacen Sorting
Size_-

Cloxing Depth Ooening Deptr Fooremg Made

\section{Tubing Sortung}

Siec

Type

Ant.

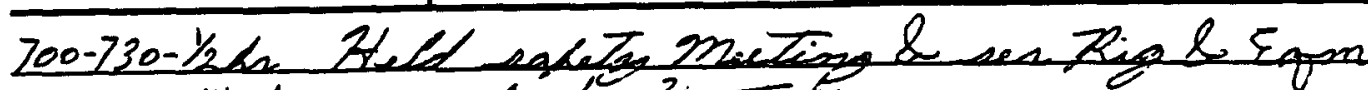
230-1200-4kh ofe lad $23 / 4$ Tultion

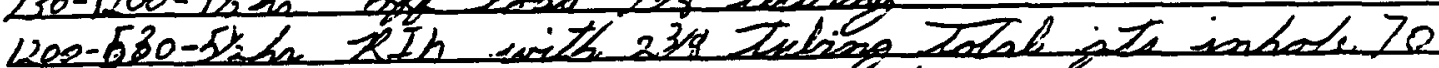
$530-600 \%$ ha shot derell ien has puant

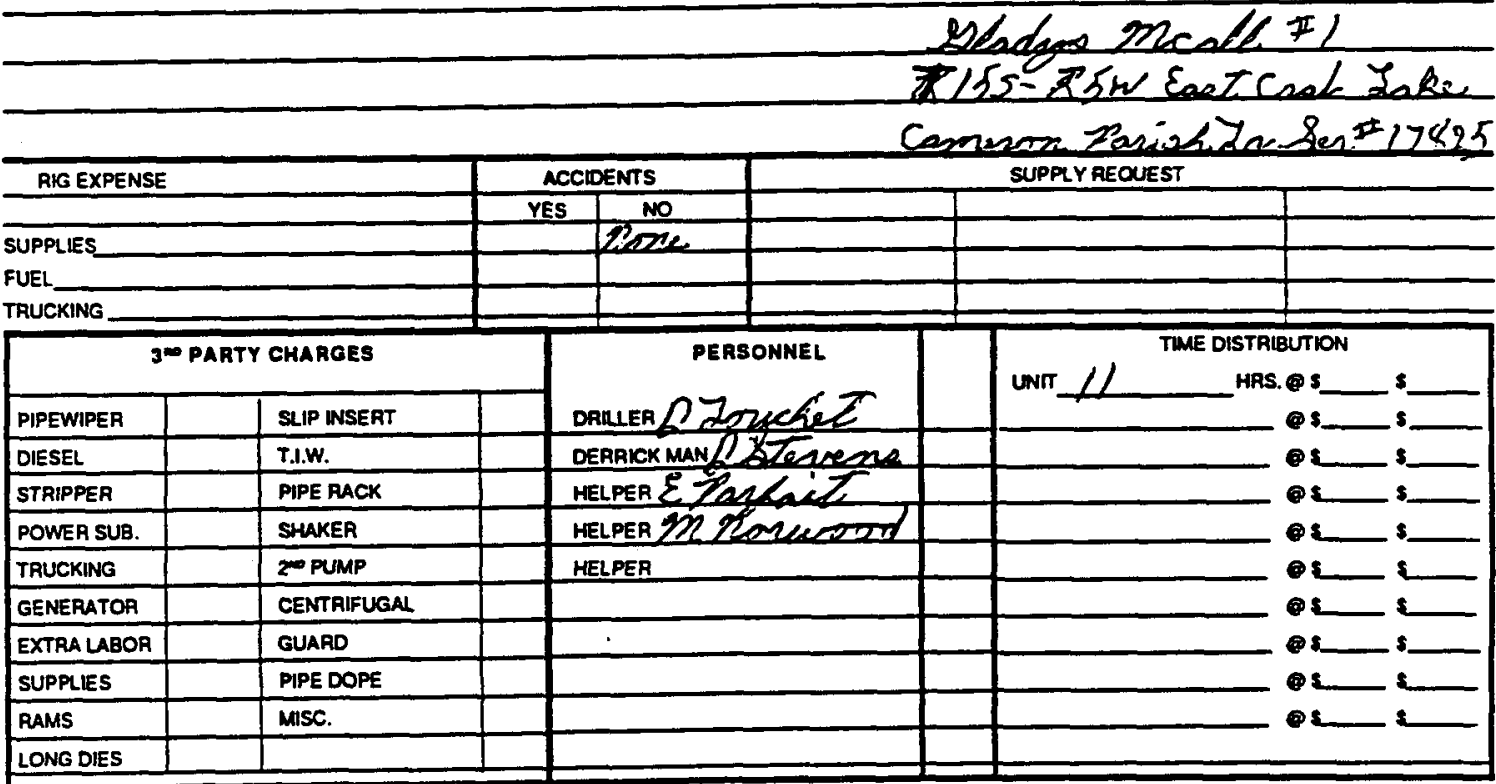

TOOLUSHer Royplas Zouchat JOB NO $24-5$ ORDER NO. COMPANY REPRESENTATIVE CONTAACT NO
$10824-5$

TERMS: NET 30 DAYS. Accounts over 30 days will be charged $11 / 2 \%$ per month not to exceed $18 \%$ ann!lly.

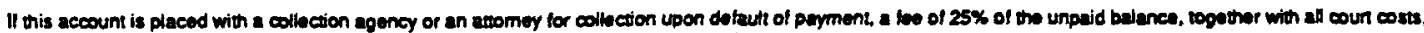
atromeys. fees, garnishment laes and $10 \%$ interest trom maturity is horeby authorized. 
Drilling

compiotion

Tamp Bation insturison

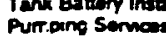

Satt Water Wot:

Plup \& Abandon

company DOE FIELD Eact calt Lake PARISH OR COUNTY_Cameron

Present Perforations

Total Depth

Present Depth

SAFETY MEETING

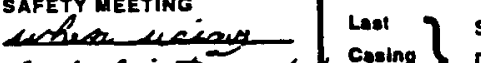

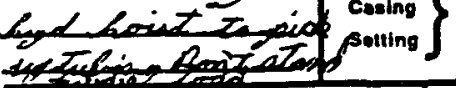

8. O. P. TEST PRESSURES

Rams - Hydril

Mud Type Vis.

Vis. Sizo.

Weight
TICKET 5817

REPORT NO. L 2

\section{DAILY WORKOVER REPORT}

DATELL-2-93

LEASE Yladsae gncall. state Ia

WELL NO. RIG NO_ 5

Present Packer Setting

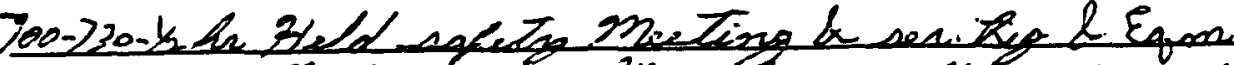

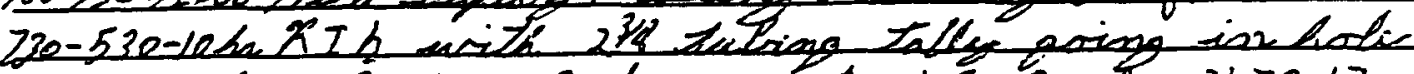

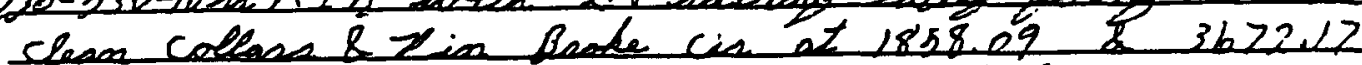
\&. 5530.26 \& 5530.26 Trtat it ion hole 180

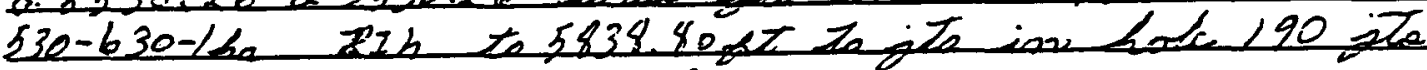
shut well in pan inbiz

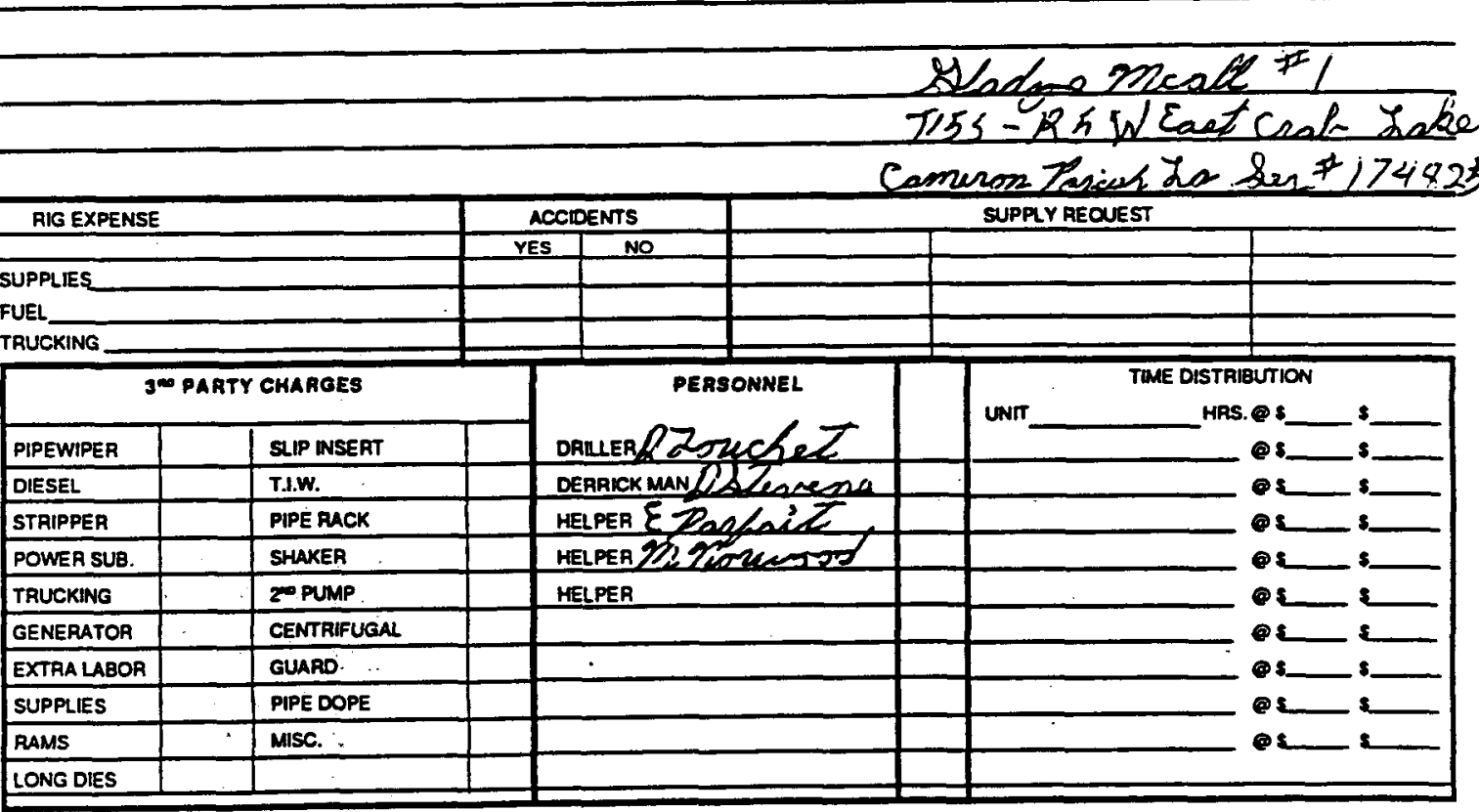

TOOLPUSER Roualar Zouchet JOB NO $24-5$ ORDER NO. COMPANY REPRESENTATIVE CONTRACT NO JOB $24-5$

TERMS: NET 30 DAYS. Accounts over 30 days will be charged $11 / 2 \%$ per month not to exceed $18 \%$ ann:lly.

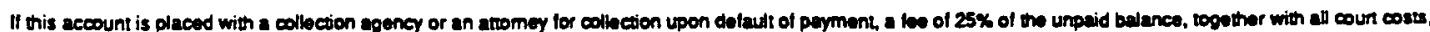
anomeys' lees, gamishment tees and $10 \%$ inter est trom maturity is hereby authorized. 
Driting

Wombiver

Combition

Tank Battery Insalaicon

Purrping Semos.

Soln Waver Wous

Plup 6 Abancon

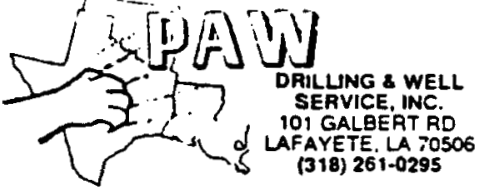

\section{DAILY WORKOVER REPORT}

TICKET 5818

REPORT NO. 19
COMPANY $Q 0 F$ FIELDEast Crak Lake PARISH OR COUNTY Cameren

Present Perforations LEASE Mladzes Mncalit state 22

Present Packer Serting
Present Depth

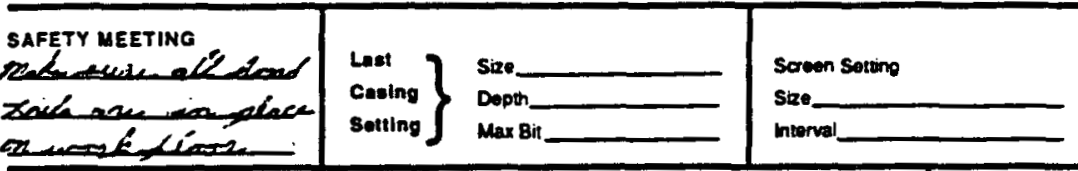

B. O.P.TEST PRESSURES

Rans Hydril

Mud Type
DATE/23-93 WELL NO. 1 RIG NO 5

Weight___ Vis.____

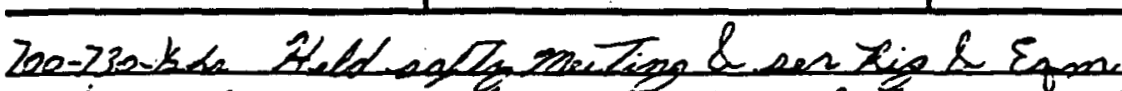

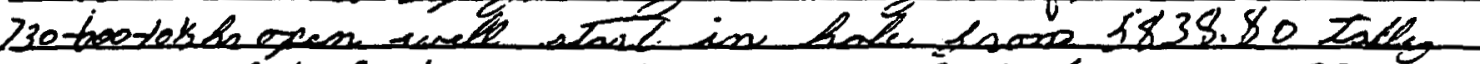
eoine in bole Backe cin at $767437-9611.05-11347.87$ shat well iso par ninte

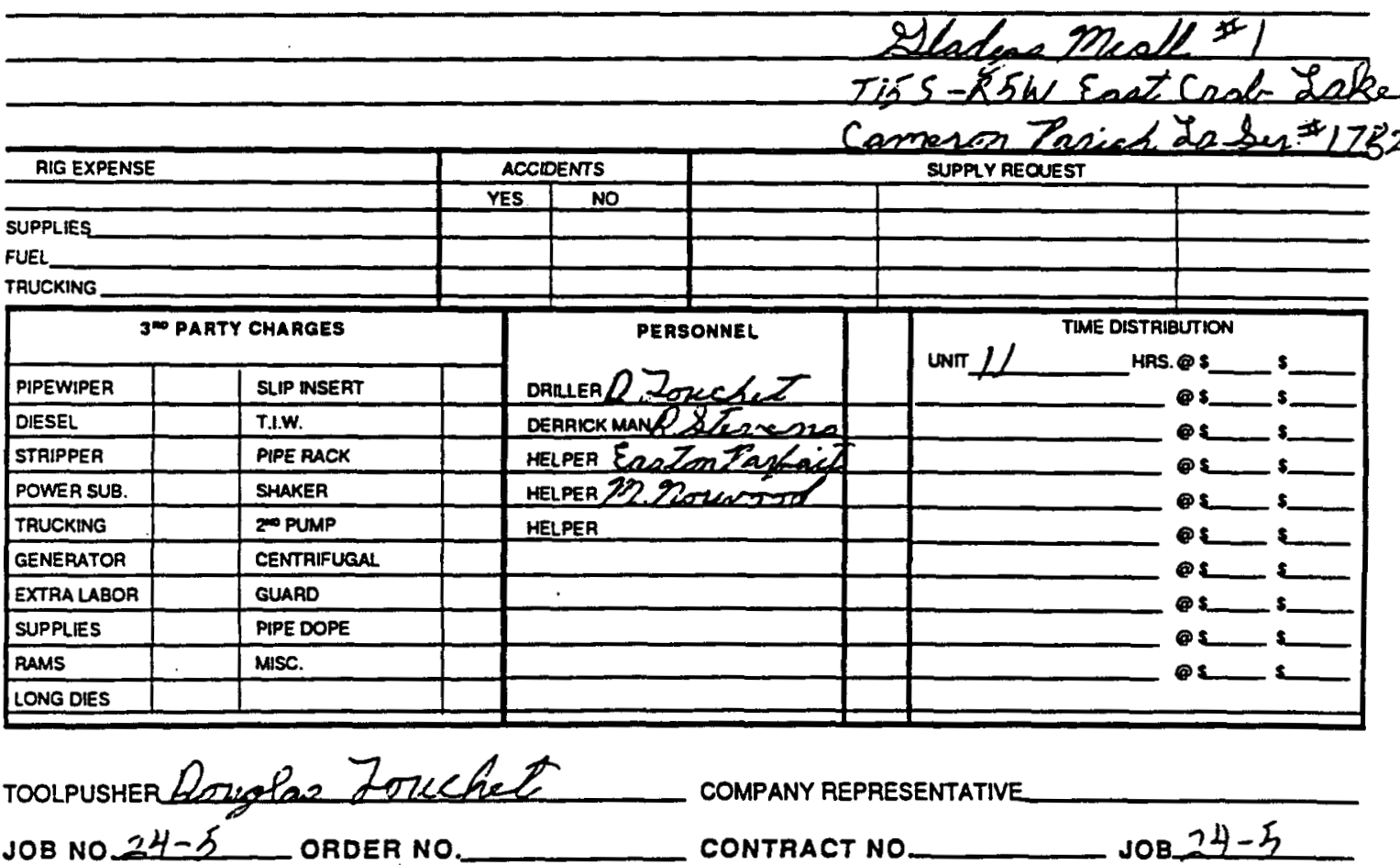

TERMS: NET 30 DAYS. Accounts over 30 days will be charged $11 / 2 \%$ per month not to exceed $18 \%$ ann:lly.

II this account is placed with a collection apency or an athomey for colloction upon delauts of payment, a toe of 25\% of the unpaid balance. topether with all coun coses, atomeys' loes, carnishment lees and $10 x$ interest from mastity is hereby authorized. 
Drilting

Womover

Compievion

Tark Banary intellabon

Purreing Semoes

Sat Waver Wellis

Pivo 8 Abencion

company $20 E$

fieldesat crata Late

PARISH OR COUNTY CaOmenoo

Present Pertorations

Total Depth

Present Depth

SAFETY MEETINC

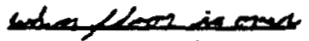

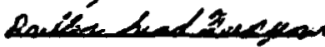

onerthention

B. O. P. TEST PAESSURES

Rams Hydril

Mud Type

Vis.

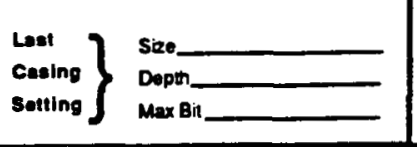

PRODUCTION PRESSURE SETTING

Make 8 Model

Sizo

Depth

\section{LEASE Yladumeall} STATE İa
TICKET 5819

REPORT NO. 14

Fookge Made ___

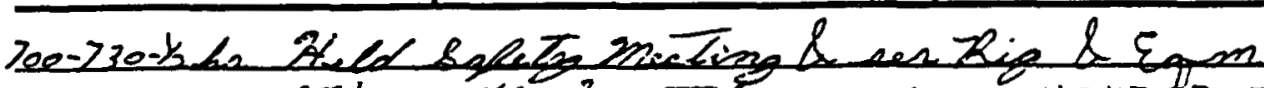

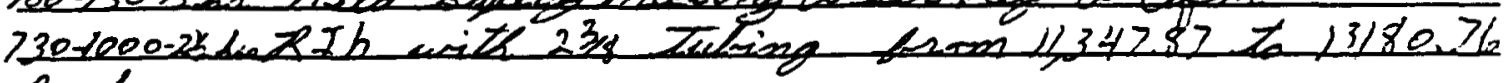
Bambin

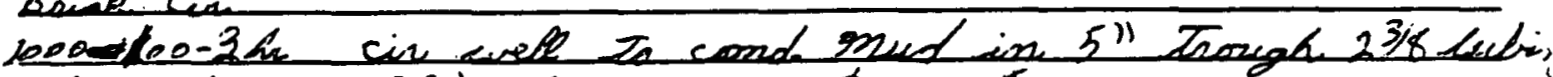
at $13208 \mathrm{AT} 2 \mathrm{BBL}$ 's ter min ot lopo purs pese 10n-230-ish pooh witi 30 th

232

462

Present Packer Setting WELL NO. 1 RIG NO 5

Typo Plug

\section{Tubing Soluing}

Sae

amt.

DRLL OEEPER

Bit Size

Cosing Dopth__ Bit Size
Exh ith 2 juth ing te 13908 totet te inhor:

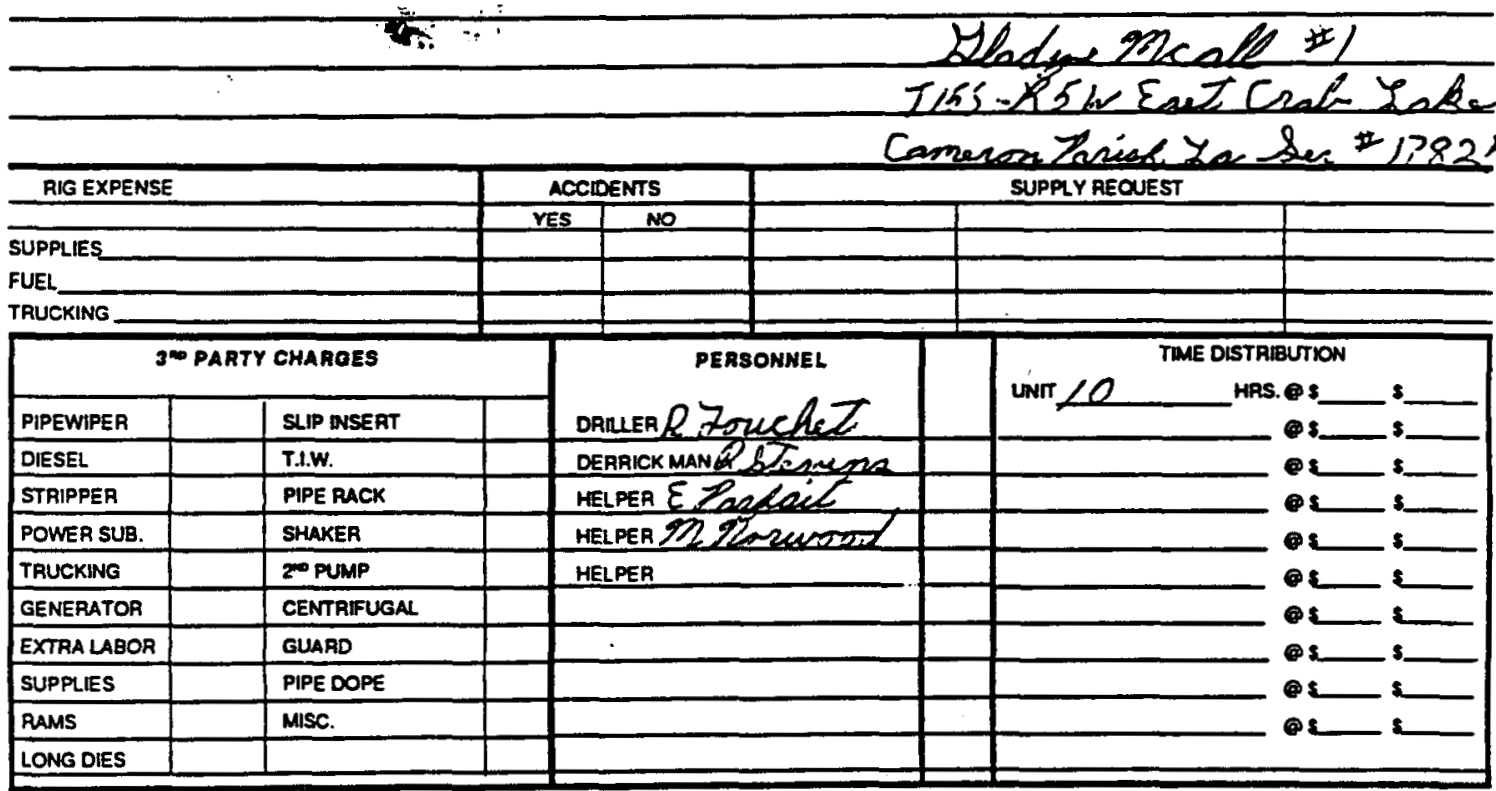

TOOLPUSHER Loygha ZosucheZ

JOB NO $24-5$ ORDER NO.
COMPANY REPRESENTATIVE CONTRACT NOL :
JOB $24-5$

TERMS: NET 30 DAYS. Accounts over 30 days will be charged $11 / 2 \%$ per month not to exceed $18 \%$ ann:lly.

If this account is placed with a collocion agency or an atorney for colbction upon detault ol payment, a toe of $25 \%$ of the unpad betance, topectier with all coun costs. anomeys' lees, garnishment loes and $10 \%$ interest fom maburity is horeby authorized. 
FIEL East cook LaAe

PARISH OR COUNTY Camenon
LEASE Lladge $930 \mathrm{LL}$ state $\mathcal{L} / 2$
DATE $10-5-93$

WELL NO.

RIG NO 5
Present Periorations

Total Depth
Present Packer Setting

Present Depth

Type Plug

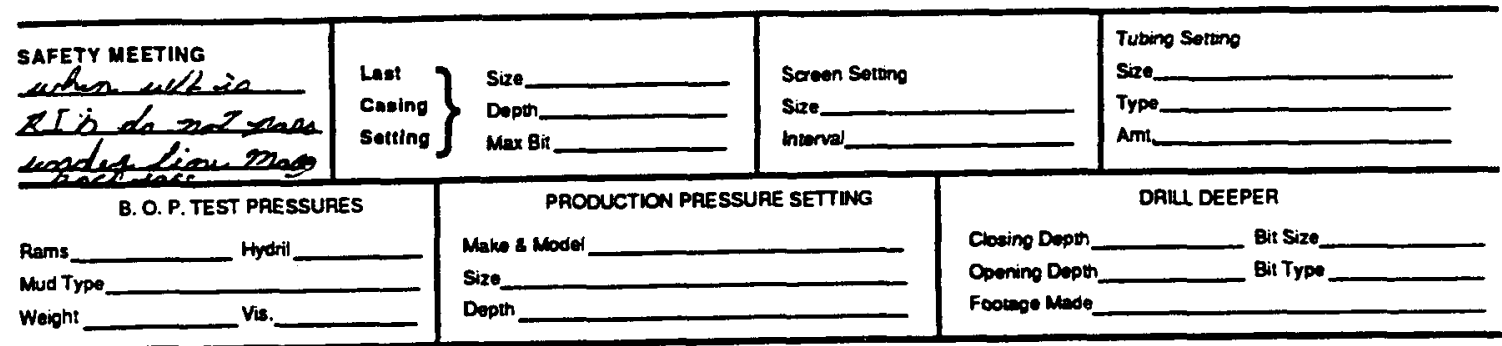

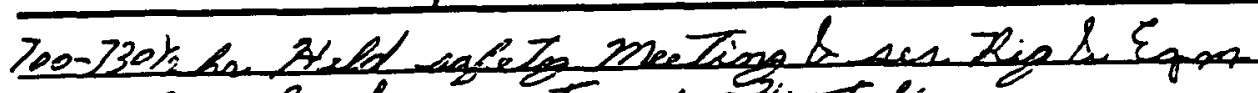

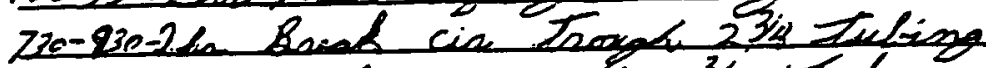

930-4307\% to Teal wite 238 Tubing 231 stolla

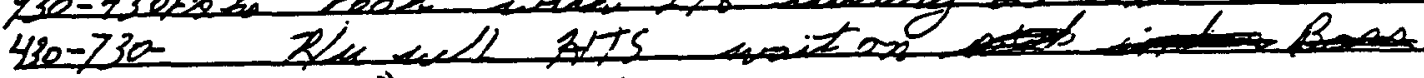
ZTh sitte $3 b_{0}$ " it cuttes

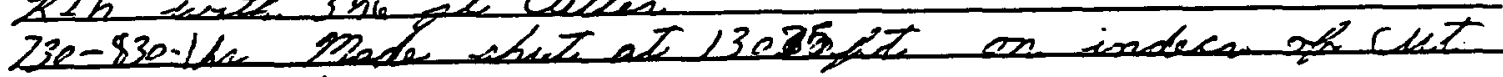
cutter sined

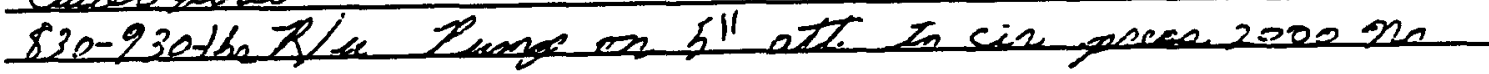
monemeat

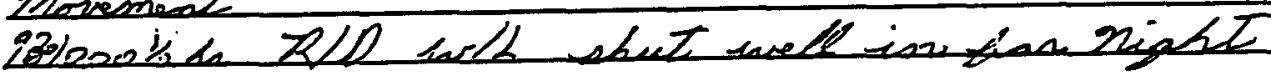

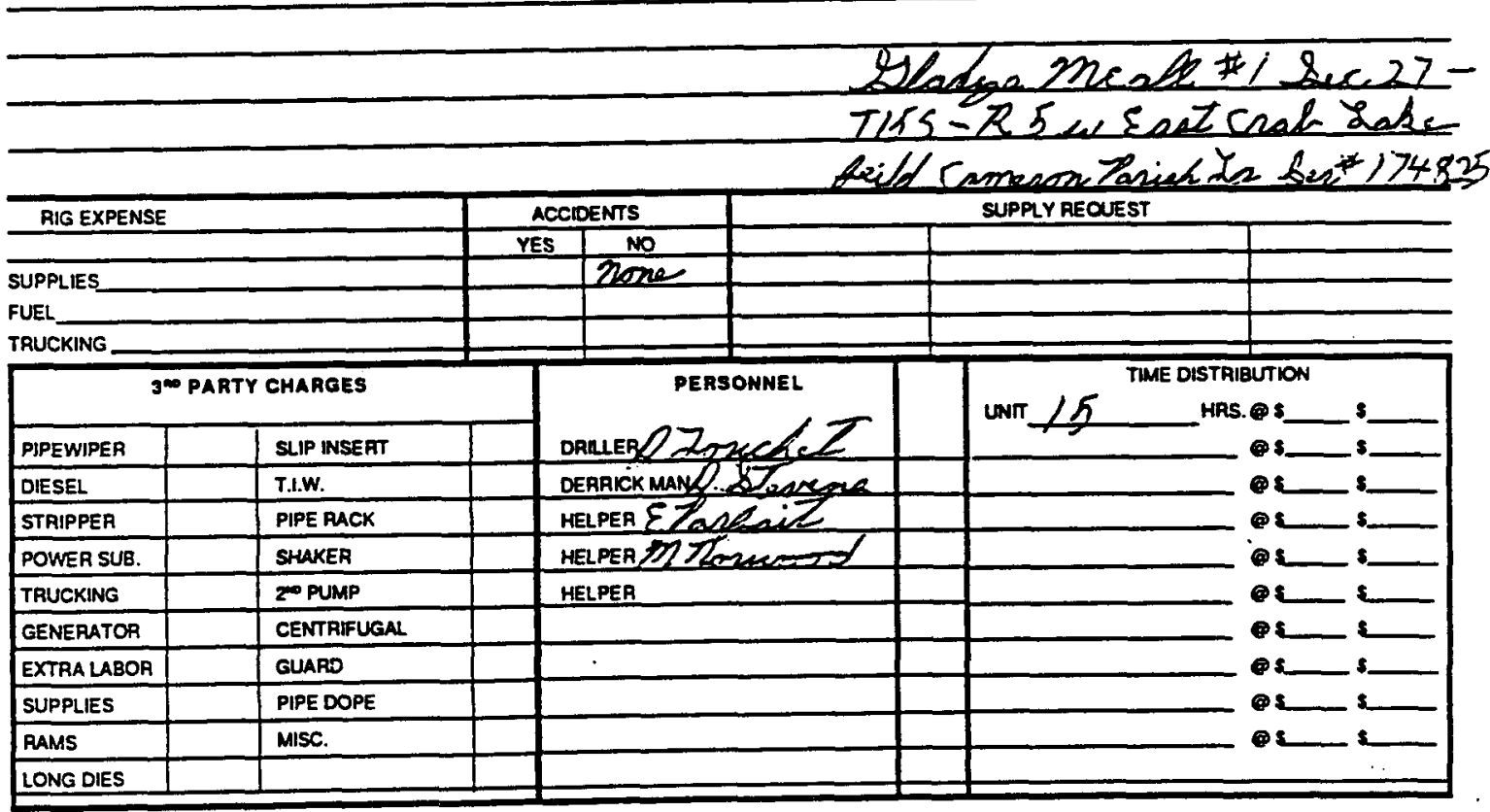

toolpusherforgalar Zozechet JOB NO $24-5^{2}$ ORDER NO.
COMPANY REPRESENTATIVE CONTRACT NO JOB_24-5

TERMS: NET 30 DAYS. Accounts over 30 days will be charged $11 / 2 \%$ per month not to exceed $18 \%$ ann:lly.

If this account is placed with a coliection ugency or an atromey for collection upon delaut of payment, a toe of $25 \%$ of the unpaid balance, topether with all coun costs. atomeys' loes, garnishment loes and $10 \%$ interest from maturity is heroby authorized. 
Driling

compovion

Tert Butery instianon

Purping Semoed

Salt Waier Wote.

Plug a abancoon
S[D]可了

DAILLUNG \& WELL

SERVICE, INC

I IO1 GALBERT RD.

(31B) 261-0295
(1)

TICKET 6821

REPORT NO. 16

\section{DAILY WORKOVER REPORT}

company $Q Q E$

FIEL Eadt Crab Lahe

LEASE ESAdter meall

DATE $10-6-93$

PARISH OR COUNTY Cameroz state Ya

WELL NO RIG NO

Present Perforations

Present Packer Setting

Total Depth

Present Depth

Type Plug

SAFETY MEETINO

stay, clase or gull

wheremationg

4040

B. O. P. TEST PRESSURES

Rams

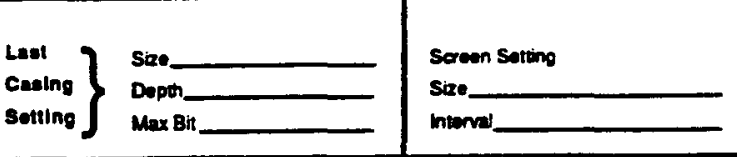

Tubing Sotting

$\sin$

Type

Ant

DRLL DEEPEA Make a Model

Clating Depth

Size

PROOUCTYON PRESSURE SETTING

Mud Type

Size

Weight

Vis.

Depih

Opening Dopth

Bit Sizo

Footage Made

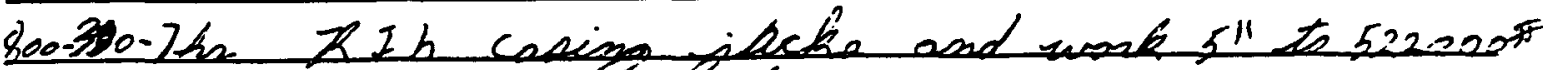
in att to psere att 1500 opt

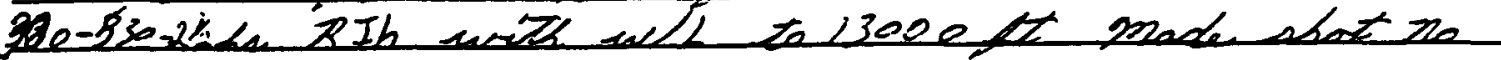
indear cut

$330-230.260$ make up cis ibogner In all 7 Ih 3000 ft

made shut poo h with sud

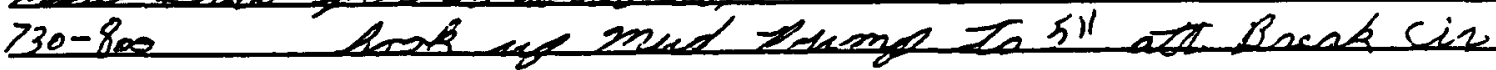

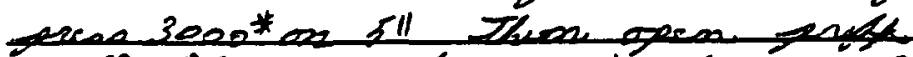

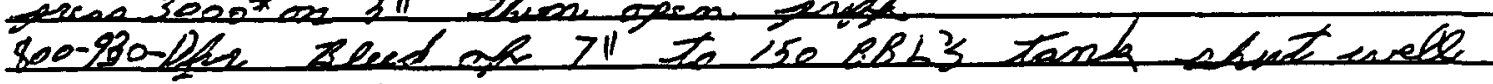
in has nipber

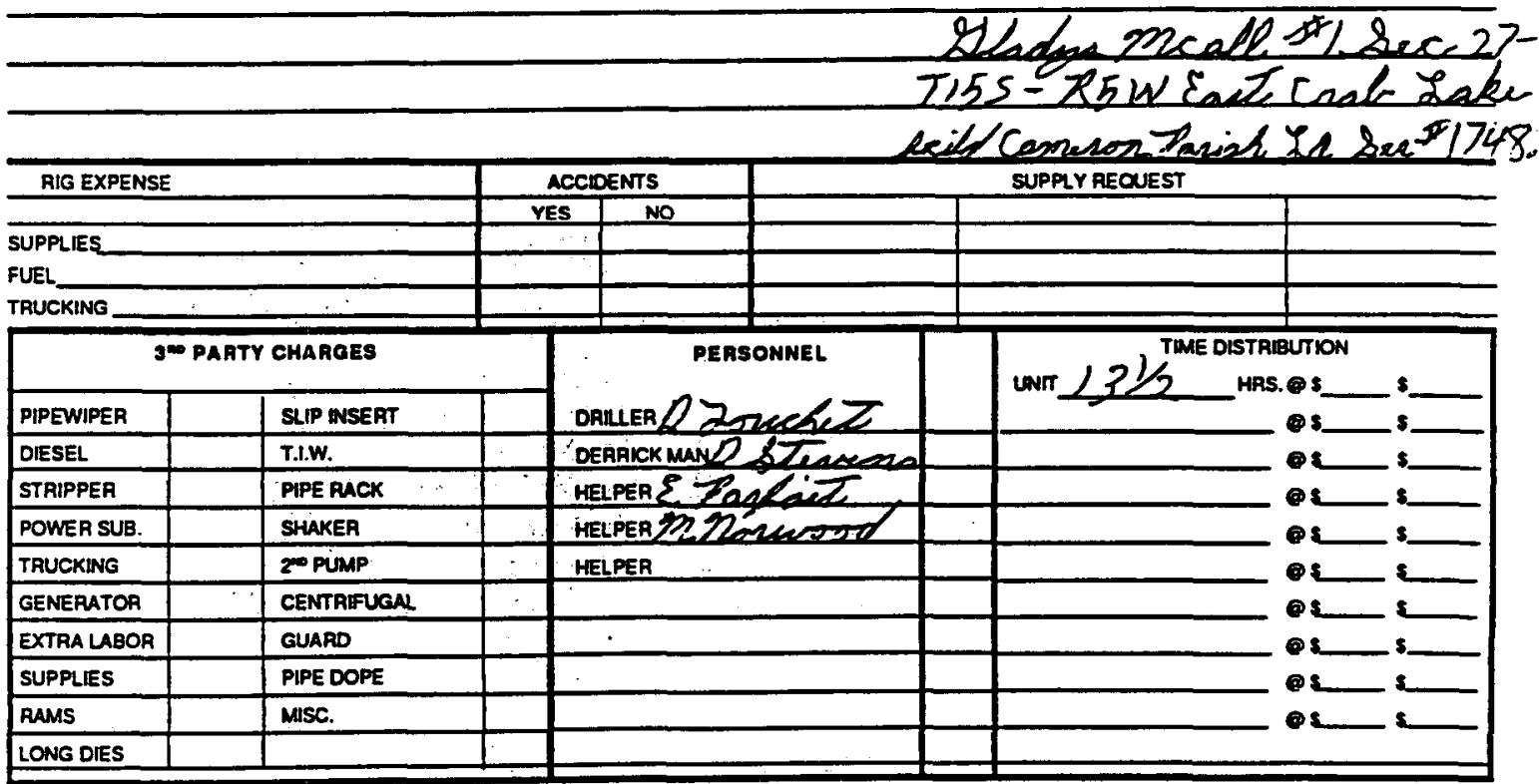

TOOLPUSHERfouplas Zowehet JOB NO $24-5$ ORDER NO
COMPANY REPRESENTATIVE

CONTRACT NO
Jов_24-5

TERMS: NET 30 DAYS. Accounts over 30 days will be charged $11 / 2 \%$ per month not to exceed $18 \%$ annilly.

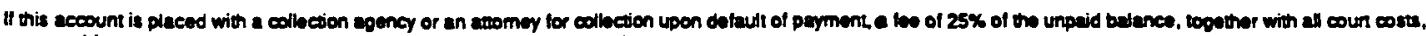
anomeys' Ioes, garnishment tees and $10 \%$ interest trem maturity is horoby authorized. 
company DQE

FieLo East cast Lake PARISH OR COUNTY Comesose LEASE 21 laderincale
DATE $\angle O-2-93$ WELL NO. 1 RIG NO_ 5

Present Pertorations

Present Packer Setting

Total Depth

Present Depth

Type Plug

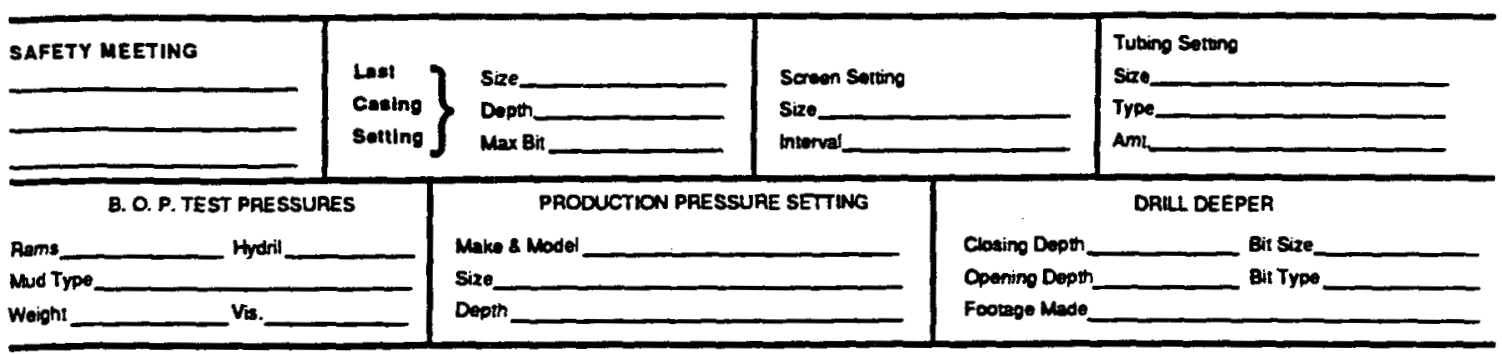

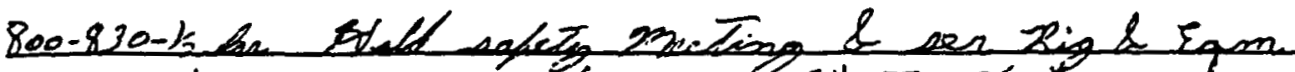

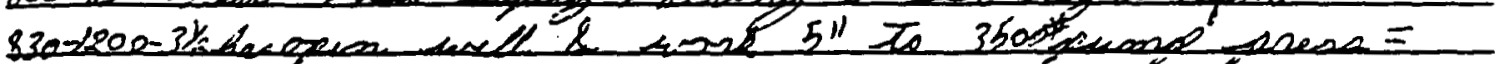

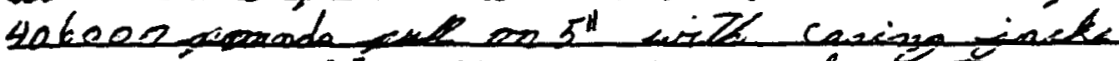

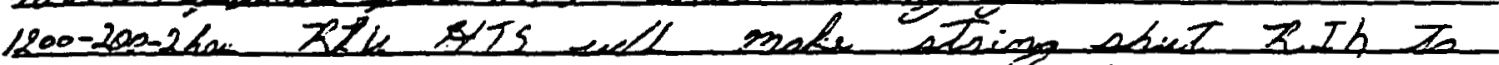

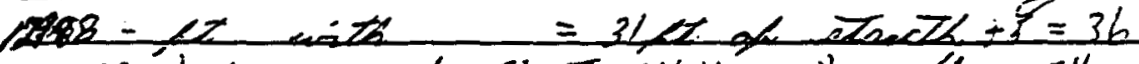
200230 ish wosk it to 464000 " pull on 5ll with inch

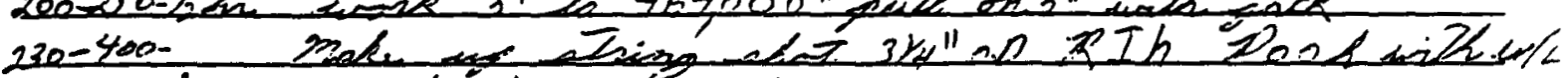

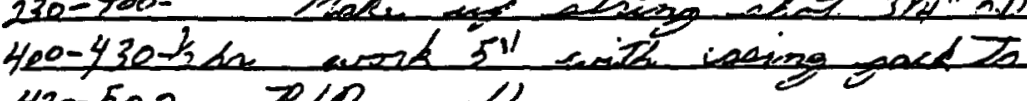
430500 T/2 rall

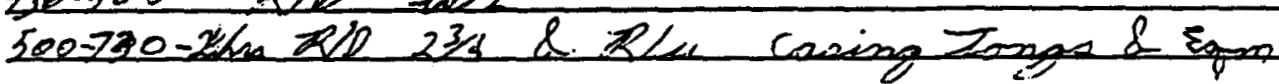

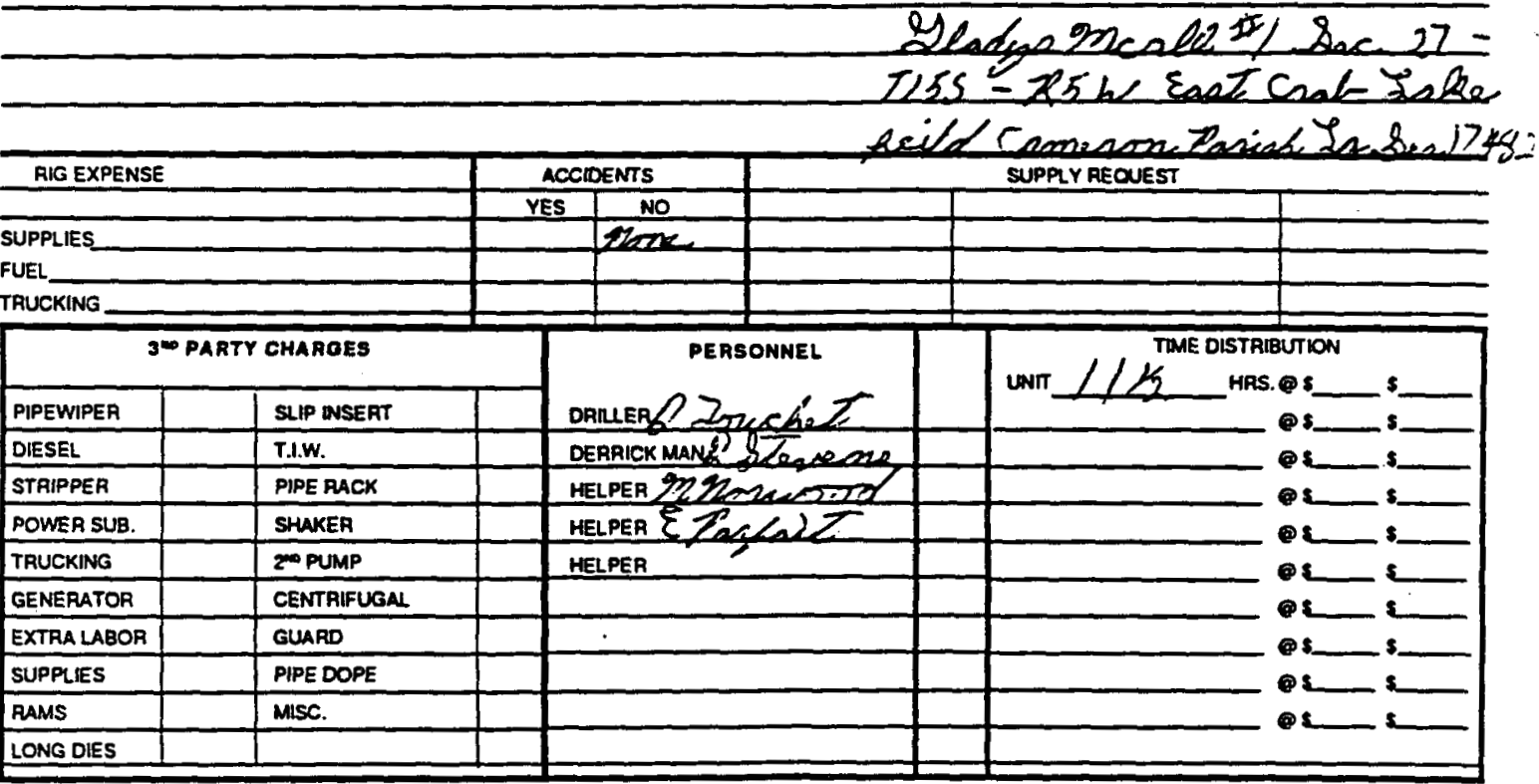

TOOLPUSHER floziglas Zozeche I JOB NO $24=5$ ORDER NO
COMPANY REPRESENTATIVE CONTRACT NO
$\mathrm{JOB} 24=5$

TERMS: NET 30 DAYS. Accounts over 30 days will be charged $11 / 2 \%$ per month nol to exceed $18 \%$ ann:lly.

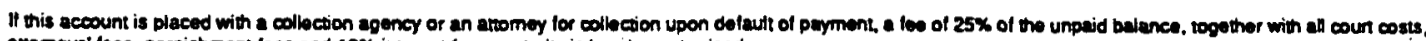
antomeys" toes, garnichment lees and $10 \%$ intorest trom maturty is horeby authorized. 


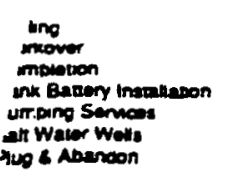

company $20 E$

FIEL Eeat csah Lake

PARISH OR COUNTY COAmera.

Present Perforations

Total Depth

Total Depth

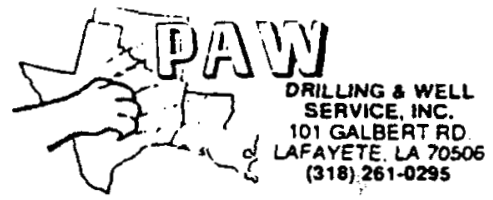

DAILY WORKOVER REPORT
TICKET Б8こう

REPORT NO. 18 DATE DO-8-23 WELL NO. 1 RIG NO 5 Present Packer Selting

Present Depth - Type Plug

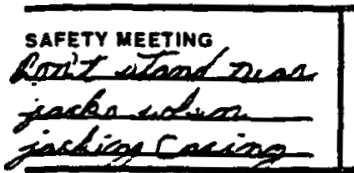
$\left.\begin{array}{ll}\text { Leat } \\ \text { Casing } \\ \text { solting }\end{array}\right\} \begin{aligned} & \text { Size } \\ & \text { Dopth } \\ & \operatorname{Max} B i\end{aligned}$

Soreen Sorting
Sase_arved

B. O.P.TEST PAESSURES

Rams Hydril.

PAODUCTION PAESSURE SETTING

Mud Type Hydril

Woigh: Vis. Make 8 Model Size Depth

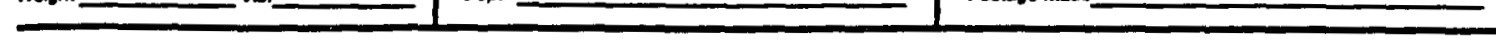

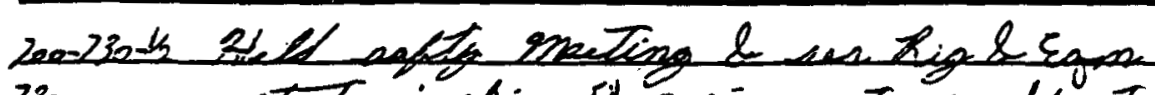

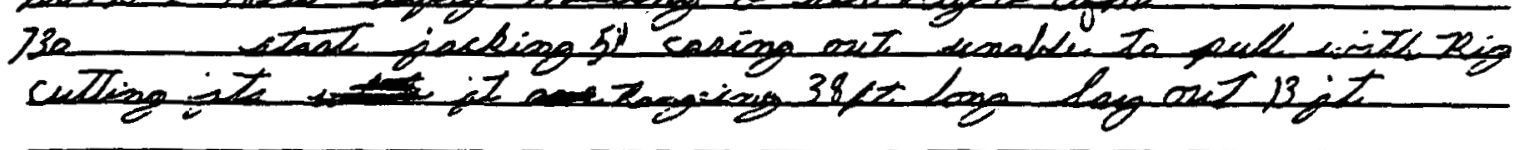

Tubing Soring

Size.

Type.

DALL DEEPER

Cosing Depth

Bit Size Bit Type

$$
\text { - }
$$

$$
\text { (2) }
$$

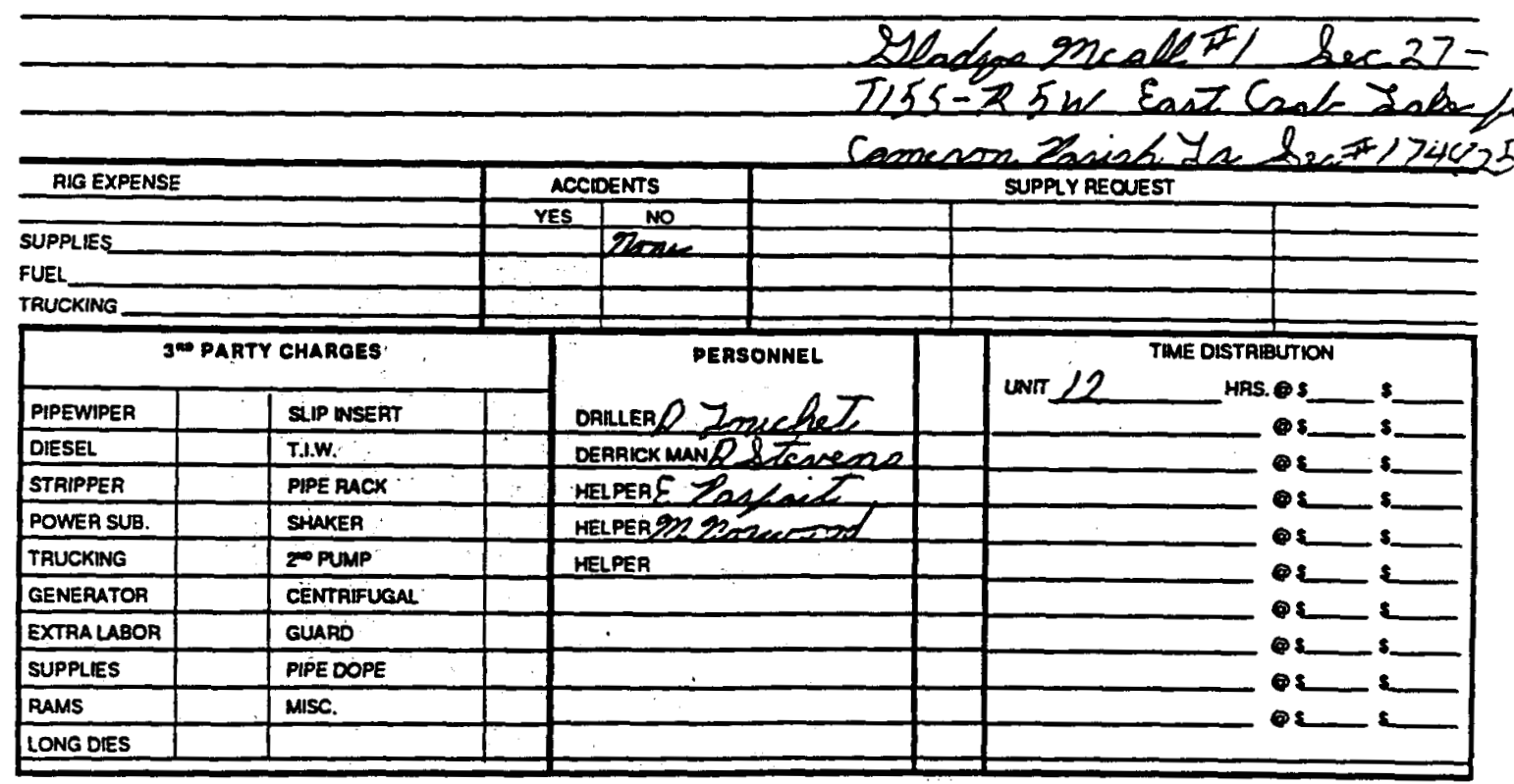

TOOLPUSHerlonghe Zonechet JOB NO $24-5$ ORDER NO.
COMPANY REPRESENTATIVE CONTRACT NO
JOB. $24-5$

TERMS: NET 30 DAYS. Accounts over 30 days will be charged $11 / 2 \%$ per month not to exceed $18 \%$ ann:lly.

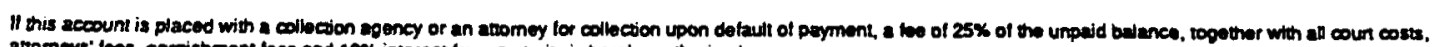
atromera' toes, garnishment fees and $10 \%$ interest trom manuity is hereby authorized. 
Aing

cnower.

crovitiven

enx Barery inarilawon

urring somo:

salt Water Walls

Plug 4 doencion

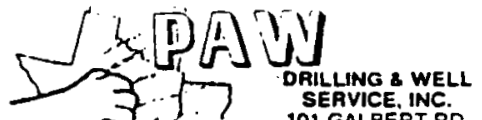

101 GALBEAT RD (318) $26,1.0295$
(2)
TICKET DSSLA:

REPORT NO. 19

DAILY WORKOVER REPORT

company DoE

FIELDEas Crab Lake LEASE Slladad Mall DATE $\angle 0-9-93$

PARISH OR COUNTY Came noOa state da WELL NO. L RIG No 5

Present Pertorations.

Present Packer Setting

Total Depth Present Depth Type Plug

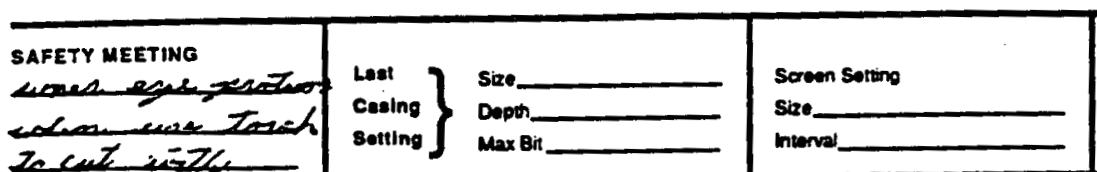

B.O.P.TEST PRESSURES

Rens - Hydril

Mud Type Vis. PAOOUCTION PRESSURE SETTING

Woight

\section{Tubing Soring}

size.

Type

Amt.

DARL OEEPEA

Cosing Deph _____ Bit Size

Foomge Mode

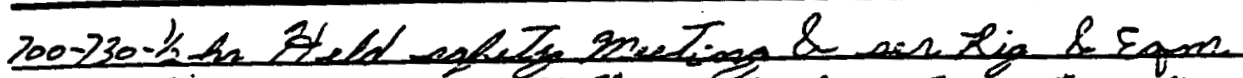

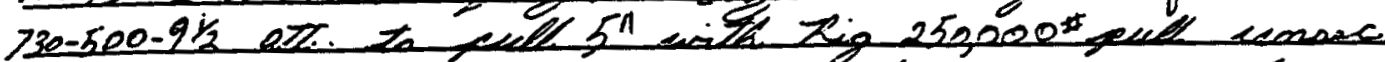

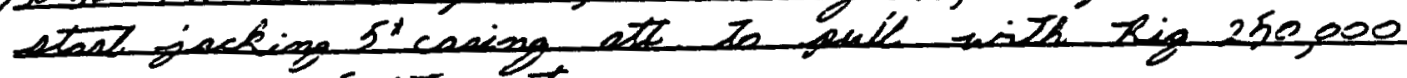
enewe eneng 5 ite ont

\section{Trab ith on geond}

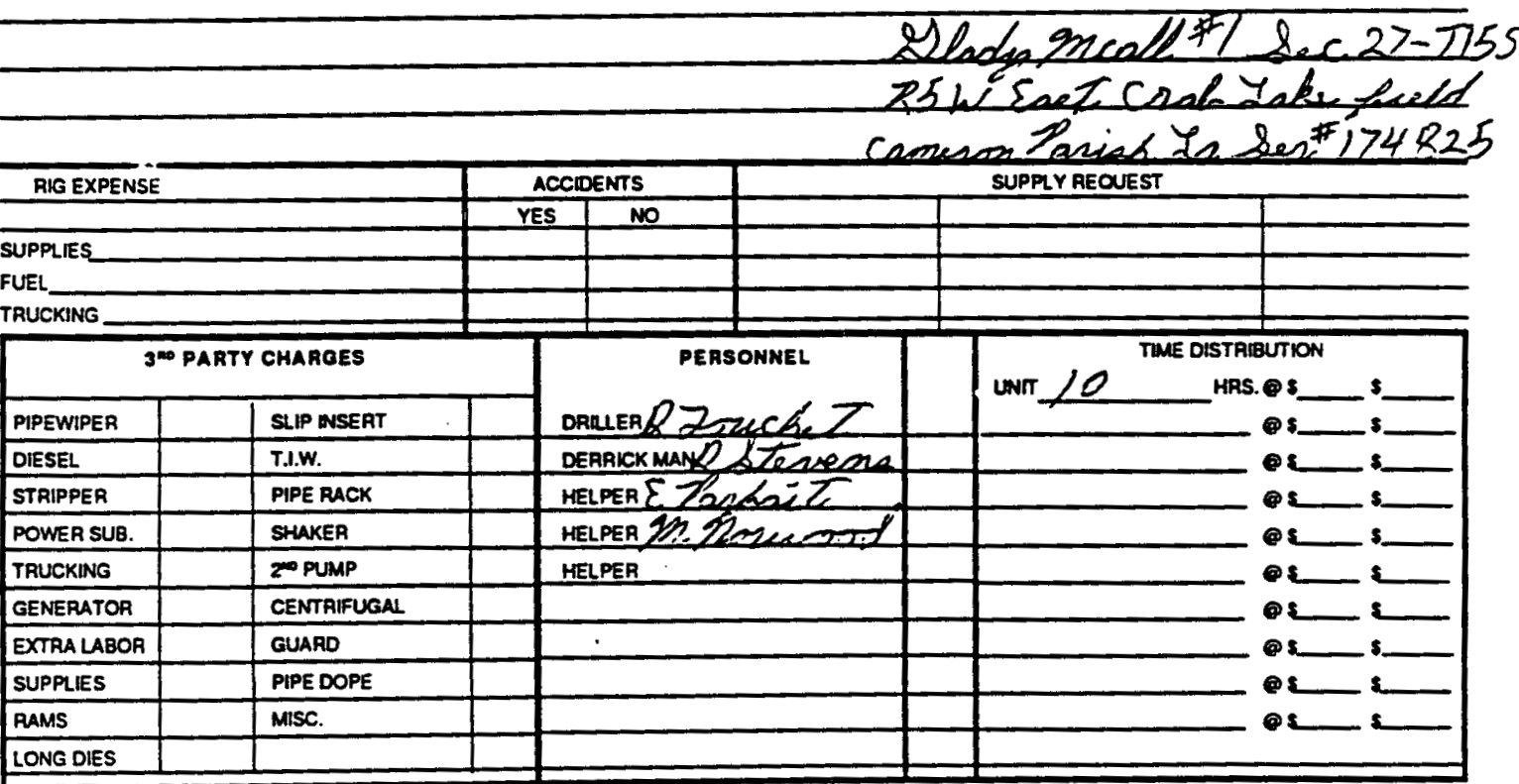

TOoLPUSнer bouplas Zouchet JOB NO $24-2$ ORDER NO.
COMPANY REPRESENTATIVE CONTRACT NO
JOB $24-5$

TERMS: NET 30 DAYS. Accounts over 30 days will be charged $11 / 2 \%$ per month not to exceed $18 \%$ ann!lly.

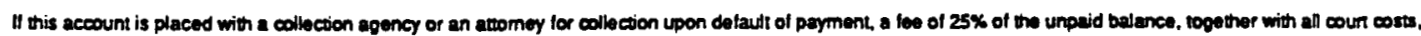
arromeys foes, garnishment fees and $10 \%$ interest trom matrity is heroby authorized. 


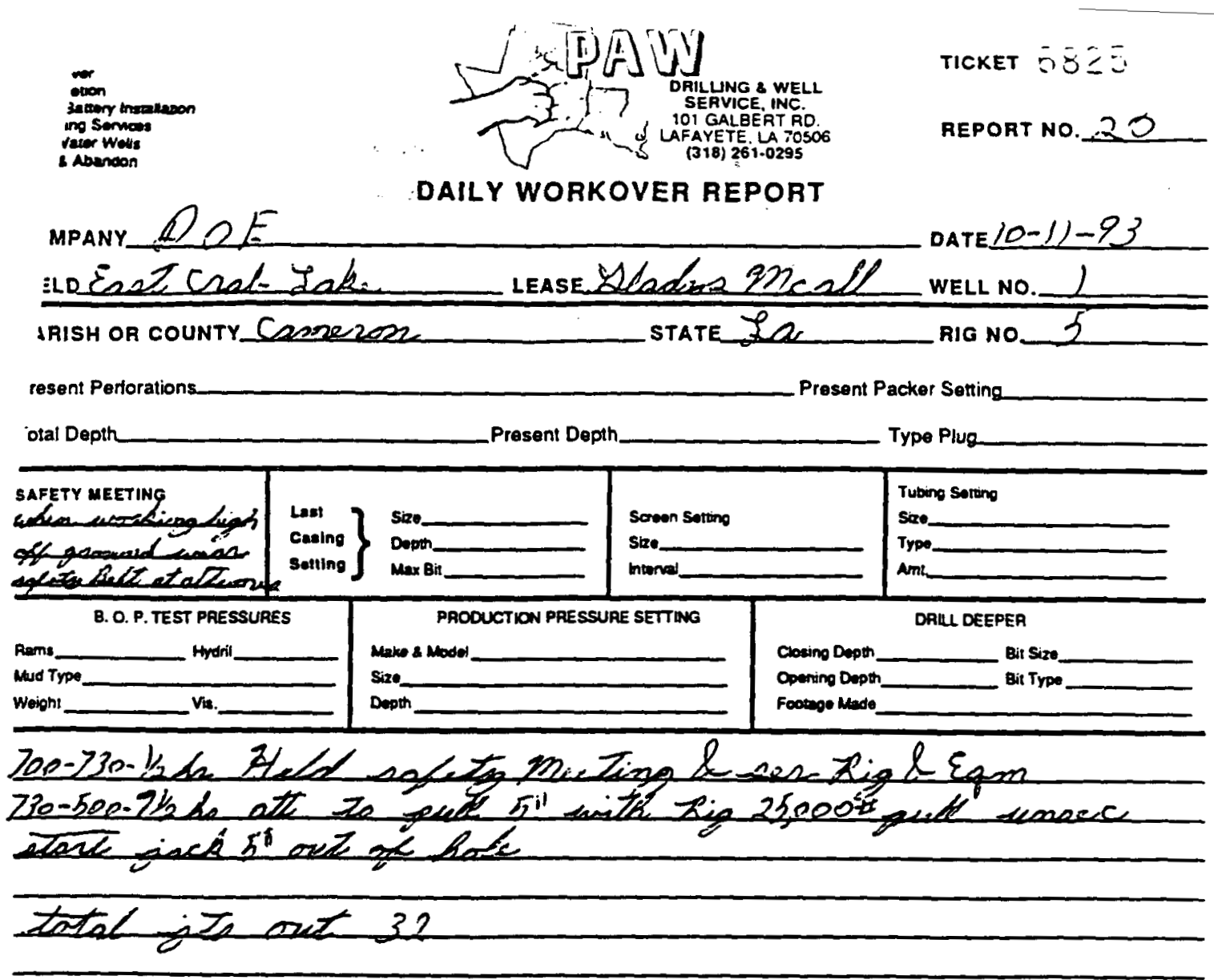

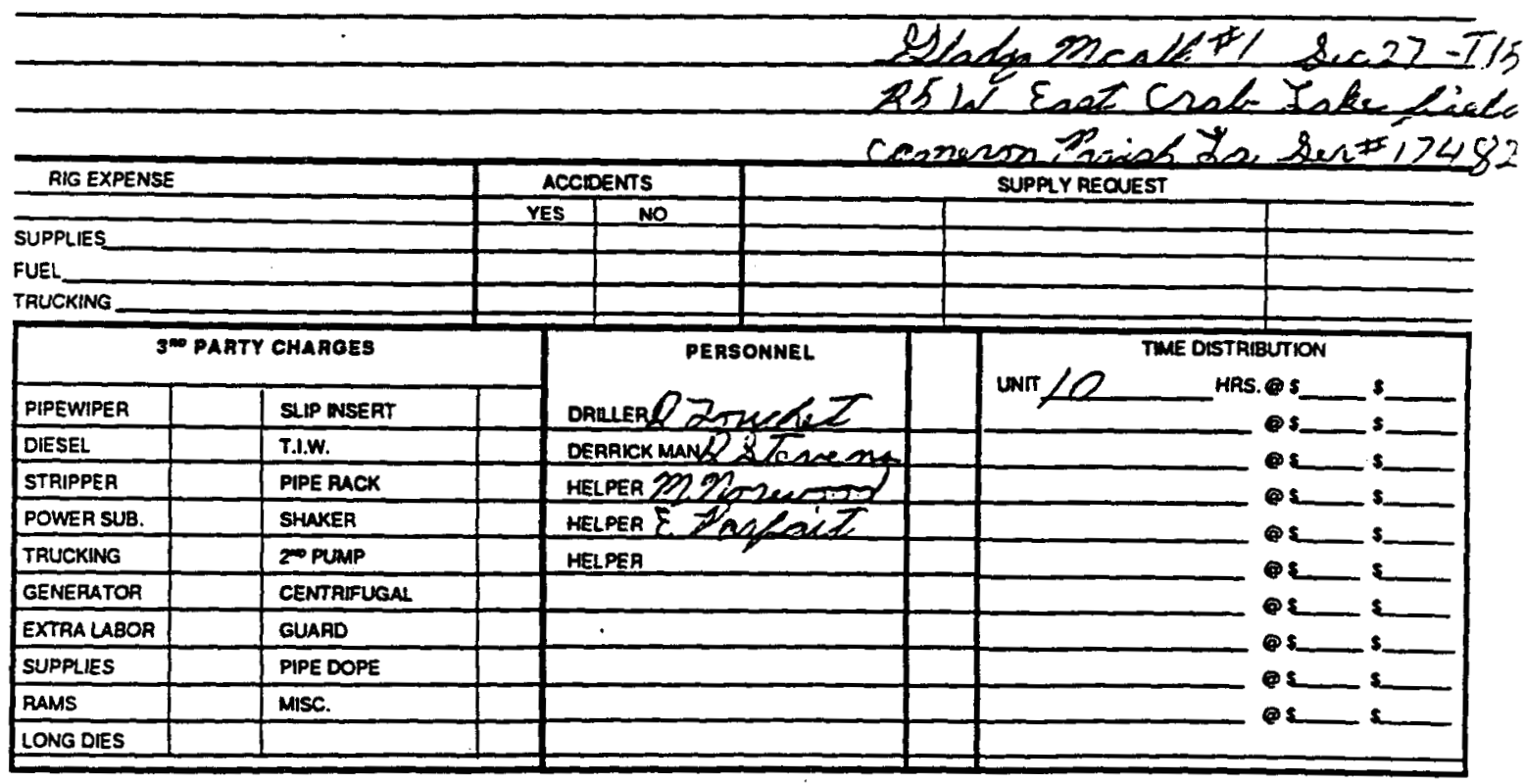

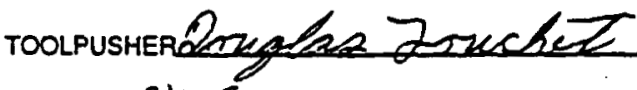
JOB NO $24-5$ ORDER NO.
COMPANY REPRESENTATIVE CONTRACT NO.
soB. $24-5$

TERMS: NET 30 DAYS. Accounts over 30 days will be charged $11 / 2 \%$ per month not to exceed $18 \%$ ann:lly.

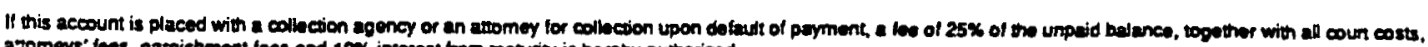
atomeys' toes, garnishment fees and $10 \%$ interest trom manurity is hereby authorized. 
DAILY WORKOVER REPORT

compalY $D Q E$

FIELDiaez crate Lake

LEASESlader 920 call state $2 a$

DATE $10-12-93$

PARISH OR COUNTY Camenoz

WELL NO._ I RIG NO 5

Presint Perforations

Present Packer Setting

Totar Depth

Present Depth

Typo Plug

\begin{tabular}{|c|c|c|c|}
\hline SAFETY MEETING & $\begin{array}{l}\text { Leat } \\
\text { Casing } \\
\text { Sotting }\end{array}$ & $\begin{array}{l}\text { Size } \\
\text { Depin- } \\
\text { Max Bin_ }\end{array}$ & $\begin{array}{l}\text { Sacen Setting } \\
\text { Saee } \\
\text { invervat }\end{array}$ \\
\hline 8. O. P. TEST PAESSU & & \multirow{3}{*}{\multicolumn{2}{|c|}{$\begin{array}{l}\text { PRODUCTION PRESSURE SETTING } \\
\text { Make \& Nodol } \\
\text { Size- } \\
\text { Depth }\end{array}$}} \\
\hline Rans____ Hudril__ & & & \\
\hline _ Vis. & & & \\
\hline
\end{tabular}

Woorgon

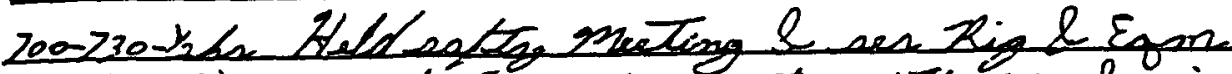

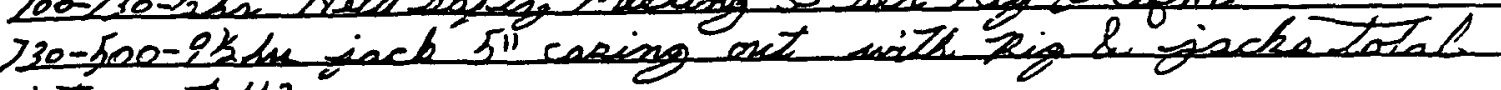
Ta on 43

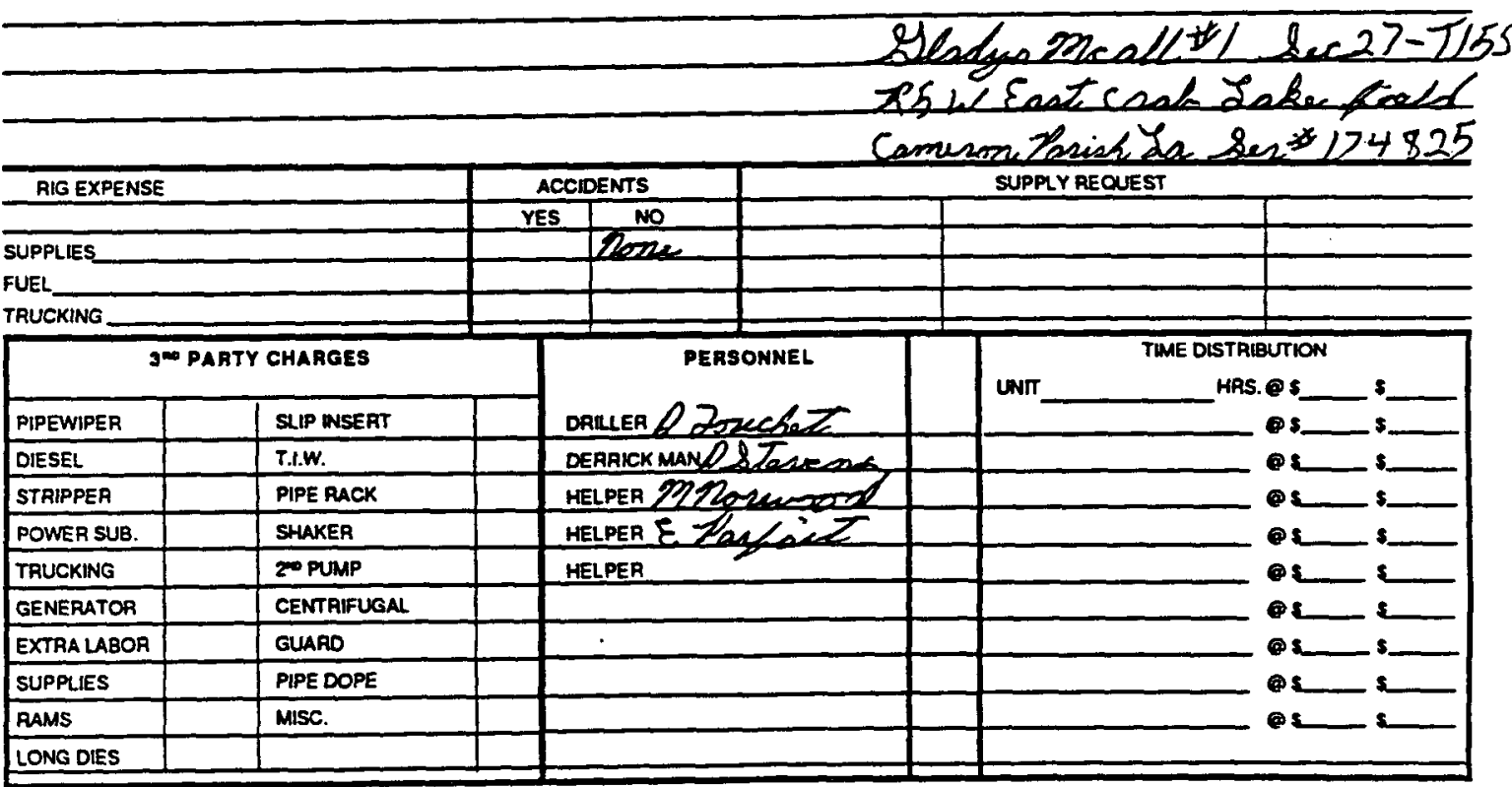

TOOLPUSHerforyglos Zowechet JOB NO $24-5$
ORDER NO
COMPANY REPRESENTATIVE

CONTRACT NO
Jов $24-5$

TERMS: NET 30 DAYS. Accounts over 30 days will be charged $11 / 2 \%$ per month not to exceed $18 \%$ ann!lly.

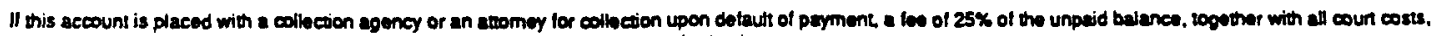
antomeys' tees, garnishment fees and $10 \%$ interest trem maturity is hereby authorized. 
company De E

\section{DAILY WORKOVER REPORT}

FIEL East crak Lake

PARISH OR COUNTY CaOmesone

\section{Lease Hladas Mcall} state Ya
DATE $10-13-93$ WELL NO. 1 RIG NO 5
Present Periorations

Total Depth

Total Depth

\section{SAFETY MEETING}

zayentedod zout

icongacentell

Troona B. O. P. TEST PRESSURES

Rams

Mad Type

Woight____ Vis.______ Hydril

Present Packer Setting

Present Depth Type Plug

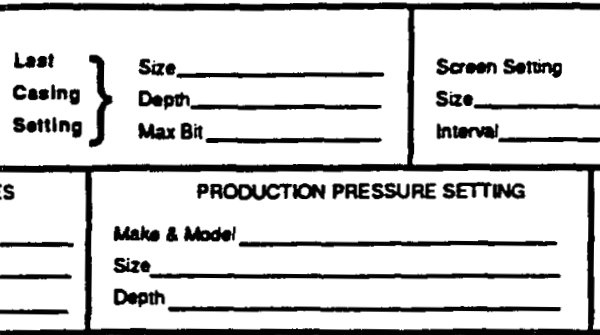

Tubing Soteing

Size.

Type

Am

DARL DEEPEA

Clowing Depth Opaning Depth Foorege Meon
Bit Sizo. Bit Typo

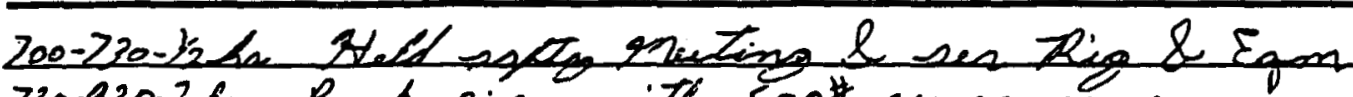

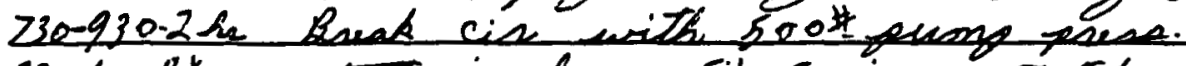
130-600-15 atast jacking 5il lasing toth ite out 50

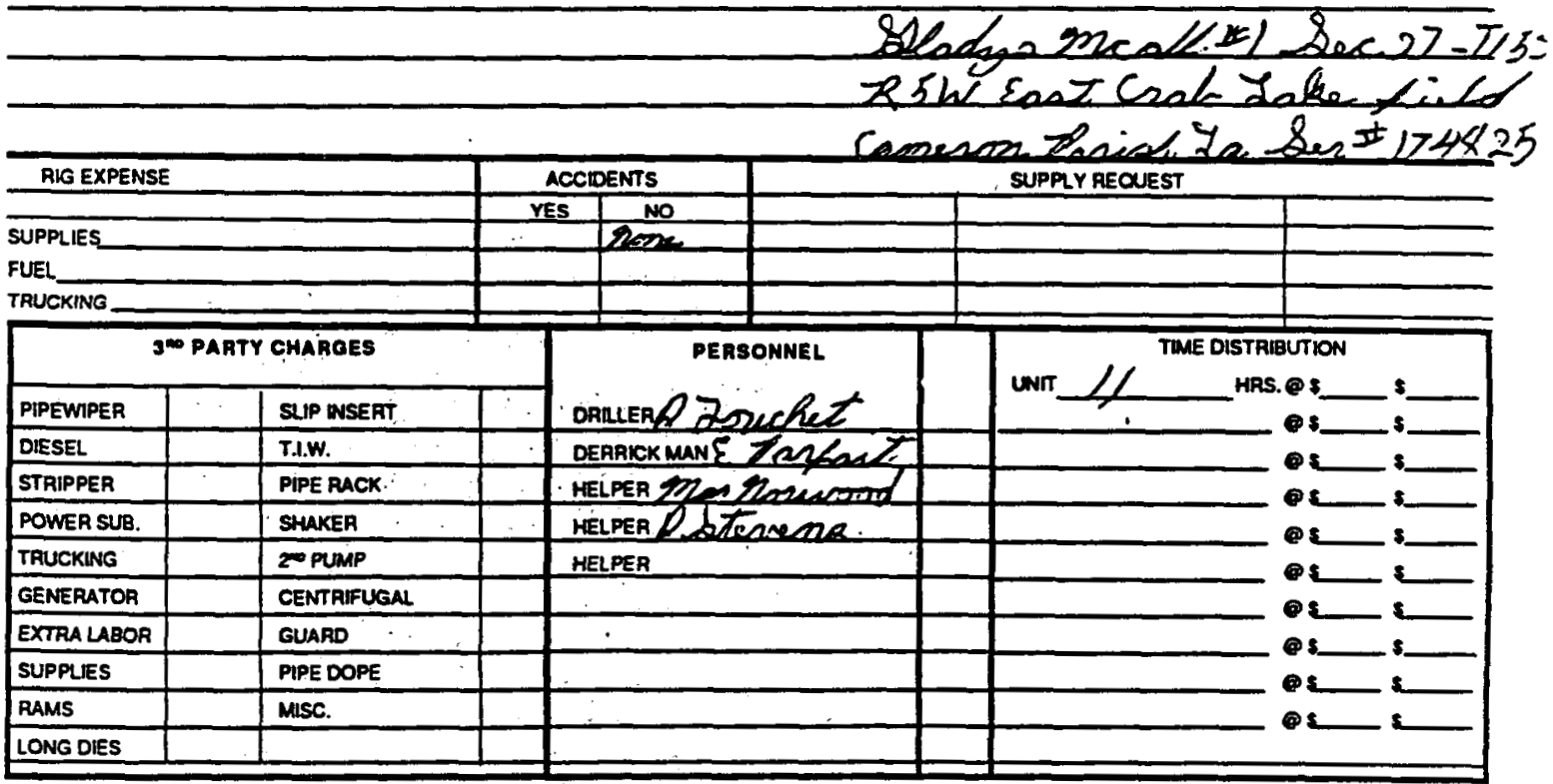

TOOLPUSнR Roughas Zosuchez JOB NO 24-5 ORDER NO. COMPANY REPRESENTATIVE CONTRACT NO $\operatorname{sos} 24=5$

TERMS: NET 30 DAYS. Accounts over 30 days will be charged $11 / 2 \%$ per month not to exceed $18 \%$ ann:lly.

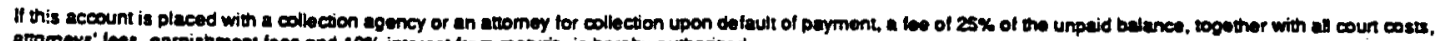
atromeys' leet. garnishment toes and $10 x$ interest trom maurity is hereby authorized. 
DAILY WORKOVER REPORT

REPORT NO. 23

company DoE LEASE Yladare 220 call DATE $\angle 2-14-93$

FIELDEeat cad Lake STATE $2 a$ WELL NO. 5

PARISH OR COUNTY COMmear

Present Packer Setting

Present Pertorations

Present Depth

Type Plug

Total Depth

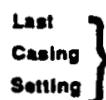

Lest

Casing

\section{zeypate tooen}

came $h$ agh In wenk wates B. O. P. TEST PRESSUAES

Rams

Mud Type Hydril

Woight vis.

-

\begin{tabular}{l} 
PRCOUCTION PRESSURE SETTING \\
Make \& Model \\
Sizo_ \\
\hline
\end{tabular}

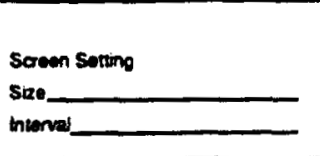

Closing Depth Foosege Meade

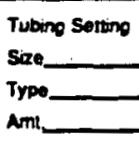

Bit Size

Bit Type

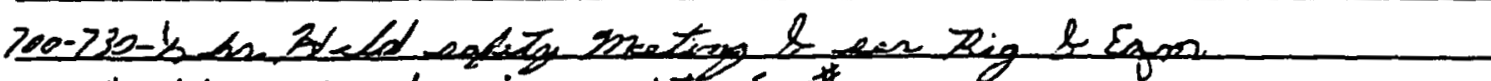

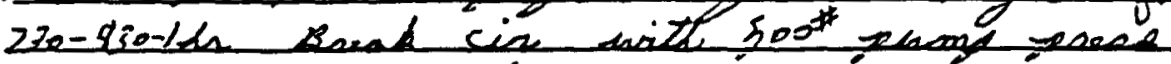

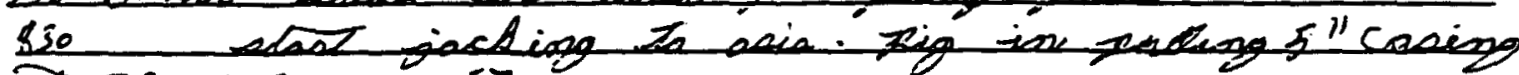
detal ito act 57

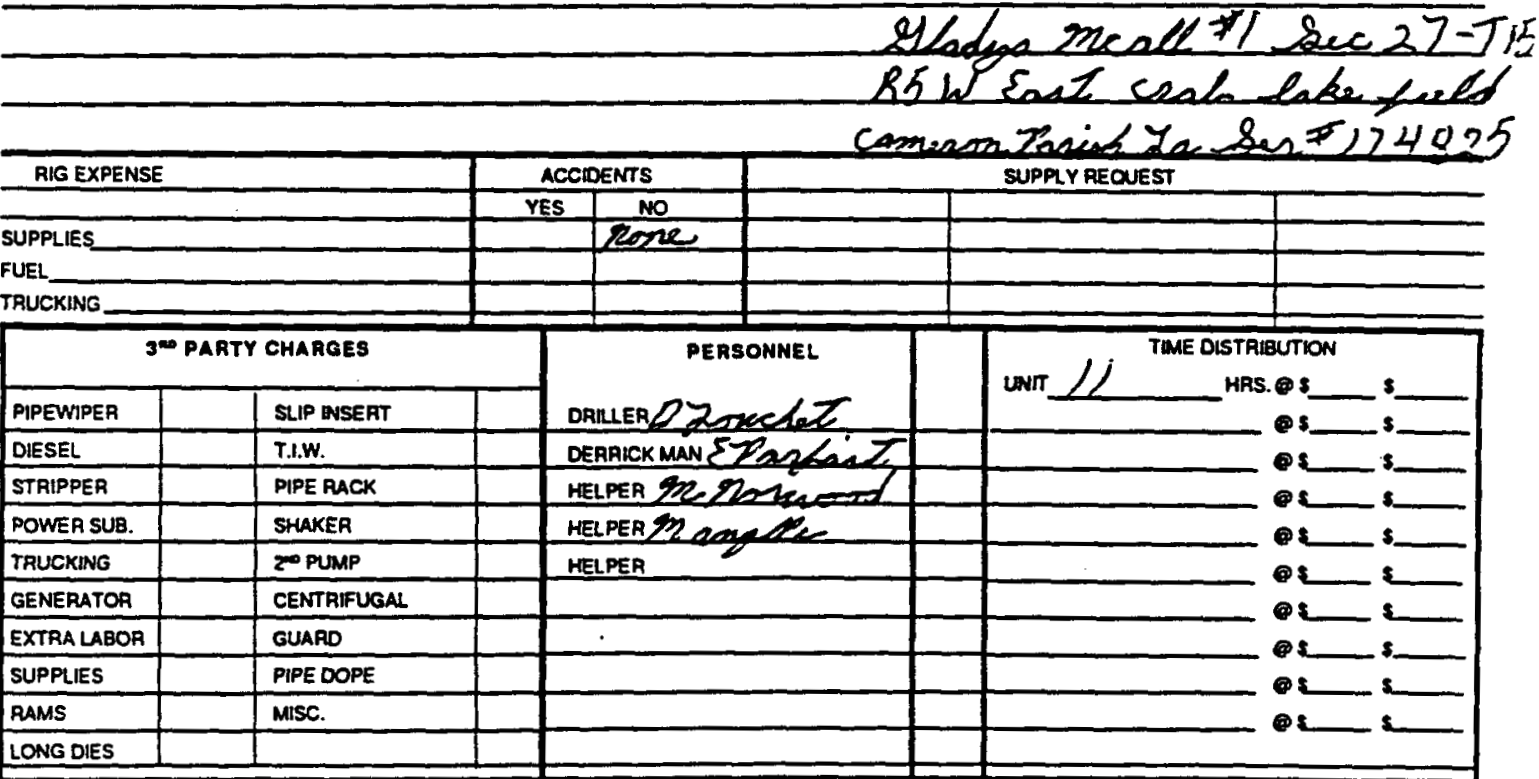

TOOLPUSHER Royglas Zerechet JOB NO24-5
COMPANY REPRESENTATIVE CONTRACT NO лов $24-5$

TERMS: NET 30 DAYS. Accounts over 30 days will be charged $11 / 2 \%$ per month not to exceed $18 \%$ ann:lly.

II this account is placed with a collection agency or an atwomoy for collaction upon delault of payment, a lee of 25\% of the ungald batance, logether with all coun costs. atomers' lows, gamishment lees and $10 \%$ interest trom makurity is hereby authorized. 
Jiting

vomover

Complation

Tensi Batury Inatalason

Purrong Samoas

Slis 8 Aaterion

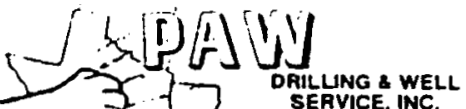

101 GALBERT R.

101 GALBERT RD
(318) 261-0295
(31ETE. LA 70506

DAILY WORKOVER REPOORT
TICKET $\hat{0} \hat{0}$

REPORT NO. 24 company $D \cap E$

IELDEsat cala Lake PARISH OR COUNTY COMmenOS

Present Perforations

Total Depth

\section{SAFETY MEETING}

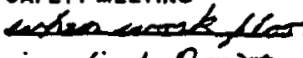

in hios ocosit

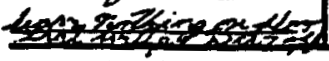
B. O. P. TEST PRESSURES

Pans

Nud Type Hydril

Woight vis.

\section{LEASE Headen moall} STATE 22
DATE $10-15-93$

WELL NO. 1 RIG NO 5

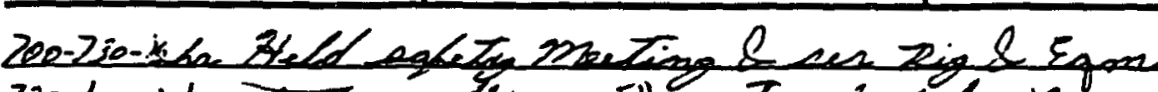

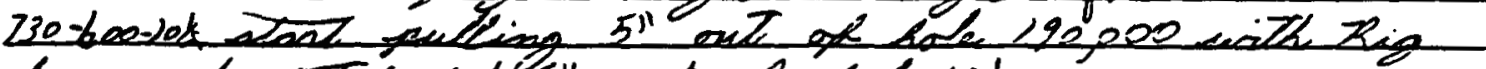

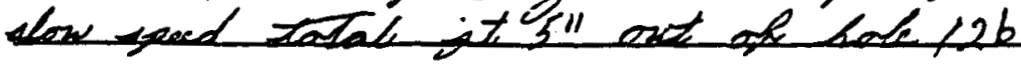

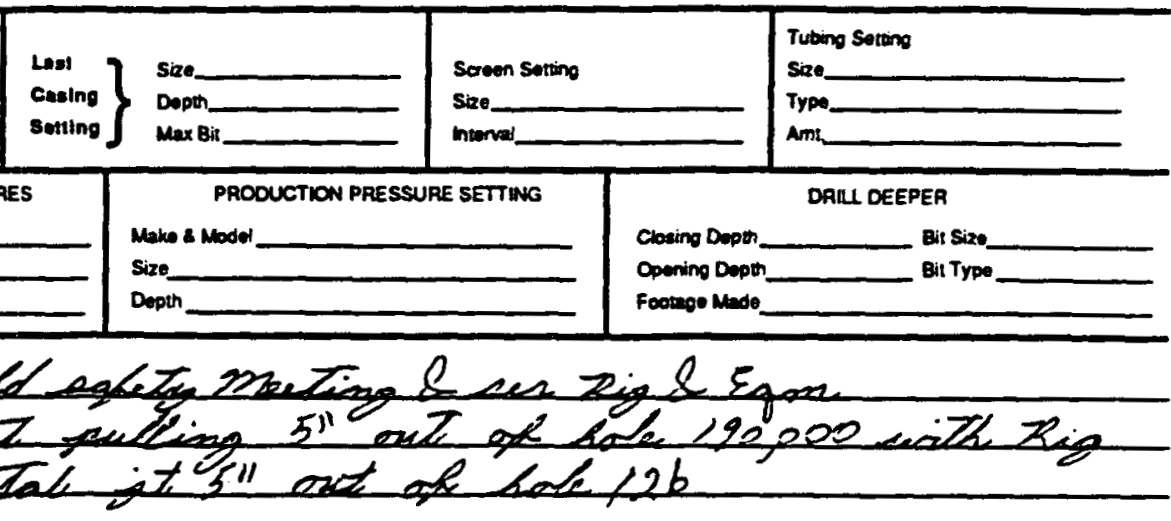

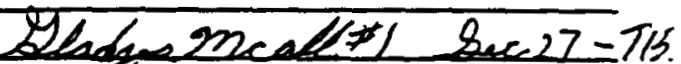
Ti5 Eact crab Iaketeld

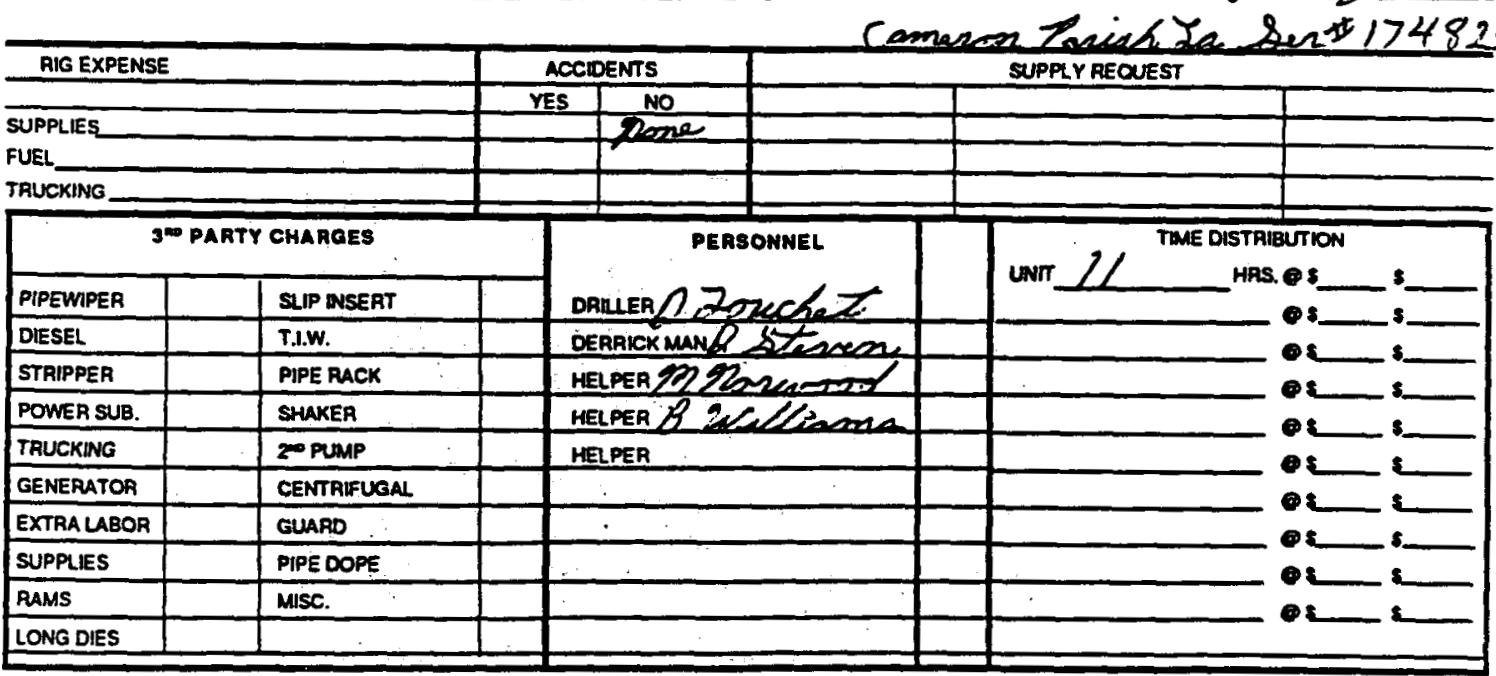

TOOLPUSHer bogyalas ZacheZ JOB NO $24-5$ ORDER NO.
COMPANY REPRESENTATIVE CONTRACT NO
Jo8. $24-5$

TERMS: NET 30 DAYS. Accounts over 30 days will be charged $11 / 2 \%$ per month not to exceed $18 \%$ ann:lly.

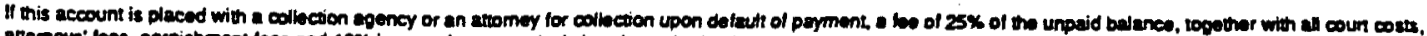
atomery' loes, garnishment tees and $10 \%$ interest from maturity is horoby authonzed. 


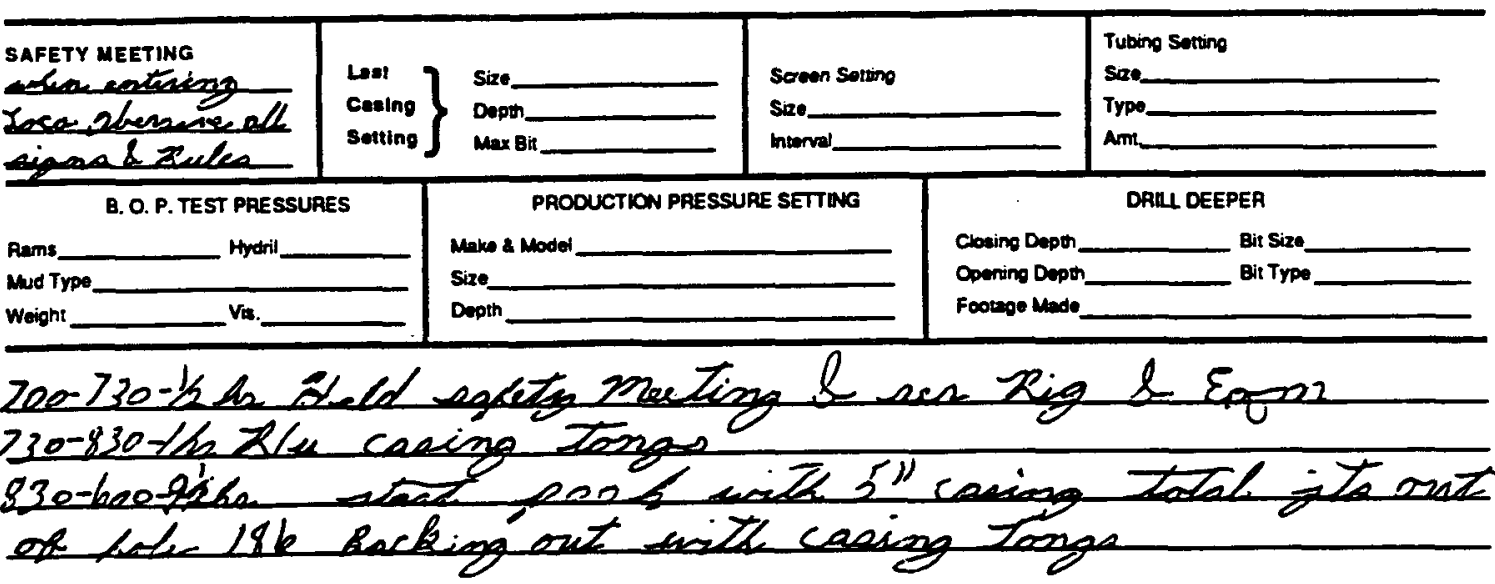

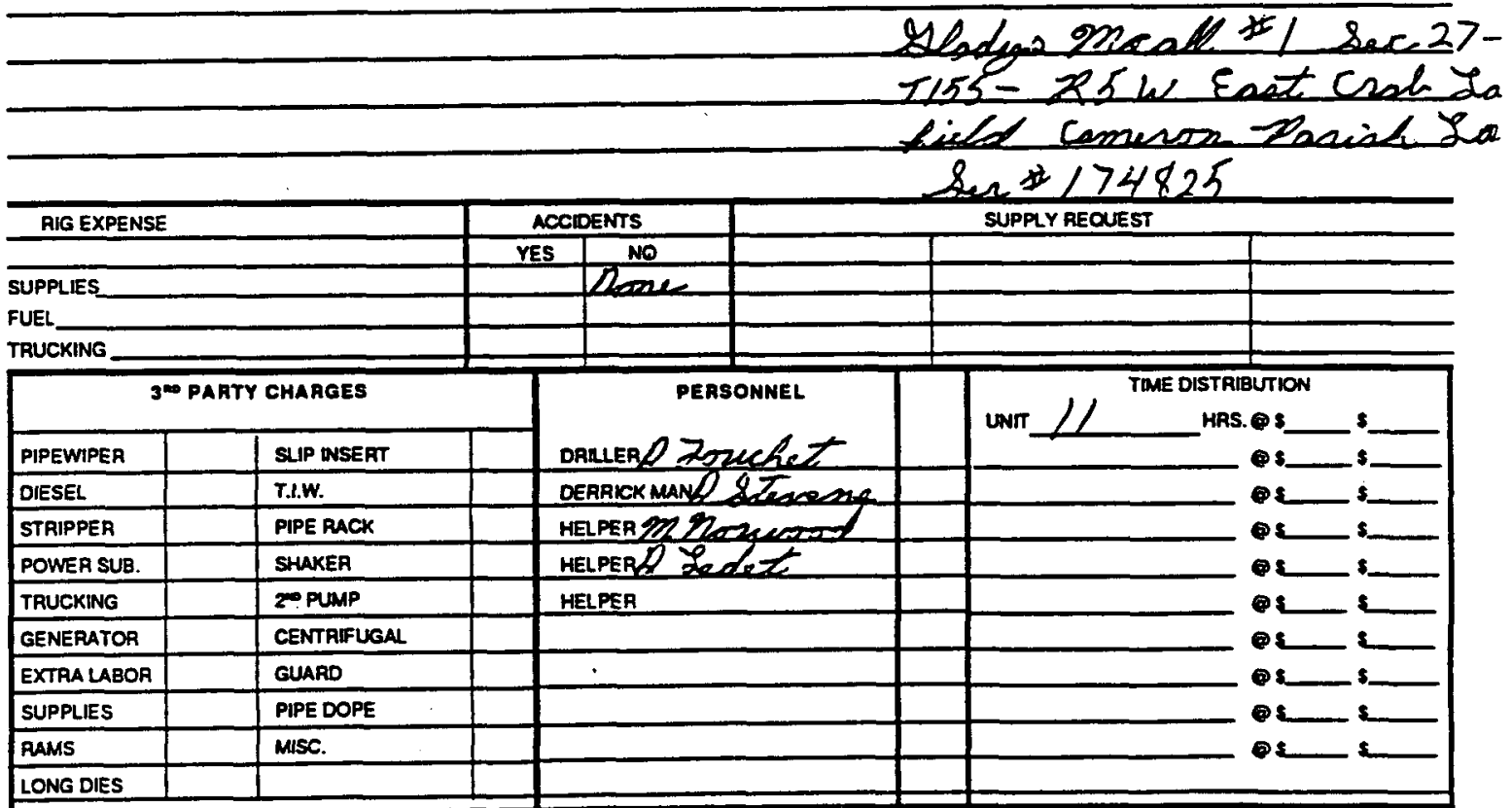
TOOLPUSHER lougglas Zrechet
JOB NO $24-5$ ORDER NO.
COMPANY REPRESENTATIVE CONTRACT NO. งов $24-5$

TERMS: NET 30 DAYS. ACcounts over 30 days will be charged $11 / 2 \%$ per month not 10 exceed $18 \%$ ann:lly.

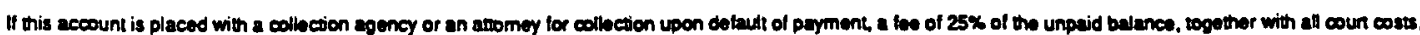
attomeys' bes. garnishment toes and $10 \%$ intoress trom masutity is heroby authorized. 
Present Pertorations

Total Depth

Present Depth

SAFETY MEETING

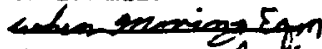

icm yen Los

ot hobutactiog

B. O. P. TEST PRESSUAES

Rems. Hydril

Mud Type

Weight Vis.

$\left.\begin{array}{l}\text { Leat } \\ \text { Cesing } \\ \text { Satting }\end{array}\right]$

Present Packer Setting Type Plug

\section{Tubing Sation}

Sige. Type. Ams DRML DEEPER Make \& Model Size. Dopth

\section{Serwen Solting}

Size

movral

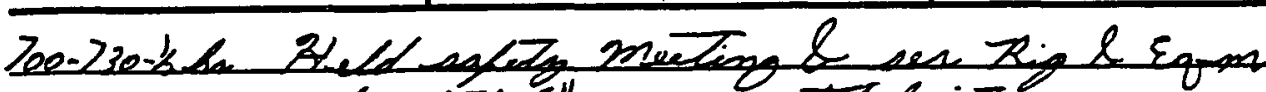

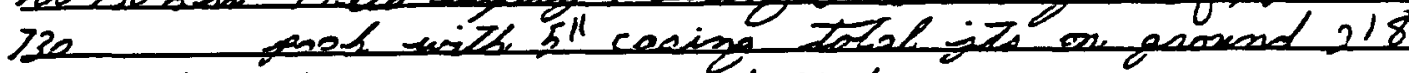
Tonded out 120 its an mach itale

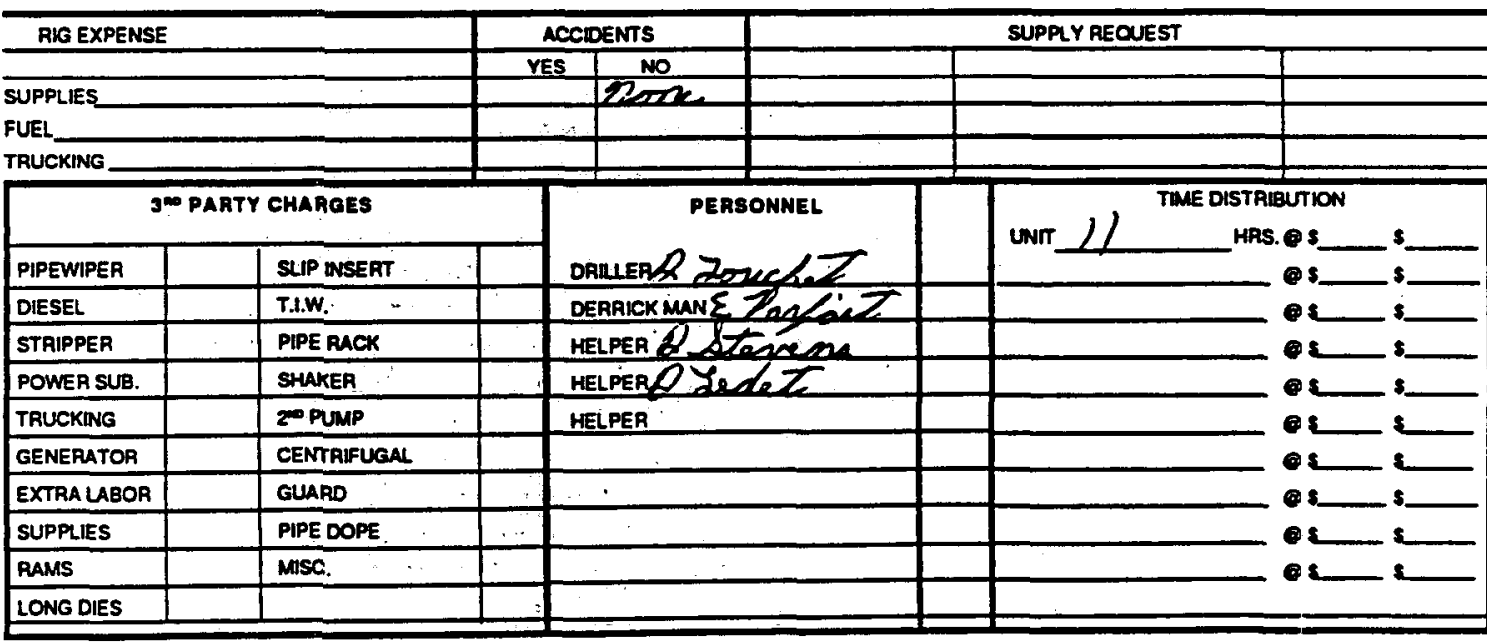

TOOLPUSHer Loughas Zouchet JOB NO24-5 ORDER NO.
COMPANY REPRESENTATIVE

CONTRACT NO
Joв_24-5

TERMS: NET 30 DAYS. Accounts over 30 days will be charged $11 / 2 \%$ per month not to exceed $18 \%$ ann:lly.

If this account is placed with a colbetion agency or an abomey for colbecion upon detaut of parment, a foe of $25 \%$ of the unpaid belance, topather with atil coun costs, attomeys' tees, garnithment lees and $10 x$ inserest from maurity is hereby authorized.

$$
\text { 6-53 Exhibil 6-M }
$$


Total Depth

Present Depth

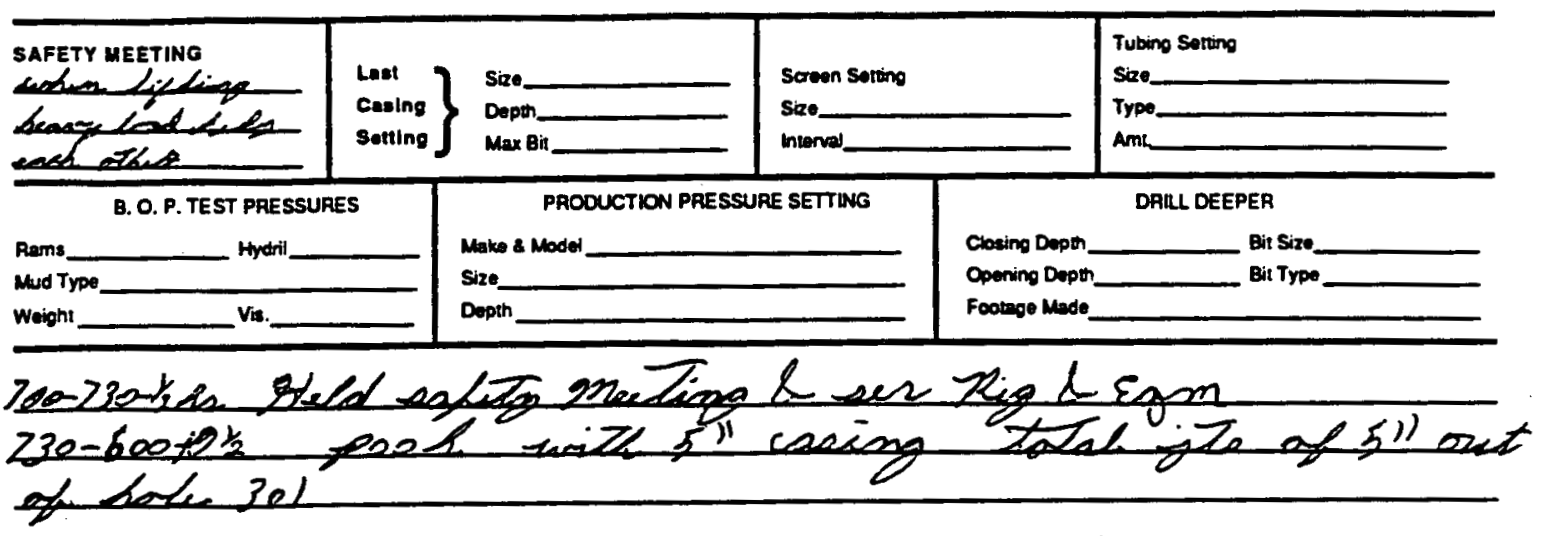

\begin{tabular}{l|c|l|l|l|l|}
\hline RIG EXPENSE & ACCIOENT & \multicolumn{3}{|c|}{ SUPPIY AECOEST } \\
\hline & YES & NO & & & \\
\hline SUPPLIES & & & & & \\
\hline
\end{tabular}

FUEL

TRUCKING

\begin{tabular}{|c|c|c|c|}
\hline \multicolumn{2}{|c|}{ 3N PARTY CHAROES } & \multirow{2}{*}{ 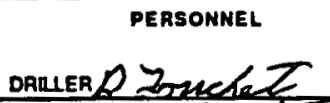 } & TMME DISTRRBUTION \\
\hline PIPEWIPER & SLIP NSERT & & \\
\hline DIESEL & J.1.W. & DERRICK MAN $\varepsilon Z_{0}^{\circ}$ & (2) \\
\hline STRIPPER & PIPE RACK & MELPER $D$ & Qs. \\
\hline POWEA SUB. & SHAKER & HELPER $D$ & (a) \\
\hline TRUCKING & 20 PUMP & HELLPER & et \\
\hline GENERATOR & CENTRIFUGAL & & es \\
\hline EXTRA LABOR & GLARD & $\cdot$ & es \\
\hline SUPPLIES & PIPE DOPE & & e2 \\
\hline PAMS & MISC. & & es \\
\hline LONG DIES & & & \\
\hline
\end{tabular}

TOOLPUSHER houphe Zruchet JOB NO $24-5$ ORDER NO
COMPANY AEPRESENTATIVE

CONTRACT NO $\operatorname{sog} 24-5$

TERMS: NET 30 DAYS. Accounts over 30 days will be charged $11 / 2 \%$ per month not to exceed $18 \%$ ann:lly.

II this account is placed with a collection agency or an abomey for coilecion upon detaut of peyment, a foe of $25 \%$ of the unpaid balance, together with all cour costs. atomeys' fees, oarnishment loes and $10 \%$ inferest trom matrity is hereby authorized. 
Drilling

Wortower

Compiotion

Tenix Babery inatuation

Purt.ping Semos:

Saln Waier Wella

Plus \& Abandon

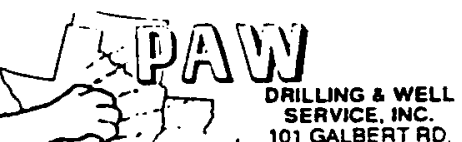

(318) 261-0295
TICKET 6833

REPORT NO28

\section{DAILY WORKOVER REPORT}

company $D Q E$

FIELD Eact crab sake

PARISH OR COUNTY CaOmen

LEASE Ylady ancall state Lel

DATE 10-19-93

WELL NO._)

RIG NO 5

Present Pertorations

Present Packer Serting

Total Depth

Present Depth

Type Plug

SAFETY MEETING

Eurvema opiads

chenemat

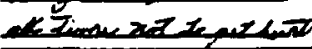

B. O. P. TEST PRESSURES

Rans Andril $\left.\begin{array}{l}\text { Leat } \\ \text { Casing } \\ \text { soting }\end{array}\right\}$ casing $\}$ Dopm Max Bin

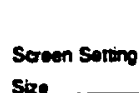

Stze. mienel. PROOUCTION PRESSURE SETTING

Mud Type Vis.

Woight Make 2 Model

Size Depin
Tubing Solting

Size.

Type

Amt.

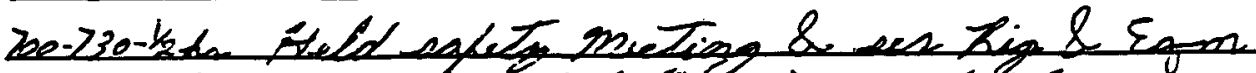
73e-12o-5in wesh int 5 canig ision

DRIL DEEPEA

Clowing Dopth Opening Depth Foorenge Made

on 2 bale $361=$

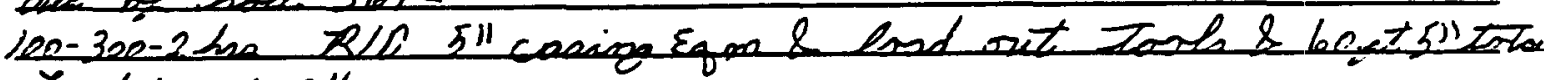
rooded ont 240

30o-4eothar Rlew 23/4 Enom

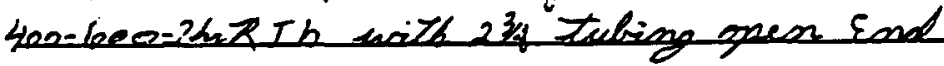

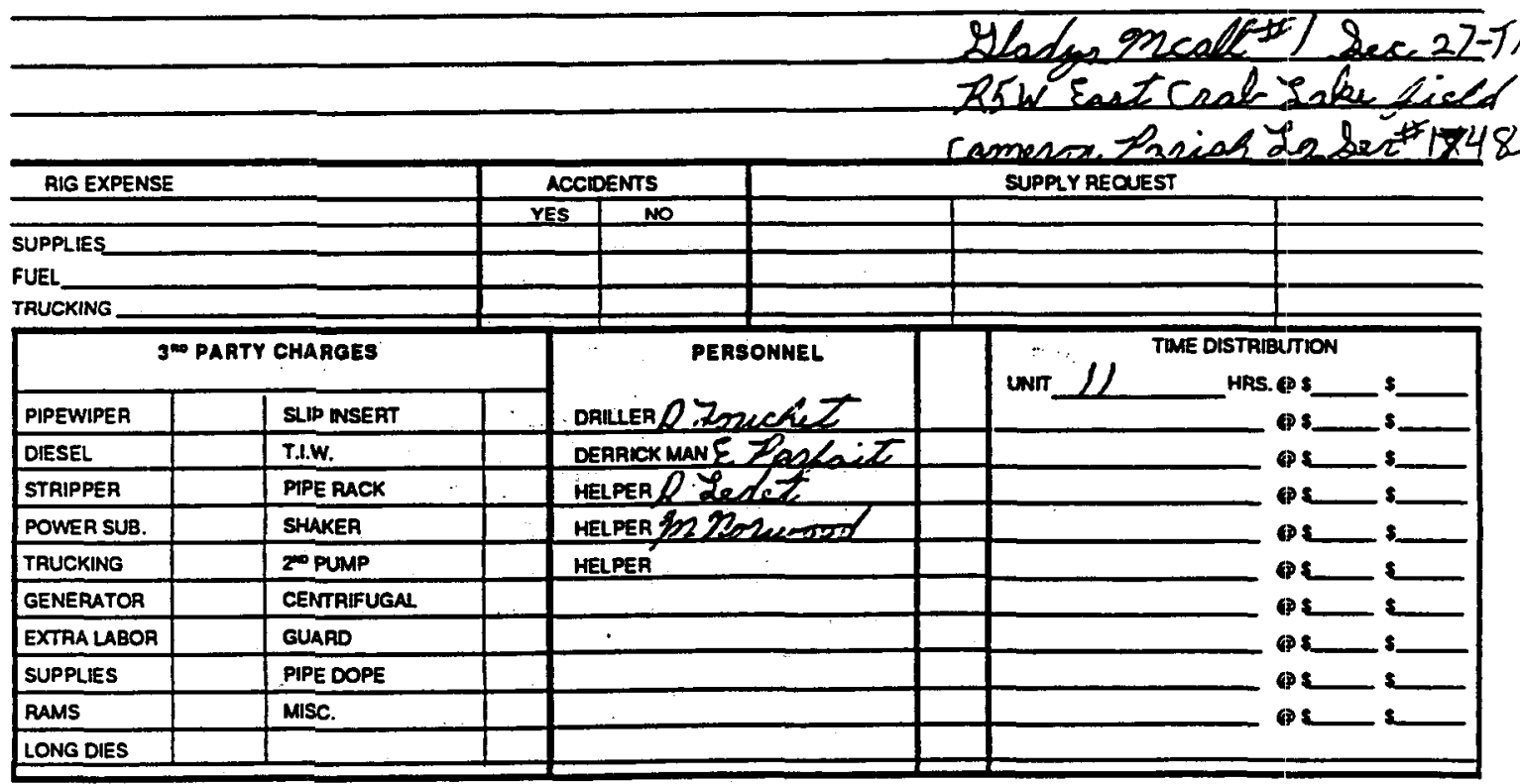

TOOLPUSHER blogylas ZorecheZ JOB NO24-5
COMPANY REPRESENTATIVE

CONTRACT NO
JOB. $24-5$

TERMS: NET 30 DAYS. Accounts over 30 days will be charged $11 / 2 \%$ per month not to exceed $18 \%$ ann:lly.

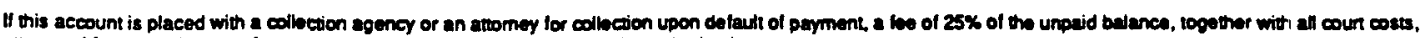
attomeys' fees, gamienment fees and $10 \%$ interest trom maturity is here by authorized. 
Total Depth

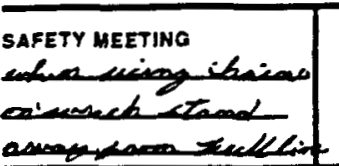

\section{B. O. P.TEST PRESSURES}

Rams

Mud Type - Hydorl

Woight vis.
Present Depth

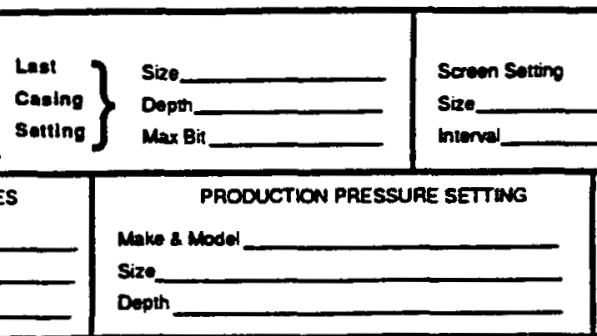

Type Plug

\section{Tubing Sotting}

Size

Type

Ams.

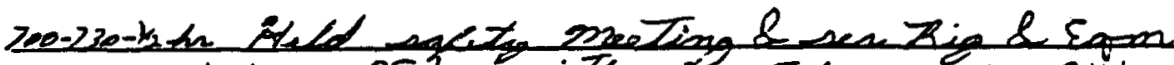

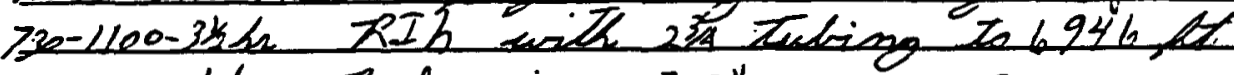
1200-1200-1h thake in 200llon pungen

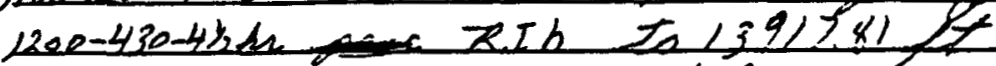

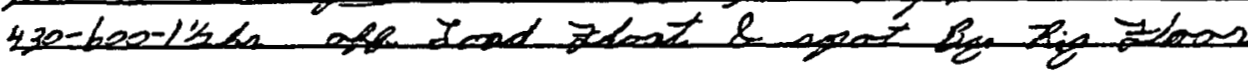

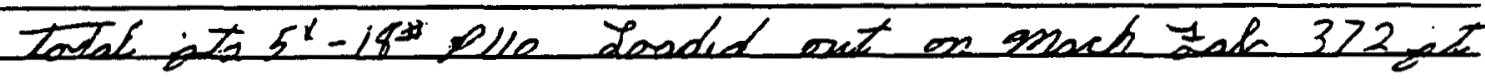

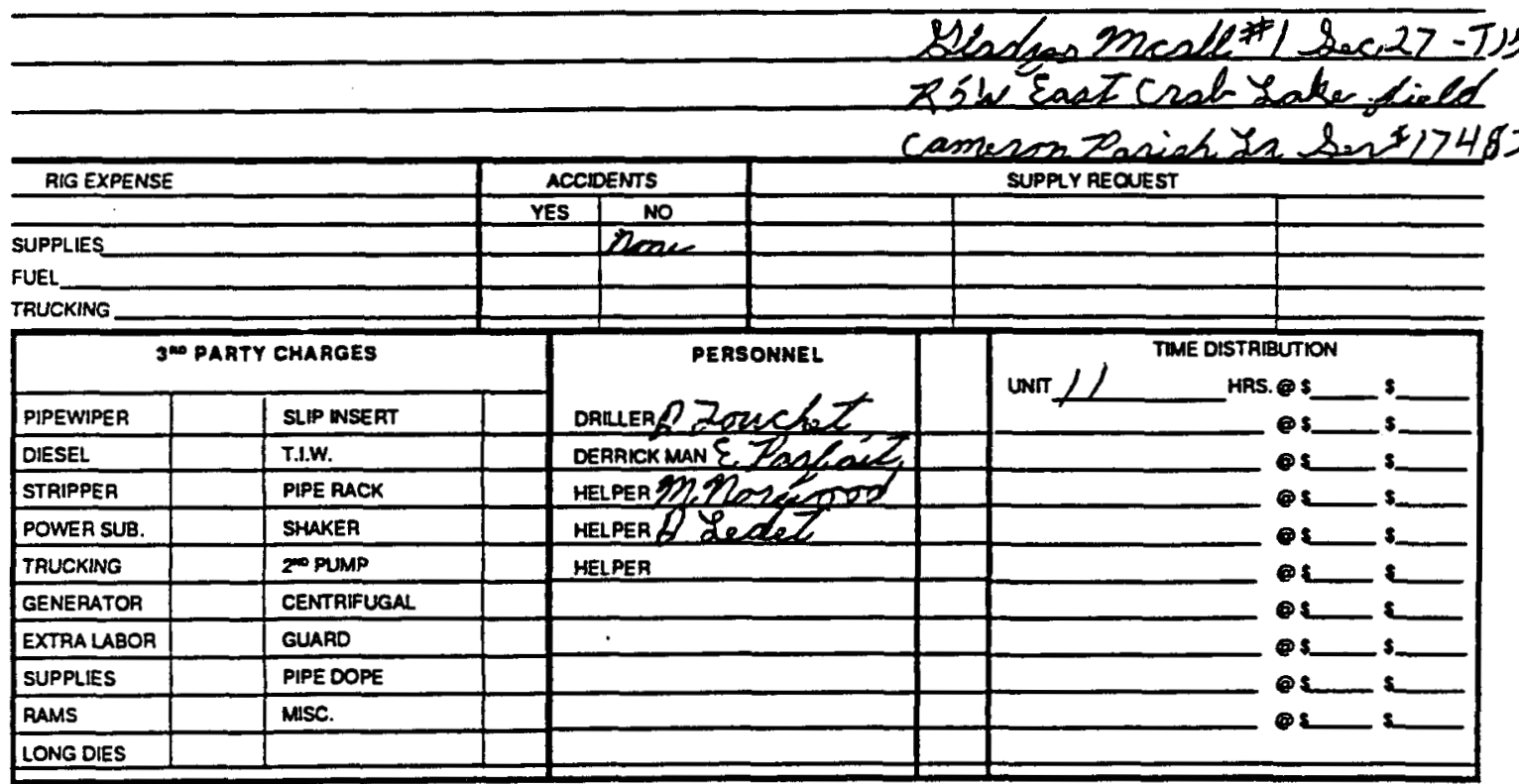

TOOLPUSHER borgalon Znuche $T$ JOB NO $24-5$ ORDER NO
COMPANY REPRESENTATIVE CONTRACT NO.
JOB_24-5

TERMS: NET 30 DAYS. Accounts over 30 days will be charged $11 / 2 \%$ per month not to exceed $18 \%$ annilly.

If this account is placed with a collection sogency of an abomey for collection upon defaut of paymont, a we of 25\% of the unpeid bulance, wopether with all coun costs, If this account is placed with a collocion agency of an abomey for collocjon upon dalaut 
Driling

Comover

Tank Banery Inatalison

Purroung Sennese

Salt Weice Well

Piug s abencion $\int\left[\begin{array}{cc}0 \\ 0\end{array}\right.$

DAILUNG \& WEL SEAVICE. INC.
IOI GALBERTRO
d LAFAYETE. LA 70506 (318) 261-0295
TICKET 6835

REPORT NO. 30

\section{DAILY WORKOVER REPORT}

company $R \rightleftharpoons E$

FIELDEat Crab take LEASE Sllodyo made DATE $12-21-93$

PARISH OR COUNTY Camesas STATEZ 2 WELL NO.. / RIG NO- 5

Present Perforations

Present Packer Setting

Total Depth

Present Depth

Type Plug

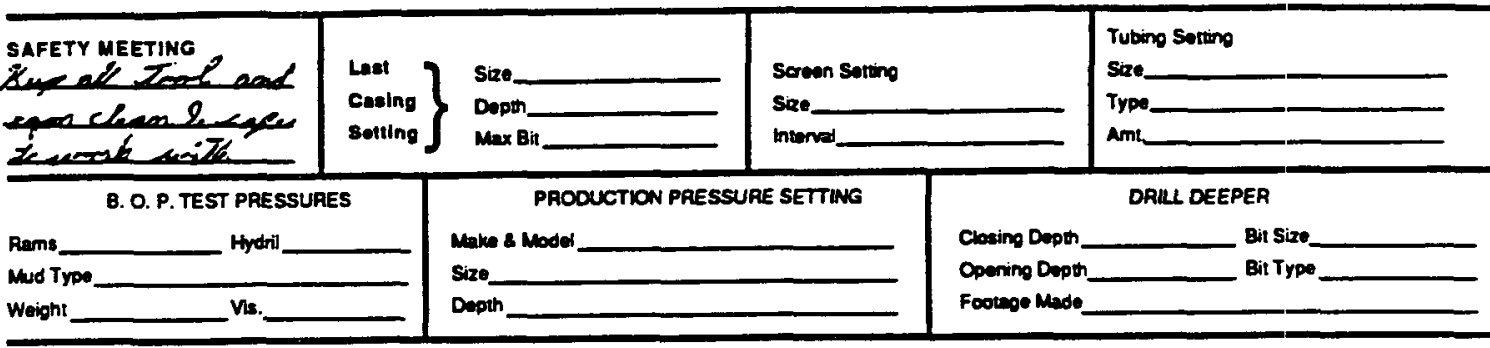

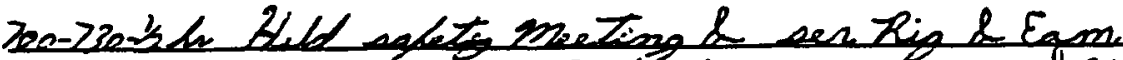

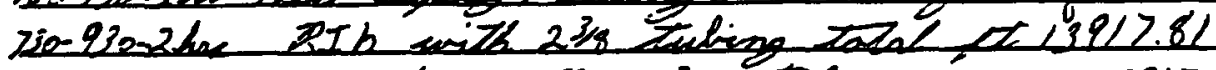

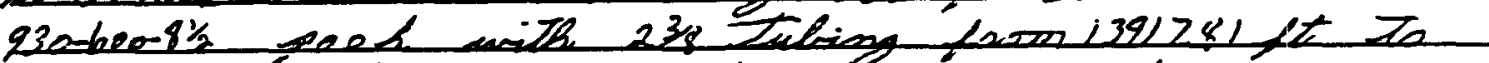

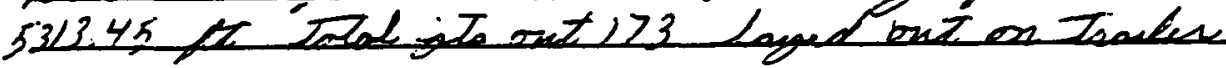

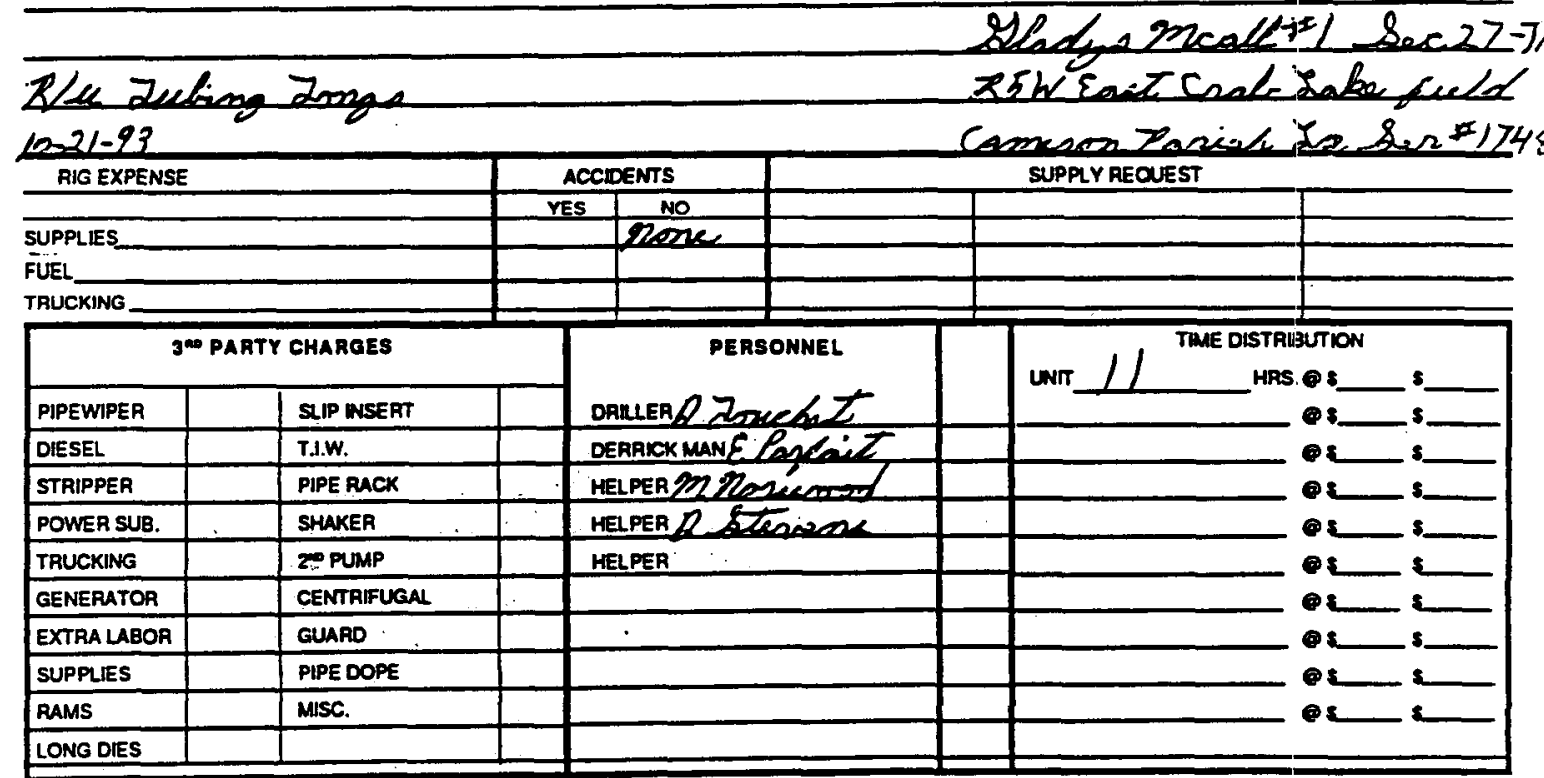

TOLLPUSHER Rousho Zuachet

JOB NO24-5
ORDER NO.
COMPANY REPRESENTATIVE

CONTRACT NO.
JOE $24-5$

TERMS: NET 30 DAYS. Accounts over 30 days will be charged $11 / 2 \%$ per month not to exceed $18 \%$ ann:lly.

If this account is placed with a colbetion epency or an atomey for colbection upon dobult of payment, a twe of $25 \%$ of the unpaid bolence, logether with all court costs. atromeys' tees, gernishment tees and $10 \%$ interest trom masurity is hereby authorized. 
Drilling

Comover

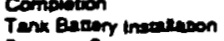

Purroing Semose

Sat Waier Welte

Plup \& abancon
S⿴囗十心

DRRLUNG \& WELL SERVICE, INC.

IOI GALBEATRO AFAYETE. LA 70506
(318) 261-0295
TICKET 5835

REPORT NO. 31

company $\ell$ eE

DAILY WORKOVER REPORT

FIELDEact crak Lake

PARISH OR COUNTY Camenom.

LEASE Headwr meall DATELD-22-73

Present Perforations. state $2 a$

WELL NO. 1 RIG NO 5

Present Packer Setting

Total Depth

Present Depth

Type Plug

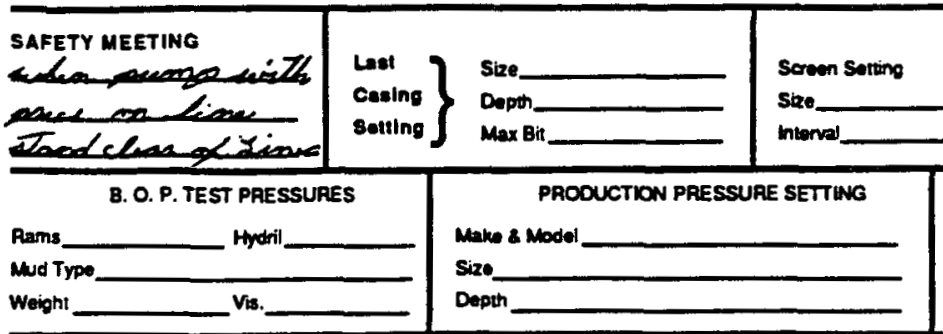

ـ

Woin

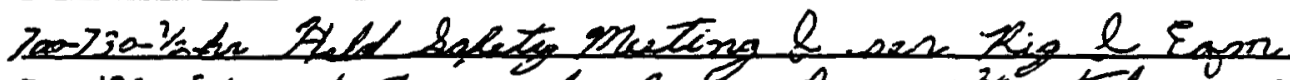

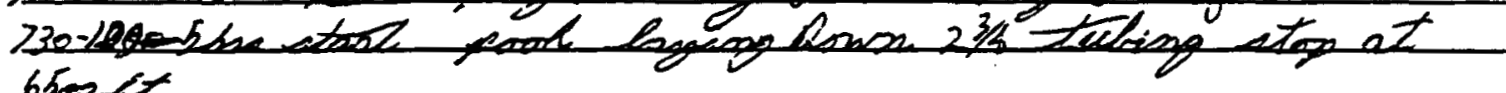
6 hospt

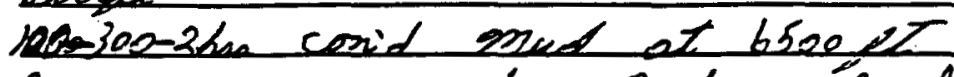
3eo-. pool Backing Back 2 k lubing

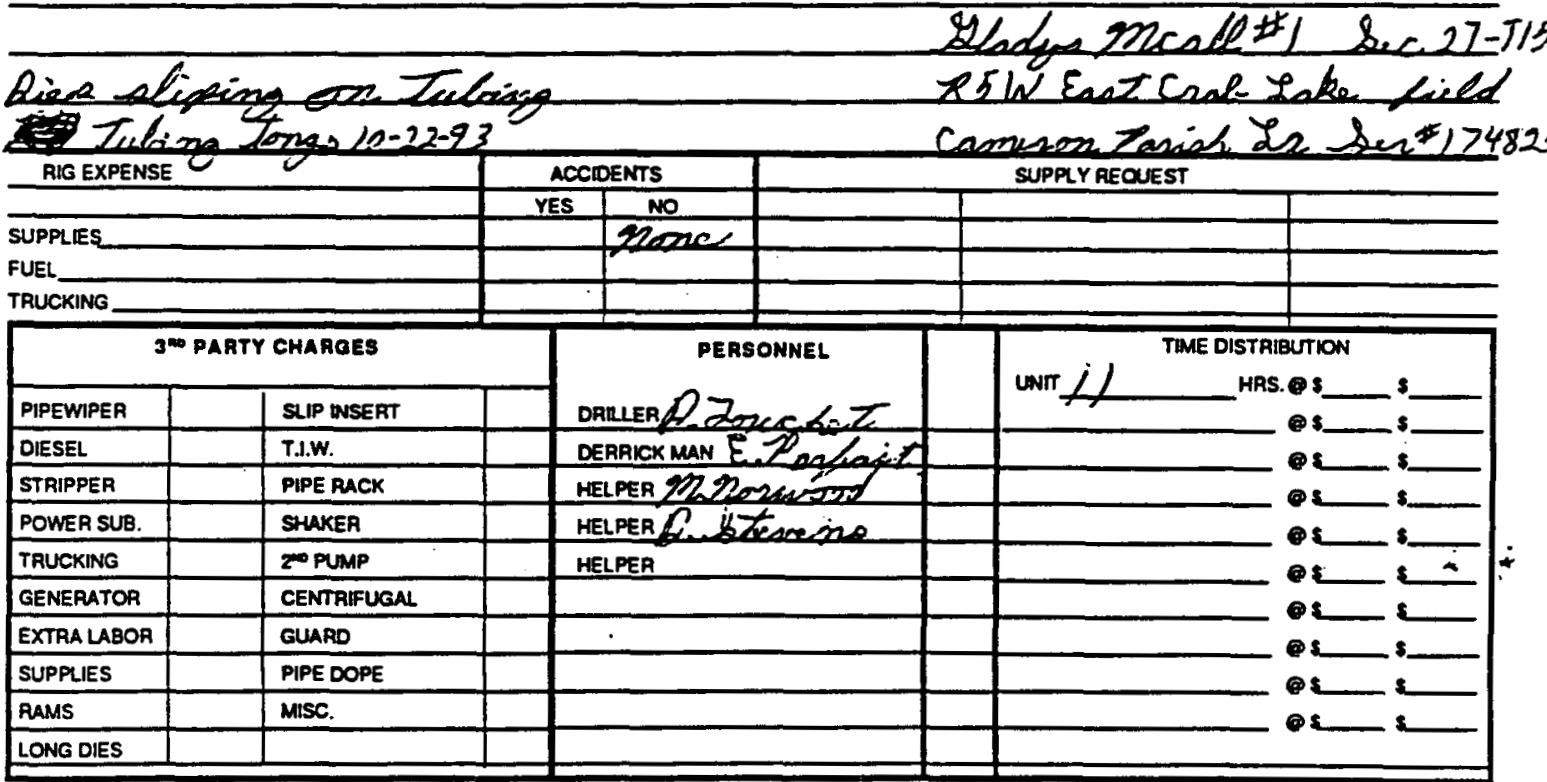

TOOLPUSHer bozyalar Zueche Z JOB NO. 2465
ORDER NO.
COMPANY REPRESENTATIVE CONTRACT NO
JOB $24-5$

TERMS: NET 30 DAYS. Accounts over 30 days will be charged $11 / 2 \%$ per month not to exceed $18 \%$ ann:lly.

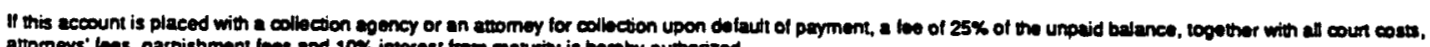
atromeys" loes, garnishment ioes and $10 \%$ imeress trom maurity is horeby authorized. 
company DOE

FIELDEact cask Lake

PARISH OR COUNTY Cameson LEASE \&ladue meall DATE $10-23-93$

Present Pertorations state 12 WELL NO._L

Total Depth

Present Packer Serting

Present Depth

Typo Plug

\begin{tabular}{lll}
\hline SAFETY WEETING & Lest \\
Casing \\
Sotting
\end{tabular}

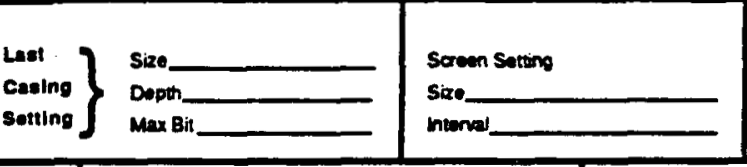

PROOUCTION PRESSURE SETTING Makk a Model

Size

Depin

\section{Tubing Sotting}

Sizo.

Type

Ant

DARL OEEPEA

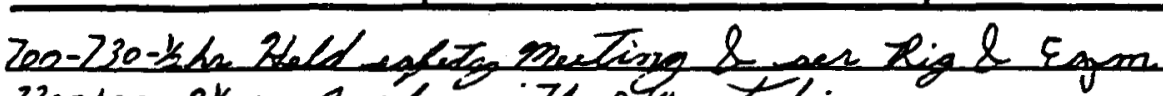

$230-10002 \mathrm{k}$ a poot with 2 ks teitiong

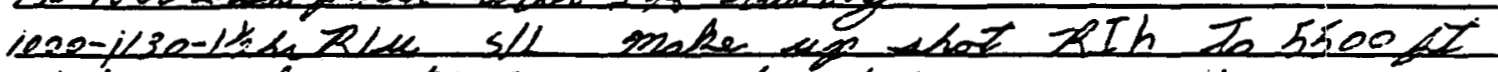
fick yecollar at sus9 ot madr shot peat will

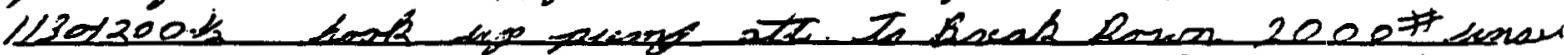

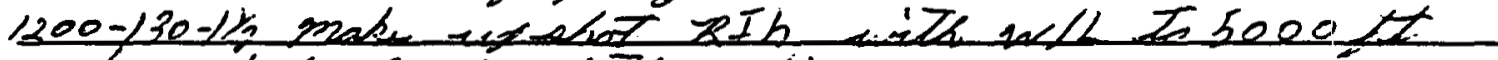
make whot trok will wil

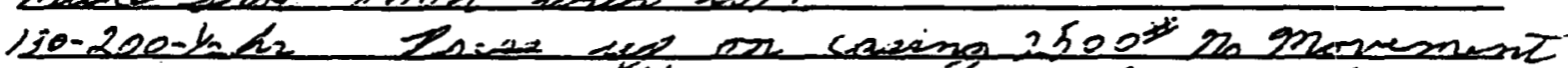

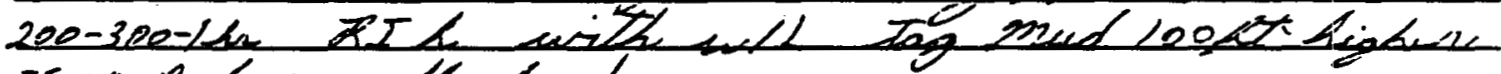
25 it indor well beed

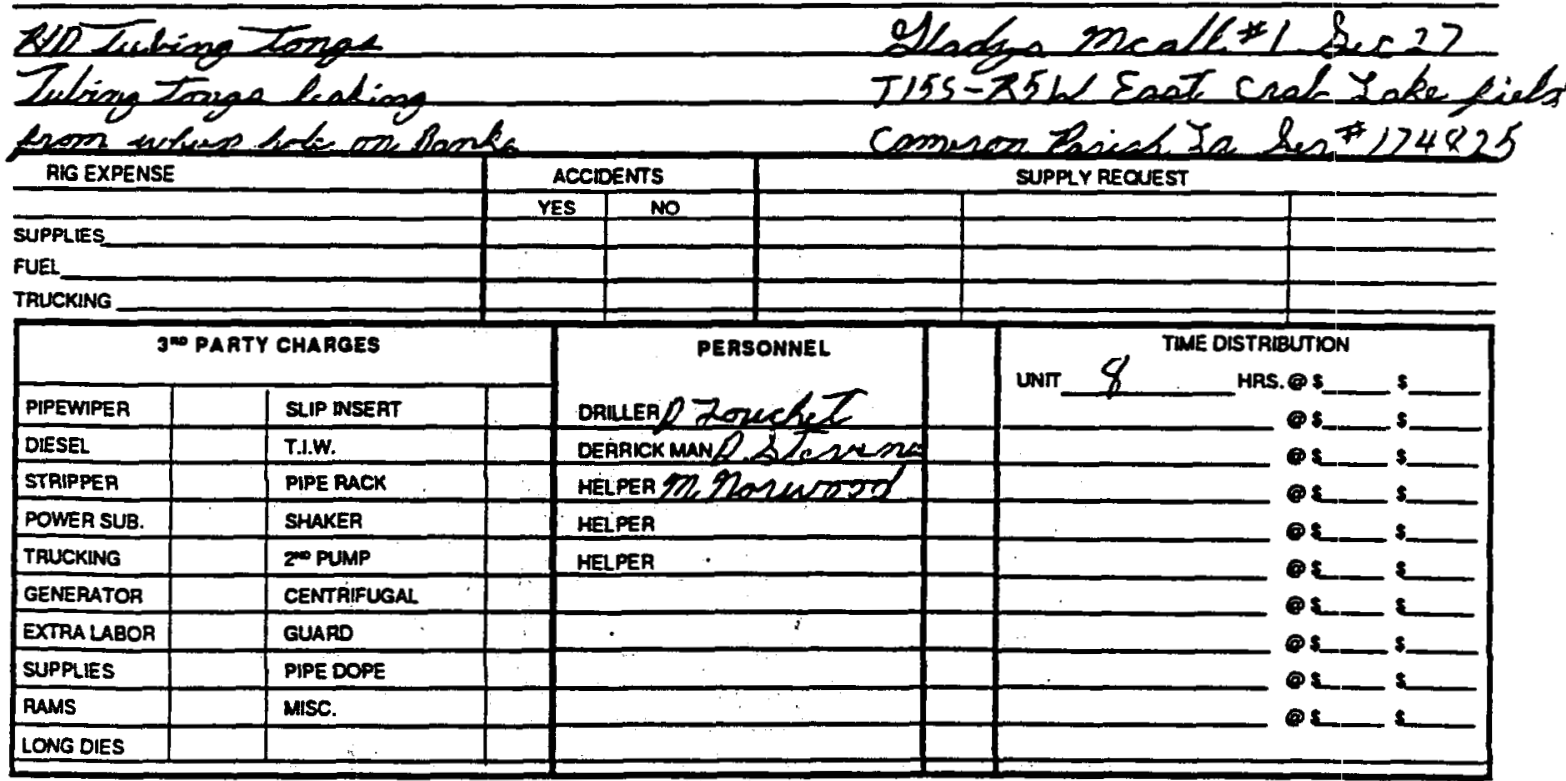

TOOLPUSHER boughe bouchet JOB NO $24-5$ ORDER NO. COMPANY REPRESENTATIVE CONTRACT NO.
JOB $24-5$

TERMS: NET 30 DAYS. Accounts over 30 days will be charged $11 / 2 \%$ per month not 10 exceed $18 \%$ anm:lly.

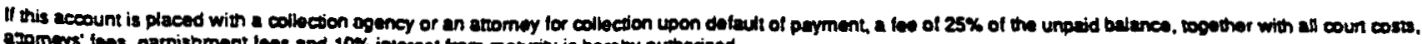
azomers: toes, parnishment lees and $10 \%$ interest from maurity is hereby authorized. 
company $D \cap E$

DAILY WORKOVER REPORT

FIELDEant crak Lake. LEAsebladap Mrall DATE $10-25-73$ PARISH OR COUNTY Camesem stateza WELL NO.)

Present Perforations

Present Packer Setting

Total Depth

Present Depth Type Plug

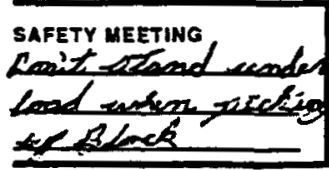
Q O. P.TEST PRESSURES

Aams

Mud Type Hydri

Weight Vis.

\begin{tabular}{l} 
Lost \\
Cesing \\
sotting \\
\hline RES \\
\hline
\end{tabular}

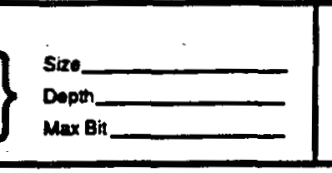
PROOUCTION PAESSURE SETTWG Make \& Model Size. Depln RIG NO 5

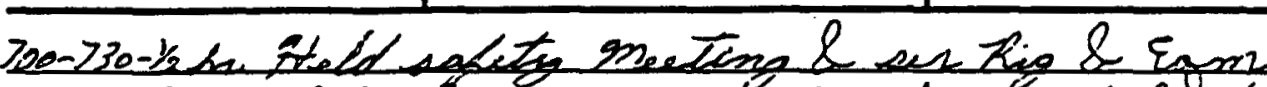

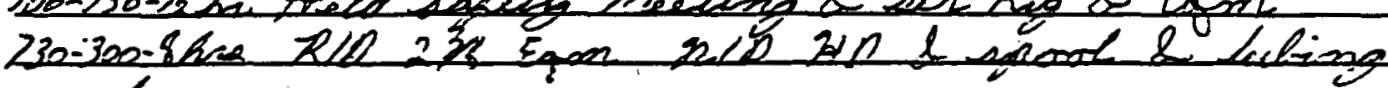
secese 300t5os-lh zRlll casing gacke

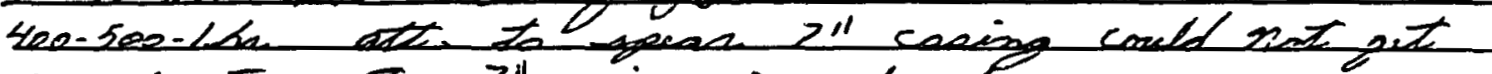

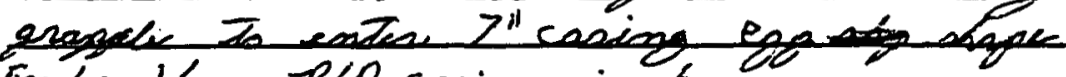

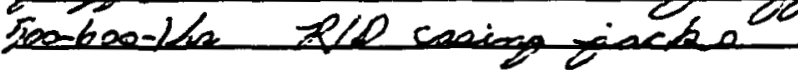

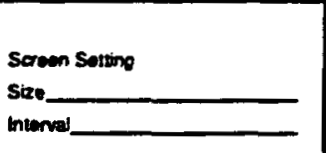

Tubing Serting

Size.

Type. Amt

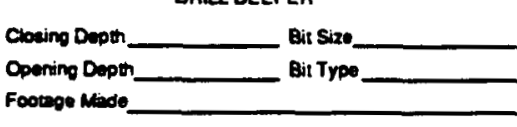

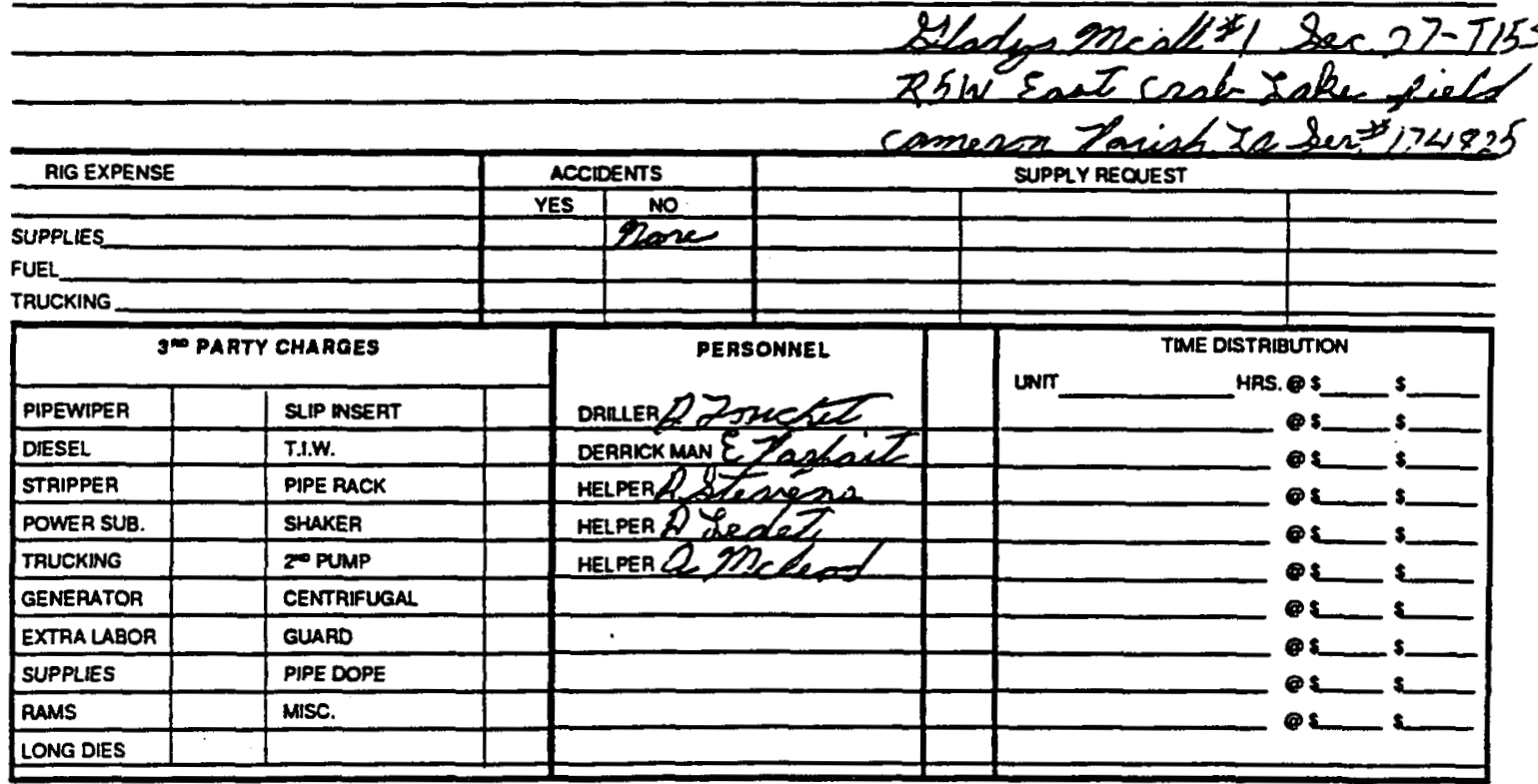

TOOLPUSHER Rougalae Zouchet JOB NO 245 -
COMPANY REPRESENTATIVE CONTRACT NO. $\operatorname{sos} 24-5$

TERMS: NET 30 DAYS. Accounts over 30 days will be charged $11 / 2 \%$ per month not to exceed $18 \%$ ann:lly.

II this account is placed with a collection epency or an adomey for collection upon detaut of payment, a be of $25 \%$ of the unpaid batance, ropether with all coun costs, attomeys' toes, garnishment loes and $10 \%$ interest from maturity is horeby authorized. 
companybeE \\ DAILY WORKOVER REPORT} DATE $20-2 k-93$

FELDEast crak Lake LEASE \&ladan mealle Well No.

PARISH OR COUNTY CAmesom. state Za RIG NO_ 5

Present Perforations

Present Packer Setting

Total Depth

Present Depth Type Plug

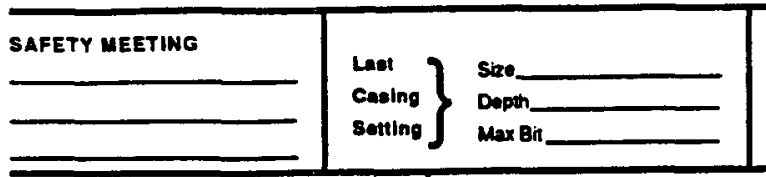

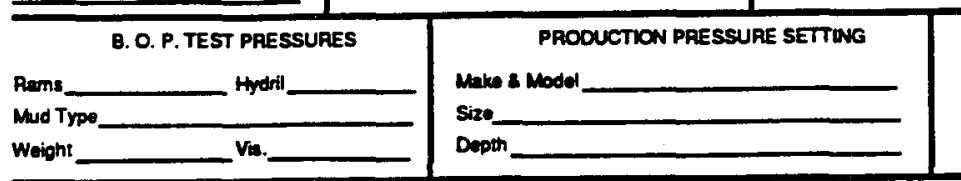

Soreen Soting

\begin{tabular}{|c|c|}
\hline \multicolumn{2}{|c|}{ DRM DEEPER } \\
\hline Closing Deptr_ & Bit Size_ \\
\hline pening Depth & Bit Type. \\
\hline cotapo Made & \\
\hline
\end{tabular}

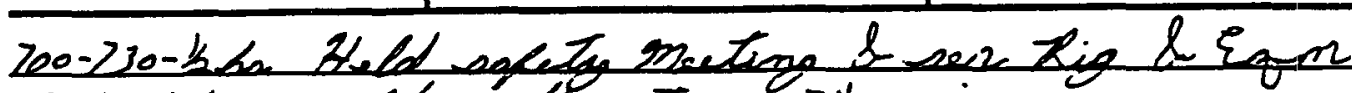

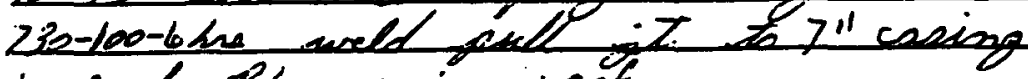

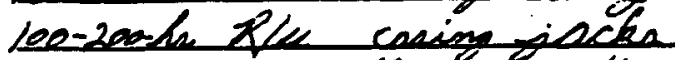

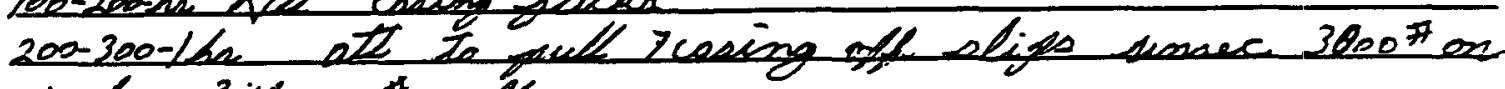
inck $a=344,000$ pell

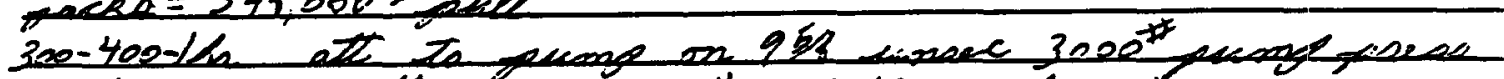

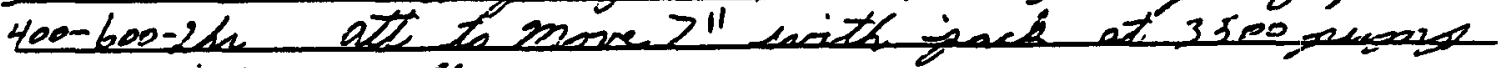

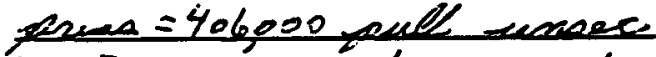

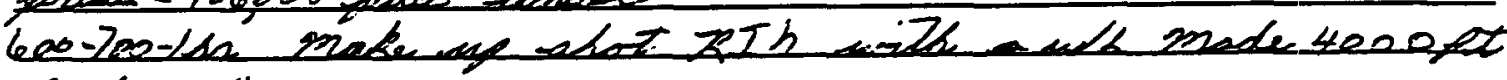
look well

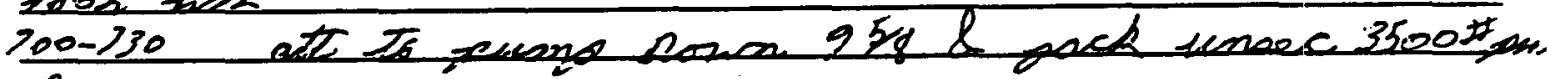
Sreas

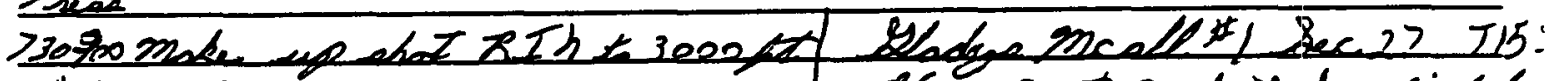
Z"foes ate 3000,1

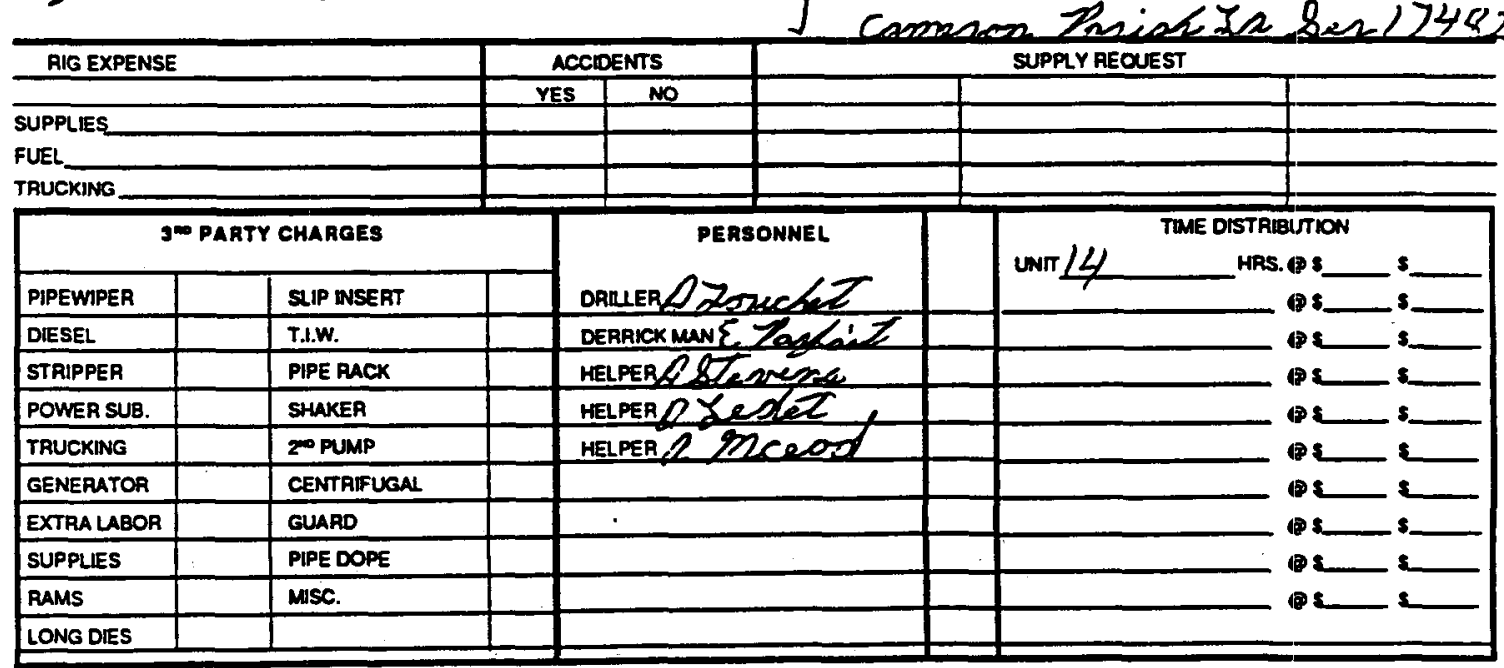

TOOLPUSHER Doziglas zowehat JOB NO $24-\zeta$ ORDER NO.
COMPANY REPRESENTATIVE

CONTRACT NO
JOB.24-5

TERMS: NET 30 DAYS. Accounts over 30 days will be charged $11 / 2 \%$ per month not to exceed $18 \%$ ann:lly.

II this account is placed with a collecion agency or an atwoney for collocion upon debult of payment, a foe of $25 \%$ of tha urpeid balanca, together with all count costa, atomeys' loes, garnishment tees and $10 \%$ interest frem maturity is mereby authorized. 
company DOE LEASE Hladas meakl WELL NO. L $L$

FIELD East Crab Take state RIG NO 5

PARISH OR COUNTY Camenom.

Present Packer Setting

Present Pertorations

Present Depth Type Plug

Total Depth

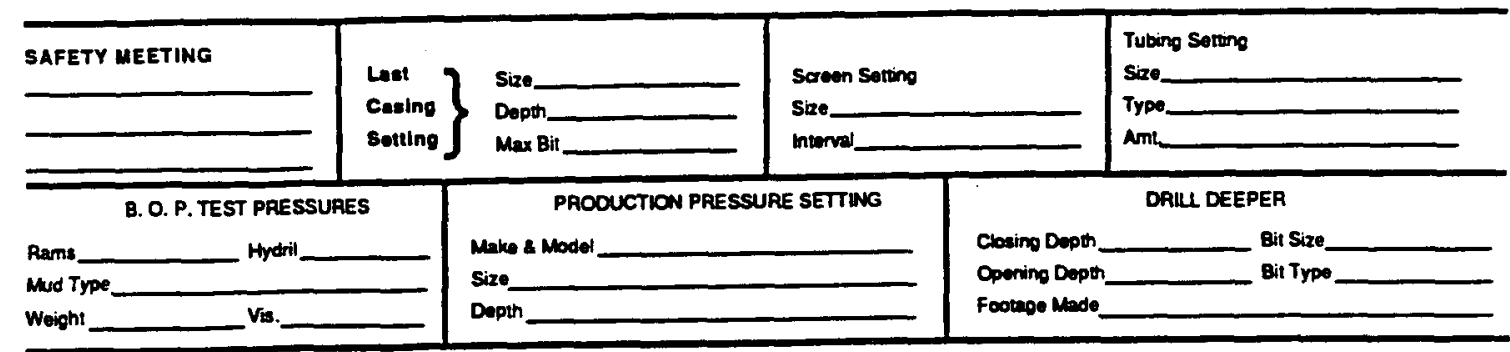

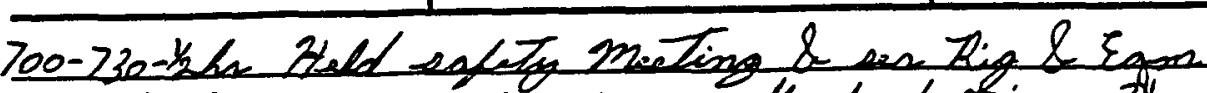

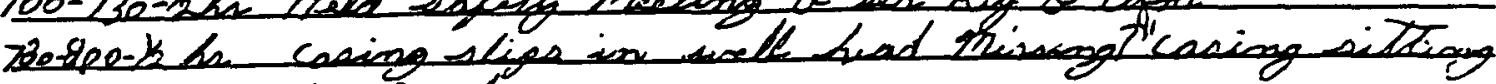
ine caniso slige bone

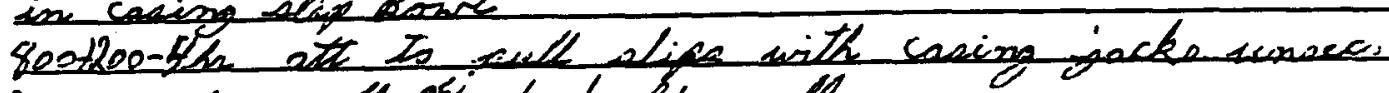

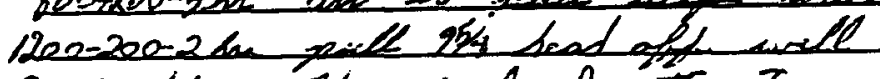

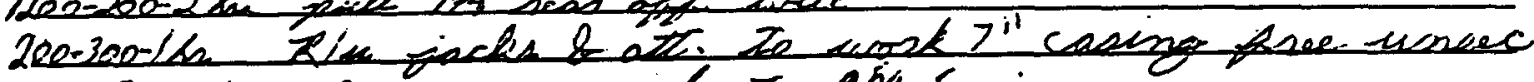

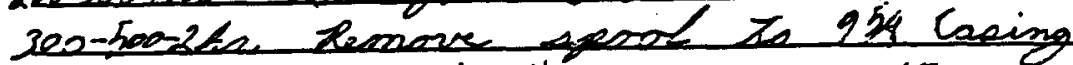

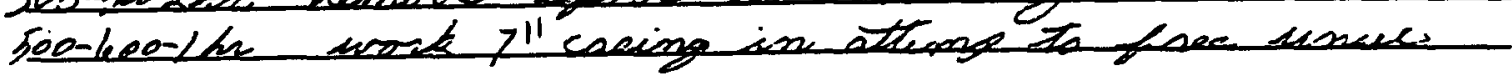

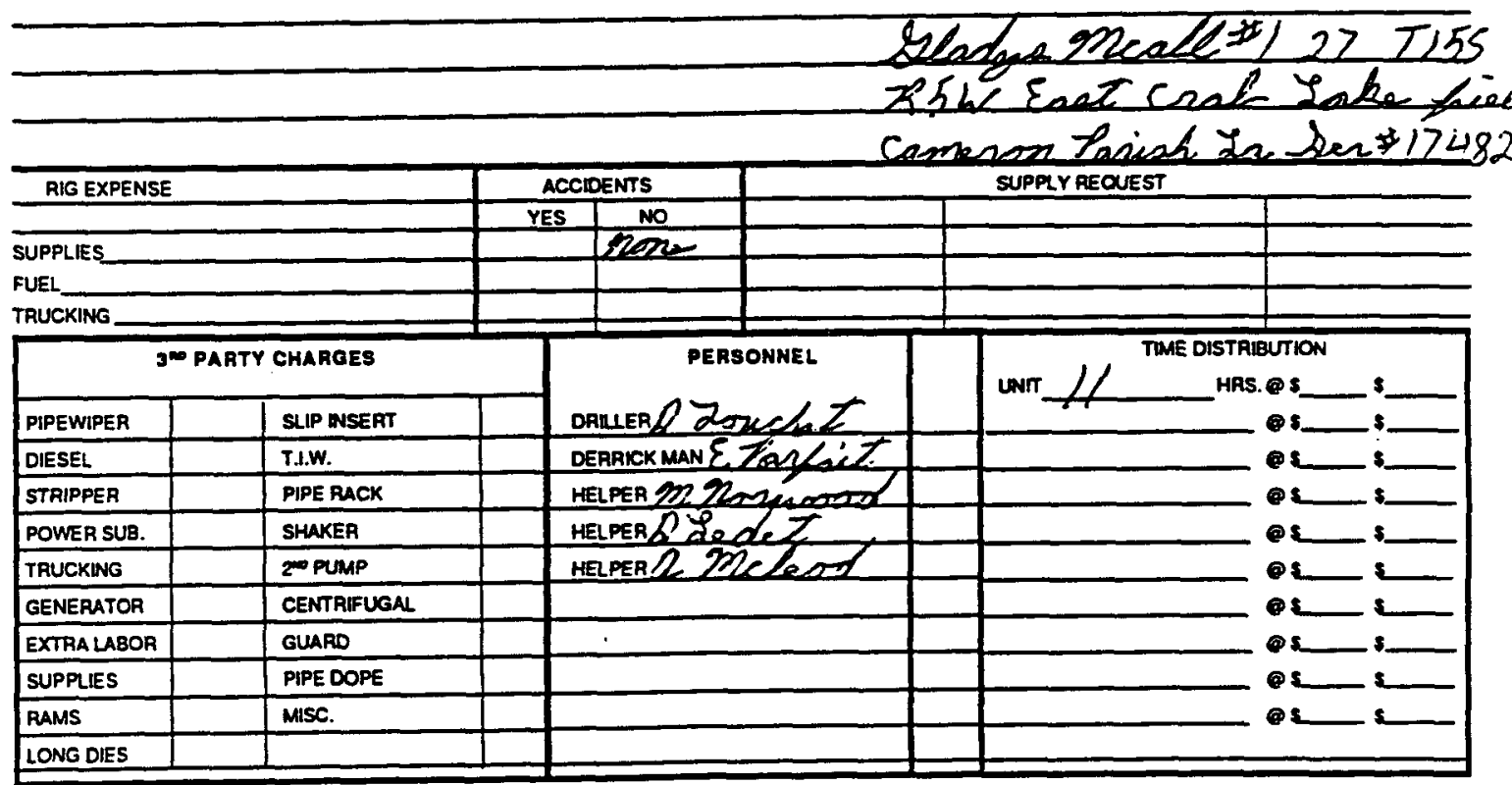

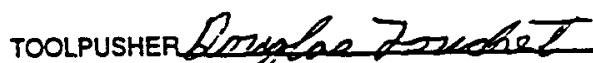
JOB NO. 24,5 ORDER NO.
COMPANY REPRESENTATIVE CONTRACT NO.
JOB $24-5$

TERMS: NET 30 DAYS. Accounts over 30 days will be charged $11 / 2 \%$ per month not to exceed $18 \%$ ann:lly.

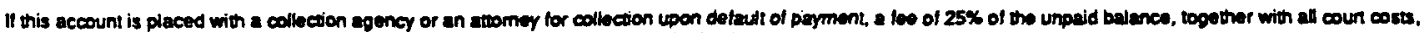
attomeys' loes, garriehment toes and $10 \%$ interest trom maturity is heveby authorized. 
Driling

Wonower

Tomplowen Banery Inatulason

Purrown Senceas

Selt Waver Welle

Plus \& Abendon

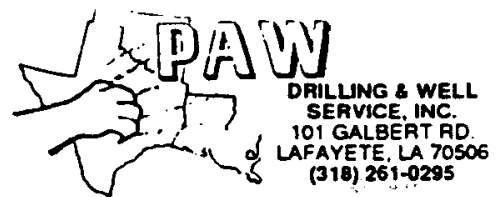

DAILY WORKOVER REPORT

COMPANY D. E

FIELDEast cast jake

PARISH OR COUNTY Camesom Lease Llada 22 call

TICKET FIRL?

REPORT NO. 36

Present Perforations state La DATE $10-28-73$ WELL NO._ RIG No 5

Present Packer Setting

Total Depth Present Depth Type Plug

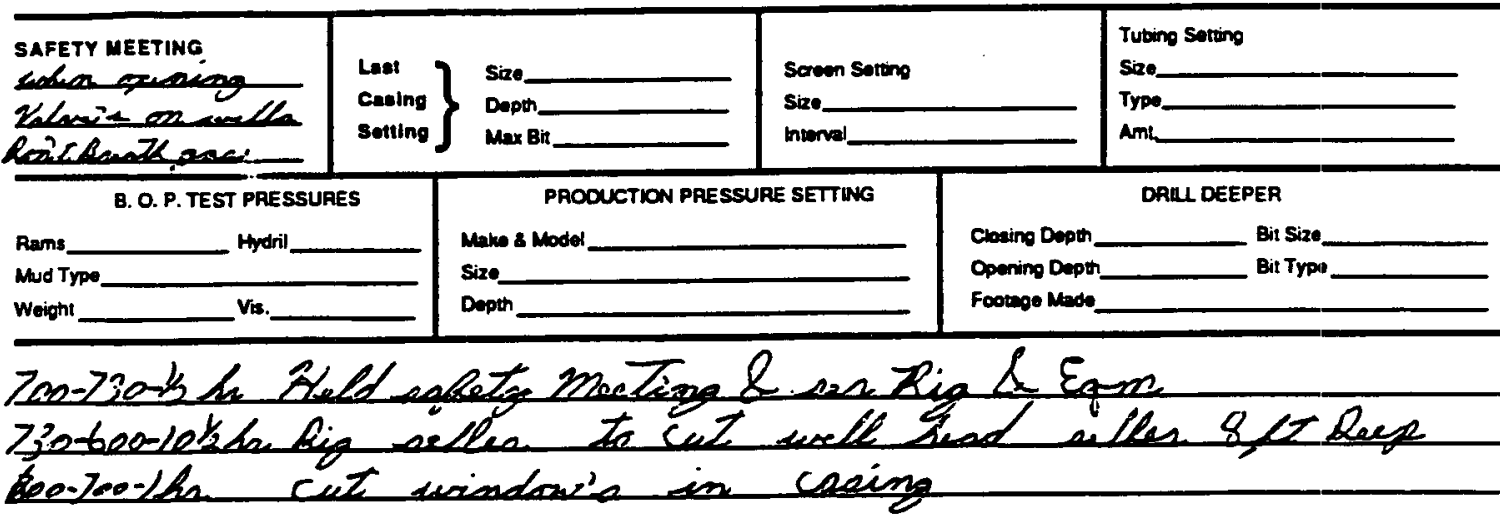

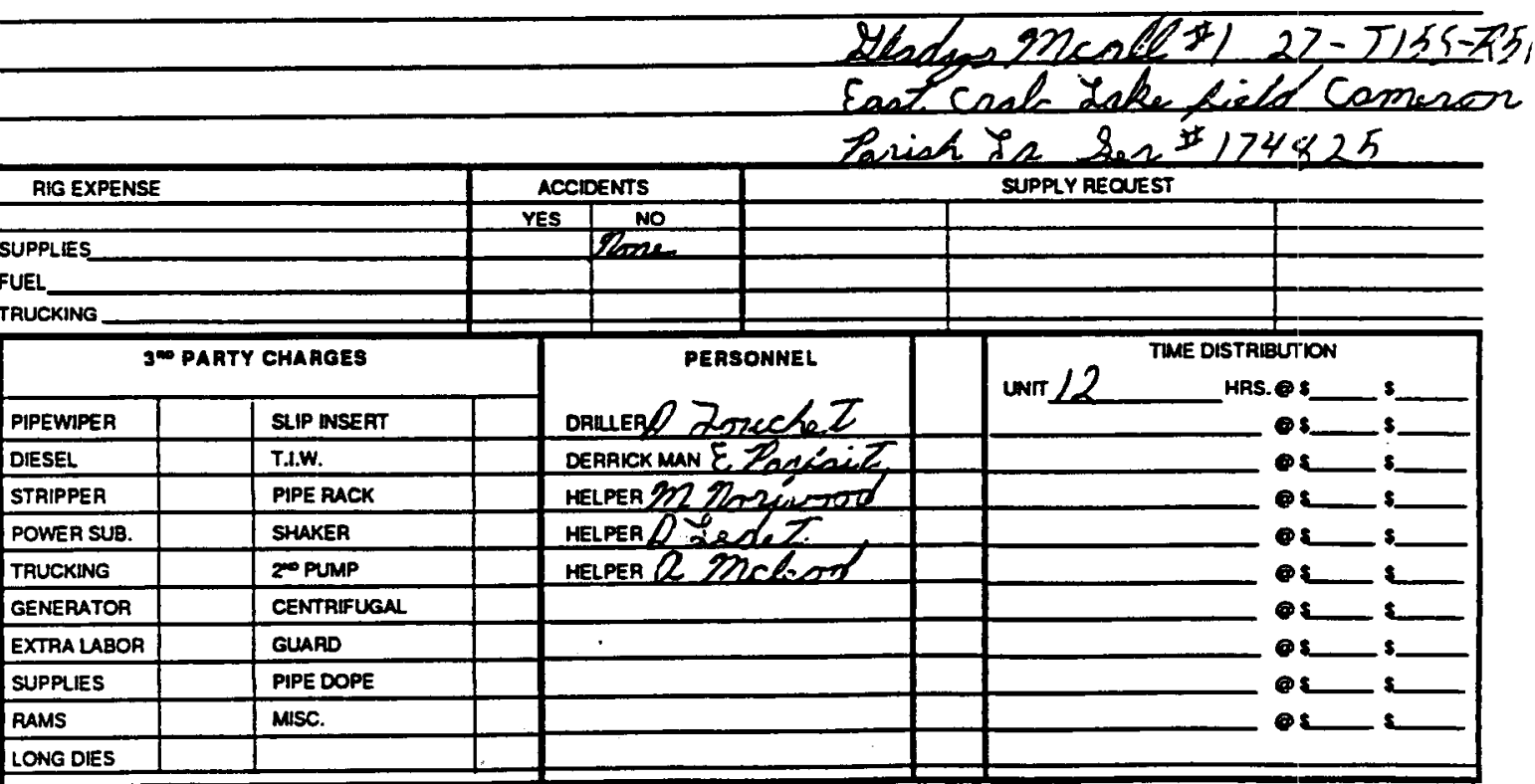

TOOLPUSHER Rouglas Zouchet JOB NO $24-5$ ORDER NO. COMPANY REPRESENTATIVE CONTRACT NO.
Jов $24-5$

TERMS: NET 30 DAYS. Accounts over 30 days will be charged $11 / 2 \%$ per month not to exceed $18 \%$ annilly.

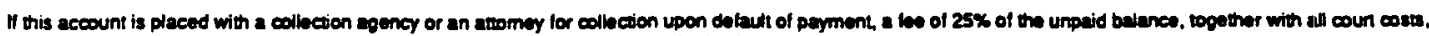
anomeys' loes, garnishment toes and $10 \%$ imerest from masurity is heraby authorized. 
company DQE

FIELOEant coak Laker

PARISH OR COUNTY COMPNOSZ

LEASE-\&lod Lae Mroall staTELLa

DATELO $-29-93$ WELL NO. 1

Present Pertorations

Present Packer Serting

Total Depth

Present Depth Type Plug

SAFEFY MEETINO Moke vecne these

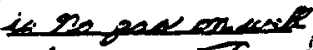
edenmang Taoush B. O. P. TEST PAESSURES

Rams Mud Type Hydril

Weight Vis.

Lest
cesing
solling

\section{Tubing Serting}

Size

Type

Ame.

DRIL DEEPER

PROOUCTION PRESSURE SETTING Make \& Model

Size

Depth
Cbaing Depth_____ Bit Size. Footapo Made

200-730-1/2h Whld aqhetor Mecting \& an Rig \& Enm

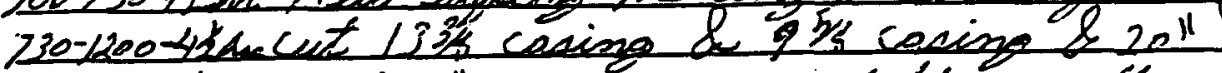

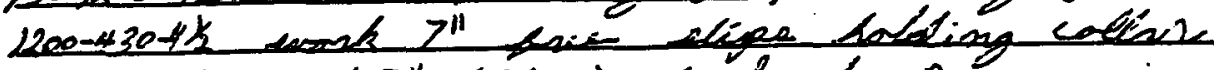

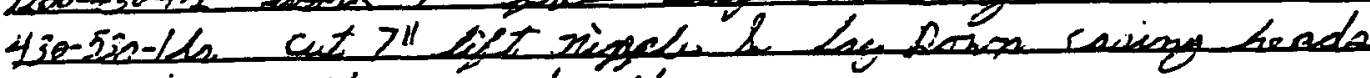

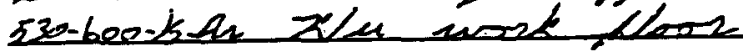

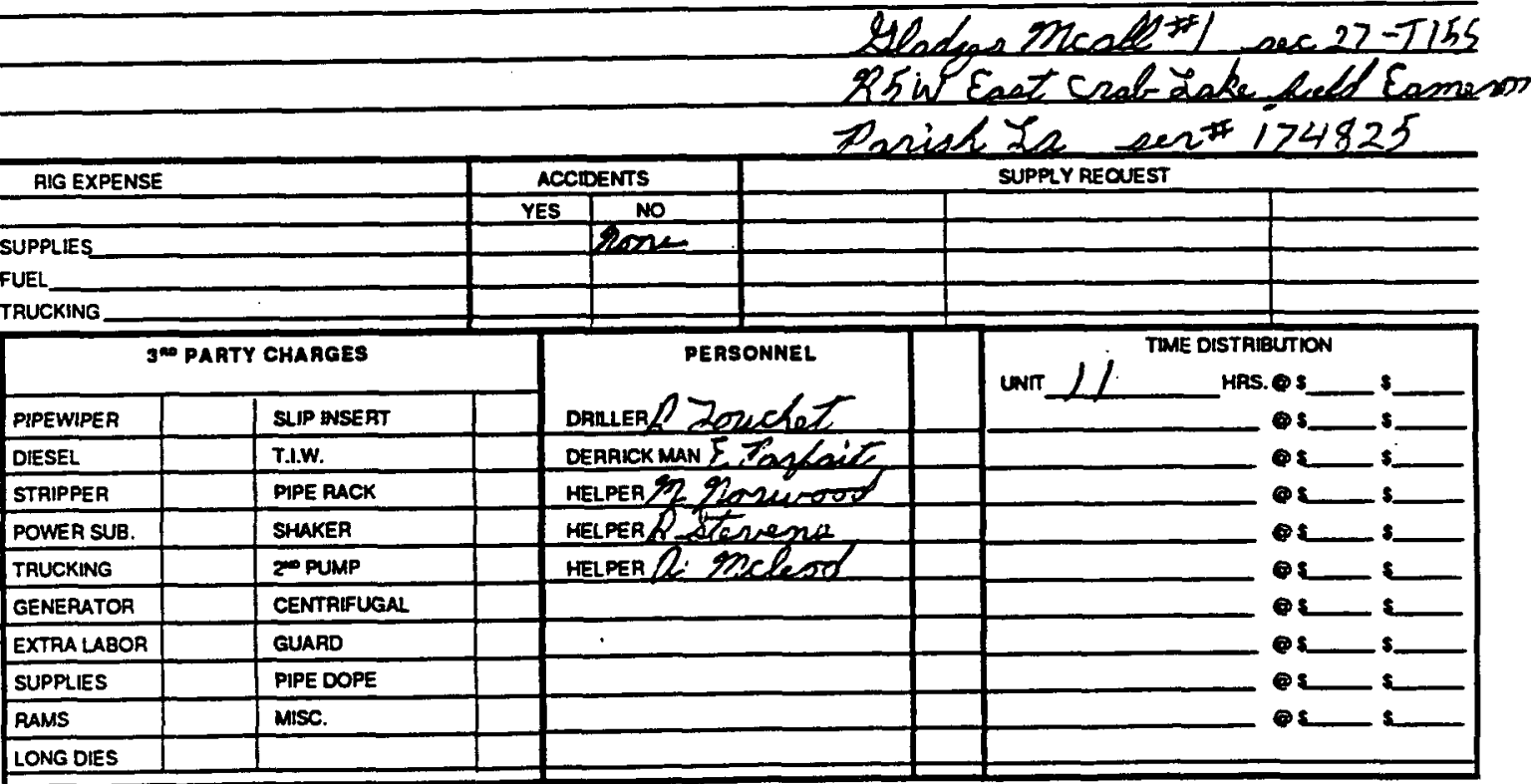

TOOLPUSHER forylar Zowechet JOB NO $24-5$ ORDER NO.
COMPANY REPRESENTATIVE CONTRACT NO $\operatorname{sog} 24-5$

TERMS: NET 30 DAYS. Accounts over 30 days will be charged $11 / 2 \%$ per month nol 10 exceed $18 \%$ ann!lly.

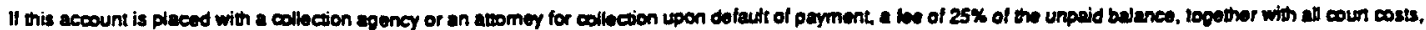
attomeys' tees. garnighment ioes and $10 \%$ interest from maturity is horeby authorized. 
Drilling

nomour

Complation

Tenk Batary Inulasoon

Purporno samom

Salt Waver Wolls

Plup 4 abanoon

company DOE

FIELOEact crab Lake PARISH OR COUNTY CamenoT

Present Peforations

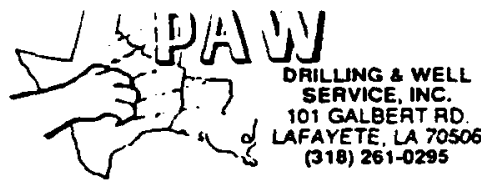

TICKET 5345

REPORT NO. 38

DAILY WORKOVER REPORT

Total Depth

Present Depth State La

DATE $10-30-93$

WELL NO. 1 RIG NO 5

Presens Packer Settine

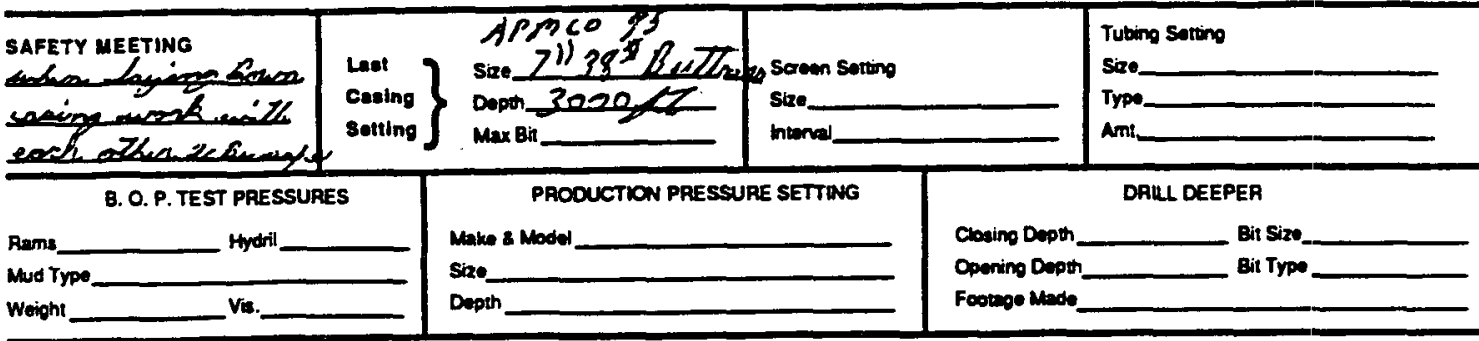

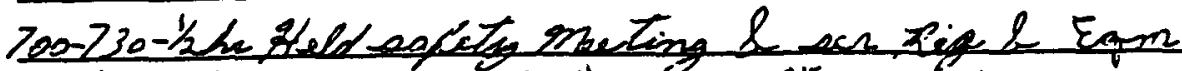

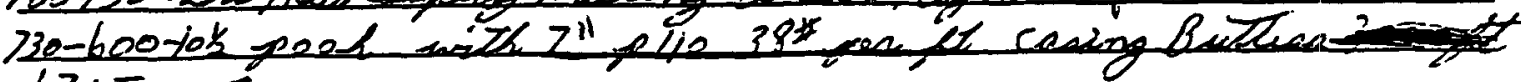
litita ont

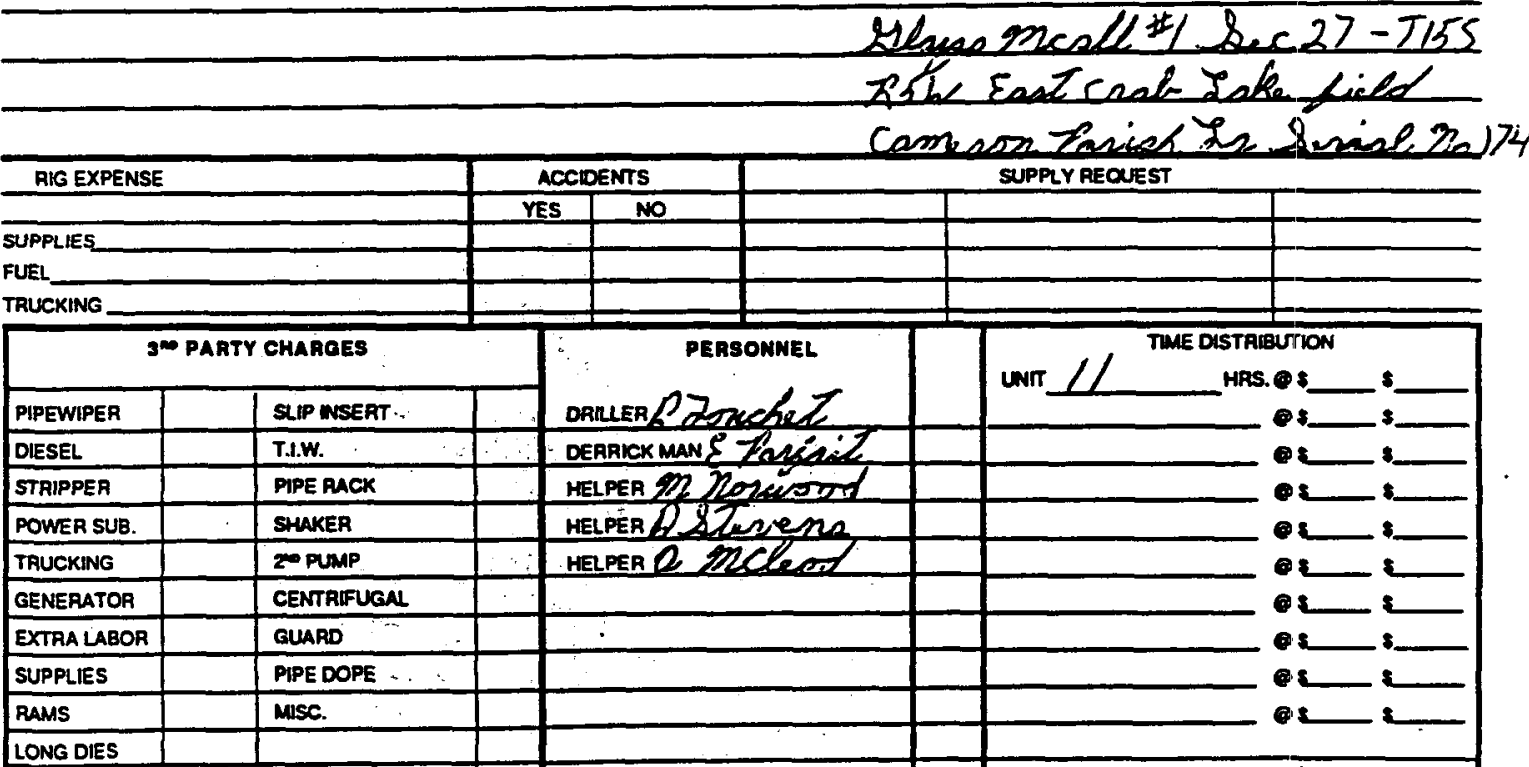

TOOLPUSHER Rozahe Zoruchet

JOB NO $24-5$

ORDER NO.
COMPANY REPRESENTATIVE CONTRACT NO
Jo8 $24-5$

TERMS: NET 30 DAYS. Accounts over 30 days will be charged $11 / 2 \%$ per month not to exceed $18 \%$ ann:lly.

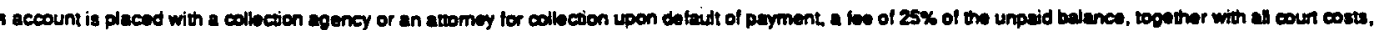
ors' loes, oarnishment toes and $10 \%$ interest trom masuring is hervey authonized. 
Driting

monten

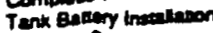

Purrpons Servace

Stut Woler Wolls

Ping \& Abancion
SULU

5 ST DRILUNG S WELL

2.1. 101 GALERTA

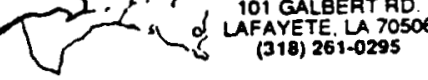

DAILY WORKOVER REPORT

TICKET $58 \hat{4 A 厶}$

REPORT NO. 39

DATE $\angle 6-1-93$

company RoE

LEASE Mladan Meaté WELL NO._ 1

FielnEat crak Lake

PARISH OR COUNTY Camenon state La RIG NO

Present Packer Setting

Present Pertorations

Present Depth Typo Plug

Total Depth

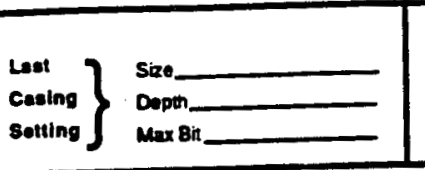

PROOUCTION PRESSURE SETTING Make \& nodel

Size

Dopen
Sowen Sorting

stzo.

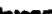

cantare chmicen o. P.TEST PRESSURES

Aems

woight Vis.

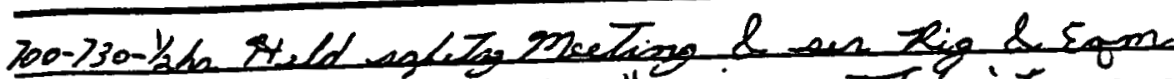

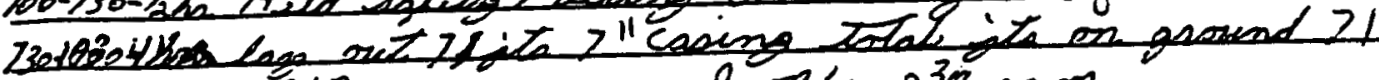

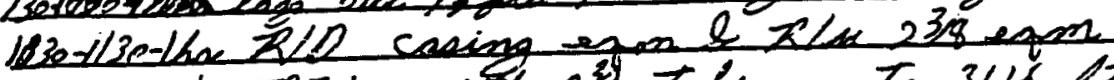
1130 -330-25diRIh wiE 234 Zuhize to 3111

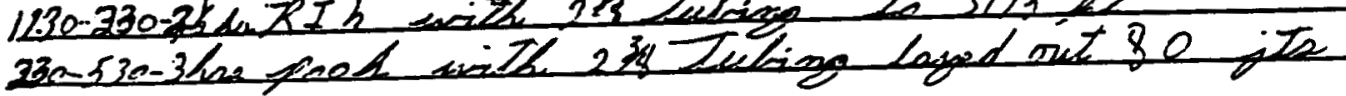

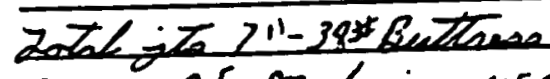

anomen 95 made in $45 a$ Ilita 3nosel

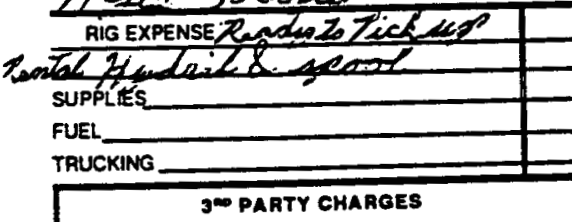

\begin{tabular}{|c|c|}
\hline PIPEWIPER & SLIP WSERT \\
\hline DIESEL & T.I.W. \\
\hline STAIPPER & PIPE RACK \\
\hline POWER SUB. & SHAKEA \\
\hline TRUCKING & 20 PUMP \\
\hline GENERATOR & CENTRIFUGAL \\
\hline EXTRA LABOR & GUARD \\
\hline SUPPLIES & PIPE DOPE \\
\hline RAMS & Musc. \\
\hline LONG DIES & \\
\hline
\end{tabular}

TOOLPUSHer hoyalos Jouchet JOB NO 24-5 ORDER NO.

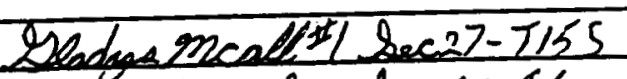
R5W Eant crabsake ficd camaron Tariah Ia per. $\$ 12825$ SUPPLY REQUEST

ACCIOENTS cone-
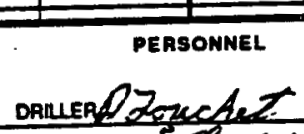
DERRICK MaN E Zay Liz

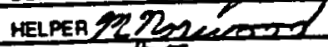

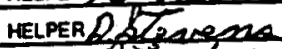
heLPER d sedet

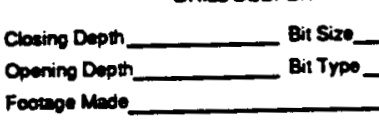

DAILL DEEPEA

See.

Type_

Am

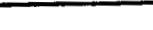

TERMS: NET 30 DAYS. Accounts over 30 days will be charged $11 / 2 \%$ per month not to exceed $18 \%$ ann!lly.

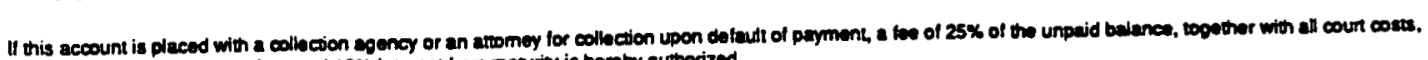

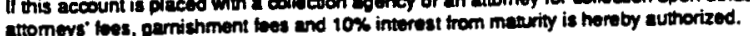


Drilking

Conower

Tenk Batwory Inakevion

Purpong someat

Sell Waser Wolle
5

LAFAYETE, LA 7050

(318) $261-0295$
TICKET 5345

REPORT NO. 40

COMPANY ROE

DAILY WORKOVER REPORT

DATE $/-2-9 i$

FIELOEant Crak Lake

LEASE Hladan 72 call

WELL NO. 1

PARISH OR COUNTY CamentR. state Yea RIG NO 5

Present Pertorations

Present Packer Sotting

Total Depth

Present Depth

Type Plug

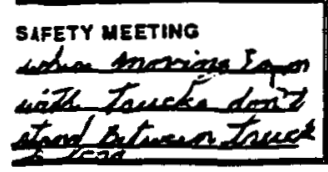

B. O. P. TEST PRESSURES

Aens Hydril

Mud Type

Weight Vis.

Last
Cusing
soining

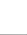

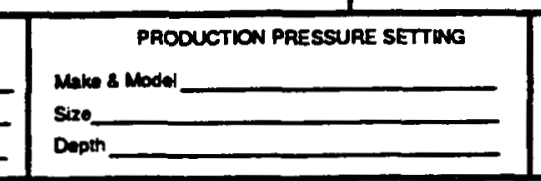

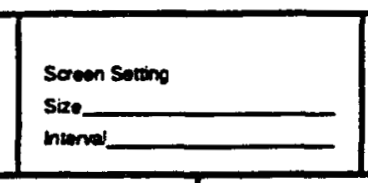

Clasing Depth
Tubing Soring

Size.

Typo.

Amt.

DRML DEEPEA

Footenge Made

Woight

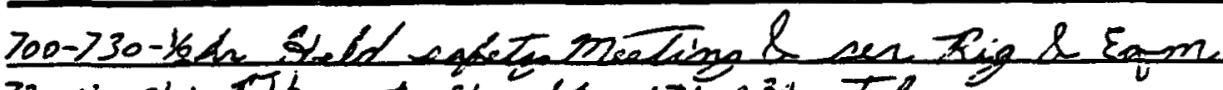

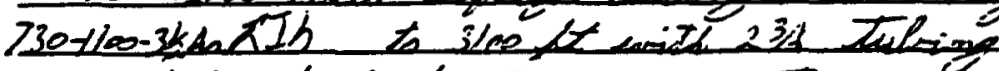

llaclliankanct Leade to mix cont

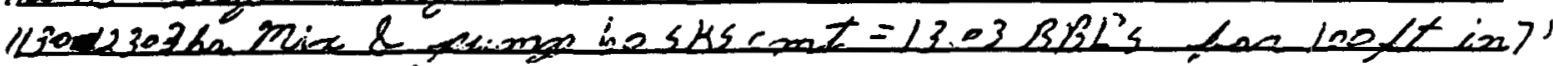

biest in 9616 caning

$230-530-3 h$ penh with 238 Zudiong

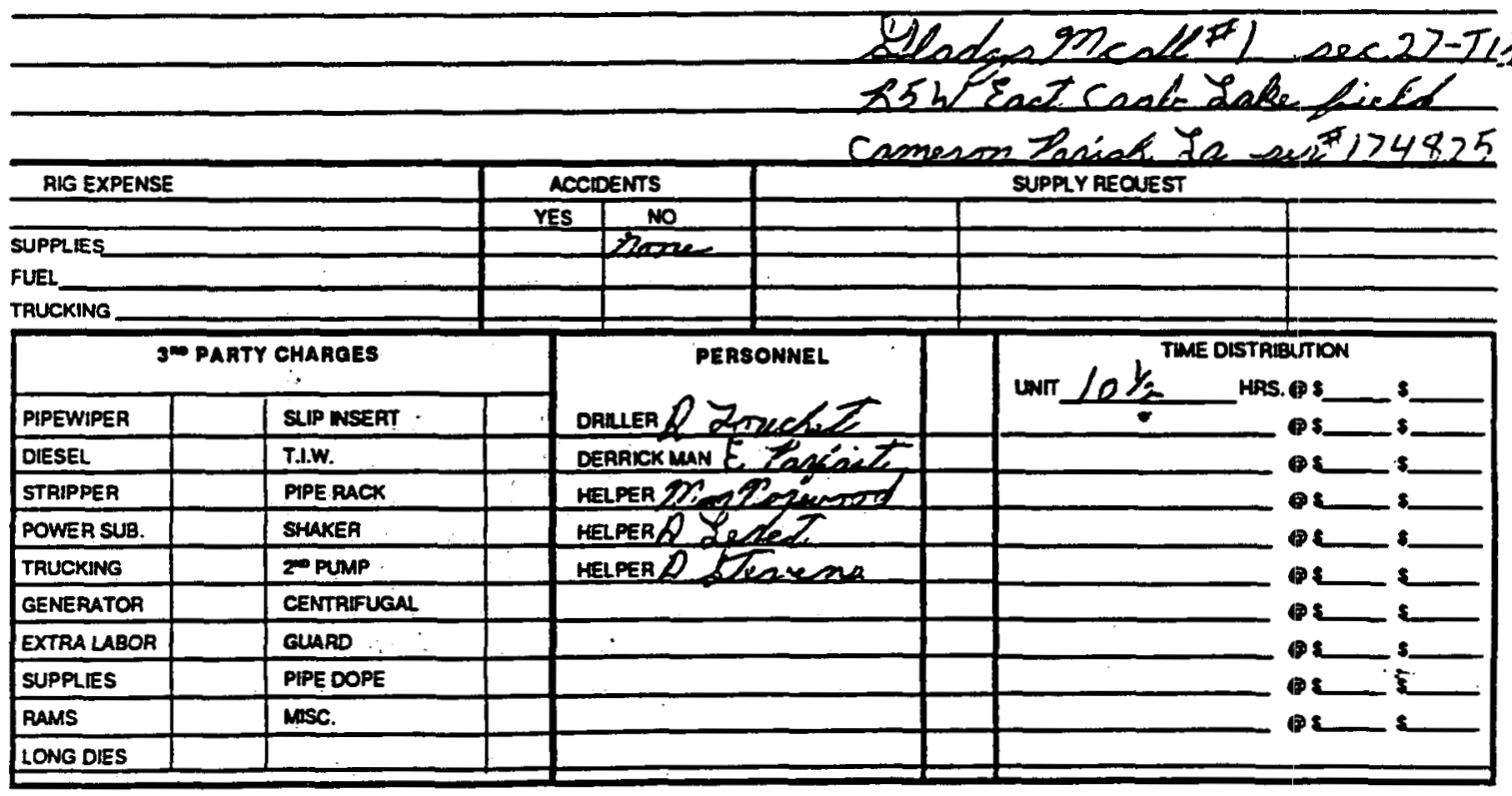

TOOLPUSHER foughe ZoucheZ

JOB NO24-5
ORDER NO
COMPANY REPRESENTATIVE

CONTRACT NO.
$108.24-5$

TERMS: NET 30 DAYS. Accounts over 30 days will be charged $11 / 2 \%$ per month not to exceed $18 \%$ ann:lly.

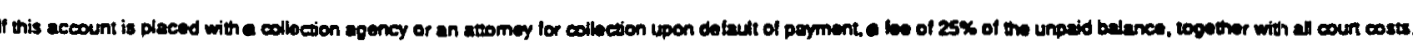
atomeys' loes, gannishment foes and $10 \%$ interest trom manurity is nereby alutorized. 
ting

nomenom

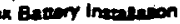

- pung semesa

Watwats $\sqrt{4}\left[\begin{array}{ll}1 \\ 4\end{array}\right.$

DRILLUNG \& WELL

SEAVICE, INC.

3 LAFAYETE LA 7050 (318) 261-0295
(3YETE. LA 7050
TICKET 6846

REPORT NO. 4)

MPANY $00 E$

DAILY WORKOVER REPORT

:Lo East coat Lake

Lease Mlady Mcall

DATE $\mu-3-93$

WELL NO. ?

RISH OR COUNTY COMmenose STATELa RIG NO

sent Pertorations

Present Packer Setting

. Depth

Present Depth

Type Plug

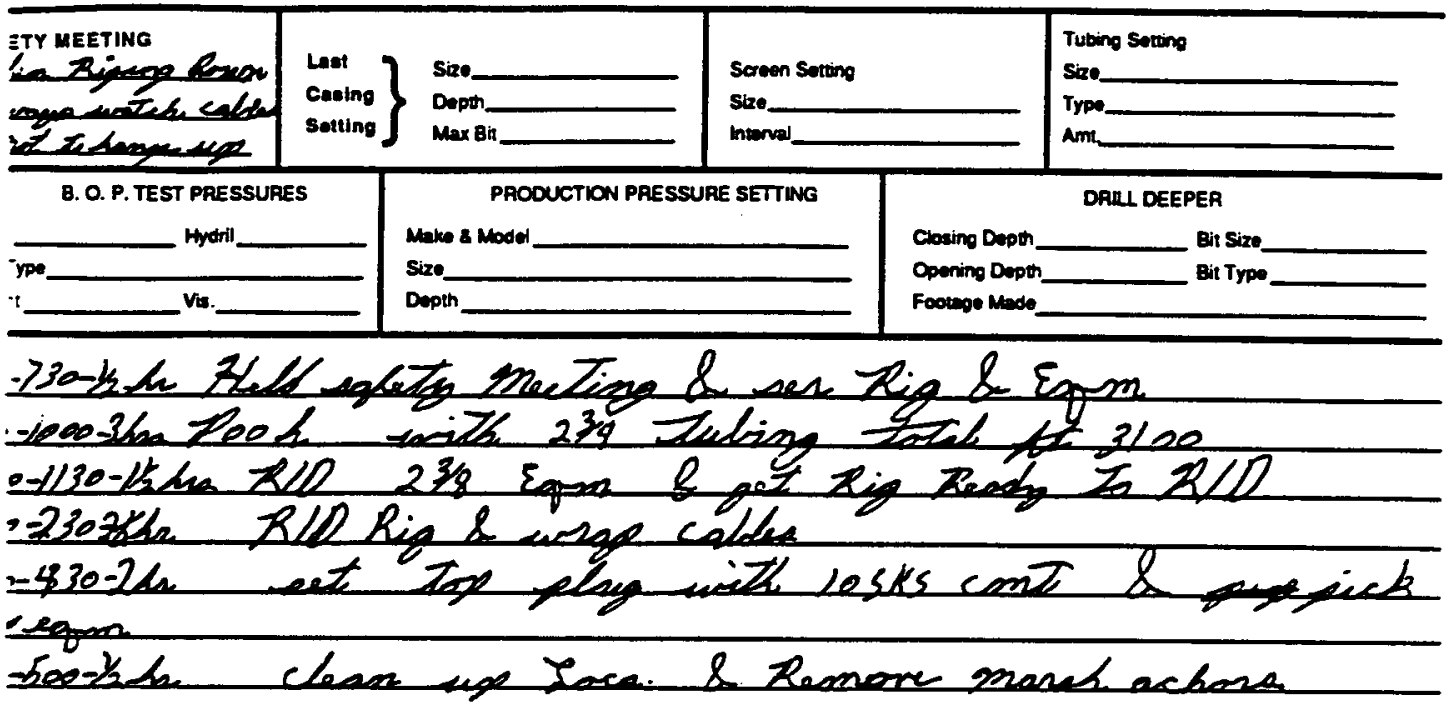

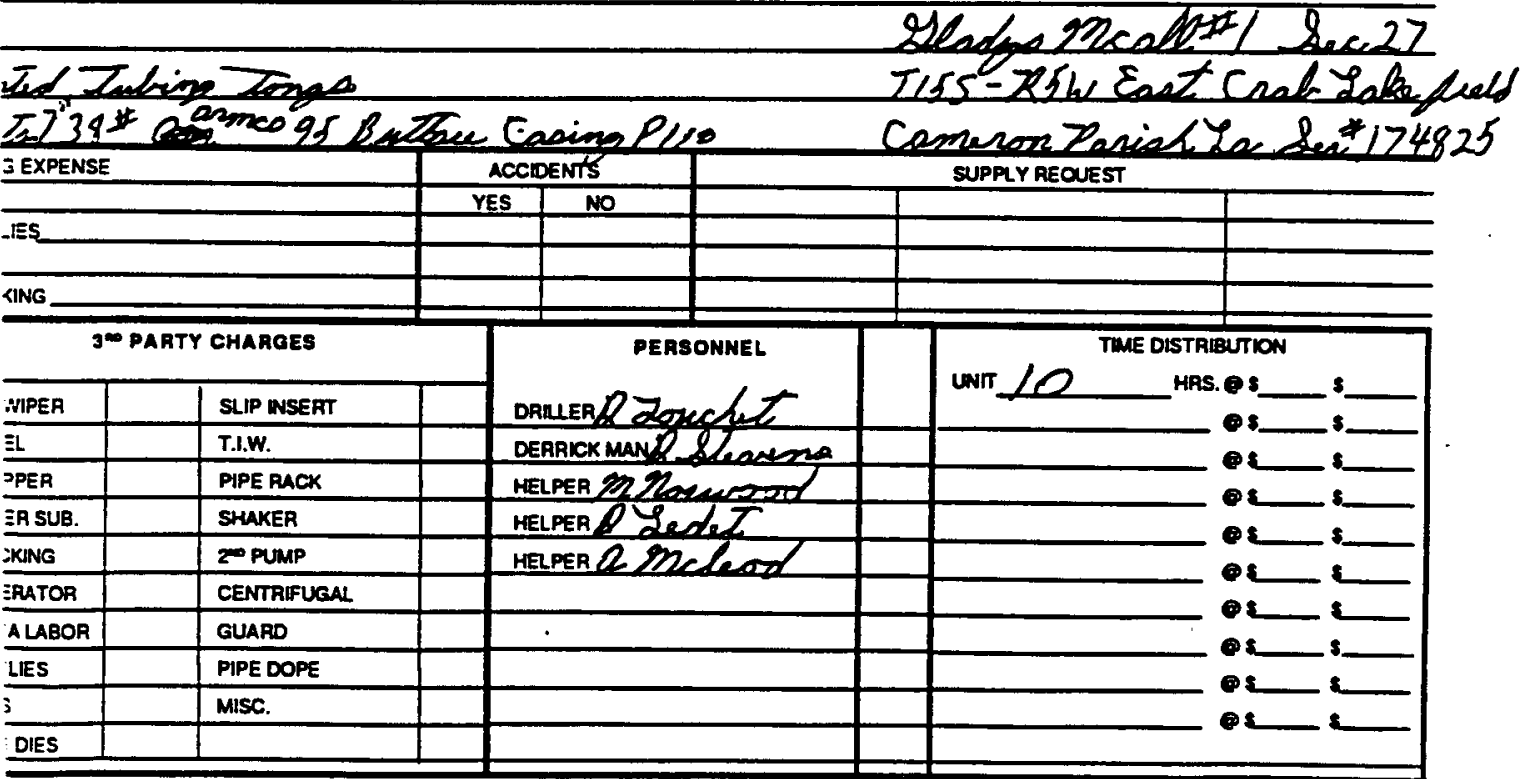

PUSHER bloyglas desuchetr

NO24-5
COMPANY REPRESENTATIVE

CONTRACT NO
JOB $24-5$

:RMS: NET 30 DAYS. Accounts over 30 days will be charged $11 / 2 \%$ per month not to exceed $18 \%$ annilly.

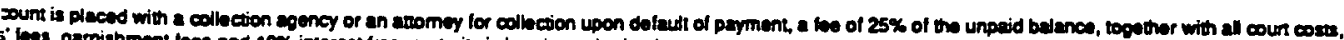
it bes, garnishment toos and $10 \%$ interest trom maurity is horeby authorized. 
Dritting

Wonower

Compicion

Tank Bavery insenis

Purrong sonves

Plis \& Abarcon

company DOE

FIELDEat crat Lake

PARISH OR COUNTY COOMneS

Present Perforations

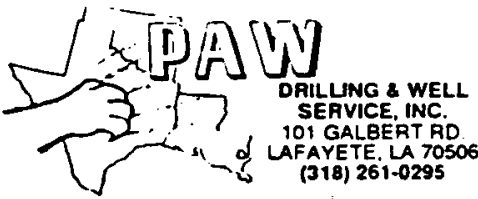

\section{DAILY WORKOVER RE'PORT}

LEASE Hlad mcall STATEZ Za
TICKET $634 ?$

REPORT NO. -1

Total Depth

Present Depth

DATELL-4-93 WELL NOSLD 1 RIG NO 5 Present Packer Setting

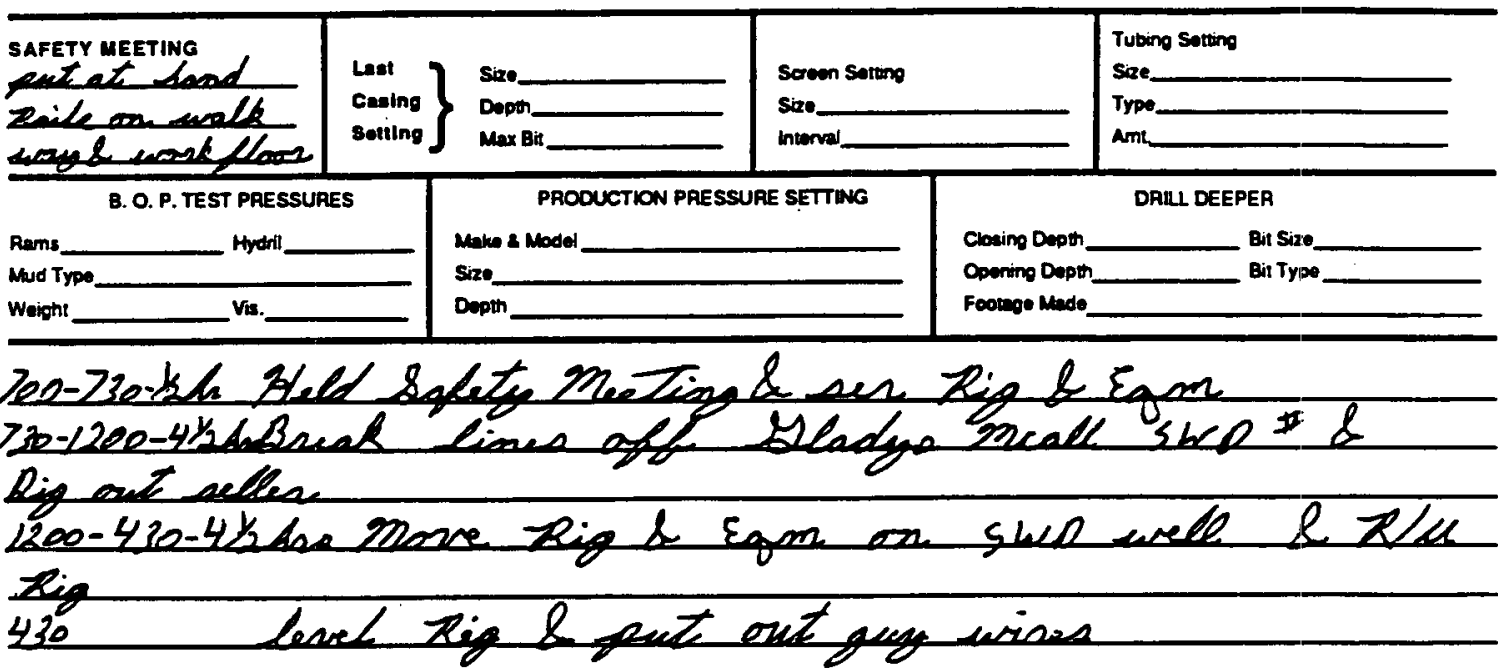

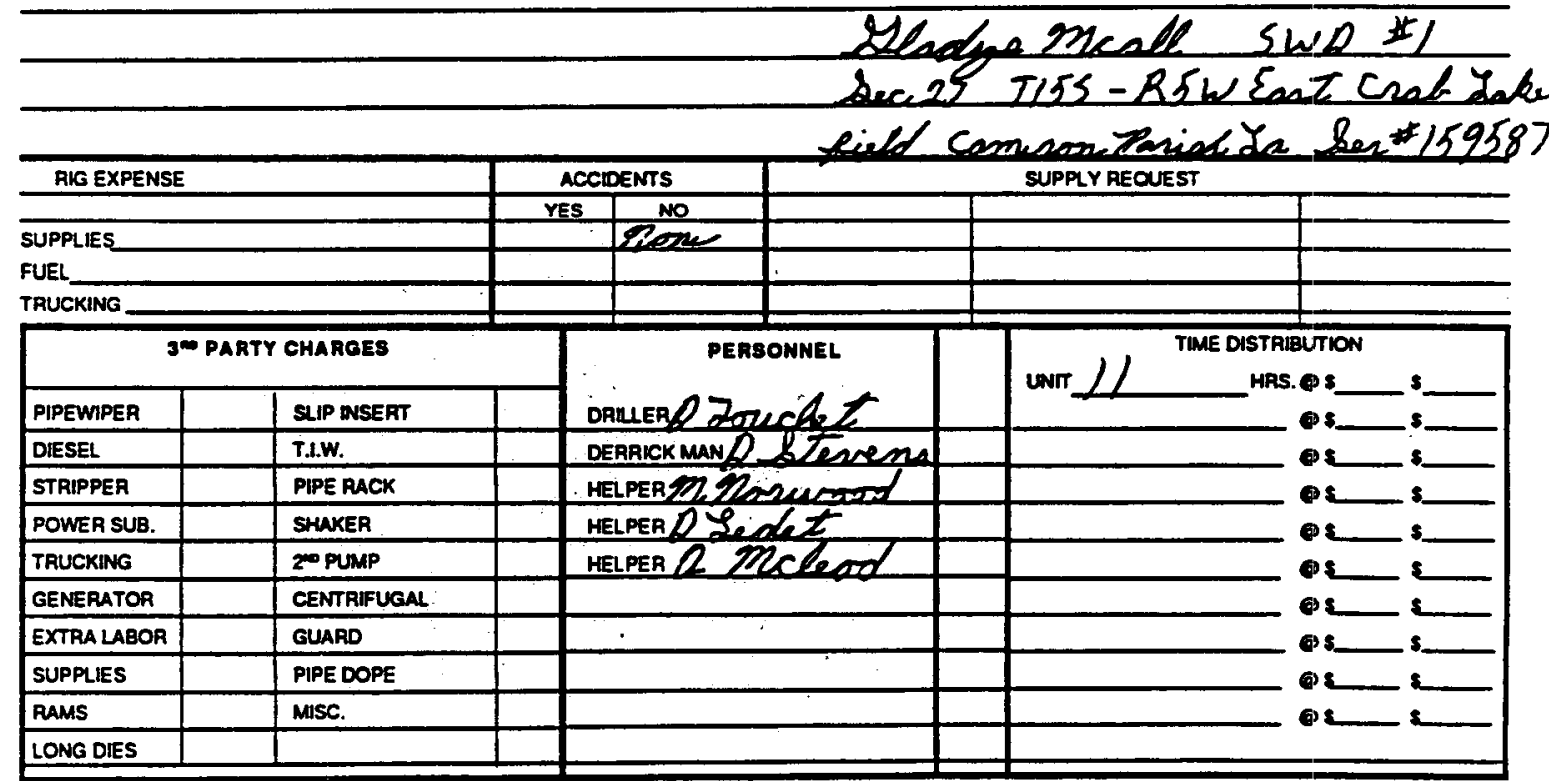

TOOLPUSHerbloyglas Jouchet JOB NO 255 ORDER NO.
COMPANY REPRESENTATIVE

CONTRACT NO
JOB_25-5

TERMS: NET 30 DAYS. Accounts over 30 days will be charged $11 / 2 \%$ per month not to exceed $18 \%$ annilly.

If this account is placed with a collection agency or an atwomey lor collection upon datauth of payment, a fee of $25 \%$ of the unpaid belance, logether with all court costs. atromeys: lees, gamishment lees and $10 x$ interest trom maturity is heroby authorized. 


\section{Lo East Crat Lake}

IISH OR COUNTY Cameson

sent Pertorations

al Depth

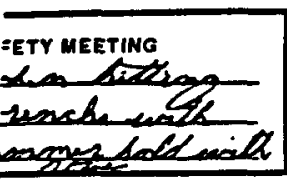

B. O. P.TEST PRESSUAES

id Trpo Hydril

right

Vis.
LEASE Yladea Mcall state La
DATE $\mu-5-93$ WELL NOSWLDI RIG NO 5

Prosent Packer Setting Present Depah Typo Plug

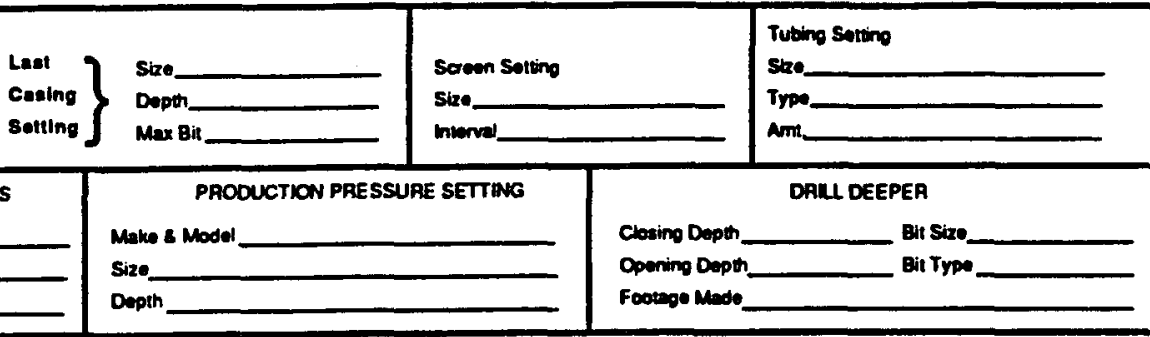

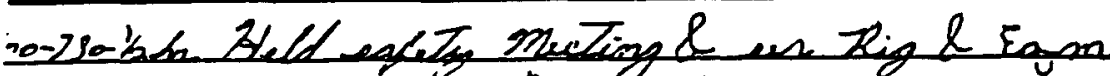

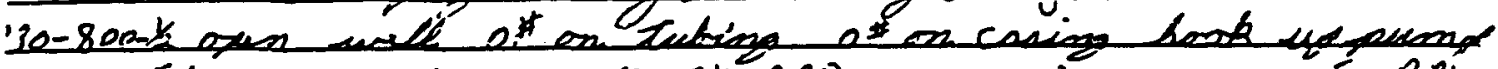

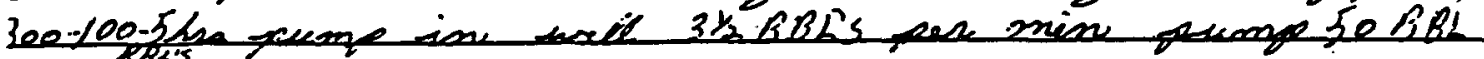

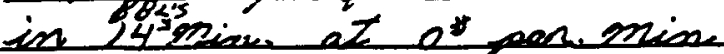

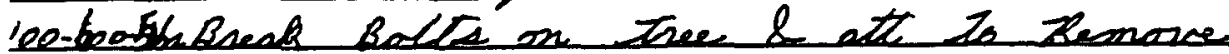

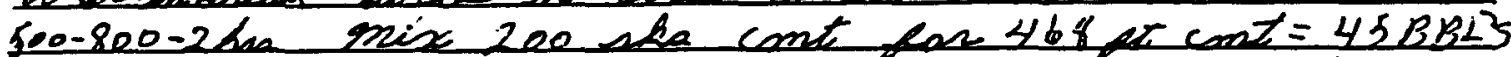

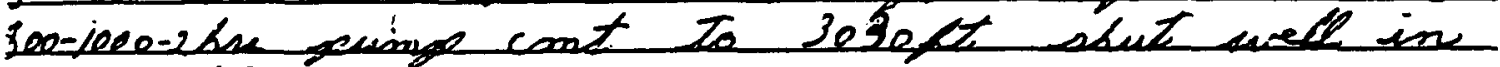
ton rigbt

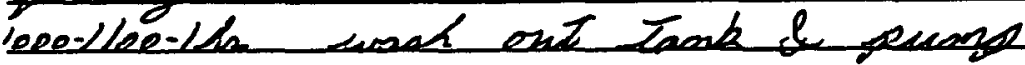

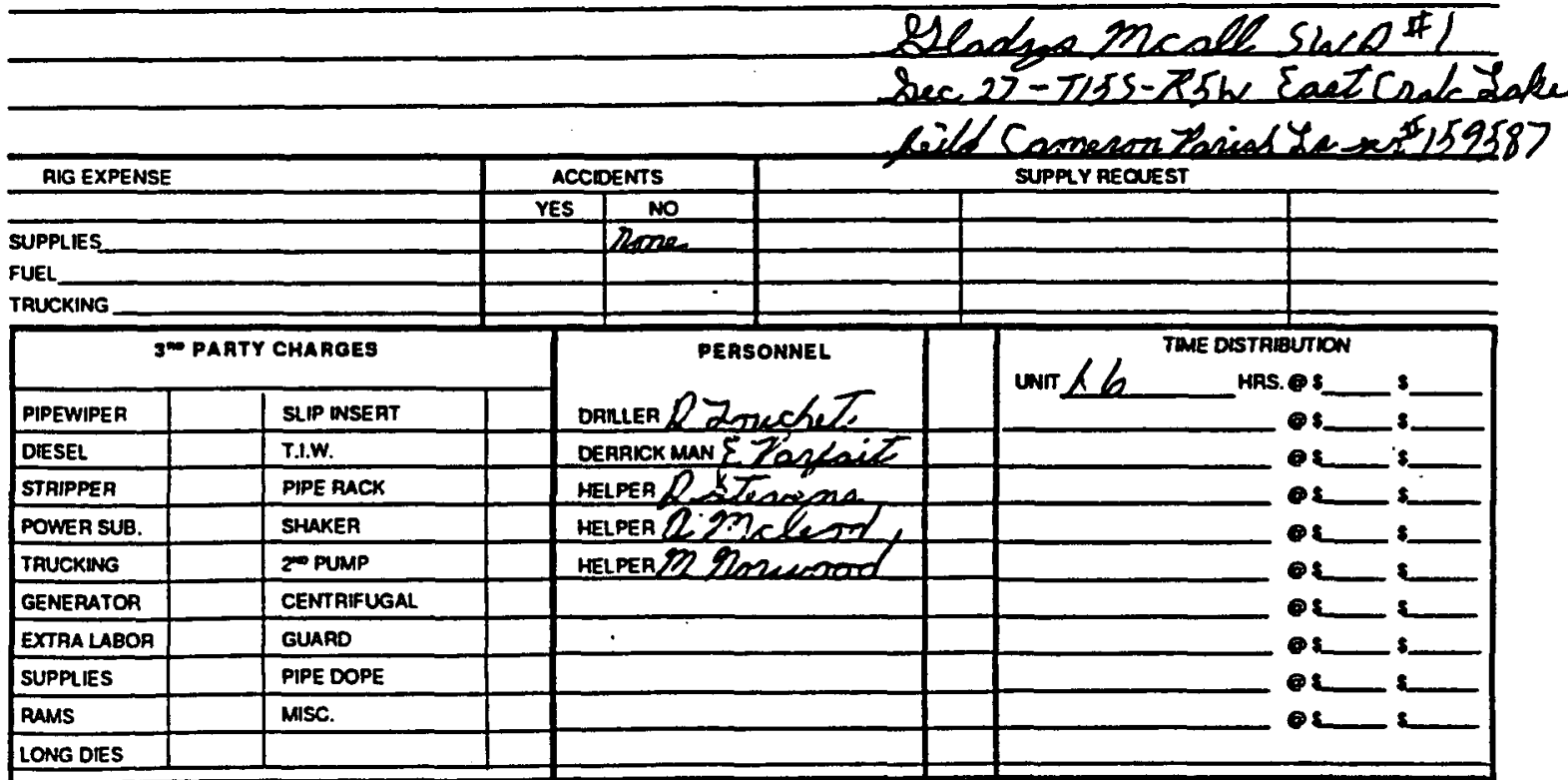

TOOLPUSHER Rozzalas Youcht JOB NO $25-5$ ORDER NO
COMPANY REPRESENTATIVE CONTRACT NO 108 $25-5$

TERMS: NET 30 DAYS. Accounts over 30 days will be charged $11 / 2 \%$ per month not to exceed $18 \%$ ann:lly.

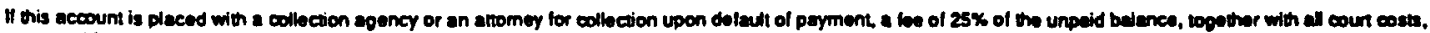
atwomers' tees, gavishment loes and $10 \%$ intereat from matavity is hereby authorized. 
Driling

Comover

Tant Batiey inatiavon

Purping Semose

Sat Wair Wells

Plug \& abencon $\sqrt{x[0][0]}$

DAILLING \& WELL

SERVICE, INC.

101 GALBERT RD. (318) 261-0295
TICKET 6849

REPORT NO. 3

company $D \cap E$

\section{DAILY WORKOVER REPORT}

FIELDEat crals jake LEASE Hhd Meall

DATE $\|-b-93$

PARISH OR COUNTY CSOMeran STATE Ia WELL NOSWO RIG NO 5

Present Pertorations

Total Depth
Present Depth

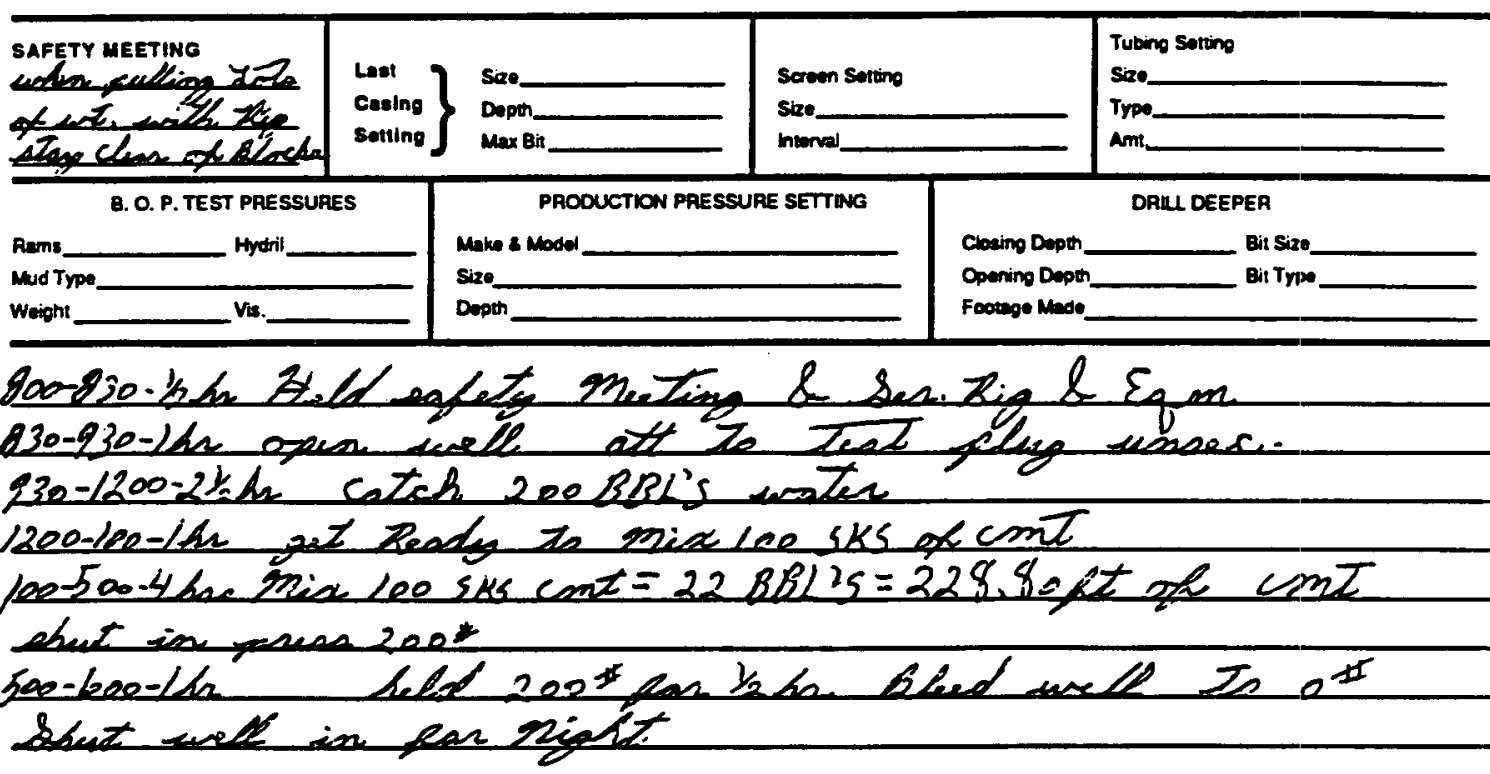

Present Packer Setting

Type Plug

Sladue mealle suen \#1 Sece 27 - I15s-R5 W Eastcral L

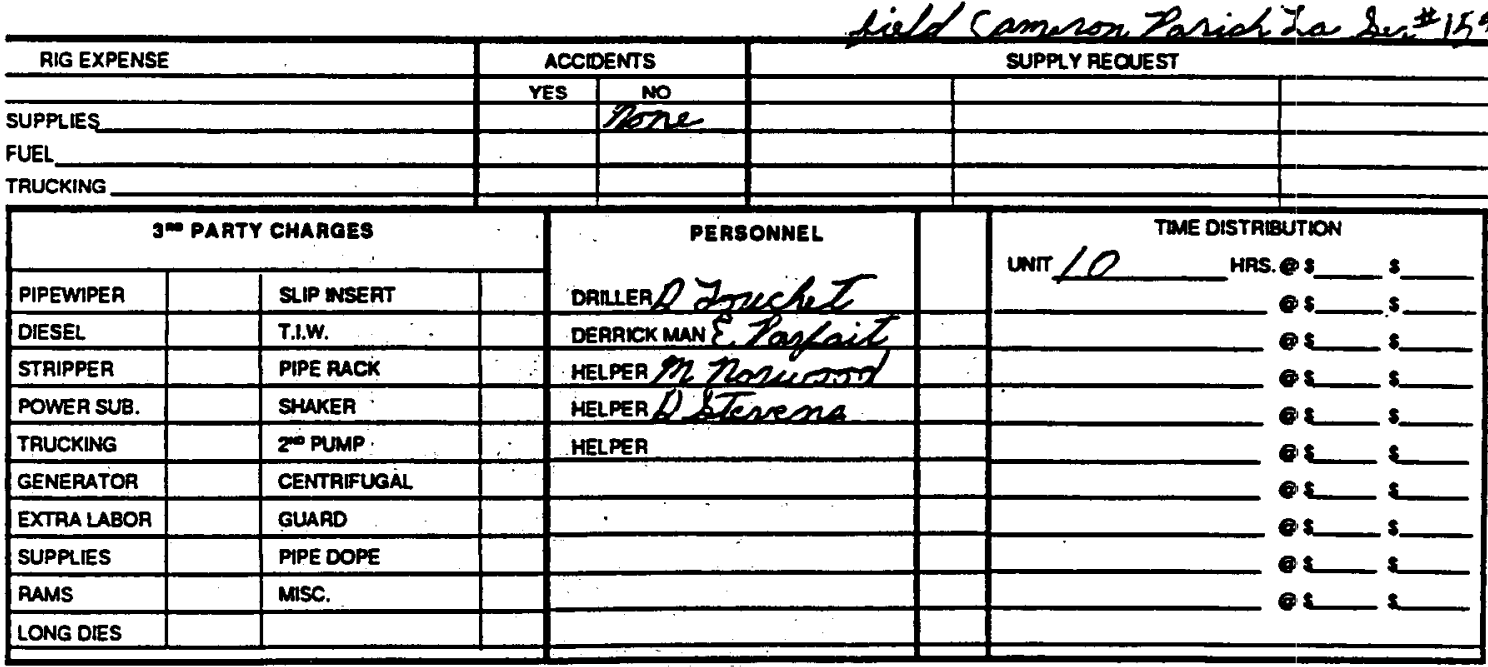

TOOLPUSHer forgalas Zouchet JOB NO $25-5$ ORDER NO
COMPANY REPRESENTATIVE

CONTRACT NO $108,25-5$

TERMS: NET 30 DAYS. ACcounts over 30 days will be charged $11 / 2 \%$ per month not to exceed $18 \%$ ann:lly.

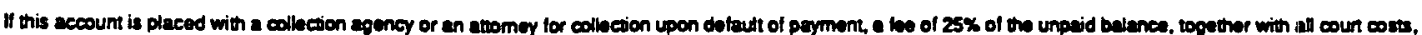
atromeys' bes. gamishment bes and $10 \%$ interest trom masurity is hereby authorized. 
Driting

womower

Compition

Tert Babery insoltason

Purping Sernes:

Sal Water Wella

Plup o Aasioion

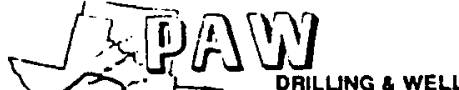

SERVICE, INC.

101 GALBERT RD.

AFAYETE, LA 705
(318) 261-0295

DAILY WORKOVER REPORT
TICKET 6850

REPORT NO. 4

DATE $\perp 1-7-93$ WELL NO.SWR \#) RIG NO 5

company DOE

FIELREat Crab toke LEASE Hladage Mcall state Yn

Present Packer Setting

Present Perforations

Present Depth

Typo Plug

Total Depth

ubing Soting

SAFETY MEETING

conda minizon

cant inena epand

anes math \& now

Last Size______ Screen Sorting

Caeing Dopth___ Size

solting Max Bit___ interval

B. O. P. TEST PRESSUAES

Rams

Mud Type Hydril

Weight

Vis.
PROOUCTION PAESSURE SETTME

Make 8 Modet

Size.

Depth sae.

Type

Amt

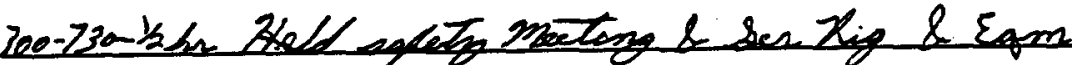

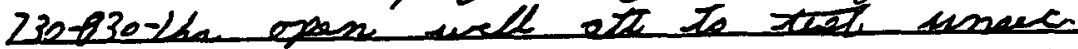

830-1200-4hac catch 200 BBL'S laed unaten.

$1200100-1 \mathrm{~h}$ get seads to mid $100 \mathrm{sks} \mathrm{cm}$

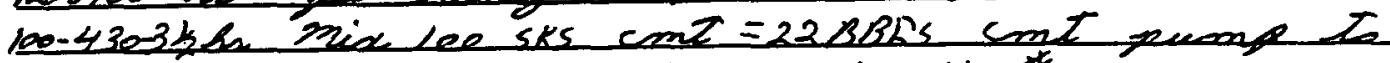

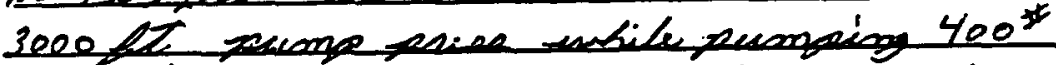

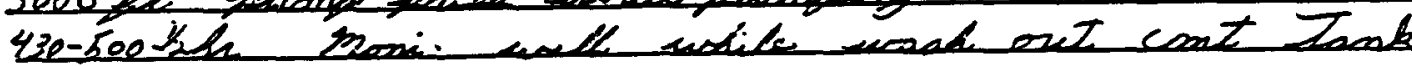
\& sume shut in of

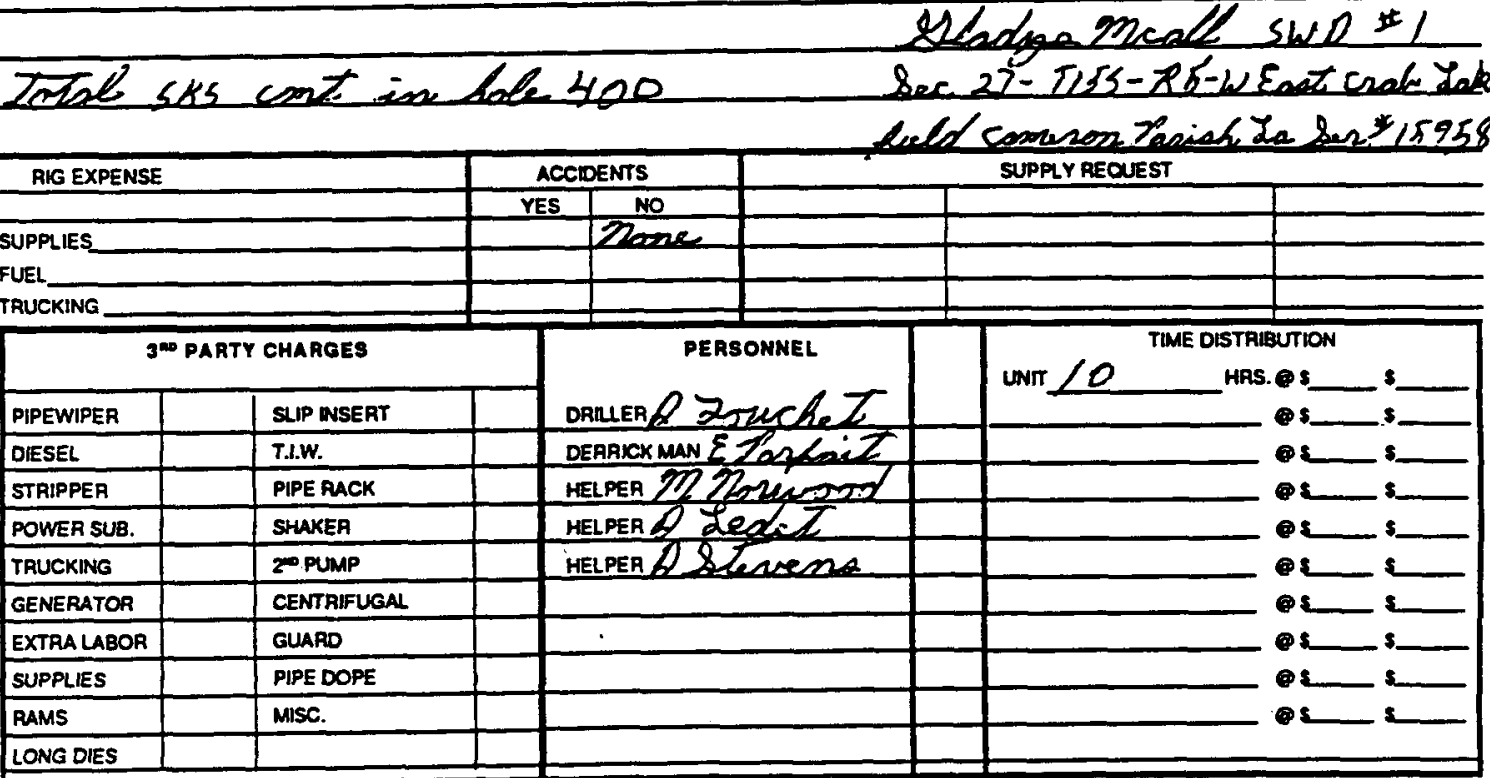

TOOLPUSHerdozyan Zuche Z JOB NO $25-5$ ORDER NO.
COMPANY REPRESENTATIVE CONTRACT NO $\operatorname{sos} 25-5$

TERMS: NET 30 DAYS. Accounts over 30 days will be charged $11 / 2 \%$ per month not to exceed $18 \%$ ann!lly.

If this account is placed with a colloction agency or an anomey for collecion upon dafaut of payment, a toe of $25 \%$ of the unpaid balence, together with all coun costs. acromeys' toes, ganishment loes and $10 \%$ interest from maurity is hereby authorized. 
$\operatorname{lng}$

mowion

- Baresy trationon

Tping semeas

t waw Wanton

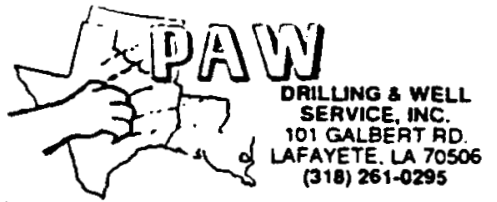

DAILY WORKOVER REPORT
TICKET 7651

REPORT NO. 5

MPANYLOE LEASE \&ladea monll DATE $11-4-93$ STATE DI WELL NO.SWD

Isent Perforations Present Packer Setting

tal Depth Present Depth Type Plug

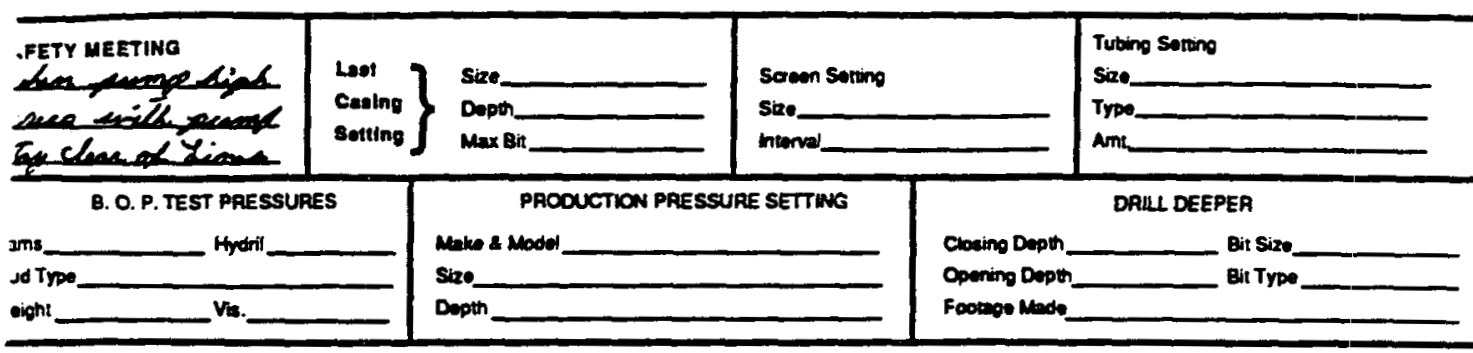

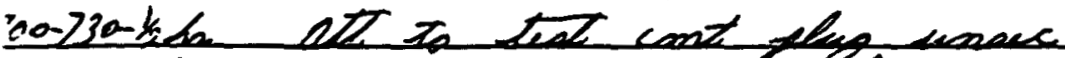

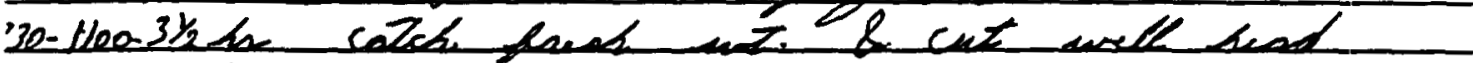
nall seats caee

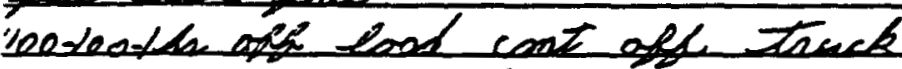

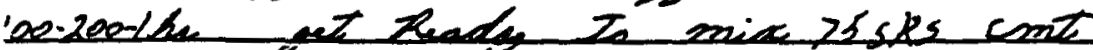

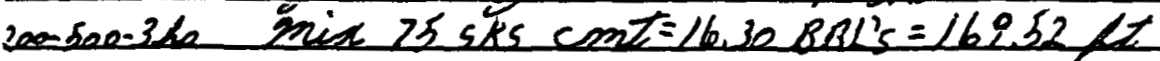

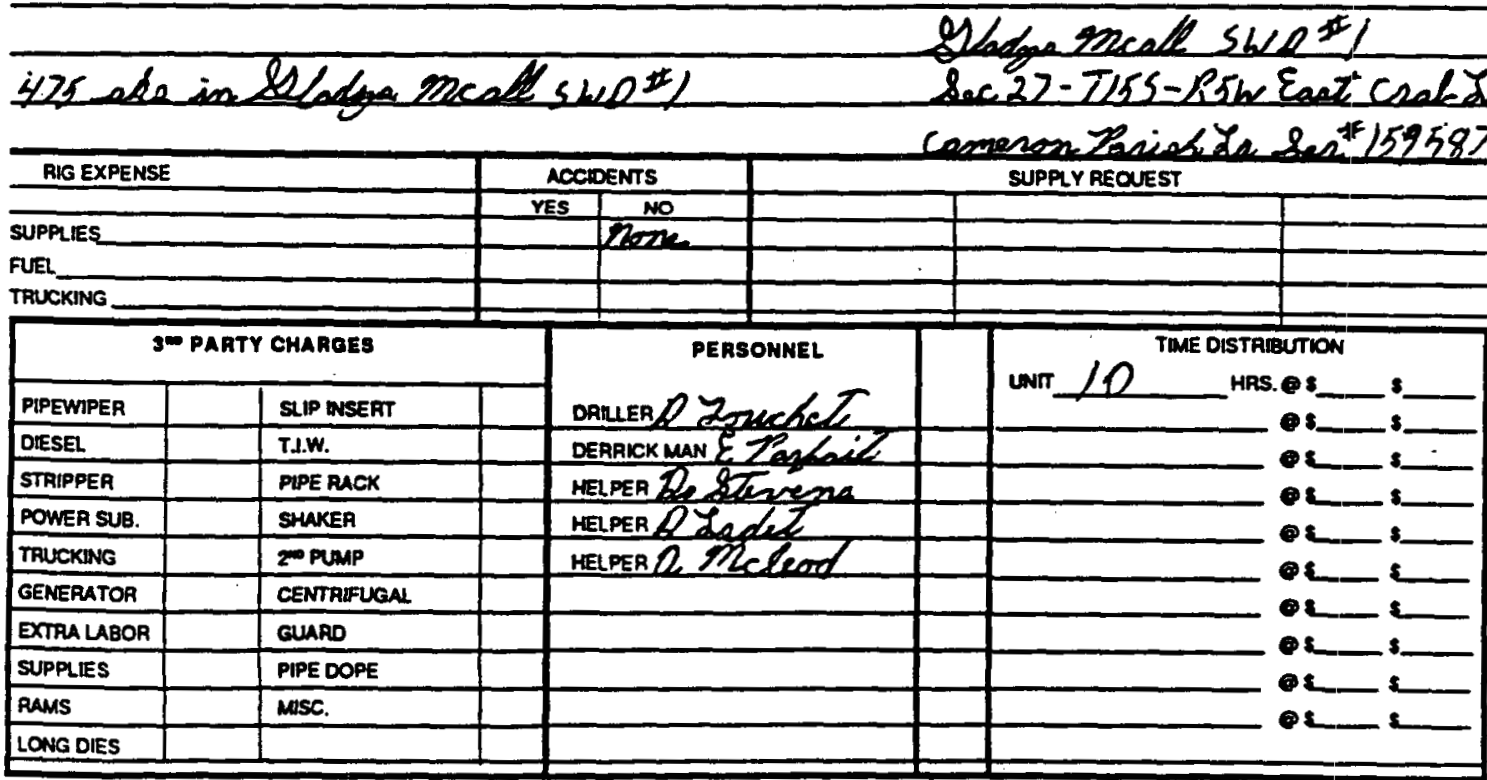

TOOLPUSHER fozelae Zouchet JOB NO $25-5$ ORDER NO.
COMPANY REPRESENTATIVE CONTRACT NO Joв $25-5$

TERMS: NET 30 DAYS. Accounts over 30 days will be charged $11 / 2 \%$ per month not to exceed $18 \%$ ann:lly.

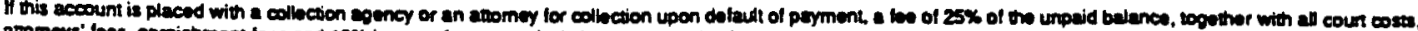

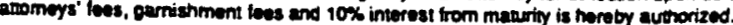


SANY $20 E$

, Earteralk Lake LEASE Ylad math DATE $11-9-93$ SH OR COUNTY Camenor STATE La WELL NO. $262 \pm 1$

nt Pertorations

Present Packer Setting

Depth Present Depth Typo Plug

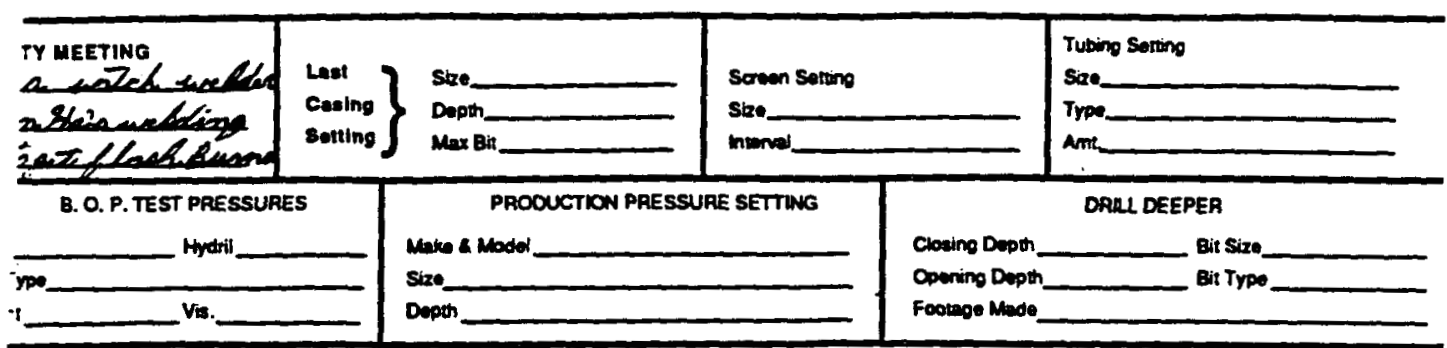

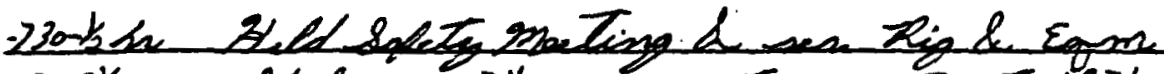

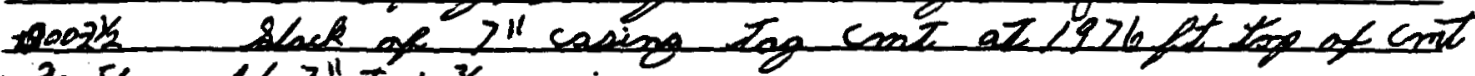

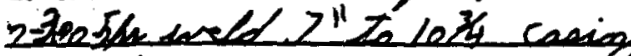

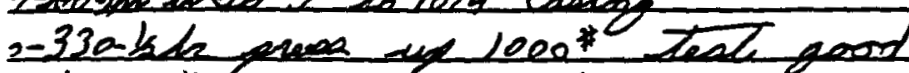

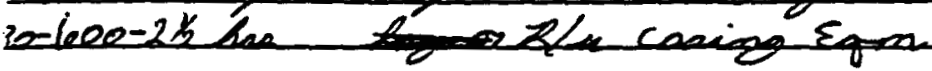

$$
2019<27123 \# 20
$$

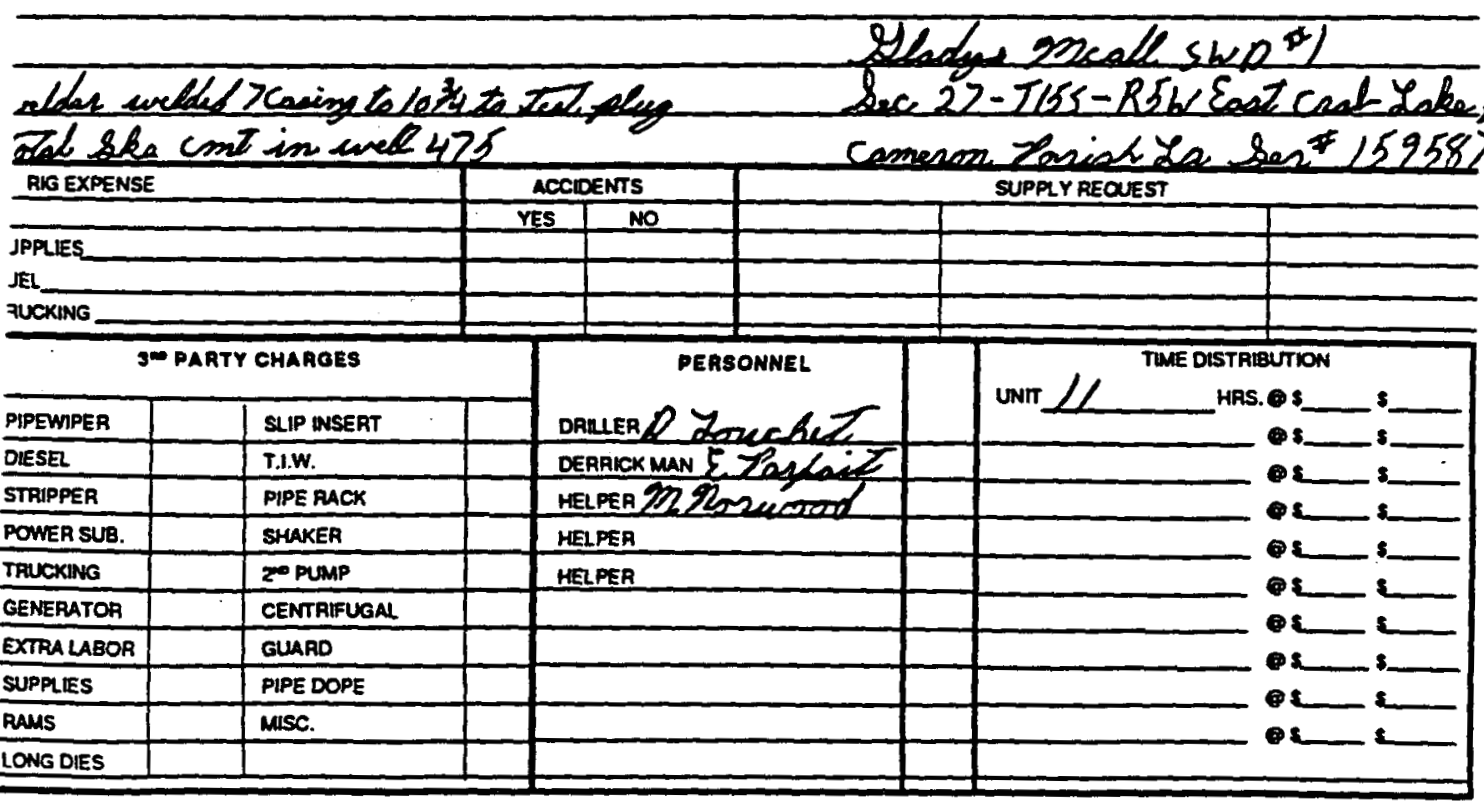

Toolpusherbozialas Zouchet JOB NO $25-5$ ORDER NO
COMPANY REPRESENTATIVE CONTRACT NO.
$10825-5$

TERMS: NET 30 DAYS. Accounts over 30 days will be charged $11 / 2 \%$ per month nol to exceed $18 \%$ ann:lly.

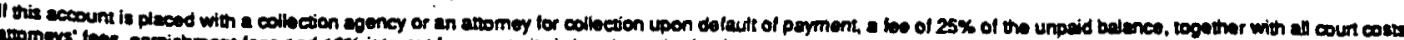
awomeys' tees, gavnishment ines and $10 x$ interest trom maturity is hereby authorized. 

stateda WELL NO. $2 \mathrm{Wn} \#$

Present Perforations

Prosent Packar Sotting

Total Dopth

Present Depth

Typo Plug

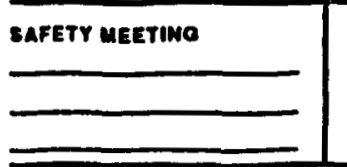
$\left.\begin{array}{l}\text { Leat } \\ \text { Ceeing } \\ \text { soting }\end{array}\right\}$ $\operatorname{lam}_{8 x}$

Socen south

9. O. P. TEST PRESSURES

Rem

mod Trom Hoth

Weith vin.
PROOUCTION PRESSURE SETTINC

\section{Mans a Meat}

Size. Dopent
Tuano Soting

san

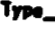
Amm

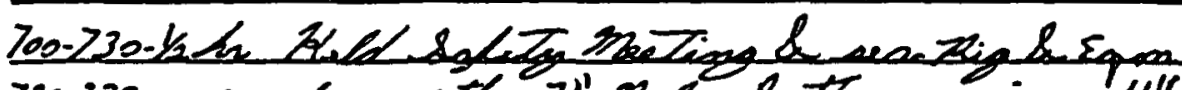

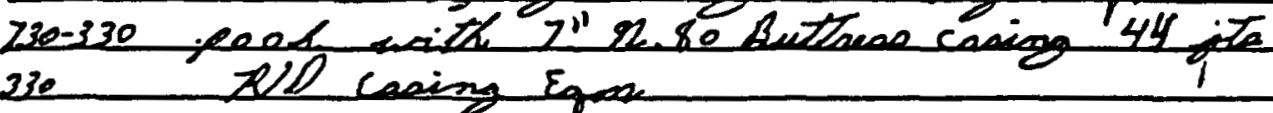

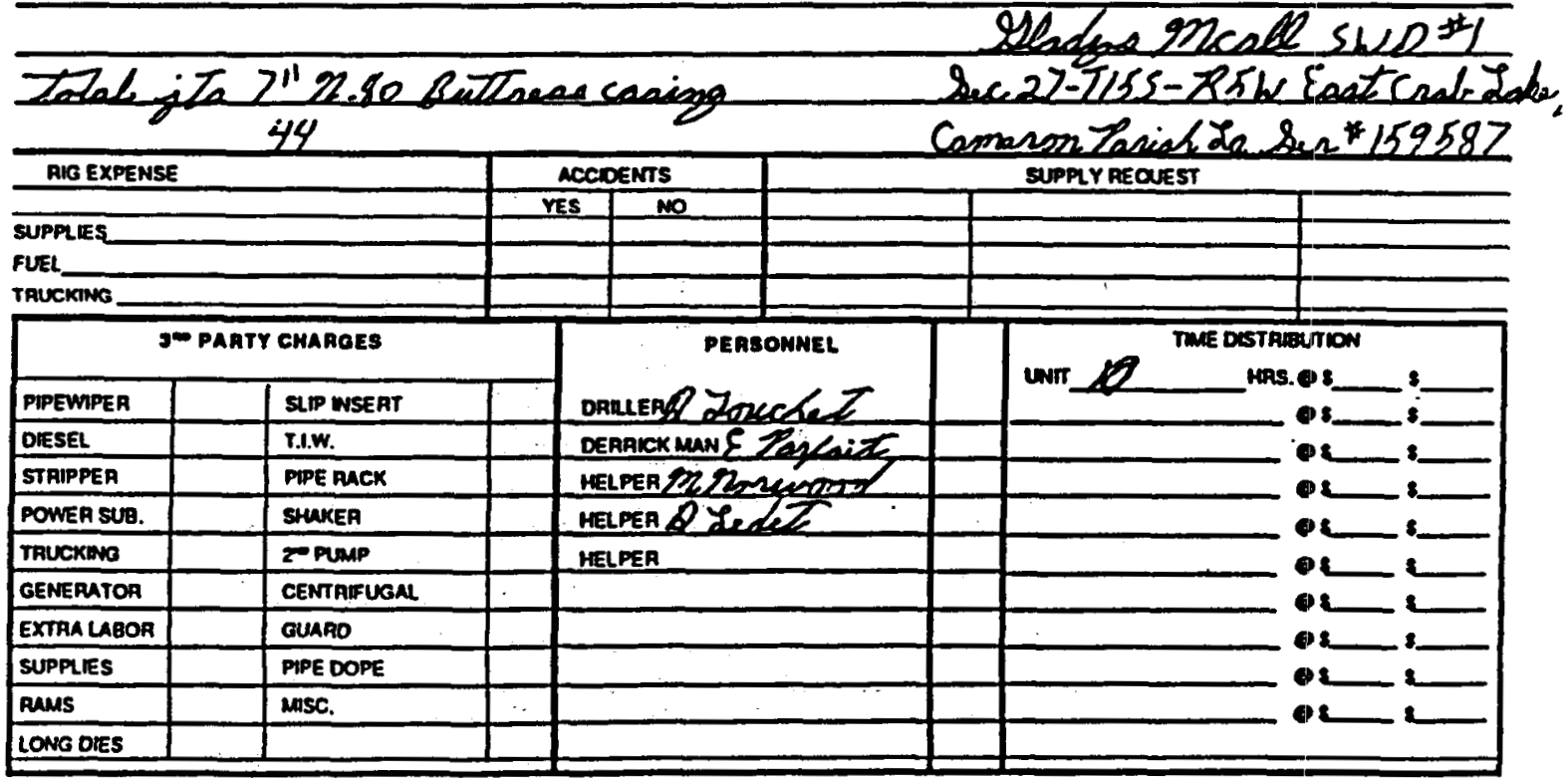

TOOLPUSHerbloyglas Zonechet JOB NO $25-5$ ORDER NO. COMPANY REPRESENTATIVE CONTRACT NO__ JOB_25-5

TERMS: NET 30 DAYS. Accounts over 30 days will be charged $11 / 2 \%$ per month not to exceed $18 \%$ ann:lly.

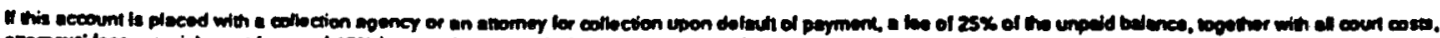

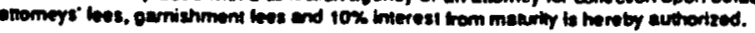


Driting

Womower

Complower

Tenx Banery trovilateon

Aurpeng Sermo.

Selt Wain Welle

Pup o Abencon

company $Q 0 E$

FIELDEast Crak Lake

PARISH OR COUNTY Comeson.

Present Perforations

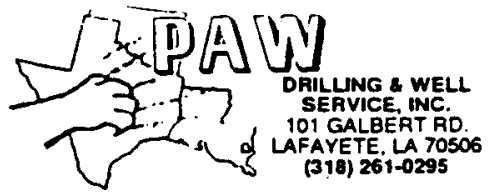

DAILY WORKOVER REPORT

TICKET $765 \%$

REPORT NO. 8

DATE $/ 1-11-93$ WELL NO, SWD\#! RIG NOL 5

LEASE Sladga Meall state $\mathscr{L} a$

Present Packer Serting

Total Depth

Present Depth

Type Plug

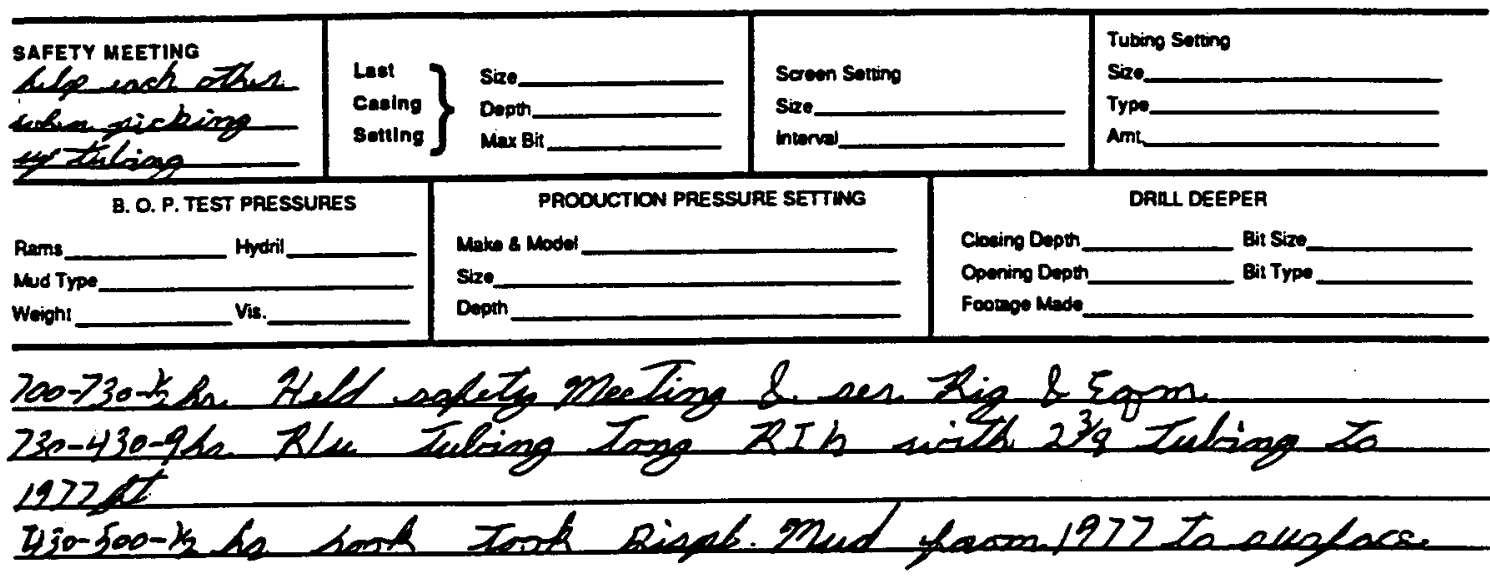

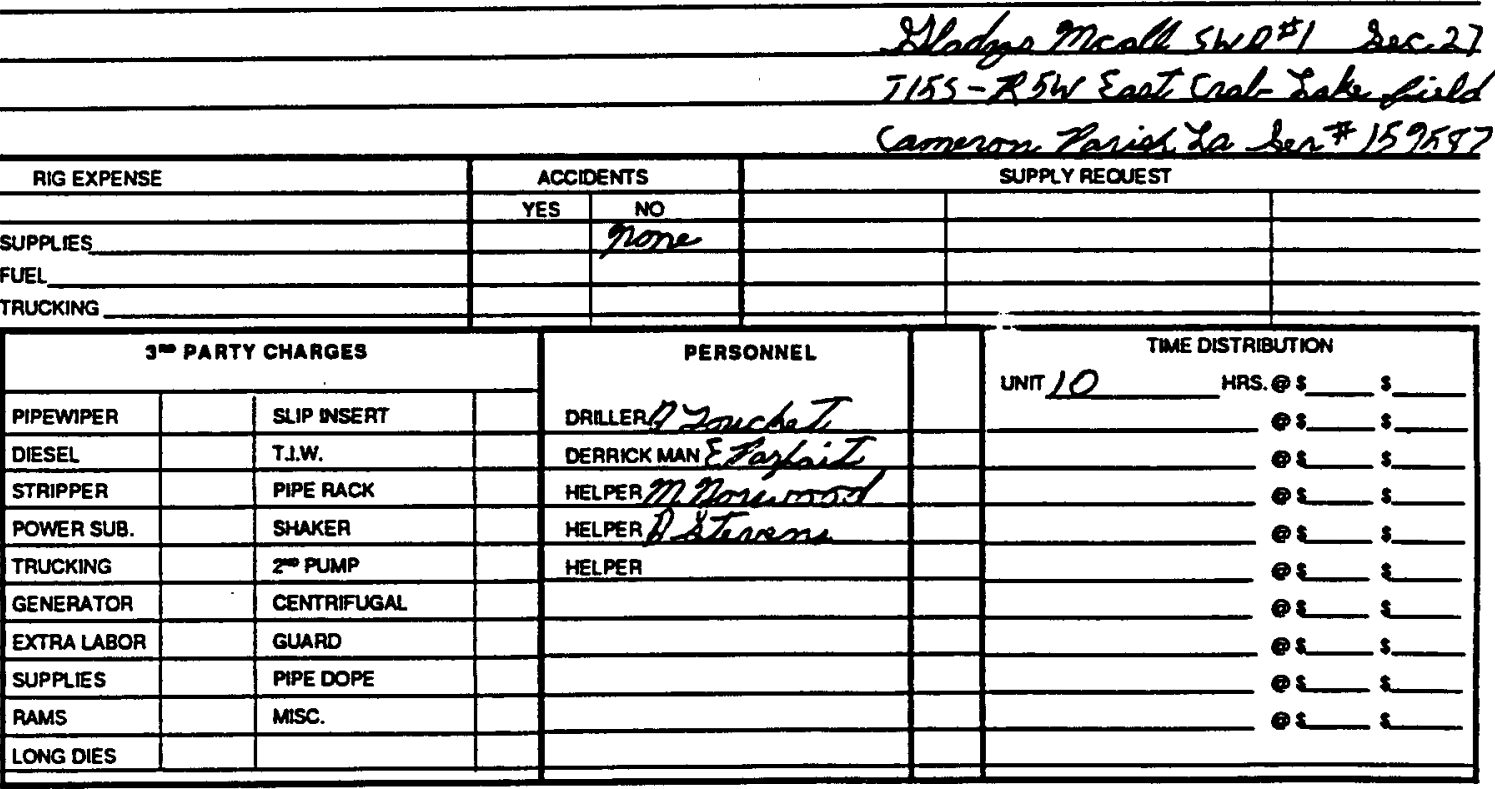

TOOLPUSHER foyelas Zouchet JOB NO $25-5$ ORDER NO.
COMPANY REPRESENTATIVE CONTRACT NO
$\operatorname{soB} 25=5$

TERMS: NET 30 DAYS. Accounts over 30 days will be charged $11 / 2 \%$ per month not to exceed $18 \%$ annilly.

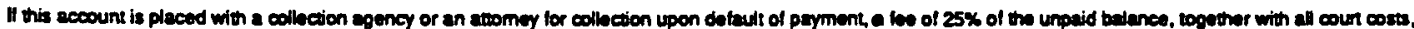
atromeys' boss, garnishment loses and $10 \%$ interest trom manuity is hareby authorized. 


\section{SAFETY MEETINO \\ $\left.\begin{array}{l}\text { Lost } \\ \text { Coaing } \\ \text { Sotting }\end{array}\right\}$} Q. O. P. TEST PAESSUAES

Rams

Mud Type Hyaril

Wright vis. sotring $\int$ Max $B_{1}$

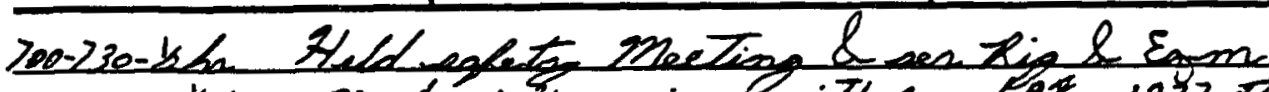

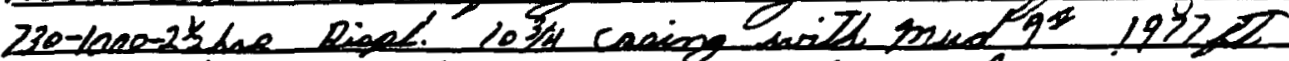

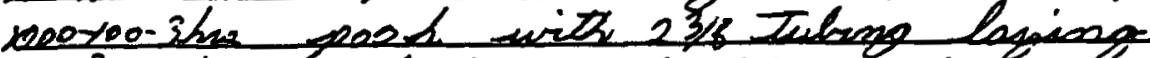

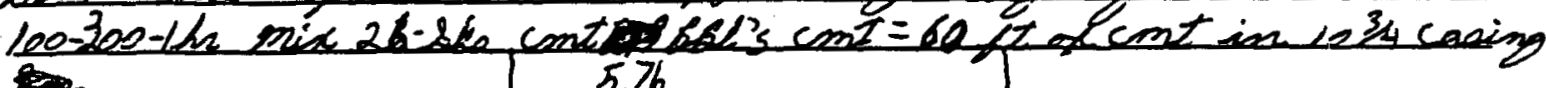
E.

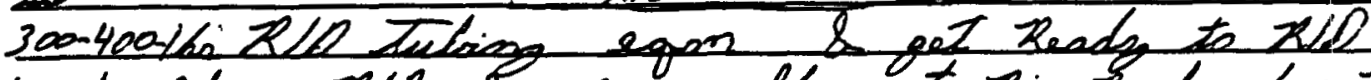

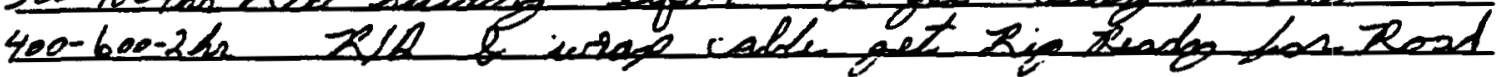

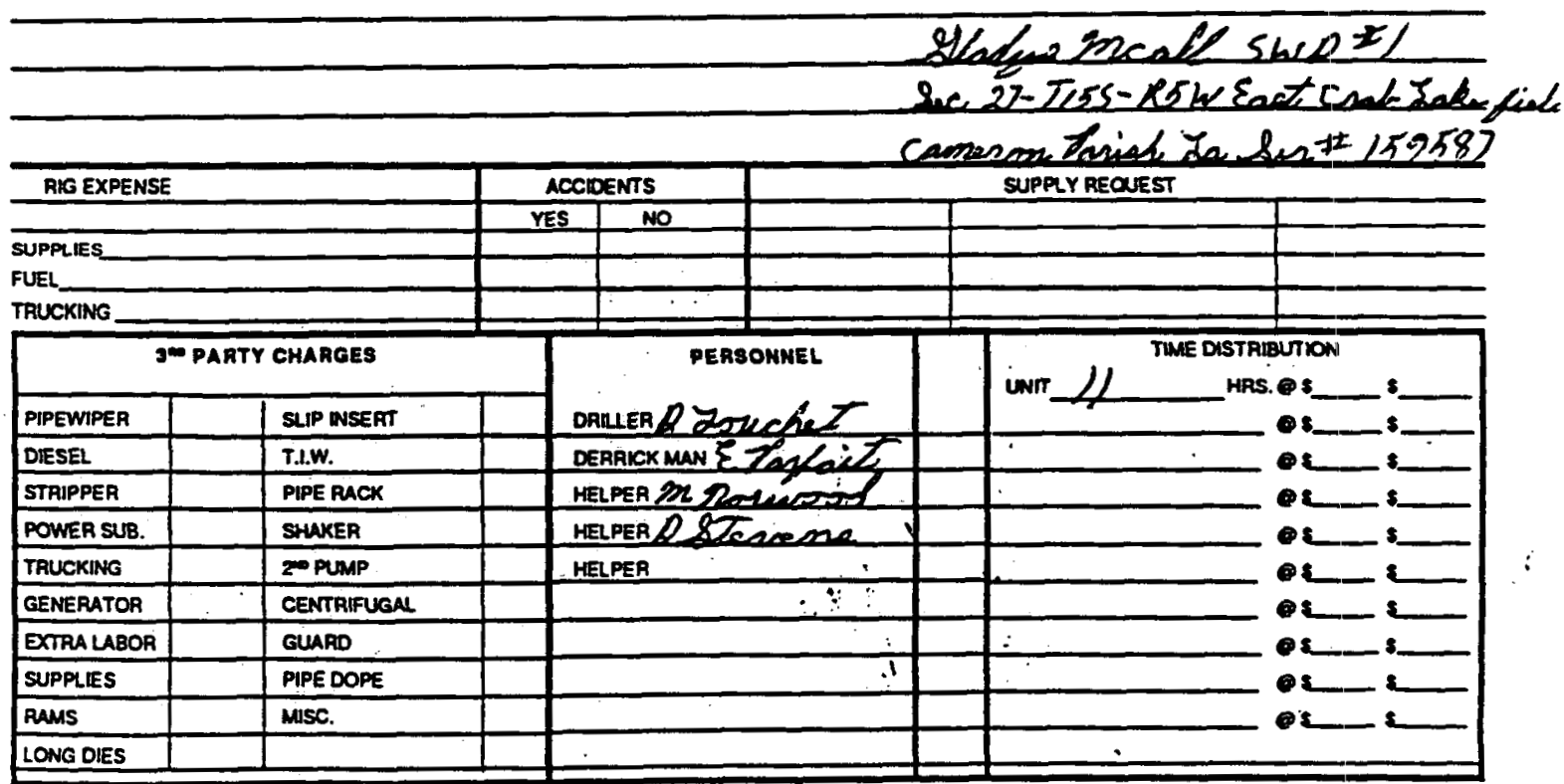

TOOLPUSHer Dogalas Zouchet JOB NO $25-5$ ORDER NO.
COMPANY REPRESENTATIVE CONTRACT NO
J08 $25-5$

TERMS: NET 30 DAYS. Accounts over 30 days will be charged $11 / 2 \%$ per month not to exceed $18 \%$ annilly.

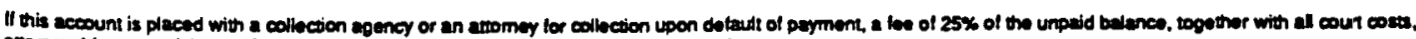
atomegs' bes. ganishment lees and $10 \%$ iniorest from masurity is hereby authorized. 
Driling

consivion

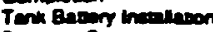

Purpons Somices

Seth Ware Wall:

Pug \& abencon

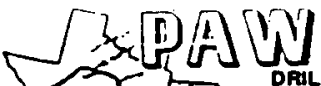

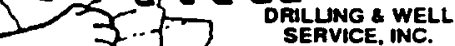
1.2. 101GALEEAT RD. of WFAYETE. LA 70506
TICKET 7655

REPORT NO. 9

\section{DAILY WORKOVER REPORT}

company $D Q E$

Fielofost crab Lake LEASE Yladue Mcall DATEL/- $15-93$

PARISH OR COUNTY COMneñ state ${ }^{2} \Omega$ WELL NO.SWD EI RIG NO 5

Present Perforations

Present Packer Setting

Total Depth

Present Depth

Type Plug

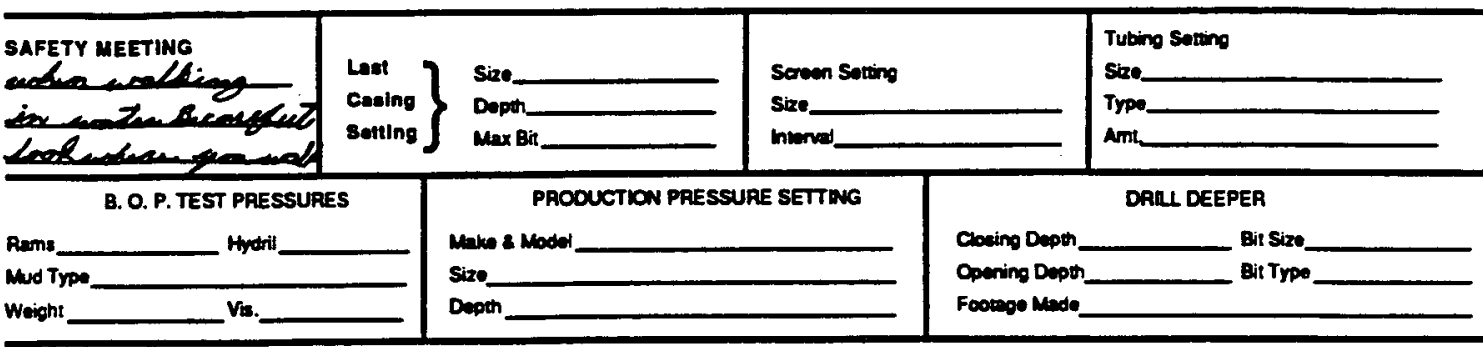

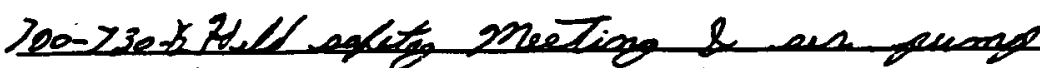

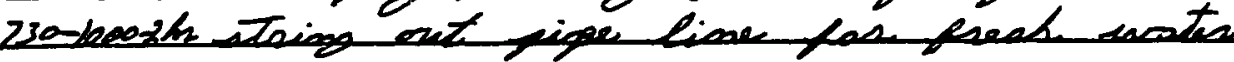

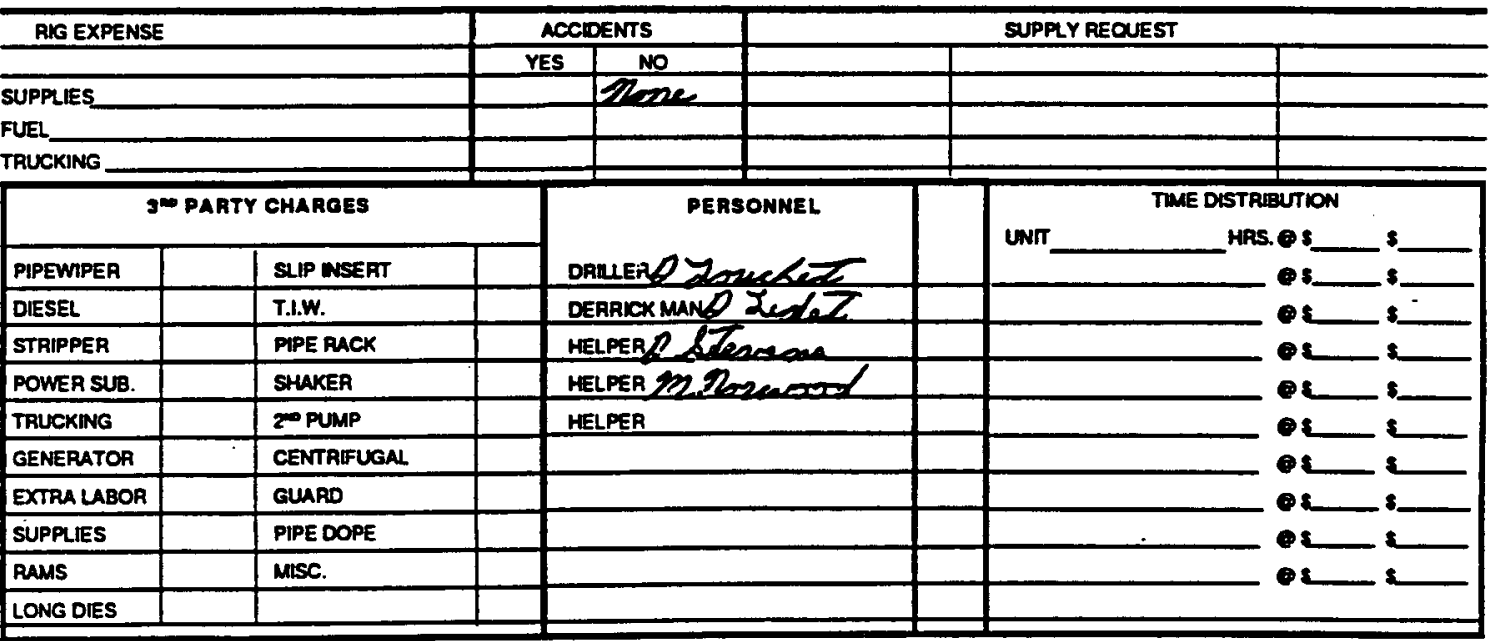

TOOLPUSHerhomalas Zeruchete JOB NO25-5 ORDER NO.
COMPANY REPRESENTATIVE

CONTRACT NO
$\operatorname{JOB} 25-5$

TERMS: NET 30 DAYS. Accounts over 30 days will be charged $11 / 2 \%$ per month not to exceed $18 \%$ ann!lly.

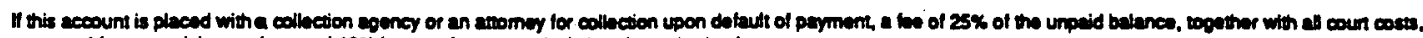

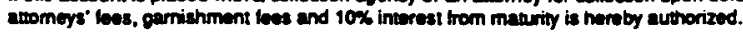




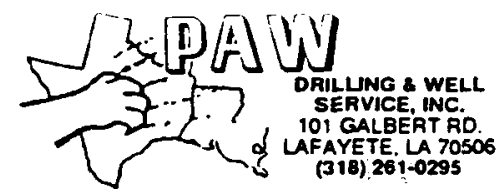

TICKET 765;

REPORT NO. 10

\section{DAILY WORKOVER REPORT}

company DOE

Fiendent crab Lake

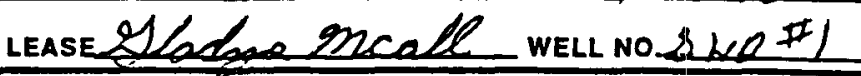

PARISH OR COUNTY COCones STATE 20 RIG NO 5

Present Pertorations

Present Packar Setting

Total Depth

Present Depth

Typo Plug

SAFETY MEETING
$\left.\begin{array}{l}\text { Lopt } \\ \text { Casing } \\ \text { sotting }\end{array}\right\}$

B. O. P. TEST PAESSURES

Rems.

Aud Type Hydril

Woight Vis.

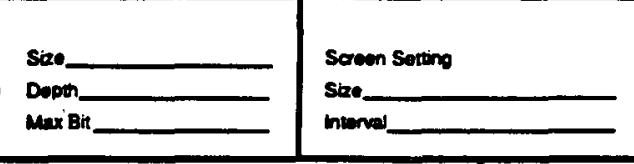

PROCUCTION PAESSURE SETTWG Nake 8 Model

Size. Depth
Couing Depen

Opening Depth

Foones Mnde

\section{Tubino Sorting}

Saze.

Troo

Amt

\section{DALL DEEPER}

Bit Size.

Bit Typu

$700-730-4 / 2 / 1$

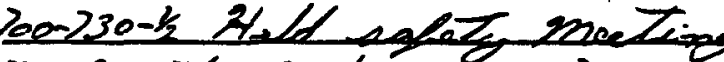

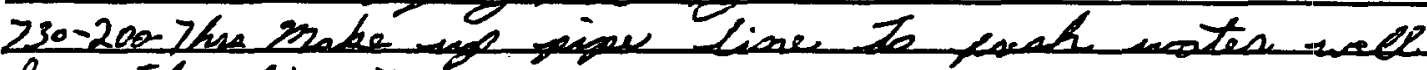
\& setch Ring Iever

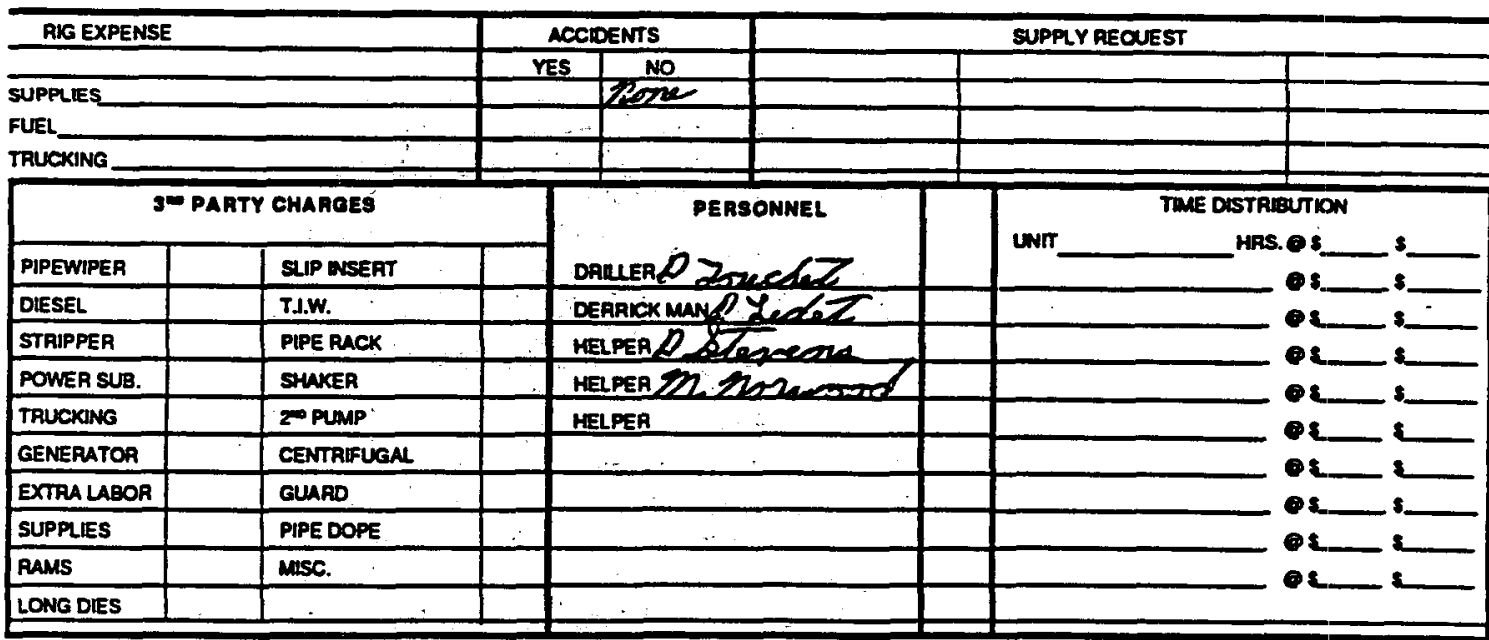

TOOLPUSHerbloyalas Zouchet JOB NO $25-5$ ORDER NO
COMPANY REPRESENTATIVE CONTRACT NO. soв $25-5$

TERMS: NET 30 DAYS. Accounts over 30 days will be charged $11 / 2 \%$ per month not to exceed $18 \%$ ann:lly.

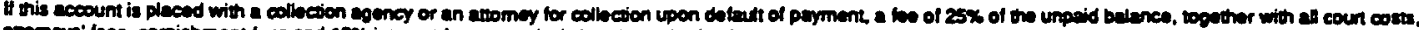

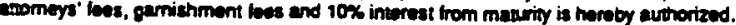


company $D O F$

DAILY WORKOVER REPORT

REPORT NO. U

\section{FIELR Eaat Crak Iake}

\section{LEAse Lladue meall}

DATE $L-17-93$ WELL NOSWR 1 RIG NO.

PARISH OR COUNTY Comm 20 STATE

Present Packer Senting

Present Pertorations Type Plug

Total Depth Present Depth

\section{Tubing Sorting}

SAFETY MEETINO entrac Ele. ugise ende cuace

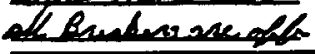

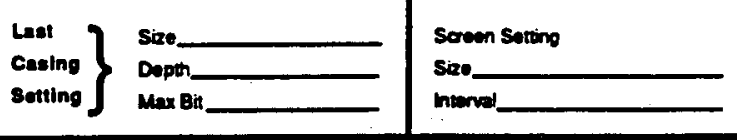
8. O. P. TEST PRESSURES

Rams. Hydril Make a Moder

mad Type Aydril Sizo

Wright vis. Dopth

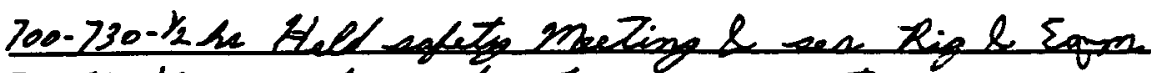
$730-930-1 \mathrm{~h}$ art sedge to mix unt

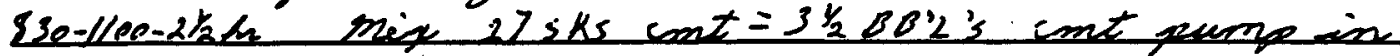
pear wet. Teet weel $=650$ pt

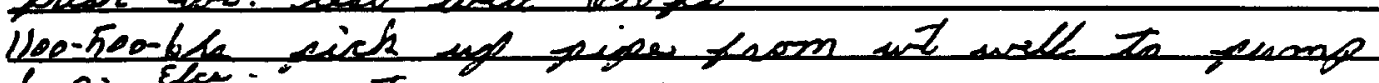

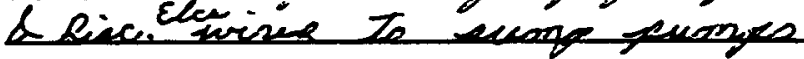

\begin{tabular}{|c|c|c|c|c|c|}
\hline \multicolumn{2}{|l|}{ AIG EXPENSE } & \multicolumn{2}{|c|}{ ACCDENTS } & \multicolumn{2}{|c|}{ SUPPLY REQUEST } \\
\hline & & YES & NO & & \\
\hline \multicolumn{2}{|l|}{ SUPPLIES } & & 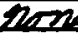 & & \\
\hline \multicolumn{6}{|l|}{ FUEL_ } \\
\hline \multicolumn{6}{|l|}{ TRUCKING } \\
\hline \multicolumn{2}{|c|}{ IN PARTY CHARGES } & & \multirow{2}{*}{ wnr } & TMEE DISTAUBUTION \\
\hline PIPEWIPEA & SLIP WSERT & & & & \\
\hline DIESEL & T.I.W. & & ARICK M & & \\
\hline STAIPPEA & PIPE PACK & & PER $\%$ & & \\
\hline POWEA SUB. & SHAKEA & & PEA 6 & & \\
\hline TRUCKING & 20 puMp & & PER & & eะ \\
\hline GENERATOA & CENTRIFUGAL & & & & (e: \\
\hline EXTRA LABOR & GUARD & & & & \\
\hline SUPPLIES & PIPE DOPE & & & & $\varepsilon$ \\
\hline RAMS & misc. & & & & Pะ \\
\hline LONG DIES & & & & & \\
\hline
\end{tabular}

TOOLPUSHER bogualas Zouched JOB NO $25-5$ ORDER NO.
COMPANY REPRESENTATIVE CONTRACT NO $\operatorname{sog} 25-5$

TERMS: NET 30 DAYS. Accounts over 30 days will be charged $11 / 2 \%$ per month not to exceed $18 \%$ ann:lly.

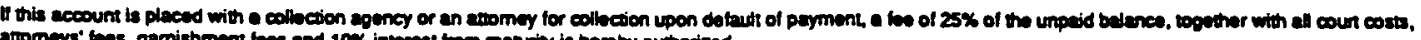
atomeys' tees, gemishment lees and $10 \%$ interest trom maurity is hereby authorized. 
Ditting

wanture

Compioten

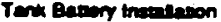

Purroun Semoses

Sin Weir Wolle

Puiv saneron

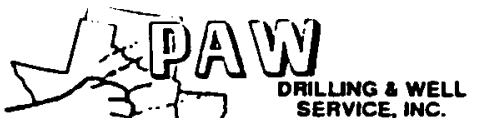

ORILLUNG \& WELL
SERVICE, INC.

101 GALBERT RD.

(318) 261.0295
TICKET T65

REPORT NO.

company $D O E$

\section{DAILY WORKOVER REPORT}

FIELREat Crab Yake Lease Stlodone Mcall

DATELL-18-23

PARISH OA COUNTY Cameion state $\mathcal{L}$ a WELL NO. $5 L D \# 1$

Present Perforations.

Present Packer Setting

Total Depth

Present Depth

Typo Plug

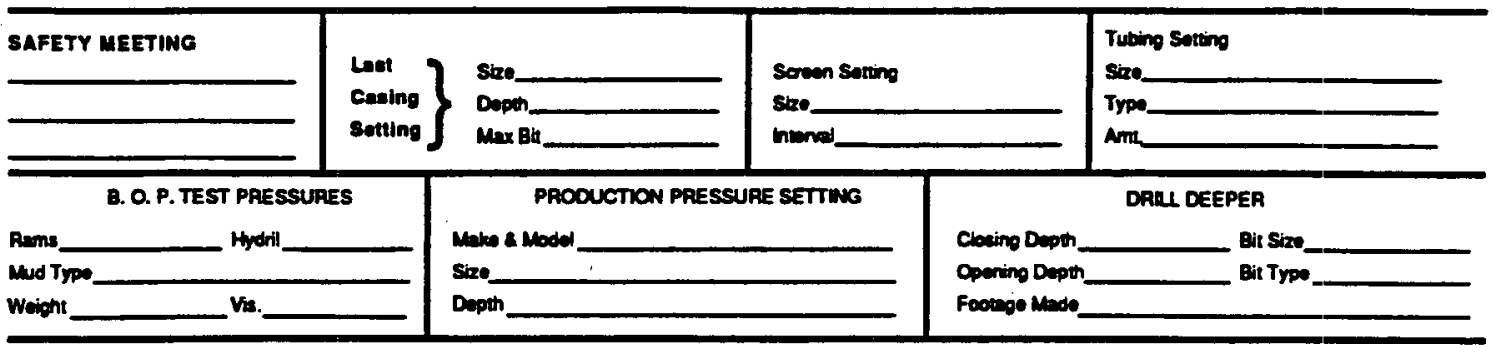

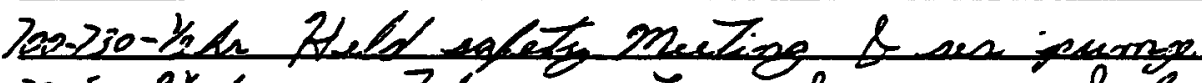

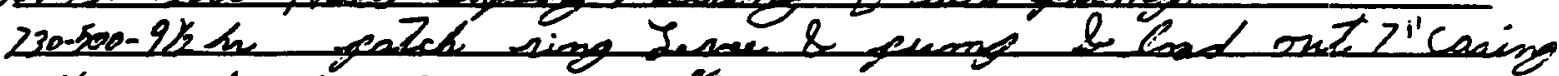

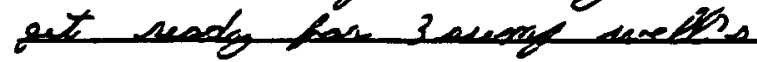

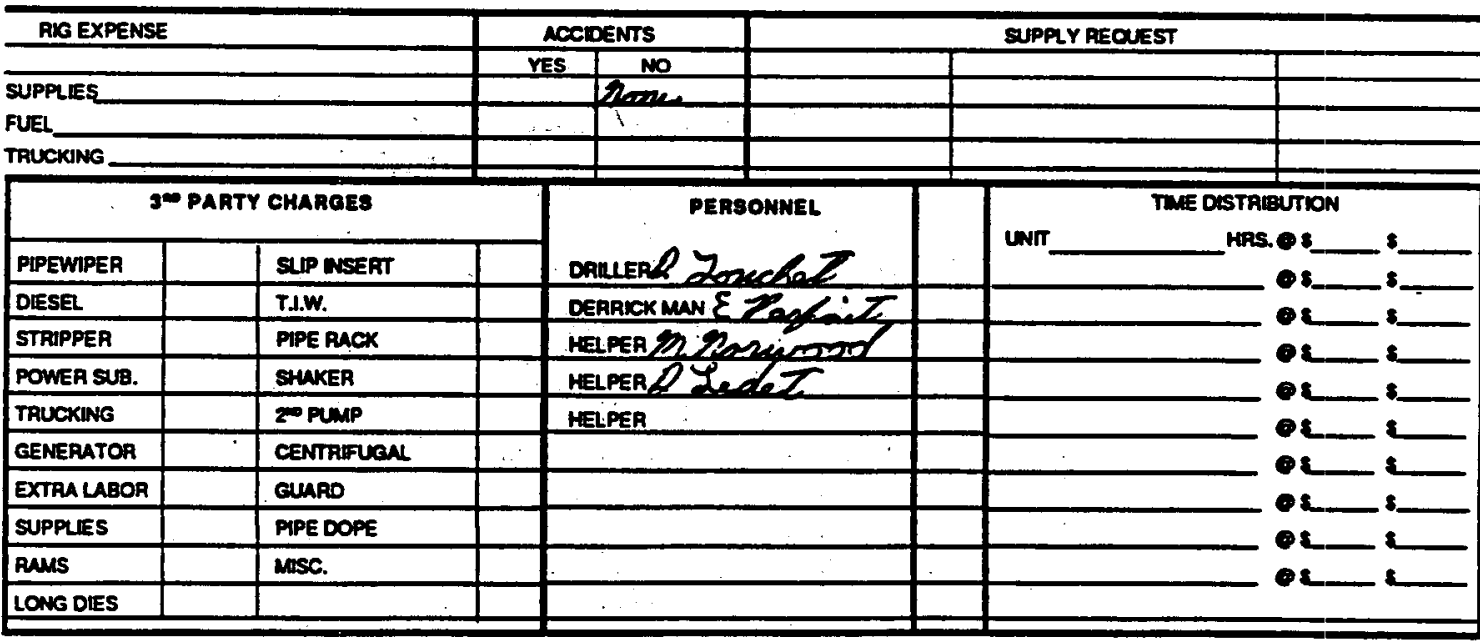

TOOLPUSHERLoziglas Jonchet JOB NO $25-5$ ORDER NO.
COMPANY REPRESENTATIVE CONTRACT NO.
$10825=5$

TERMS: NET 30 DAYS. Accounts over 30 days will be charged $11 / 2 \%$ per month not to exceed $18 \%$ anmilly.

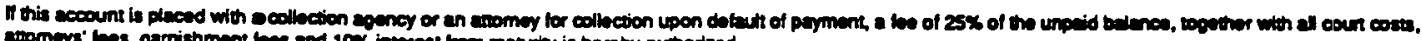

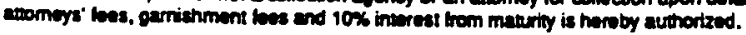


Driling

Nonower

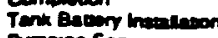

purroun Servece

Salt Woin Wols

Plus of Abencon $\triangle B[\mathrm{~A}$

S

of LAFAYTE. LA T0506

DAILY WORKOVER REPORT
TICKET $766 \mathrm{i}$

REPORT NO.
cOMPANYQDE -

FIELREant crak Lake

PARISH OR COUNTY Camenan

Present Perforations

Total Depth

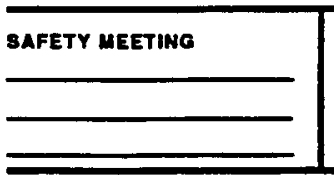

B. O. P. TEST PAESSURES

Rems

Med Type

Hydril

Weight Vis.

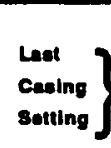

sotting

\section{LEASE Hadas micall} state La
DATE $11-19-93$ WELL NOSWO RIG NO 5

Presont Packer Setting

Present Depth

Type Plue

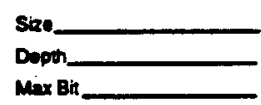

$\max B \min$

Soreen Sorting
stee.

PRODUCTION PRESSURE SETTING Make \& Model

Size Depth
Clacing Depth

Opening Depth Fooluse Medo

\section{Tubing Sorting}

Sace

Trpe Arm.

ORLL DEEPER

Bin $\sin$

Bin Typo

\begin{tabular}{l} 
AIG EXPENSE \\
\hline
\end{tabular}

TOOLPUSHER Rogighas Donechet

JOB NO $26-5$
ORDER NO.
COMPANY REPRESENTATIVE

CONTRACT NO
JOB $26-5$

TERMS: NET 30 DAYS. Accounts over 30 days will be charged $11 / 2 \%$ per month not to exceed $18 \%$ anmlly.

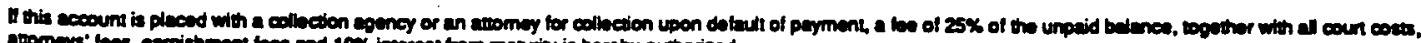

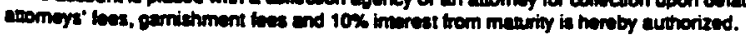




\section{EXHIBIT 6-N}

\section{Current Condition of Gladys McCall Site}




\section{CURRENT CONDITION OF WELL}

1. GLADYS MCCALL PRODUCTION WELL
(A) Surface Pressure e: 5,335 psi $\pm 9 \| / \mathrm{gal}$ brine
(B) Bottom Hole Pressure e: $\pm 12,300$ psi
(C) Bottom Hole Temperature $\mathrm{E}: \pm 300^{\mathrm{c}} \mathrm{F}$
(D) Special Problems:

(1) $7^{\prime \prime} \times 9-5 / 8^{\prime \prime}$ casing uncemented from 6,000' to surface.

(2) $7^{\prime \prime}$ casing run in two sections. Tieback at $12,616^{\prime}$ may be damaged.

(3) There is a methane gas cap $\pm 500^{\prime}$ on top of the brine that contains $\pm 10 \% \mathrm{CO}_{2}^{-}$and a trace of $\mathrm{H}_{2} \mathrm{~S}$.

(4) It is possible that some of the gas has hydrated and left an ice plug in the tubing. 


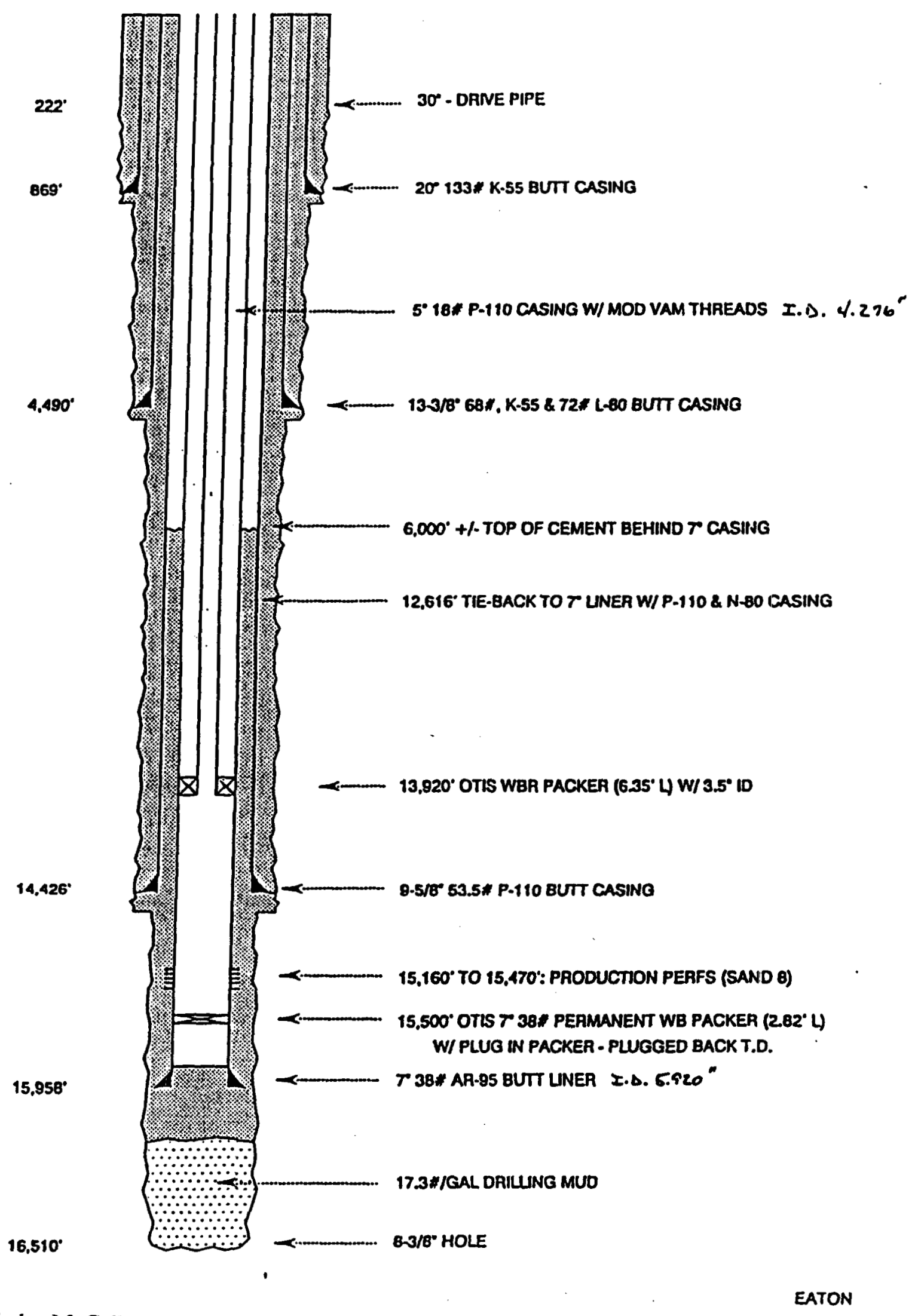

Figure 6-1. Gladys McCall well schematic as recompleted by T-F\&S, August 15, 1983. 


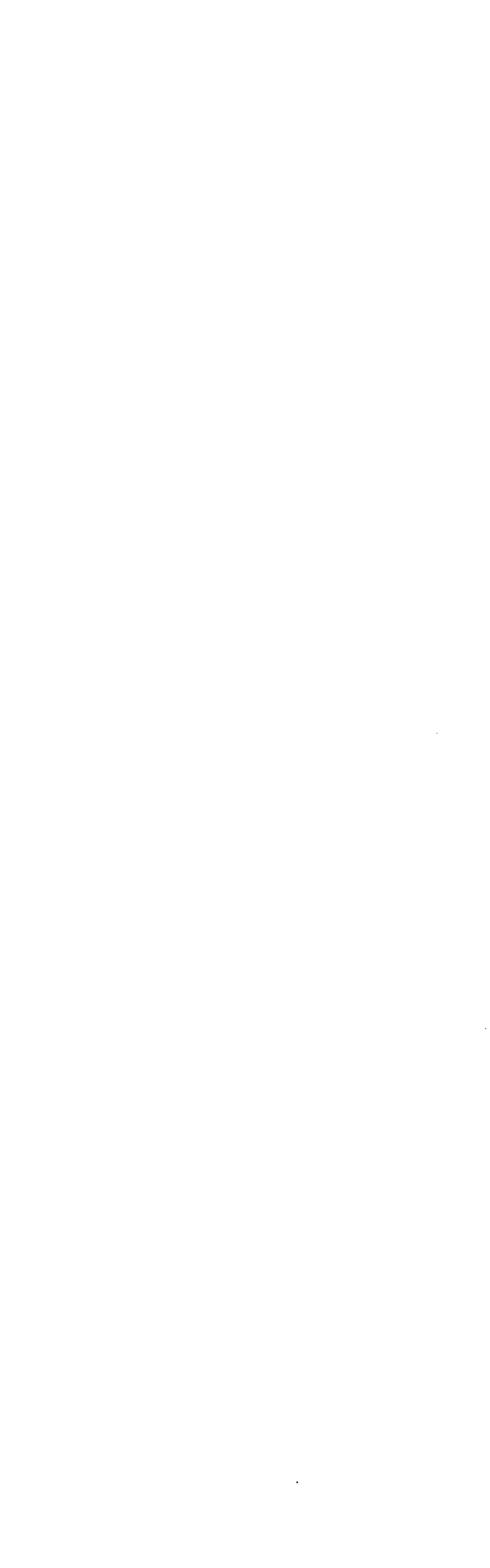


PACKER INFORMATION

GLADYS MCCALL NO. 1

Type: Otis WBR Packer - 13,920.00 to 13,926.25'

Ratch Latch - $13,917.18^{\prime}$ to $13,920.00^{\prime}$

Seal Bore Extension (PBR) 24.83'

Top 13,892.35'; Bott om 13,917.18'

Otis Packer Seal Assembly (w/3.480" I.D.)

Locator Sub $2.00^{\prime} 13,880.35^{\prime}$

Seal Extension 9.75' 13,890.10'

Seal Mandrel 2.14' 13,892.24'

Seal Extension 7.85' 13,900.09'

Seal Mandrel 2.10' 13,902.19',

Mule Shoe $0.84^{\prime} 13,903.03^{\prime}$ 


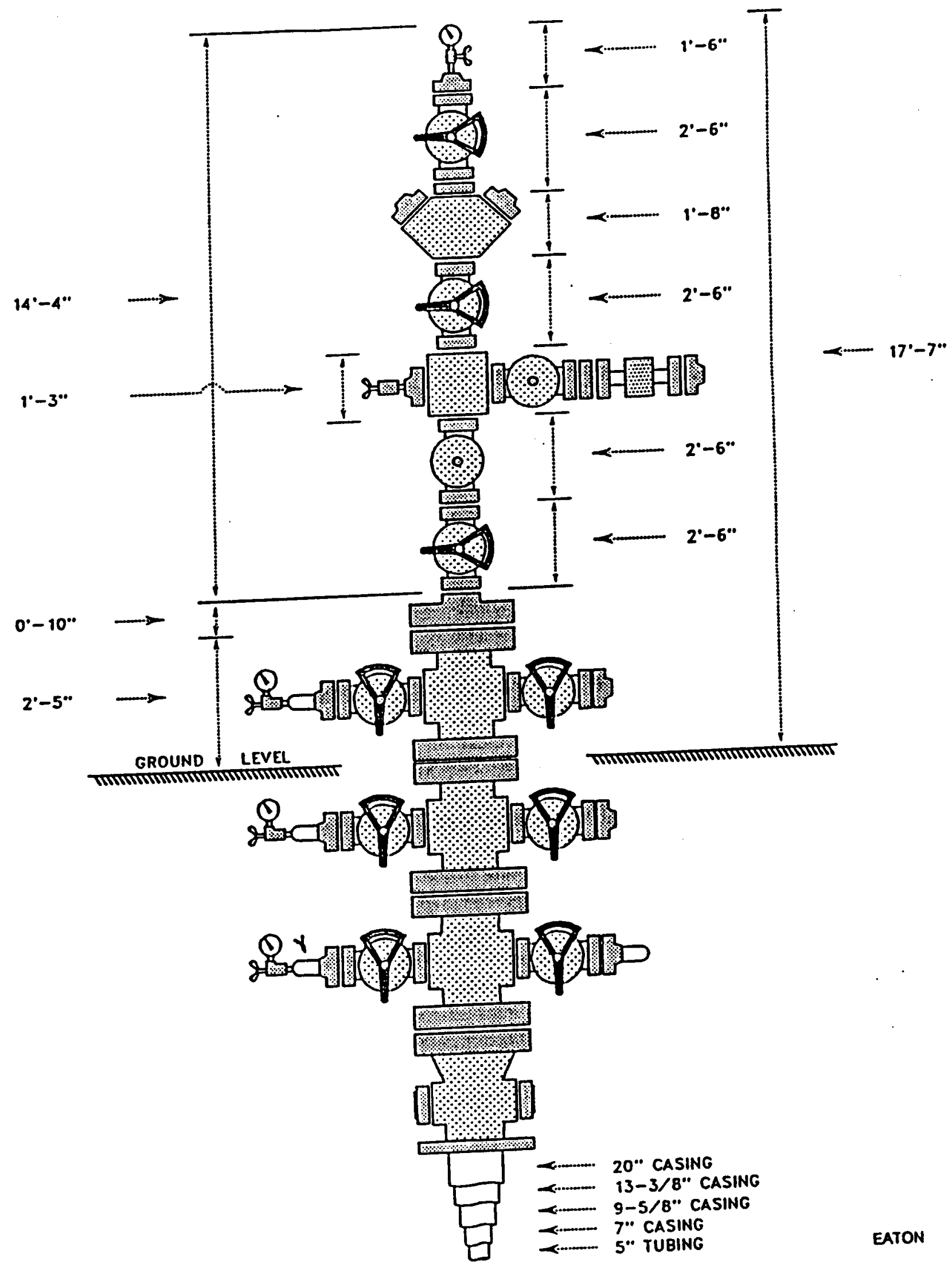

Figure 6-2a. Gladys McCall No. 1 production wellhead description schematic as of June 1990. 


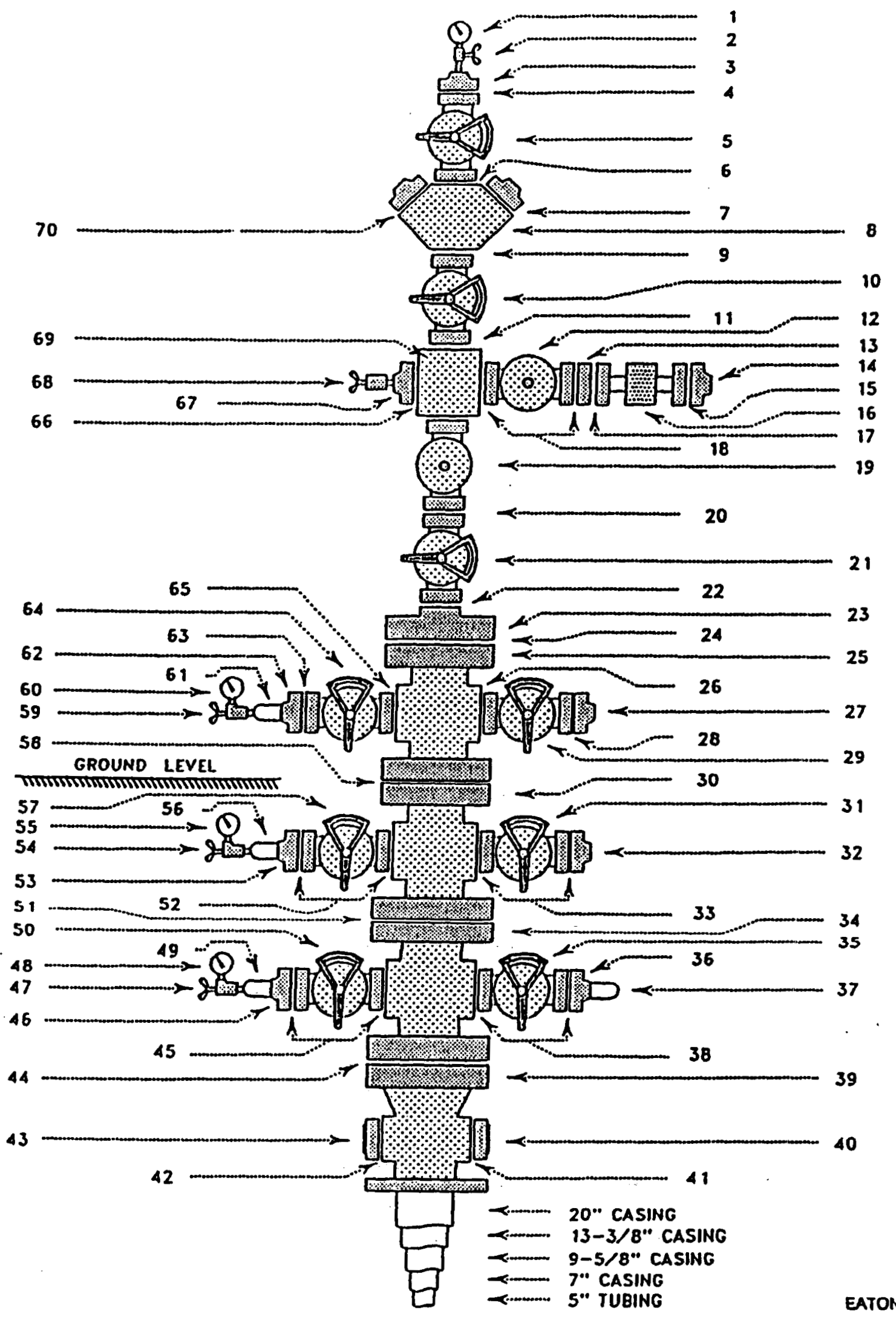

Figure 6-2b. Gladys McCall No. 1 production wellhead description schematic as of June 1990. 


\section{GLADYS MCCALL NO. 1 PRODUCTION WELLHEAD}

1. $1-1 / 2^{\prime \prime} 10,000 \#$ W.P. 316 S.S. Marsh pressure gauge

2. $1 / 2^{\prime \prime}$ LP 10,000 W.P. S.S. NACE straight gauge cock

3. $5-1 / 8^{n} 10,000 \#$ W.P. $6 \mathrm{BX}$ w/1/2" LP tap, type III LA, blind flange

4. BX-169, API 316 S.S. ring gasket

5. 5-1/8" 10,000 \# W.P. 6 BX FE $\times$ FE, E trim for $450^{\circ} \mathrm{F}$ Gray gate valve w/bevel gear operator

6. BX-169, API 316 S.S. ring gasket

7. BX-155, API S.S. ring gasket

8. $5-1 / 8^{\prime \prime} 10,000$ \#.P. $6 \mathrm{BX} \times 4-1 / 16^{\prime \prime} 10,000$ \# W.P. $6 \mathrm{BX}$ on 45 degree, type II LA NACE dual studded $Y$ block

9. BX-169, API 316 S.S. ring gasket

10. $5-1 / 8^{\prime \prime} 10,000$ \# W.P.; 6 BX FE x FE, E trim for $450^{\circ} \mathrm{F}$ Gray gate valve w/bevel gear operator

11. BX-169, API 316 S.S. ring gasket

12. 4-1/16" 10,000\# W.P., C, $\times 4-1 / 16^{\prime \prime} 10,000$ \#.P. 6 BX FE $\times$ FE, E-trim w/Graysafe operator HA-7 for $450^{\circ} \mathrm{F}$ and below

13. 4-1/16" 10,000\# W.P. $6 \mathrm{BX} \times 4-1 / 16^{\prime \prime} 10,000$ \# W.P. $6 \mathrm{BX}$ spacer flange

14. $2-1 / 16^{\prime \prime} 10,000$ \# W.P. $6 \mathrm{BX}$ w/2" tap flange

15. BX-152, API 316 S.S. ring gasket

16. 4-1/16"10,000\# W.P. x 2-1/16"10,000\# W.P. Gray hydraulic accumulator

17. BX-155, API 316 S.S. ring gasket

18. BX-155, API 316 S.S. ring gaskets

19. 5-1/8" 10,000\# W.P. "C" $\times$ 5-1/8" 10,000\# W.P. 6 BX FE $\times$ FE, E-trim for $450^{\circ} \mathrm{F}$ $w /$ Graysafe HA-10 operator w/manual override 


\section{GLADYS MCCALL NO. 1 PRODUCTION WELLHEAD}

20. BX-169, API 316 S.S. ring gasket

21. 5-1/8" 10,000\# W.P. $6 \mathrm{BX} \times \mathrm{FE}$, E-trim for $450^{\circ} \mathrm{F}$, Gray gate valve w/bevel gear operator

22. BX-169, API 316 S.S. ring gasket

23. 5-1/8" 10,000 \# W.P. $6 \mathrm{BX} \times 9^{\prime \prime} 10,000$ \# W.P. $6 \mathrm{BX}$, type III 410 S.S. NACE, tubing bonnet, $K$

24. BX-157, API 316 S.S. ring gasket

25. 9" 10,000\# W.P. MSP x 11" 10,000\# W.P. MSP x 2-1/16" 10,000\# W.P. 6 BX outlets, LA NACE CWCT-D15 tubing head

26. BX-152, API 316 S.S. ring gasket

27. 2-1/16"10,000\# W.P., 6 BX, Type II LA NACE blind flange

28. BX-152, API 316 S.S. ring gasket

29. 2-1/16"10,000\# W.P; "C", x 2-1/16" 10,000\# W.P. 6 BX FE x FE, E-trim pkg for $350^{\circ} \mathrm{F}$ service, Gray gate valve

30. 13-5/8" 5,000\# W.P. $6 \mathrm{BX} \times 11^{\prime \prime} 10,000$ \# W.P. $6 \mathrm{BX}, \mathrm{CWCT}, 9-5 / 8^{\prime \prime}$ casing spool

31. 1-13/16" 10,000\# W.P. "C" x 1-13/16" 10,000\# W.P. 6 BX FE X FE w/D-trim Gray gate valve

32. 1-13/16"10,000\# W.P. $6 \mathrm{BX}$, blind flange

33. BX-151, API CAD PLT ring gaskets

34. 20" 2,000\# W.P. $\times 13-5 / 8^{n}$ 5,000\# W.P. 6 BX, CWCT, 13-3/8" casing spool

35. 2-1/16" 5,000\# W.P. "D" x 2-1/16" 5,000\# W.P. FE x FE w/A-trim Gray gate valve

36. 2-1/16" 5,000\# W.P. tapped $w / 2^{\prime \prime} N P T$, flange

37. $2 " w / 1 / 2^{\prime \prime}$ LP tap bull plug 


\section{GLADYS MCCALL NO. 1 PRODUCTION WELLHEAD}

38. R-24, APL, CAD PLT, ring gaskets

39. $20^{n}$ SOW 2,000 \# W.P. CWCT Gray casing head w/two $2^{n} 5,000$ \# W.P. std outlets and $32^{\prime \prime}$ base plate

40. $2-1 / 16^{\prime \prime} 5,000$ \# W.P. blind flange

41. R-24, API ring gasket.

42. R-24, API ring gasket

43. $2-1 / 16^{\prime \prime} 5,000 \#$ W.P. blind flange

44. R-73, API, CAD PLT, ring gasket

45. R-24, API, CAD PLT, ring gaskets

46. $2-1 / 16^{\prime \prime}, 5000$ \# W.P. tapped $w / 2^{n}$ NPT, flange

47. $1 / 2^{\prime \prime}$ LP 5,000\# W.P.S.S. NACE straight gauge cock

48. $1 / 2^{n} \times 4-1 / 2^{n} 5,000$ \#.P. 316 S.S. Marsh pressure gauge

49. $2^{\prime \prime} w / 1 / 2^{\prime \prime} L P$ tap bull plug

50. 2-1/16" 5,000\# W.P. "D" $\times 2$ 2-1/16" 5,000\# W.P. FE $\times$ FE w/A-trim Gray gate valve

51. BX-160, API CAD PLT, ring gasket

52. BX-151, API, CAD PLT, ring gaskets

53. 1-13/16" 10,000\# W.P. 6 BX, Thd w/2" L.P. for 5,000\# W.P., Type II LA NACE flange

54. 1/2" L.P. 5,000\# W.P. S.S. NACE straight gauge cock

55. $1 / 2^{\prime \prime} \times 4-1 / 2^{\prime \prime} 10,000 \#$ W.P. 316 S.S. Marsh pressure gauge

56. 2" CS NACE, 4" LGW w/1/2" LP tap bull plug

57. 1-13/16" 10,000\# W.P. "C' $\times$ 1-13/16" 10,000\# W.P. 6 BX FE x FE w/D-trim Gray gate valve

58. BX-158, API 316 S.S. ring gasket

59. $1 / 2^{n}$ LP 10,000 \# W.P. S.S. NACE straight gauge cock 


\section{GLADYS MCCALL NO. 1 PRODUCTION WELLHEAD}

60. $1 / 2^{n} \times 4-1 / 2^{n} 10,000 \#$ W.P., 100-3-SS-MS, 315 S.S. Marsh pressure gauge

61. 2" CS NACE $\times 4^{\prime \prime} L G w / 1 / 2^{\prime \prime} L P$ tap bull plug

62. $2-1 / 16^{\prime \prime} 10,000 \#$ W.P. 6 BX, type II, LA NACE w/2n tap, Dange

63. BX-152, API 316 S.S. ring gasket

64. 2-1/16" 10,000\# W.P. "C", x 2-1/16" 10,000\# W.P. 6 BX FE x FE E-trim pkg for $350^{\circ} \mathrm{F}$ service, Gray gate valve

65. BX-152, API 316 S.S. ring gasket

66. BX-155, API 316 S.S. ring gasket

67. $4-1 / 16^{\prime \prime} 10,000 \#$ W.P. $6 \mathrm{BX}, 4135 \mathrm{w} / 1 / 2^{\prime \prime}$ tap, flange

68. $1 / 2^{m} 10,000$ \# W.P. Weld-O-Let needle valve

69. 5-1/8" 10,000\# W.P. 6 BX x 4-1/16" 10,000\# W.P. 6 BX x 4-1/16" 10,000\# W.P. 6 BX, type II LA NACE, w/A206 bolting studded cross

70. BX-155, API 316 S.S. ring gasket 


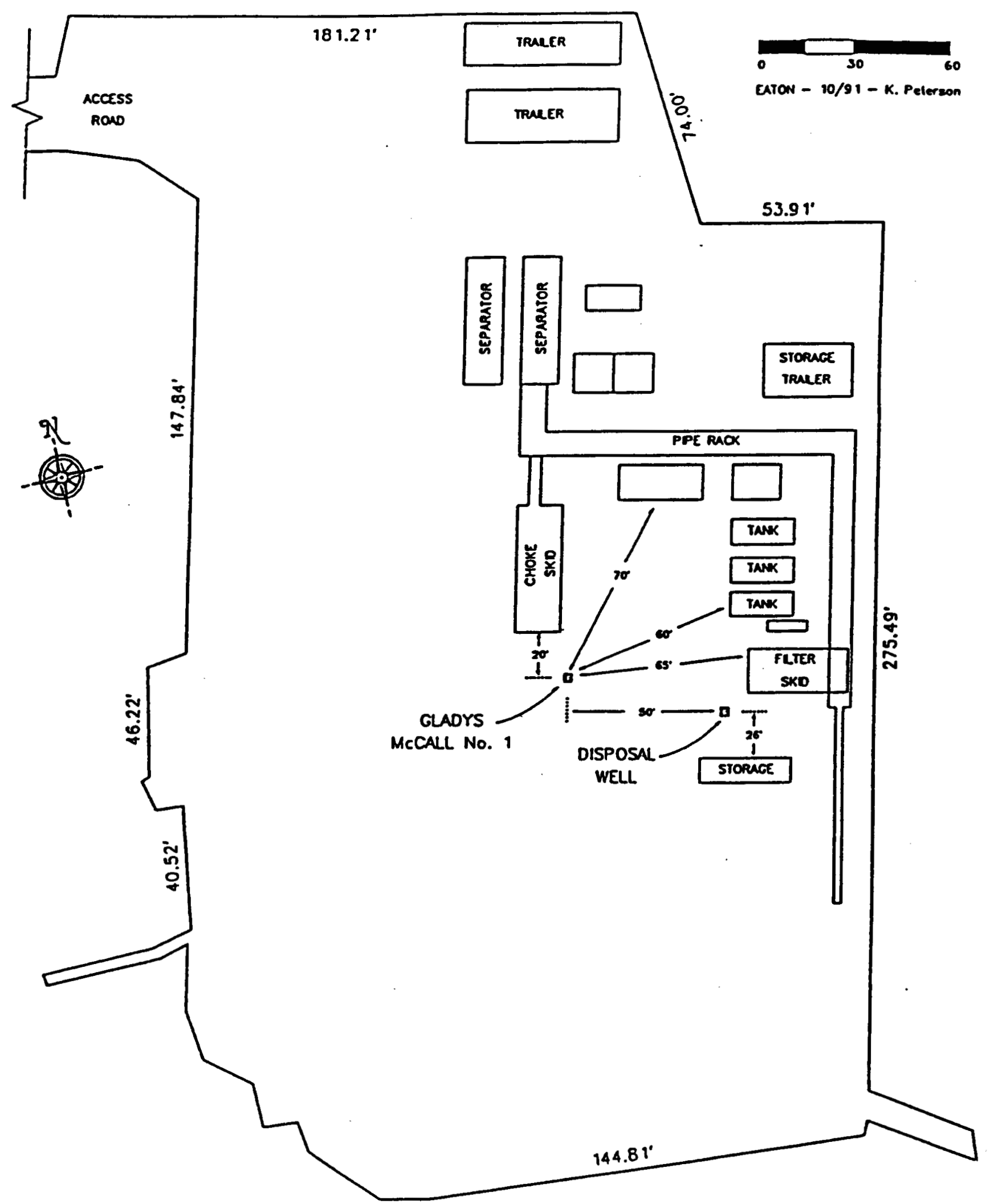

NOTE: All dimensions provided for the outer perimeter of this localion are actual measuremenis. However. the measurements from the Glodys McCall No. 1 to the existing production equipment are approximote of best and should be recognized as such. All bidders will be given the opporlunily to visil the localion. 


\section{GLADYS MCCALL}

Surface production equipment - major components only:

1. Separator - horizontal brine/methane

Manufacturer - Enfab, Inc., Houst on, TX

ASME coded vesse 1

National Board No. - 18

Year built - 1981

Size - 54" I.D. $\times 30^{\prime} .0^{\prime \prime}$ long

MAWP - 1440 psig $2105^{\circ} \mathrm{F}$

Serial No. - 2048

Complete with relief valves, controls, etc.

2. Gas cooler - horizontal (fin/fan)

Manufacturer - Seton-Scherr, Inc., Houst on, TX

ASME coded vesse l

National Board No. - 626

Year built - 1982

MAWP - 1290 psig $350^{\circ} \mathrm{F}$

Serial No. - H81280

3. Brine filter skid - five (5) 12-3/4" 0.D. pots

Manufacturer - Chemco Engineering Co.

ASME coded vessel

National Board No. - N/A

Year built - 1982

MAWP - 869 psig $350^{\circ} \mathrm{F}$

Serial No. - 24211691

4. Gas compressor - IGL Ariel single stag w/150

H.P. electric motor

Manufacturer - Compressor Sytems, Inc.

Unit No. - 3095C

Serial No. - H9386-4-6534

5. Generator $w /$ diesel engine

Manufacturer - International Electric

Mode 1 - E7188

Serial No. - HB-0963-09

6. Flare stack

Manufacturer - John Zink

Year built - 1981

Serial No. - S12422

7. Three (3) 200 bbl steel skid mounted tanks Approx. year built - 1981 

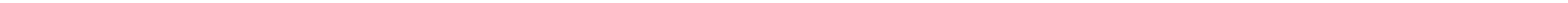


\section{EXHIBIT 6-O}

PAW Drilling \& Well Service, Inc.

Daily Workover Reports for Willis Hulin Site

From 2-7-94 Through 3-17-94 


$$
\sqrt{2}
$$




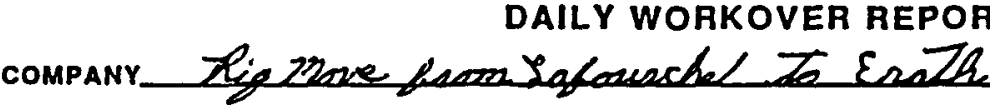

FIELD

PARISH OR COUNTY STATE WELL NO.

\section{BAFETY MEETINO mateh ell callea metren $x^{\circ}$ piga

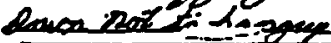

B. O. P. TEST PAESSUARS

Rom - Moth

Mod Th vis.

Woight -

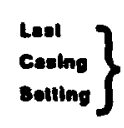

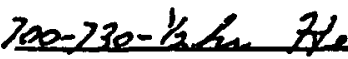

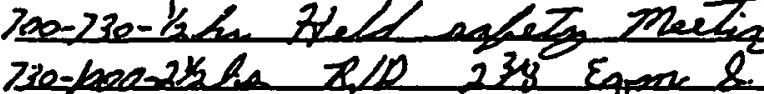

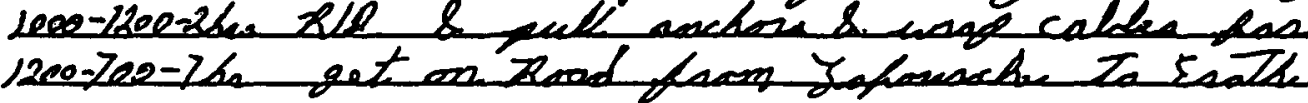

Type Plug

DARL DEEPER

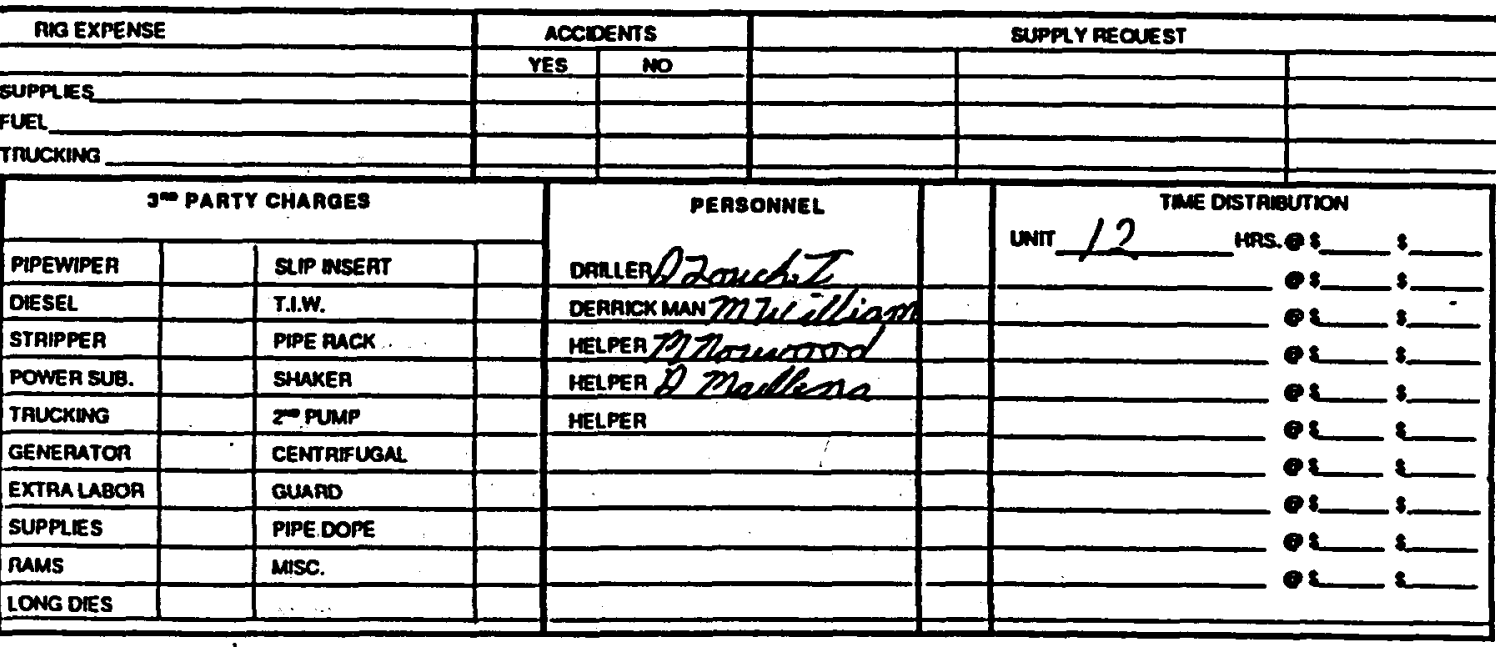

TOOLPUSHER R'oughan Zozuchez JOB NO 32.3 ORDER NO.
COMPANY REPRESENTATIVE

CONTRACT NO JOB

TERMS: NET 30 DAYS. Accounis over 30 days will be charged $11 / 2 \%$ per month nol 10 exceed $18 \%$ annilly.

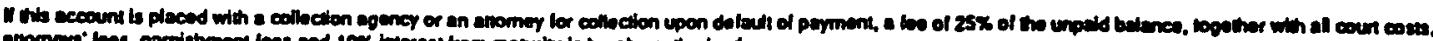

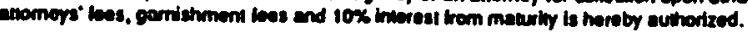



WELL NO. 1

Prosen! Peiloralions

Tolal Deplh

SAEETY MEETINO abmogeroben cuen mentianclowd Bhacizigainatere ๑. O. P. TEST PrESSUARS

Nud Trpe Hrint

Wolph Vis. state La

Present Deplh

Present Pecker Sotting PIG NO 5

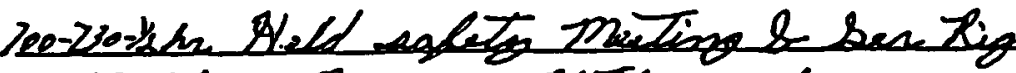

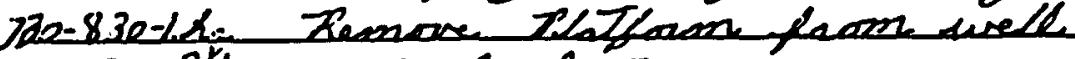
Bie-13eo-3kn spati tige \& Eqaon 1200.

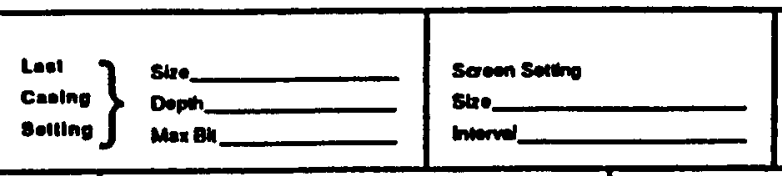
PRCOUCTION PRESSURE SETTWK Make \& Model

Sive Depen

Footion unde
Type Puna

Tutho seting

tho.

Trpe.

Ant.

Clocing Deph________ Bu Sine.

Oprimg Deph____ En Trpe

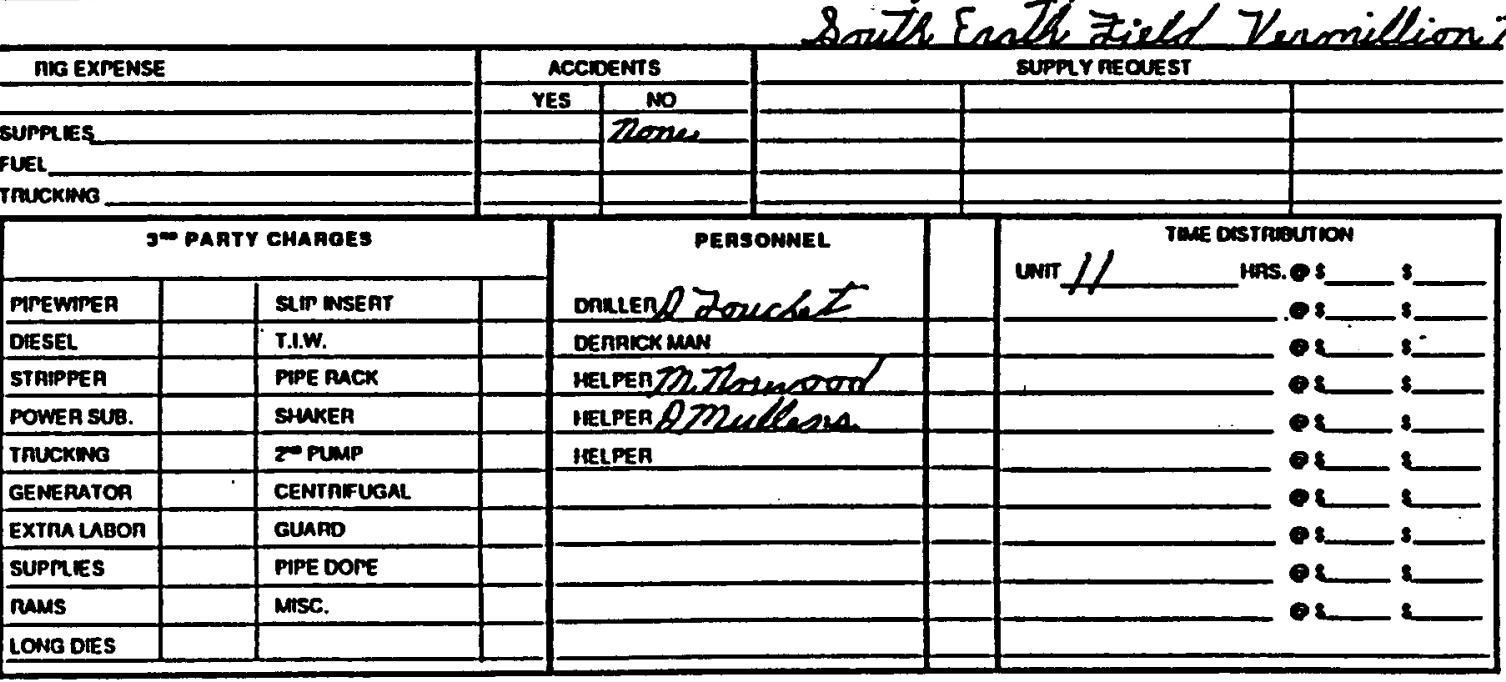

TOOLPUSHER Dosyglae Zosucht JOB NO $32-5$ ORDER NO.
COMPANY REPRESENTATIVE

CONTRACT NO_ JOB $32-5$

TERMS: NET 30 DAYS. Accounis over 30 days will be charged $11 / 2 \%$ per month nol 10 exceed $18 \%$ anmily.

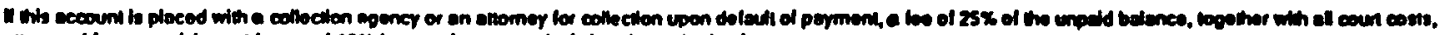

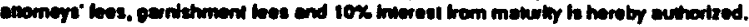


Draling

Workover.

Tenk Batary inverlation

fumping Semices

Sals Woier Wolls

Plug 2 Abandon
SxAB

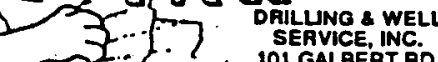

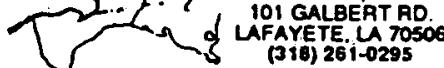

DAILY WORKOVER REPORT
TICKET 7777

REPORT NO. 2

COMPANY LIS. DOF

FIELR \&owith Eante

Leasezlllia Zulim. DATE_2-9-94

PARISH OR COUNTY Yenomillisare state ja WELL NO. 1 RIG NO 5

Present Pertoralions.

Present Packer Solting

Total Depth

Present Depth

Type Plug

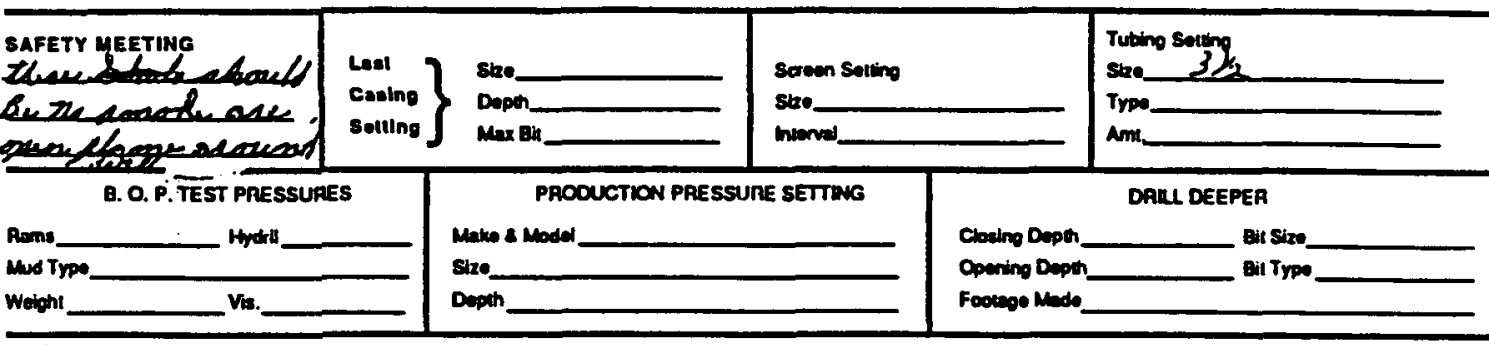

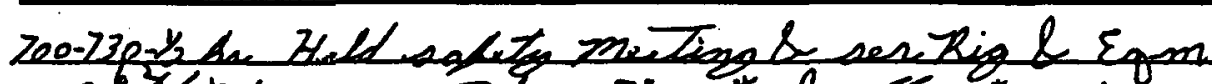

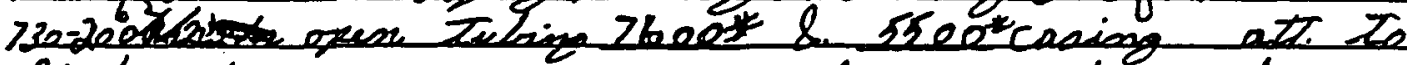
bled tectiong flowing casizg flow thessicale

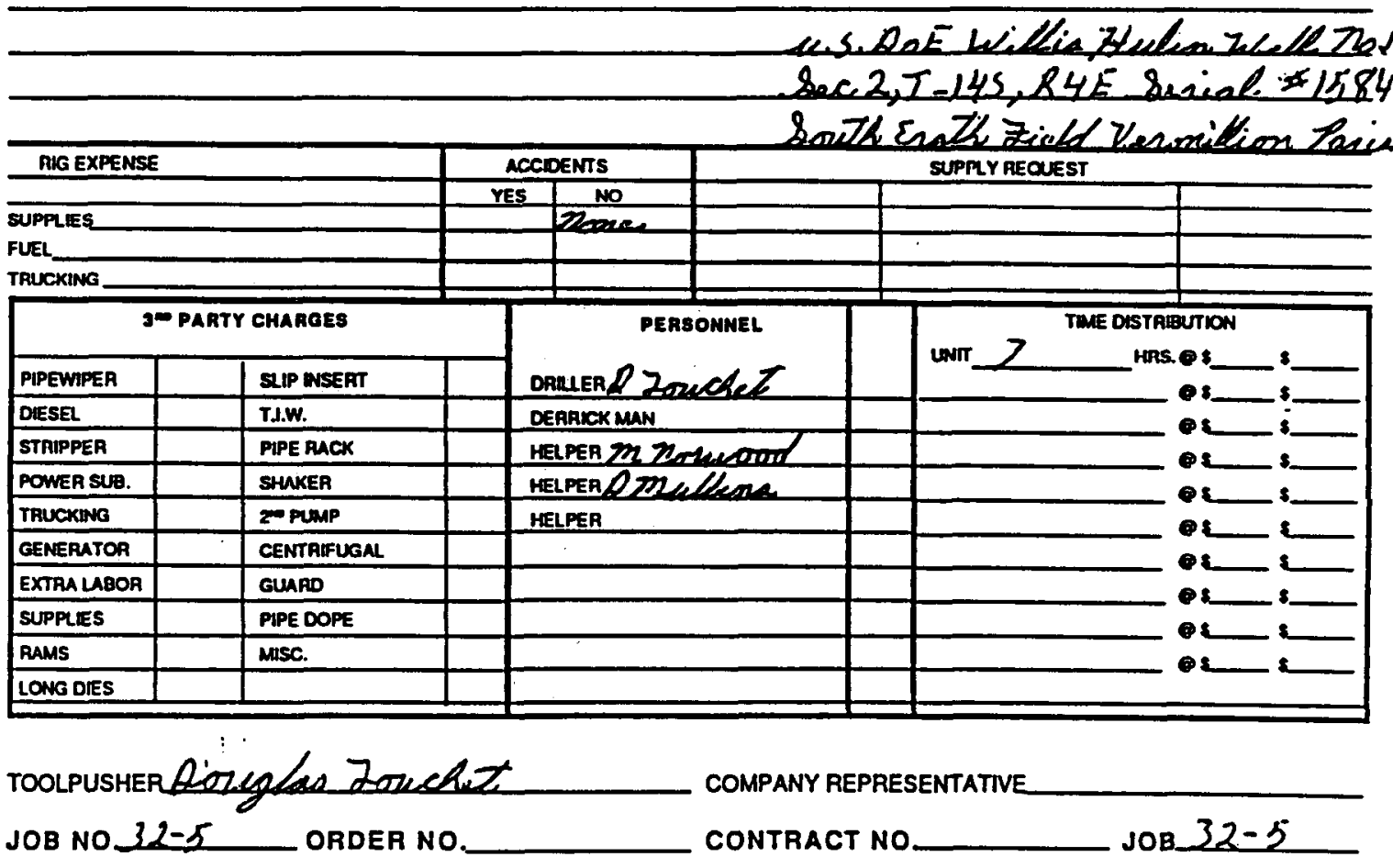

TERMS: NET 30 DAYS. Accounts over 30 days will be charged $11 / 2 \%$ per month nol 10 exceed $18 \%$ annilly.

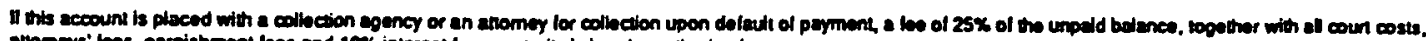
atomeys' loes, garnithment less and $10 x$ interest trom maturity la heroby authonzed. 

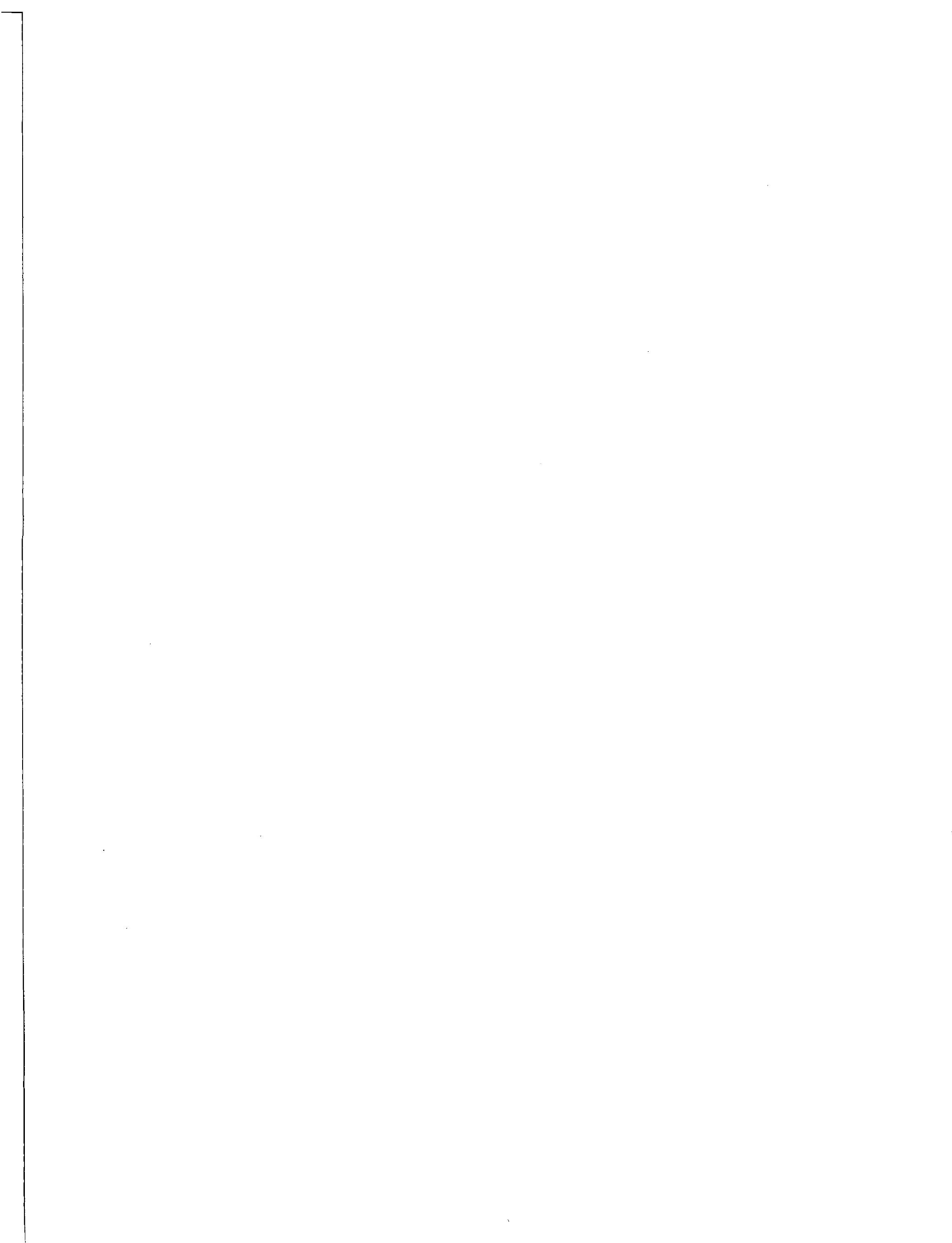
Driling

Workover.

Tank Banery inutulation

Purraing Semices

Salk Waier Wolls

Plug 4 Abandon
1

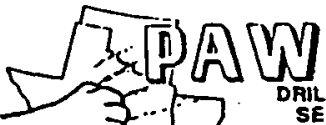

I 7 ... DERLANG WELL 7.2. 101 GALEERTRO W of LAFAETE. W70506

DAILY WORKOVER REPORT

TICKET $777 \%$

REPORT NO. 3

DATE $2-10-94$

WELL NO. I

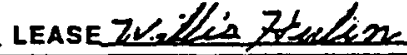
state 20 RIG NO \{

Present Pertorations

Present Packer Sotting

Total Depth

Present Depth

Typo Plug

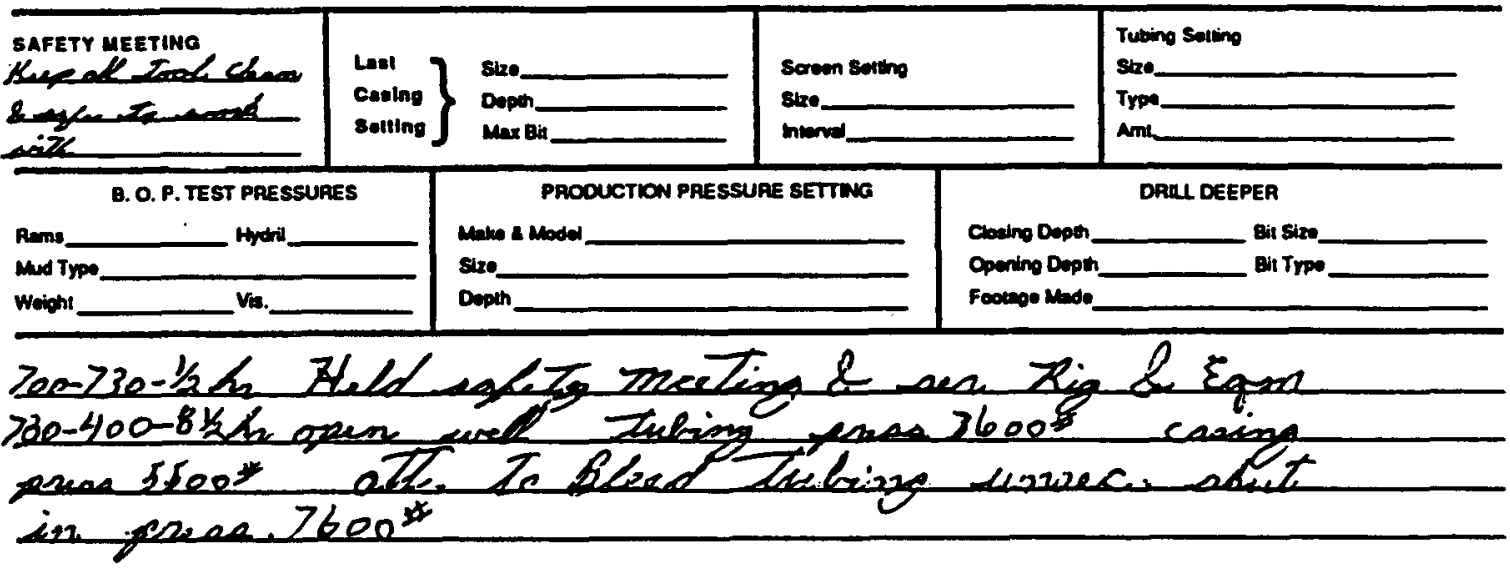

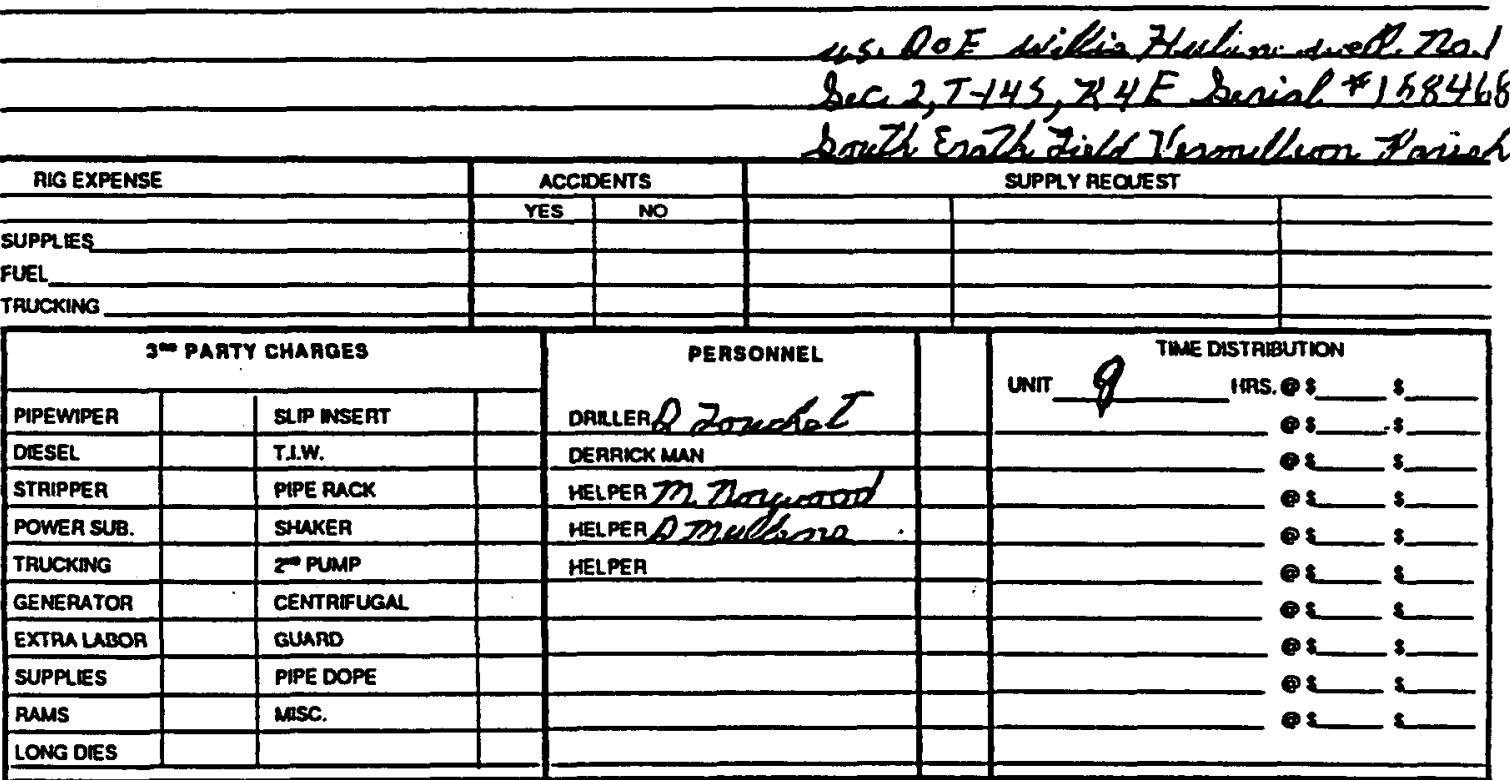

TOOLPUSHER Dongefar Zazehed JOB NO $32-5$ ORDER NO
COMPANY REPRESENTATIVE

CONTRACT NO
$108,32-5$

TERMS: NET 30 DAYS. Accounls over 30 days will be charged $11 / 2 \%$ per month not to exceed $18 \%$ ann!lly.

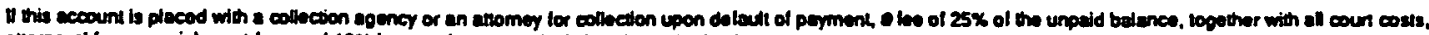

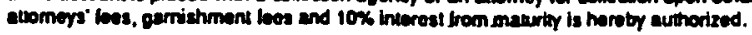




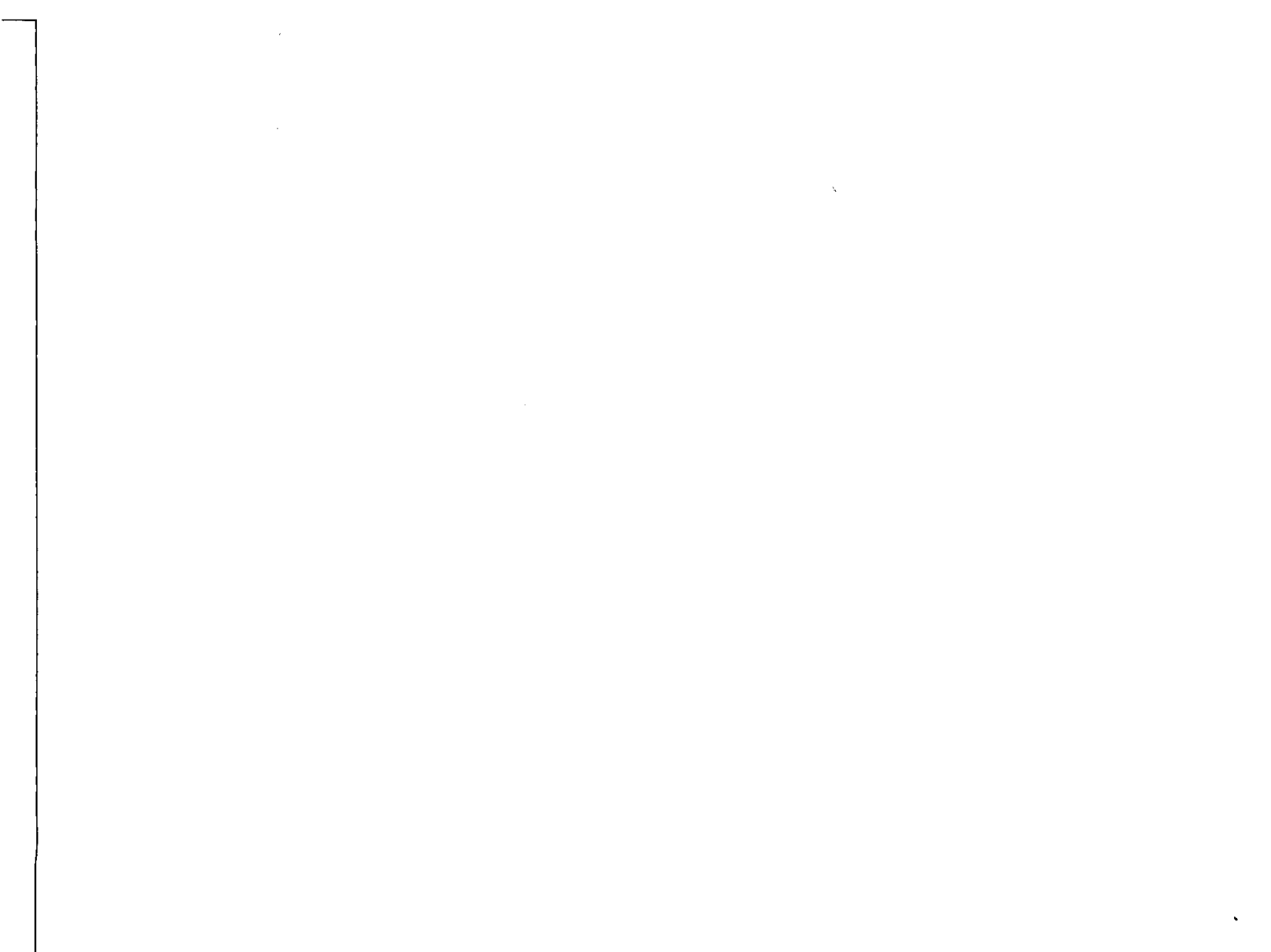


DAILY WORKOVER REPORT

companY WL DOE

Fielo Sonith santh

LEASEZLLillia Fulin

DATE $2-11-24$

PARISH OR COUNTY fleanillioms state $L a$ WELL NO._

Present Pertorations

Present Packer Satting

Total Depth Present Depih Type Plug

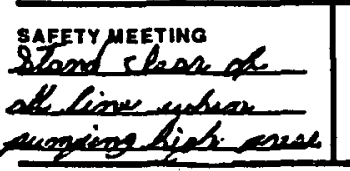
D P TEST PREsSURES

Aloms

Mud Type Hydril

Woight. Vis.

$\left.\begin{array}{l}\text { Laet } \\ \text { Cacing } \\ \text { selting }\end{array}\right\}$

$\int$

Tubing Soting

\section{PROOUCTION PRESSURE SETTWK}

Make os Model

Sbe

Depth
Bit Size.

Opening Deph ___ Bit Trpe

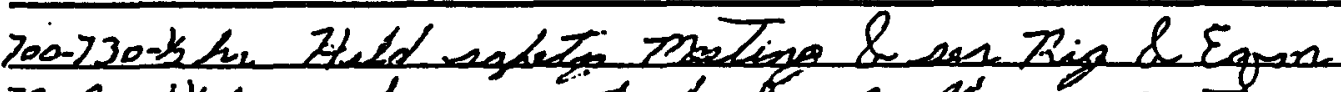

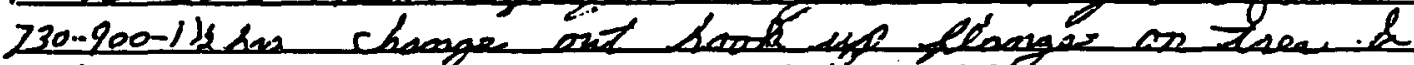
take on 172 seg mied Lanen EQY $2018 B 2$

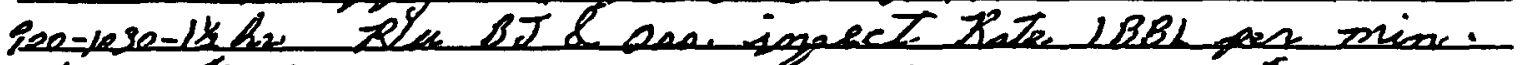

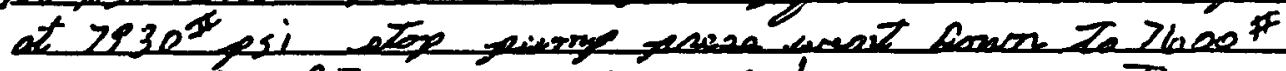

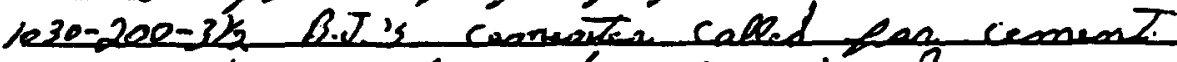

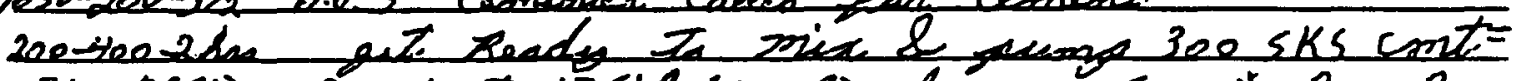

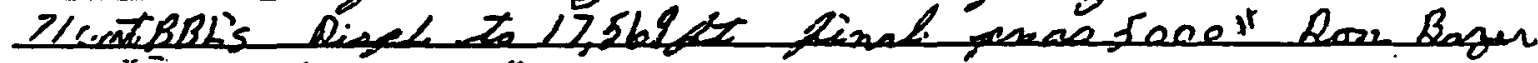
sugeceter chat iasm wark teo-seadh $X 18$ OLL top cont chent at 13,569 -....

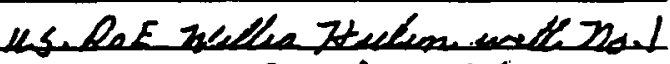
$\sec 2, T-145,548$ senal $\$ 158468$

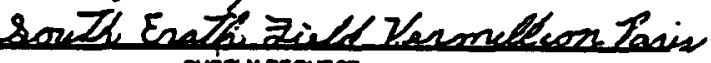

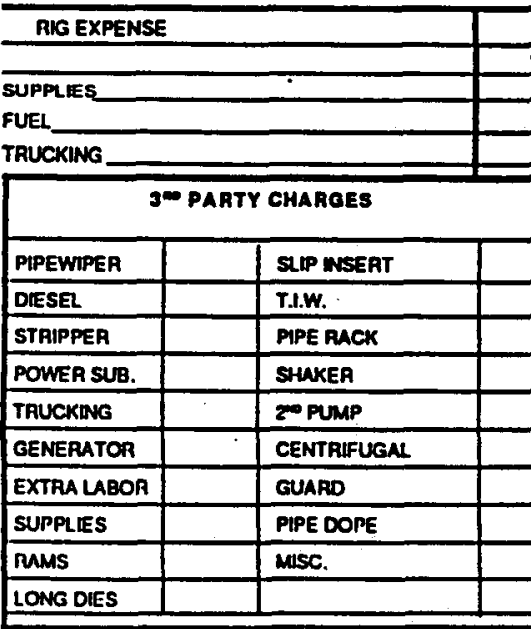
SUPPLY Y REOUEST

toolpusher floyglas zozechat JOB NO $22-5$ ORDER NO. COMPANY REPRESENTATIVE CONTRACT NO $\operatorname{sog} 32-5$

TERMS: NET 30 DAYS. Accounts over 30 days will be charged $11 / 2 \%$ per month not to exceed $18 \%$ ann:lly.

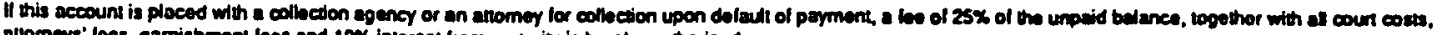
altomeys' leos, garnighment lases and $10 \%$ interest trom maturity is hareby authorized. 

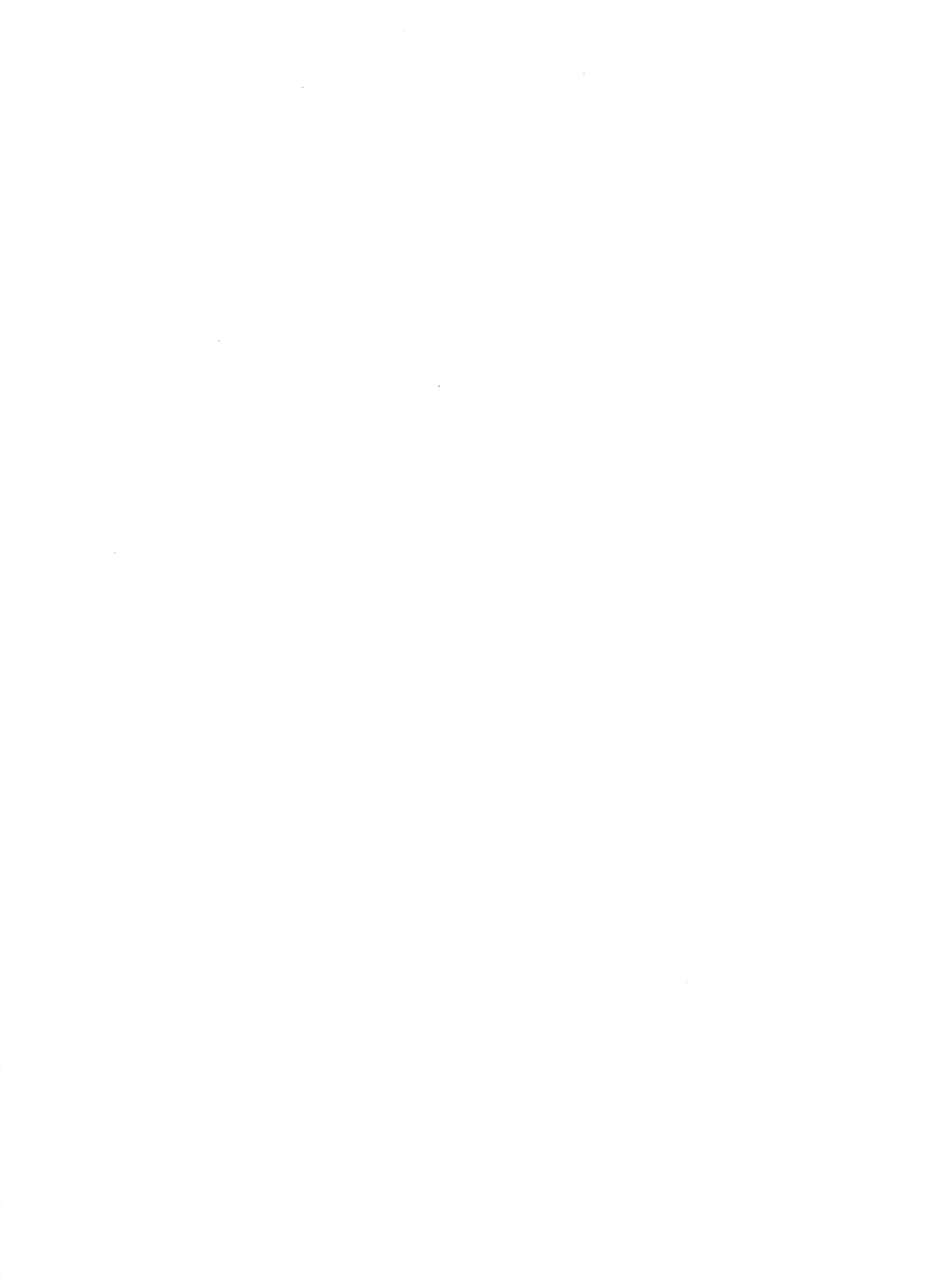
priting

Workover

Complotion

Tenk Bartory installabon

Purping Servicas

Salt Water Wolls

Plup 4 Abandon

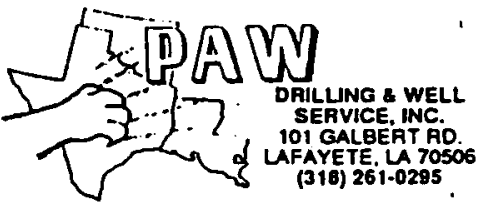

DAILY WORKOVER REPORT
TICKET $7 \% 8$ i.

REPORT NO. 6

companY $/ 4$ S.DEE

FIELL Sordh. EAaTh

LEASEZLillís ZYealion

DATE $2-15-94$

PARISH OR COUNTY thamillicen state Ia WELL NO. I RIG NO $h$

Present Periorations

Present Packer Selting

Total Depth

Present Depth

Typo Plug

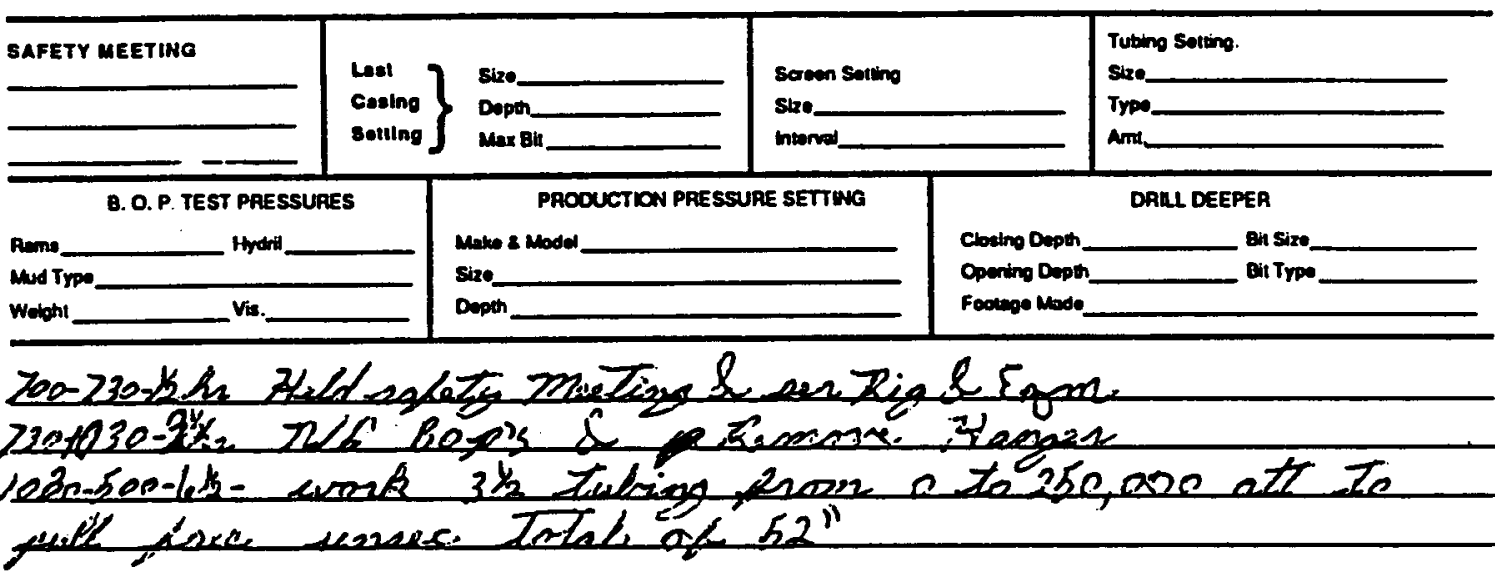

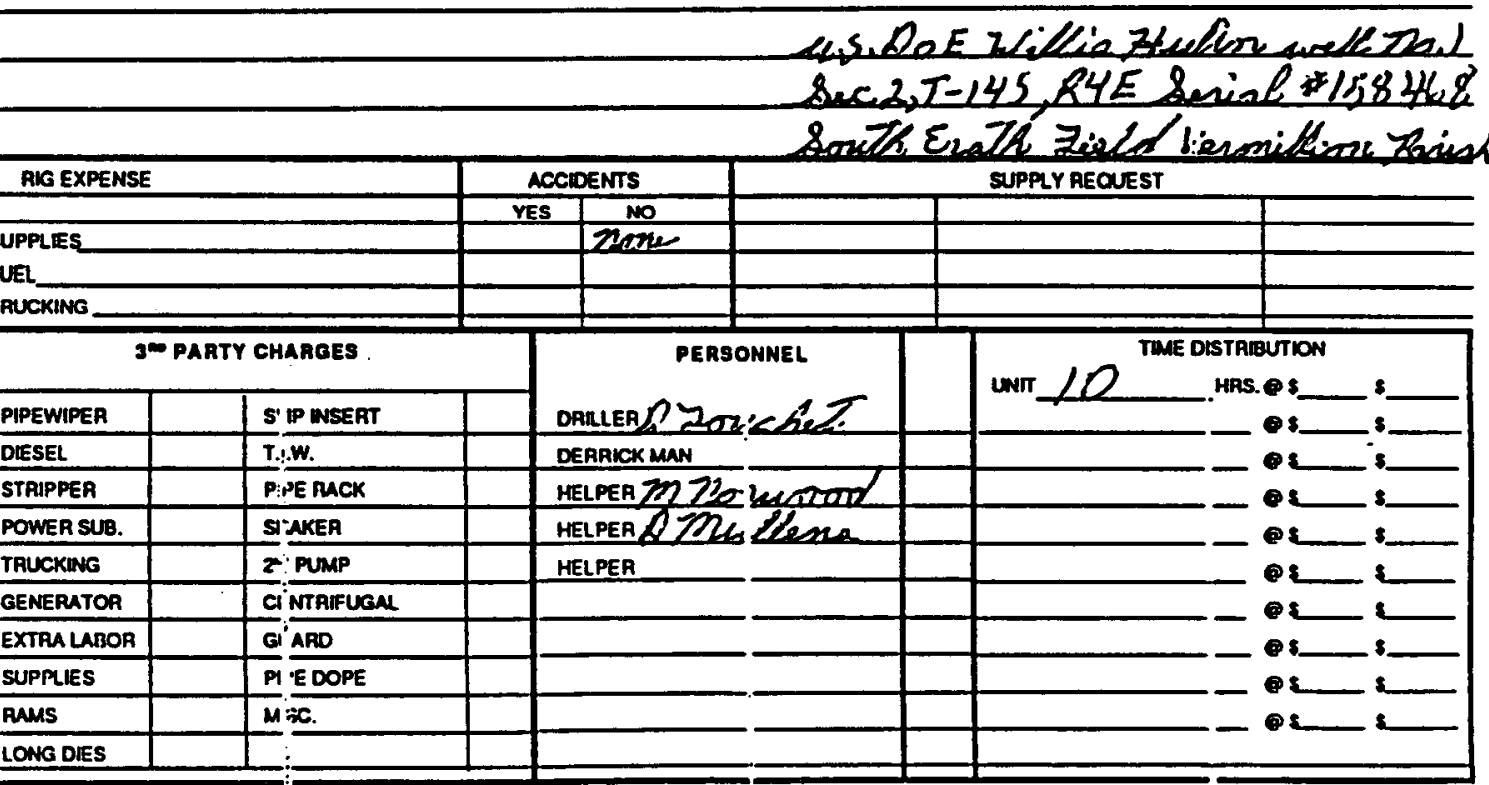

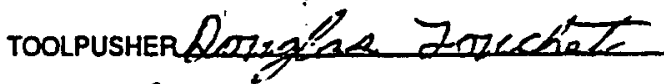
JOB NO $32-2$ ORDER NO.
COMPANY REPRESENTATINE CONTRACT NO
$10837-5$

TERMS: NET 30 DAYS. Accounts over 30 days will be charged $11 / 2 \%$ per month nol to exceed $18 \%$ ann:lly.

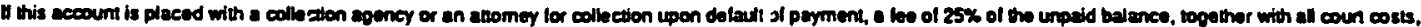
alvomeys' bes, garniehment loes and $10 \%$ intereat trom maturily is hereby authorized. 
company ils. DOE

DAILY WORKOVER REPORT

FIELDESXTt: Enath

FIELRobethe Enals,

LEASE

DATE2 $2-16-94$

PARISH OR COUNTY zrenizzillicre

state 20 WELL NO. 1

Present Pellorations

Present Packer Sotting

Total Depth

Present Depth

Typo Pling

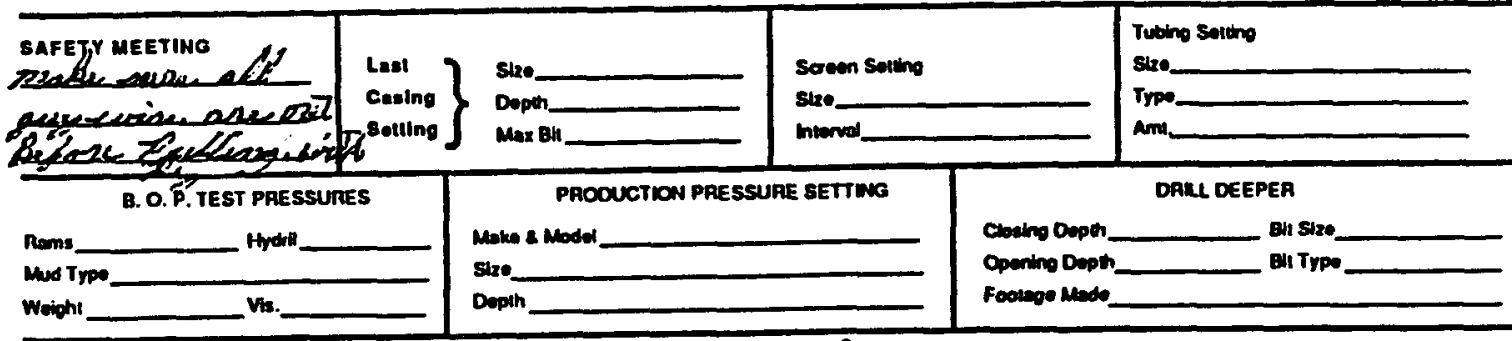

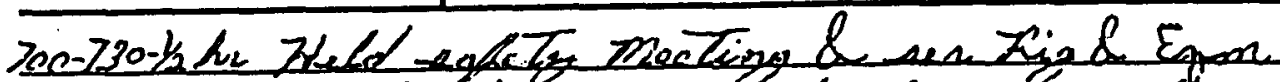

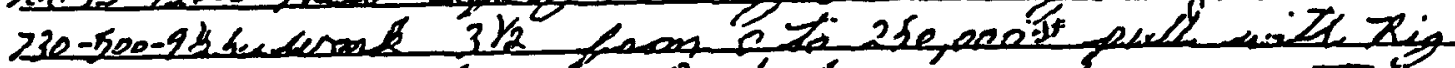

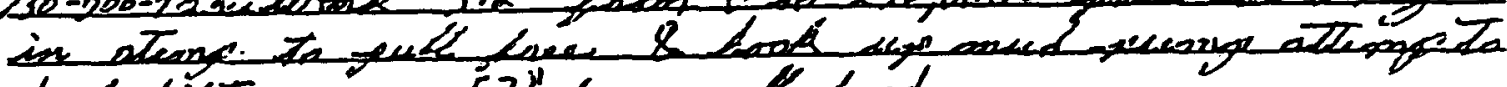

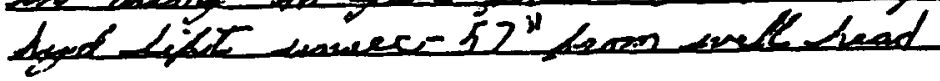

werance ablec to

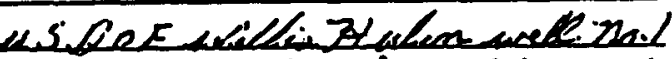

aluch ofs 1722,2 in hole Sco.2,T-145, T4E \&anial *1584k8

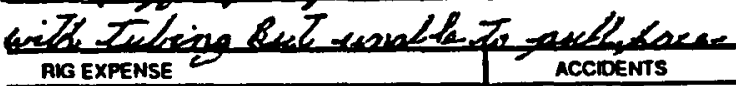
honith Erath Ficht Tomition tasion

\begin{tabular}{|l|l|}
\hline \multicolumn{2}{|c|}{ ACCIOENTS } \\
\hline YES & N \\
\hline & ZDa \\
\hline & \\
\hline &
\end{tabular}

trackine

\begin{tabular}{|c|c|}
\hline \multicolumn{2}{|c|}{ JW PARTY СНАНEES } \\
\hline PIPEWIPER & SUIP WSEAT \\
\hline DIESEL & T.I.W. \\
\hline STMIPPER & PIPE RACK \\
\hline POWEA SUB. & SHUKEA \\
\hline TRUCKING & 20 PUMP \\
\hline GENEPATOR & CENTRIFUGN \\
\hline EXTRALABOR & GUARD \\
\hline SUPPLES & PIPE DOPE \\
\hline RuMS & Musc. \\
\hline LONG DIES & \\
\hline
\end{tabular}

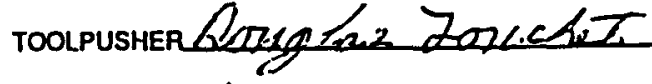
JOB NO $22-5$ ORDER NO
COMPANY REPRESENTATIVE CONTAACT NO JOB $322-5$

TERMS: NET 30 DAYS. Accounts over 30 days will be charged $11 / 2 \%$ per month not to exceed $18 \%$ anntlly.

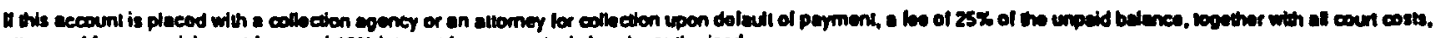

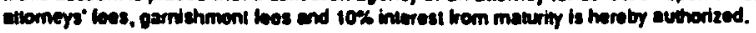


Driling

Completicin

Tent Basery trotalaion

Purping Sermess

Sall Water Wells

Puos 5 Abendon
S

2.1.

(918) 261.0295

DAILY WORKOVER REPOOT

companY H.S. SOE 5

FIELabosith. Erathe

LEASEJuillis ZHuli.n state La.

TICKET 778.1

REPORT NO. 8

PARISH OR COUNTY Thempolithions

Present Packer Solting

Present Periorations

Typo Plug

Total Deplh

Present Depth

DATE2-17-94

WELL NO. 1

RIG NO $\sqrt{3}$

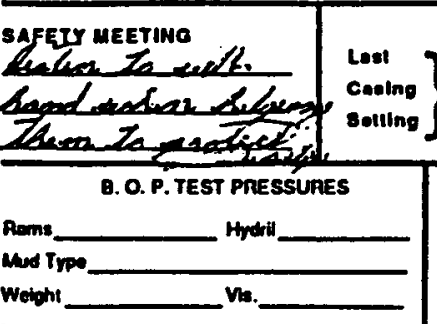

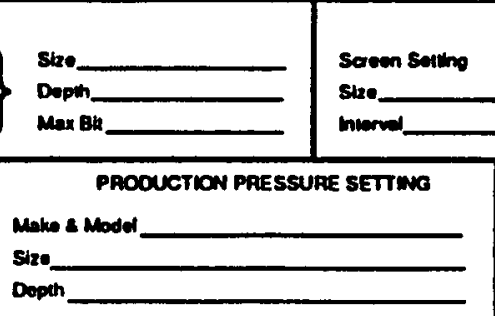

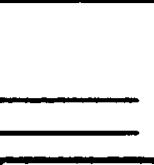

Cosing Doper Fooverop Mlode
Tuting Sorting

Stro.

Tyou.

Ane

ORIL DEEPER

Bn Sizo Bil Trpo

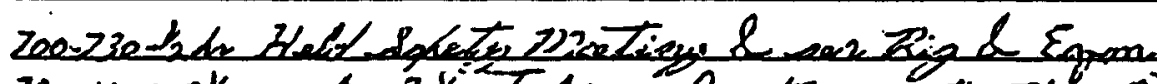

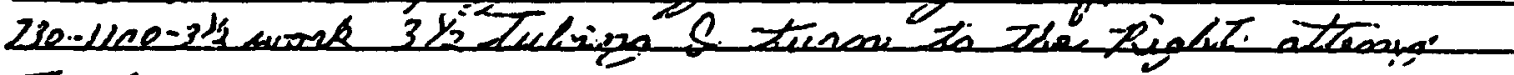
If pures coneeces

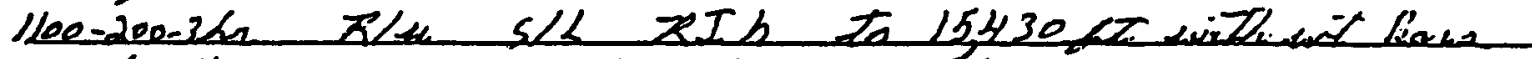

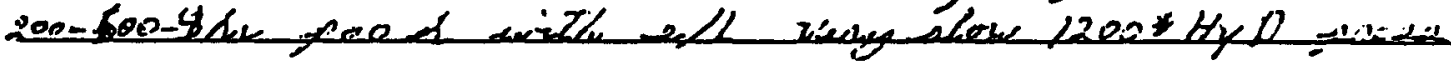

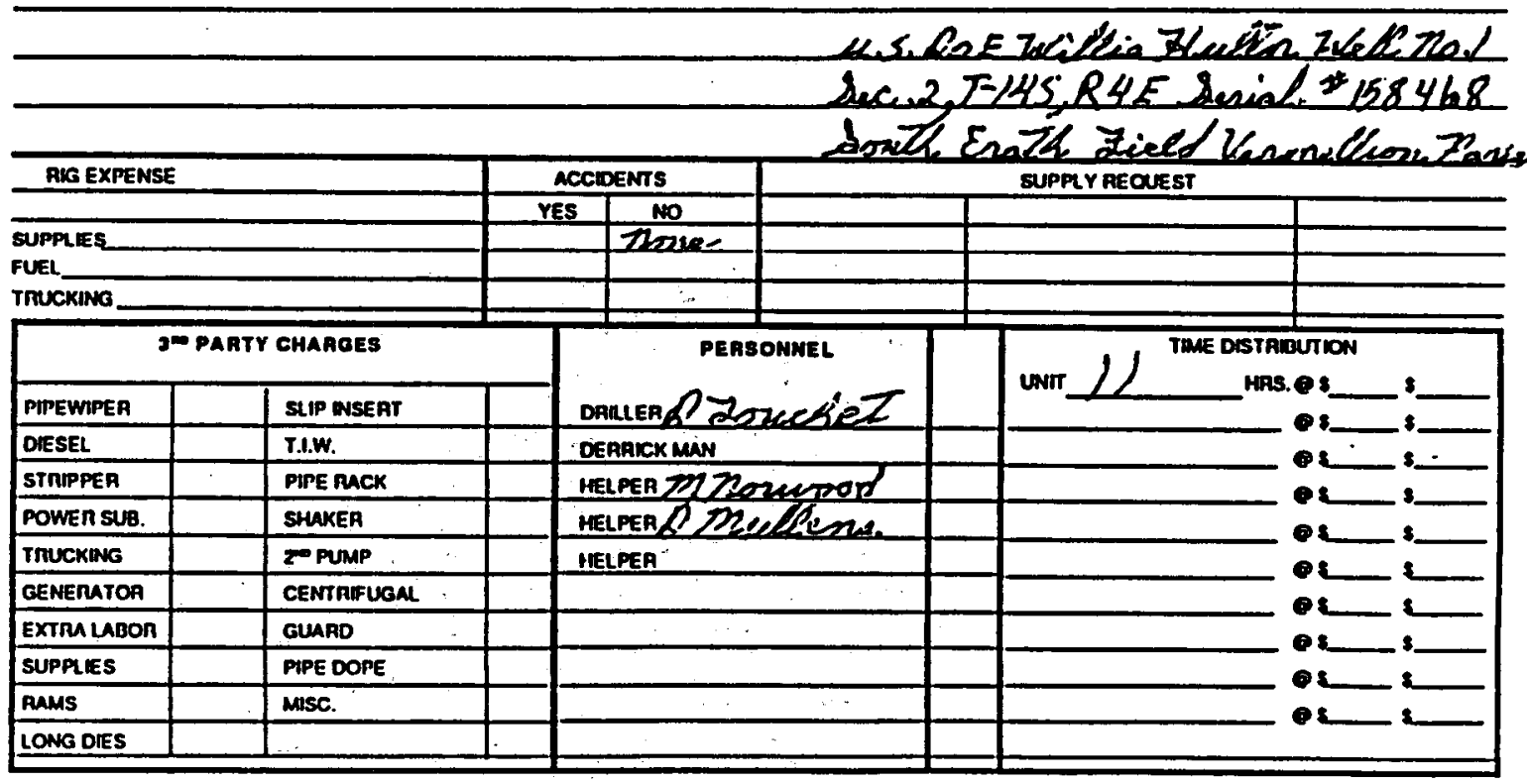

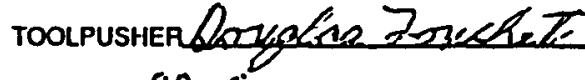
JOB NO $32-32$ ORDER NO.
COMPANY REPRESENTATINE

CONTRACT NO.
JOB $22.2-5$

TERMS: NET 30 DAYS. Accounls over 30 days will be charged $11 / 2 \%$ per monlh not to exceed $18 \%$ ann:lly.

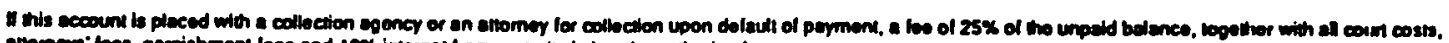

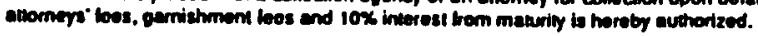


companY ULS.LOLE

DATEO-18-94

PARISH OR COUNTY We-worullition Leasezialliezbeulion state $\mathscr{L} a$

WELL NO. $)$

Present Pertorations Present Packer Selling

Total Depth Present Depth Typo Plug

SAFETY MEETING

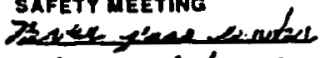

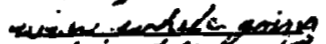

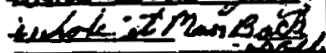
B. O. P. TEST PRESSURES

Mud Trpe Hydill_

Weight Vis.

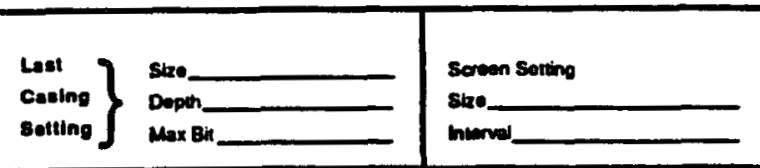

PAOOUCTION PAESSUTE SETTING Malke I Model

Size.

Dopoth

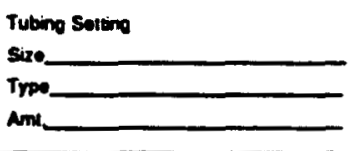

ORLL DEEPEA

Coakng Deph Opening Depth Foosere Made

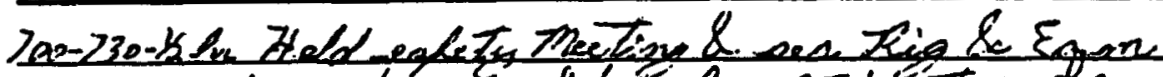

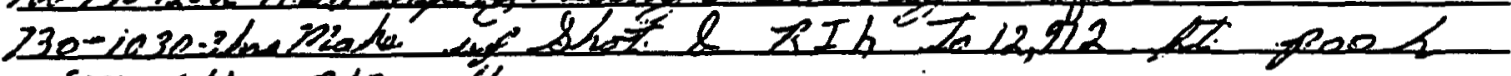
with $s / b$ R/P will

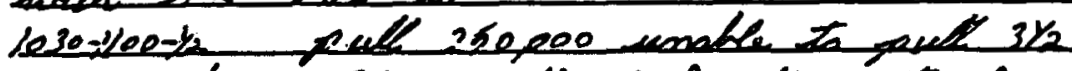

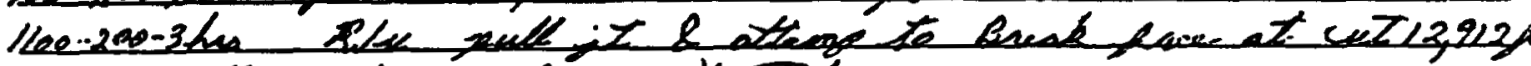

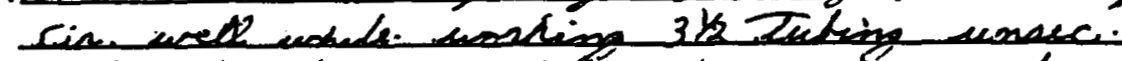

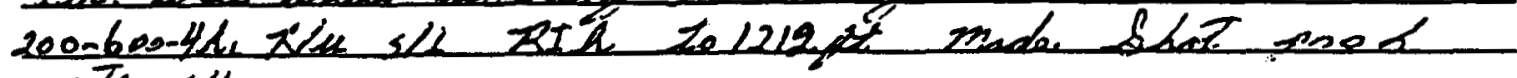
sith s/t

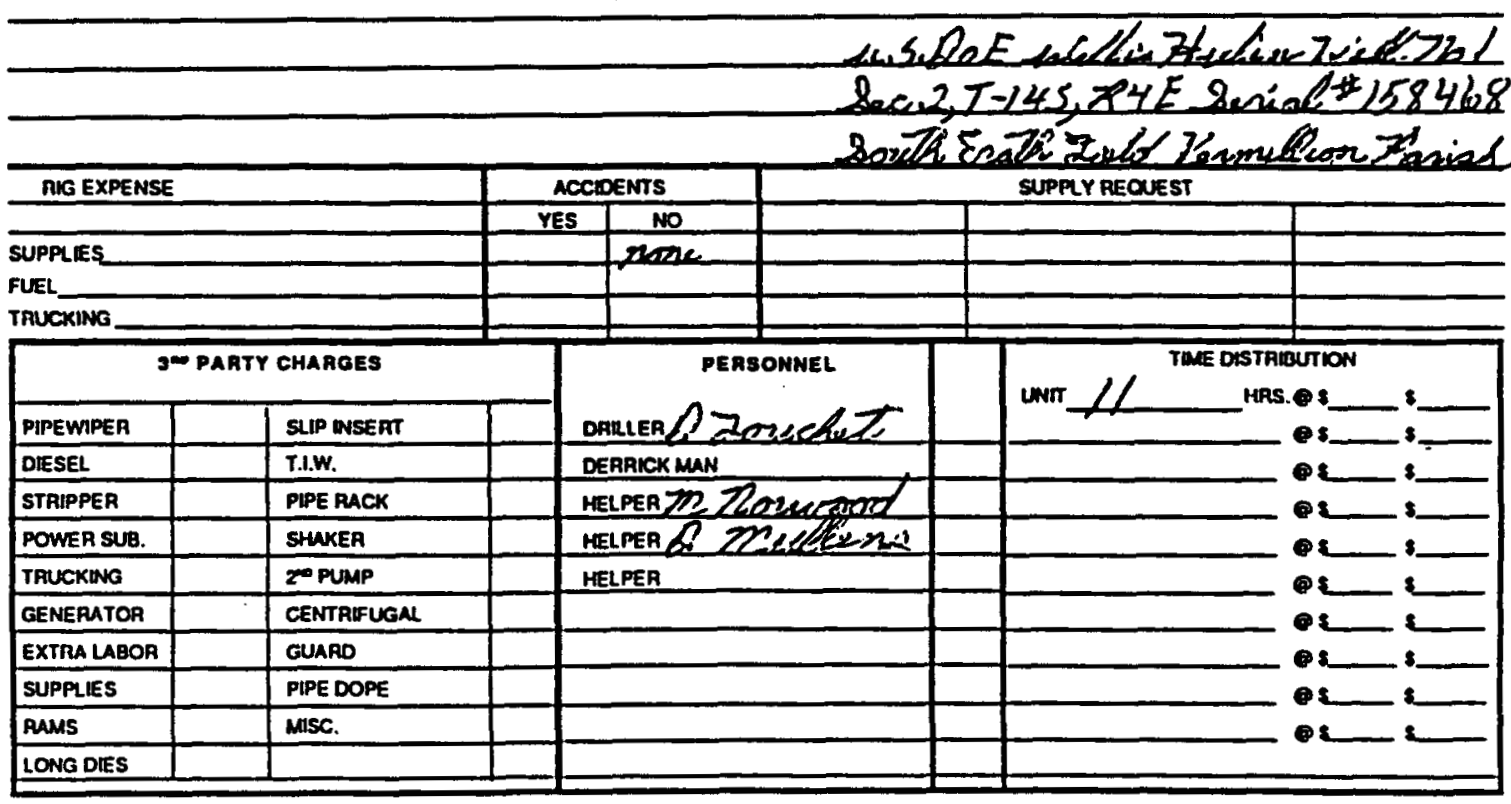

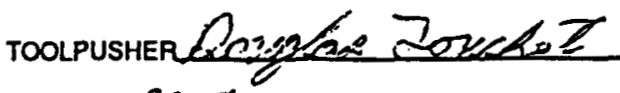
JOB NO $32=5$ ORDER NO.
COMPANY REPRESENTATIVE CONTRACT NO JOB $32-5$

TERMS: NET 30 DAYS. Accounts over 30 days will be charged $11 / 2 \%$ per month not 10 exceed $18 \%$ ann:lly.

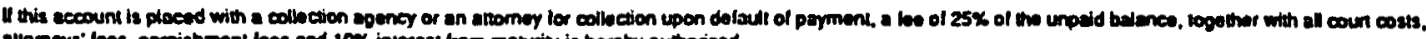
athomeys" loes, gamighment leos and $10 \%$ interest bom matuxty is hereby authorized. 
Driling

Wornower

Complotion

Tenk Bavery Inasalawon

Purping Someo:

Selk Warer Wolls

Plug \& abandon

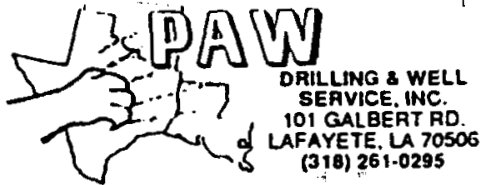

FAYETE L 7050 (318) $261-0295$

DAILY WORKOVER REPORT
TICKET $\%$

REPORT NO. 10
companY MSLLEE

FIELQ Lomit/ Enat/

PARISH OR COUNTY Thesanilleion
LEASE Willis Zlellizh. state in.
DATE $2-18-74$

WELL NO._. RIG No ?
Present Pertorations

Tolal Depth

SAFETY MEETINO

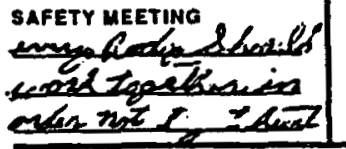

o. O. P. TEST PRESSUPES

Romi

Mus Type Hydil

Weipht

Present Packer Solling

Present Depth

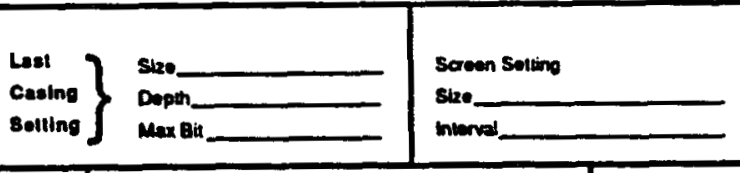

PROOUCTION PRESSURE SETTING Makno 2 Model

Siza.

Depen
Type Plug
Tutions Setion

Sise

Typo.

Amt___

DRRL DEEPER

Closing Dopth____ Bit Sire

Opening Deph

Footuge Made

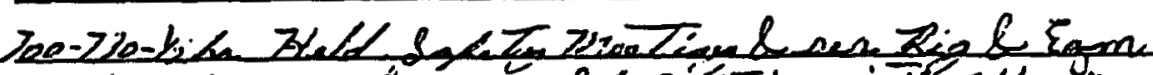

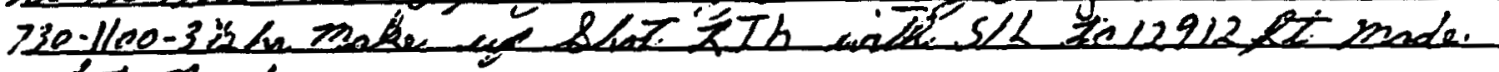
akot Peol

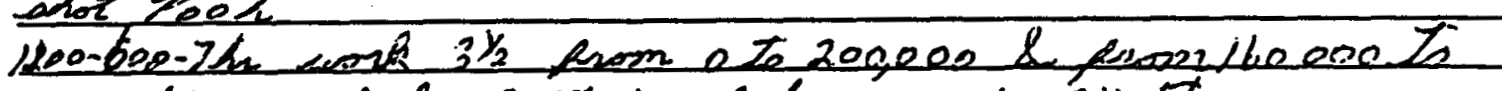

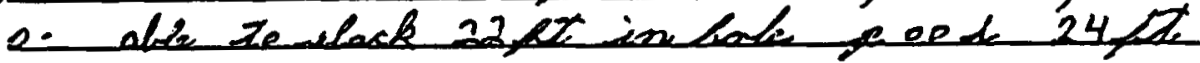

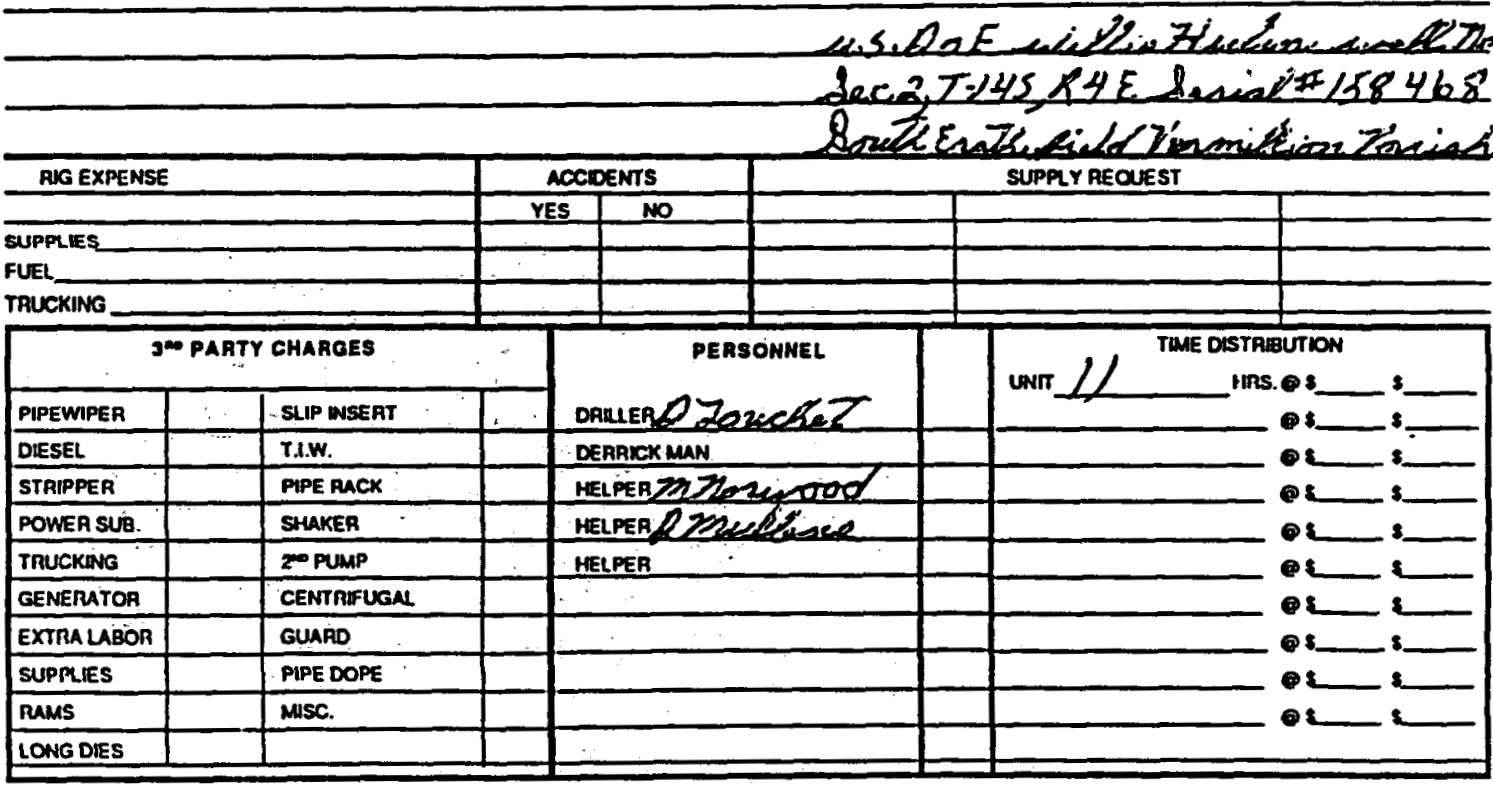

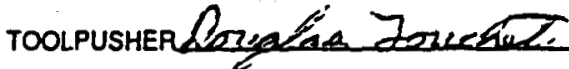
JOB NO $32-5$
ORDER NO.
COMPANY REPRESENTATIVE

CONTRACT NO.
Joo $32-5$

TERMS: NET 30 DAYS. Accounts over 30 days will be charged $11 / 2 \%$ per month not 10 exceed $18 \%$ ann:lly.

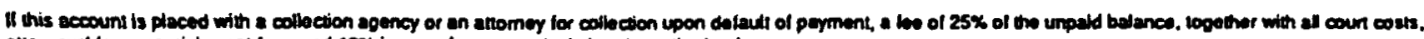
attomeys" toes, garnichment ioes and $10 \%$ inierest trom maturity is heroby authorized. 
company H. LeE

FIELD bontte Enater

LEASE ZWilles Zwulin DATE2-20-94 PARISH OR COUNTY TLARMiltion. STATE La WELL NO. 1

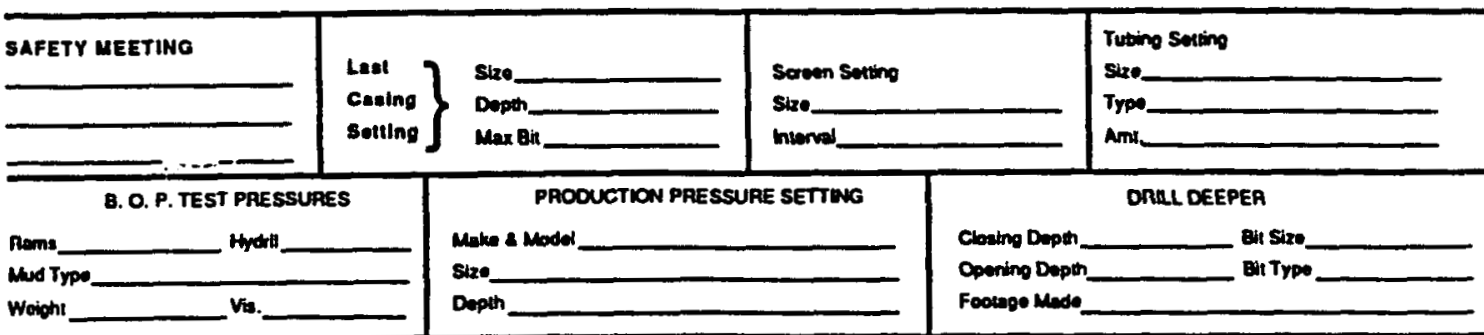

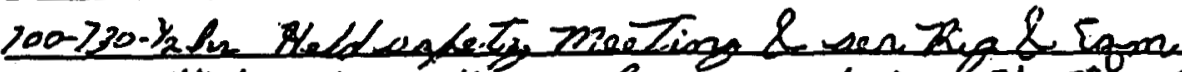

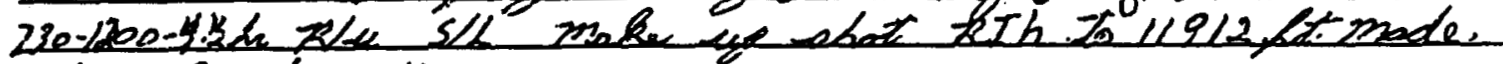
shot Peeh adl

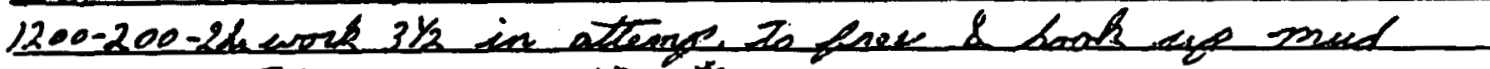

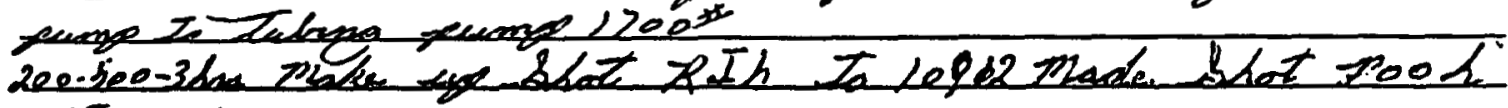
evith $5 / 6$

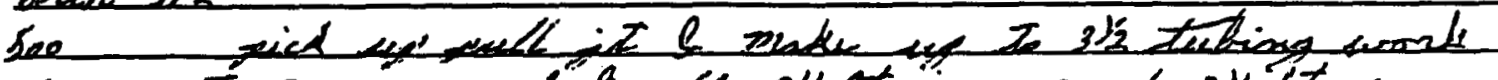

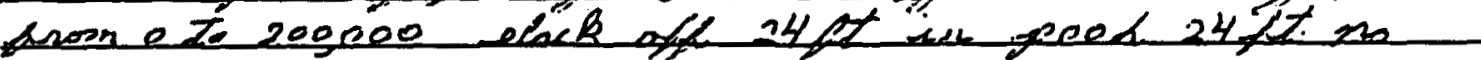
Leas nomore

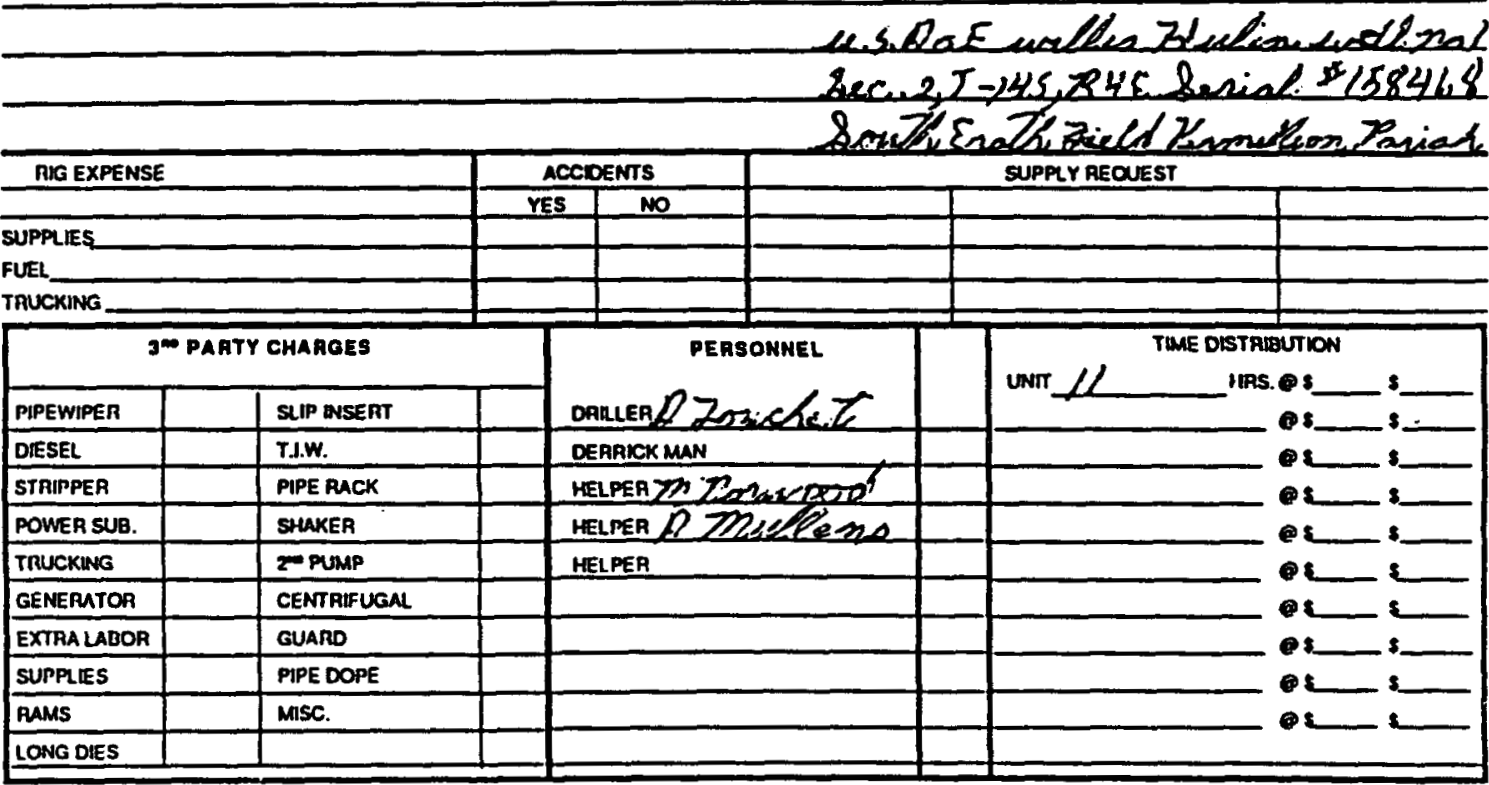

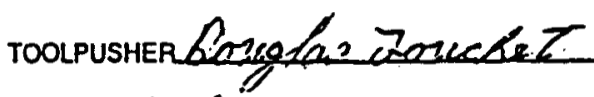
JOB NO $32-5$ ORDER NO.
COMPANY REPRESENTATIVE

CONTAACT NO JOB_32- 5

TERMS: NET 30 DAYS. Accounls over 30 days will be charged $11 / 2 \%$ per month not to exceed $18 \%$ ann:lly.

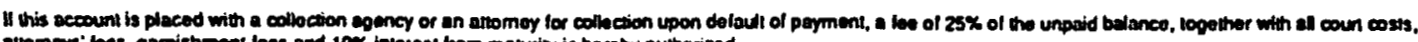
attomers' bess. parrishmont loes and $10 x$ inderevl trom maturity is hareby authorized. 
Dithing

Workover

Tomp eanery ingtallason

Purping Semces

Sal Whice Wells

Plwo $\&$ abendon
J A

S - I D D ILLNG a WELL SERVICE, INC.

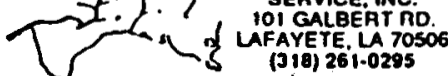

DAILY WORKOVER REPORT
TICKET $778 \%$

REPORT NO. 12

company de. $L E R$

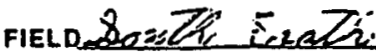

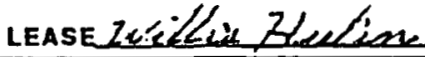

DATE $2-21-24$

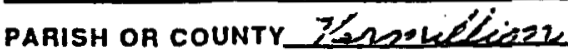
state L2a. WELL NO. $l$ RIG NO

Preseni Perlorations

Presenl Packer Selting

Total Depth

Present Depth

Trpo Plug

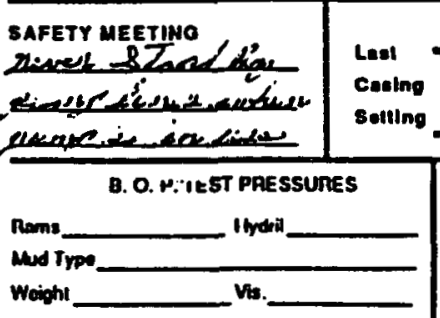

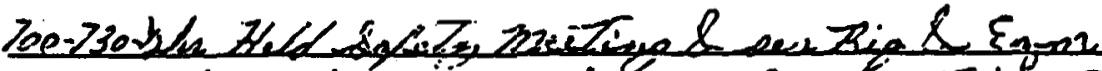

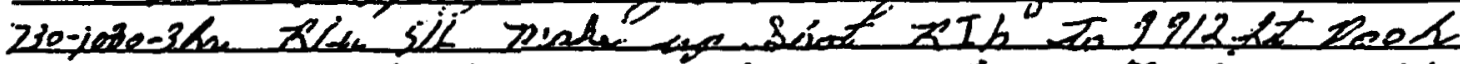

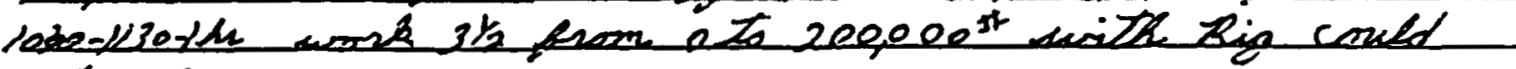
not zule Raw.

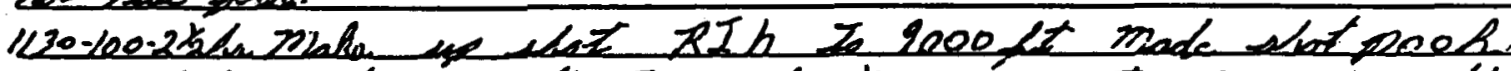

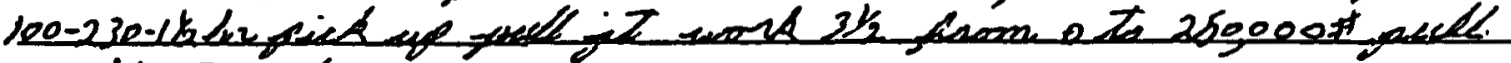

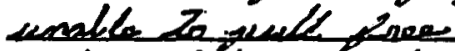

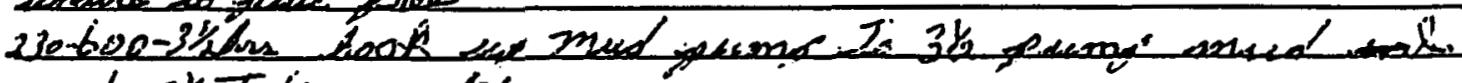

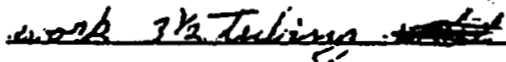

6 Model

8130

Doph

\section{Tuting Soling}

Trpe

Ant

Dnul DEEPEA Cosing Deph ___ Bir Size. Opening Deper. Butrpo

Foolage Mach 

state La. WELL NO. $L$

Present Pertorations

Present Packer Setting

Tolal Deplh

SAFETY MEETINO

B. 0. F. TEST PRESSUAES

Rame.

und Troe Iindrit

Woinght va.
Present Depth

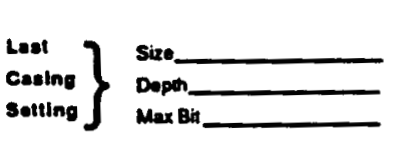

PROOUCTION PAESSURE SETTING Make 1 ubde

Sizo.

Depth
Typo Plug

Sarem Sating
stee

\section{Tuting Selting}

Sko.

Type

Ant

DAML DEEPEP

Cloding Depth

Opening Depph

Foouge Made AIG NO $h$

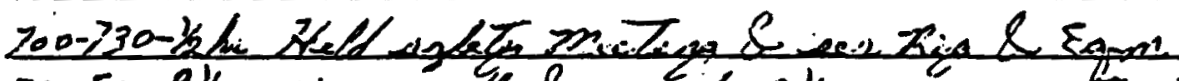

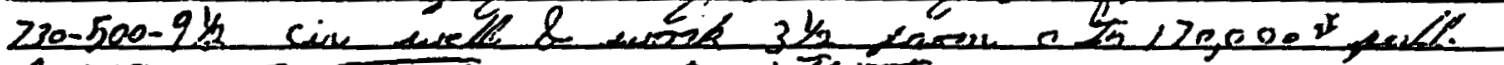

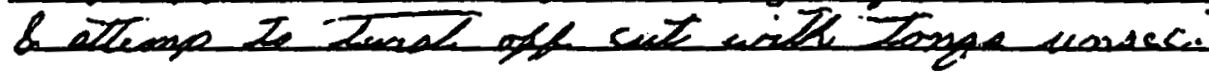

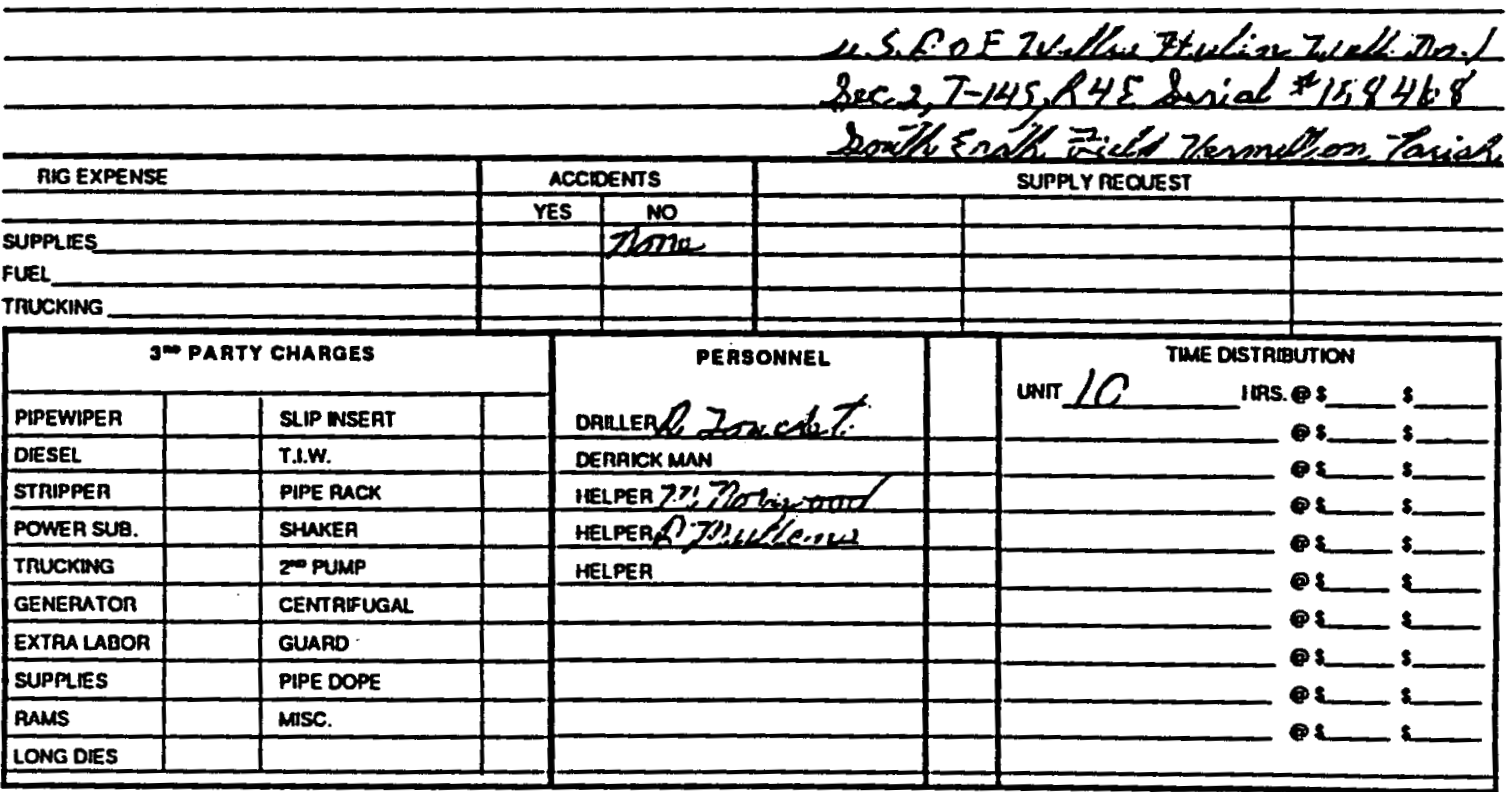

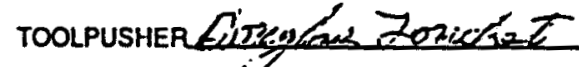
JOB NO $39^{\circ}-5^{\circ}$ ORDER NO.
COMPANY REPRESENTATIVE

CONTRACT NO sos $32-5$

TERMS: NET 30 DAYS. Accounts over 30 days will be charged $11 / 2 \%$ per month not to exceed $18 \%$ ann:lly.

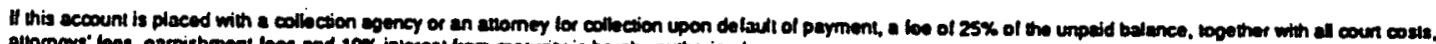

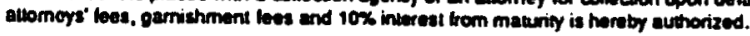


COMPANY MLS. ROE

DAILY WORKOVER REPORT RIG NO, 5

Total Depth

Present Depth

Prosent Packer Solting

SAFETY MEETING

begall teol Chan

Leativ to weard

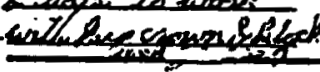
Q. O. P. TEST PRESSURES

$\left.\begin{array}{l}\text { Leat } \\ \text { Cesing } \\ \text { Sotting }\end{array}\right\}$

Rams Hydril

Mud Trpo Vis.

\begin{tabular}{|c|c|}
\hline sko. & Soreen Selting \\
\hline $\begin{array}{l}\text { Dopotr- } \\
\text { Max Bir. }\end{array}$ & Sizo- \\
\hline
\end{tabular}

PAOOUCTION PAESSURE SETTWG

Woight Makn \& Modol

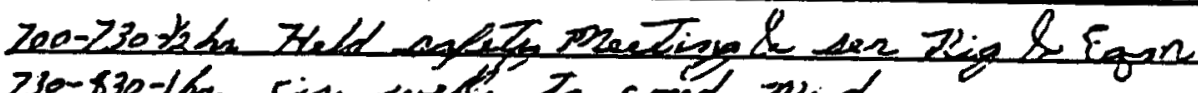

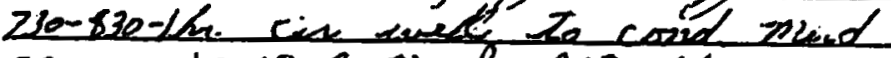

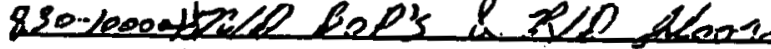

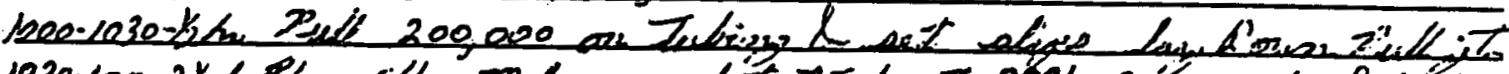

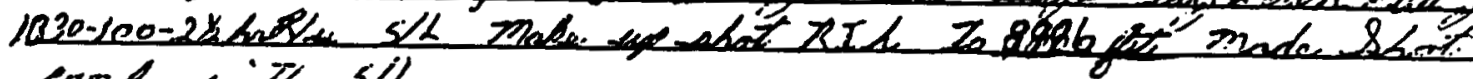
food aith sil

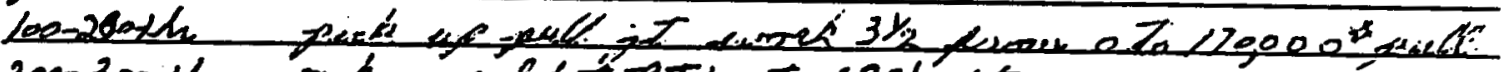

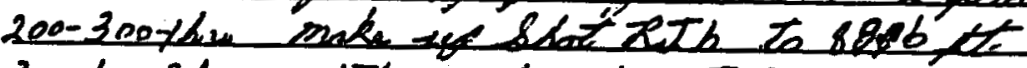

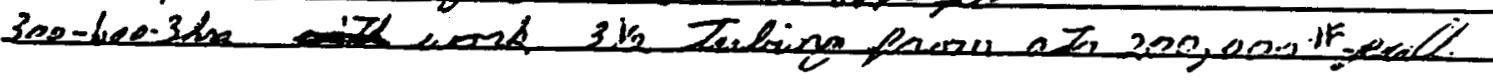

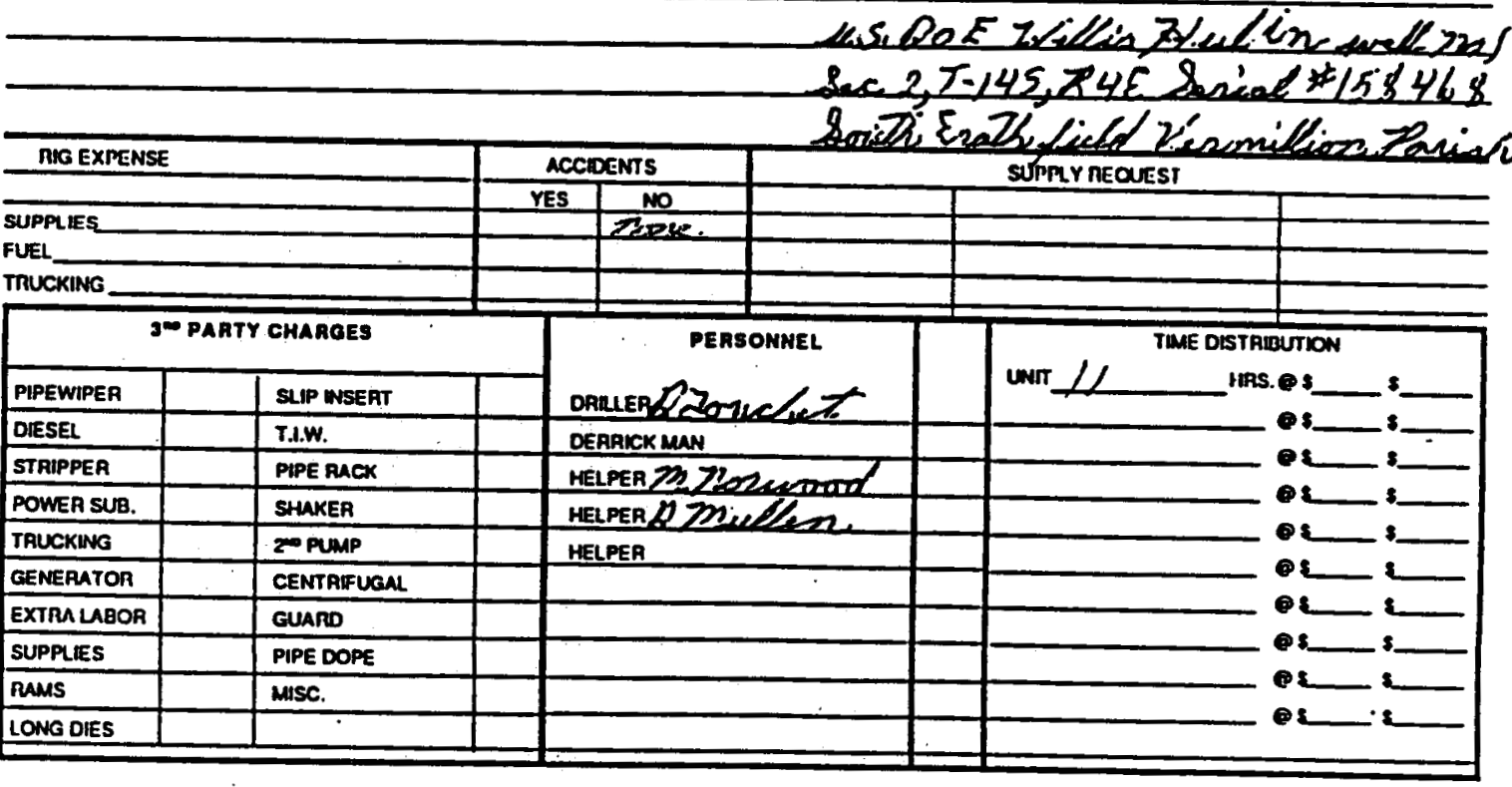

TOOLPUSHERfiorgalon Zouccait JOB NO $32-\Upsilon^{\prime \prime}$ ORDER NO.
COMPANY REPRESENTATIVE CONTRACT NO Jo8 $32-5$

TERM5: NET 30 DAYS. Accounts over 30 days will be charged $11 / 2 \%$ per month not to exceed $18 \%$ ann.lly.

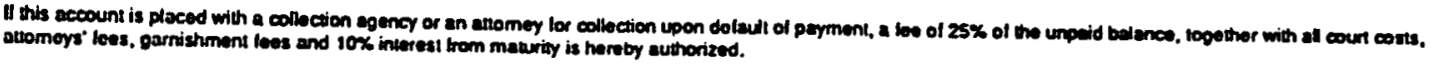


Drilkn

Complever

Tent Bantery installation

Purping Semcos

Salt Waver Wolls

Plup \& Abandon I SSin P 101 GALBERT RD.
TICKET $/ \%$ GI!

REPORT NO. 15

DAILY WORKOVER REPORT

coMPANY dP.LDEE

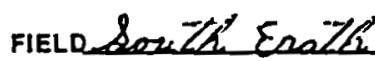
LEASEThillisu Zullinz

DATE2-24-24

PARISH OR COUNTY Thewnilézimse STATELTa WELL NO. 1 RIG NO 5

Present Pertorations

Present Packer Solting

Total Depth Present Depth Type Plug

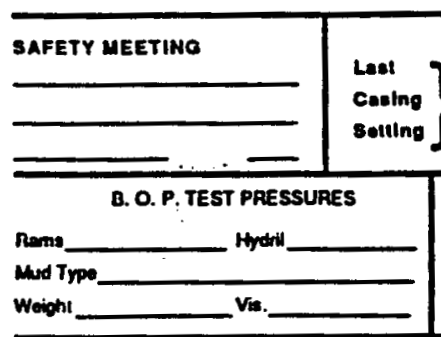

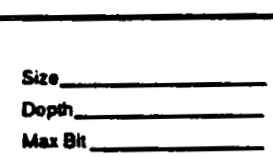

Max Bn

PROOUCTION PRESSURE SETTING
Make \& Model
Dize
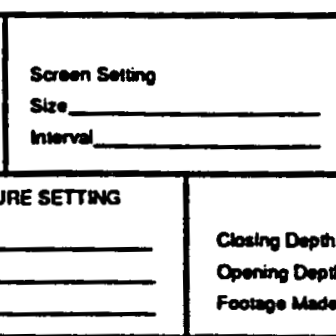

Cosing Depth

Opening Oepth

Fortope Hade

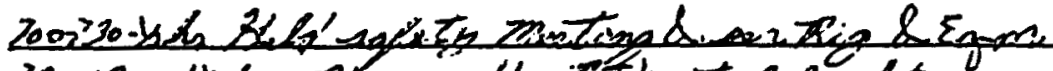

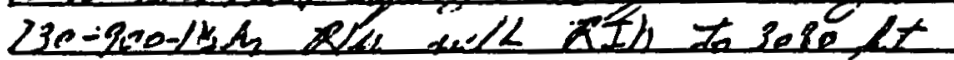

Tubing Setting

size

Trpe

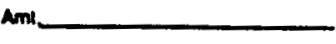

DARL DEEPER

Bit Size

Leo-1100-2h cin wet cosk mul

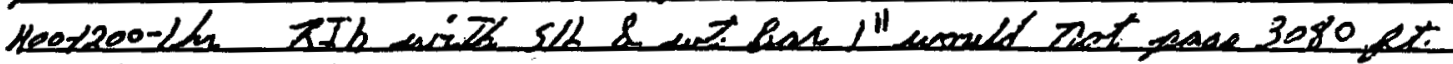

food with sll

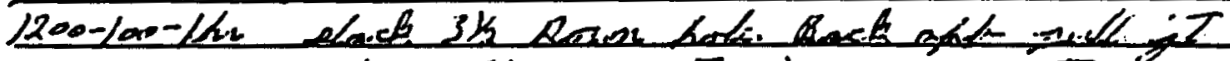

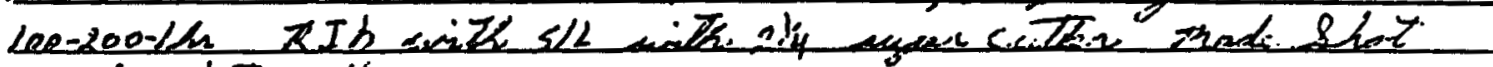
posed anth $5 / 4$

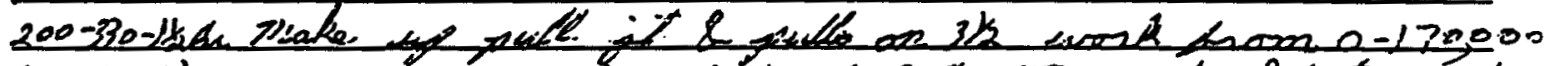

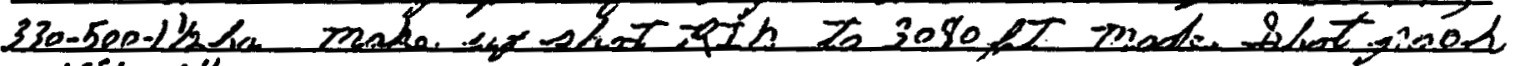
sith S/L

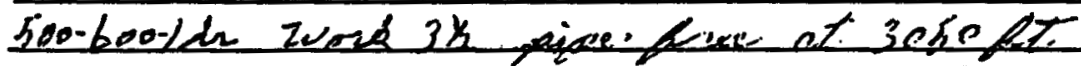

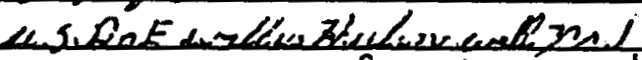

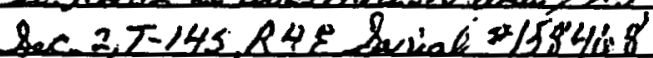

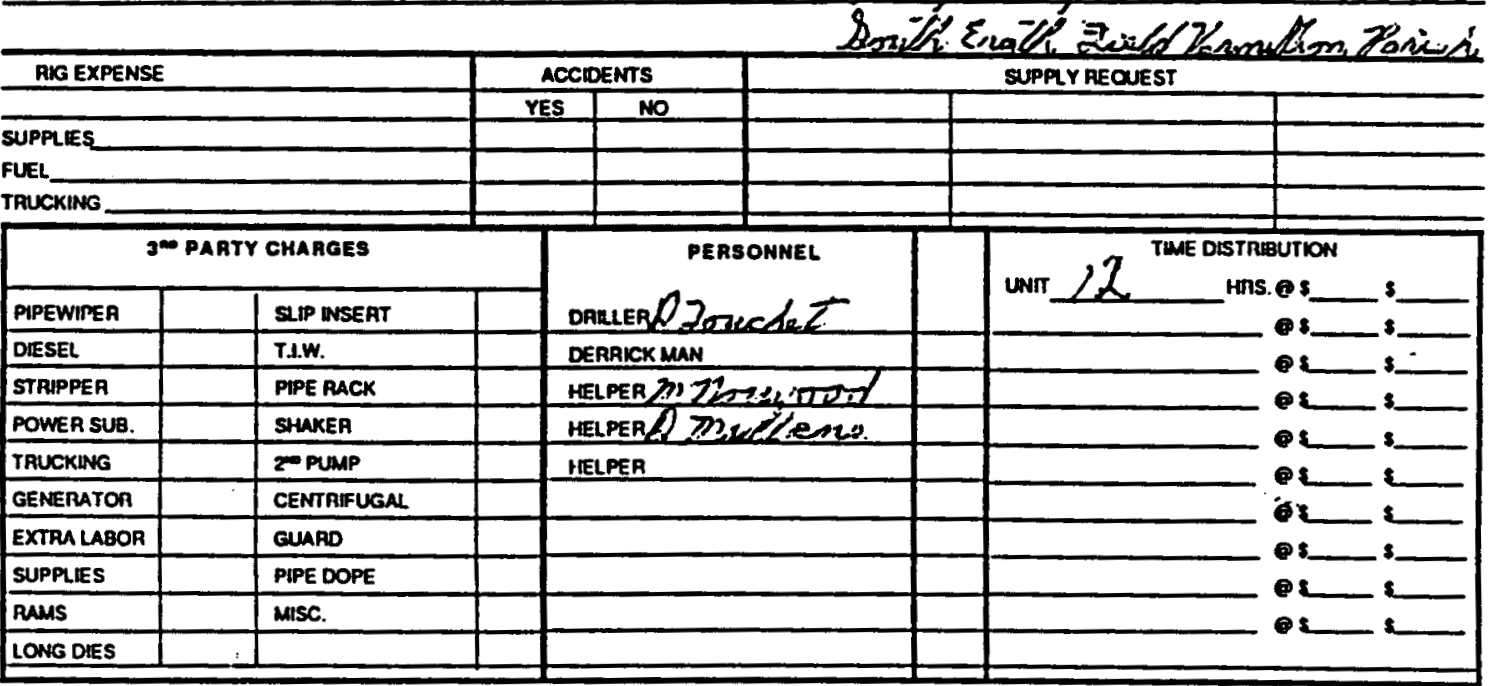

TOOLPUSHER forgýlas Zonchet JOB NO, $32-5$ ORDER NO.
COMPANY REPRESENTATIVE

CONTRACT NO
JOB $32-5$

TERMS: NET 30 DAYS. Accounts over 30 days will be charged $11 / 2 \%$ per month not to exceed $18 \%$ ann:ly.

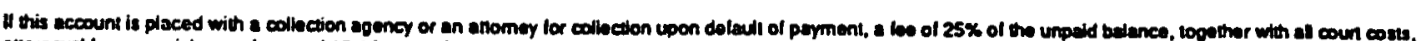
auomey' leas, ganizhmont loes end $10 \%$ inierest trom maturity is horeby authorized. 
tomover

omplotion

Cenk Banery instalation

Purreing semoes

Sin Waiv Wots

Plug \& Abardion

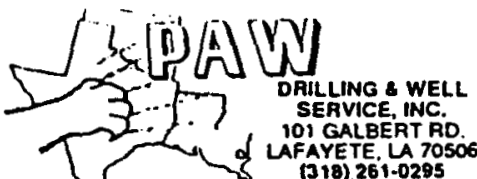

TF)
(318) 261.0285

TICKET \% /9i.

REPORT NO. 1,5

DAILY WORKOVER REPORT

DATE $2-25-94$

COMPANY'LS. GeE LEASE belilles Zlealia WELL NO. 1

FIELD Lowti Erath STATE $X^{2}$ RIG NO 5

Present Pertorations

Presant Packer Solting

Total Depth

Present Depth

Type Plug

\begin{tabular}{|c|c|c|c|c|c|}
\hline $\begin{array}{l}\text { SAFETY MEE } \\
\text { Mefestat } \\
\text { Ziequed }\end{array}$ & $\begin{array}{l}\text { Lest } \\
\text { Ceaing } \\
\text { sottling }\end{array}$ & 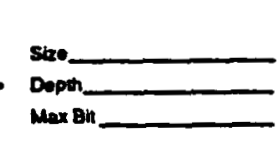 & $\begin{array}{l}\text { socen secting } \\
\text { steo } \\
\text { mienval }\end{array}$ & & 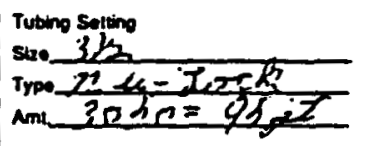 \\
\hline \multicolumn{2}{|c|}{ B. O. P. TEST PRESSURES } & \multicolumn{2}{|c|}{ PROOUCTION PRESSURE SETTWG } & \multicolumn{2}{|r|}{ DRRL DEEPER } \\
\hline \multicolumn{2}{|l|}{ 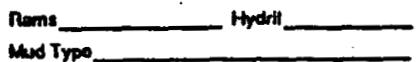 } & \multirow{3}{*}{\multicolumn{2}{|c|}{$\begin{array}{l}\text { Melos \& Modol } \\
\text { Size } \\
\text { Deosin }\end{array}$}} & \multirow{3}{*}{ 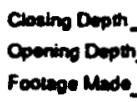 } & \multirow{3}{*}{ Bin Sine } \\
\hline$\infty$ Typo & & & & & \\
\hline - vas. & & & & & \\
\hline
\end{tabular}

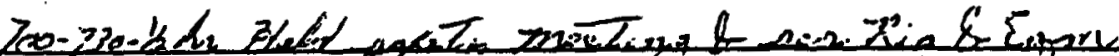

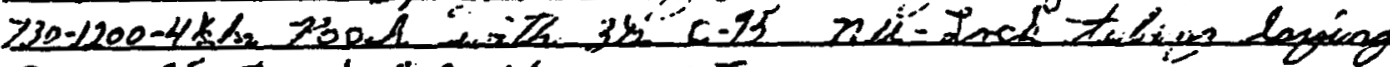

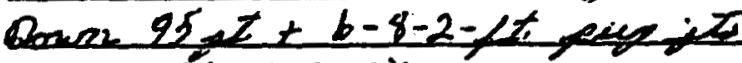

$2300-100-1 / 42$ Z1R $3 \%$ son

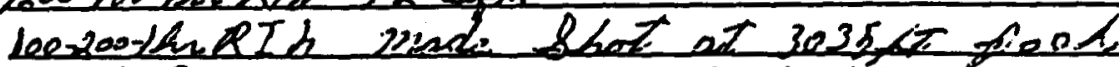

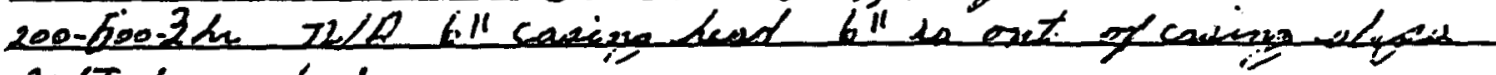
30,0 ghoer buad

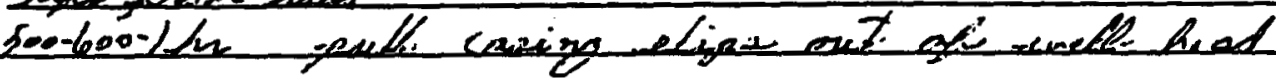

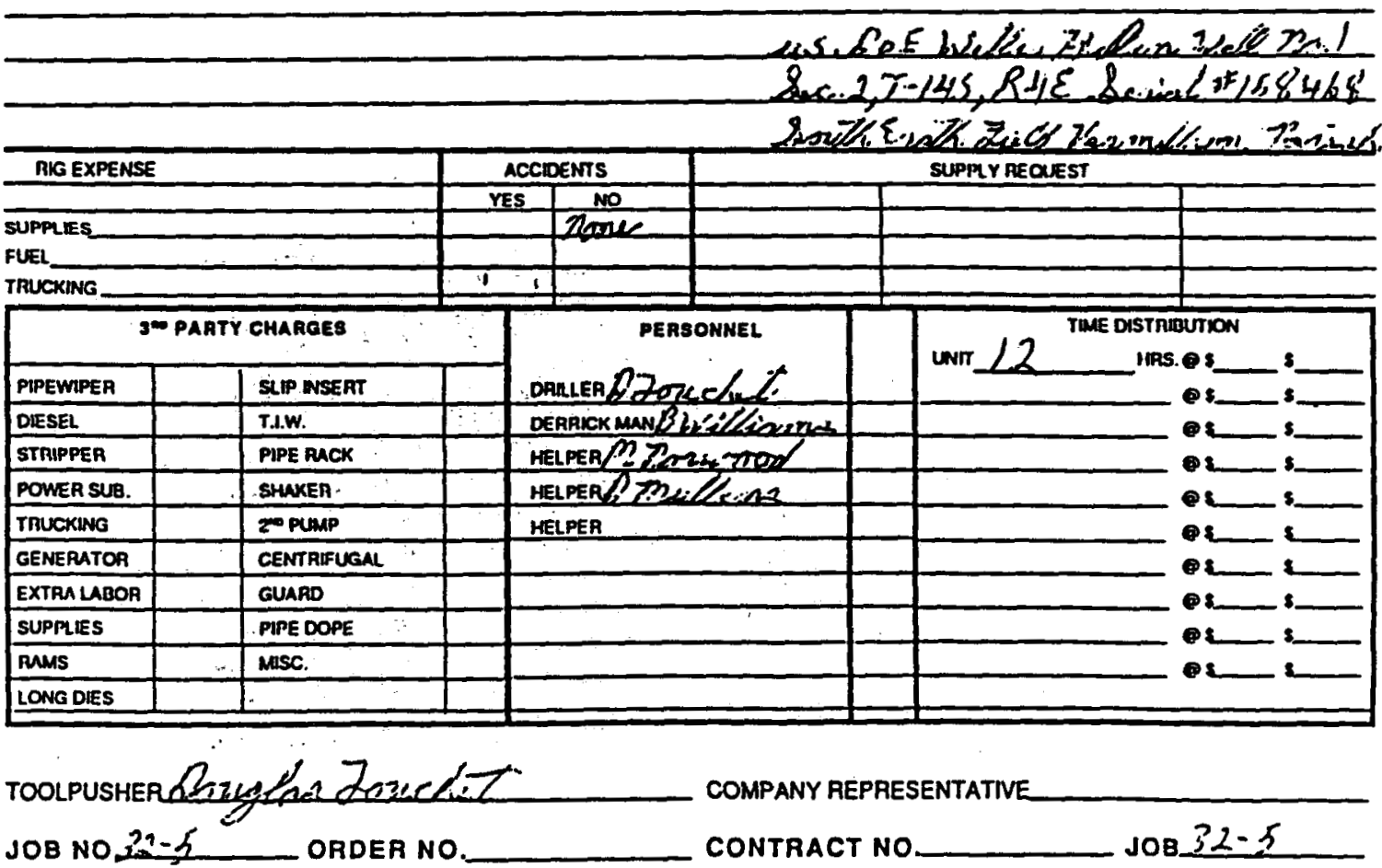

TERMS: NET 30 DAYS. Accounts over 30 days will be charged $11 / 2 \%$ per month not to exceed $18 \%$ ann!lly.

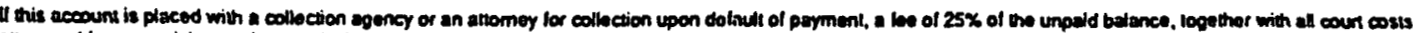
attorneyr' leas, garnizhment kes and $10 x$ inierest trom maurity is hereby authorized. 


\section{DAILY WORKOVER REPORT}

COMPANY LWS $20 E$

FIELR boyte Enate

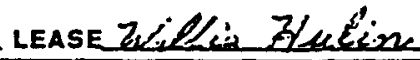
DATE $2-28-92$ PARISH OR COUNTY Zeancielliosos STATE Ta WELL NO._ RIG NO 5

Present Perloralions

Present Packer Solting

Total Depth

Present Depth Type Plug

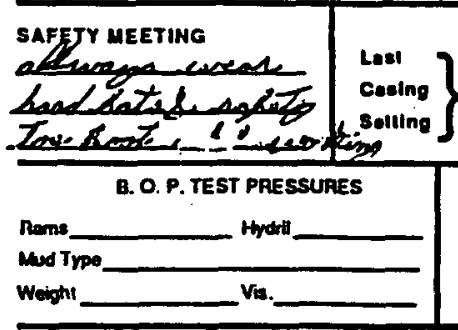

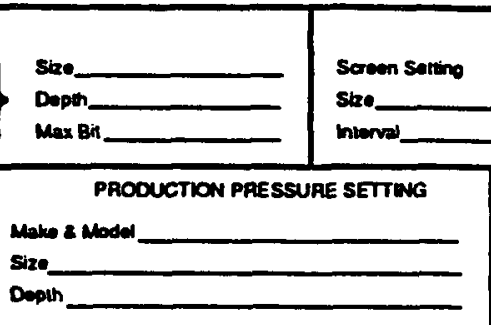

ubing Salsing Sare

Trpo Am.

DALL DEEPEA

Cloeting Depth____ Bir Size

Foovinge Made

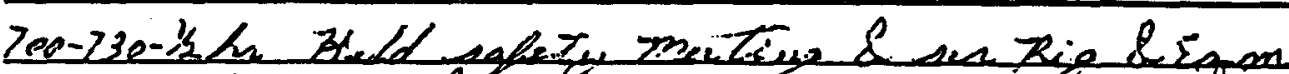

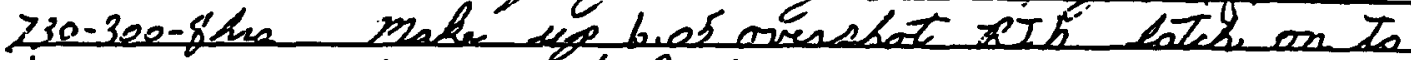

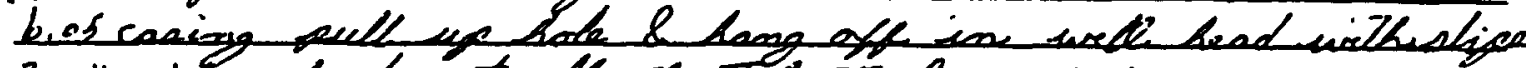
300-400-1h lood ont all Fentel tool an Jion

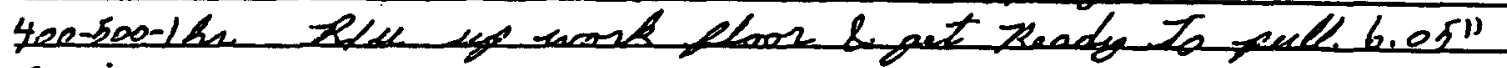
casing

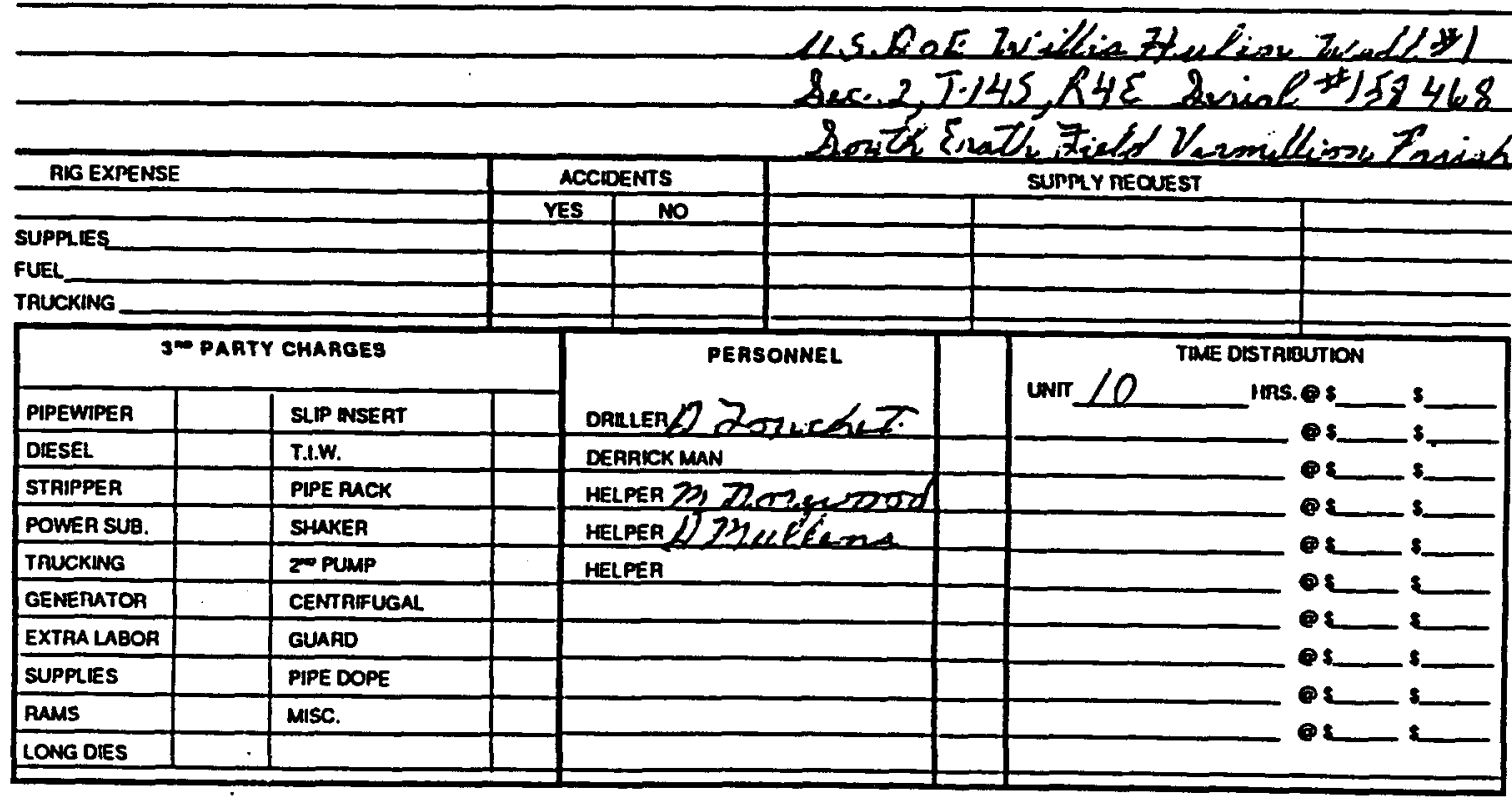

TOOLUSHERkiosuglise donechet دOB NO $\$ 2-5$ ORDER NO COMPANY REPRESENTATIVE CONTRACT NO_ JOB_ $325-5$

TERMS: NET 30 DAYS. Accounis over 30 days will be charged $11 / 2 \%$ per month not to exceed $18 \%$ ann:lly.

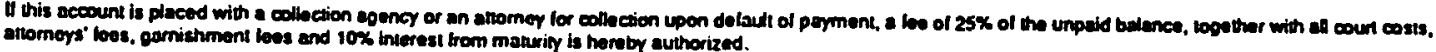


Drilling

Wortover

Tenk Butien batallaven

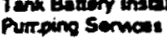

Purping Sernols

Plup \& Abandon

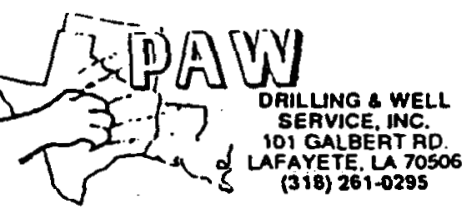

DAILY WORKOVER REPORT
TICKET $779 \%$

REPORT NO. 17

coMPanY UST RoE DATE $3-1-94$

FIELD \&outh Erath LEASEWLllea Zulion. WELL NO. PARISH OR COUNTY JeAm illion state fel RIG NO 5

Present Perforations

Present Packer Setting

Total Depth Present Depth Type Plug

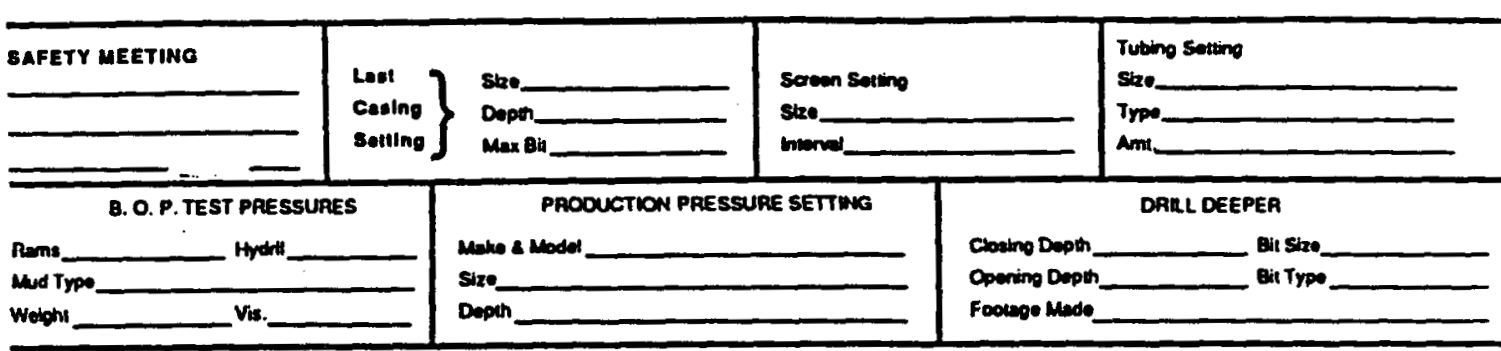

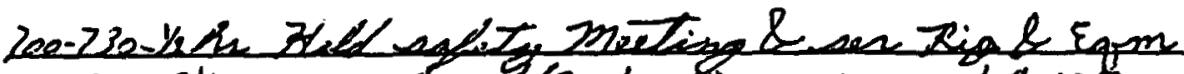

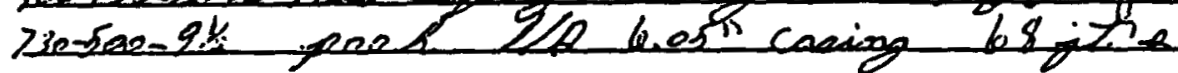

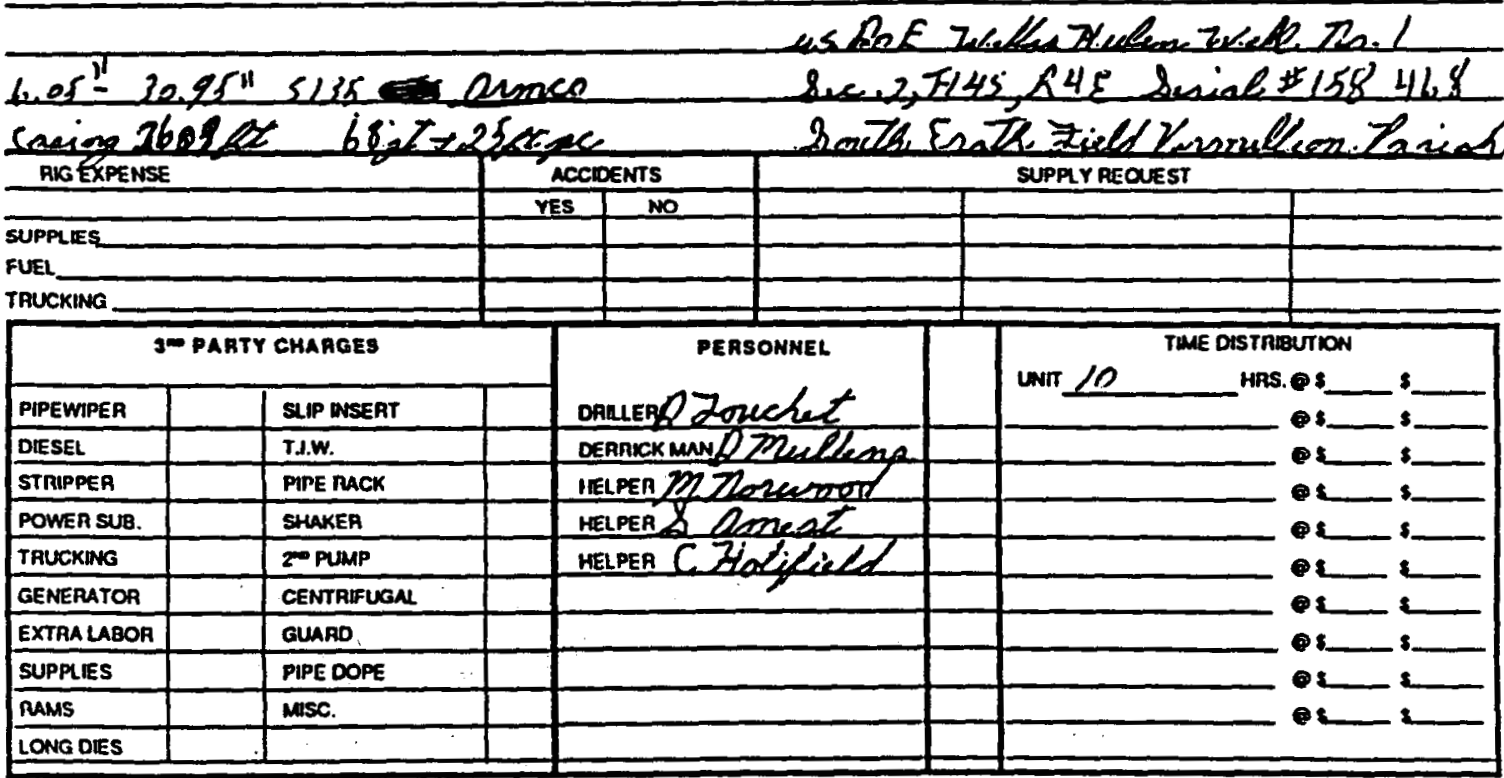

Tolpusher Roziglar Zozuchet. JOB NO 225 ORDER NO.
COMPANY REPRESENTATIVE CONTRACT NO.
Jов $32-5$

TERMS: NET 30 DAYS. Accounts over 30 days will be charged $11 / 2 \%$ per month not to exceed $18 \%$ annilly.

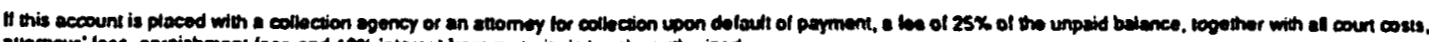
atbormer' lose, gacrishment bes and $10 \%$ inierest bom maturity is heroby authorized. 
Dring

Cornover

Tank Babiery insulation

Purping Services

Salt Waier Wiels

Plug a Abandon $\int \mathbb{S}$

S S...? DRILLING \& WELL

2. 101 GALBERT RO

U $\begin{aligned} & \text { LAFAYETE. LA 70506 } \\ & \text { (318) } 261.0295\end{aligned}$

DAILY WORKOVER REPORT
TICKET $7 / 94$

REPORT NO. $\angle \Psi$

COMPANY_LS, ROE DATE $3: 2-94$

FIELD \&ouTh Eath

LEASE Whillie Zteclion WELL NO. 1

PARISH OR COUNTY Ilesonillivime state ja RIG NO 5

Present Perforalion

Present Packer Selting

Total Depth

Present Depth

Type Plug

SAFETY MEETING

Lece handizile

ore erout ctooses

ot.all Times

B.O. P. TEST PRESSURES

Sizo- screon Sorting

Casing Depth__ Stree

sonting $\int$ Max Bn

Wud Typo O.P. TEST PRESSURES

PROOUCTION PRESSURE SETTHC

Make 2 Model

Woish Dopech

Oponing Depth

Tubing Soting

Size.

Trom

DARL DEEPER

Bir size

Bit Tros

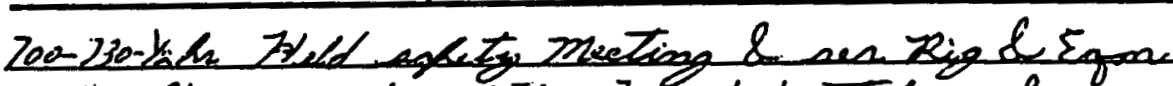

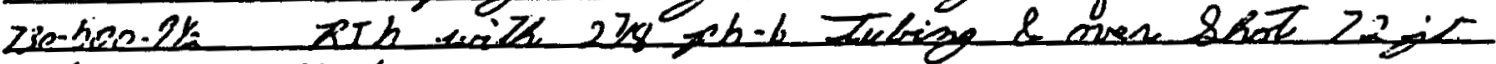
takng tiandex

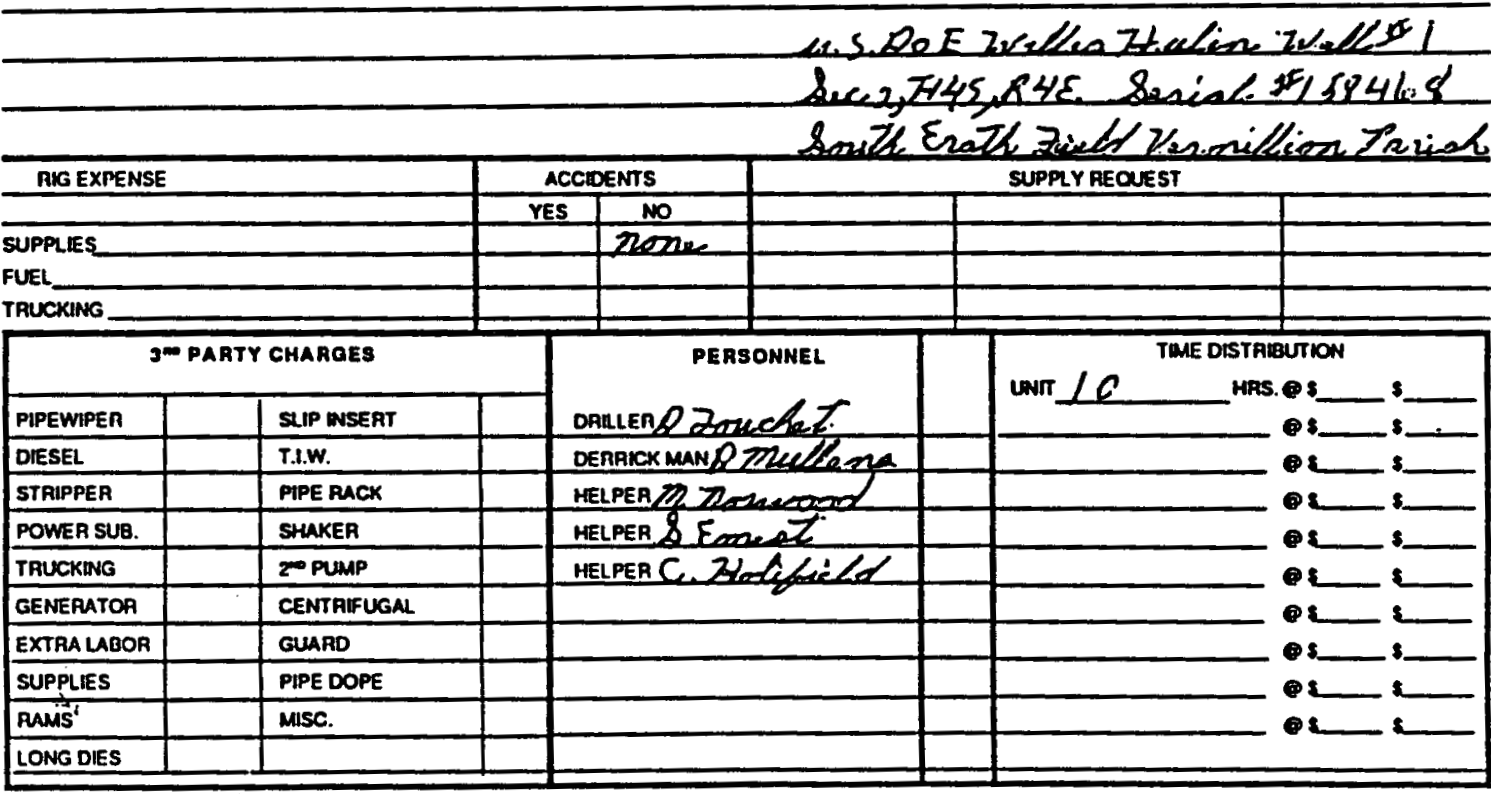

TOOLUSHer Rogeglas Zoouctet Јов Nо $32-5$
ORDER NO
COMPANY REPRESENTATIVE

CONTRACT NO Jов $32-5$

TERMS: NET 30 DAYS. Accounts over 30 days will be charged $11 / 2 \%$ per month not 10 exceed $18 \%$ anm.ly.

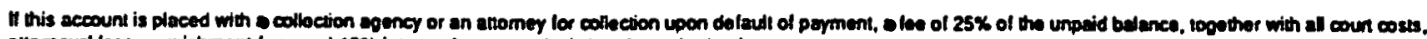
allomers' foes, gamishment leos and $10 \%$ intersest trom mahuity is theroby autherized. 
companY th S DQE

FIELD sozTh Enoth

DAILY WORKOVER REPORT

REPORT NO. 19

PARISH OR COUNTY Thanomil Kion

LEASE Thillia Zufun

DATE $3-3-94$

WELL NO. 1

state da RIG NO 5

Present Perforations

Present Packer Selting

Total Depth

SAFETY MEEYJNG

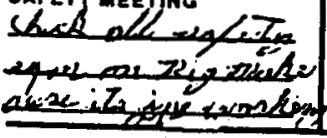

B. O. P. TEST PRESSURES

Roms

Mud Trpe Hydarit

Woight

vis.

Present Deplh

Trpe Plug

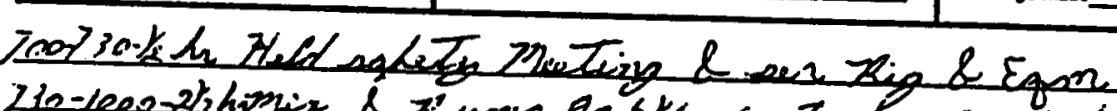

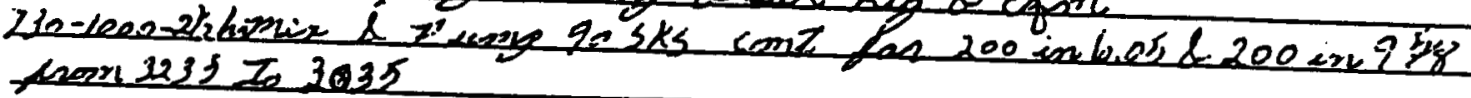

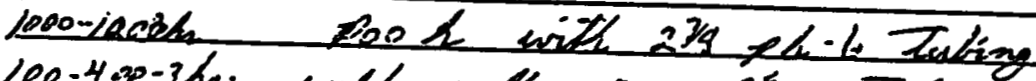

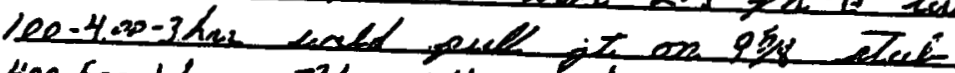

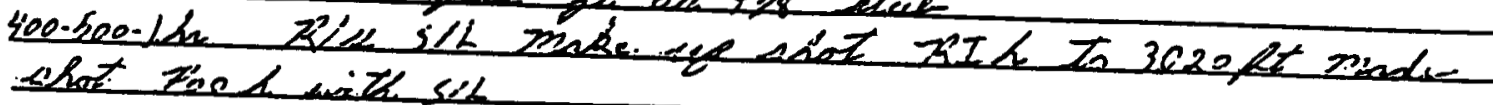

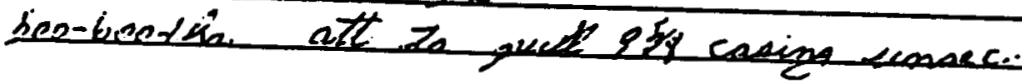

$\rightarrow$ ation.

Se,ita b.es asance $=3035 \mathrm{KL}$

coneene 30.98 AIG'EXPENSE

SUPPLIES
FUEL
TRUCKING
3O PARTY CHAROES

PIPEWIPER 3- PARTY CHAROES

DIESEL

STRIPPER POWER SUB.

TRUCKiNG

GENERATOR EXTAM LABOA SUPMIES

RAMS

LONG DIES

\begin{tabular}{|l|l|}
\hline SLIP NSEAT & \\
\hline T.IW. & \\
\hline PIPE MUCK & \\
\hline SHAKER & \\
\hline Z PUMP & \\
\hline CENTRIFUGAL & \\
\hline GUARD & \\
\hline PIPE DOPE & \\
\hline MUSC. & \\
\hline & \\
\hline
\end{tabular}

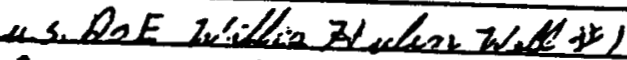
Sec 2, T.145, R4E Sesial "I5146:8

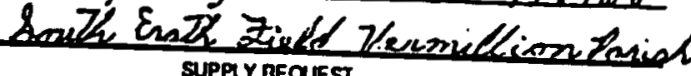
\begin{tabular}{l|l} 
ACCIOENTS \\
YES & NO
\end{tabular}
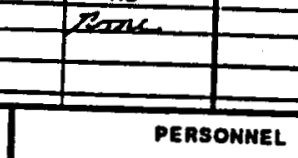

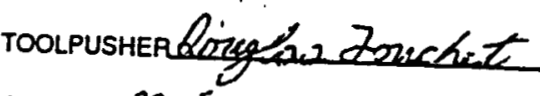
JOB NO $32-5$ ORDER NO. COMPANY REPRESENTATIVE CONTRACT NO. JOB_32-5

TERMS: NET 30 DAYS. Accounts over 30 days will be charged $11 / 2 \%$ per month not to exceed $18 \%$ ann:lly.

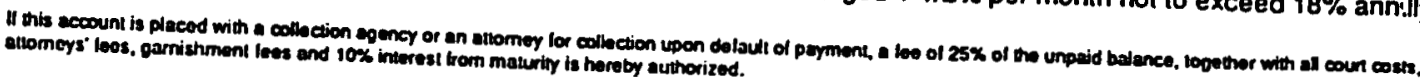
6-119 
Driting

Wortover

Complotion

Tenk Batery insulation

Purping Somos:

Salt Water Wolls

Plup a Abasdon
S

DRILLING \& WELL

SEAVICE. INC.
IOIGALEERT RD.
(318) 261.0295

(318) 261.0295
TICKET 779 म

REPOAT NO. 70 DATE $2-4-94$ WELL NO. 1 RIG NO 5

COMPANY de SRE

DAILY WORKOVER REPORT

FIELD \&oneth Enath LEASE wille' Ztuline state Il

Present Packer Setting

Present Perforations

Present Depth Type Plug

Total Depth $\left.\begin{array}{l}\text { Lavt } \\ \text { Coeing } \\ \text { soiting }\end{array}\right\}$

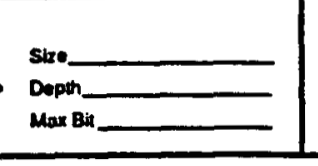

PROOUCTION PRESSURE SETTWG B. O.P. TEST PRESSURES

Rams Hydall

Mad Trpo

Mons 2 Model____

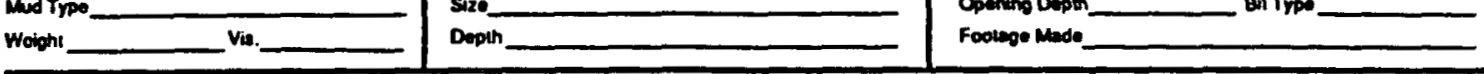

Socoen Setting

Tuting Solting

Sire.

Trpa

Ant.

DRRLL DEEPER

Cooing Deper. Ooening Depth

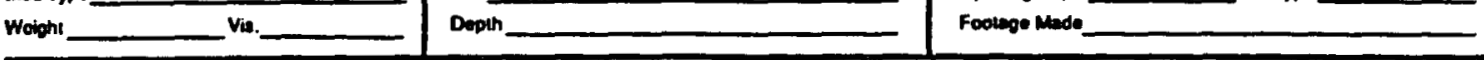

on Sizo

Bin Trpo

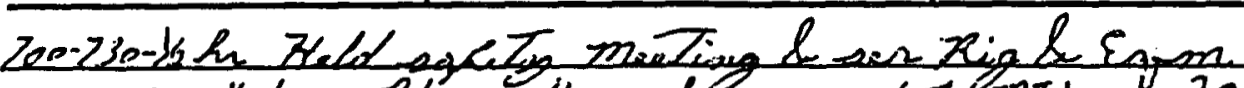

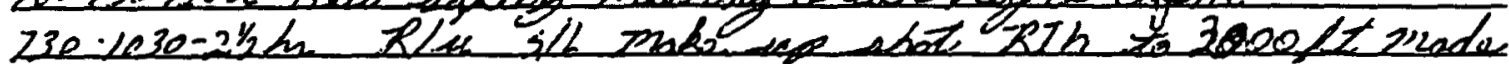
abet ziod 710 s/L

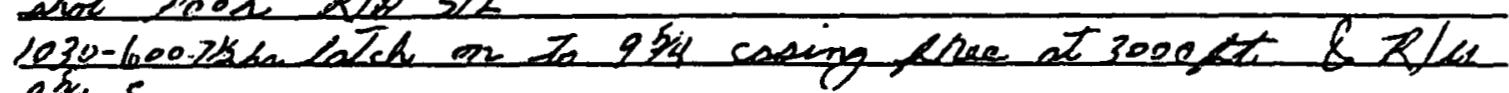
$2 \sum^{2}$ Eqem

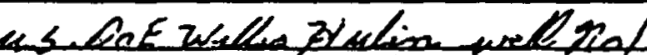

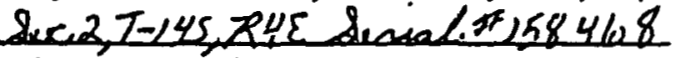

\begin{tabular}{l} 
RIG EXPENSE \\
\hline
\end{tabular}

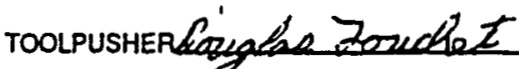
JOB NO $32-5$ OROER NO.
COMPANY REPRESENTATIVE

CONTRACT NO
J08 $32-5$

TERMS: NET 30 DAYS. Accounis over 30 days will be charged $11 / 2 \%$ per month not to exceed $18 \%$ ann!lly.

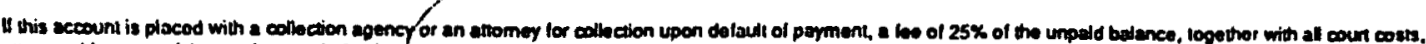

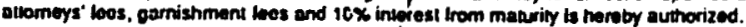


DAILY WORKOVER REPORT

companY LLS DEE

FIELO Sascith Eanth

LEASE willon Heulio

PARISH OR COUNTY Wenellliom. state 24 WELL NO._L

Present Perlorations

Present Packer Selting

Total Depth

Prosent Depth Type Plug

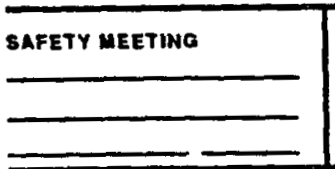

O. P. TEST PAESSURES

Noms.

und Trpe Hyorll

Weight

vis.

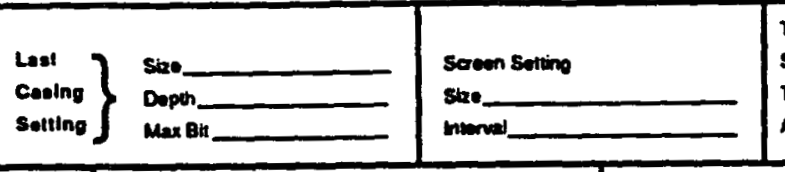

PROOUCTION PRESSURE SETTWKC

Mako 8 Model

Size

Daph
Tubing soltong

Skre

Troe

Amm

DALL DEEPER

Closing Depth.

Opening Oevph

Feotoon Mode

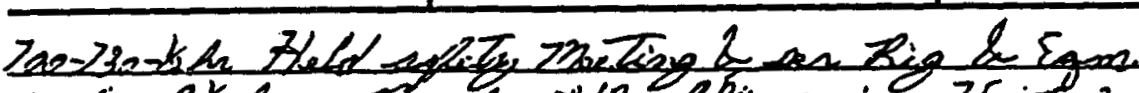

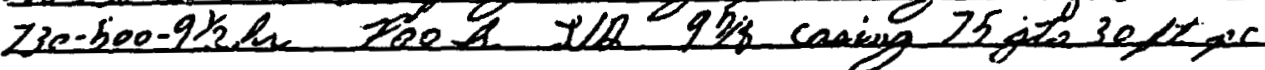

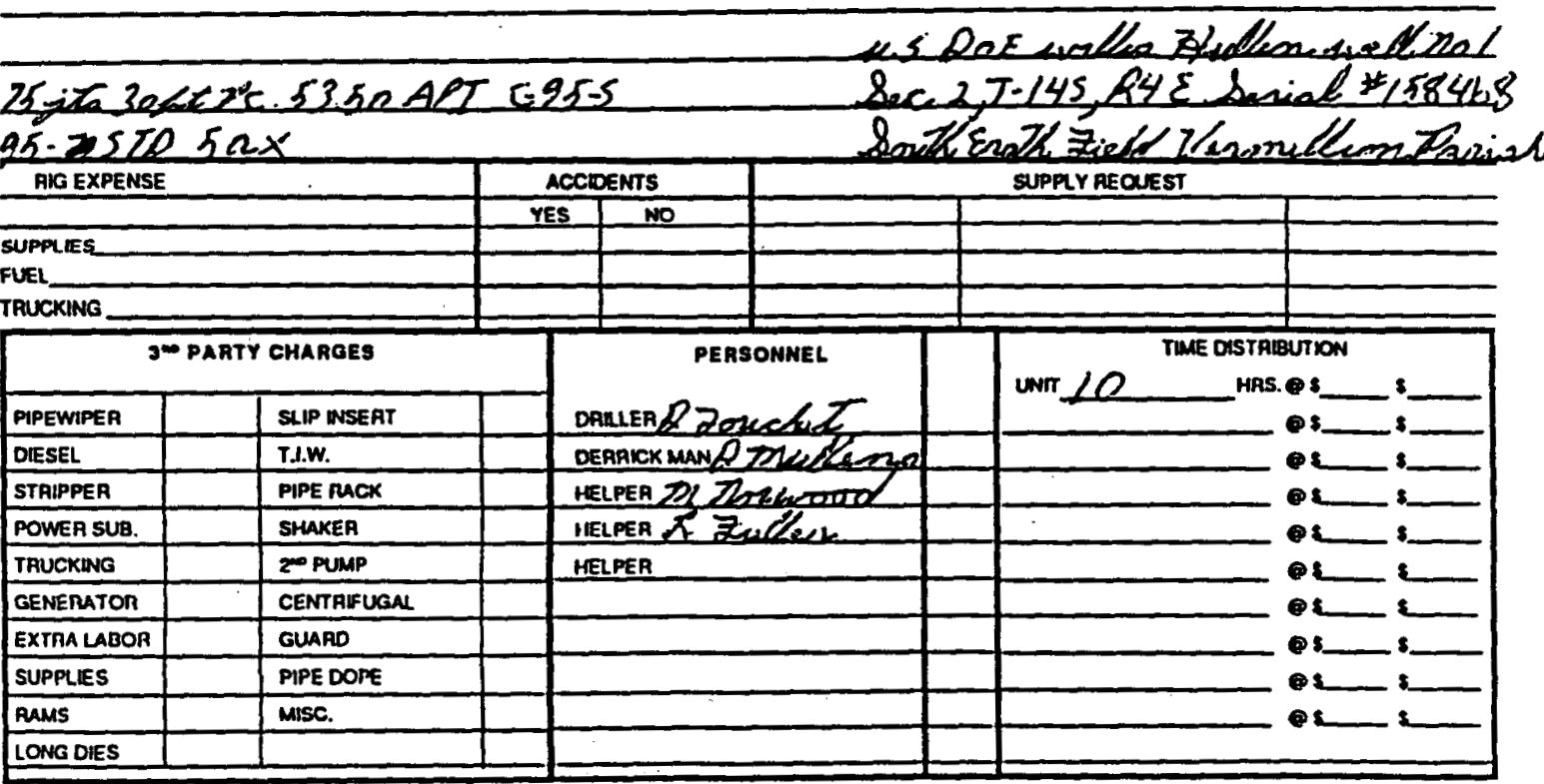

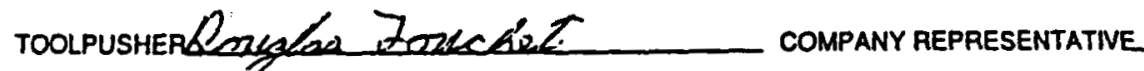
JOB NO $32-5$ ORDER NO.
CONTRACT NO_ JOB_Z2-5

TERMS: NET 30 DAYS. Accounts over 30 days will be charged $11 / 2 \%$ per month nol 10 exceed $18 \%$ ann:lly.

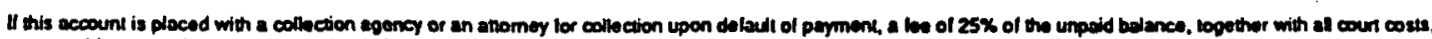
allomers" leos, parnishment lecs and lox iniorest trom maurity ls hersby authorized. 
Driling

Complotion.

Tank Batery Inatallation

Purreing Semose

Saln Water Wells

Plus \& Abandon
$S$ S

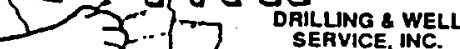
7... ? 101 GalGe INC. of LAFAYETE. LA 7050
(318) 261-0295

DAILY WORKOVER REPORT
TICKET $\% 98$

REPORT NO. 27

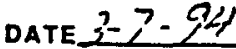
WELL NO. 1 RIG NO 5

COMPANY USPRE

FIELD Sosaté Esath

LEASEdwillia Hution state Jala.

Present Packer Sotting

Present Pertoralions

Type Plug

Total Depth

Present Depth

\section{Typo Plug}

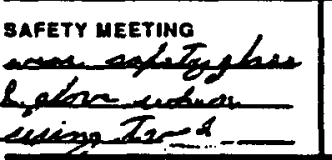
$\left.\begin{array}{l}\text { Lest } \\ \text { Casing } \\ \text { sotting }\end{array}\right\}$

Casing Depen

Max Bia

B. O. P. TEST PRESSURES

Rems Hydrill

Mud Type Hyon

Woiphi _ _ Vis

Sis.

PROOUCTION PRESSURE SETTWO

Mane a Moder

Dopeh
Tuting Sorting

Size

Type Am

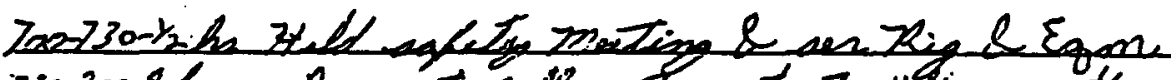

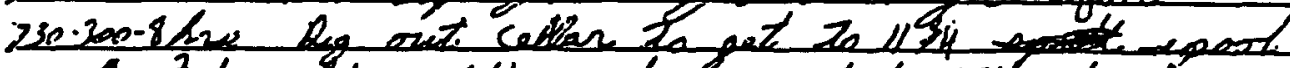

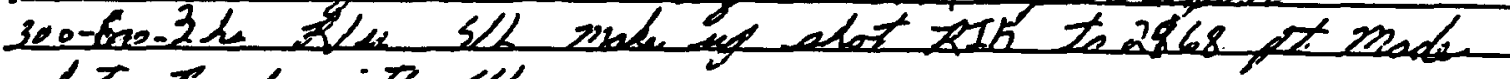
abati liod with s/L

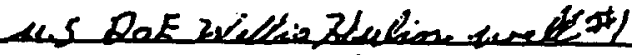
$\operatorname{Aec} 2.7-145,7425$ \&esial $\# 158468$

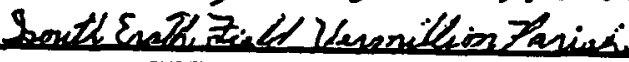

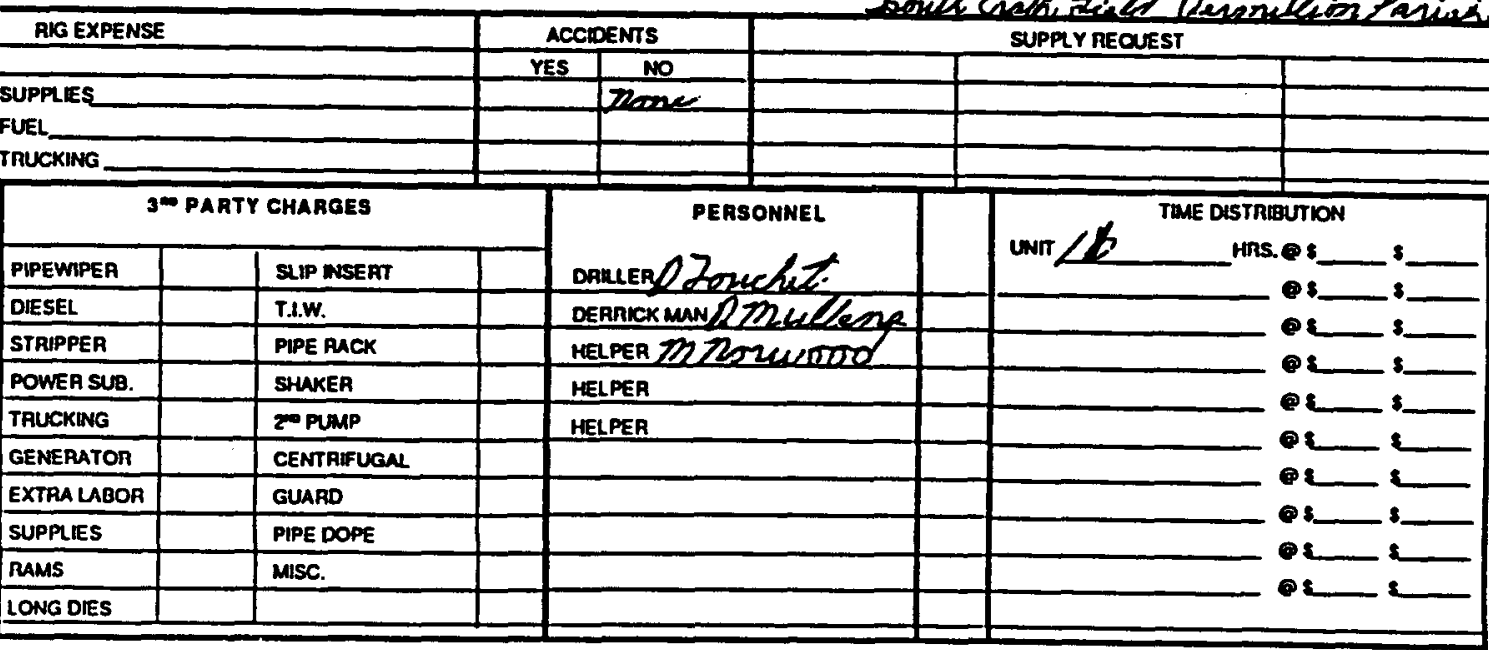

TOOLPUSHER Roryghas Zonuchet. JOB NO $32-5$ ORDER NO.
COMPANY REPRESENTATIVE

CONTRACT NO
JOB_32-5

TERMS: NET 30 DAYS. Accounts over 30 days will be charged $11 / 2 \%$ per month not to exceed $18 \%$ anmilly.

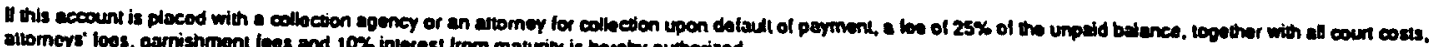
allorneys" loos, garnistmont lees and $10 x$ interest trom maturity is hereby authorized. 
companY HS. ROE

DAILY WORKOVER REPORT

FIELD bouti kasth

PARISH OR COUNTY TLermilfiom LEASE Willic Zuchion DATE $\approx 8-94$

Present Pertotalions state Ja WELL NO. L 1 RIG NO 5

Tolal Depin

Present Depth

Present Packer Setting

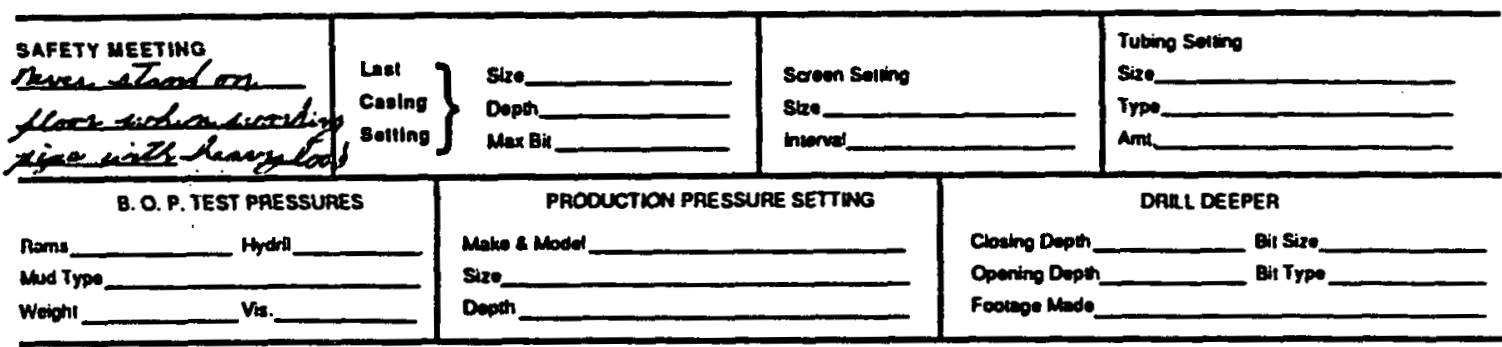

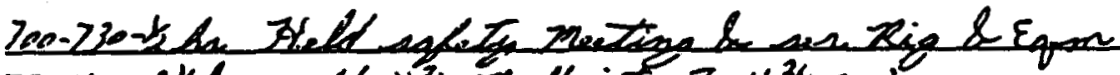

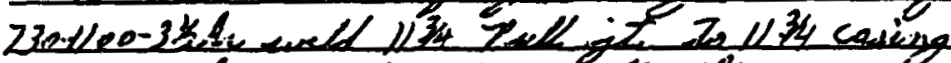

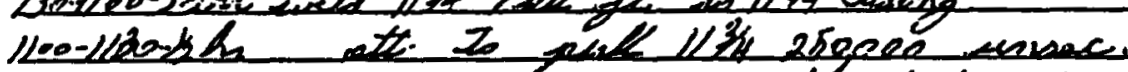

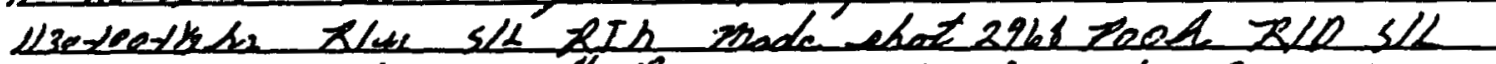

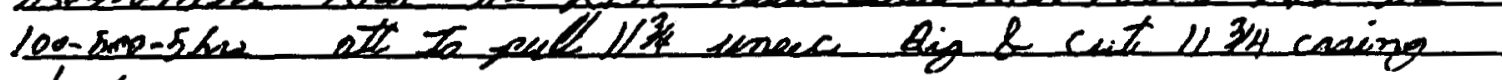
liead

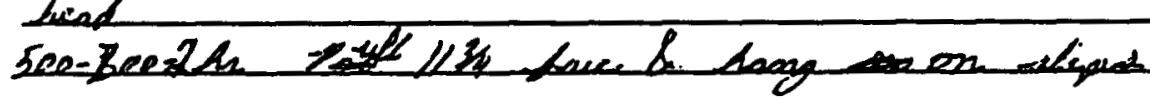

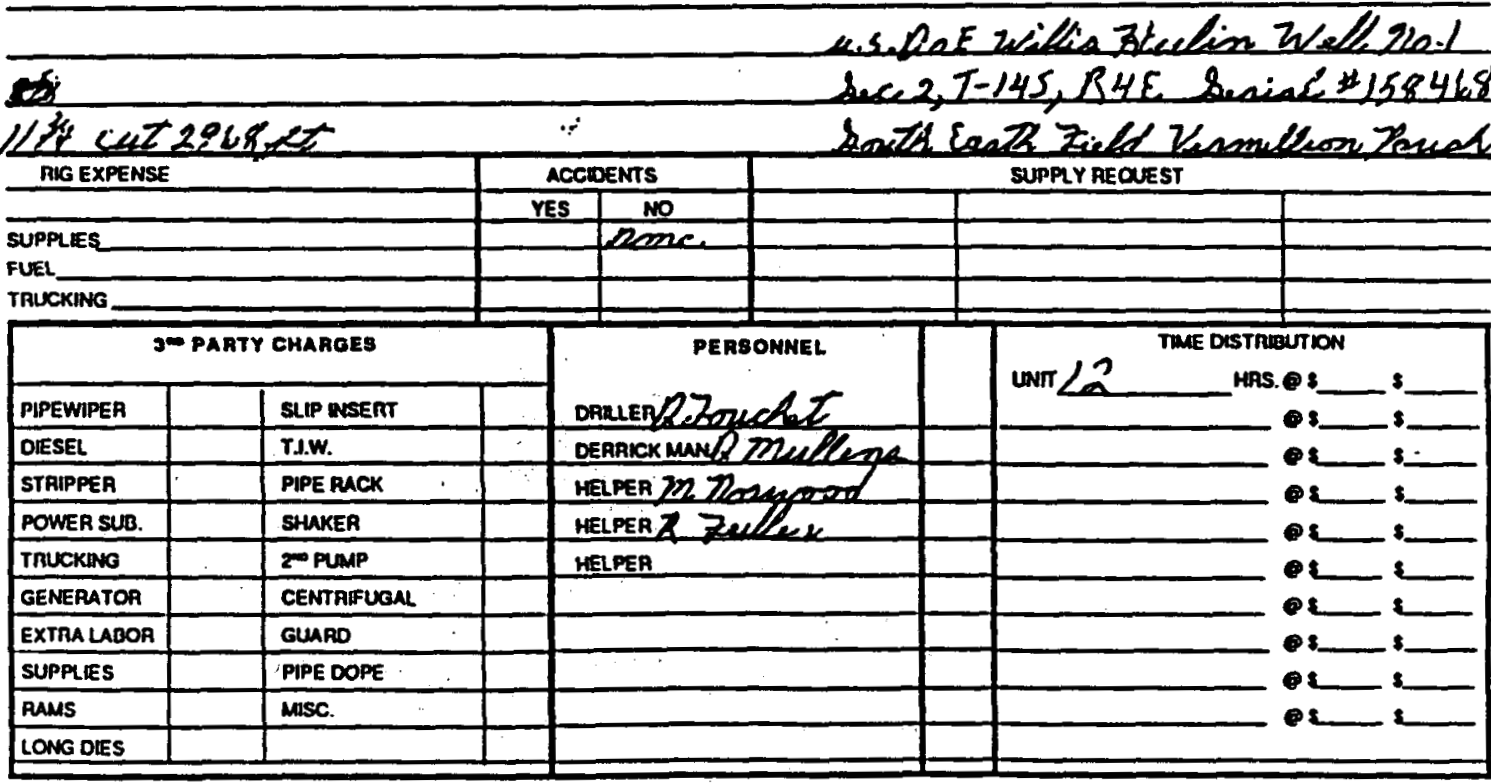

TOOLPUSHER Royglas Zonchat JOB NO $32-5$
ORDER NO.
COMPANY REPRESENTATIVE CONTRACT NO_ JOB 32.5

TERMS: NET 30 DAYS. Accounts over 30 days will be charged $11 / 2 \%$ per month not 10 exceed $18 \%$ ann:lly.

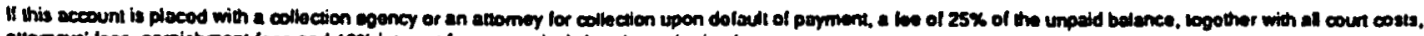
attomer' loos. parnishment leses and $10 \%$ intesest hom maturity is hernby authorized. 
COMPANYLL. L. $12=5$

DAILY WORKOVER REPORT

REPOAT NO. 24

FIELD\&ozith Enath

PARISH OR COUNTY Zurmillicon
LEASE-willeis Zluhlion state Ia
DATE $3-9-94$ WELL NO. $)$ RIG NO 5

Present Perlorations

Present Packer Selting

Total Depth Present Depth Type Plug

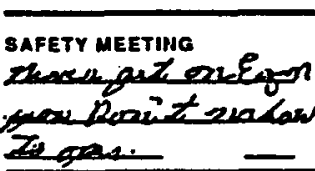
B. O. P. TEST PAESSURES

Rams

und Typo Aydit Vis.

Woight

$\left.\begin{array}{l}\text { Lest } \\ \text { Casing } \\ \text { solting }\end{array}\right\} \begin{aligned} & \text { stze } \\ & \text { Dopph } \\ & \text { Max Bu }\end{aligned}$

PROOUCTKON PRESSURE SETTWG
Matue 8 Model

Size Depth

Screen Sotion
Ske.

Tubing Soning

sine

Trpe

Ani
DRUL DEEPER

Closing Doph ___ Bir Size

Opering Depth_____ Bil Trpe

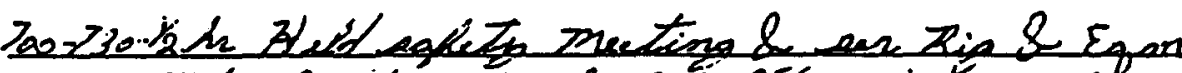

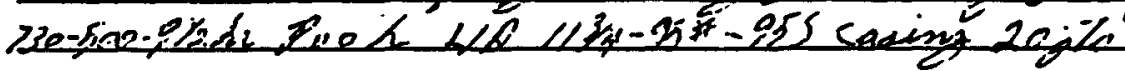

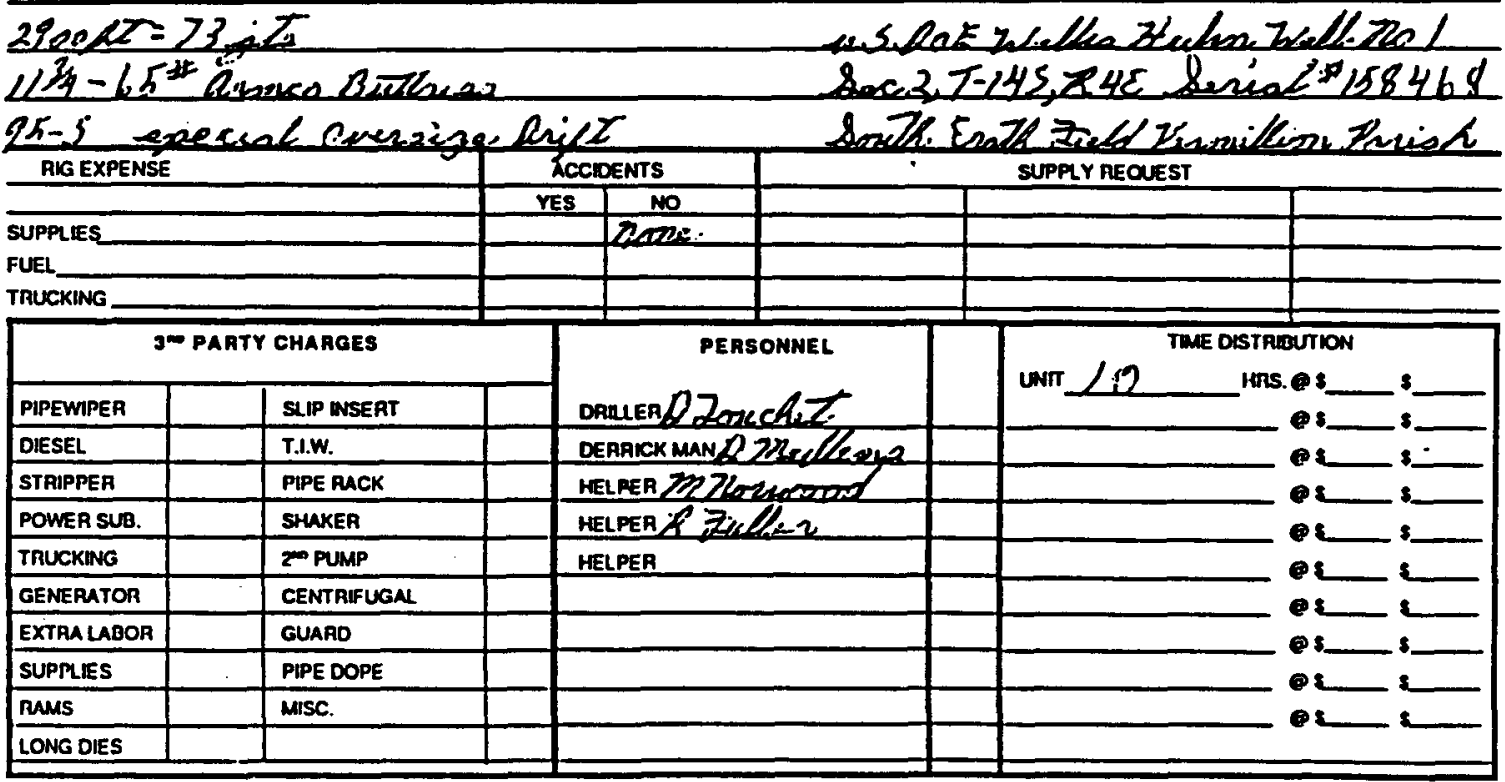

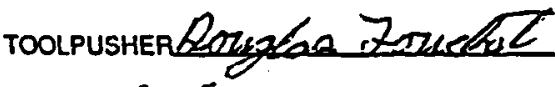
JOB NO $32-5$ ORDER NO
COMPANY REPRESENTATIVE

CONTRACT NO. $\operatorname{sog} 22-5$

TERMS: NET 30 DAYS. Accounts over 30 days will be charged $11 / 2 \%$ per month nol to exceed $18 \%$ ann:lly.

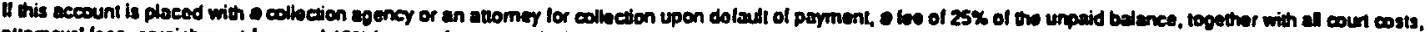
attomers" loes. parrishment lees and $10 \%$ inverest hom maturity is horeby authorited. 


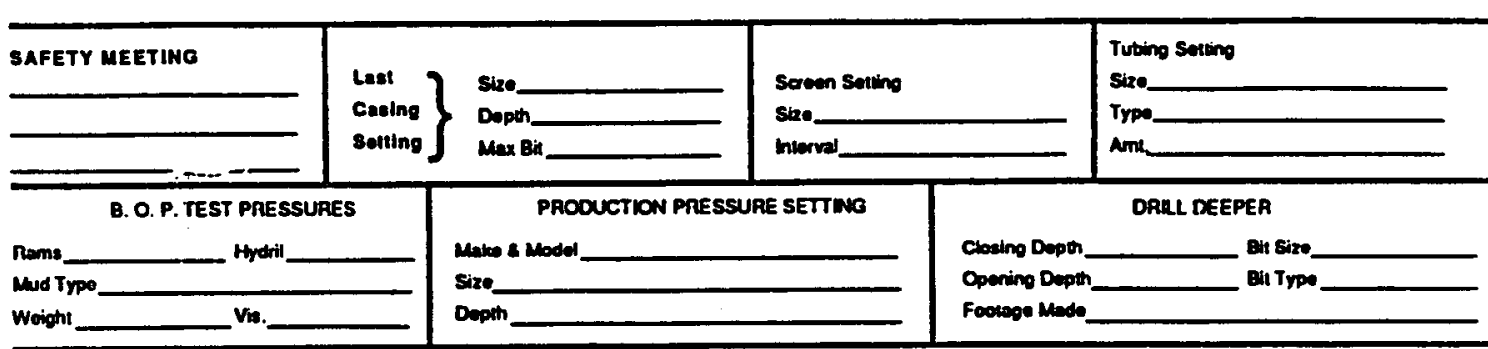

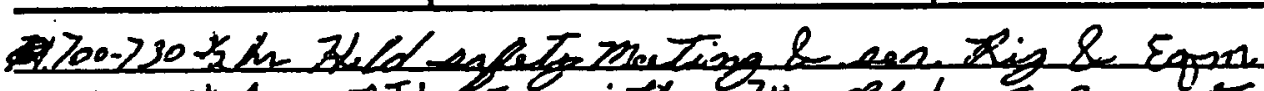

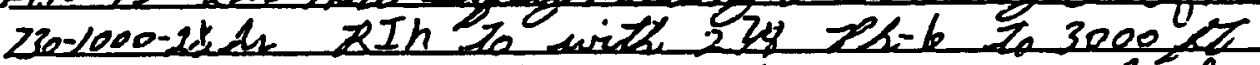

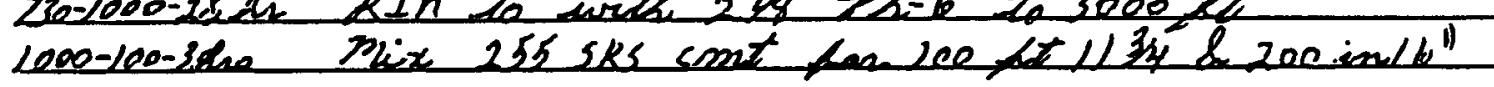

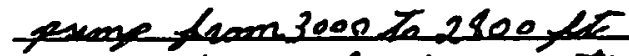
$100.500 .4 \mathrm{~h}$ tooh with $2 \% 2 \mathrm{~L}-6$ Present Packer Setting

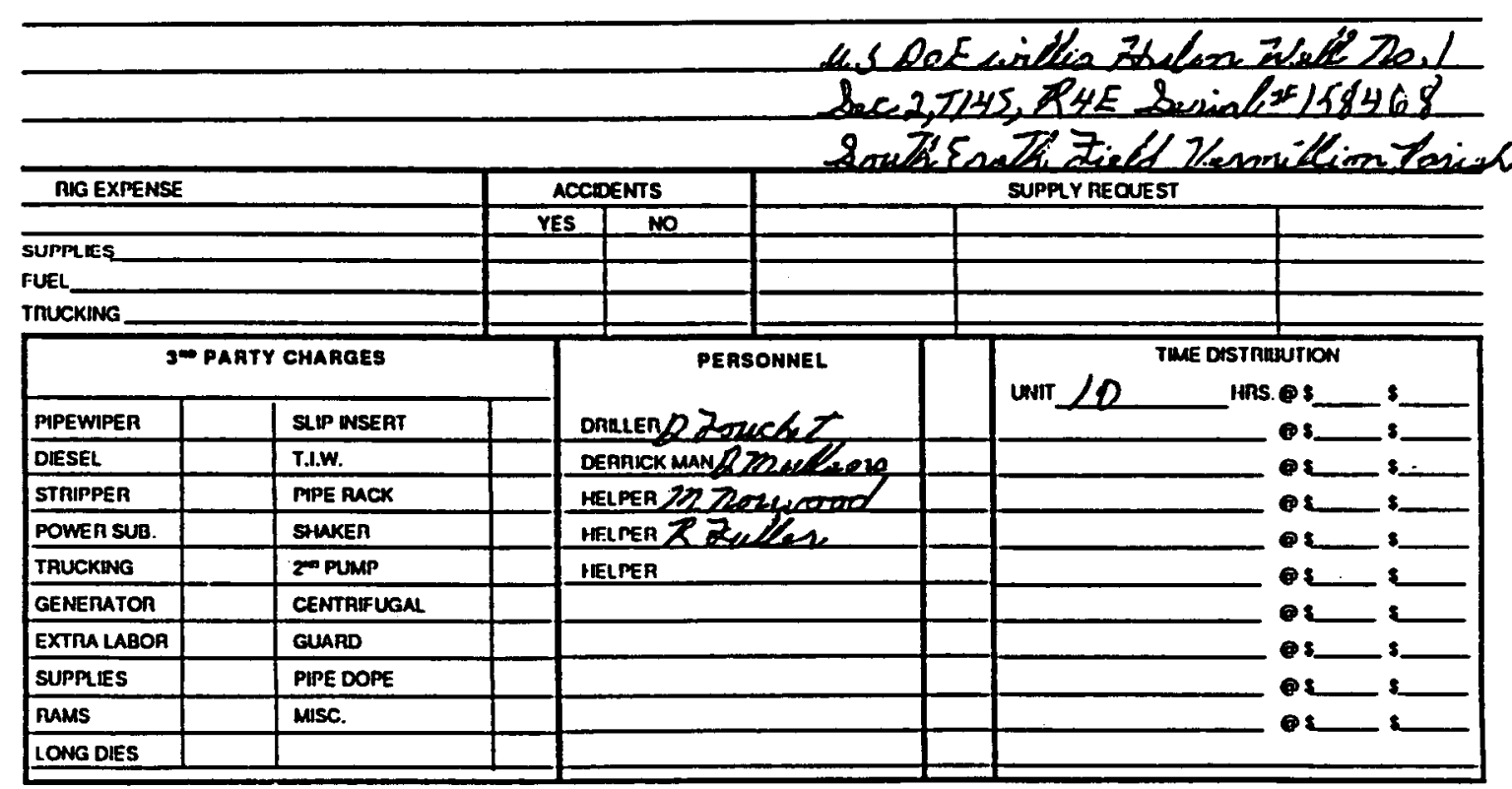

TOOLPUSHerblozelave Zoicshat JOB NO 32.5 ORDER NO.
COMPANY REPRESENTATIVE CONTRACT NO. JoB $32-5$

TERMS: NET 30 DAYS. Accounts over 30 days will be charged $11 / 2 \%$ per month nol to exceed $18 \%$ ann!lly. 
Diting

Complowion

Tank Batery instatavon

Purroing Sonvicas

Salt Water Wolle

Pleog 8 Abandon

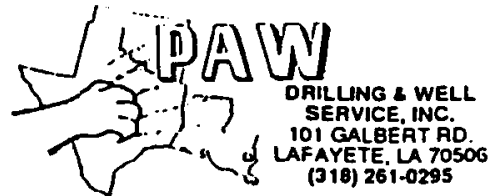

DAILY WORKOVER REPORT
TICKET /110\%

REPORT NO. $2 k$

cOMPANY WLS ROE DATE $3-11-93$

FIELD\&ozath Enath LEASEdwithis zhelien WELL NO. $j$

PARISH OR COUNTY Thenondlleon state Ia RIG NO 5

Present Perforations

Prosent Packer Sotting

Tolal Deplh

Present Depth

Typo Plug

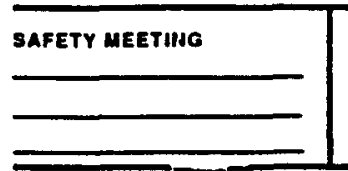

B. O. P.TEST PRESSURES

Pans. Mud Typo Hydrix

Wright

Via.

$\left.\begin{array}{l}\text { Leat } \\ \text { Cesing } \\ \text { sotting }\end{array}\right]$

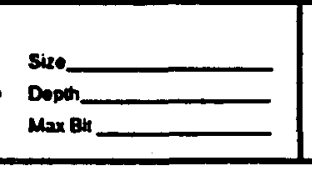

PRODUCTION PRESSURE SETTUAC

Sire.

Depeth

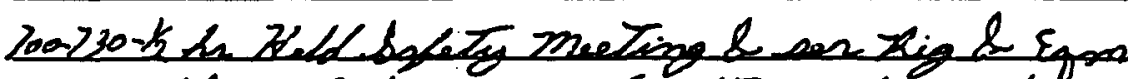

\section{$230-830-2 \mathrm{~h}$ ZIh io 2500 de ect zend 7} \$30-103e-2hes mix 2005ks cont tas 200, it cont pleyg-ioullall them $2600762309 \mathrm{ft}$

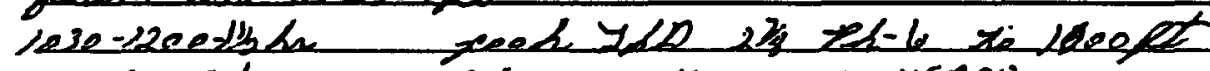

$1200-200-2 \mathrm{hr}$ mix zee sks cunti = 45ebl's

Tarepelt

$200-300$ peok to leept 2

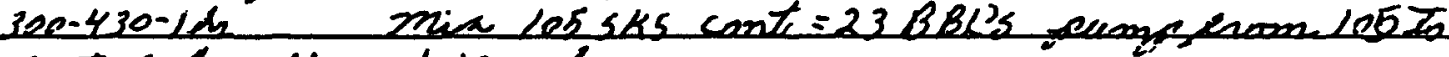
5ethelone sround Yearl $430-600-143$

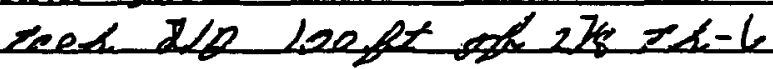

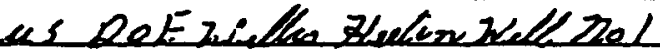

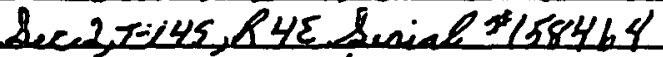

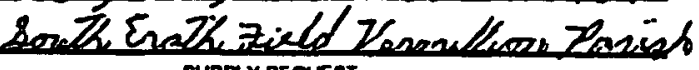

\begin{tabular}{|c|c|}
\hline \multicolumn{2}{|l|}{ RIG EXPENSE } \\
\hline \multicolumn{2}{|l|}{ SUPPLES } \\
\hline \multicolumn{2}{|l|}{ FUEL_. } \\
\hline \multicolumn{2}{|l|}{ TRUCKING. } \\
\hline \multicolumn{2}{|c|}{ 3⿻ PARTY CHAROES } \\
\hline PIPEWIPEA & SUIP WSERT \\
\hline DIESEL & T.I.W. \\
\hline STAIPPEA & PIPE RACK \\
\hline POWEA SUB. & SHAKEA \\
\hline TRUCKANG & 20 PUMP \\
\hline GENERATOR & CENTRUVUGAL \\
\hline EXTRA LABOR & GUARD \\
\hline SUPTLIES & PIPE DOPE \\
\hline RAMS & MSC. \\
\hline LONG DIES & \\
\hline
\end{tabular}
ACCDENTS SUPPLY REOEST

\begin{tabular}{|l|l}
\hline \multicolumn{2}{|c|}{ ACCENTS } \\
\hline YES & NO \\
\hline & \\
\hline & \\
\hline
\end{tabular}

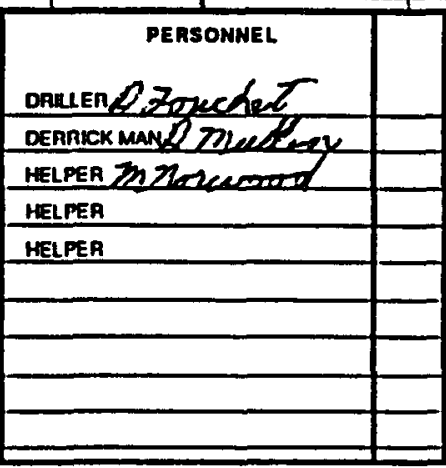

UNI $L I^{\text {TIME DISTAIBUTION }}$

TOOLPUSHER Sozghas Inectivet. JOB NO, $22-5$ ORDER NO. COMPANY REPRESENTATIVE CONTRACT NO $20832-5$

TERMS: NET 30 DAYS. Accounts over 30 days will be charged $11 / 2 \%$ per month nol 10 exceed $18 \%$ ann:lly.

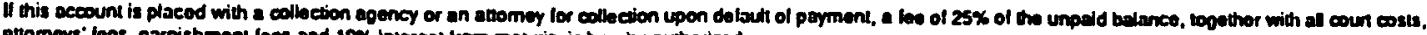
attomeys" lees, garnishmens loes and $10 \%$ interess trom maturing is heroby authorized. 
COMPANY DDE

\section{DAILY WORKOVER REPORT}

FIELR\&outh. Enate

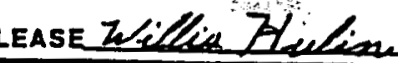

DATE $3-\angle 4-94$

PARISH OR COUNTY Tenmilliogr. state La WELL No.SLNe*I

Present Perlorations RIG NO 5

Total Depth

Present Depth

Present Packer Setting

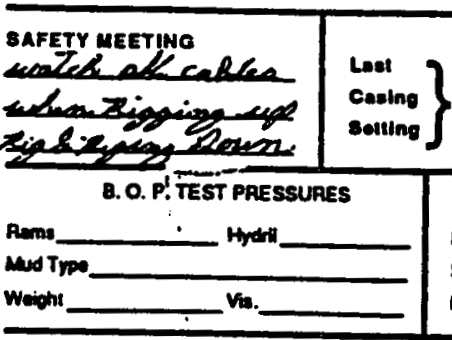

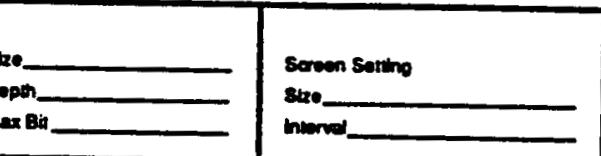

PROOUCTION PRESSURE SETTUNE Merses s moder

Size. Depth
Type Plug

DRUL OEEPER

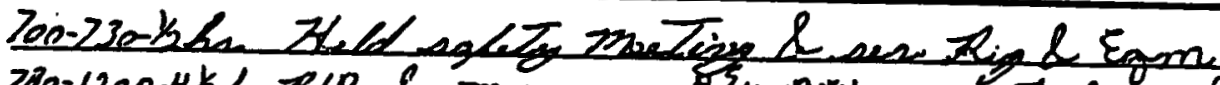

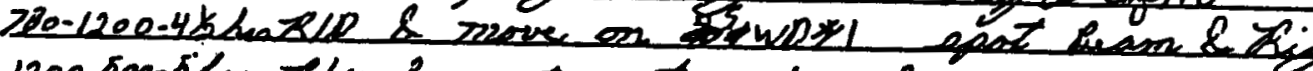

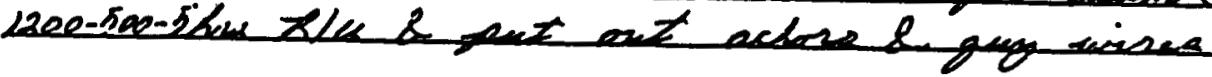

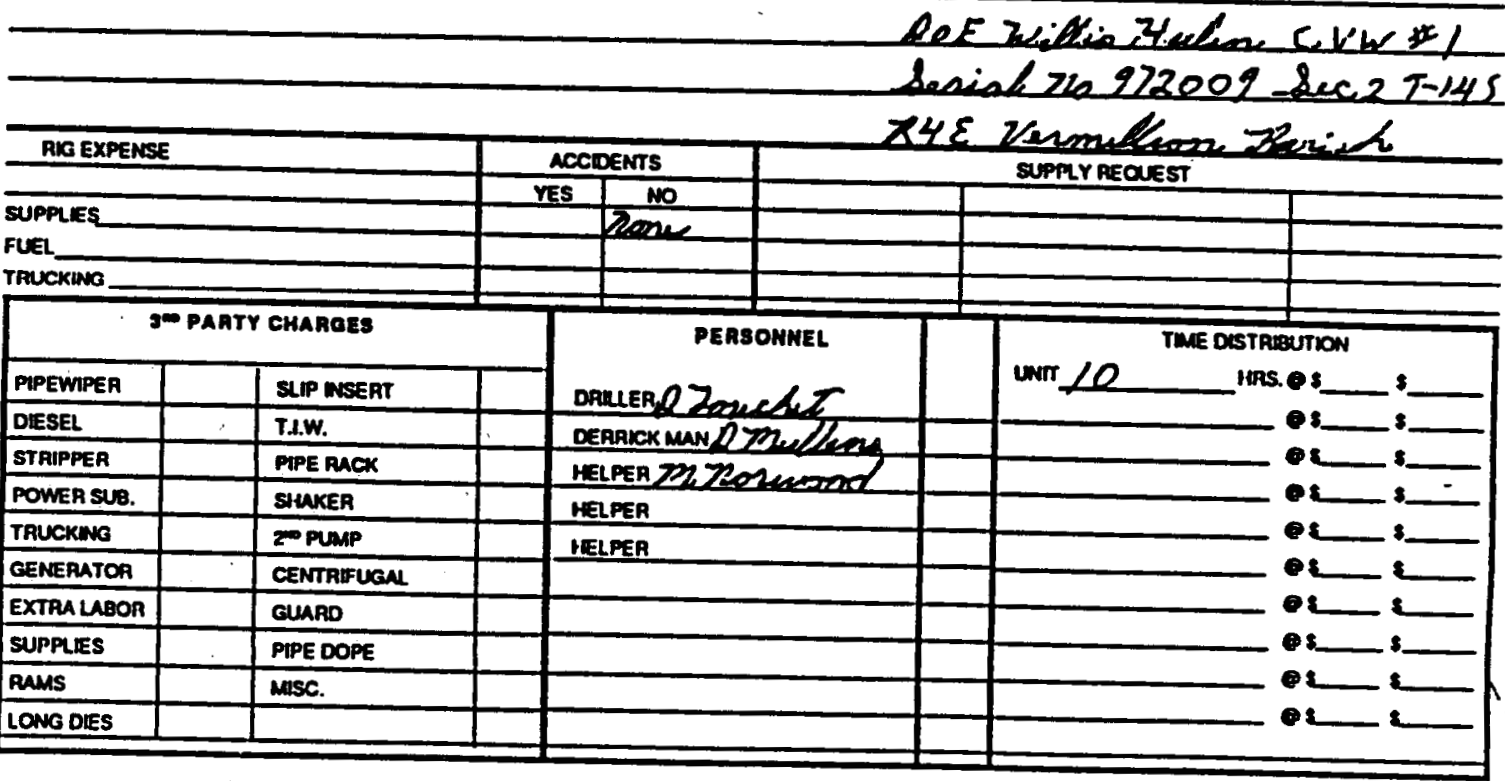

TOOLPUSHer Razegha Zonchity JOB NO $33-5$ ORDER NO
COMPANY REPRESENTATIVE CONTRACT NO лов $33-5$

TERMS: NET 30 DAYS. Accounts over 30 days will be charged $11 / 2 \%$ per month not 10 exceed $18 \%$ ann!lly.

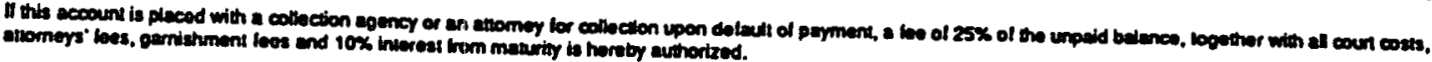




\section{Horiover}

Compiotion

Tent Banay inatulation

Purreing Sermeas

Suln Wain Welle

Pluo 4 Abendon

company $27 \%$

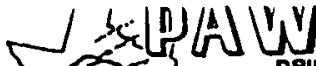

DAREAVG WELL WLL

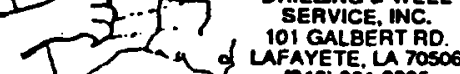

(B18) $261-0285$

DAILY WORKOVER REPORT

FIELL \&onells. Ea:ll.

PARISH OR COUNTY T'ermilleimese

LEASEZlillia Ztuham. state ja

Presont Packor Selting

Present Pertorations

Present Depth

Type Plug

Total Depth

Lot

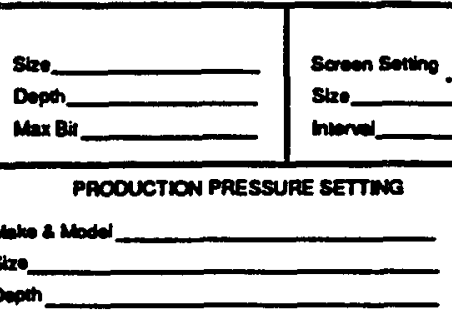

Tutions Sering

ses_of

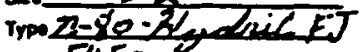

ind 350

DAUL OEEPEA

Cloaing Demph______ Bit Sirso

Coming Depth

Butro

Fookeng Mende

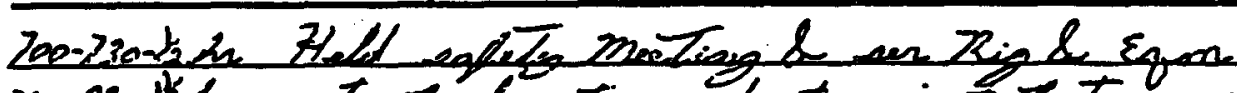

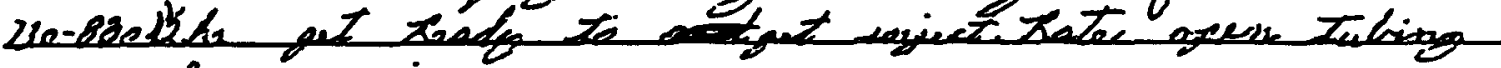
0 poran \& a exs casint

2iso-ijomen

930-1300-2k/m

iquect pesalis at epoen

to 6500 er fimal tmary paran $200^{*}$

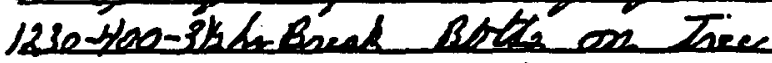

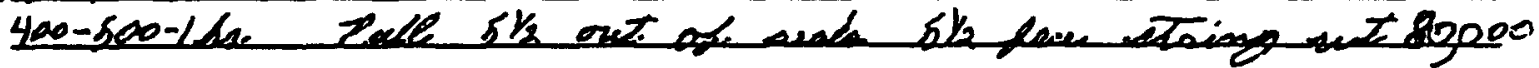

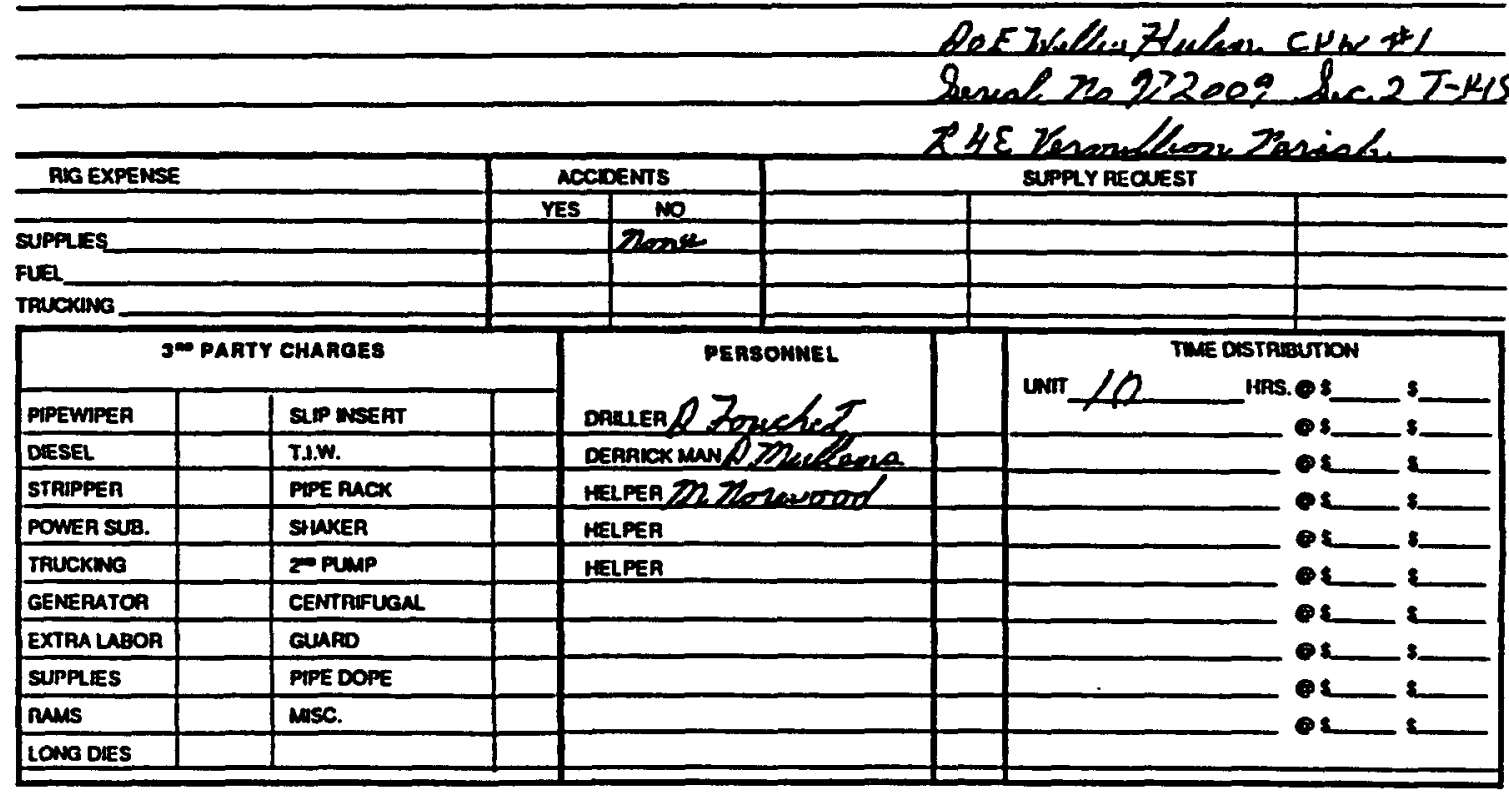

TOOLPUSHER Llonglaw Zozeckat JOB NO $33-5$ ORDER NO.
COMPANY REPRESENTATIVE

CONTRACT NO
JOB. $3.3-5$

TERMS: NET 30 DAYS. Accounts over 30 days will be charged $11 / 2 \%$ per month not to exceed $18 \%$ annilly.

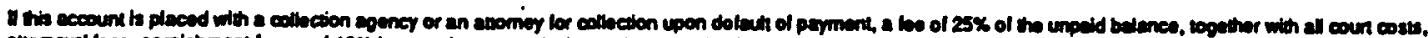

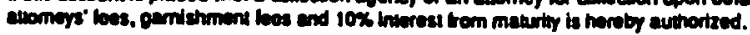




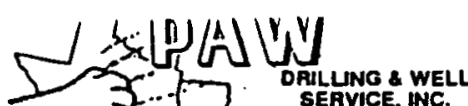

1:2. 101 GALEERT RO.

1O1 GALEERT AO.

(310) 261 -0285

DAILY WORKOVER REPORT

COMPANY DOE

LEASELitillis Z Xeclion. state $\mathscr{L}$

PARISH OR COUNTY Jesuritllían
TICKET / /OS

REPORT NO. 3

DATE $3-1 k-94$ WELL NO.SWLR \pm 1 RIG No 5

Presont Packer Solting

Present Perdorations

Present Deplh

Typo Plug

Total Depth

$\left.\begin{array}{l}\text { Lest } \\ \text { Coulng } \\ \text { solling }\end{array}\right\}$

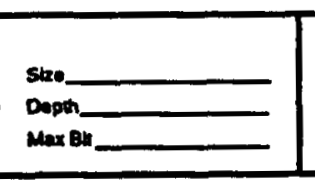

PRODUCTION PRESSUAE SETImV Malue \& Model

size.

Dopth

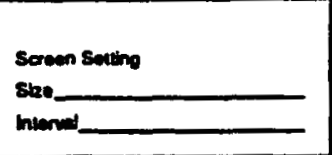

senosing $51 / 27$

Troo $\bar{Z}-80-7 y$ sil $E I$

$\mathrm{am}$ <460

Reons Hratil

Waid The vir.

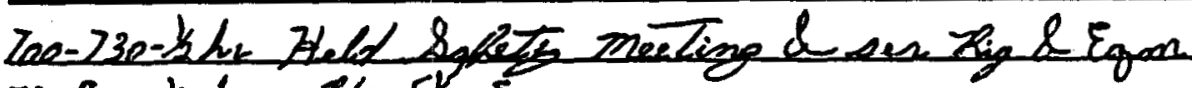

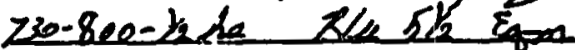

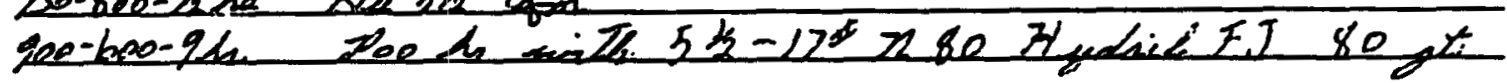

AIG EXPENSE

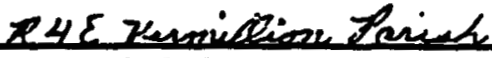

\begin{tabular}{l|l|l|}
\hline RUG EXPENSE & \multicolumn{2}{|c}{ NCCIOENTS } \\
\hline & YES & MO \\
\hline SUPPLIES & & \\
FUEL & & \\
TRUCKNG & & \\
\hline
\end{tabular}

TRuYCrang

\begin{tabular}{|c|c|c|}
\hline \multicolumn{3}{|c|}{ J" PARTY CHAROES } \\
\hline PIPEWIPEA & SLIP WSEAT & \\
\hline DIESEL & T.I.W. & \\
\hline STRIPPEA & PIPE RICK & \\
\hline POWER SUS. & SHAKER & \\
\hline TRUCKANG & Z0 PUMPP & \\
\hline GENERATOR & CENTAIFUEAL & \\
\hline EXTRA LABOA & GUARD & \\
\hline SLPPLIES & PIPE DOPE & \\
\hline raus & masc. & \\
\hline LONG DIES & & \\
\hline
\end{tabular}

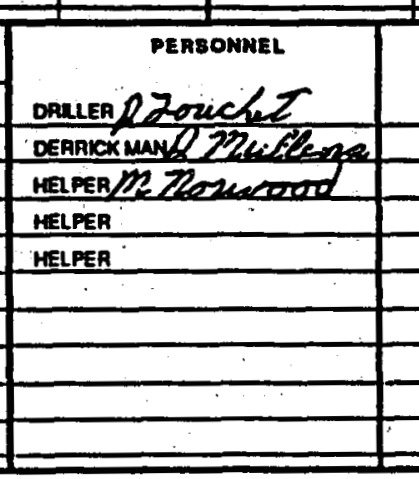
EUPPLYREQUEST

JOB NO 33.5 ORDER NO.

COMPANY REPRESENTATIVE

CONTRACT NO งов $33-5$

TERMS: NET 30 DAYS. Accounts over 30 days will be charged $11 / 2 \%$ per month not to exceed $18 \%$ annsly.

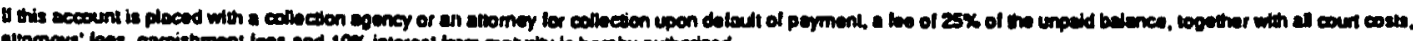

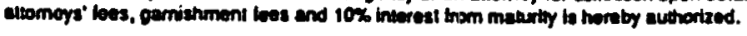


company BOE LEASEZTillia ZJulion DATE $3-17-94$

FIELr Saith sacuth. PARISH OR COUNTY Theimalleosa state La. WELL NO.SWR \#) RIG NO 5

Present Pertorations

Present Packer Setting

Tolal Depth Present Depth Typo Plug

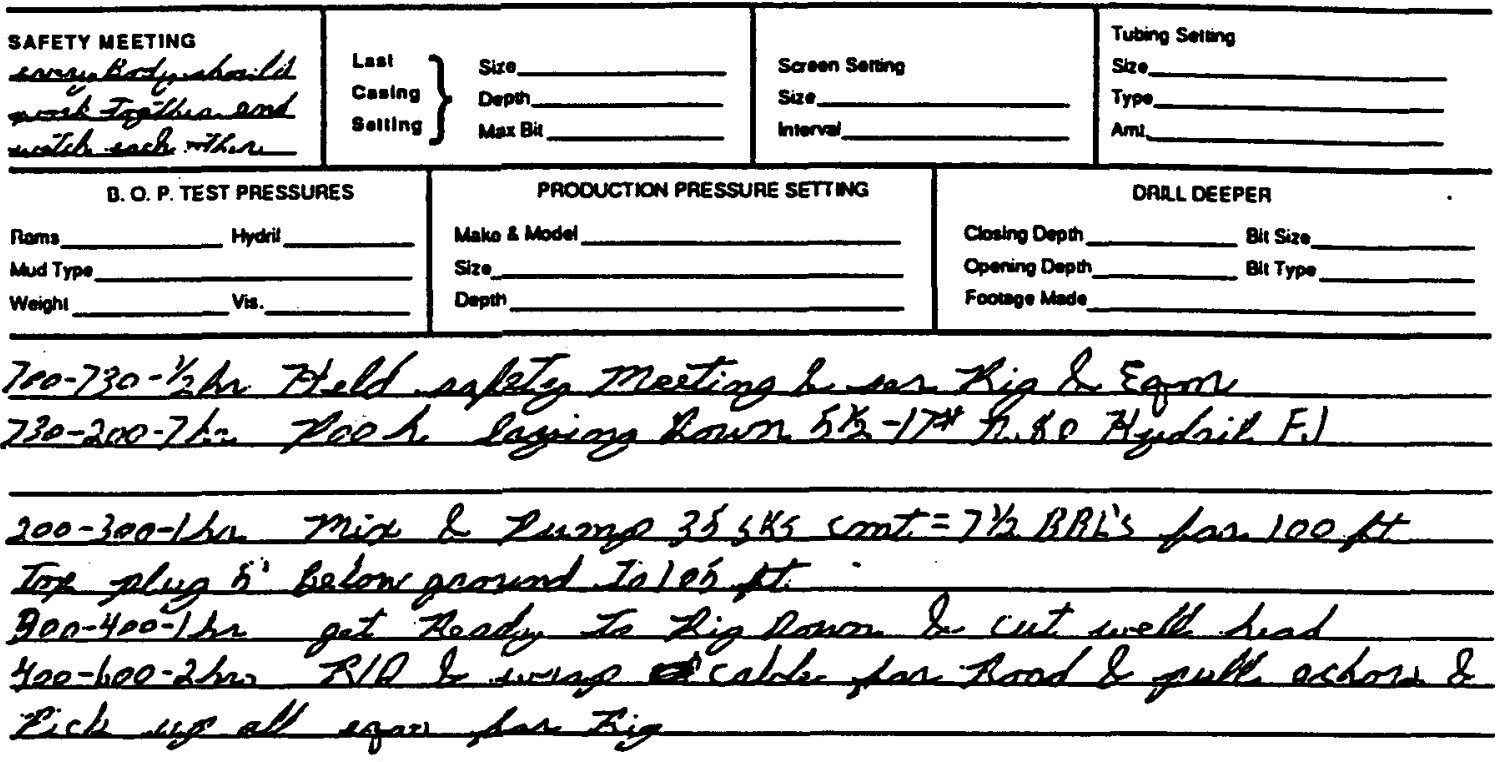

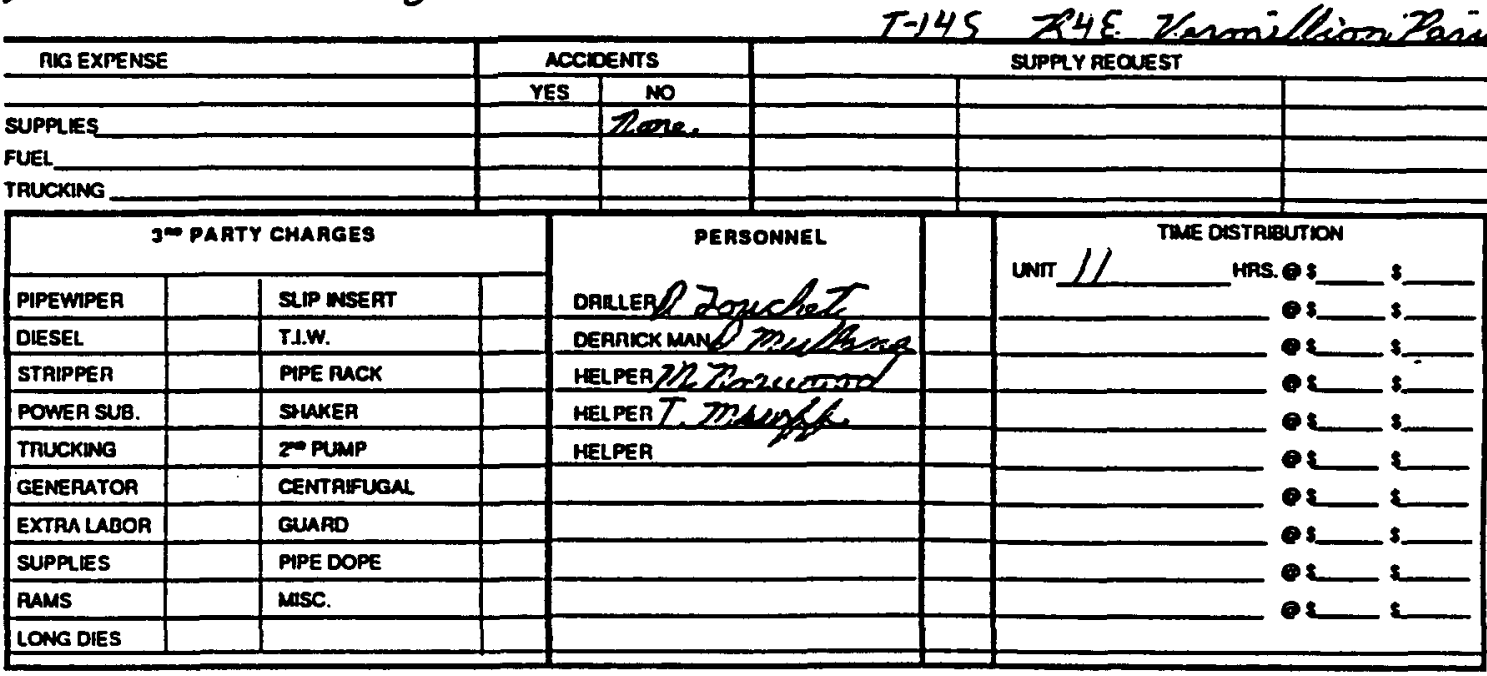

TOOLUSHER flogetaz Zomechet دOB NO $33-5$ ORDER NO. COMPANY REPRESENTATIVE CONTRACT NO. лов $33 \div 5$

TEAMS: NET 30 DAYS. Accounts over 30 days will be charged $11 / 2 \%$ per month nol to exceed $18 \%$ ann:lly.

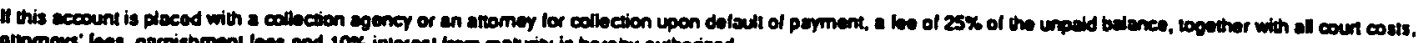

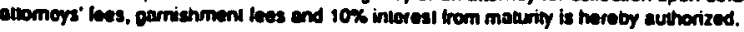




\section{EXHIBIT 6-P}

Current Condition of Willis Hulin Well Site 

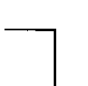


\section{CURRENT CONDITION OF WELLS}

1. WILLIS HULIN PRODUCTION WELL

(A) Surface pressure: 7,600 psi - 2000' of diesel is on top of the $9 \| / g a l$ brine.

(B) Bottom hole pressure: $\pm 18,000$ psi

(C) Bottom hole temperature: $\pm 350^{\circ} \mathrm{F}$

(D) Special problems:

(1) $17.2 \| / \mathrm{gal}$ mud is in the $3-1 / 2^{\prime \prime} \times 6.05^{\prime \prime}$ annulus.

(2) The well was drilled by The Superior Oil Company. Prior to the workover, pressure was on $9-5 / 8^{\prime \prime} \times 11$ $3 / 4^{\prime \prime}$ annulus, the $9-5 / 8^{\prime \prime} \times 6.05$ annulus and the 3 $1 / 2 " \times 6.0-5 "$ annulus.

(3) The 5" tieback at 19,192' was partially collapsed and had to be opened using a watermelon mill.

(4) There are two packers in the 6.05" casing. The bottom one has the packing mandrel up for an outside seal and the top has a normal seal bore assembly.

(5) As shown in the well schematic, each of the annuli has little cement in them.

(6) Due to the 1-13/16" valves on the wellhead, a small thru tubing wireline gun was used to perforate and the perforations are probably quite small.

(7) There is a methane gas cap $\pm 500^{\prime}$ with $\pm 20 \% \mathrm{CO}_{2}$
and $2 \% \mathrm{H}_{2} \mathrm{~S}$.

2. WILLIS HULIN SALTWATER DISPOSAL WELL

(A) There is no pressure on this well.

(B) The bottom hole temperature is probably less than $180^{\circ} \mathrm{F}$.

(C) The well had to be acidized twice to reduce the injection pressure.

(1) There is a possibility that this well has backflowed and sanded up.

(2) Several barrels of mud were inadvertently flowed into the disposal formation during the short test, due to collapsed filters. It is doubtful that enough brine was injected to disperse it very far from the well bore. 

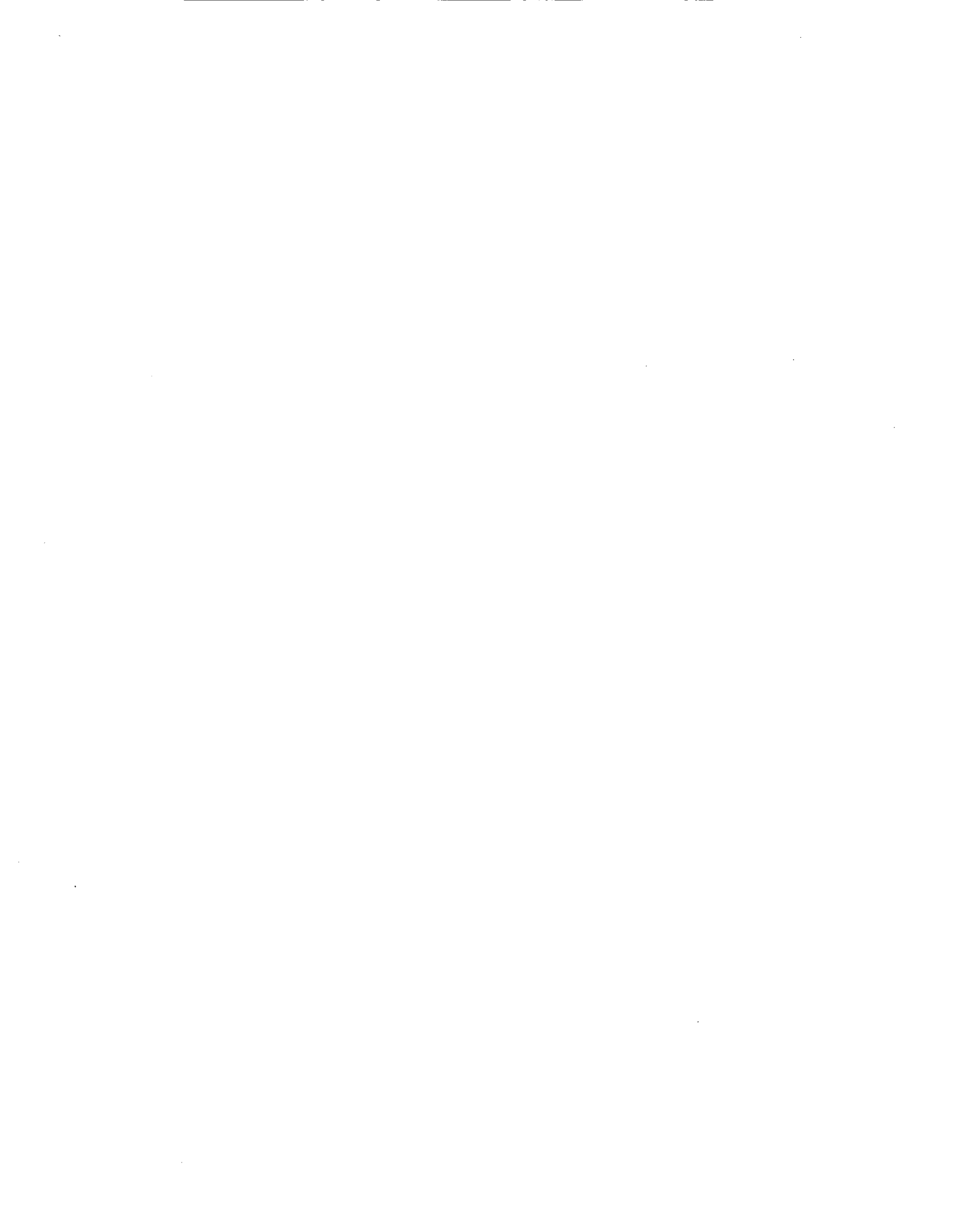


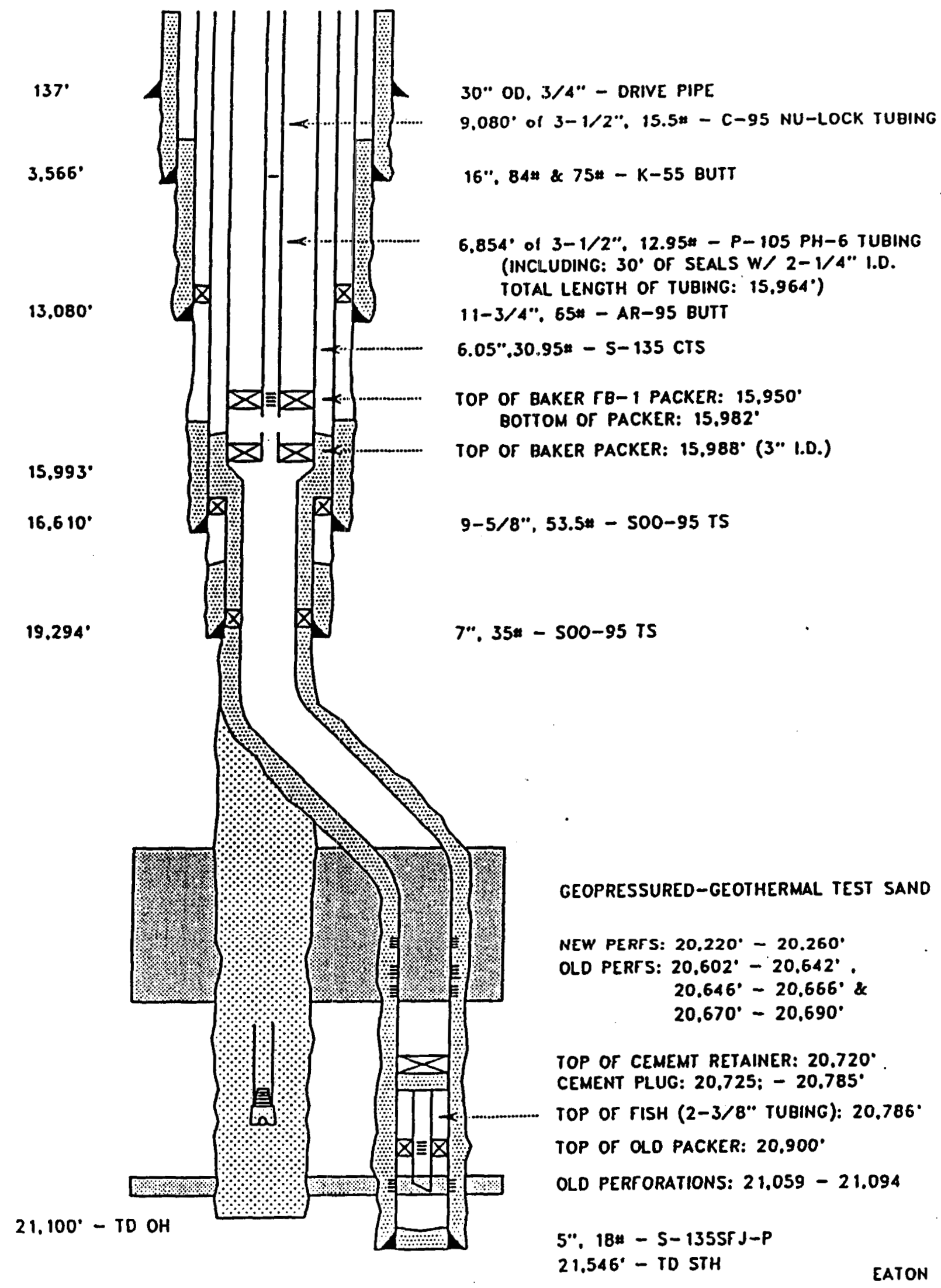

Figure 6-3. Willis Hulin No. 1 well schematic as completed by EOC, January 3, 1990. 


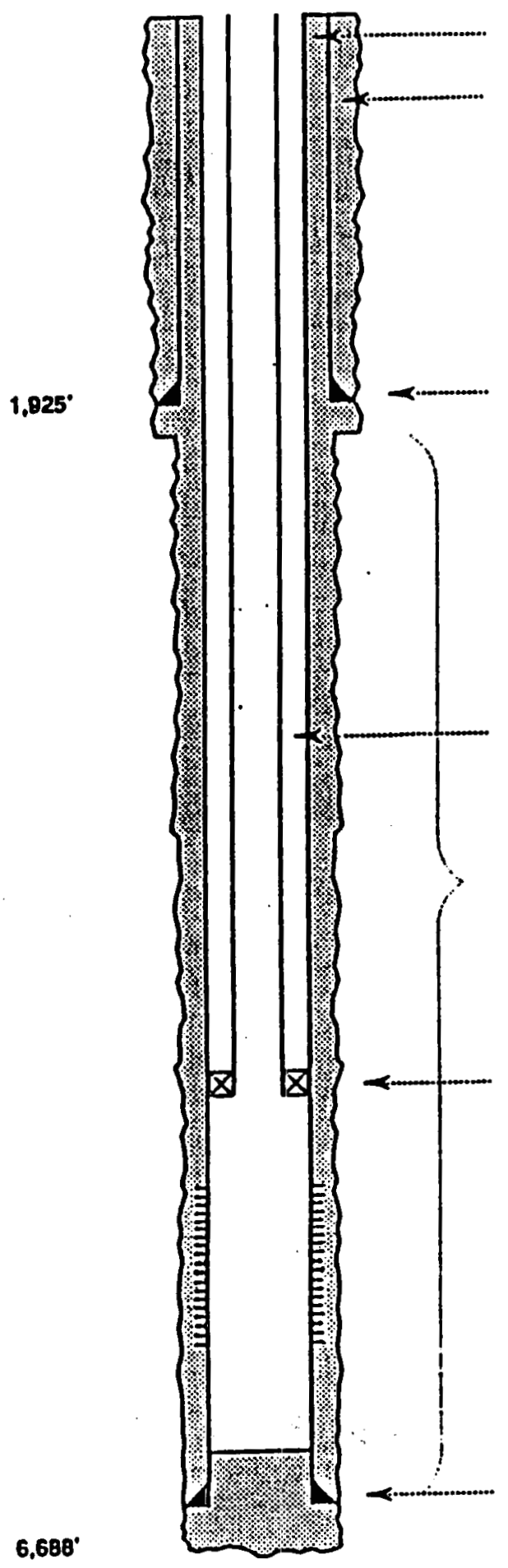

HTLD \& PAEMIUM CEMENT: 1,361 SACKS, TOP OF CEMENT: $0^{\circ}$

HTLD \& PREMIUM CEMENT: 1.470 SACKS. TOP OF CEMENT: $0^{\circ}$

17-1/20 HOLE

13-3/8 54.50\% K-5S STC SURFACE CASWO: $0^{\circ}$ TO $1.825^{\circ}$

5-1/2 17.00 N N-80 HYORIL FJ WNECTION

TUBING: $0^{\circ}$ TO 5,450'

PERMITTED DISPOSAL ZONE: 2,000' TO 6,700"

9.5/8' TIW SS-BB PERMANENT

PACKER SET $85,450^{\circ}$

6,530' TO 6,590', WJECTION PEAFORATIONS

PETO 6,644:, DAILLED OUT TO

0.5/8* 43.50 N-80 SFJP CASING, $0^{\circ}$ TO 6,687"

TOTAL DEPTH; $6,688^{\circ}$

EATON - KPP

Figure 6-4. Willis Hulin CVW No. 1 well schematic as completed by EOC, February 28, 1989. 
PACRER INFORMATION

WILLIS HULIN NO. 1

Type: (Top Packer) $\begin{gathered}\text { Baker 45-30 FB-1 Retainer Production } \\ \text { Packer }\end{gathered}$

Set at $-15,950^{\prime}$

Length Feet - 2.38

O.D. Inches - 4.562

I.D. Inches - 3.00

40-30 Seal Bore Extension

Length Feet - 19.34

$0 . D$. Inches - 3.780

I.D. Inches - 3.00

Concentric Coupling

Length Feet - .66

O.D. Inches - 4.440

I.D. Inches - 3.00

40-30 Seal Bore Extension (end of tool)

Length Feet - 9.64

$0 . D$. Inches - 3.780

I.D. Inches - 3.00

Total length (top packer) - 32.02 Feet

Type: (Lower Packer) Baker 45 FA-36 Retainer Production Packer

Length Feet -2.43

$0 . D$. Inches - 4.562

I.D. Inches $3.625 \times 3.00$

WILLIS HULIN CVW NO. 1

Type: TIW SS-BB Perm. Packer 5,450.00' to 5,473.25'

Packer and Seal Bore Extension - 23.25'

Packer I.D. - 6.00"

Seal Bore Assembly $17.36^{\prime}$ long with 5.8125 "I.D. 


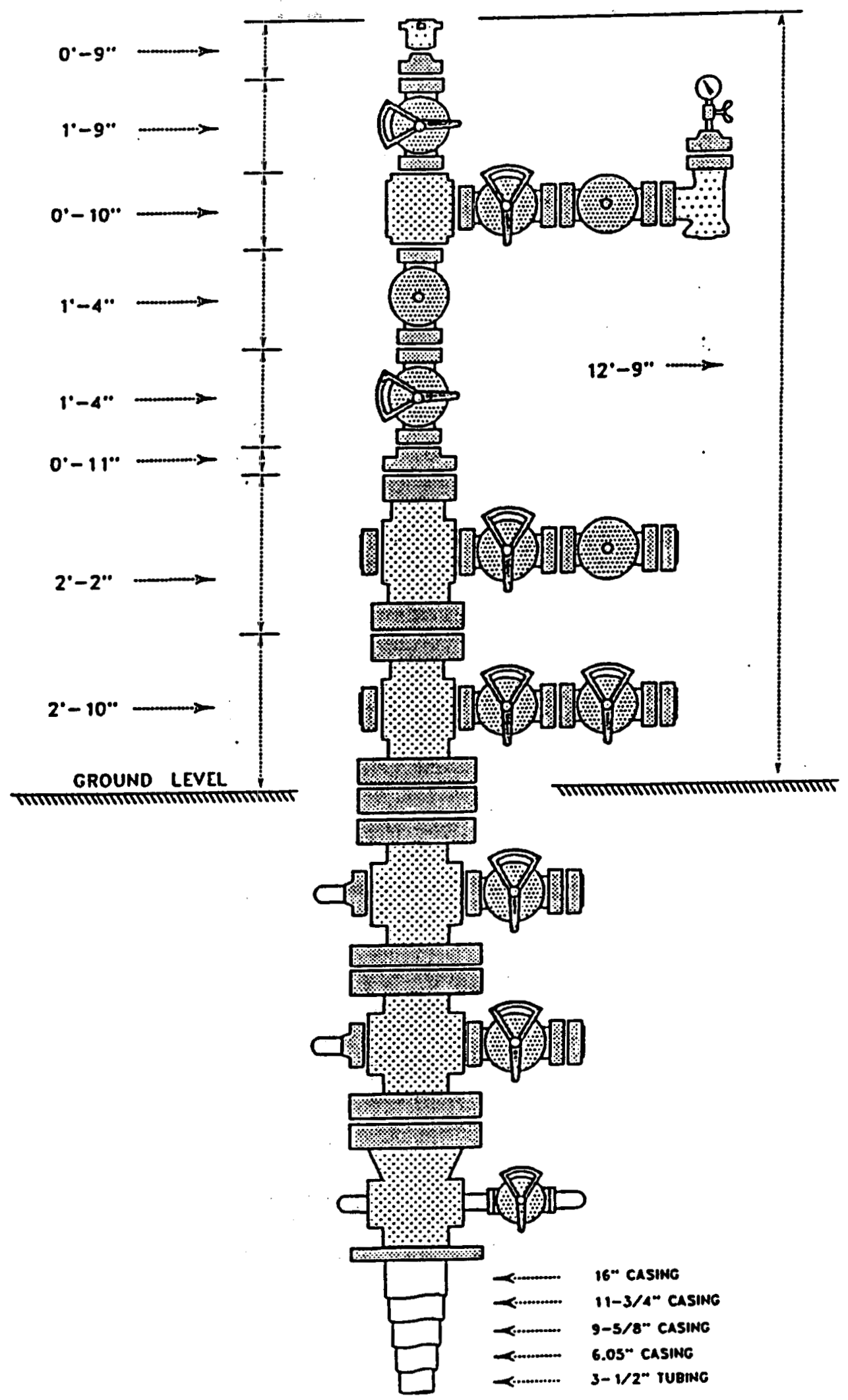

Figure 6-5a. Willis Hulin No. 1 wellhead dimensions schematic as of October 1990. 


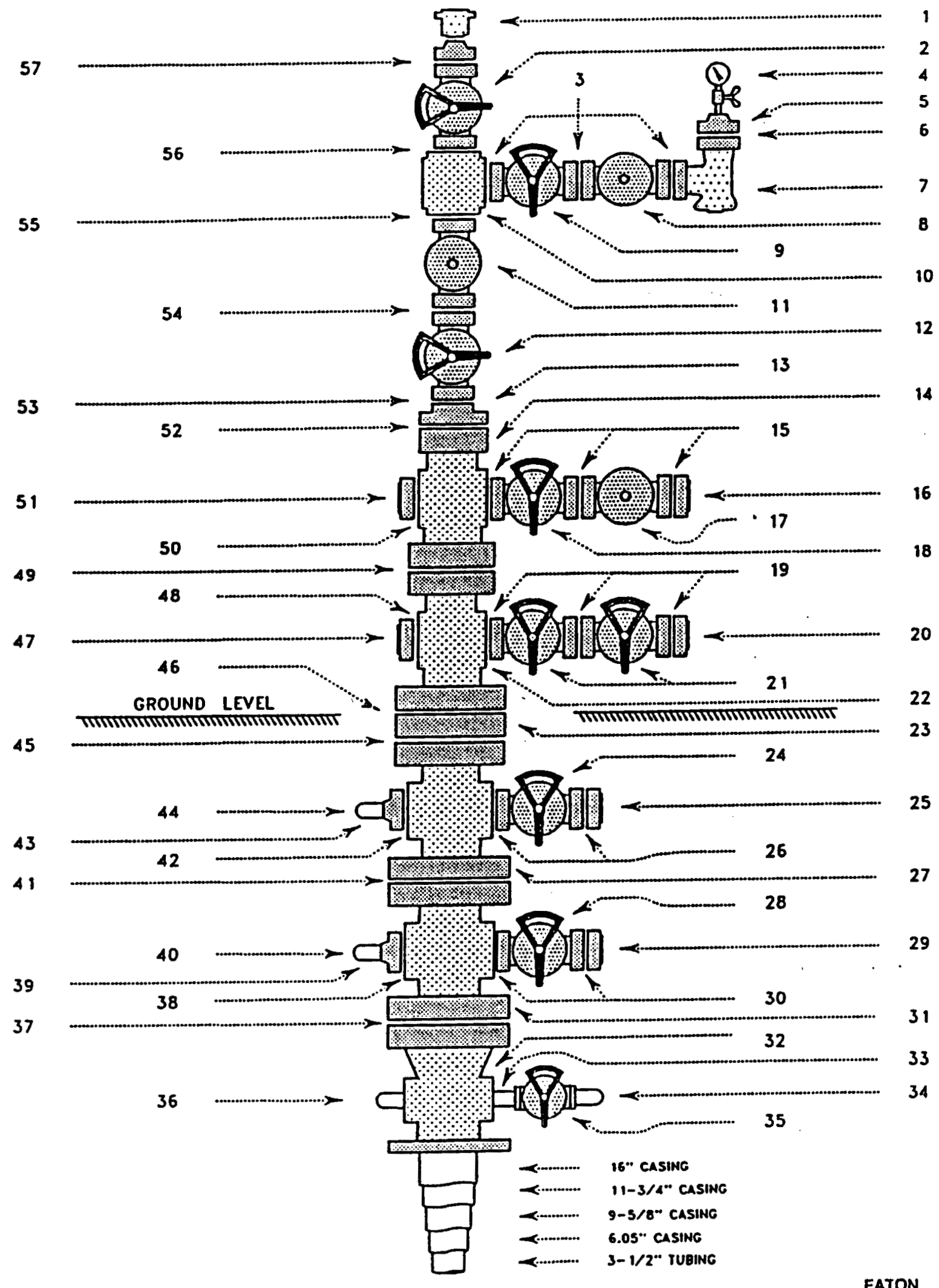

Figure 6-5b. Willis Hulin No. 1 wellhead dimensions schematic as of October 1990. 


\section{WILLIS HULIN NO. 1 PRODUCTION WELLHEAD}

1. 1-13/16" B-11-A-0 20,000\# W.P. (special O-ring seal) treecap

2. 1-13/16" 20,000\# W.P. WKM "m-1" FE $\times$ FE gate valve w/T-26 hi-temp trim (S/N 584198-1)

3. BX-151 API 304 S.S. ring gaskets

4. $1-3 / 8^{\prime \prime}$ S.S. straight gauge cock $w / 0-10,000 \#$ W.P. S.S. pressure gauge $w / 4-1 / 2^{\prime \prime}$ face

5. 1-13/16" 20,000\# W.P. flange tapped w/1-3/8" autoclave, 12 's UNC

6. BX-151 API 304 S.S. ring gasket

7. $1-13 / 16^{\prime \prime} 20,000$ \# W.P. OCT; "PC" FE x FE positive choke

8. $1-13 / 16^{\prime \prime} 20,000$ \# W.P. WKM " $m-1$ " FE $\times$ FE gate valve w/Otis type " $u$ " hydraulic operator w/T-26 hi-temp trim (S/N 581833-4)

9. 1-13/16" 20,000\# W.P. WKM "m-1" FE $x$ FE gate valve w/T-26 hi-temp trim (S/N $536612-3)$

10. $1-13 / 16^{\prime \prime} \times 1-13 / 16^{\prime \prime} \times 1-13 / 16^{\prime \prime} 20,000 \#$ W.P. studded T-608 flow tee

11. 1-13/16" 20,000\# W.P. WKM "m-1" FE $x$ FE gate valve w/Otis type "u" hydraulic operator w/T-26 hi-temp trim (S/N Z-584563-1)

12. 1-13/16" 20,000\# W.P. WKM "m-1" FE x FE gate valve w/T-26 hi-temp trim (S/N $538396-4)$

13. 7-1/16" 20,000\# W.P. open face bottom $\times 1-13 / 16$ " 20,000\# W.P. studded top OCT "A-5-P" S.S. tubing head bonnet adaptor w/test port and w/bottom bored for hipressure extended neck tubing hanger

14. 7-1/16" 20,000\# W.P. x 7-1/16" 20,000\# W.P. OCT type "TCM-BG" tubing head w/two (2) 1-13/16" 20,000\# W.P. F.P.O.'s and w/bottom bored for hi-pressure extended neck tubing hanger 


\section{WILLIS HULIN NO. 1 PRODUCTION WELLHEAD}

15. BX-151 API 304 S.S. ring gaskets

16. $1-13 / 16^{\prime \prime} 20,000 \#$ W.P. blind flange tapped w/1-1/8" N.F.T.

17. $1-13 / 16 " 20,000 \#$ W.P. WKM "m-1" FE $\times$ FE gate valve w/Otis type "u" hydraulic operator w/T-26 hi-temp trim (S/N Z-580038-3)

18. 1-13/16" 20,000\# W.P. WKM "m-1" FE x FE gate valve w/T-26 hi-temp trim (S/N 575456-1)

19. BX-151 API 304 S.S. ring gaskets

20. $1-13 / 16^{n} 20,000$ \# W.P. blind flange tapped w/1-1/8" N.F.T.

21. 1-13/16" 20,000\# W.P. WKM "m-1" FE $\times$ FE gate valves $w / T-26$ hi-temp trim (S/N's 575778-1 \& 575822-4)

22. 7-1/16" 20,000\# W.P. $\times 11^{\prime \prime} 15,000$ \#.P. FE $\times$ FE, 6.05" OCT type "TCM-00" tubing head w/two (2) 1-13/16" 20,000\# W.P. F.P.O.'s (S/N - none)

Note: includes 6" $\times 3-1 / 2^{\prime \prime}$ Armco Nu-Lock type "TC-1A-EN" tubing hanger, grooved for an OCT $3^{\prime \prime}$ type "IS" back pressure valve w/6.05" casing pack-off at the bottom of the $7-1 / 16^{\prime \prime} \times 11^{\prime \prime}$ tubing head

23. $11^{\prime \prime} 15,000 \#$ W.P. $\times 11^{\prime \prime} 10,000 \#$ W.P. DSA w/internal $6.05^{\prime \prime}$ casing pack-off

24. 1-13/16" 10,000\# W.P. WKM "m-1" FE x FE gate valve w/T-22 trim (S/N 5351784)

25. 1-13/16" $10,000 \#$ W.P. blind flange tapped w/1-1/8" N.F.T.

26. BX-151 API 304 S.S. ring gaskets

27. 11" 10,000\# W.P. $x$ 13-5/8" 5,000\# W.P. FE $x$ FE, 9-5/8" OCT type "C-29-L-00" casing spool (S/N 54290)

Note: includes - $10^{\prime \prime} \times 6-1 / 16^{\prime \prime}$ OCT type "C-29" casing hanger at the top of the csg spool and a 9-5/8" csg pack-off at the bottom 


\section{WILLIS HULIN NO. 1 PRODUCTION WELLHEAD}

28. 2-1/16" 5,000\# W.P. WKM FE $\times$ FE gate valve w/T-22 trim (S/N 33969)

29. $2-1 / 16^{\prime \prime} 5,000 \#$ W.P. blind flange tapped w/1-1/8" N.F.T.

30. R-24 API ring gaskets

31. 13-5/8" 5,000\# W.P. $\times 16-3 / 4^{\prime \prime} 3,000$ \# W.P. FE $\times$ FE, 11-3/4" OCT type "C-29-L-00" casing spool (S/N. 24884)

Note: includes $12^{\prime \prime} \times 9-5 / 8^{\prime \prime}$ OCT type "C-29" csg hanger at the top of the csg spool and a 11-3/4" csg pack-off at the bottom

32. $16-3 / 4^{\prime \prime} 3,000$ \# W.P. OCT type "C-22" SOW casing head $w / 2^{\prime \prime}$ thick $\times 34^{\prime \prime}$ O.D. base plate and eight (8) $2^{\prime \prime}$ thick gussets ( $\mathrm{S} / \mathrm{N}$ none)

Note: includes $16-3 / 4^{\prime \prime} \times 11-3 / 4^{\prime \prime}$ OCT type "C-22" casing hanger at the top of the csg head

33. $2^{\prime \prime} \times 6^{\prime \prime} \mathrm{XXH}$ nipple

34. $2^{\prime \prime} \mathrm{XXH}$ bull plug

35. $2-1 / 16^{\prime \prime} 3,000 \#$ W.P. WKM thread $\mathrm{x}$ thread S.S. gate valve $\mathrm{w} / \mathrm{T}-21$ trim (S/N $555530-1)$

36. $2^{\prime \prime} \mathrm{XXH}$ bull plug

37. R-66 API ring gasket

38. $\mathrm{R}-24$ API ring gasket

39. 2-1/16" 5,000\# W.P. companion flange w/2" N.F.T. 


\section{WILLIS HULIN NO. 1 PRODUCTION WELLHEAD}

40. $2^{\prime \prime} \mathrm{XXH}$ bull plug

41. BX-160 API ring gasket

42. BX-151 API ring gasket

43. $1-13 / 16^{\prime \prime} 10,000 \#$ W.P. companion flange $w / 2^{n}$ N.F.T.

44. $\quad 2^{n} \mathrm{XXH}$ bull plug

45. BX-158 API ring gasket

46. BX-158 API ring gasket

47. $1-13 / 16^{\prime \prime} 20,000 \#$ W.P. blind flange

48. BX-151 API 304 S.S. ring gasket

49. BX-156 API 304 S.S. ring gasket

50. BX-151 API 304 S.S. ring gasket

51. 1-13/16" 20,000 \# W.P. blind flange

52. BX-156 API 304 S.S. ring gasket

53. BX-151 API 304 S.S. ring gasket

54. BX-151 API 304 S.S. ring gasket

55. BX-151 API 304 S.S. ring gasket

56. BX-151 API 304 S.S. ring gasket

57. BX-151 API 304 S.S. ring gasket 


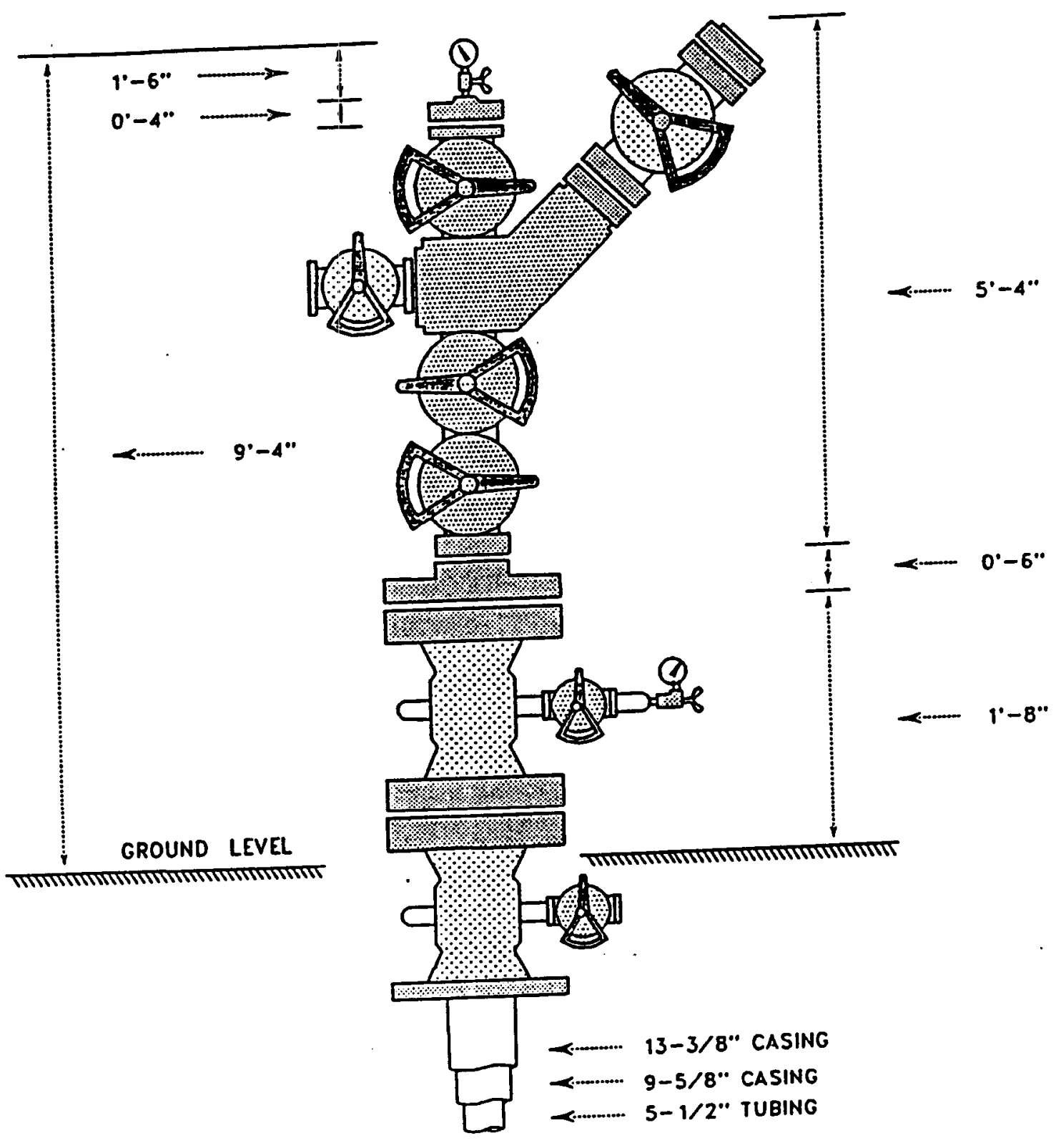

Figure 6-6a. Willis Hulin CVW No. 1 disposal wellhead dimensions as completed by EOC, EATON February 1989. 


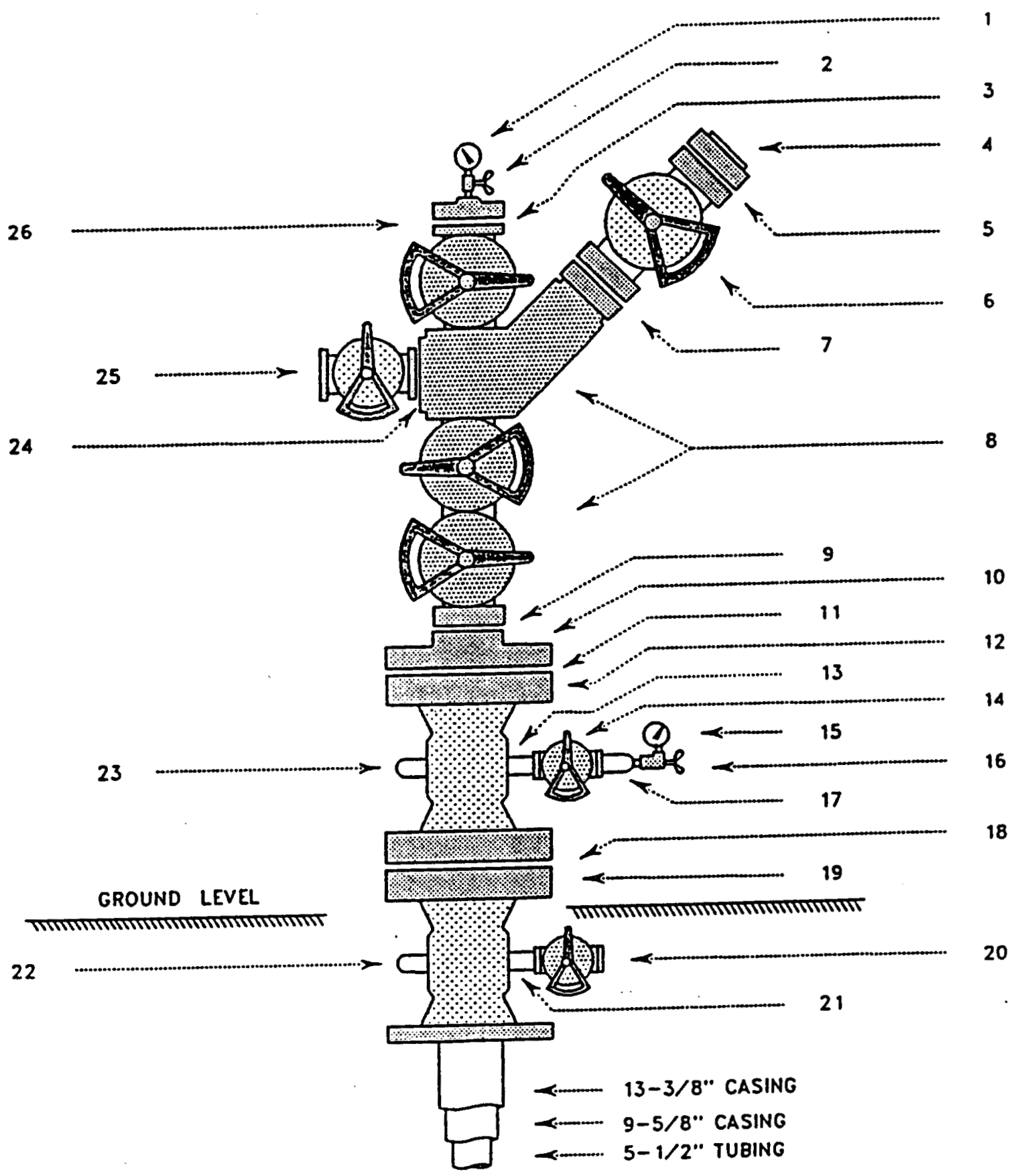

Figure 6-6b. Willis Hulin CVW No. 1 disposal wellhead dimensions as completed by EOC, EATON February 1989. 


\section{WILLIS HULIN CV W NO. 1 DISPOSAL WELLHEAD}

1. $\quad 1 / 2^{\prime \prime}$ N.P.T. $\times 4-1 / 2^{\prime \prime}$ face, $0-5,000$ PSI W.P. pressure gauge

2. $\quad 1 / 2^{\prime \prime}$ N.P.T. $5,000 \#$ W.P. needle valve

3. $2-7 / 8^{\prime \prime} 8 \mathrm{Rd}$ nipple $w / 1 / 2^{\prime \prime}$ N.P.T. tap

4. $7-1 / 16^{\prime \prime} 5,000$ \# W.P. flange w/2-7/8" 8 Rd R.F.

5. $7-1 / 16^{\prime \prime} 5,000$ \# W.P. flange $\times 6^{\prime \prime}$ weid neck

6. R-46 API 316 S.S. ring gasket

7. $7-1 / 16^{\prime \prime} 5,000 \#$ "OCT", Model 20 , balanced stem FE $\times$ FE gate valve (7-1/8" drift)

8. R-46 API 316 S.S. ring gasket

9. Composite tree consisting of: two (2) master valves and one (1) swab valve, each being 7-1/16" 5,000\# "OCT", Model 20, balanced stem gate valves (7-1/8" drift); one (1) 7-1/16" 5,000\# studded wing angled at 45 degrees from tree body, and one (1) $4-1 / 16^{\prime \prime} 5,000$ \# flanged wing at 90 degrees to body

10. R-50 API 316 S.S. ring gasket

11. 11" 5,000\# W.P. $\times 9$ 9" 5,000\# W.P. DSA

12. R-54 API 316 S. S. ring gasket

13. $13-3 / 8^{n} 3,000 \#$ W.P. $\times 11^{\prime \prime} 5,000$ \# W.P. w/two (2) $2^{n}$ L.P.S.O.'s, tubing spool

14. $\quad 2$ " L.P. $\times 6$ " long, XXHVY nipple

15. 2" L.P. API 3,000\# W.P. gate valve

16. $1 / 2^{\prime \prime}$ N.P.T. $\times 4-1 / 2^{\prime \prime}$ face, $0-5,000 \#$ pressure gauge

17. $1 / 2^{\prime \prime}$ N.P.T. needle valve

18. 2" L.P., tapped w/1/2" N.P.T., XXHVY bull plug

19. R-57 API 316 S.S. ring gasket 


\section{WILLIS HULIN C V W NO. 1 DISPOSAL WELLHEAD}

20. $13-3 / 8^{\prime \prime}$ S.O.W. $\times 13-5 / 8^{\prime \prime}$ API 3,000\# W.P. w/two (2) $2^{\prime \prime}$ L.P.S.O.'s and base plate for $20^{\prime \prime}$, casinghead

21. 2" L.P. 3,000\# W.P. ball valve

22. $2^{\prime \prime}$ L.P. $\times 6^{\prime \prime}$ long, XXHVY nipple

23. $\quad 2^{n}$ L.P. solid, SSHVY bull plug

24. $\quad 2^{n}$ L.P. solid, XXHVY bull plug

25. R-39 API 316 S.S. ring gasket

26. 4-1/16" 5,000\# "OCT" Model 20, balanced stem FE x FE gate valve

27. R-46 API 316 S.S. gasket 


\section{Exhibit 6-P}

\section{Attachment 4}

\section{(blank page)}


6-148 
Attachment 5

Page 1 of 1

\section{WILLIS HULIN}

Surface production equipment - major components only:

1. Glycol Dehydration Unit; Manufacturer - Ken Wind Co.

Skid mounted unit with 6 tray absorber tower $\left(12-3 / 4^{\prime \prime}\right.$ O.D. $x$ $20^{\prime} \mathrm{high}$ ), a 125,000 BIU/Hr Glycol regenerator, and associated scrubbers, accumulators, separators and pumps.

Model No.: SB10-6H

S/N: $8402-215$

Heater S/N: 40370

Manufactured approx. 1984

Reconditioned/preserved - 9/91 


\section{6-150}




\section{Exhibit 6-Q}

Turnkey Bids for McCall and Hulin Sites 
6-152 


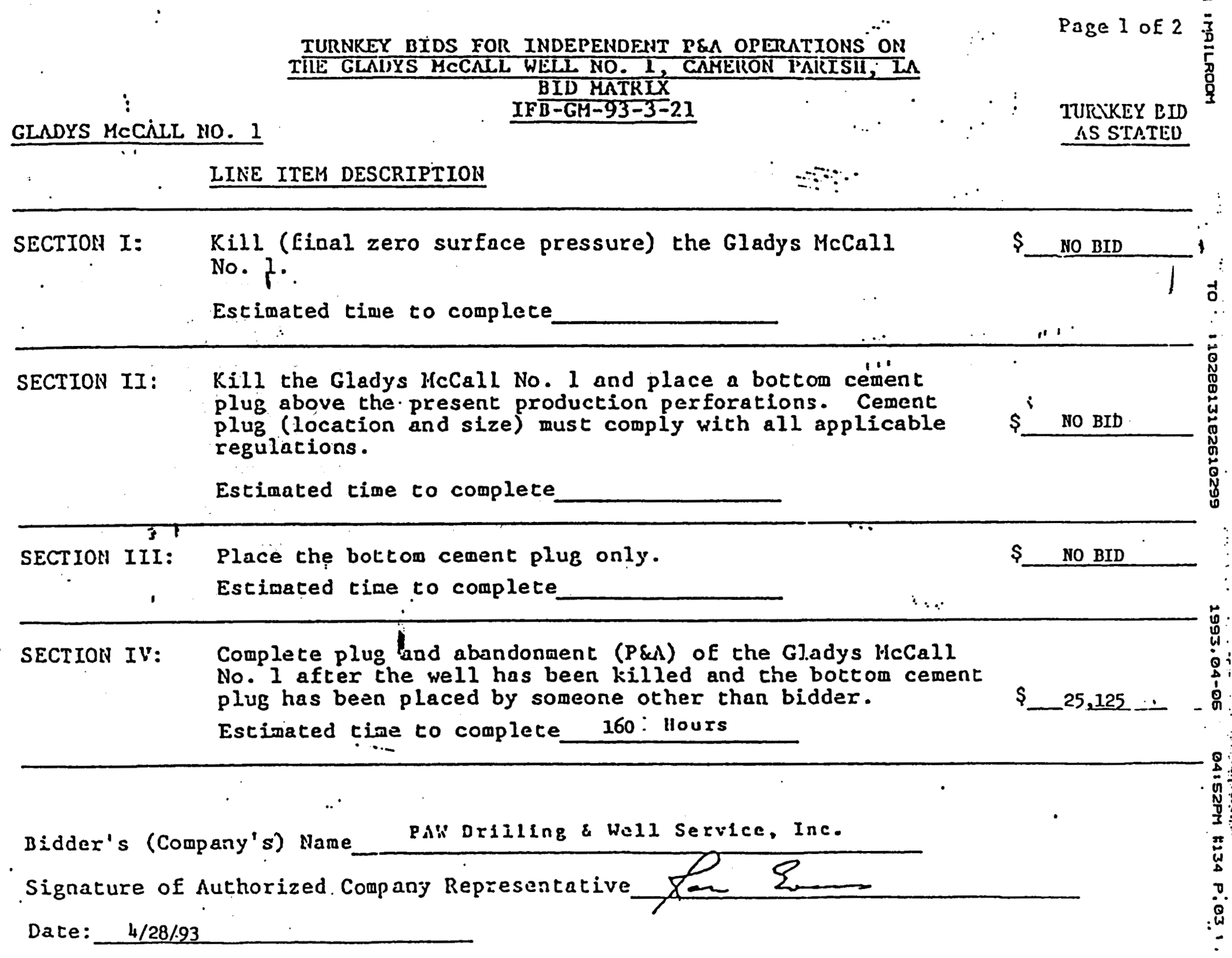


TURNREY BIDS FOR INDEPENDENT PEA OPERATIONS ON *" TIE GLANYS MCCALL WELL NO. $I$, CAHERON PARISII, IA BID MUTRIX

GLADYS McCríl. NO. 1
TURHIKEY BID $\Lambda S$ STATED

\section{LINE ITEH DESCRIPTION}

SECTION V: To kill the Gladys McCall No. 1, place the bottcm cement plug, and complete plug and abandonment. (P\&A) of the well. Escimaled rime to complete 180

Hours

$\$ 40.125$

\section{$\because \cdots$}

SECTION VI: Cost to provide a "Performance Bond", with "Payment :". Clause", as described in Note Ho. 8, Pages 3 and 4, of this IFB..

$\stackrel{i}{\grave{c}}$
Have any of the above bids been affected by bidder's interest in salvagling any casing/tubling or surface production equipment?

¿ 'If yes, please attach an itemized list of all items biddex is interested in obtaining. sll salvageable suríace \& dowrinole equiprent

Bidder's (Company's) Name PriW Drzlling \& 'Nell Service, Inc.

- Signature of Authorized Company Representative

Dace: 
TURNKEY BIDS FOR INDEPENDENT PEA OPEKA'IONS : ON TIIE WILLIS IUULIN WELI HO. 1 AND WILLIS UULIN CVW NO. I, VERMILXON PARISI, IA BID MATRLX

WILLIS IILILIN NO. 1

IINE ITEM DESCRIPTIOL: $=:-0^{\circ}$

SECTION I: Kill (final zero surface pressure) the Willis liulin No. 1 .

Estimated tine to complete

SECTION II: Kill the Willis Hulin No. I and place a bottom cement

plug above the present production perforations. Cement

plug (location and size) must comply with all applicable regulations.

Estimated time to complete

\begin{tabular}{llll}
\hline SECTION IIfi: & $\begin{array}{l}\text { Place the bottom cement plug only. } \\
\text { Estimated time to complete }\end{array}$ & $\cdots$ & Ho Bid \\
\hline
\end{tabular}

SECTIOK IV: Complete plug and abandonment (P\&A) of the Willis Hulin No. I after tte well has been killed and the bottom cement plug has been placed by someone other than bidder. Estimated time to complete 130 liours

Bicider's (Company's) Name PAh Drilling \& Well Service, Inc. Signature of Authorized Company Representative

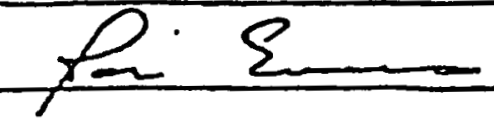

Dáte: $4 / 28 / 93$ 
TURNKEY BIDS FOR INDEPENDENT. P\&A OPERATIONS ON. .-

Page 2 of 2

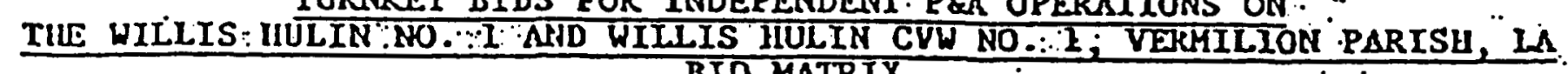

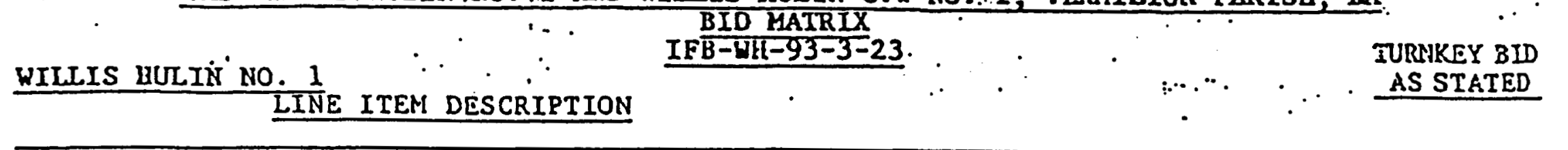

SECTIOL: V: To kill the Willis llulin No. 1, place the bottow cenent

plug; and complete plug and abandonment. (P\&A) of the :well. \$ 51,100

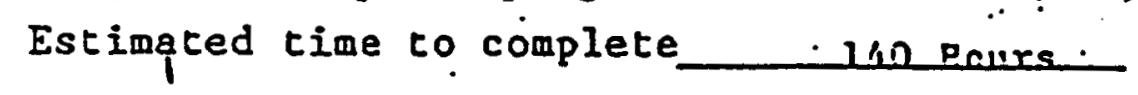
SECTION VI: $\quad$ Cost to provide a."Performance Bond", with "'Payment
Clause", as described in Hote No. 8, Pages 3 and 4 , of this 'IFB.

Have any of the above bids been affected by bidder's incerest in salvaging any casing/tubing or surface production equipment?

...

$\because:$

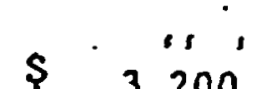

$\$ 1200$

$\cdot$

$\underbrace{x \times}_{\text {NOS }}$

If yes, please attach an itemized list of all items.

\$: biclder is interested in obtaining. "All salvagea

All salvageable dọinhole surface equip.

\section{WILLIS IIULIN CWW NO. 1}

SECTION VIII: Plug and abaadory (PSA) the Willis Hulin CWW No. 1

Estimated tine co complete 35 Hours

SECTIOH IX: Has the above bid been affected by bidder's incerest in

in salvaging any casing/tubing or che disposal wellhead?

$x x$ YES

II yes, please atrach an ftemized list of al? items bidder

$\$$

is incerested in obtaining.

All salvageable countole 8 surace equip.

Bidder's (Company's) ilame Paji Drillins s veil Serufce, lac.
Signacure of Auctosized Company Representative 


\section{Exhibit 6-R}

\section{EG\&G Idaho, Inc. \\ Costs Savings Report}


6-158 
EG\&G IDAHO, INC.

Transporation \& Renewable Energy Programs

Ted L. Rasmussen, Unit Manager

\section{COSTS SAVINGS}

Identified bellow are cost savings resulting from Quality Project Management Procedures. A savings of $\$ 3.1$ million resulted when EG\&G Idaho, Inc. replaced the site operator for three geothermal test sites and instituted proper project management, intensive investigation of work to be performed (resulting in knowing the proper way to accomplish the work) and day to day control of contracts by the project manager Bennie N. Rinehart.

DOE cost estimate with the original contractor:

$\begin{array}{rc}\text { P\&A Wells (3) } & \$ 1,592,442 \\ \text { Restoration } & \$ 347,620^{*} \\ \text { Administration (11m) } & \$ 1,007,776 \\ \text { NORM Storage (10y) } & \$ 158,400 \\ \text { Total Cost } & \$ 3,106,238\end{array}$

* Note: The site restoration for Gladys McCall was estimated to be $\$ 115,435$ by the original contractor. When it was placed out for bid the cost came in at $\$ 868,350$. EG\&G Idaho, Inc. changed the restoration $p l a n$ and completed it for $\$ 78,806$. Using this amount then the savings shown below would be increased by $\$ 789,544$ to $\$ 3,191,782$.

EG\&G Idaho, Inc. cost

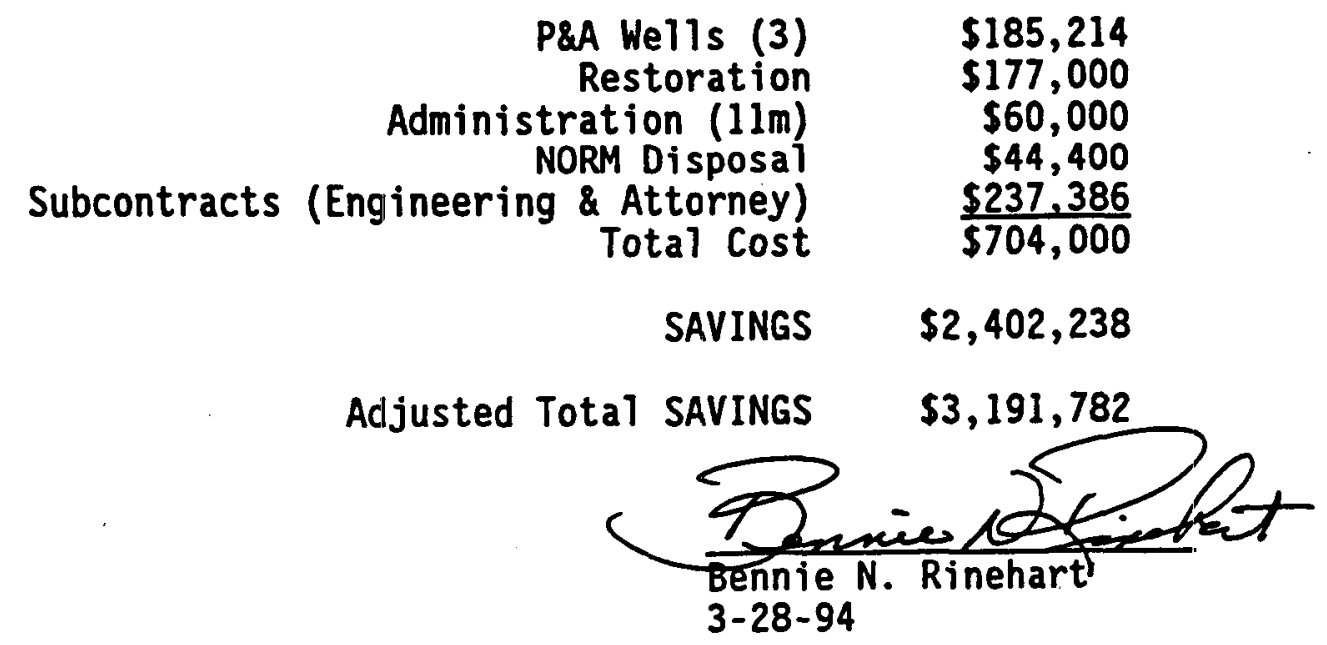




\section{Exhibit 6-S}

PAW Drilling \& Well Service, Inc. P\&A Cost and Salvage Report 
Workover

r-illing

rey

.10re
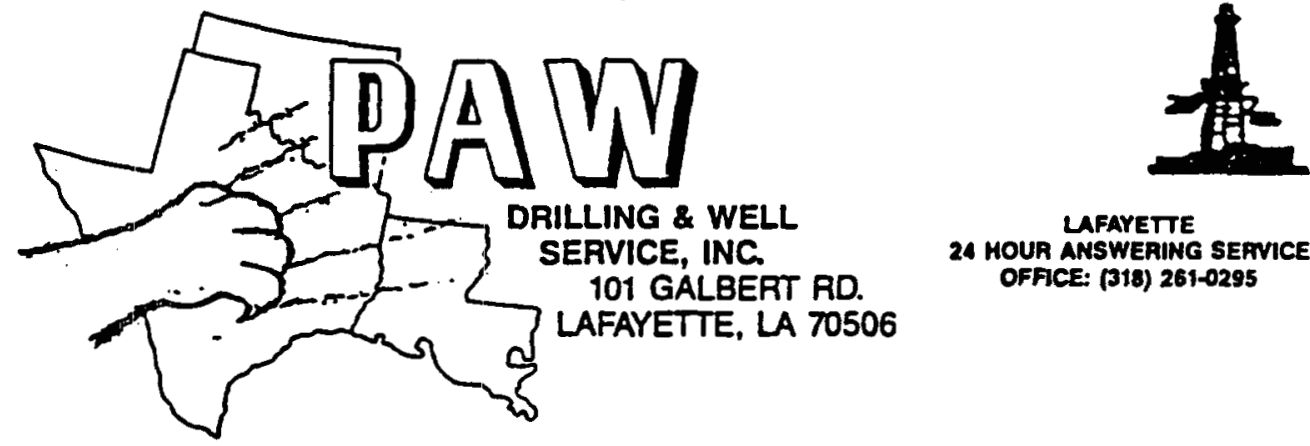

LAFAYETTE

Offshore

August 6, 1993

E G \& G Idaho, Inc.

P. O. Box 1625

Idaho Fal1s, ID 83415

Attn: Mr. Mike Bolender

RE: P \& A Geopressured Wells - EG\&G Idaho No C93-160650

Pursuant to my conversations with Mr. Bill Crownover and Mr. Ben Rinehart, we are pleased to submit the following information for your review.

1. Gladys McCall \#1 Well

Cameron Parish, IaA

2. Gladys McCall SWDW \#1

Cameron Parish, IAA

3. W. Hulin 1 Well

Vermilion Parish, LA

4. W. Hulin CVW \#1

Vermilion Parish, IA

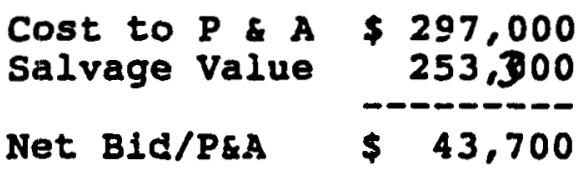

Cost to P A $\$ 12,000$

Salvage Value 12,000

P\&A for salvage -0-

Cost to P \& $\$ 151,100$

Salvage Value

Net $B 1 d / P \& A$ \$ $\$ 4,300$

Cost to P A $\$ 12,000$

Salvage value $\quad 12,000$

P\&A for salvage -0- 
